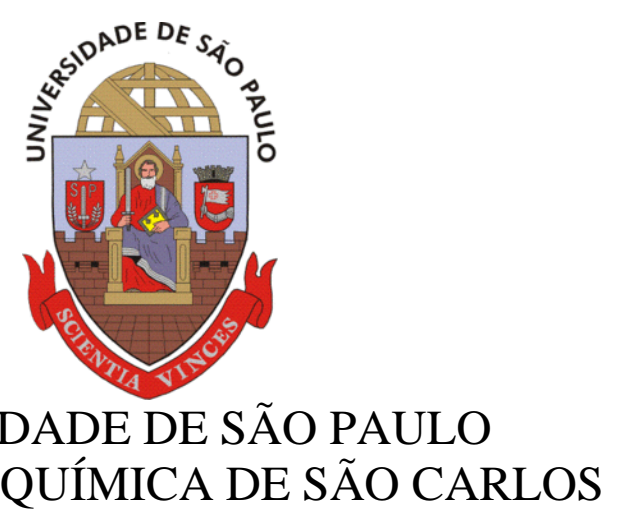

UNIVERSIDADE DE SÃO PAULO INSTITUTO DE QUIIMICA DE SÃO CARLOS

Estudos de biotransformação de pesticidas organofosforados e biometilação de compostos fenólicos por fungos de ambiente marinho

Paulo Roberto Serrão Soares 
Paulo Roberto Serrão Soares

\section{Estudos de biotransformação de pesticidas organofosforados e biometilação de compostos fenólicos por fungos de ambiente marinho}

Dissertação apresentada ao Instituto de Química de São Carlos da Universidade de São Paulo para a obtenção do título de Mestre em Ciências.

Área de concentração: Química Orgânica e Biológica.

Orientador: Prof. Dr. André Luiz Meleiro Porto.

São Carlos

2016 
Autorizo a reprodução e divulgação total ou parcial deste trabalho, por qualquer meio convencional ou eletrônico para fins de estudo e pesquisa, desde que citada a fonte.

\section{Assinatura: Poun lo Ruluto Lenáo Loomes Data: $12 / 07 / 2016$}

\section{Soares, Paulo Roberto Serrào}

Estudos de biotransformação de pesticidas organofosforados e biometilaçâo de compostos fenólicos por fungos de ambiente marinho. / Paulo Roberto Serrảo Soares. - São Carlos, 2016.

$330 \mathrm{f}$.

Dissertação (Mestrado em Química Orgânica e Biológica) - Instituto de Química de São Carlos / Universidade de São Paulo, 2016.

\section{Orientador: Prof. Dr. André Luiz Meleiro Porto}

1. Biodegradaçâo. 2. Bioconjugaçâo. 3. Pesticidas. 4. Fungos de ambiente marinho. L. Título.

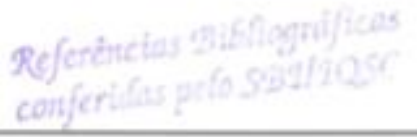


Aos meus amados e queridos pais, Alberto $e$ Sandra, pelo empenho na minha educação. A vocês devo tudo que consegui hoje. 
Dedico essa dissertação, in memoriam, ao meu avô Jorge e minha avó Matilde, exemplos em minha vida. 
"Só existem duas maneiras de você viver sua vida. Uma é como se nada fosse um milagre. A outra, como se tudo fosse um milagre." Albert Einstein 


\section{RESUMO}

Os pesticidas organofosforados são amplamente utilizados na agricultura, pois são muito eficazes no controle de pragas, promovendo um aumento na produtividade dos alimentos. Contudo, sua utilização indiscriminada provoca graves problemas ambientais e para a saúde humana, uma vez que são tóxicos também para as espécies que não são alvos e acumulam grandes quantidades de metabólitos tóxicos, como por exemplo, fenois. Os compostos fenólicos enquadram-se nos resíduos resultantes da degradação de compostos naturais e xenobióticos da atividade antrópica. Este trabalho teve por objetivo estudar as reações de conjugação de fase II em compostos fenólicos derivados da hidrólise de pesticidas organosfosforados (clorpirifós, metil paration e profenofós) e a biotransformação de outros fenois por enzimas provenientes de fungos de ambiente marinho. Primeiramente foi realizado um screening com os fungos de ambiente marinho Aspergillus sydowii CBMAI 934, A. sydowii CBMAI 935, A. sydowii CBMAI 1241, Penicillium decaturense CBMAI 1234, P. raistrickii CBMAI 931, P. raistrickii CBMAI 1235 e Trichoderma sp. CBMAI 932 para avaliar a resistência destes microrganismos frente à toxicidade dos pesticidas organofosforados para posterior escolha da cepa mais resistente e melhor adaptada aos pesticidas testados nesse trabalho. O fungo selecionado para as reações em meio líquido de malte $2 \%$, que melhor adaptou-se na presença dos pesticidas testados foi a cepa do fungo $A$. sydowii CBMAI 935. Foram realizadas curvas analíticas com o objetivo de estimar a extensão da biodegradação dos pesticidas clorpirifós, metil paration, profenofós e seus respectivos produtos de hidrólise, os fenois 3,5,6-tricloro-2-piridinol, 4-nitrofenol e 4-bromo-2clorofenol, respectivamente. As reações de biotransformação em meio líquido de malte $2 \%$ foram avaliadas com 10,20, $30 \mathrm{~d}$ de reação com concentração inicial dos pesticidas organofosforados de $50 \mathrm{mg} \cdot \mathrm{L}^{-1}$. Todos os metabólitos encontrados nas reações de biotransformação dos pesticidas organofosforados com o fungo A. sydowii CBMAI 935 foram comparados com os seus padrões analíticos e sintéticos (metilação) com o objetivo de corroborar as reações de bioconjugação. Através deste estudo foi possível sugerir a presença de enzimas fosfotriesterases e enzimas metiltransferases provenientes do fungo A. sydowii CBMAI 935. Enzimas que promoveram a hidrólise e metilação dos pesticidas e compostos fenólicos testados nesse trabalho. Segundo a literatura, as reações de biotransforrmação e bioconjugação dos pesticidas orgafosforados, diminuem consideravelmente a toxicidade desses compostos recalcitrantes. 


\begin{abstract}
Organophosphate pesticides are widely used in agriculture, as they are very effective in pest control, promoting an increase in productivity of food. However, indiscriminate use causes serious problems environmental and for human health, since they are also toxic to non-target species and accumulate large amounts of toxic metabolites, such as phenols. Phenolic compounds are part of the waste resulting from the degradation of natural compounds and xenobiotics of human activity. This work aimed to study the phase II conjugation reactions in phenolic compounds derived from hydrolysis of pesticides organophosphates (chlorpyrifos, methyl parathion and profenofos) and the biotransformation of other phenols for enzymes from marine environment fungi. First was conducted a screening with the marine environment fungi. Aspergillus sydowii CBMAI 934, A. sydowii CBMAI 935, A. sydowii CBMAI 1241, Penicillium decaturense CBMAI 1234, P. raistrickii CBMAI 931, P. raistrickii CBMAI 1235 and Trichoderma sp. CBMAI 932 to evaluate the resistance of these microorganisms front the toxicity of organophosphate pesticides to later choose the most resistant strain and better adapted to pesticides tested in this work. The fungus selected to the reactions in liquid medium $2 \%$ malt, which best adapted in the presence of the pesticide tested was the fungal strain of A. sydowii CBMAI 935. Standard curves were performed in order to estimate the extent of biodegradation of pesticides chlorpyrifos, methyl parathion, profenofos and their hydrolysis products, phenols 3,5,6-trichloro-2-pyridinol, 4-nitrophenol and 4-bromo- 2chlorophenol, respectively. The biotransformation reactions in liquid medium $2 \%$ malt were evaluated in 10, 20, 30 days reaction of with initial concentration of organophosphate pesticides of $50 \mathrm{mg} . \mathrm{L}^{-1}$. All metabolites found in the biotransformation reactions of organophosphate pesticides with the fungus A. sydowii CBMAI 935 were compared with their synthetic and analytical standards (methylation) in order to corroborate the bioconjugation reactions. Through this study was possible suggest the presence of enzymes phosphotriestesterases and methyltransferases from fungus A. sydowii CBMAI 935. Enzymes that promote hydrolysis and methylation of pesticides and phenolic compounds tested in this work. According to the literature, the reactions of biotransformation and biodegradation of organophosphate pesticides, greatly reduce the toxicity of recalcitrant compounds.
\end{abstract}




\section{AGRADECIMENTOS}

Ao meu Deus por ter me dado saúde e força para superar as dificuldades.

Aos meus irmãos Adriana, Alberto, Elen e Eduardo pelo apoio.

A minha namorada, Julhiany, que é minha fonte de inspiração.

Ao meu orientador, Prof. Dr. André Luiz Meleiro Porto, pela confiança no meu trabalho, paciência e apoio dedicado durante este período.

Aos colegas Sandra Ribeiro (in memorian), Irlon Maciel, Natália Alvarenga, David Quintero, William Birolli, Darlisson de Alenxandria, lara Matos, Rafaely Lima, Charlene Anjos, Juliana Scramin, Juliana Barreiro e Samuel Filipe e faço menção aos alunos de Iniciação Científica: Eloá Borges, Beatriz Anjos, Aline Morais, Graciele Neves, Muriel Thaiara, Leonardo Totti, Marylyn Arai e Lucas Casari, membros do Grupo de Química Orgânica e Biocatálise (GQOB) do qual faço parte.

Aos técnicos do Laboratório, Marília Peret e João Pedro Lima, por me darem apoio, me ensinaram muitas coisas das quais eu não tinha domínio.

A FAPEAM pelo apoio financeiro recebido através da bolsa de mestrado (EDITAL N. OO2/2014 - RH-MESTRADO - FLUXO CONTÍNUO).

Ao Instituto de Química de São Carlos (IQSC) e a Universidade de São Paulo (USP) pela oportunidade de realizar este trabalho.

A Fundação de Amparo à pesquisa do Estado de São Paulo (FAPESP) pelo auxílio à pesquisa prestado.

A todos os amigos e funcionários do IQSC que de forma direta ou indireta, contribuíram para a conclusão deste trabalho.

Aos professores Antonio Carlos Bender Burtoloso, Antonio Aprígio da Silva Curvelo e Maria do Carmo Calijuri que foram membros da banca de qualificação de mestrado e contribuíram de forma significativa para o êxito desse trabalho. 


\section{LISTA DE FIGURAS}

Figura 1.

Figura 2.

Figura 3.

Figura 4.

Figura 5.

Figura 6.

Figura 7.

Figura 8.

Figura 9.

Figura 10.

Figura 11.

Figura 12.

Figura 13.

Figura 14.

Figura 15.

Figura 16.

Figura 17.

Figura 18.

Figura 19.

Figura 20.

Figura 21.

Figura 22.

Figura 23.

Figura 24.

Figura 25.

Figura 26.

Figura 27.

Figura 28.

Figura 29.

Figura 30.
Estruturas químicas de alguns dos pesticidas utilizados na agricultura nas décadas de 30 e 40

\section{1} Estruturas químicas de pesticidas organoclorados utilizados na agricultura que tiveram seu uso

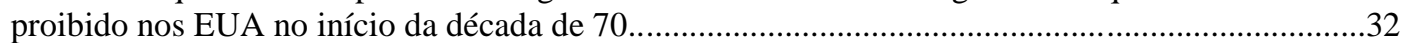

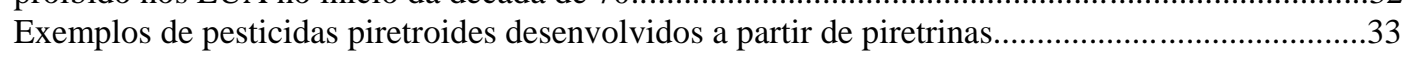
Taxa de crescimento do consumo de agrotóxicos no Brasil (2005- 2015)........................................34 Variações no consumo de agrotóxicos e na produção de commodities no Brasil (20002012)...

Amostra de alimentos produzidos no Brasil com resíduos de agrotóxicos.........................................39

Processos físicos, químicos e biológicos que controlam a persistência ou degradação de pesticidas

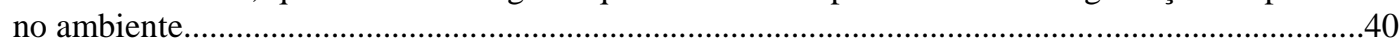

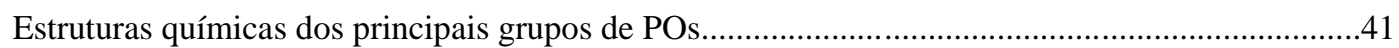

Exemplos de POs mais comercializados..................................................................................

Esquema do processo de transmissão e controle nervoso nas sinapses pela

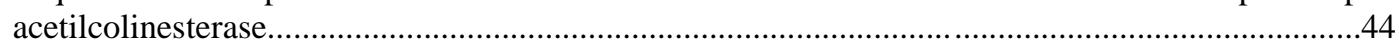

Exemplo do processo de hidrólise do neutransmissor acetilcolina (ACh) pela enzima

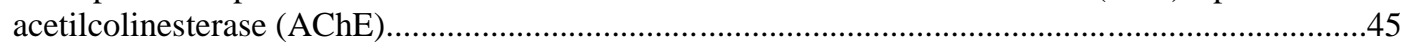
Proposta de mecanismo de hidrólise da acetilcolina pela enzima

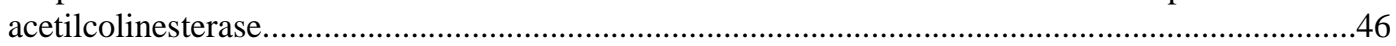
Proposta de mecanismo de inibição da enzima acetilcolinesterase por pesticidas

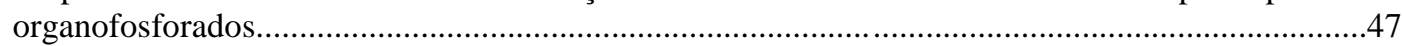

Proposta de rotas de degradação do clorpirifós por microrganismos.............................................49

Proposta de rotas de degradação do metil paration em humanos.......................................................51

Proposta de rotas de degradação do metil paration por microrganismos........................................52

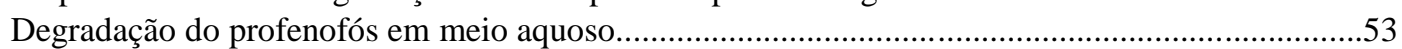

Vias metabólicas do profenofós em seres humanos......................................................................54

Rotas de biodegradação do fenol mediadas pelas enzimas a) fenol hidroxilase e b) fenol 2monoxigenase ...............................................................................................................5

Via de degradação por enzimas fosfotriesterases na fase I e metiltransferases na fase II para o

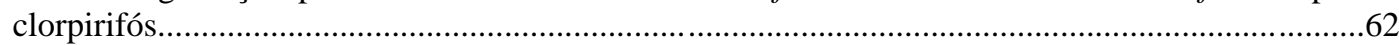
Representação de resíduos de aminoácidos: ácido aspártico, histidina e lisina coordenados com $\mathrm{Zn}^{2+}$ no sítio ativo da enzima fosfotriesterase.......................................................................63 Representação estrututal das enzimas chalcona $O$-metiltranferase (ChOMT) e isoflavona $O$ -

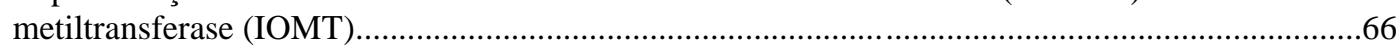
Mecanismo enzimático de biometilação da chalcona (E)-1-(2,4diidroxifenil)-3-(4hidroxifenil)prop-2-en-1-ona para (E)-1-(4-diidroxi-2-metoxifenil)-3-(4-hiroxifenil)pro-2-em-1-ona pela enzima chalcona $O$-metiltranferase (ChOMT). .67

Mecanismo enzimático de biometilação do flavonoide 7-hidroxi-3-(4-hidroxifenil)-4H-cromen-4ona para 3-(4-hidroxifenil)-7-metoxi-4H-cromen-4-ona pela enzima isoflavona $O$-metiltransferase (IOMT). .68 Diversidade química de produtos naturais que podem ser biometilados por enzimas metiltransferases de produtos naturais e orto-metiltransferases. As hidroxilas com círculos pontilhados representam os locais de possíveis metilações.......................................................69 Diversidade química de produtos naturais que podem ser biometilados por enzimas metiltransferases de produtos naturais. Os grupamentos com círculos pontilhados representam os locais de possíveis metilações.................................................................................................70 Ilustração de biometilação por enzimas metiltransferases e posterior degradação do pentaclorofenol pelo fungo Anthracophyllum discolor ..................................................................................... 71 Regressão linear utilizada para obtenção da equação da reta e coeficiente de

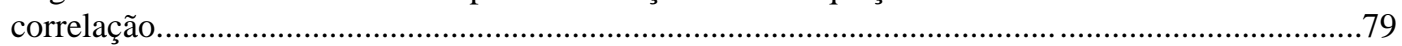
Curva analítica obtida por CLAE-UV para o pesticida clorpirifós para a faixa de concentração entre 20-600 mg. $\mathrm{L}^{-1}$...... ...83 Curva analítica obtida por CLAE-UV para o composto fenólico 3,5,6-tricloro-2-piridinol para a faixa de concentração entre $20-600 \mathrm{mg} . \mathrm{L}^{-1}$....... 
Figura 31.

Figura 32.

Figura 33.

Figura 34.

Figura 35.

Figura 36.

Figura 37.

Figura 38.

Figura 39.

Figura 40.

Figura 41.

Figura 42.

Figura 43.

Figura 44.

Figura 45.

Figura 46.

Figura 47.

Figura 48.

Figura 49.

Figura 50.

Figura 51.

Figura 52.

Figura 53.

Figura 54.

Figura 55.

Figura 56.

Figura 57.

Figura 58.
Curva analítica obtida por CLAE-UV para o pesticida metil paration para a faixa de concentração entre 20-600 mg. $\mathrm{L}^{-1}$

Curva analítica obtida por CLAE-UV para o composto fenólico 4-nitrofenol para a faixa de concentração entre $20-600 \mathrm{mg} . \mathrm{L}^{-1}$

Curva analítica obtida por CLAE-UV para o pesticida profenofós para a faixa de concentração entre 20-600 mg. $\mathrm{L}^{-1}$......

Curva analítica obtida por CLAE-UV para o composto fenólico 4-bromo-2-clorofenol para a faixa de concentração entre 20-600 mg. $\mathrm{L}^{-1}$.

Reação de metilação do pentaclorofenol.

Esquema de ampliação dos blocos de uma câmara de Neubauer.

Equação para o cálculo da densidade de esporos na solução

Fluxograma das etapas de preparação da suspensão de esporos.....................................................97

Fluxograma das etapas de preparação e extração da fase micelial e caldo enzimático das reações com o fungo A. sydowii CBMAI 935 para os pesticidas clorpirifós, metil paration e profenofós (extração dos micélios e caldo enzimático separadamente).

.99

Fluxograma das etapas de preparação e extração da fase micelial e caldo enzimático das reações com A. sydowii CBMAI 935 e 3,5,6-tricloro-2-piridinol, 4-nitrofenol, 4-bromo-2-clorofenol (extração dos micélios e caldo enzimático separadamente).

101

Fluxograma das etapas de preparação e extração da fase micelial e caldo enzimático das reações com A. sydowii CBMAI 935 com o fenol, 2-clorofenol, 2-cloro-5-hidroxipiridina, 4-(4hidroxifenil)ciclo-hexanona, pentaclorofenol e naringenina (extração dos micélios e caldo enzimático separadamente)...

Cultivo do fungo $P$. raistrickii CBMAI 931 na ausência de clorpirifós (placa controle) e com 5, 10 e $15 \mu \mathrm{L}$ de clorpirifós/placa. (A) 5 dias de cultivo e (B) 10 dias de cultivo.

Cultivo do fungo Trichoderma sp. CBMAI 932 na ausência de clorpirifós (placa controle) e com 5 , 10 e $15 \mu \mathrm{L}$ de clorpirifós/placa. (A) 5 dias de cultivo e (B) 10 dias de cultivo.............................110 Cultivo do fungo A. sydowii CBMAI 934 na ausência de clorpirifós (placa controle) e com 5, 10 e $15 \mu \mathrm{L}$ de clorpirifós/placa. (A) 5 dias de cultivo e (B) 10 dias de cultivo.....................................112 Cultivo do fungo A. sydowii CBMAI 935 na ausência de clorpirifós (placa controle) e com 5, 10 e $15 \mu \mathrm{L}$ de clorpirifós/placa. (A) 5 dias de cultivo e (B) 10 dias de cultivo......................................114 Cultivo do fungo Penicillium decaturense CBMAI 1234 na ausência de clorpirifós (placa controle) e com 5, 10 e $15 \mu \mathrm{L}$ de clorpirifós/placa. (A) 5 dias de cultivo e (B) 10 dias de cultivo...... .116 Cultivo do fungo Penicillium raistrickii CBMAI 1235 na ausência de clorpirifós (placa controle) e com 5, 10 e $15 \mu \mathrm{L}$ de clorpirifós/placa. (A) 5 dias de cultivo e (B) 10 dias de cultivo...................118 Cultivo do fungo A. sydowii CBMAI 1241 na ausência de clorpirifós (placa controle) e com 5, 10 e $15 \mu \mathrm{L}$ de clorpirifós/placa. (A) 5 dias de cultivo e (B) 10 dias de cultivo....................................120 Cromatograma obtido por CG-EM das extrações do micélio (cor preta) e do caldo enzimático (cor vermelha) com o fungo A. sydowii CBMAI 935 na ausência do pesticida clorpirifós (reação controle) durante 10 dias

.126

Cromatogramas obtidos por CG-EM das extrações das células úmidas e do caldo enzimático do fungo A. sydowii CBMAI 935 na ausência do pesticida clorpirifós (reação controle), durante 10 dias. (a) extração do caldo enzimático e (b) extração das células úmidas

Cromatograma obtido por CG-EM das reações de controle do fungo A. sydowii CBMAI 935 e o pesticida clorpirifós, durante 10 dias.....

Cromatograma obtido por CG-EM da reação de controle abiótico do pesticida clorpirifós na ausência do fungo A. sydowii CBMAI 935 durante 10 dias...........................................................128

Cromatograma obtido por CG-EM do padrão analítico do pesticida clorpirifós............................129 Espectro de massas obtido por CG-EM $(70 \mathrm{eV})$ para o padrão analítico do pesticida clorpirifós.

Cromatograma obtido por CG-EM das extrações do micélio e do caldo enzimático do fungo $A$. sydowii CBMAI 935 na presença do pesticida comercial clorpirifós durante 10

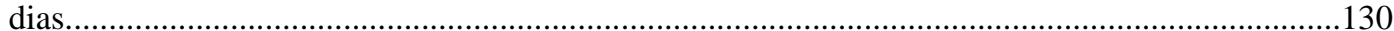

Cromatogramas obtidos por CG-EM das extrações do micélio e do caldo enzimático do fungo $A$. sydowii CBMAI 935 na presença do pesticida comercial clorpirifós durante 10 dias. (a) Extração do caldo enzimático e (b) Extração do micélio. .130

Cromatograma obtido por CG-EM das extrações do caldo enzimático do fungo A. sydowii CBMAI 935 na presença do pesticida comercial clorpirifós durante 10 dias.

Cromatograma obtido por CG-EM das extrações do micélio do fungo A. sydowii CBMAI 935 na presença do pesticida comercial clorpirifós durante 10 dias. 
Figura 59.

Figura 60.

Figura 61.

Figura 62.

Figura 63.

Figura 64. Figura 65.

Figura 66.

Figura 67.

Figura 68. Figura 69.

Figura 70.

Figura 71.

Figura 72.

Figura 73.

Figura 74.

Figura 75.

Figura 76.

Figura 77.

Figura 78.

Figura 79.

Figura 80.

Figura 81.
Cromatogramas obtidos por CG-EM das extrações do micélio e caldo enzimático do fungo $A$. sydowii CBMAI 935 na presença do pesticida clorpirifós, durante 10 dias

133

Cromatograma selecionado do pesticida comercial clorpirifós obtido por CG-EM das extrações do caldo enzimático do fungo A. sydowii CBMAI $935 \mathrm{em} 10$ dias de reação de biotransformação.....................................................................................................135 Espectro de massas obtido por CG-EM (70 eV) para o pesticida comercial clorpirifós das extrações do micélio do fungo A. sydowii CBMAI em 10 dias....................................................136 Cromatograma selecionado do metabólito 3,5,6-tricloro-2-piridinol obtido por CG-EM das extrações do micélio do fungo A. sydowii CBMAI 935 na presença do pesticida comercial clorpirifós durante 10 dias.

138

Espectro de massas obtido por CG-EM $(70 \mathrm{eV})$ para o metabólito 3,5,6-tricloro-2-piridinol frente a reação de biotransformação do pesticida comercial clorpirifós com o fungo A. sydowii CBMAI 935 durante 10 dias 139

Cromatograma obtido por CG-EM do padrão analítico do 3,5,6-tricloro-2-piridinol.

140

Espectro de massas obtido por CG-EM $(70 \mathrm{eV})$ para o padrão analítico do 3,5,6-tricloro-2piridinol..... 140

Cromatograma selecionado obtido por CG-EM do metabólito 2,3,5-tricloro-6-metoxipiridina das extrações do micélio do fungo A. sydowii CBMAI 935 na presença do pesticida comercial clorpirifós durante 10 dias.

141

Espectro de massas obtido por CG-EM $(70 \mathrm{eV})$ para o metabólito 2,3,5-tricloro-6-metoxipiridina das extrações do micélio do fungo A. sydowii CBMAI 935 na presença do pesticida comercial clorpirifós durante 10 dias. 142 Cromatograma obtido por CG-EM do padrão sintético do 2,3,5-tricloro-6-metoxipiridina...........143 Espectro de massas obtido por CG-EM $(70 \mathrm{eV})$ do padrão sintético do 2,3,5-tricloro-6metoxipiridina. 143 Cromatograma selecionado obtido por CG-EM do metabólito 3,5,6-tricloro-1-metil-2-piridinona das extrações do micélio do fungo A. sydowii CBMAI 935 na presença do pesticida comercial clorpirifós durante 10 dias. 144 Espectro de massas obtido por CG-EM (70 eV) para o metabólito 3,5,6-tricloro-1-metil-2piridinona das extrações do micélio do fungo A. sydowii CBMAI 935 na presença do pesticida comercial clorpirifós durante 10 dias. 145

Cromatograma selecionado obtido por CG-EM do metabólito ditiofosfato de tetraetila das extrações do micélio do fungo A. sydowii CBMAI 935 na presença do pesticida comercial clorpirifós durante 10 dias. 146 Espectro de massas obtido por CG-EM $(70 \mathrm{eV})$ para o metabólito ditiofosfato de tetraetila das extrações do micélio do fungo A. sydowii CBMAI 935 na presença do pesticida comercial clorpirifós durante 10 dias.

147

Cromatograma selecionado do pesticida comercial clorpirifós obtido por CG-EM das extrações do caldo enzimático do fungo $A$. sydowii CBMAI $935 \mathrm{em} 20$ dias de reação de biotransformação.......................................................................................................... 148 Espectro de massas obtido por CG-EM (70 eV) para o pesticida comercial clorpirifós das extrações do micélio do fungo A. sydowii CBMAI em 20 dias...................................................149 Cromatograma selecionado do metabólito 3,5,6-tricloro-2-piridinol obtido por CG-EM das extrações do micélio do fungo A. sydowii CBMAI 935 na presença do pesticida comercial clorpirifós durante 20 dias.

149

Espectro de massas obtido por CG-EM $(70 \mathrm{eV})$ para o metabólito 3,5,6-tricloro-2-piridinol frente a reação de biotransformação do pesticida comercial clorpirifós com o fungo A. sydowii CBMAI 935 durante 20 dias

Cromatograma selecionado obtido por CG-EM do metabólito 2,3,5-tricloro-6-metoxipiridina das extrações do micélio do fungo A. sydowii CBMAI 935 na presença do pesticida comercial clorpirifós durante 20 dias.

Espectro de massas obtido por CG-EM (70 eV) para o metabólito 2,3,5-tricloro-6-metoxipiridina das extrações do micélio do fungo A. sydowii CBMAI 935 na presença do pesticida comercial clorpirifós durante 20 dias.

151

Cromatograma selecionado obtido por CG-EM do metabólito 3,5,6-tricloro-1-metil-2-piridinona das extrações do micélio do fungo A. sydowii CBMAI 935 na presença do pesticida comercial clorpirifós durante 20 dias.

Espectro de massas obtido por CG-EM (70 eV) para o metabólito 3,5,6-tricloro-1-metil-2piridinona das extrações do micélio do fungo A. sydowii CBMAI 935 na presença do pesticida comercial clorpirifós durante 20 dias. 
Figura 82.

Figura 83.

Figura 84.

Figura 85.

Figura 86.

Figura 87.

Figura 88.

Figura 89.

Figura 90.

Figura 91.

Figura 92.

Figura 93.

Figura 94.

Figura 95.

Figura 96.

Figura 97.

Figura 98.

Figura 99.

Figura 100.

Figura 101.

Figura 102.

Figura 103.

Figura 104.

Figura 105.
Cromatograma selecionado obtido por CG-EM do metabólito ditiofosfato de tetraetila das extrações do micélio do fungo A. sydowii CBMAI 935 na presença do pesticida comercial clorpirifós durante 20 dias. 153

Espectro de massas obtido por CG-EM $(70 \mathrm{eV})$ para o metabólito ditiofosfato de tetraetila das extrações do micélio do fungo A. sydowii CBMAI 935 na presença do pesticida comercial clorpirifós durante 20 dias....

154

Cromatogramas obtidos por CG-EM das extrações do micélio (cor preta) e do caldo enzimático (cor vermelha) com o fungo A. sydowii CBMAI 935 na ausência do pesticida comercial metil paration (reação de controle biótico) durante 10 dias... .157 Cromatogramas obtidos por CG-EM das extrações do micélio e do caldo enzimático do fungo $A$. sydowii CBMAI 935 na ausência do pesticida comercial metil paration (reação de controle biótico) durante 10 dias. (a) Extração do caldo enzimático e (b) Extração do

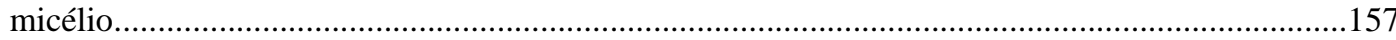
Cromatograma obtido por CG-EM da reação de controle biótico do fungo A. sydowii CBMAI 935 e o pesticida comercial metil paration durante 10 dias.................................................................158 Cromatograma obtido por CG-EM da reação de controle abiótico do pesticida comercial metil paration na ausência do fungo A. sydowii CBMAI 935 durante 10 dias.......................................159 Cromatogramas selecionados e obtidos por CG-EM da reação de controle abiótico do pesticida comercial metil paration na ausência do fungo A. sydowii CBMAI 935 durante 10

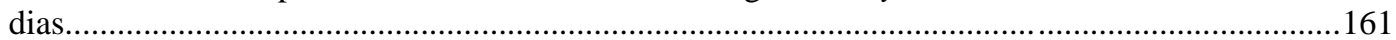

Cromatograma obtido por CG-EM do padrão analítico do pesticida metil paration......................162 Espectro de massas obtido por CG-EM $(70 \mathrm{eV})$ para o padrão analítico do metil paration...........162 Cromatograma obtido por CG-EM das extrações do micélio e do caldo enzimático do fungo $A$. sydowii CBMAI 935 na presença do pesticida comercial metil paration durante 10

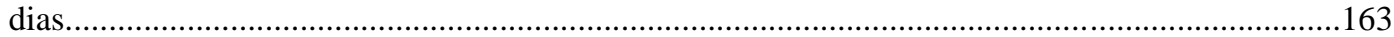
Cromatogramas obtidos por CG-EM das extrações do micélio e do caldo enzimático do fungo $A$. sydowii CBMAI 935 na presença do pesticida comercial metil paration durante 10 dias. (a) Extração do caldo enzimático e (b) Extração do micélio.............................................................163 Cromatograma obtido por CG-EM das extrações do caldo enzimático do fungo A. sydowii CBMAI 935 na presença do pesticida comercial metil paration durante 10 dias.......................................164 Cromatograma obtido por CG-EM das extrações do micélio do fungo A. sydowii CBMAI 935 na presença do pesticida comercial metil paration, durante 10 dias................................................165 Cromatograma selecionado do pesticida comercial metil paration obtido por CG-EM das extrações do caldo enzimático do A. sydowii CBMAI 935 em 10 dias de reação de biotransformação..........................................................................................................167 Espectro de massas obtido por CG-EM $(70 \mathrm{eV})$ para o pesticida comercial metil paration das extrações do caldo enzimático do A. sydowii CBMAI 935 em 10 dias.........................................167 Cromatograma selecionado do pesticida comercial metil paration obtido por CG-EM das extrações do micélio do A. sydowii CBMAI $935 \mathrm{em} 10$ dias de reação de biotransformação.............................................................................................................. 168 Espectro de massas obtido por CG-EM $(70 \mathrm{eV})$ para o pesticida comercial metil paration nas extrações do micélio do A. sydowii CBMAI 935 em 10 dias de reação de

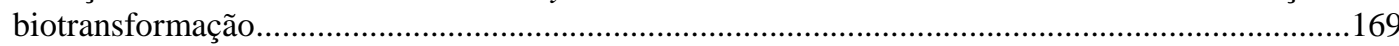
Cromatograma selecionado para o metabólito metil paraoxon obtido por CG-EM das extrações do micélio do A. sydowii CBMAI 935 em 10 dias de reação de biotransformação..............................170 Espectro de massas obtido por CG-EM $(70 \mathrm{eV})$ para o metabólito metil paraoxon nas extrações do micélio do A. sydowii CBMAI em 10 dias...............................................................................170 Cromatograma selecionado do metabólito $O$-(4-nitrofenil)fosforotioato de $O, S$-dimetila obtido por CG-EM das extrações do micélio do A. sydowii CBMAI 935 em 10 dias de reação de biotransformação.

Espectro de massas obtido em CG-EM $(70 \mathrm{eV})$ para o metabólito $O$-(4-nitrofenil)fosforotioato de $O, S$-dimetila nas extrações do micélio do A. sydowii CBMAI em 10 dias....................................172 Cromatograma selecionado do metabólito 4-nitrofenol obtido por CG-EM das extrações do caldo enzimático do A. sydowii CBMAI 935 na presença do pesticida comercial metil paration durante 10 dias.

Espectro de massas obtido por CG-EM $(70 \mathrm{eV})$ para o metabólito 4-nitrofenol das extrações do caldo enzimático do A. sydowii CBMAI 935 na presença do pesticida comercial metil paration durante 10 dias.

Cromatograma selecionado do metabólito 4-nitrofenol obtido por CG-EM das extrações do micélio do A. sydowii CBMAI 935 na presença do pesticida comercial metil paration durante 10 
dias

Figura 106.

Figura 107.

Espectro de massas obtido por CG-EM $(70 \mathrm{eV})$ para o metabólito 4-nitrofenol das extrações do micélio do A. sydowii CBMAI 935 na presença do pesticida comercial metil paration durante 10 dias.

Figura 108.

Cromatograma obtido por CG-EM do padrão analítico do 4-nitrofenol.

.175

Espectro de massas obtido por CG-EM $(70 \mathrm{eV})$ para o padrão analítico do 4nitrofenol

Figura 109. Espectro de massas obtido por CG-EM $(70 \mathrm{eV})$ para o metabólito 4-nitrofenol das extrações do micélio do A. sydowii CBMAI 935 na presença do pesticida comercial metil paration, durante 10 dias.

Figura 110. Cromatograma selecionado do metabólito 1-metoxi-4-nitrobenzeno obtido por CG-EM das extrações do caldo enzimático do fungo A. sydowii CBMAI 935 na presença do pesticida comercial metil paration durante 10 dias.

Figura 111.

Figura 112. Cromatograma selecionado do metabólito 1-metoxi-4-nitrobenzeno obtido por CG-EM das extrações do caldo enzimático do fungo A. sydowii CBMAI 935 na presença do pesticida comercial metil paration durante 10 dias.

Espectro de massas obtido por CG-EM (70 eV) para o metabólito 1-metoxi-4-nitrobenzeno das extrações do caldo enzimático do A. sydowii CBMAI 935 na presença do pesticida comercial metil paration durante 10 dias

Figura 113.

Cromatograma selecionado do metabólito $O, O, S$-fosforotioato de trimetila obtido por CG-EM das extrações do caldo enzimático do A. sydowii CBMAI 935 em 10 dias de reação de biotransformação do pesticida comercial metil paration.............................................................178

Figura 114. Espectro de massas obtido por CG-EM $(70 \mathrm{eV})$ para o metabólito $O, O, S$-fosforotioato de trimetila nas extrações do caldo enzimático do A. sydowii CBMAI em 10 dias do pesticida comercial meti paration.

Figura 115.

Figura 116. biotransformação do pesticida comercial metil paration.........179 Espectro de massas obtido em CG-EM $(70 \mathrm{eV})$ para o metabólito $O, O, S$-fosforotioato de trimetila nas extrações do caldo enzimático do A. sydowii CBMAI em 10 dias do pesticida comercial metil paration

Figura 117. Cromatogramas obtidos por CG-EM das extrações do micélio (cor preta) e do caldo enzimático (cor vermelha) com o fungo A. sydowii CBMAI 935 na ausência do pesticida comercial profenofós (reação de controle biótico) durante 10 dias.

Figura 118.

Figura 119. Cromatogramas obtidos por CG-EM das extrações do micélio e do caldo enzimático do fungo $A$. sydowii CBMAI 935 na ausência do pesticida comercial profenofós (reação de controle biótico) durante 10 dias. (a) Extração do caldo enzimático e (b) Extração do micélio.

Cromatograma obtido por CG-EM da reação de controle biótico do fungo A. sydowii CBMAI 935 e o pesticida comercial profenofós durante 10 dias

Figura 120.

Figura 121. Figura 122.

Figura 123.

Figura 124. Cromatograma obtido por CG-EM da reação de controle abiótico do pesticida comercial profenofós na ausência do fungo A. sydowii CBMAI 935 durante 10 dias. 185 Cromatograma obtido por CG-EM do padrão analítico do pesticida profenofós..........................,186 Espectros de massas obtido por CG-EM (70 eV) (a) para o padrão analítico do profenofós e (b) para o metabólito 4-bromo-2-clorofenol

Cromatograma obtido por CG-EM das extrações do micélio e do caldo enzimático do fungo $A$. sydowii CBMAI 935 na presença do pesticida comercial profenofós durante 10 dias

Cromatogramas obtidos por CG-EM das extrações do micélio e do caldo enzimático do fungo $A$. sydowii CBMAI 935 na presença do pesticida comercial profenofós durante 10 dias. (a) Extração do caldo enzimático e (b) Extração do micélio. 188

Figura 125. Cromatograma obtido por CG-EM das extrações do caldo enzimático do fungo A. sydowii CBMAI 935 na presença do pesticida comercial profenofós durante 10 dias............................................189

Figura 126. Cromatograma obtido por CG-EM das extrações do micélio do fungo A. sydowii CBMAI 935 na presença do pesticida comercial profenofós durante 10 dias......................................................190

Figura 127. Cromatograma selecionado do pesticida comercial profenofós, obtido por CG-EM das extrações do caldo enzimático do fungo A. sydowii CBMAI $935 \mathrm{em} 10$ dias de reação de

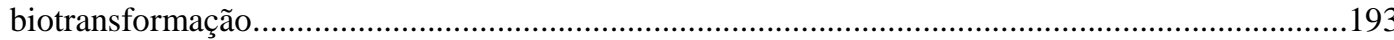

Figura 128. Espectro de massas obtido por CG-EM $(70 \mathrm{eV})$ para o pesticida comercial profenofós das extrações do caldo enzimático do fungo A. sydowii CBMAI 935 em 10 dias de reação de biotransformação 
Figura 129. Cromatograma selecionado do pesticida comercial profenofós obtido por CG-EM das extrações do micélio do fungo $A$. sydowii CBMAI $935 \mathrm{em} 10$ dias de reação de biotransformação........................................................................................................... 194

Figura 130. Espectro de massas obtido por CG-EM $(70 \mathrm{eV})$ para o pesticida comercial profenofós nas extrações do micélio do fungo A. sydowii CBMAI 935 em 10 dias de reação de

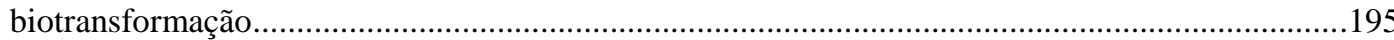

Figura 131. Cromatograma selecionado do metabólito 4-bromo-2-clorofenol obtido por CG-EM das extrações do caldo enzimático do fungo A. sydowii CBMAI 935 na presença do pesticida comercial profenofós durante 10 dias de reação de biotransformação.

Figura 132. Espectro de massas obtido por CG-EM (70 eV) para o metabólito 4-bromo-2-clorofenol das extrações do caldo enzimático do fungo A. sydowii CBMAI 935 na presença do pesticida comercial profenofós durante 10 dias de reação de biotransformação.

Figura 133. Espectro de massas obtido por CG-EM (70 eV) para o metabólito 4-bromo-2-clorofenol das extrações do micélio do fungo A. sydowii CBMAI 935 na presença do pesticida comercial profenofós durante 10 dias de reação de biotransformação. .198

Figura 134. Cromatograma selecionado do metabólito 4-bromo-2-cloro-1-metoxibenzeno obtido por CG-EM das extrações do caldo enzimático do fungo A. sydowii CBMAI 935 na presença do pesticida comercial profenofós durante 10 dias de reação de biotransformação...... 199

Figura 135. Espectro de massas obtido em CG-EM (70 eV) para o metabólito 4-bromo-2-cloro-1metoxibenzeno das extrações do micélio do fungo A. sydowii CBMAI 935 na presença do pesticida comercial profenofós durante 10 dias de reação de biotranformação. ..200

Figura 136. Cromatograma selecionado do metabólito fosforotioato de $O, O$-dietil- $S$-propila obtido por CG-EM das extrações do caldo enzimático do fungo A. sydowii CBMAI 935 com o pesticida comercial profenofós em 10 dias de reação de biotransformação.

Figura 137. Espectro de massas obtido por CG-EM (70 eV) para o metabólito fosforotioato de $O, O$-dietil- $S$ propila nas extrações do caldo enzimático do fungo A. sydowii CBMAI com o pesticida comercial profenofós em 10 dias de reação de biotransformação.

Figura 138. Cromatograma selecionado do piretroide cipermetrina obtido por CG-EM das extrações do micélio do fungo A. sydowii CBMAI 935 com o padrão comercial do pesticida profenofós em 10 dias de reação de biotransformação...... .203

Figura 139. $\quad$ Espectro de massas obtido por CG-EM $(70 \mathrm{eV})$ para o piretroide cipermetrina nas extrações do micélio do fungo A. sydowii CBMAI com o pesticida comercial profenofós em 10 dias de reação de biotransformação.

Figura 140. Cromatograma obtido por CG-EM do padrão analítico do piretroide cipermetrina...... .204

Figura 141.

Figura 142. Espectro de massas obtido por CG-EM $(70 \mathrm{eV})$ para o padrão analítico do piretroide cipermetrina .204

Cromatograma selecionado do metabólito 3-fenoxibenzaldeído obtido por CG-EM das extrações do micélio do fungo A. sydowii CBMAI 935 com o pesticida comercial profenofós em 10 dias de reação de biotransformação.. .205

Figura 143.

Figura 144. Espectro de massas obtido por CG-EM $(70 \mathrm{eV})$ para o metabólito 3-fenoxibenzaldeído nas extrações do micélio do fungo A. sydowii CBMAI com o pesticida comercial profenofós em 10 dias de reação de biotransformação. .205 Cromatogramas obtidos por CG-EM das extrações do micélio (cor preta) e do caldo enzimático (cor vermelha) com o fungo A. sydowii CBMAI 935 na ausência do composto fenólico 3,5,6tricloro-2-piridinol (reação de controle biótico) durante 10 dias de reação de biotransformação.........................................................................................................209

Figura 145. Cromatogramas obtidos por CG-EM das extrações do micélio e do caldo enzimático do fungo $A$. sydowii CBMAI 935 na ausência do composto fenólico 3,5,6-tricloro-2-piridinol (reação de controle biótico) durante 10 dias. (a) Extração do caldo enzimático e (b) Extração do

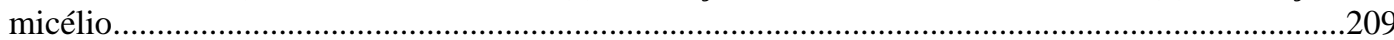

Figura 146. Cromatogramas obtidos por CG-EM da reação de controle biótico do fungo A. sydowii CBMAI 935 e o composto fenólico 3,5,6-tricloro-2-piridinol em 10 dias de reação de

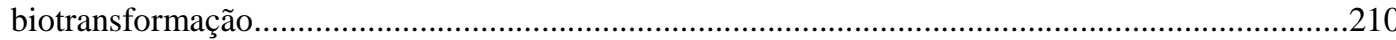

Figura 147. Cromatograma obtido por CG-EM da reação de controle abiótico do composto fenólico 3,5,6tricloro-2-piridinol na ausência do fungo A. sydowii CBMAI 935 durante 10 dias de reação de biotransformação.

Figura 148. Cromatograma obtido por CG-EM e selecionado do composto fenólico 3,5,6-tricloro-2-piridinol da extração do micélio do fungo $A$. sydowii CBMAI 935 durante 10 dias de reação de biotransformação.......................................................................................................212

Figura 149. Espectro de massas obtido por CG-EM (70 eV) para o composto fenólico 3,5,6-tricloro-2- 
piridinol.

Cromatograma obtido por CG-EM e selecionado do metabólito 2,3,5-tricloro-6-metoxipiridina das extrações do micélio do fungo A. sydowii CBMAI 935 na presença do composto fenólico 3,5,6tricloro-2-piridinol durante 10 dias de reação de biotransformação.

Figura 151.

Figura 152.

Figura 153.

Figura 154.

Figura 155.

Figura 156.

Figura 157.

Figura 158.

Figura 159.

Figura 160.

Figura 161.

Figura 162.

Figura 163.

Figura 164.

Figura 165.

Figura 166. Figura 167.

Figura 168.

Figura 169.

Figura 170.

Figura 171.
Espectro de massas obtido por CG-EM $(70 \mathrm{eV})$ para o metabólito 2,3,5-tricloro-6-metoxipiridina durante 10 dias de reação de biotransformação.

2014

Cromatogramas obtidos por CG-EM das extrações do micélio (cor preta) e do caldo enzimático (cor vermelha) com o fungo A. sydowii CBMAI 935 na ausência do composto fenólico 4-nitrofenol (reação de controle biótico) durante 10 dias de reação de biotransformação. 2017 Cromatogramas obtidos por CG-EM das extrações do micélio e do caldo enzimático do fungo $A$. sydowii CBMAI 935 na ausência do composto fenólico 4-nitrofenol (reação de controle biótico) durante 10 dias. (a) Extração do caldo enzimático e (b) Extração do micélio................................218 Cromatograma obtido por CG-EM da reação de controle biótico do fungo A. sydowii CBMAI 935 e o composto fenólico 4-nitrofenol em 10 dias de reação de biotransformação...............................219 Cromatograma obtido por CG-EM da reação de controle abiótico do composto fenólico 4nitrofenol na ausência do fungo A. sydowii CBMAI 935 durante 10 dias de reação de

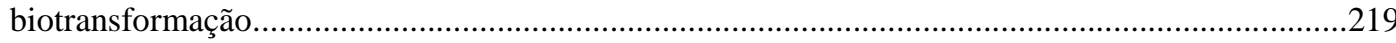
Ampliação do cromatograma do metabólito 1-metoxi-4-nitrobenzeno obtido por CG-EM das extrações do caldo enzimático do fungo A. sydowii CBMAI 935 na presença do composto fenólico 4-nitrofenol durante 10 dias de reação de biotransformação. ..220 Espectro de massas obtido em CG-EM (70 eV) para o metabólito 1-metoxi-4-nitrobenzeno das extrações do micélio do fungo A. sydowii CBMAI 935 na presença do composto fenólico 4nitrofenol durante 10 dias de reação de biotransformação

.221

Cromatogramas obtidos por CG-EM das extrações do micélio (cor preta) e do caldo enzimático (cor vermelha) com o fungo A. sydowii CBMAI 935 na ausência do composto fenólico 4-bromo-2clorofenol (reação de controle biótico) durante 10 dias de biotransformação.................................222 Cromatogramas obtidos por CG-EM das extrações do micélio e do caldo enzimático do fungo $A$. sydowii CBMAI 935 na ausência do composto fenólico 4-bromo-2-clorofenol (reação de controle biótico) durante 10 dias. (a) Extração do caldo enzimático e (b) Extração do

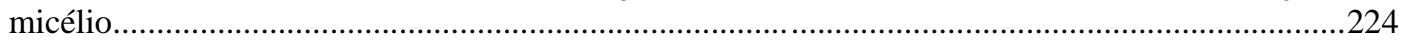
Cromatograma obtido por CG-EM da reação de controle biótico do fungo A. sydowii CBMAI 935 e o composto fenólico 4-bromo-2-clorofenol em 10 dias de reação de biotransformação..................225 Cromatograma obtido por CG-EM da reação de controle abiótico do composto fenólico 4-bromo-2clorofenol na ausência do fungo A. sydowii CBMAI 935 durante 10 dias de reação de

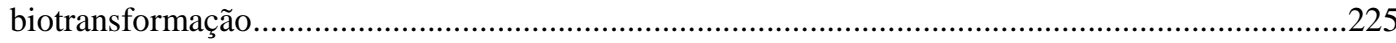
Cromatograma selecionado do composto fenólico 4-bromo-2-clorofenol obtido por CG-EM das extrações do micélio do A. sydowii CBMAI 935 durante 10 dias de reação de biotransformação......................................................................................................226 Espectro de massas obtido por CG-EM $(70 \mathrm{eV})$ para o composto fenólico 4-bromo-2-clorofenol das extrações do micélio do fungo $A$. sydowii CBMAI 935 durante 10 dias de reação de

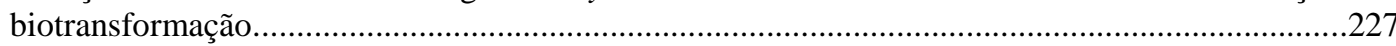
Ampliação do cromatograma do metabólito 4-bromo-2-cloro-1-metoxibenzeno obtido por CG-EM do caldo enzimático do fungo A. sydowii CBMAI 935 durante 10 dias de reação de biotransformação com o composto fenólico 4-bromo-2-clorofenol...............................................228 Espectro de massas obtido por CG-EM (70 eV) para o metabólito 4-bromo-2-cloro-1metoxibenzeno das extrações do micélio do A. sydowii CBMAI 935 durante 10 dias de reação de

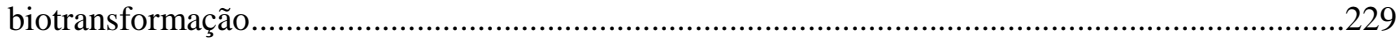
Estrutura química básica dos subtipos de flavonoides mais comuns...........................................232 Cromatogramas obtidos por CG-EM das extrações do micélio (cor preta) e do caldo enzimático (cor vermelha) com o fungo A. sydowii CBMAI 935 na ausência do flavonoide naringenina (reação de controle biótico) durante 10 dias.....

233

Cromatogramas obtidos por CG-EM das extrações do micélio e do caldo enzimático do fungo $A$. sydowii CBMAI 935 na ausência do flavonoide naringenina (reação de controle biótico) durante 10 dias. (a) Extração do caldo enzimático e (b) Extração do micélio...................................................234 Cromatograma obtido por CG-EM da reação de controle biótico do fungo A. sydowii CBMAI 935 e o flavonoide naringenina em 10 dias de reação de biotransformação............................................235 Ampliação do cromatograma obtido por CG-EM da reação de biotransformação do flavonoide naringenina pelo fungo A. sydowii CBMAI 935 em 10 dias de reação........................................235 Cromatograma obtido por CG-EM da reação de controle abiótico do flavonoide naringenina na ausência do fungo A. sydowii CBMAI 935 durante 10 dias. 
Figura 172. Cromatograma obtido por CLAE-UV da reação entre o padrão racêmico da naringenina e o fungo A. sydowii CBMAI 935 em 10 dias de reação. Com sinais nos tempos de retenção em 31, 145 e 34,123 minutos

Figura 173. Cromatograma obtido por CG-EM do metabólito 5,7-dimetoxi-2-(4-metoxifenil)cromen-4-ona isolado a partir das reações de biotransformação do flavonoide naringenina com o fungo A. sydowii CBMAI 935 durante 10 dias...

Figura 174. Espectro de massas obtido por CG-EM (70 eV) para o metabólito 5,7-dimetoxi-2-(4metoxifenil)cromen-4-ona isolado a partir das reações de biotransformação do flavonoide naringenina com o fungo A. sydowii CBMAI 935 durante 10 dias.

Figura 175. Cromatograma obtido por CLAE-UV do metabólito 5,7-dimetoxi-2-(4-metoxifenil)croman-4-ona (isolado) e o fungo A. sydowii CBMAI 935 em 10 dias de reação. Com sinais nos tempos de retenção em 27, 399 e 33, 258 minutos. .238

Figura 176.

Figura 177. Cromatogramas sobrepostos obtidos por CLAE-UV do metabólito 5,7-dimetoxi-2-(4metoxifenil)croman-4-ona (isolado) e naringenina com o fungo A. sydowii CBMAI 935 em 10 dias de reação. .238

Cromatograma obtido por CG-EM do metabólito (E)-3-(4-metoxifenil)-1-(2,4,6trimetoxifenil)prop-2-en-1-ona isolado a partir das reações de biotransformação do flavonoide naringenina com o fungo A. sydowii CBMAI 935 durante 10

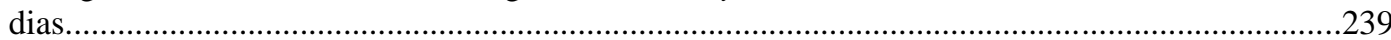

Figura 178. Espectro de massas obtido por CG-EM (70 eV) para o metabólito (E)-3-(4-metoxifenil)-1-(2,4,6trimetoxifenil)prop-2-en-1-ona isolado a partir das reações de biotransformação do flavonoide naringenina com o fungo A. sydowii CBMAI 935 durante 10

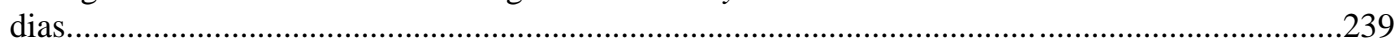

Figura 179. Cromatograma obtido por CLAE-UV do metabólito (E)-3-(4-metoxifenil)-1-(2,4,6trimetoxifenil)prop-2-en-1-ona (isolado) com o fungo A. sydowii CBMAI 935 em 10 dias de reação. Com sinal no tempo de retenção em $30, \quad 062$

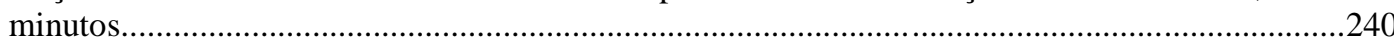

Figura 180. Cromatograma obtido por CG-EM da reação de controle biótico do fungo A. sydowii CBMAI 935 e o composto fenólico pentaclorofenol em 10 dias de reação de

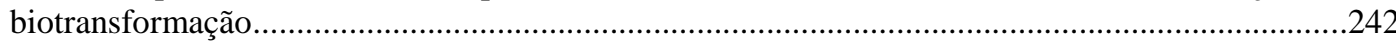

Figura 181. Ampliações dos Cromatograma selecionado e espectros de massas obtidos por CG-EM dos metabólitos gerados a partir das reações de biotransformação do composto fenólico pentaclorofenol com o fungo A. sydowii CBMAI 935 durante 10

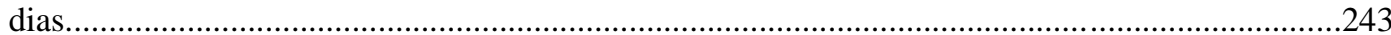

Figura 182. Cromatograma obtido por CG-EM do padrão analítico do composto fenólico pentaclorofenol...................................................................................................................245

Figura 183. Espectro de massas obtido por CG-EM (70 eV) para o padrão analítico do composto fenólico

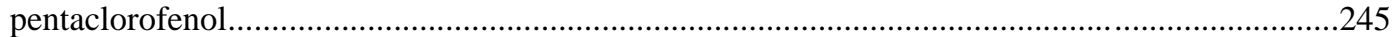

Figura 184. Cromatograma obtido por CG-EM do padrão analítico do composto fenólico 2,3,4,6tetraclorofenol............................................................................................................246

Figura 185. Espectro de massas obtido por CG-EM (70 eV) para o padrão analítico do composto fenólico

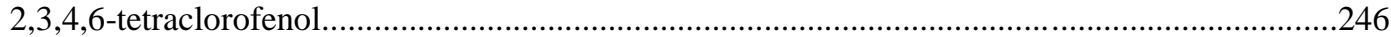

Figura 186. Cromatograma obtido por CG-EM do padrão sintético do composto 1,2,3,4,5-pentaclorofenol-6metoxibenzeno.

Figura 187. Espectro de massas obtido por CG-EM (70 eV) para o padrão sintético do composto 1,2,3,4,5pentaclorofenol-6-metoxibenzeno. .247

Figura 188. Cromatograma obtido por CG-EM da reação de controle biótico do fungo A. sydowii CBMAI 935 e o composto fenólico hidroxibenzeno em 10 dias de reação de

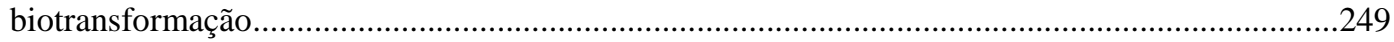

Figura 189. Cromatograma obtido por CG-EM do padrão analítico do composto fenólico hidroxibenzeno..........................................................................................................250

Figura 190. Espectro de massas obtido por CG-EM $(70 \mathrm{eV})$ para o padrão analítico do composto fenólico

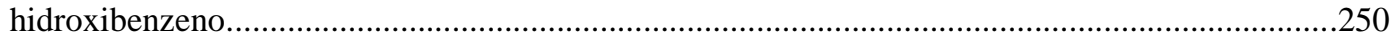

Figura 191. Cromatograma obtido por CG-EM do padrão sintético do composto

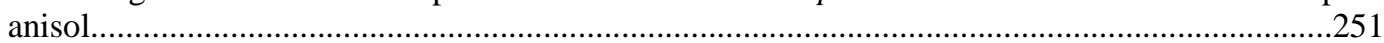

Figura 192. Espectro de massas obtido por CG-EM (70 eV) para o padrão sintético do composto

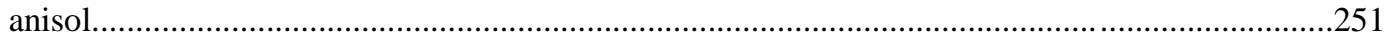

Figura 193. Cromatograma obtido por CG-EM da reação de controle biótico do fungo A. sydowii CBMAI 935 e o composto fenólico 2-clorofenol em 10 dias de reação de

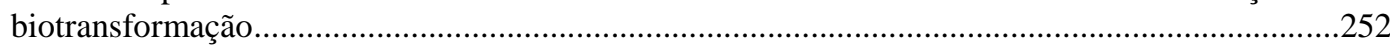


Figura 194. Cromatograma obtido por CG-EM do padrão analítico do composto fenólico 2clorofenol.............................................................................................................253

Figura 195. Espectro de massas obtido por CG-EM $(70 \mathrm{eV})$ para o padrão analítico do composto fenólico 2 clorofenol. .253

Figura 196. Cromatograma obtido por CG-EM do padrão sintético do composto 1-cloro-2-

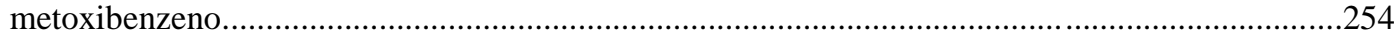

Figura 197. Espectro de massas obtido por CG-EM (70 eV) para o padrão sintético do composto 1-cloro-2metoxibenzeno......................................................................................................254

Figura 198. Cromatograma obtido por CG-EM da reação de controle biótico do fungo A. sydowii CBMAI 935 e o composto fenólico 2-cloro-5-hidroxipiridina em 10 dias de reação de

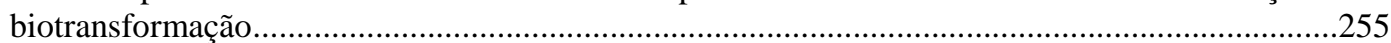

Figura 199. Cromatograma obtido por CG-EM do padrão analítico do composto fenólico 2-cloro-5-

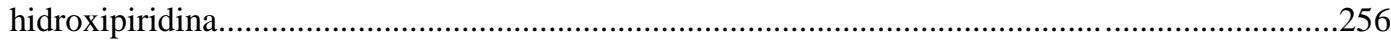

Figura 200. Espectro de massas obtido por CG-EM $(70 \mathrm{eV})$ para o padrão analítico do composto fenólico 2cloro-5-hidroxipiridina..................................................................................................256

Figura 201. Cromatograma obtido por CG-EM do padrão sintético do composto 2-cloro-5-

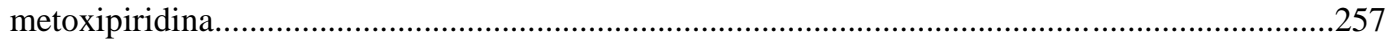

Figura 202. Espectro de massas obtido por CG-EM (70 eV) para o padrão sintético do composto 2-cloro-5-

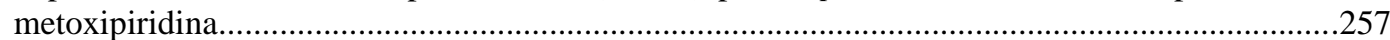

Figura 203. Cromatograma obtido por CG-EM da reação de controle biótico do fungo A. sydowii CBMAI 935 e o composto fenólico 4-(4-hidroxifenil)ciclo-hexanona em 10 dias de reação de biotransformação.................................................................................................258

Figura 204. Cromatograma obtido por CG-EM do padrão analítico do composto fenólico 4-(4hidroxifenil)ciclo-hexanona.........................................................................................260

Figura 205. Espectro de massas obtido por CG-EM (70 eV) para o padrão analítico do composto fenólico 4-(4-

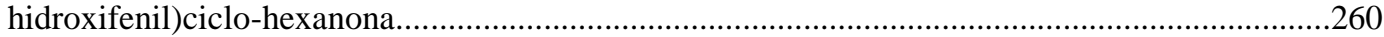

Figura 206. Cromatograma obtido por CG-EM do padrão sintético do composto fenólico 4-(4-hidroxiciclohexil) fenol

Figura 207. Espectro de massas obtido por CG-EM (70 eV) para o padrão sintético do composto fenólico 4-(4hidroxiciclo-hexil) fenol. 


\section{LISTA DE ESQUEMAS}

Esquema 1. Proposta de reações e metabólitos de biotransformação de fase I e de faseII do pesticida comercial clorpirifós pelo fungo A. sydowii CBMAI 935 durante 10 dias.

Esquema 2. Proposta de fragmentação para pesticida comercial

Esquema 3. Proposta de fragmentação para o metabólito 3,5,6-tricloro-2piridinol............................................................................................... 139

Esquema 4. Proposta de fragmentação para o metabólito 2,3,5-tricloro-6metoxipiridina......................................................................................... 143

Esquema 5. Proposta de fragmentação para o metabólito 3,5,6-tricloro-1-metil-2-

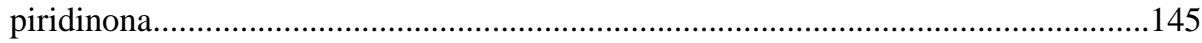

Esquema 6. Proposta de fragmentação para o metabólito ditilfosfato de

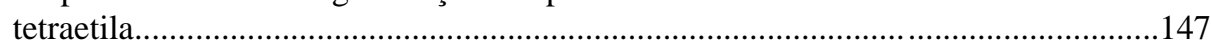

Esquema 7. Proposta de mecanismos enzimáticos de enzimas fosfotriesterases e $O$ metiltransferases durante 10, 20 e 30 dias de reação de biotransformação do pesticida comercial clorpirifós com o fungo de ambiente marinho A. sydowii CBMAI

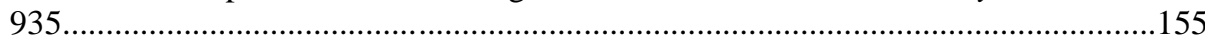

Esquema 8. Proposta de reações e metabólitos de biotransformação de fase I e de faselI do pesticida comercial metil paration pelo fungo A. sydowii CBMAI 935 durante 10 dias.

Esquema 9. Proposta de fragmentação para o pesticida comercial metil

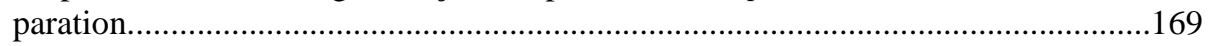

$\begin{array}{ll}\text { Esquema 10. } & \text { Proposta de fragmentação para o metabólito metil paraoxon..................................171 } \\ \text { Esquema 11. } & \text { Proposta de fragmentação para o 4-nitrofenol...................................................176 }\end{array}$

Esquema 12. Proposta de mecanismos enzimáticos de enzimas fosfotriesterases e $O$ metiltransferases durante 10, 20 e 30 dias de reação de biotransformação do pesticida comercial metil paration com o fungo de ambiente marinho A. sydowii CBMAI

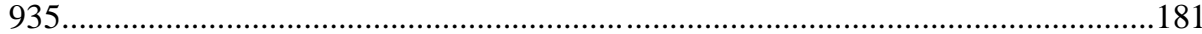

Esquema 13. Proposta de reações e metabólitos de biotransformação de fase $I$ e de fase II do pesticida comercial profenofós pelo fungo A. sydowii CBMAI 935 durante 10 dias.

Esquema 14. Possível rota de biodegradação da ciepermetrina por microrganismos....................192

Esquema 15.

Esquema 16.

Esquema 17.

Esquema 18.

Esquema 19.

Proposta de fragmentação para o profenofós................................................................196

Proposta de fragmentação para o 4-bromo-2-clorofenol............................................199

Proposta de fragmentação para o 4-bromo-2-cloro-1-metoxibenzeno......................200

Proposta de fragmentação para o metabólito $O, O$-dietil- $S$-propila............................202

Proposta de mecanismos enzimáticos de enzimas fosfotriesterases e $O$ metiltransferases durante 10, 20 e 30 dias de reação de biotransformação do pesticida comercial profenofós com o fungo de ambiente marinho A. sydowii CBMAI

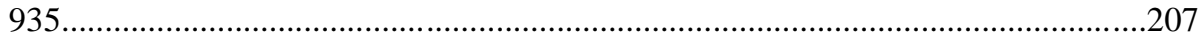

Esquema 20. Proposta de fragmentação para o composto 3,5,6-tricloro-2-piridinol......................213

Esquema 21. Proposta de fragmentação para o composto 2,3,5-tricloro-6-metoxipiridina..........214

Esquema 22. Proposta de mecanismo enzimático de metiltranferases durante a reação de biotransformação do composto fenólico 3,5,6-tricloro-2-piridinol pelo fungo $A$. sydowii CBMAI 935 durante 10, 20 e 30 dias de reação.

Esquema 23. Proposta de fragmentação para o composto 1-metoxi-4-nitrobenzeno.

Esquema 24. Proposta de mecanismo enzimático da reação de biotransformação do composto fenólico 4-nitrofenol pelo fungo A. sydowii CBMAI 935 durante 10, 20 e 30 dias de reação.

Esquema 25. Proposta de fragmentação do composto 4-bromo-2-clorofenol. 227

Esquema 26 Proposta de fragmentação do composto 4-bromo-2-cloro-1metoxibenzeno

Esquema 27. Proposta de mecanismo enzimático da reação de biotransformação do composto fenólico 4-bromo-2-clorofenol pelo fungo A. sydowii CBMAI 935 durante 10, 20 e 30 dias de reação.

Esquema 28. Proposta de reação de biotransformação do flavonoide naringenina pelo fungo $A$. 
sydowii CBMAI 935 durante 10 dias de reação

Esquema 29. Proposta de reação de biotransformação do pentaclorofenol pelo fungo A. sydowii CBMAI 935 durante 10 dias de reação..................................................................247

Esquema 30. Proposta de reação de biotransformação do composto fenólico hidroxibenzeno pelo fungo A. sydowii CBMAI 935 durante 10 dias de reação.

Esquema 31. Proposta de reação de biotransformação do composto fenólico 2-clorofenol pelo fungo A. sydowii CBMAI 935 durante 10 dias de reação.........................................254

Esquema 32. Proposta de reação de biotransformação do 2-cloro-5-hidroxipiridina pelo fungo $A$. sydowii CBMAI 935 durante 10 dias de reação.......................................................257

Esquema 33. Proposta de reação de biotransformação do 4-(4-hidroxifenil)ciclo-hexanona pelo fungo A. sydowii CBMAI 935 durante 10 dias de reação.........................................260 


\section{LISTA DE TABELAS}

Tabela 1. Pesticidas cuja ingestão diária teórica máxima ultrapassou a dose diária

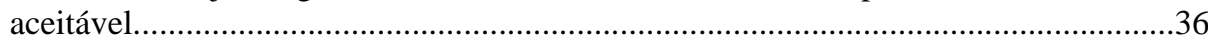

Tabela 2. Dados de tempos de retenção e íons moleculares dos POs e seus respectivos fenois, produtos de conjugação e demais compostos fenólicos por análise em CG-EM, (IE, 70

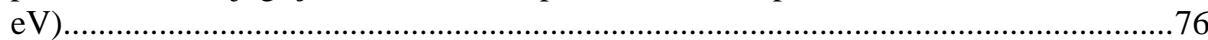

Tabela 3. Tempos de retenção e gradientes da fase móvel para as análises em CLAE-UV utilizando coluna C18 e coluna quiral para o flavonoide naringenina........................77

Tabela 4. Dados para obtenção da curva analítica para o clorpirifós e 3,5,6-tricloro-2-piridinol pela técnica de padronização externa......................................................................80

Tabela 5. Dados para obtenção da curva analítica para o metil paration e 4-nitrofenol pela

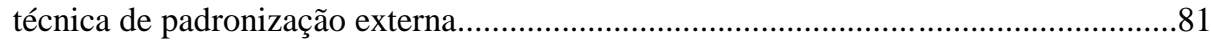

Tabela 6. Dados para obtenção da curva analítica para o profenofós e 4-bromo-2-clorofenol pela técnica de padronização externa......................................................................82

Tabela 7. Análise em duplicata com $2 \mu \mathrm{L}$ de clorpirifós para determinação da concentração do pesticida na amostra comercial de Lorsban 480 BR.................................................8

Tabela 8. Análise em duplicata com $2 \mu \mathrm{L}$ de metil paration para determinação da concentração do pesticida na amostra comercial de Folisuper 600 BR............................................89

Tabela 9. Análise em duplicata com $20 \mu \mathrm{L}$ de profenofós para determinação da concentração do pesticida na amostra comercial de Polytrin 400/40 CE...........................................89

Tabela 10. Compostos fenólicos que foram metilados, através de metodologia de síntese clássica e seus respectivos produtos de reação com seus devidos rendimentos........................91

Tabela 11. Concentrações de pesticidas organofosforados nas placas de Petri para avaliação do crescimento de fungos de ambiente marinho em meio de cultura sólido de malte $2 \%$ e Agar. .107

Tabela 12. Avaliação do halo de crescimento em meio de cultura sólido malte $2 \%$ e Agar do fungo de ambiente marinho $P$. raistrickii CBMAI 931 frente ao pesticida comercial clorpirifós nos volumes de $5 \mu \mathrm{L}$ de pesticida/100 $\mu \mathrm{L}$ de DMSO, $10 \mu \mathrm{L}$ de pesticida/200 $\mu \mathrm{L}$ de DMSO e $15 \mu \mathrm{L}$ de pesticida/ $300 \mu \mathrm{L}$ de DMSO durante 10 dias em condições padrões $\left(32^{\circ} \mathrm{C}, \mathrm{pH} 5,0\right)$...... 109

Tabela 13. Avaliação do halo de crescimento em meio de cultura sólido malte $2 \%$ e Agar do fungo de ambiente marinho Trichoderma sp. CBMAI 932 frente ao pesticida comercial clorpirifós nos volumes de $5 \mu \mathrm{L}$ de pesticida/100 $\mu \mathrm{L}$ de DMSO, $10 \mu \mathrm{L}$ de pesticida/200 $\mu \mathrm{L}$ de DMSO e $15 \mu \mathrm{L}$ de pesticida/ $300 \mu \mathrm{L}$ de DMSO durante 10 dias em condições padrões $\left(32^{\circ} \mathrm{C}, \mathrm{pH} 5,0\right)$...

Tabela 14. Avaliação do halo de crescimento em meio de cultura sólido malte $2 \%$ e Agar do fungo de ambiente marinho A. sydowii CBMAI 934 frente ao pesticida comercial clorpirifós nos volumes de $5 \mu \mathrm{L}$ de pesticida/100 $\mu \mathrm{L}$ de DMSO, $10 \mu \mathrm{L}$ de pesticida/200 $\mu \mathrm{L}$ de DMSO e $15 \mu \mathrm{L}$ de pesticida/ $300 \mu \mathrm{L}$ de DMSO durante 10 dias em condições padrões $\left(32^{\circ} \mathrm{C}, \mathrm{pH} 5,0\right)$......

Tabela 15. Avaliação do halo de crescimento em meio de cultura sólido malte $2 \%$ e Agar do fungo de ambiente marinho A. sydowii CBMAI 935 frente ao pesticida comercial clorpirifós nos volumes de $5 \mu \mathrm{L}$ de pesticida/100 $\mu \mathrm{L}$ de DMSO, $10 \mu \mathrm{L}$ de pesticida/200 $\mu \mathrm{L}$ de DMSO e $15 \mu \mathrm{L}$ de pesticida/ $300 \mu \mathrm{L}$ de DMSO durante 10 dias em condições padrões $\left(32^{\circ} \mathrm{C}, \mathrm{pH} 5,0\right)$.

Tabela 16. Avaliação do halo de crescimento em meio de cultura sólido malte $2 \%$ e Agar do fungo de ambiente marinho $P$. decaturense CBMAI 1234 frente ao pesticida comercial clorpirifós nos volumes de $5 \mu \mathrm{L}$ de pesticida/100 $\mu \mathrm{L}$ de DMSO, $10 \mu \mathrm{L}$ de pesticida/200 $\mu \mathrm{L}$ de DMSO e $15 \mu \mathrm{L}$ de pesticida/ $300 \mu \mathrm{L}$ de DMSO durante 10 dias em condições padrões $\left(32^{\circ} \mathrm{C}, \mathrm{pH} 5,0\right)$..

Tabela 17. Avaliação do halo de crescimento em meio de cultura sólido malte $2 \%$ e Agar do fungo de ambiente marinho $P$. raistrickii CBMAI 1235 frente ao pesticida comercial clorpirifós nos volumes de $5 \mu \mathrm{L}$ de pesticida/100 $\mu \mathrm{L}$ de DMSO, $10 \mu \mathrm{L}$ de pesticida/200 $\mu \mathrm{L}$ de DMSO e $15 \mu \mathrm{L}$ de pesticida/ $300 \mu \mathrm{L}$ de DMSO durante 10 dias em condições padrões $\left(32^{\circ} \mathrm{C}, \mathrm{pH} 5,0\right)$.. 
Tabela 18. Avaliação do halo de crescimento em meio de cultura sólido malte $2 \%$ e Agar do fungo de ambiente marinho A. sydowii CBMAI 1241 frente ao pesticida comercial clorpirifós nos volumes de $5 \mu \mathrm{L}$ de pesticida/100 $\mu \mathrm{L}$ de DMSO, $10 \mu \mathrm{L}$ de pesticida/200 $\mu \mathrm{L}$ de DMSO e $15 \mu \mathrm{L}$ de pesticida/ $300 \mu \mathrm{L}$ de DMSO durante 10 dias em condições padrões $\left(32^{\circ} \mathrm{C}, \mathrm{pH} 5,0\right)$ 


\section{LISTA DE ABREVIATURAS E SIGLAS}

ANVISA Agência Nacional de Vigilância Sanitária

AChE Acetilcolinesterase

ACh Acetilcolina

BCF 4-bromo-2-clorofenol

CYP Citocromo P450

CP Clorpirifós

CBEs Carboxilesterases

CBMAI Coleção Brasileira de Microrganismos de Meio Ambiente e Indústria

CG-EM Cromatografia a gás acoplada ao espectrômetro de massas

CONAMA Conselho Nacional de Meio Ambiente

CLAE Cromatografia líquida de alta eficiência

ChOMT Chalcona $O$-metiltranferase

DMSO Dimetilsulfóxido

DDT $\quad p$-Diclorodifeniltricloroetano

EPA Environmental Protection Agency (Agência de Proteção Ambiental)

FDA Food and Drug Administration

FAO Food and Agriculture Organization of the United Nations

(Organização para a Alimentação e Agricultura das Nações Unidas)

IUPAC International Union of Pure and Applied Chemistry

(União Internacional de Química Pura e Aplicada)

IDTM Ingestão diária teórica máxima

IOMT Isoflavona $O$-metiltransferase

LMR Limite máximo de resíduos

MP Metil paration

MPH Metil paration hidrolase

$\mathrm{OPH} \quad$ Organofosforado hidrolase

OMS Organização Mundial da Saúde

OPAA Organofosforado ácido anidrolase

PIB Produto interno bruto 
PON 1 Paraoxonase 1

PTEs Fosfotriesterases

PNF 4-Nitrofenol

PO Pesticidas organofosforados

PARA Programa de análise de resíduos de agrotóxicos

Renaciat Rede nacional de informação toxocológica

SAM $\quad S$-adenosil-L-metionina

SAH $\quad S$-adenosil-L-homocisteína

TCP 3,5,6-tricloro-2-piridinol 


\section{SUMÁRIO}

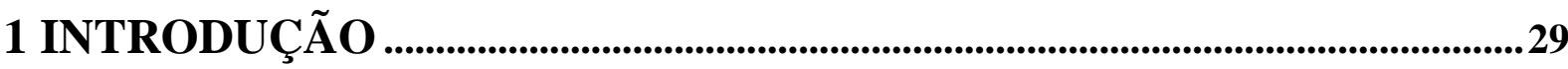

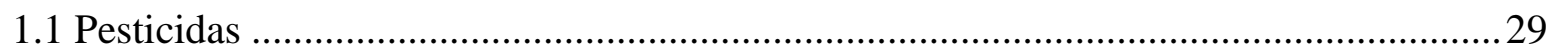

1.1.1 Aspectos gerais, histórico e comercialização de agrotóxicos no Brasil ....................29

1.1.2 Legislação, riscos à saúde e destino dos pesticidas no meio ambiente ……………....35

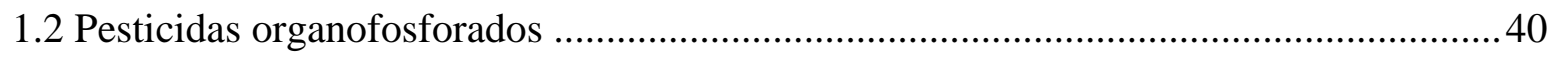

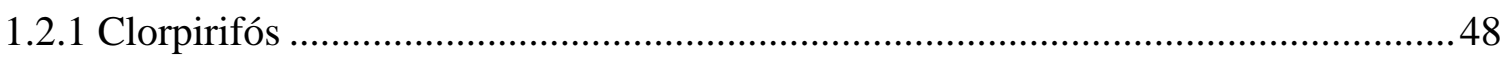

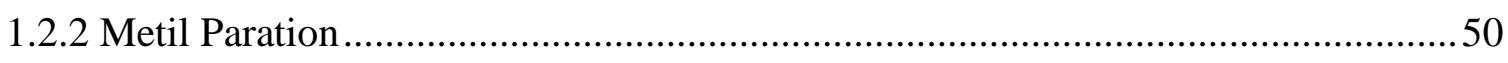

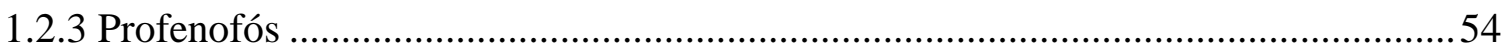

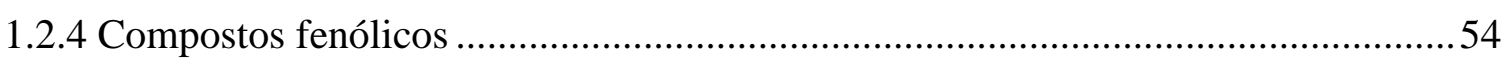

1.3 Fungos de ambiente marinho como fontes enzimáticas .................................................59

1.4 Biometilação de compostos fenólicos por microrganismos ...................................................

2 OBJETIVOS .....................................................................................................................73

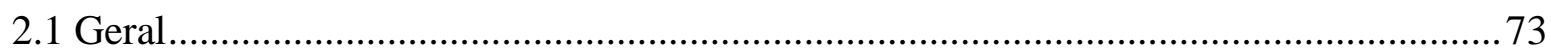

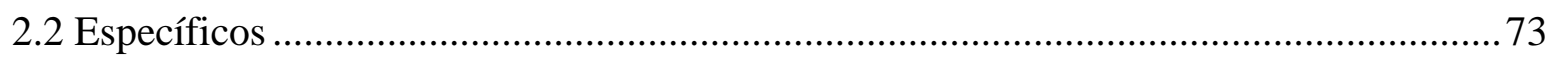

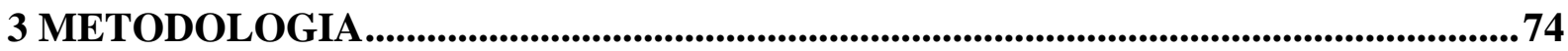

3.1 Pesticidas organofosforados, compostos fenólicos, reagentes de síntese de metilação,

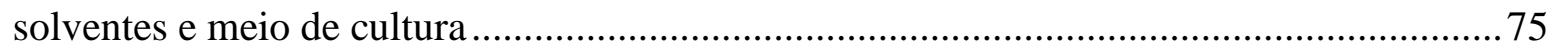

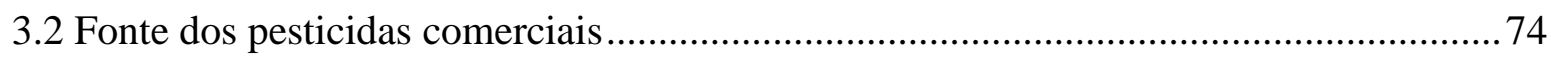

3.3 Equipamentos e curvas analíticas para quantificação dos compostos ............................ 75

3.3.1 Cromatografia a gás acoplada ao espectrômetro de massas (CG-EM) ………….......75

3.3.2 Cromatografia líquida de alta eficiência (CLAE-UV) ..............................................77

3.4 Curvas analíticas para a quantificação dos pesticidas e seus metabólitos pela técnica de

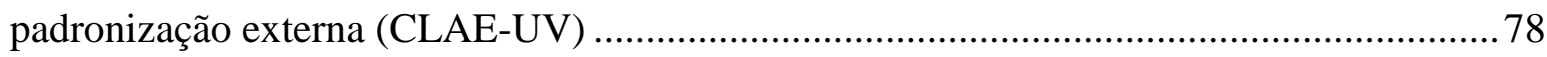

3.4.1 Preparo das soluções de estoque e solução de trabalho para obtenção das curvas

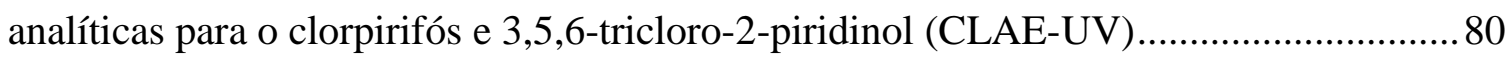

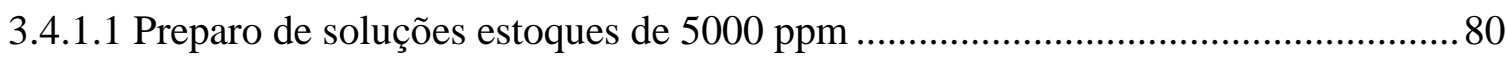

3.4.1.2 Preparo das soluções de trabalho para obtenção de curva analítica pela técnica de

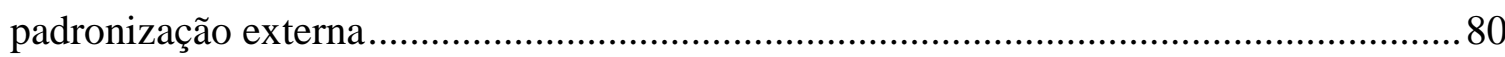

3.4.2 Preparo das soluções de estoque e solução de trabalho para obtenção das curvas

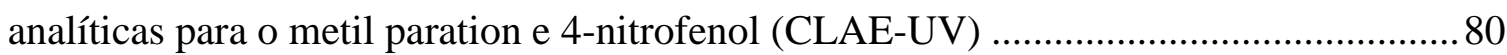

3.4.2.1 Preparo das soluções de estoques de 5000 ppm..................................................... 80

3.4.2.2 Preparo das soluções de trabalho para obtenção de curva analítica pela técnica de

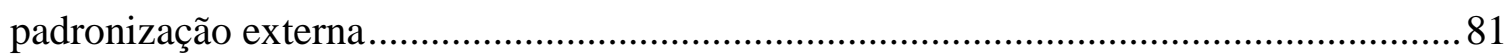

3.4.3 Preparo das soluções de estoque e solução de trabalho para obtenção das curvas analíticas para o profenofós e 4-bromo-2-clorofenol (CLAE-UV)...................................... 81

3.4.3.1 Preparo de soluções de estoques de $5000 \mathrm{mg} . \mathrm{L}^{-1}$................................................. 81

3.4.3.2 Preparo das soluções de trabalho para obtenção de curva analítica pela técnica de

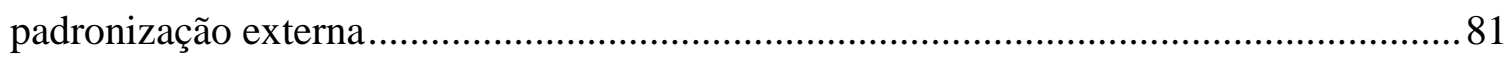

3.4.4 Curvas analíticas para a determinação da concentração do pesticida clorpirifós e seu metabólito 3,5,6-tricloro-2-piridinol através da técnica de padronização externa (CLAEUV). 
3.4.5 Curvas analíticas para a determinação da concentração do pesticida metil paration e seu metabólito 4-nitrofenol através da técnica de padronização externa (CLAE-UV)..... 84 3.4.6 Curvas analíticas para a determinação da concentração do pesticida profenofós e seu metabólito 4-bromo-2-clorofenol através da técnica de padronização externa (CLAEUV).

3.5 Avaliação da concentração dos ingredientes ativos dos pesticidas nas amostras comerciais .87

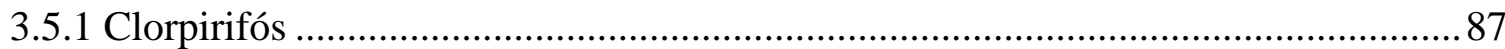

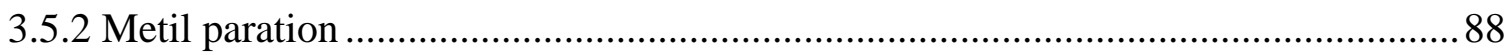

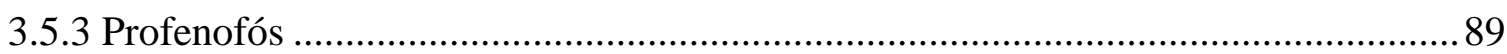

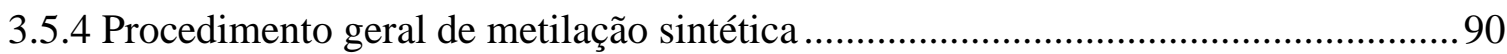

3.5.5 Cromatografia em coluna (CC) utilizando sílica gel............................................ 92

3.5.6 Espectroscopia de ressonância magnética nuclear (RMN) …................................ 92

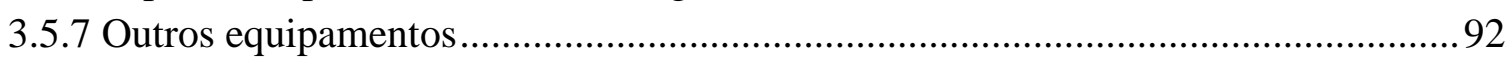

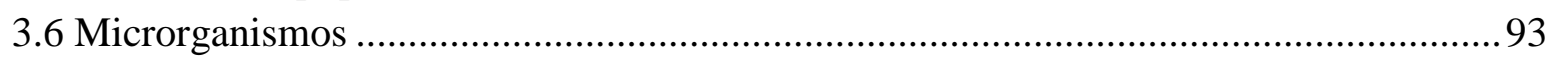

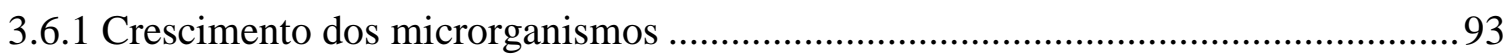

3.6.1.1 Sais necessários para o preparo da água do mar artificial....................................93

3.6.1.2 Composição e preparo do meio de cultura para o cultivo de microrganismos......93

3.6.2 Seleção dos fungos em meio de cultura sólido de malte 2\% e Agar frente aos pesticidas clorpirifós, metil paration e profenofós

3.6.3 Padronização dos inóculos dos fungos filamentosos pela técnica de suspenção de esporos para as reações com os pesticidas clorpirifós, metil paration e profenofós

3.6.3.1 Preparo dos tubos inclinados em meio de cultura sólido de malte 2\% e Agar para

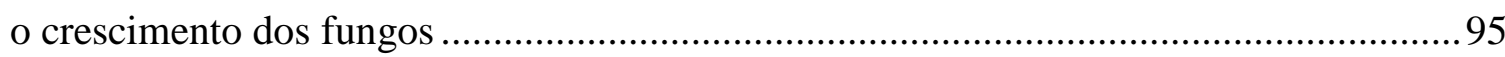

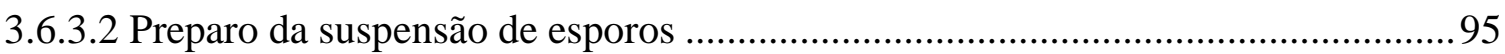

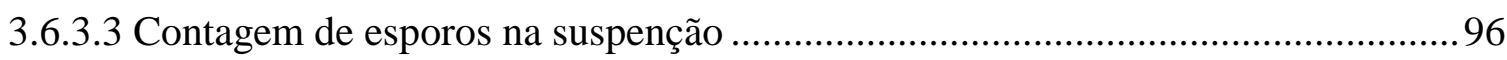

3.7 Reações de biotransformação de clorpirifós, metil paration e profenofós...................... 97

3.7.1 Reações de biotransformação entre os pesticidas comerciais clorpirifós, metil paration e profenofós pelo fungo de ambiente marinho A. sydowii CBMAI 935

3.7.1.1 Controle da reação para os pesticidas comerciais clorpirifós, metil paration e profenofós (estabilidade dos pesticidas)

3.7.1.2 Controle das reações para o fungo A. sydowii CBMAI 935 (ausência de pesticida)

3.7.2 Reação de biotransformação entre os compostos fenólicos 3,5,6-tricloro-2-piridinol, 4-nitrofenol, 4-bromo-2-clorofenol e demais compostos fenólicos com o fungo de ambiente marinho A. sydowii CBMAI 935

3.7.2.1 Controle das reações para os compostos fenólicos derivados dos pesticidas organofosforados (estabilidade dos compostos fenólicos).

3.7.2.2 Controle das reações para o fungo A. sydowii CBMAI 935 (ausência de compostos fenólicos)

3.7.3 Reação de biotransformação entre os compostos fenólicos (fenol, 2-clorofenol, 2cloro-5-hidroxipiridina, 4-(4-hidroxifenil)ciclo-hexanona, pentaclorofenol e naringenina) com o fungo de ambiente marinho A. sydowii CBMAI 
3.7.3.1 Controle das reações para os compostos fenólicos testados (estabilidade dos compostos fenólicos)

3.7.3.2 Controle das reações para o fungo A. sydowii CBMAI 935 (ausência de

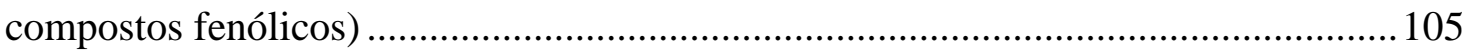

\section{RESULTADOS E DISCUSSÃO}

4.1 Seleção dos fungos em meio de cultura sólido de malte $2 \%$ e Ágar frente aos pesticidas comerciais clorpirifós, metil paration e profenofós 106

4.1.1 Clorpirifós 108

4.2 Reações de biotransformação dos pesticidas organofosforados e de compostos fenólicos em meio de cultura líquido de malte $2 \%$ em 10, 20 e 30 dias pelo fungo de ambiente marinho A. sydowii CBMAI 935

4.2.1 Reações de biotransformação do pesticida organofosforado clorpirifós em 10, 20 e 30 dias pelo fungo de ambiente marinho A. sydowii CBMAI 935. 125

4.2.1.1 Avaliação da biotransformação do clorpirifós em 10 dias de reação com o fungo A. sydowii CBMAI 935 125

4.2.1.2 Avaliação da biotransformação do clorpirifós em 20 dias de reação com o fungo A. sydowii CBMAI 935 148 4.2.1.3 Avaliação da biotransformação do clorpirifós em 30 dias de reação com o fungo A. sydowii CBMAI 935 153

4.2.2 Reações de biotransformação do pesticida organofosforado metil paration em 10, 20 e 30 dias pelo fungo de ambiente marinho A. sydowii CBMAI 935

4.2.2.1 Avaliação da biotransformação do metil paration em 10 dias de reação com o fungo de ambiente marinho A. sydowii CBMAI 935

4.2.2.2 Avaliação da biotransformação do metil paration em 20 e 30 dias de reação com o fungo A. sydowii CBMAI 935

4.2.3 Reações de biotransformação do pesticida organofosforado profenofós em 10, 20 e 30 dias pelo fungo de ambiente marinho A. sydowii CBMAI 935. 182

4.2.3.1 Avaliação da biotransformação do profenofós em 10 dias de reação com o fungo A. sydowii CBMAI 935 182

4.2.3.2 Avaliação da biotransformação do profenofós em 20 e 30 dias de reação com o fungo A. sydowii CBMAI 935.

4.2.4 Reações de biotransformação do composto fenólico 3,5,6-tricloro-2-piridinol em 10, 20 e 30 dias pelo fungo de ambiente marinho A. sydowii CBMAI 935 208

4.2.4.1 Avaliação da biotransformação do composto fenólico 3,5,6-tricloro-2-piridinol em 10 dias de reação com o fungo A. sydowii CBMAI 935 208

4.2.4.2 Avaliação da biotransformação do composto fenólico 3,5,6-tricloro-2-piridinol em 20 e 30 dias de reação com o fungo A. sydowii CBMAI 935

4.2.5 Reações de biotransformação do composto fenólico 4-nitrofenol em 10, 20 e 30 dias pelo fungo de ambiente marinho A. sydowii CBMAI 935

4.2.5.1 Avaliação da biotransformação do composto fenólico 4-nitrofenol em 10 dias de reação com o fungo A. sydowii CBMAI 935

4.2.5.2 Avaliação da biotransformação do composto fenólico 4-nitrofenol em 20 e 30 dias de reação com o fungo A. sydowii CBMAI 935 
4.2.6 Reações de biotransformação do composto fenólico 4-bromol-2-clorofenol em 10, 20 e 30 dias pelo fungo de ambiente marinho A. sydowii CBMAI 935

4.2.6.1 Avaliação da biotransformação do composto fenólico 4-bromo-2-clorofenol em 10 dias de reação com o fungo A. sydowii CBMAI 935

4.2.6.2 Avaliação da biotransformação do composto fenólico 4-bromo-2-clorofenol em 20 e 30 dias de reação com o fungo A. sydowii CBMAI 935 229

4.2.7 Avaliação da biotransformação dos compostos fenólicos em 10 dias de reação pelo fungo de ambiente marinho A. sydowii CBMAI 935

4.2.7.1 Avaliação da biotransformação do flavonoide naringenina em 10 dias de reação com o fungo A. sydowii CBMAI 935

4.2.7.2 Avaliação da biotransformação do composto fenólico pentaclorofenol em 10 dias de reação com o fungo A. sydowii CBMAI 935 .

4.2.7.3 Avaliação da biotransformação do composto fenólico hidroxibenzeno em 10 dias de reação com o fungo A. sydowii CBMAI 935 .............................................................. 248 4.2.7.4 Avaliação da biotransformação do composto fenólico 2-clorofenol em 10 dias de reação com o fungo A. sydowii CBMAI 935

4.2.7.5 Avaliação da biotransformação do composto fenólico 2-cloro-5-hidroxipiridina em 10 dias de reação com o fungo A. sydowii CBMAI 935

4.2.7.6 Avaliação da biotransformação do composto fenólico 4-(4-hidroxifenil)ciclohexanona em 10 dias de reação com o fungo A. sydowii CBMAI 935.

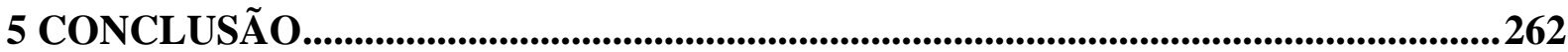

6 REFERÊNCIAS BIBLIOGRÁFICAS ......................................................................263

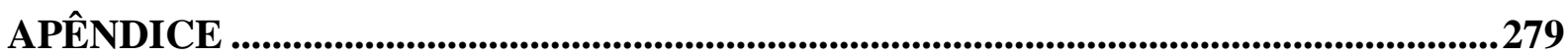




\section{INTRODUÇÃO}

\subsection{Pesticidas}

\subsubsection{Aspectos gerais, histórico e comercialização de agrotóxicos no Brasil}

O homem caracteriza-se pela sua capacidade de modificar e adaptar-se ao meio ambiente utilizando e transformando os recursos naturais disponíveis. Por muito tempo o homem nem sempre se preocupou com a conservação dos recursos naturais e, principalmente, com os tratamentos de resíduos gerados em suas atividades. ${ }^{1}$ Contudo, uma nova filosofia de trabalho e conscientização foi surgindo no final do século XX com os 12 princípios da Química Verde. ${ }^{1}$

O Brasil é um país fortemente agrícola e grande parte das riquezas geradas na sua economia (produto interno bruto) é proveniente da agricultura e pecuária. Porém, com a mecanização e expansão do agronegócio a produção extensiva de monoculturas tem propiciado o uso de toneladas de pesticidas que são anualmente lançados no meio ambiente. Além do acúmulo de pesticidas pelo seu uso indiscriminado, estes geram produtos de degradação que permanecem no solo ou são carreados para lençois freáticos. Ainda a toxicidade ao meio ambiente dos metabólitos produzidos pode ser superior ao pesticida de origem. $^{2}$

Os pesticidas são substâncias com propriedades letais que podem ser utilizados para eliminar ou controlar um organismo alvo, interferindo em seu processo vital e reprodutivo. Em relação a sua função, todos têm a mesma ação comum, que é bloquear os processos metabólicos vitais dos organismos para os quais são tóxicos. ${ }^{3}$ Outro termo ainda pode ser utilizado com esta finalidade, os agroquímicos, que no sentido geral, inclui todos os compostos químicos utilizados na agricultura, com a finalidade de eliminar, controlar, destruir e impedir a proliferação dos mais variados tipos de pragas. ${ }^{4}$ Desempenham um papel importante na agricultura, pois são eficazes no controle de pragas, promovendo um aumento na produtividade e qualidade dos alimentos. No entanto, enquanto os pesticidas podem ter um efeito benéfico sobre a produção agrícola, sua utilização indiscriminada pode provocar graves problemas ambientais e para a saúde humana, uma vez que são tóxicos também para as espécies não alvo. ${ }^{4,5}$ 
Segundo a Agência Nacional de Vigilância Sanitária (ANVISA), os pesticidas são todas as substâncias ou misturas que têm, como objetivo, impedir, destruir, repelir ou mitigar qualquer praga. São compostos bioativos capazes de prevenir, combater ou exterminar espécies que causam danos nas plantações durante as etapas de produção de alimentos. Esta definição também compreende as substâncias utilizadas no combate a insetos domésticos ou agentes preventivos à ação de vetores de doenças. ${ }^{6}$

Os pesticidas são um dos contaminantes mais perigosos ao meio ambiente, não apenas por sua toxicidade, mas também porque podem bioacumular, além de participar de processos químicos, físicos e biológicos. ${ }^{7}$ São compostos exógenos ao meio no qual se encontram e por esse motivo são considerados como substâncias xenobióticas. ${ }^{8}$

A classificação dessas substâncias obedece a dois critérios principais: classe química $e$ organismo alvo. ${ }^{9}$ De acordo com o organismo alvo, podem ser, por exemplo: inseticidas, acaricidas, fungicidas ou herbicidas. ${ }^{10}$ Em relação à estrutura química, eles podem pertencer à classe dos organoclorados, organofosforados, carbamatos, piretroides, entre outros. ${ }^{11}$

Em 2500 a.C., os sumérios utilizavam o enxofre no combate a insetos. O piretro, provenientes de flores secas de plantas do gênero Chrysanthemum cinerariaefolium era utilizado desde 400 a.C. para controlar piolhos. No século XIV, os chineses começaram a utilizar compostos de arsênio para controlar insetos. Eles também desenvolveram outros métodos de controle de pragas, incluindo o uso de ervas, óleos e cinzas, para tratar sementes e grãos armazenados, bem como compostos à base de mercúrio para combater piolhos e outras pragas. ${ }^{12}$ No entanto, os primeiros efeitos prejudiciais destas substâncias surgiram após o início da revolução industrial, com relatos públicos de intoxicação por arsênio, chumbo, organoclorados entre outros. ${ }^{13}$

A expansão da aplicação aérea de pesticidas ocorreu aproximadamente nas décadas de 30 e 40. Nessa época aproximadamente 30 pesticidas estavam em uso, por exemplo, os compostos orgânicos (pentaclorofenol e 4,6-dinitro-o-cresol) utilizados como herbicidas e o para-diclorodifeniltricloroetano-(DDT) utilizado como inseticida ${ }^{13}$ (Figura 1). 
Figura 1. Estruturas químicas de alguns dos pesticidas utilizados na agricultura nas décadas de 30 e 40 .<smiles>Clc1ccc(C(c2ccc(Cl)cc2)C(Cl)(Cl)Cl)cc1</smiles>

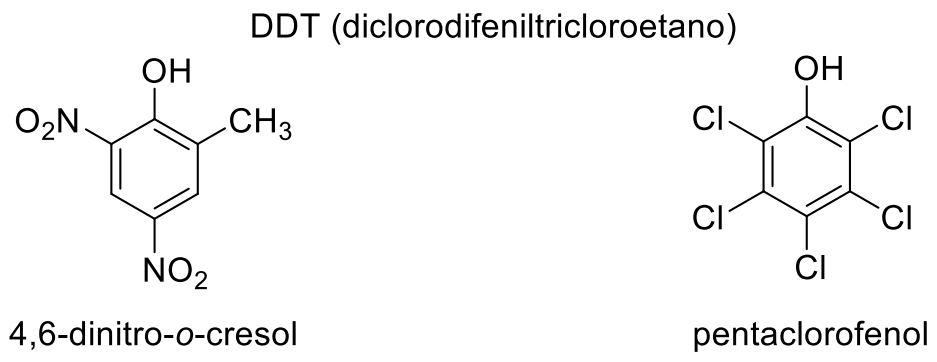

Fonte: Autoria própria.

Em 1939, o químico suíço Paul Hermann Müller descobriu as propriedades inseticidas do organoclorado $p$-diclorodifeniltricloroetano, com sua utilização aumentando exponencialmente após a Segunda Guerra Mundial. ${ }^{13}$ Inicialmente, os efeitos benéficos do DDT causaram uma revolução, devido à alta eficiência no controle de pragas e seu uso foi incentivado indiscriminadamente. Porém, os efeitos prejudiciais do DDT em humanos e em animais só foram percebidos após 20 anos, até que apareceram graves sintomas patogênicos.

$\mathrm{Na}$ década de 70, outros pesticids organoclorados foram banidos da agricultura, devido suas elevadas toxicidades, tais como o DDT, hexaclorocicloexano, aldrin e clordano (Figura 2). ${ }^{14}$ 
Figura 2. Estruturas químicas de pesticidas organoclorados utilizados na agricultura que tiveram seu uso proibido nos EUA no início da década de 70.<smiles>ClC1C(Cl)C(Cl)C(Cl)C(Cl)C1Cl</smiles>

Hexaclorocicloexano

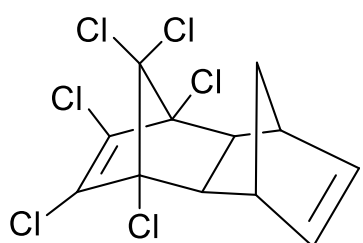

Aldrin<smiles>ClC1=C(Cl)C2(Cl)C3C(Cl)C(Cl)CC3C1(Cl)C2(Cl)Cl</smiles>

Clordano

Fonte: Adaptado de FREIRE, R. S.; PELEGRINI, R.; KUBOTA, L. T.; DURÁN, N.; PERALTA-ZAMORA, P. Novas tendências para o tratamento de resíduos industriais contendo espécies organocloradas. Química Nova, v. 23 , n. 4 , p. $504-511,2000{ }^{14}$

Compostos orgânicos de origem vegetal também foram utilizados no combate às pragas. É o caso do piretro ou pó da Pérsia, proveniente de flores secas de Chrysanthemum cinerariaefolim e Chrysanthemum coccineu, encontrada na Iugoslávia e no Cáucaso, que teve seu uso difundido no século XIX. ${ }^{12}$ Os constituintes químicos presentes no piretro e que são responsáveis pela atividade inseticida são as piretrinas. Em razão da baixa disponibilidade e fotoinstabilidade, estas não são usadas na agricultura, apenas em ambientes domésticos. Esse fato colaborou para o desenvolvimento de produtos fotoestáveis análogos aos produtos naturais, denominados genericamente de piretroides (Figura 3). ${ }^{12}$ 
Figura 3. Exemplos de pesticidas piretroides desenvolvidos a partir de piretrinas.<smiles>CC1(C)C(C=C(Cl)Cl)C1C(=O)OC(C#N)c1cccc(Oc2ccccc2)c1</smiles><smiles>CC1(C)C(C=C(Cl)Cl)C1C(=O)OCc1cccc(Oc2ccccc2)c1</smiles>

Permetrina

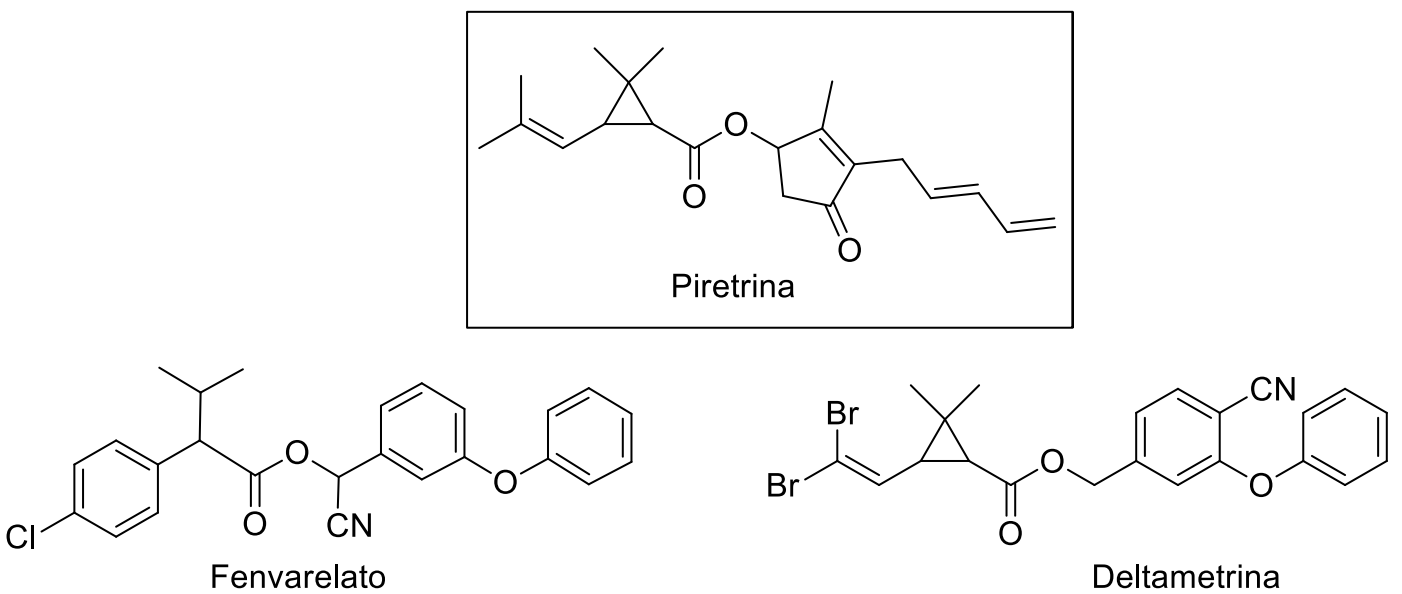

Fonte: Adaptado de FORTES, M. E.; ZAPPE, J. A. A química dos agrotóxicos. Química Nova na Escola, v. 34, n. 1, p.10-15, 2012. ${ }^{114}$

O uso dos pesticidas no Brasil tem uma importância bastante relevante devido às inúmeras atividades agrícolas exercidas em várias regiões do país, colocando-o numa posição de grande produtor e com isso, proporcionando o crescimento da economia a cada ano, sendo então, responsável por aproximadamente $21 \%$ do PIB (Produto Interno Bruto) através do agronegócio. $^{15}$

Em 2008, o Brasil ultrapassou os Estados Unidos e assumiu o posto de maior mercado mundial de agrotóxicos. Segundo a ANVISA, 64\% dos alimentos estão contaminados por agrotóxicos. Nos últimos dez anos, o mercado brasileiro cresceu $190 \%$ enquanto o mercado mundial de agrotóxicos cresceu $93 \%$.

Na safra, que envolve o segundo semestre de 2010 e o primeiro semestre de 2011, o mercado nacional de venda de agrotóxicos movimentou 936 mil toneladas de produtos, das quais 833 mil toneladas produzidas no país e 246 mil toneladas importadas. ${ }^{17}$

O Ministério da Agricultura, Pecuária e Abastecimento constatou que o consumo de agrotóxicos cresceu significativamente no Brasil nos últimos dez anos (Figura 4). ${ }^{18}$ 
Figura 4. Taxa de crescimento do consumo de agrotóxicos no Brasil (2005- 2015).

\section{CRESCIMENTO}

- Em dez anos, aumento da produção agrícola fez crescer o uso de agrotóxicos no Brasil

Área plantada

EM MILHOOES DE HECTÁRES
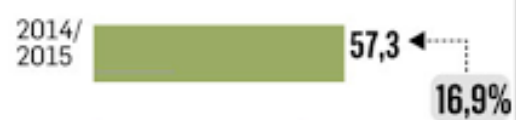

$2004 /$
2005 49,0
Grãos

EM MILHŌES DE TONELADAS

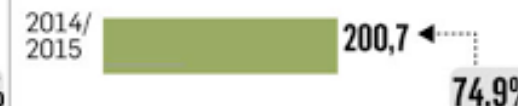

2004
114,7
Consumo agroquímicos *

EM TONELADAS

$2014 / 5352,34$

$2004 /$

Fonte: Adaptado de MINISTÉRIO DA AGRICULTURA, PECUÁRIA E ABASTECIMENTO. Estatísticas. São Paulo, 2016. Disponível em: <http:// www.agricultura.gov.br/vegetal/estatísticas> JORNAL ESTADÃO. Disponível em: <http://www.estadao.com.br/infográfico>. Acesso em: 14 fev. 2016. ${ }^{18}$

A Figura 5 mostra as quatro commodities agrícolas de grande interesse do agronegócio (soja, cana, milho e algodão) que concentram o consumo de agrotóxicos no Brasil.

Em 2012 e 2013 essas culturas foram responsáveis, respectivamente, por 78,5\% e 80\% do total de agrotóxicos vendidos no Brasil, sendo a soja responsável por aproximadamente metade do consumo. ${ }^{16}$ Observa-se a correlação entre o consumo de mais agrotóxicos e o aumento na produção dessas commodities.

O aumento na venda de agrotóxicos foi de $288 \%$ (em US\$) e $162 \%$ (em toneladas), entre 2000 e 2012, a produção de soja cresceu 100\%, a de milho $120 \%$, a de cana-de-açúcar $121 \%$ e a de algodão $147 \%$ (em toneladas). ${ }^{16}$ 
Figura 5. Variações no consumo de agrotóxicos e na produção de commodities no Brasil (2000-2012).

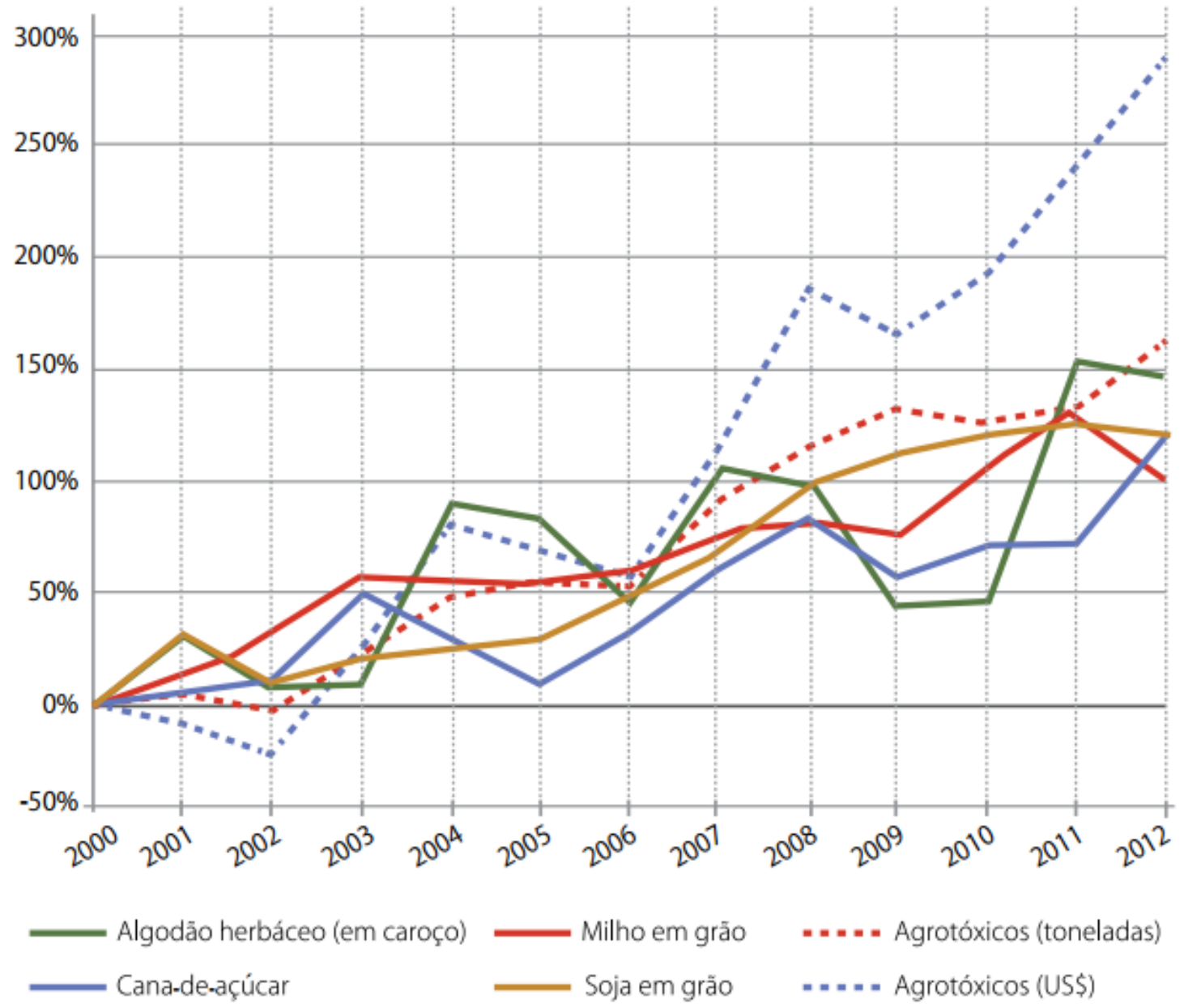

Fonte: SINDICATO NACIONAL DA INDÚSTRIA DE PRODUTOS PARA DEFESA AGRÍCOLA (SINDAG). Investimento em tecnologia produziu safra recorde. Conexão Sindag Especial, ano 8, n. 42, 2013. ${ }^{16}$

\subsubsection{Legislação, riscos à saúde e destino dos pesticidas no meio ambiente}

A União Europeia, através do Regulamento (CE) nº 396/2005 do Parlamento Europeu e do Conselho, de 23 de Fevereiro de 2005, fixou os teores máximos autorizados de resíduos de pesticidas que se podem encontrar nos produtos de origem vegetal ou animal destinados ao consumo humano ou animal. Nos Estados Unidos, a Environmental Protection Agency (Agência de Proteção Ambiental) (EPA) e a Organização Mundia de Saúde (OMS) estabeleceram níveis máximos para pesticidas baseados em estudos toxicológicos e epidemiológicos. ${ }^{19,20,21,160}$

Para os compostos da Tabela 1, a maioria dos alimentos foram identificados como os que mais contribuíram para a Ingestão Diária Teórica Máxima (IDTM) que é definida como o 
somatório do limite máximo de resíduos (LMR), em $\mathrm{mg} / \mathrm{kg}$, multiplicado pelo consumo do alimento (C), em kg/dia. A caracterização do risco (\%IDA) é feita comparando-se a IDTM com a dose diária aceitável (IDA), em $\mathrm{mg} / \mathrm{kg}$ peso corpóreo/dia, do pesticida, assumindo um peso corporal de $60 \mathrm{~kg} .{ }^{160}$

Os cereais de alto consumo pela população brasileira (arroz e feijão), as frutas, principalmente as cítricas, e o tomate foram os principais alimentos responsáveis pela ingestão de pesticidas. Em alguns casos observa-se que uma só cultura é responsável por quase toda a ingestão, como as frutas cítricas nos pesticidas metidation e carbofenotion e o tomate em prothiofos. ${ }^{160}$

Tabela 1. Pesticidas cuja ingestão diária teórica máxima ultrapassou a dose diária aceitável.

\begin{tabular}{|c|c|c|c|c|}
\hline Pesticida & $\% I D A_{N}{ }^{1,2}$ & Alimento ${ }^{3}$ & $\begin{array}{c}\text { IDA }^{4} \\
(\mathrm{mg} / \mathrm{kg} \mathrm{pc} / \mathrm{dia})\end{array}$ & $\begin{array}{r}\text { Outras IDA } \\
\text { (mg/kg pc/dia) }\end{array}$ \\
\hline Paration metilico ${ }^{5}$ & $9.300(7.300-13.000)$ & Frutas e cereais (61\%) & 0,00002 (EPA) & \multirow{12}{*}{$\begin{array}{r}0,0002(\mathrm{~A}): 0,003(\mathrm{C}) \\
0,02(\mathrm{G}) \\
0,0005(\mathrm{~A}) ; 0,004(\mathrm{C}, \mathrm{G}) \\
0,02(\mathrm{~A}) ; 0,03(\mathrm{C}, \mathrm{G}) \\
0,0003(\mathrm{C}) ; 0,001(\mathrm{~A}) \\
0,03(\mathrm{C}, \mathrm{G}) \\
0,01(\mathrm{~A}) \\
0,001(\mathrm{~A}) ; 0,02(\mathrm{C}) \\
0,01(\mathrm{~A}) ; 0,1(\mathrm{EPA}) \\
0,0006(\mathrm{~A}) ; 0,004(\mathrm{G}, \mathrm{C}) \\
0,002(\mathrm{C}) \\
0,001(\mathrm{~A}) ; 0,002(\mathrm{C}) \\
0,002(\mathrm{C}) ; 0,01(\mathrm{G}) \\
0,02(\mathrm{~A})\end{array}$} \\
\hline Diclorvos 5 & $2.400(1.700-3.400)$ & Arroz (61\%) & 0,00017 (EPA) & \\
\hline Pirimifos metilicos & $2.100(1.700-3.700$ & Citros $(66 \%)$ & 0,00025 (EPA) & \\
\hline Dissulfoton 5 & $1.900(1.500-2.300)$ & Batata e feijăo $(60 \%)$ & 0,000043 (EPA) & \\
\hline Mancozeb & $850(610-1.300)$ & Arroz e tomate $(67 \%)$ & 0,006 (A) & \\
\hline Ziran $^{6}$ & $890(650-1.300)$ & Citros $(72 \%)$ & 0,003 (C) & \\
\hline Etion $^{5}$ & $870(720-1.100)$ & Citros e feijáo $(53 \%)$ & 0,0005 (EPA) & \\
\hline Carbaril & $660(580-910)$ & Citros, arróz e feijâo (52\%) & 0,003 (C) & \\
\hline Metamidofos ${ }^{5}$ & $460(270-740)$ & Batata e tomate $(52 \%)$ & 0,0001 (EPA) & \\
\hline Dicofol & $420(310-610)$ & Citros $(84 \%)$ & $0,001(\mathrm{~A})$ & \\
\hline Diazinon 5 & $330(300-500)$ & Frutas $(46 \%)$ & 0,0007 (EPA) & \\
\hline Dimetoato ${ }^{5}$ & $380(280-570)$ & Citros (73\%) & 0,0005 (EPA) & \\
\hline Prothiofos 5 & $270(180-400)$ & Tomate $(96 \%)$ & $0,0001(\mathrm{~A})$ & \\
\hline Maneb $^{6}$ & $270(210-350)$ & $\begin{array}{l}\text { Arroz, tomate, mamao, } \\
\text { citrus e cebola }(35 \%)\end{array}$ & 0,005 (EPA) & $0,03(\mathrm{C}, \mathrm{G})$ \\
\hline Dicloran & $140(120-160)$ & Feijao $(69 \%)$ & $0,01(\mathrm{C})$ & \multirow{4}{*}{$\begin{array}{r}0,07(\mathrm{~A}) \\
0,0015 \text { (EPA): } 0,01 \text { (A) } \\
0,1 \text { (C);0,05 (EPA) } \\
0,00025 \text { (EPA) } \\
0,0005 \text { (G): } 0,0008 \text { (C) }\end{array}$} \\
\hline Metidation 5 & $140(100-210)$ & Citros $(99 \%)$ & $0,001(\mathrm{C}, \mathrm{G})$ & \\
\hline Benomil & $120(95-160)$ & Citros $(48 \%)$ & $0,006(\mathrm{~A})$ & \\
\hline Fenamifos ${ }^{5}$ & $110(80-140)$ & Banana e batata $(74 \%)$ & $0,0001(\mathrm{~A})$ & \\
\hline Azinfos etílico ${ }^{5}$ & $100(80-140)$ & Citrus $(70 \%)$ & 0,002 (A) & \\
\hline Malation 5 & $90(70-140)$ & Cereais (54\%) & 0,002 (EPA) & $0,3(\mathrm{C})$ \\
\hline Mevinfos ${ }^{5}$ & $90(60-120)$ & Citros (50\%) & $0,0008(C, A)$ & \\
\hline Dicrotrofos $^{5}$ & $90(70-130)$ & Citros (79\%) & 0,0001 (EPA) & \\
\hline Carbofenotion ${ }^{5}$ & $70(50-110)$ & Citros (100\%) & $0,0002(\mathrm{~A})$ & \\
\hline
\end{tabular}

EPA: Environmental Protection Agency (USA)

1. Cálculo da \%IDA nacional utilizou o consumo médio nacional; valores entre parênteses representam a faixa de \%IDA, utilizando o consumo nas regioes metropolitanas: 2 . Os valores foram arredondados para 1 algarismo ou 2 algarismos significativos; 20. Percentual de contribuiçåo do alimento para a IDTM; 4. IDA utilizada no calculo da \%IDA; 5 . Inseticidas organofosforados; 6 . LMR considerados como dissulfeto de carbono $\left(\mathrm{CS}_{2}\right)$ : $\mathrm{A}=$ Australlia $^{18} \mathrm{C}=$ Codex alimentarius, ${ }^{3}$ EPA $=\mathrm{Agéncia} \mathrm{de} \mathrm{Proteçâo}$ Ambiental dos Estados Unidos, ${ }^{7 \cdot 10} \mathrm{G}=$ Alemanha. ${ }^{13}$

Fonte: CALDAS, E.D.; SOUZA, L.C.K.R. Avaliação de risco crônico da ingestão de resíduos de pesticidas na dieta brasileira, Journal of Plublic Health, v. 34, n. 5, p. 529-537, 2000. ${ }^{160}$

O Brasil atualmente vem alinhando-se às melhores legislações quanto ao uso de agroquímicos no que se refere aos testes solicitados para sua utilização e comercialização. ${ }^{19}$

No Brasil, o Ministério da Agricultura regulamenta e fiscaliza a produção, venda e utilização dos agrotóxicos, em conjunto com o Conselho Nacional do Meio Ambiente (CONAMA) e ANVISA. ${ }^{22,23}$ 
A ANVISA coordena as ações na área de toxicologia com o objetivo de regulamentar, analisar, controlar e fiscalizar produtos e serviços que envolvam riscos à saúde como agrotóxicos e outras substâncias químicas de interesse toxicológico. A agência realiza a avaliação toxicológica para fins de registro dos agrotóxicos, a reavaliação de moléculas já registradas e normatiza e elabora regulamentos técnicos dos ingredientes ativos dos agrotóxicos. Além disso, coordena o Programa de Análise de Resíduos de Agrotóxicos nos Alimentos (PARA) e a Rede Nacional de Centros de Informação Toxicológica (Renaciat) e promove capacitações em toxicologia. ${ }^{6}$

O Ministério da Agricultura atua através de Leis e Decretos. No caso específico dos agrotóxicos, tem-se a Portaria ${ }^{\circ}$ 007, de 13 de janeiro de 1981, que regulamenta os produtos fitossanitários e agrotóxicos que têm venda livre nas formulações classificadas nas classes toxicológicas III, pouco tóxicos, e IV, praticamente não tóxicos, e obrigatoriedade de venda controlada as formulações das classes I, altamente tóxicos, e II, medianamente tóxicos, e aquelas com características altamente poluentes que não tenham sido classificadas nas classes I e II. ${ }^{22,23}$

$\mathrm{Na}$ agricultura em grande escala, ou monocultura destinada diretamente à industrialização, o uso de agrotóxicos e fertilizantes tem sido constante e os resultados muitas vezes refletem problemas sérios no ambiente. Como exemplo, o uso indiscriminado de diversos tipos de pesticidas tem causado, segundo cálculos da Organização Mundial de Saúde, envenenamentos acidentais em cerca de 1,5 milhões de pessoas, com 28.000 óbitos/ano em todo o mundo. ${ }^{24}$

No Brasil, o assunto é bastante preocupante, quando os pesquisadores alertam que o uso indiscriminado de agrotóxicos, com valores da ordem de US\$ 1,4 bilhão e com um crescimento de 6,5\% ao ano, faz do país um dos líderes no uso de defensivos agrícolas. ${ }^{27,28}$ Além disto, a Associação de Engenheiros Agrônomos do Estado de São Paulo (AEAESP) denunciou que, no final de cada safra, a maioria das embalagens é descartada indevidamente, abandonada no meio da plantação ou atirada nos rios contribuindo para a contaminação ambiental.

A extensão da contaminação ambiental por pesticidas não é bem conhecida, entretanto, são alarmantes as informações coletadas pelas agências controladoras da saúde pública e do meio ambiente. Nos Estados Unidos, entre 1982 e 1985, o Food and Drug Administration (FDA) detectou resíduos dos pesticidas em $48 \%$ dos vegetais frescos e nas frutas consumidas frequentemente pela população americana. ${ }^{25}$ Ainda, de acordo com as estimativas da Environmental Protection Agency, os pesticidas contaminaram a água e o solo em 38 estados 
americanos. As estimativas de 6.000 casos de câncer por ano podem ter sido causadas por pesticidas aprovados pelas leis vigentes. A maioria das 50.000 formulações de pesticidas encontradas no mercado não foi testada com relação aos efeitos de longo prazo. Existem evidências que a aplicação dos pesticidas e herbicidas pelos agricultores aumenta o risco de casos de leucemia, câncer, doenças do sistema nervoso e nascimentos de prematuros com deficiências genéticas. ${ }^{26}$

Segundo a ANVISA, os organofosforados, que são substâncias presentes nos acaricidas, fungicidas, inseticidas, bactericidas, cupinicidas e formicidas, podem destruir células musculares e comprometer o sistema nervoso, provocando problemas cardiorrespiratórios. ${ }^{29}$

A Agência Nacional de Vigilância Sanitária analisou, no período de 2011 e 2012, 3.062 amostras de 25 culturas vegetais, que foram monitoradas até 2015 (Figura 6). ${ }^{29}$

O relatório final do Programa de Análise de Resíduos de Agrotóxicos de Alimentos destaca que as doenças crônicas não transmissíveis que têm os agrotóxicos entre seus agentes causadores são hoje um problema mundial de saúde pública. ${ }^{29}$

A OMS prevê um aumento de 15\%, entre 2015 e 2020, dos óbitos causados por essas doenças. No Brasil, elas já representam a principal causa de óbito por intoxicação, sendo responsáveis por $74 \%$ das mortes ocorridas em 2008 (893.900 óbitos). ${ }^{26}$ 
Figura 6. Amostra de alimentos produzidos no Brasil com resíduos de agrotóxicos.

\section{Amostras de alimentos com resíduos de agrotóxicos}

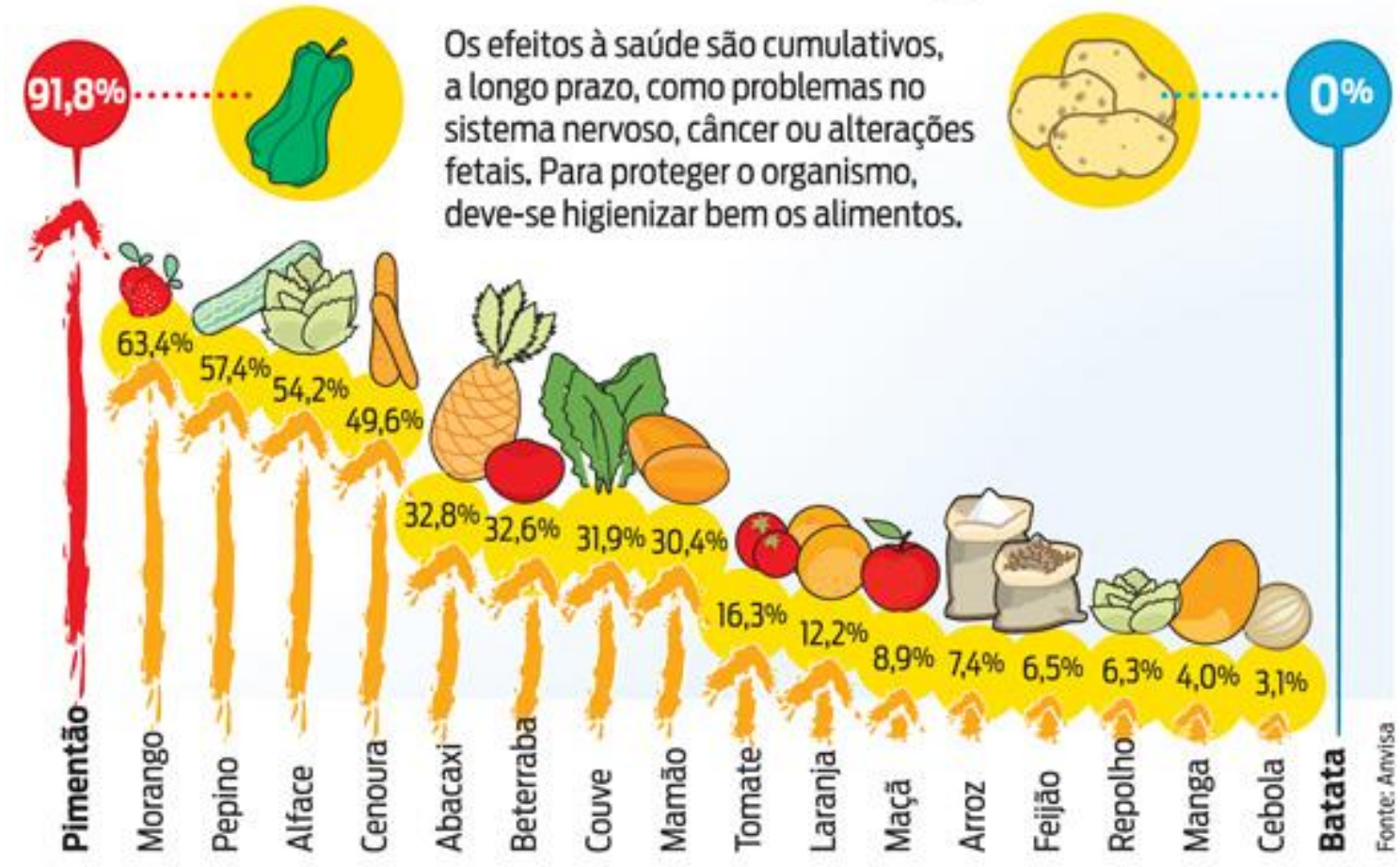

Fonte: AGÊNCIA NACIONAL DE VIGILÂNCIA SANITÁRIA (ANVISA). Estudo traça perfil do mercado de agrotóxicos no Brasil. 2015. Disponível em: <http://s.anvisa.gov.br/wps/s/r/oFb〉. Acesso em: 22 mar. 2016. 2,15

A interação de pesticidas com solos, águas superficiais e subterrâneas é complexa, sendo controlada por diversas reações biológicas, químicas e físicas. Sendo assim, os processos de transformação e degradação de pesticidas dependem tanto das características do solo, quanto do pesticida em questão. ${ }^{30,31}$

O método biológico, frente à degradação de substâncias químicas, especialmente de pesticidas e seus metabólitos, pode apresentar várias vantagens em relação aos métodos químicos e físicos pelo menor custo e toxidez ao meio ambiente. ${ }^{33,34}$ Os processos biológicos são bastante vantajosos e os microrganismos, devido a versatilidade enzimática, são eficazes em degradar compostos xenobióticos. Os microrganismos na natureza, além de outras funções que desempenham, atuam como decompositores e têm importante papel na reciclagem de nutrientes. $^{32}$

A biodegradação por enzimas de fungos e bactérias tem sido apontada como uma técnica promissora para a degradação de substâncias onde o tratamento ou remoção destas é impraticável, por exemplo, os pesticidas aplicados em extensas áreas agrícolas. ${ }^{35,36}$ Embora o 
processo biológico seja lento, tem como vantagem também a total mineralização de compostos orgânicos, inclusive aqueles mais recalcitrantes.

Assim, estudos mais detalhados são requeridos constantemente para se conhecer a diversidade microbiana, os mecanismos enzimáticos de biorremediação, os metabólitos formados, as enzimas que são produzidas por estes organismos, bem como, as interações com o ecossistema que favoreçam a descontaminação do meio ambiente. ${ }^{37}$

A Figura 7 mostra os possíveis caminhos que podem percorrer uma substância no meio ambiente pela ação química, física e biológica.

Figura 7. Processos físicos, químicos e biológicos que controlam a persistência ou degradação de pesticidas no ambiente.

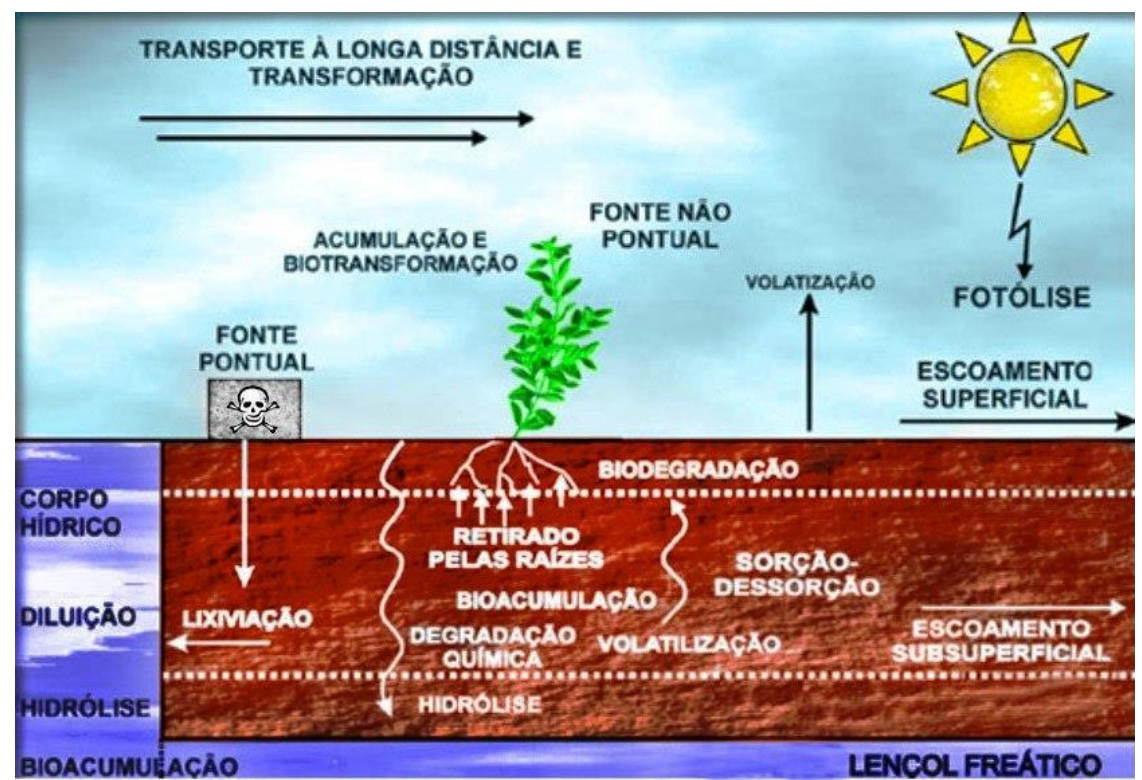

Fonte: SILVA, R.L. Desenvolvimento de método para determinação de resíduos de pesticidas em alface (Lactuca sativa L.) produzida em sistema convencional. 2010. 85f. Dissertação (Mestrado em Química)Universidade Federal de Sergipe, São Cristóvão, 2010. ${ }^{161}$

\subsection{Pesticidas organofosforados}

Os pesticidas organofosforados (POs) são ésteres derivados do ácido fosfórico, do ácido tiofosfórico ou do ácido ditiofosfórico compostos por um átomo de fósforo pentavalente também chamados de organofosfatos, os quais incluem derivados alifáticos, aromáticos e heterocíclicos. ${ }^{38}$ Estas substâncias podem ser representadas pela fórmula geral apresentada na Figura 8, onde os grupamentos $\mathrm{R}_{1}$ e $\mathrm{R}_{2}$ podem ser metil ou etil. ${ }^{38}$ Sendo ésteres, essas moléculas têm posições suscetíveis à hidrólise. As principais reações envolvendo os POs incluem hidrólise, oxidação, alquilação e desalquilação. ${ }^{39}$ 
Figura 8. Estruturas químicas dos principais grupos de POs.

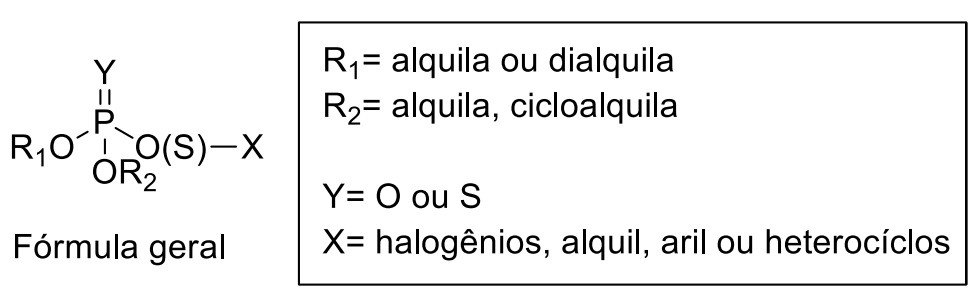<smiles>[R20]P([R20])([R])=O</smiles>

Fosfatos<smiles>[R20]P([R6])([Y])=S</smiles>

fosforoditioatos<smiles>[R20]P([R6])([R])=S</smiles>

O-fosforotioatos

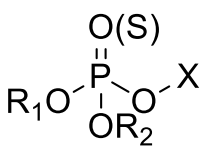

fosfonatos<smiles>[R20]P([R20])([R])=O</smiles>

$S$-fosforotioatos<smiles>[X]N([X])P([R6])([R6])([O-])[O-]</smiles>

Fosforamidatos

Fonte: Adaptado de MARONI, M.; COLOSIO, C.; FERIOLI, A.; FAIT, A. Biological monitoring of pesticide exposure: Toxicology, v. 143, p. 1-118, 2000. ${ }^{40}$

$\mathrm{O}$ átomo de fósforo da molécula do OP é polarizável, usualmente, os grupamentos $\mathrm{R}_{1} \mathrm{e}$ $\mathrm{R}_{2}$ são grupos arilas ou alquilas que estão ligados diretamente ao átomo de fósforo, formando fosfinatos, ou através de um átomo de oxigênio ou de enxofre, formando fosfatos e fosforotioatos. ${ }^{63,64} \mathrm{O} \mathrm{R}_{1}$ pode estar diretamente ligado ao átomo de fósforo e o $\mathrm{R}_{2}$ pode estar ligado por um átomo de oxigênio ou de enxofre, formando fosfonatos ou tiofosfonatos. Ainda, os fosforamidatos apresentam um grupo $\mathrm{NH}_{2}$ na molécula. Os grupos amino dos fosforamidatos podem ser não-substituídos, mono ou di-substituídos. Os átomos que podem formar ligação dupla com o fósforo podem ser: oxigênio, enxofre, selênio. ${ }^{64,}{ }^{65}$ Inseticidas têm tipicamente grupos ésteres $\mathrm{R}_{1}$ e $\mathrm{R}_{2}$ idênticos, dando origem aos POs aquirais. $\mathrm{O}$ grupo $\mathrm{X}$ que pode estar ligado ao átomo de fósforo através de um átomo de oxigênio ou enxofre, é chamado grupo de saída, uma vez que é liberado do átomo de fósforo quando o PO é hidrolisado. $\mathrm{O}$ grupo $\mathrm{X}$ pode pertencer a uma ampla gama de halogênios, alifáticos, aromáticos ou heterocíclicos, mas é mais comumente designado como um grupo fenol ou tiol com a cadeia linear, ramificada ou aromática. ${ }^{41,43,42}$

Pesticidas organofosforados possuem elevada lipossolubilidade, sendo absorvidos pelo organismo humano por via respiratória, dérmica, membranas mucosas e trato intestinal. Concentram-se, após absorção, nos tecidos adiposos, fígado, rins, glândulas salivares, 
pâncreas, pulmões, sistema nervoso central, músculos, paredes do estômago e do intestino. Sua toxicidade aumenta quando ocorrem reações de dessulfuração metabólica oxidativas, transformando a ligação $\mathrm{P}=\mathrm{S}$ em $\mathrm{P}=\mathrm{O} .{ }^{44}$

Foi comprovado que a toxicidade elevada para a espécie humana de diversos organofosforados está relacionada às ligações $\mathrm{P}=\mathrm{O}$ em sua estrutura molecular ou de seus metabólitos fenólicos. Esta ligação possibilita maior transferência de elétrons do fósforo para o oxigênio, resultando em cargas mais intensas nos dois elementos e, como consequência, interações mais fortes entre o organofosforado com o centro esterásico da enzima acetilcolinesterase. $^{63}$

Geralmente, o processo de metabolização de xenobióticos em seres humanos ocorre no fígado e inclui as chamadas reações de fase I e II. As reações de fase I são responsáveis pela transformação do xenobiótico lipofílico em uma forma mais solúvel em água (polar), por meio de reações de oxidação, redução e hidrólise. As reações da fase II são destoxicantes e responsáveis pela conjugação dos xenobióticos a substratos endógenos como açúcares, ácidos graxos e alquilações. ${ }^{45}$

Os principais POs comercializados pelas companhias agroquímicas são o metil paration, clorpirifós, profenofós, paration, fenitrotion e diazinon (Figura 9). ${ }^{46}$

Figura 9. Exemplos de POs mais comercializados.<smiles>COP(=S)(OC)Oc1ccc([N+](=O)[O-])cc1</smiles>

Metil paration<smiles>CCOP(=S)(OCC)Oc1ccc([N+](=O)[O-])cc1</smiles>

Paration<smiles>CCOP(=S)(OCC)Oc1nc(Cl)c(Cl)cc1Cl</smiles>

Clorpirifós<smiles>COP(=S)(OC)Oc1ccc([N+](=O)[O-])c(C)c1</smiles>

Fenitrotion<smiles>CCCSP(=O)(OCC)Oc1ccc(Br)cc1Cl</smiles>

Profenofós<smiles>CCOP(=S)(OCC)Oc1cc(C)nc(C(C)C)n1</smiles>

Diazinon

Fonte: Adaptado de PORTO, A. L. M. P.; MELGAR, G. Z.; KASEMODEL, M. C.; NITSCHKE, M. Biodegradation of pesticides. In: STOYTCHEVA, M. Pesticides in the modern world-pesticides use and management. Croatia: InTech, p. 407-438, 2011. ${ }^{46}$ 
Os POs têm sido amplamente utilizados em substituição aos compostos organoclorados, por causa do seu baixo custo, facilidade de síntese, biodegradabilidade aumentada e acumulação reduzida nos organismos vivos (comparada aos organoclorados). ${ }^{47}$ Porém, os POs são altamente tóxicos, uma vez que são potentes inibidores irreversíveis da acetilcolinesterase (AChE), enzima que têm um efeito sobre o sistema nervoso dos organismos vivos, incluindo o homem. ${ }^{48}$ Exercem seus principais efeitos toxicológicos pela fosforilação irreversível de esterases no sistema nervoso central. ${ }^{48}$ Os efeitos tóxicos agudos estão relacionados com a inibição da AChE.

A acetilcolinesterase é uma enzima pertencente a família das colinesterases, sendo responsável pela finalização da transmissão dos impulsos nervosos nas sinapses colinérgicas pela hidrólise do neurotransmissor acetilcolina (ACh). A AChE está presente no sistema nervoso central e periférico. ${ }^{49}$

No sistema nervoso periférico ela é responsável pela modulação dos impulsos nervosos que controlam os batimentos cardíacos, pela dilatação dos vasos sanguíneos e pela contração dos músculos lisos enquanto que no sistema nervoso central ela está envolvida no controle motor, na cognição e na memória. A ACh é um neurotransmissor formado na região terminal dos neurônios, chamada de axônio terminal (Figura 10). ${ }^{50}$ Ela permanece armazenada em vesículas sinápticas e, quando um impulso nervoso chega no axônio terminal, é liberada pelo neurônio para a região sináptica, onde é atraída pelos receptores colinérgicos que estão localizados no próximo neurônio. Quando a ACh interage com os receptores regenera o impulso nervoso no neurônio, levando assim a continuidade da transmissão. Uma vez transmitido, o impulso nervoso é importante para que o processo de interação da ACh com o receptor seja interrompido, para evitar o excesso de transmissão nervosa, que pode levar a problemas de funcionamento do organismo. ${ }^{50}$ 
Figura 10. Esquema do processo de transmissão e controle nervoso nas sinapses pela acetilcolinesterase.

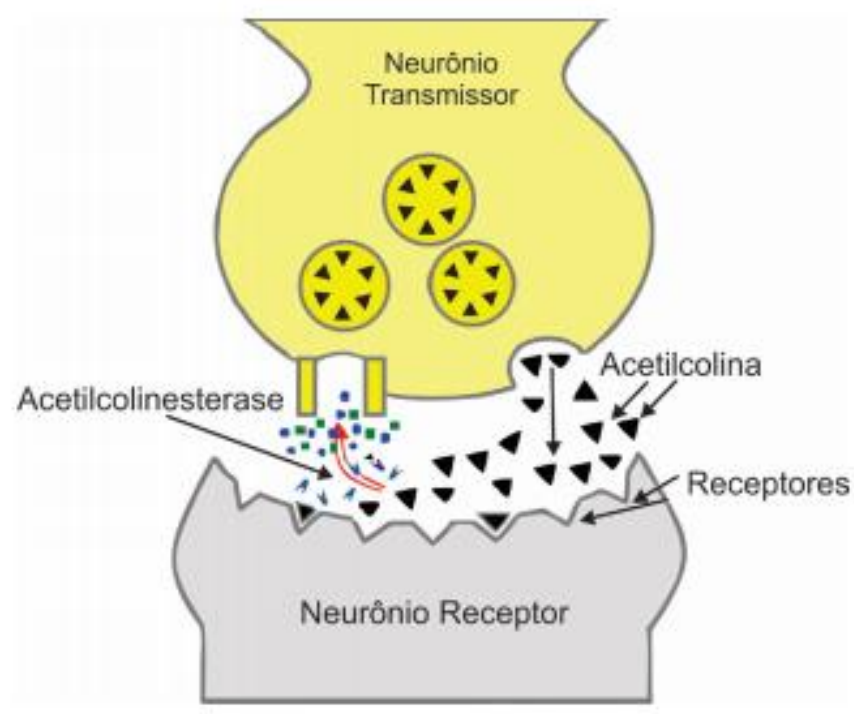

Fonte: PETRONILHO, E.C.; PINTO, A.C.; VILLAR, J.D.F. Acetilcolinesterase: Alzheimer e guerra química. Grupo de Química Medicinal, Departamento de Química, Instituto Militar de Engenharia, Universidade Federal do Rio de Janeiro-UFRJ. Revista Militar de Ciência e Tecnologia, p. 03-14, 2011. ${ }^{87}$

O organismo humano possui a enzima AChE, que recolhe o neurotransmissor ACh e realiza uma modificação na sua estrutura molecular convertendo-a em colina (Ch), que é reabsorvida pelos neurônios para ser novamente reconvertida em $\mathrm{ACh}$, permitindo assim a sua reutilização na transmissão de impulsos nervosos. A modificação da ACh ocorre por um processo de hidrólise, como mostrado na Figura 11. ${ }^{50}$ 
Figura 11. Exemplo do processo de hidrólise do neutransmissor acetilcolina (ACh) pela enzima acetilcolinesterase (AChE).

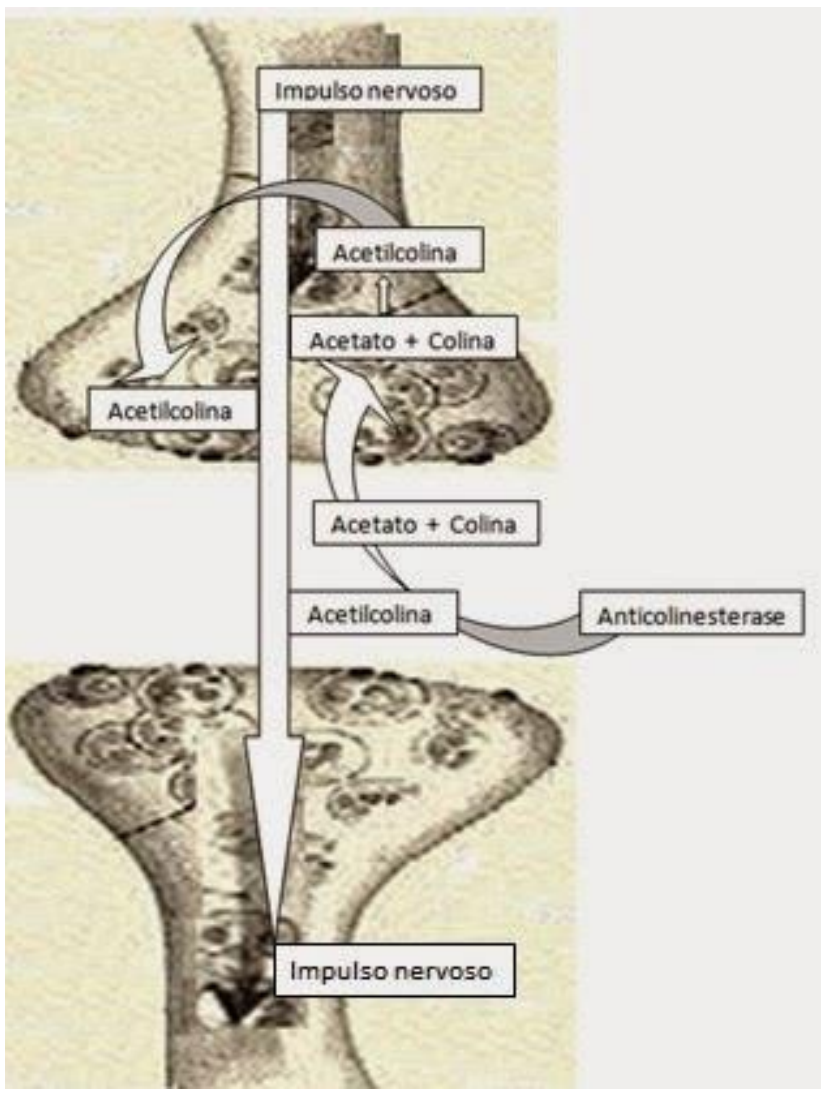<smiles>CC(=O)OCC[N+](C)(C)C</smiles>

Acetilcolina (ACh)

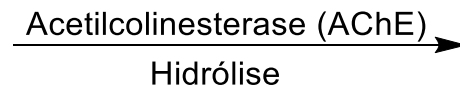

Hidrólise<smiles>CC(=O)O</smiles>

Ácido acético (Ac)<smiles>C[N+](C)(C)CCO</smiles>

Colina (Ch)

Fonte: Adaptado de MATIAS, R.S.; Como agem os inseticidas nos insetos. 2014. Disponível em: <http: //matiassinantropicos.blogspot.com.br/>. Acesso em 25 de jan. de 2016. ${ }^{88}$ e PETRONILHO, E.C.; PINTO, A.C.; VILLAR, J.D.F. Acetilcolinesterase: Alzheimer e guerra química. Grupo de Química Medicinal, Departamento de Química, Instituto Militar de Engenharia, Universidade Federal do Rio de Janeiro-UFRJ. Revista Militar de Ciência e Tecnologia, p. 03-14, 2011. ${ }^{87}$

A AChE é uma enzima que possui alta eficiência catalítica, com capacidade de hidrolisar até $6 \times 10^{5}$ moléculas de ACh por molécula de enzima por minuto (Figura 12). ${ }^{51}$

Esta enzima possui um sítio ativo onde existem três resíduos principais de aminoácidos, os quais estão envolvidos diretamente no processo de hidrólise da ACh, a serina número 200 (Ser200), a histidina número 440 (His440) e o ácido glutâmico número 327 (Glu327), como mostrado na Figura 13. ${ }^{52}$ No sítio ativo também existe uma região aniônica, que serve para 
interagir com a parte catiônica da ACh e que orienta este substrato na posição necessária para sofrer o processo de hidrólise. ${ }^{53}$

Figura 12. Proposta de mecanismo de hidrólise da acetilcolina pela enzima acetilcolinesterase.

Unidades de AChE

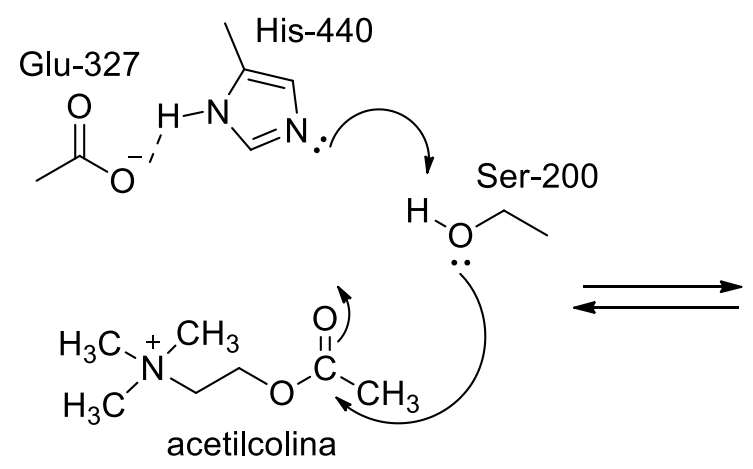<smiles></smiles>

Acetilcolinesterase ativa<smiles>CC([O-])(COCC[Se])COCC[N+](C)(C)C</smiles>

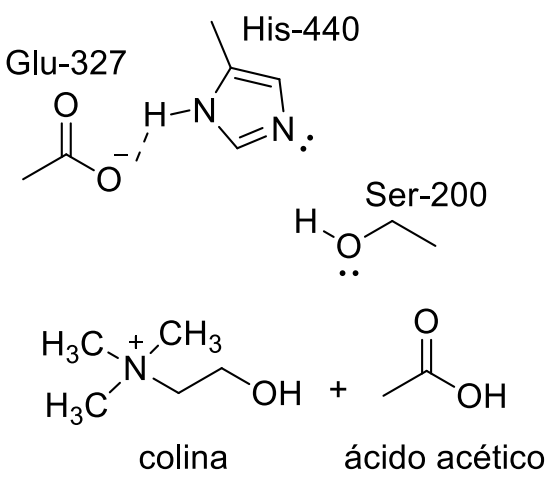

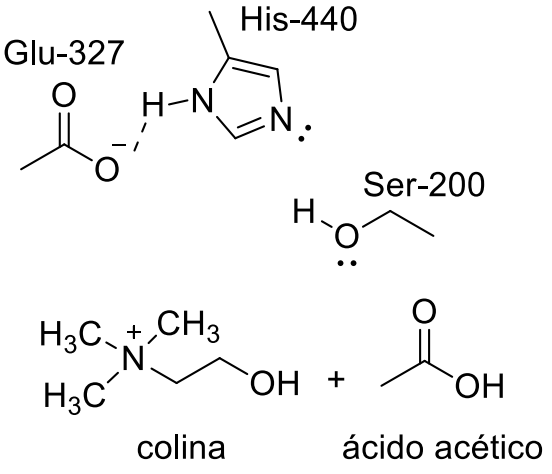
hidrólise<smiles>[V]=C=[V]</smiles><smiles></smiles><smiles>C[N+](C)(C)CC[O-]</smiles><smiles>CC(=O)OC[Se][O+2]([O-])[O-]</smiles>

Fonte: Adaptado de SANTOS, V. M. R.; DONNICI, C. L.; DACOSTA, J. B. N.; CAIXEIRO, J. M. R. Compostos organofosforados pentavalentes: Histórico, métodos sintéticos de preparação e aplicações como inseticidas e agentes antitumorais. Química Nova, v. 30, n. 1, p. 159-170, $2007 .{ }^{47}$

O processo de intoxicação por neurotóxicos ocorre no sistema nervoso central e no sistema nervoso periférico. Os POs têm grande afinidade pela enzima AChE que, uma vez inibida, não será mais capaz de hidrolisar a ACh. A inibição ocorre no interior do sítio ativo, e inicia-se com o resíduo de aminoácido serina da tríade catalítica. No caso da acetilcolinesterase humana (HuAChE), o pesticida organofosforado liga-se covalentemente à serina. Esta ligação ocorre entre o átomo de fósforo do PO e o átomo de oxigênio da serina, com subsequente saída do grupo $-\mathrm{X}$ do orgafosforado. ${ }^{54}$ Ao contrário da enzima acetilada, a enzima fosforilada reage lentamente com água, permitindo a desalquilação de um substituinte alcóxi $\left(\mathrm{R}_{2}\right)$ ligado ao átomo de fósforo. Os compostos organofosforados, assim, inativam a 
AChE pela fosforilação da serina no sítio ativo da enzima. O resultado é a formação de uma forte ligação entre o resíduo de histidina protonado do sítio catalítico e o átomo de oxigênio negativamente carregado do organofosforado. A histidina protonada não atua como um catalisador básico nas etapas subsequentes para promover a hidrólise da enzima fosforilada, que é um passo crucial para a reativação da AChE (Figura 13). ${ }^{47}$

Figura 13. Proposta de mecanismo de inibição da enzima acetilcolinesterase por pesticidas organofosforados.

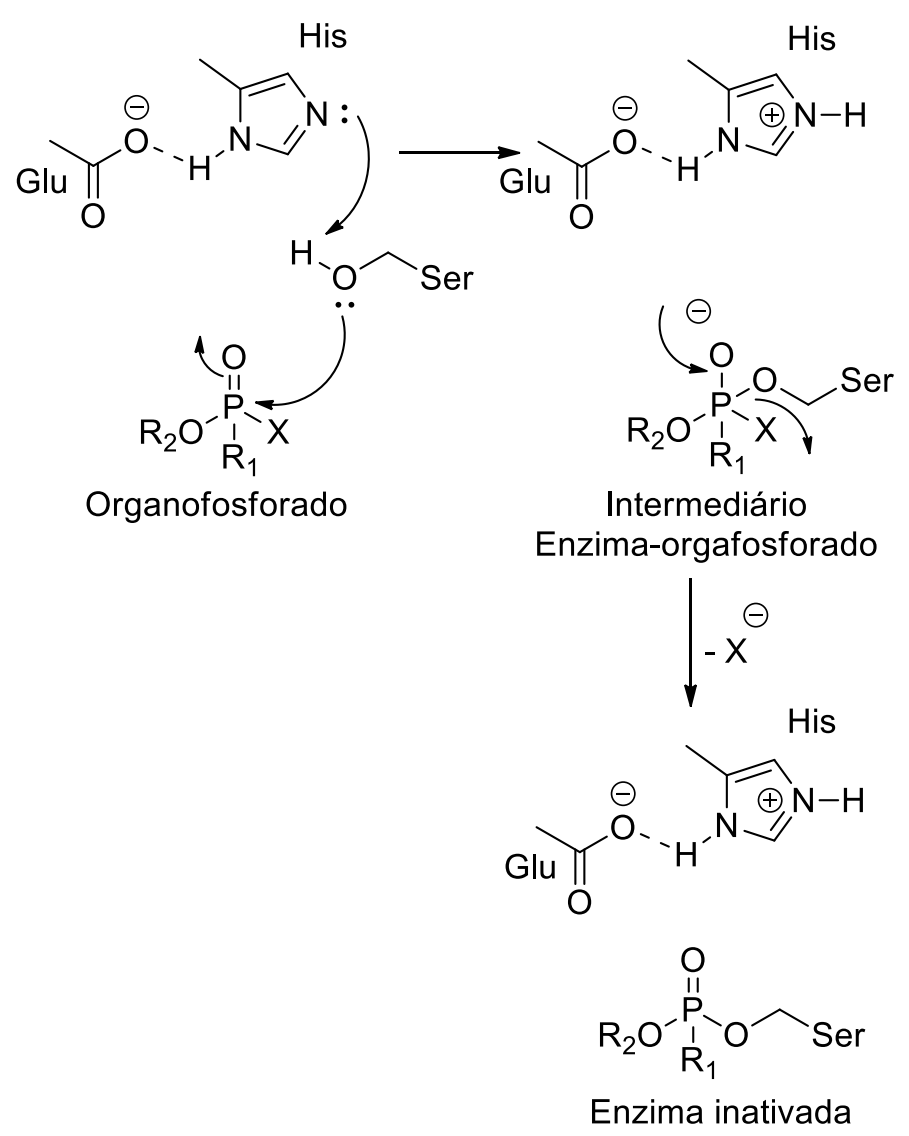

Fonte: ORDENTLICH, A.; BARAK, D.; SOD-MORIAH, G.; KAPLAN, D.; MIZHARI, D. Stereoselectivity toward VX is determined by interactions with residues of the acyl pocket as well as of the peripheral anionic site of AChE. Biochemistry, v. 43, p. $11255-11265,2004 .{ }^{54}$

A inibição da $\mathrm{AChE}$ depende da estrutura química do inibidor organofosforado. A interação entre a esterase e o PO parece envolver apenas o sítio ativo, onde um complexo muito estável é formado e, esta estabilidade, está relacionada com a estrutura química específica do inibidor. A inibição da acetilcolinesterase é irreversível, impedindo o substrato ACh de reagir com o sítio da esterase. Como consequência, a acumulação de ACh resulta em todos os sintomas de envenenamento por ACh causada por organofosforados. ${ }^{47}$ Os sintomas da intoxicação aparecem após cerca de aproximadamente 50\% da AChE ser inibida, podendo 
causar agitação, fraqueza muscular, hipersalivação e suor. Intoxicações graves podem causar insuficiência respiratória, perda de consciência, convulsões e morte. ${ }^{55,56}$

\subsubsection{Clorpirifós}

Clorpirifós, fosforotioato de $O, O$-dietil- $O$-3,5,6-tricloro-2-piridinila é um inseticida da classe dos organofosforados que inibe a transmissão dos receptores do sistema nervoso. É utilizado para controlar vários tipos de insetos. O clorpirifós é moderadamente tóxico (Classificação Toxicológica II) e já foram atribuídos ao uso deste pesticida, efeitos neurológicos, atrasos e problemas no desenvolvimento de crianças, assim como, problemas no sistema autoimune. ${ }^{59}$

O pesticida possui formulação líquida, emulsionável, miscível com a maioria dos solventes orgânicos comuns e é fotoestável. ${ }^{60}$ Não é muito solúvel em água, de maneira que geralmente se mistura com ácidos graxos antes de ser aplicado nas plantas ou em animais. $\mathrm{O}$ clorpirifós também pode ser utilizado em cultivos de cereais, algodão, frutas como as amêndoas, maçãs, laranjas, legumes e hortaliças.

O clorpirifós é bastante utilizado nas estufas de plantas ornamentais e é muito eficaz no controle de pragas, tais como, mosquitos, formigas, moscas e térmitas. ${ }^{59,60} \mathrm{Em}$ alguns casos é aplicado diretamente sobre ovelhas e aves. ${ }^{59}$

O clorpirifós age por contato e ingestão. Como todo inseticida do grupo dos organofosforados, o clorpirifós liga-se ao centro esterásico da acetilcolinesterase, impossibilitando-a de exercer sua função, ou seja, a hidrólise do neurotransmissor acetilcolina, em colina e ácido acético. Nos insetos, interfere com a transmissão dos impulsos nervosos, levando-os à paralisia e morte. ${ }^{60}$

O destino do clorpirifós no meio ambiente depende além de suas propriedades físicas e químicas, pelas características do solo, práticas de aplicação e condições do meio, tais como vento, temperatura, umidade entre outros. Decorrido certo período, o clorpirifós pode sofrer modificações em sua estrutura, a qual se dá principalmente pelos mecanismos de volatização, hidrólise, fotólise e biodegradação. ${ }^{61}$

A Figura 14 mostra uma proposta de biodegradação do clorpirifós. ${ }^{57}$ 
Figura 14. Proposta de rotas de degradação do clorpirifós por microrganismos.

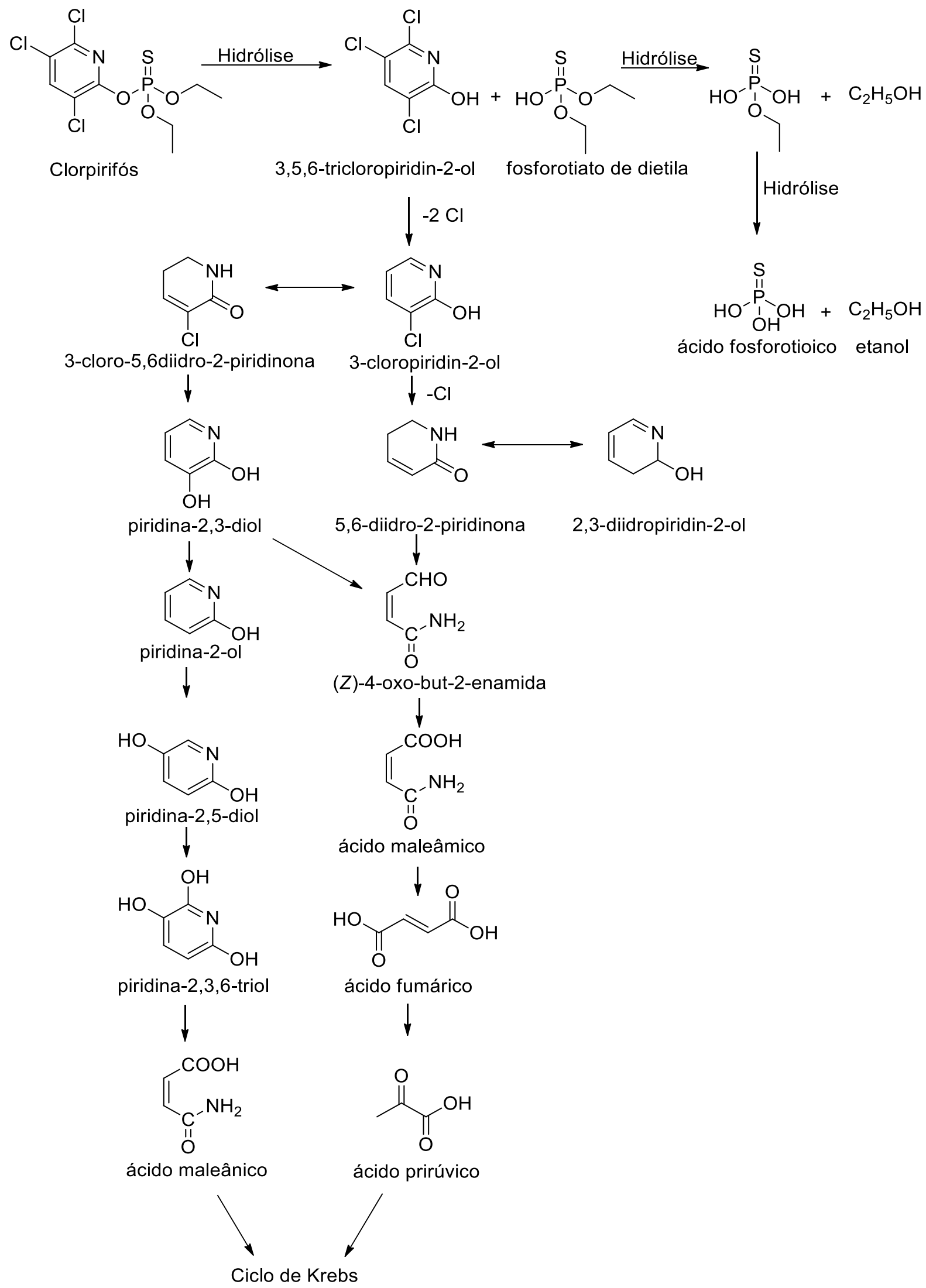

Fonte: Adaptado de BRAJESH K. SINGH.; ALLAN WALKER. Microbial degradation of organophosphorus compounds. FEMS Microbiology Reviews v. 30, p. 428-471, 2006. ${ }^{57}$ 


\subsubsection{Metil paration}

Metil paration, fosforotioato de $O, O$-dimetil- $O$-4-nitrofenila, pertence ao grupo químico dos organofosforados, potente inibidor irreversível da enzima acetilcolinesterase (Classificação Toxicológica I) é um pesticida altamente tóxico que age diretamente sobre o sistema nervoso central, onde afeta diversos órgãos vitais de mamíferos e insetos. ${ }^{62} \mathrm{O}$ metil paration é um importante pesticida utilizado na agricultura para o controle de insetos e é usado em substituição ao seu análogo Etil paration, que foi banido em diversos países devido a sua alta toxicidade para mamíferos. ${ }^{66,67}$

Um aspecto importante do metil paration é que durante sua biotransformação é formado o metabólito metil paraoxon, que aumenta e prolonga os efeitos tóxicos desse princípio ativo. ${ }^{65}$ Segundo a United Nations Environment Programme e a Food and Agriculture Organization das Nações Unidas a rotulagem do metil paration deve conter no mínimo as seguintes indicações de risco: extremamente tóxico, perigoso para o meio ambiente, se aquecido pode causar explosão, inflamável, tóxico em contato com a pele, muito tóxico se inalado ou ingerido, perigo de dano grave à saúde pela exposição prolongada, muito tóxico aos organismos aquáticos, pode causar efeitos adversos a longo prazo no ambiente aquático, tóxico para abelhas. ${ }^{68}$

A principal via de exposição do metil paration em humanos é a inalatória, porém o contato dérmico e a ingestão acidental ou intencional representam vias de exposição frequentes e significativas. ${ }^{69}$ Diversos fatores podem interferir na absorção do organofosforado, modificando a toxicocinética e a toxicidade desse composto. ${ }^{70} \mathrm{~A}$ temperatura ambiente elevada e a alta umidade relativa aumentam a absorção cutânea, possivelmente em consequência do aumento da taxa de respiração, da frequência e do fluxo sanguíneo nos tecidos e órgãos. Fatores genéticos ou comportamentais como ingestão de bebidas alcoólicas também modificam a absorção e distribuição desse composto. ${ }^{7}$

O metil paration é metabolizado majoritariamente no fígado, originando o dimetiltiofosfato, o dimetilfosfato e o 4-nitrofenol. ${ }^{72} \mathrm{O}$ metil paration em humanos é metabolizado por enzimas esterases do citocromo P450 (CYP) na fase I e enzimas glatationa$S$ - tranferases na fase $I I .^{73}$

A Figura 15 ilustra algumas rotas de biodegradação do metil paration em humanos. ${ }^{74}$ 
Figura 15. Proposta de rotas de degradação do metil paration em humanos.

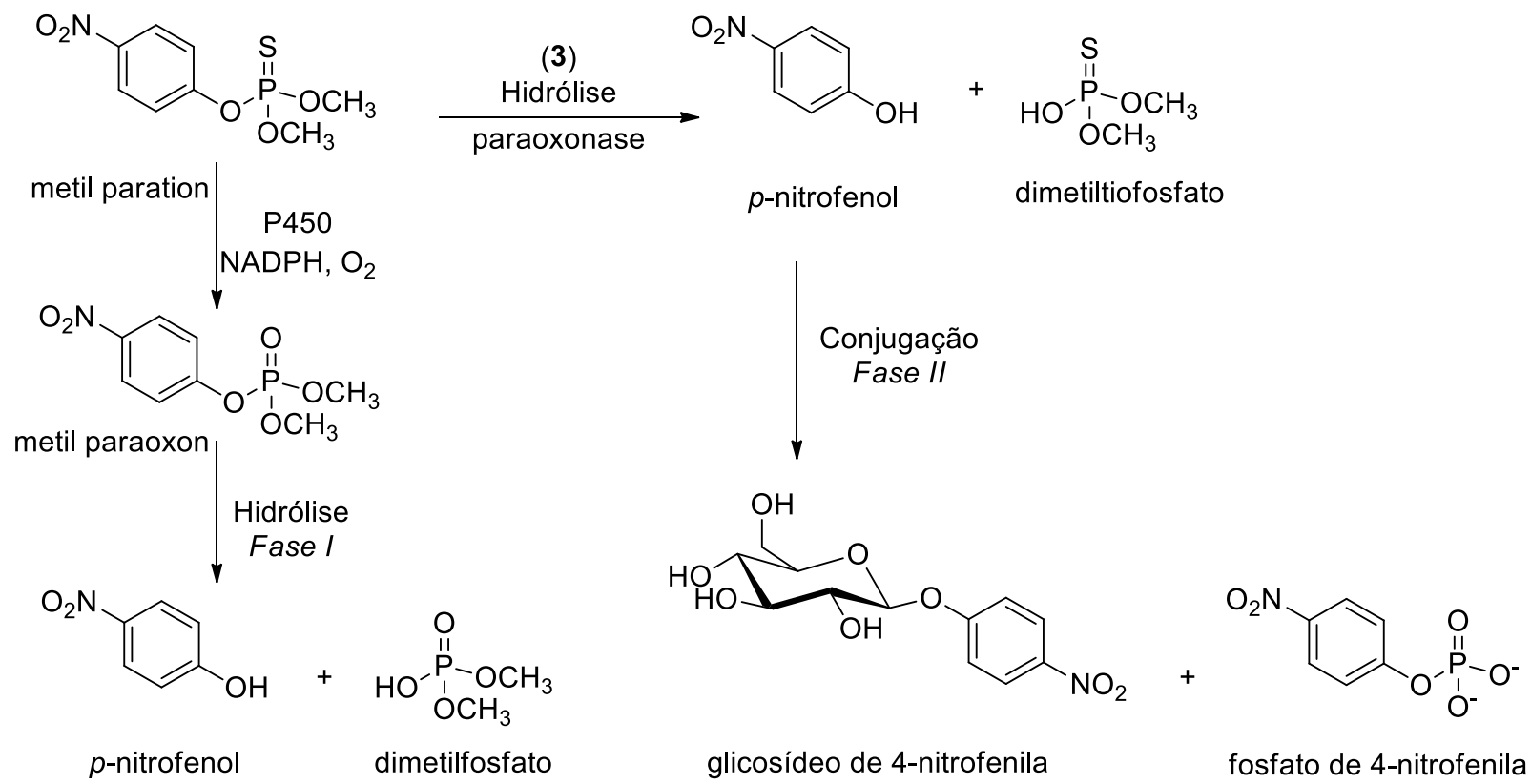

Fonte: Adaptado de SILVA, N.A. Biodegradação dos pesticidas clorpirifós, metil paration e profenofós por fungos de origem marinha. 2013. 159 f. Dissertação (Mestrado em Química)-Instituto de Química de São Carlos-Universidade São Paulo, São Carlos, 2013. ${ }^{74}$

Nas reações de fase I do metabolismo do metil paration ocorrem três reações: (1) dessulfuração pelo citocromo P450 (CYP) formando metil paraoxon que é a forma mais tóxica do metil paration com o envolvimento da CYP3A4 e CYP2B; ${ }^{75,76,77}$ (2) hidrólise pela CYP formando o 4-nitrofenol e o dimetilfosfato; ${ }^{78}$ (3) hidrólise pela ação da paraoxonase. ${ }^{79}$ As reações de fase II envolvem a conjugação do 4-nitrofenol com a glutationa através da ação das enzimas transferases formando, respectivamente, glicosídeo de 4-nitrofenila e fosfato de 4-nitrofenila. ${ }^{80,81,73}$

Decorrido certo período, o metil paration pode sofrer modificações em sua estrutura, a qual se dá principalmente pelos mecanismos de volatização, hidrólise, fotólise e biodegradação. ${ }^{61}$

A Figura 16 ilustra uma possível rota de biodegradação do metil paration. ${ }^{57}$ 
Figura 16. Proposta de rotas de degradação do metil paration por microrganismos.<smiles>COP(=O)(OC)Oc1ccc([N+](=O)[O-])cc1</smiles><smiles>COP(=S)(OC)Oc1ccc([N+](=O)[O-])cc1</smiles>

Metil paration

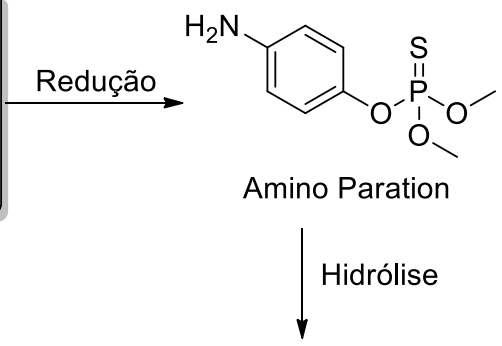<smiles>COP(=O)(O)OC</smiles>

4-nitrobenzeno-1,2-diol<smiles>[3H][V]</smiles>

$\mathrm{HO}$<smiles>Cc1ccc(O)c(O)c1</smiles>

benzeno-1,2,4-triol<smiles>O=C1C=CC(=O)CC(C(=O)O)C1</smiles>

ácido (Z)-4-oxo-hex-2-enodioico<smiles>COP(O)(=S)OC</smiles>
p-nitrofenol<smiles>CC(C)C(C)C</smiles>

tiofosfato de dimetila

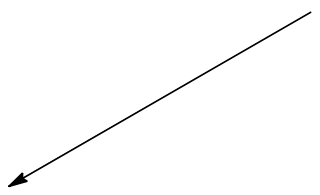<smiles>O=C1C=CC(=O)C=C1</smiles>
benzoquinona<smiles>O</smiles><smiles>OC1C=CC(C2CC2)C=C1</smiles>
hidroquinona<smiles>CC(C)(C)c1cc(O)ccc1C(=O)O</smiles>

cis, semialdeído mucônico trans-4-hidroxi

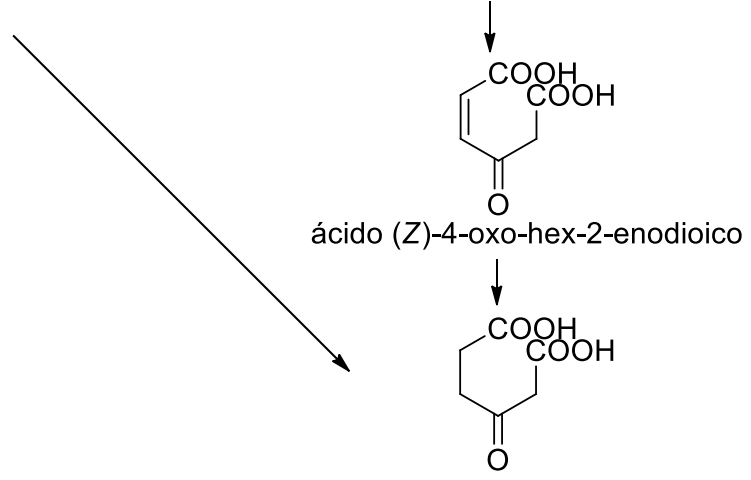

ácido3-oxo-hexanodioico Ciclo de Krebs

Fonte: Adaptado de BRAJESH K. SINGH.; ALLAN WALKER. Microbial degradation of organophosphorus compounds. FEMS Microbiology Reviews v. 30, p. 428-471, 2006. ${ }^{57}$ 


\subsubsection{Profenofós}

Profenofós, fosforotioato de $O$-4-bromo-2-clorofenil- $O$-etil- $S$-propila, é classificado como pesticida organofosforado, possui ação acaricida e inseticida. Este pesticida é aplicado na estrutura foliar nas culturas de algodão, amendoim, batata, café, cebola, ervilha, feijão, feijão-vagem, girassol, mandioca, melancia, milho, pepino, repolho, soja, tomate e trigo na agricultura brasileira. ${ }^{83} \mathrm{O}$ profenofós é classificado como um pesticida moderadamente perigoso (Classe Toxicológica II) pela Organização Mundial da Saúde. ${ }^{84,85}$

O pesticida foi registrado pela primeira vez nos Estados Unidos em 1982. ${ }^{89}$ O profenofós é extremamente tóxico para peixes e macroinvertebrados e a sua ação tóxica aguda é a inibição da enzima acetilcolinesterase, resultando também em toxicidade para seres humanos. $90,91,92$

Estudos mostraram que o modo de biotransformação do profenofós em meio ácido e neutro é a alquilação, mas em meio alcalino sofre hidrólise, resultando no fenol e no ácido fosfórico dialquilado (Figura 17). ${ }^{101,102}$

Figura 17. Degradação do profenofós em meio aquoso.

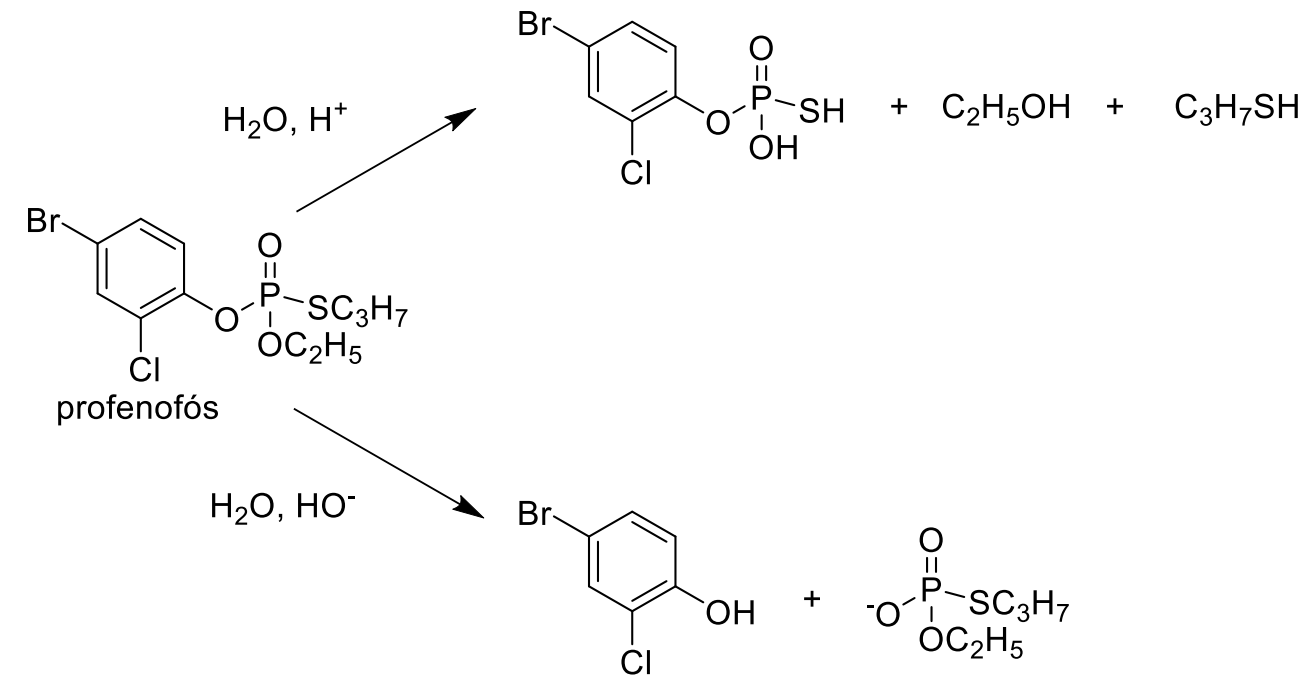

Fonte: SILVA, N.A.; BIROLLI, W.G.; SELEGHIM M.H.R.; PORTO, A.L.M. Biodegradation of the Organophosphate Pesticide Profenofos by Marine Fungi. Applied Bioremediation, cap.7, p. 149-180, $2013 .{ }^{103}$ 
Algumas vias de degradação para o profenofós são descritas na literatura, um exemplo é a rota metabólica em culturas de algodão que foi investigada e envolve a clivagem do éster de fosforotioato para a obtenção de 4-bromo-2-clorofenol, seguido de conjugação com uma molécula de glicose. ${ }^{93}$

Estudos utilizando ratos como cobaias, revelaram que o profenofós é rapidamente absorvido pelo trato gastrointestinal para o sistema circulatório e excretado pela urina (94\% da dose em 24 horas). ${ }^{86}$ Os metabólitos são resultantes da degradação do profenofós por hidrólise e conjugação dos compostos fenólicos. Esses metabólitos podem ser encontrados tanto na urina como nas fezes. Não houve evidências de bioacumulação do produto nos tecidos dos animais nem diferenças de eliminação entre machos e fêmeas. ${ }^{86}$ A Figura 18 ilustra as vias metabólicas do profenofós em seres humanos com seus respectivos produtos de hidrólise mediados por reações de fase I e seus metabólitos conjugados mediados por reações de fase II. ${ }^{86}$

Figura 18. Vias metabólicas do profenofós em seres humanos.

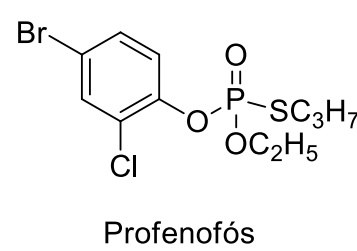<smiles>OC1OC(Oc2ccc(Br)cc2Cl)C(O)C(O)C1O</smiles>

glicosídeo de 4-bromo-2-clorofenila

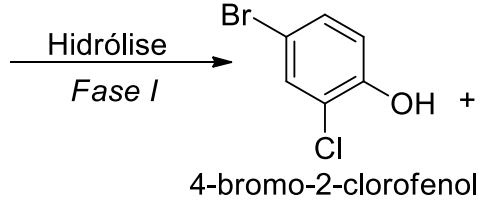

4-bromo-2-clorofenol

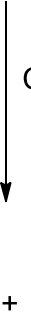

fosfato de 4-bromo-2-clorofenila

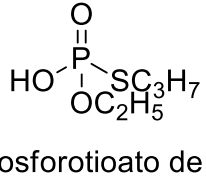

O-etil S-propila

$$
\text { Conjugação }
$$$$
\text { Fase II }
$$<smiles>O=P([O-])(O)Oc1ccc(Br)cc1Cl</smiles>

.; SUZUKI O.; Profenofos Fonte: Adaptado de GOTOH M. ; SAKATA M.; ENDO T , HAYASHI H.; SENO H.; S
metabolites in human poisoning. Forensic Science International, p. 221-2261, 2000. ${ }^{162}$

\subsubsection{Compostos fenólicos}

Os compostos fenólicos enquadram-se nos resíduos resultantes da biodegradação de produtos naturais e da atividade antrópica. Assim, são frequentemente encontrados no solo e na água, mas apesar de serem amplamente distribuídos na natureza fazem parte dos principais poluentes tóxicos residuais descartados por uma variedade de atividades industriais, como têxteis, refino de petróleo, papel e celulose, farmacêutica, revestimento de metais, preservação 
de madeira, corantes, resinas e plásticos, conversão de carvão, além de serem componentes de muitos pesticidas. ${ }^{94,95,96}$

A toxicidade destes compostos fenólicos em ambientes aquáticos tem sido estudada e é conhecido que a presença destes contaminantes, em níveis de partes por milhão (ppm), afeta significantemente as propriedades organolépticas da água. Outra característica indesejável destes contaminantes é o fato de que, no processo de cloração da água potável, a sua reação com cloro produz clorofenois e policlorofenois que são carcinogênicos. ${ }^{96}$

Alguns compostos fenólicos estão naturalmente presentes na água do mar, uma vez que alguns bromofenois são produzidos por algumas espécies de algas vermelhas; entretanto, diversos estudos têm mostrado que a água poluída é a principal fonte de absorção de fenol por organismos aquáticos. ${ }^{96,97} \mathrm{Em}$ efluentes industriais podem ser encontrados mais de um tipo de poluente fenólico. Aqueles que apresentam estruturas mais complexas são frequentemente mais tóxicos que o fenol. Os cresois, clorofenois e resorcinol, por exemplo, são encontrados em efluentes industriais, os quais são compostos potencialmente tóxicos ao meio ambiente. ${ }^{96}$

A necessidade do restabelecimento das áreas contaminadas tem levado ao desenvolvimento de métodos para a remoção de fenol do ambiente aquático. O objetivo principal é alcançar uma completa mineralização do poluente a dióxido de carbono e água e, além disso, reduzir a toxicidade dos compostos intermediários. ${ }^{96}$

A resolução CONAMA n 430, publicada em 13 de maio de 2011, complementa e altera a Resolução CONAMA 357/2005 e definiu como padrão de lançamento para efluentes industriais o teor de $0,5 \mathrm{mg} . \mathrm{L}^{-1}$ de fenois totais, expresso como $\mathrm{C}_{6} \mathrm{H}_{5} \mathrm{OH} .{ }^{98}$

Como a legislação ambiental e os exigentes padrões de qualidade de saúde pública tornam-se cada vez mais restritivos o uso de substâncias tóxicas, bem como métodos eficientes de tratamentos destes poluentes. Assim, surgem demandas para definir estratégias para o desenvolvimento de tecnologias limpas, melhorias nos processos existentes e desenvolvimento de sistemas industriais fechados de purificação e reciclagem de águas. Com estas ações, pretende-se buscar soluções para os problemas estabelecidos e se antecipar com relação às novas fontes poluidoras. ${ }^{100}$

Os compostos fenólicos podem sofrer biodegradação por fungos e bactérias. Através do metabolismo microbiano, que consiste basicamente, de uma série de reações enzimáticas e divide-se em três fases principais: hidrólise, ciclo de Krebs e cadeia respiratória. ${ }^{141,142}$

A Figura 19 ilustra duas rotas de biodegradação do fenol, sendo a primeira rota mediada pela enzima fenol 2-hidroxilase e a segunda rota mediada pela enzima fenol 2-monoxigenase. 
$\mathrm{Na}$ rota $\mathrm{A}$ de biodegradação do fenol o oxigênio é usado pela enzima fenol 2-hidroxilase para adicionar uma segunda hidroxila na posição orto. A reação requer uma redução do cofator NADH. ${ }^{142,143} \mathrm{O}$ resultado é catecol (1,2-diidroxibenzeno) molécula que pode ser degradada por duas rotas alternativas, dependendo do microrganismo. Na rota orto- $\beta$ cetoadipato, o anel aromático é clivado entre as hidroxilas do catecol pela enzima catecol 1,2dioxigenase. Resultando no ácido cis,cis-mucônico, que posteriormente é metabolizado via $\beta$ cetoadipato, para o ciclo de Krebs. Seguindo a rota meta, a fissão do anel ocorre na parte adjacente aos dois grupos hidroxila do catecol. A enzima catecol 2,3-dioxigenase transforma catecol em 2-hidroximucônico semialdeído, que é posteriormente metabolizado pelo ciclo de Krebs. ${ }^{141,142,143}$

$\mathrm{Na}$ rota $\mathrm{B}$ de biodegradação do fenol, o oxigênio é usado pela enzima fenol 2monoxigenase para adicionar uma segunda hidroxila ao grupamento fenólico na posição orto. Em seguida a enzima catecol 1,2-dioxigenase é responsável pela catálise da orto-clivagem na qual, a abertura do anel benzênico ocorre na ligação carbono-carbono entre os dois grupos hidroxila do catecol. A enzima catecol 2,3-dioxigenase catalisa a meta-clivagem em que a abertura do anel ocorre na ligação carbono-carbono mais próxima. ${ }^{144,145}$ 
Figura 19. Rotas de biodegradação do fenol mediadas pelas enzimas a) fenol 2-hidoxilase e b) fenol 2monoxigenase.

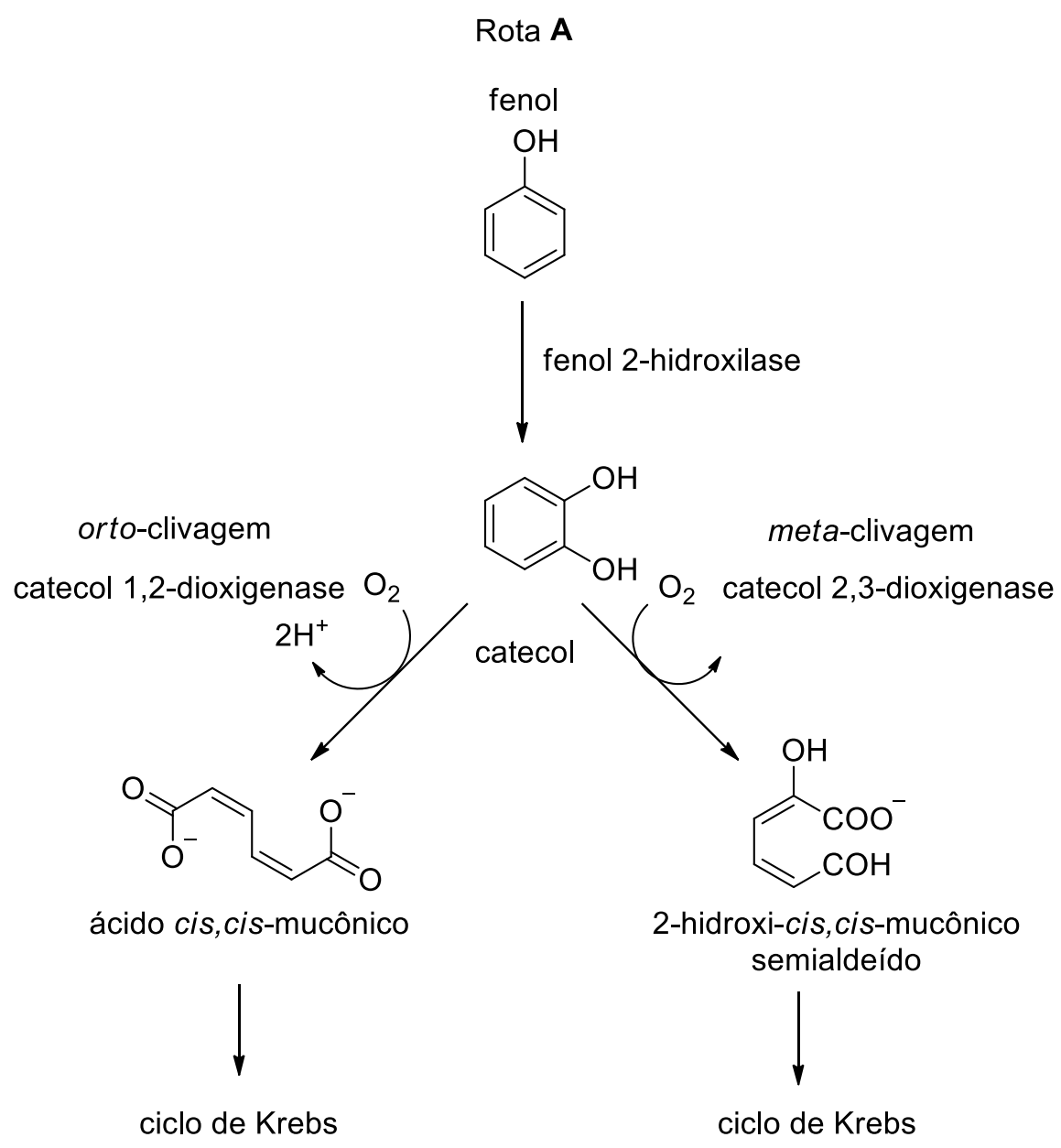

Fonte: SCHIE, P.M.; YOUNG, L.Y., Biodegradation of phenol: Mechanisms and applications, Biorremetion Journal, v. 4/1, p. 1-18, 2000. ${ }^{143}$ 


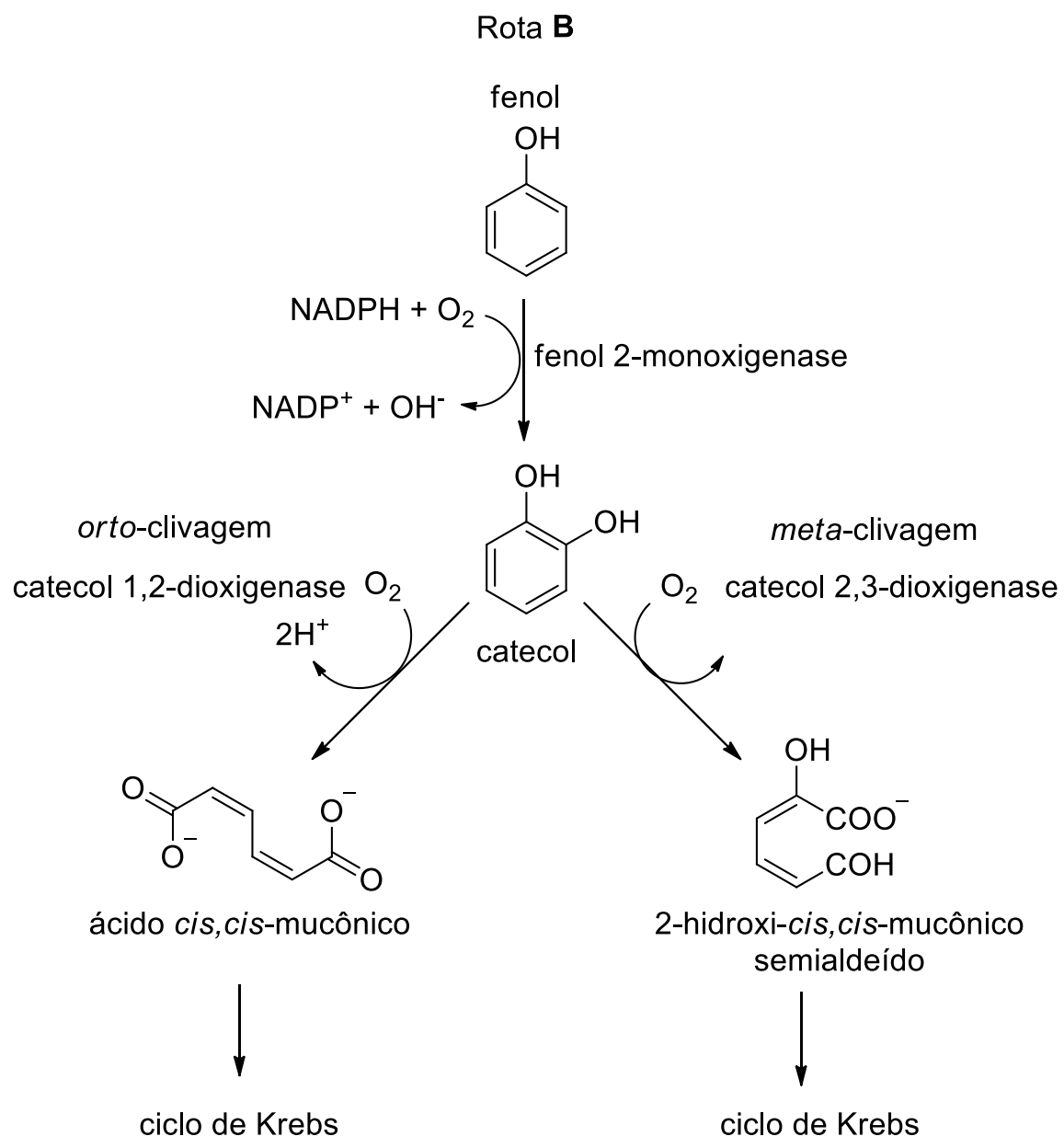

Fonte: ORJUELA, G.L Isolamento de cepas bacterianas degradadoras de hidrocarbonetos. $2016.107 \mathrm{f}$. Tese (Doutorado em Microbiologia)-Institudo de biociências, Letras e Ciências Exatas-Universidade Estadual Paulista “Júlio de Mesquita Filho”, São José do Rio Preto 2016. ${ }^{145}$ 


\subsection{Fungos de ambiente marinho como fontes enzimáticas}

Os processos biológicos são bastante vantajosos e os microrganismos, devido à sua versatilidade enzimática, são eficazes em degradar compostos xenobióticos. Os microrganismos na natureza, além de outras funções que desempenham, atuam como decompositores e desempenham importante papel na reciclagem de nutrientes. ${ }^{107}$ A triagem de microrganismos fúngicos para a produção de enzimas oxidantes de compostos tóxicos até a sua mineralização é de fundamental importância para que os mesmos possam ser utilizados em biotransformações. Os fungos secretam uma diversidade de enzimas no ambiente que são utilizadas para auxiliar sua nutrição. Desta forma, são responsáveis pela deterioração de vários materiais naturais, refinados ou processados. ${ }^{105}$

A utilização de fungos tem sido investigada em processos de biorremediação em virtude do alto potencial degradativo, biossortivo (metais tóxicos e corantes) e dos mecanismos de resistência em condições ambientais diversas. ${ }^{106}$

Os fungos de ambiente marinho são adaptados a alta salinidade e condições extremas, desenvolvendo atributos que lhes conferem a capacidade de produzir compostos biologicamente ativos diferentes de seus respectivos representantes que habitam o meio terrestre. ${ }^{115}$ São capazes de utilizar os pesticidas como fonte de alimento e energia em transformações catalisadas por suas enzimas, as quais resultam em modificações na estrutura química, propriedades toxicológicas e no potencial poluente desses compostos. ${ }^{116}$

Os fungos são organismos eucariotos que se diferem das bactérias em tamanho, genoma e em muitas das suas funções celulares que são típicas de organismos complexos. Apresentam crescimento celular vegetativo na forma de micélios e hifas seguidos pela mudança da forma e estrutura (morfogênese) com a formação de esporos assexuados e sexuados. ${ }^{108}$ Os mesmos apresentam crescimentos vegetativos associados com a divisão nuclear mitótica. A parede celular do fungo não contém glicopeptídeo, presentes nas bactérias, mas vários tipos de polissacarídeos (celulose, quitina e quitosana) e glicoproteínas. ${ }^{109}$ Os fungos, em geral, são vantajosos para serem utilizados em processos de biorremediação, pois são facilmente obtidos na forma de culturas puras, são cultiváveis em laboratórios, são resistentes a xenobióticos recalcitrantes e tóxicos, apresentam longo período de vida, estão distribuídos em todos os ambientes do planeta e ainda são eucariotos, cujo metabolismo enzimático, mimetiza os mamíferos. ${ }^{108}$

Os fungos marinhos podem ser divididos em dois grupos, fungos marinhos obrigatórios e fungos marinhos facultativos. Essa divisão depende de quanto à sua habilidade de crescer e se 
reproduzir. Fungos marinhos obrigatórios são aqueles que crescem e reproduzem exclusivamente no ambiente marinho, enquanto os fungos marinhos facultativos são aqueles de ambiente terrestre ou de água doce que são capazes de crescerem e se reproduzirem em ambientes marinhos. 108

A utilização de microrganismos nos processos biotecnológicos de biotransformações de resíduos tóxicos mediados por fungos ou bactérias são os principais responsáveis pela degradação de xenobióticos em um ambiente contaminado, por exemplo, por policíclicos aromáticos. Além de promover menores investimentos, a chamada biotecnologia ambiental por usar os processos microbiológicos que ocorrem normalmente na natureza para remover poluentes e é viável de ser aplicada em localidades praticamente impossíveis de serem tratadas por outros processos, como é o caso das extensas áreas agriculturáveis e mares, que são o destino final de muitos poluentes. ${ }^{109}$

\subsection{Biometilação de compostos fenólicos por microrganismos}

Em organismos vivos as reações de biotransformação são categorizadas, não somente pela natureza da reação envolvida (oxidação, redução, hidrólise). Essas reações são categorizadas principalmente pela sequência normal com que elas ocorrem e geralmente são catalisadas pelas enzimas biotransformadoras de xenobióticos que são classificadas em reações de fase I (ou pré-sintéticas) e reações de fase II (sintéticas ou de conjugação). ${ }^{110}$

Um fator importante na toxicidade de um xenobiótico é a sua capacidade de ser excretado. Os rins dos vertebrados são constituídos de maneira a excretar compostos eletrólitos. Assim, quanto mais ionizado estiver um ácido orgânico no $\mathrm{pH}$ do meio, mais rapidamente ele será excretado pelos rins. A ionização, por sua vez, depende do momento dipolar ou grau de polaridade da molécula ou íon, ou seja, da distância entre o centro geométrico de todas as cargas positivas e de todas as cargas negativas. Moléculas com momento de dipolo baixo (carga positiva perto da carga negativa) terão uma simetria maior e, portanto, uma ionização mais difícil. Já moléculas com maiores dipolos, ou seja, onde as cargas positivas e negativas estão polarizadas terão uma menor simetria e, consequentemente, maior ionização. ${ }^{111}$ Nas reações de conjugação, os xenobióticos provenientes ou não da fase pré-sintética (fase I) ligam-se aos substratos endógenos do organismo formando metabólitos mais excretáveis e menos tóxicos, ou seja, na conjugação observa-se uma modificação na estrutura do xenobiótico, uma maior polaridade, maior ionização, maior excreção e menor toxicidade. $^{111}$ 
O processo de degradação de compostos por fungos é conhecido como micodegradação. Nesse processo o composto é degradado em moléculas menores, que podem ser tóxicos ou não, ou ainda removidos por mecanismos de absorção, adsorção ou por reações de conjugação de fase II. ${ }^{117}$ Estas conjugações introduzem grupos endógenos, os quais são usualmente polares e presentes em abundância in vivo, resultando em produtos mais polares, exceto em reações de metilação e, portanto os compostos formados são mais facilmente eliminados. É importante ressaltar que os xenobióticos conjugados podem sofrer as reações inversas gerando metabólitos modificados novamente. ${ }^{118}$

A metilação é uma biotransformação onipresente na natureza, utilizada no metabolismo e muitas vezes é a chave para a homeostase metabólica que é a tendência existente em alguns organismos para o equilíbrio e conservação de elementos fisiológicos e do metabolismo através de alguns mecanismos de regulação. ${ }^{119}$

A Figura 20 ilustra a rota de biodegradação por via enzimática do pesticida clorpirifós e serve como exemplo de reação de biotransformação de um xenobiótico tóxico mediado por enzimas provenientes de microrganismos.

O processo de biodegradação do pesticida leva a uma série de complexas reações enzimáticas que envolvem três fases, cada fase é realizada por diferentes enzimas. ${ }^{123,146}$

A primeira etapa do processo envolve reações de oxidação, redução e hidrólise, essas reações de biotransformação aumentam a solubilidade do composto em meio aquoso. Geralmente ocorre a oxidação do pesticida clorpirifós, formando o composto clorpirifós-oxon por enzimas do citocromo P450, peroxidases e oxidases de polifenol. ${ }^{123}$

As enzimas mais conhecidas que hidrolisam pesticidas organofosforados são: aril dialquil fosfatases, organofosforado hidrolases e fosfotriesterases. Microrganismos degradadores do clorpirifós são capazes de produzir qualquer uma destas enzimas, tais como: organohidrolases (OPHs), ${ }^{148,123}$ fosfotriesterases (PTEs) e metil paration hidrolases (MPHs). ${ }^{149,123}$ Estas enzimas se diferem na sequência da proteína, estrutura tridimensional e mecanismo catalítico, mas eles também compartilham várias características comuns. Todas estas enzimas hidrolases são dependentes de metais na forma de cátions bivalentes como $\mathrm{Cd}^{2+}, \mathrm{Co}^{2+}, \mathrm{Ni}^{2+}$, $\mathrm{Mn}^{2+}$ e $\mathrm{Zn}^{2+}$ que contenham um sítio ativo hidrofóbico com três cavidades de ligação para acomodar os grupos éster do substrato. A ativação do centro do substrato de fósforo ocorre por uma interação direta entre o oxigênio fosforílico e um metal divalente no sítio ativo da enzima. ${ }^{150,123}$

Posteriormente, na fase II ocorre a conjugação do pesticida ou a conjugação dos metabólitos gerados a partir do pesticida com açúcares, aminoácidos e grupos metilas e etilas. 
Os produtos formados podem aumentar a solubilidade com a água e têm a tendência de reduzir a toxicidade em comparação com o composto progenitor. ${ }^{123,146}$

A Figuara 20 mostra a ação de enzimas nas reações de fase $I$ e de fase II na biotransformação do clorpirifós.

Figura 20. Via de degradação por enzimas fosfotriesterases na fase I e metiltransferases na fase II para o clorpirifós.

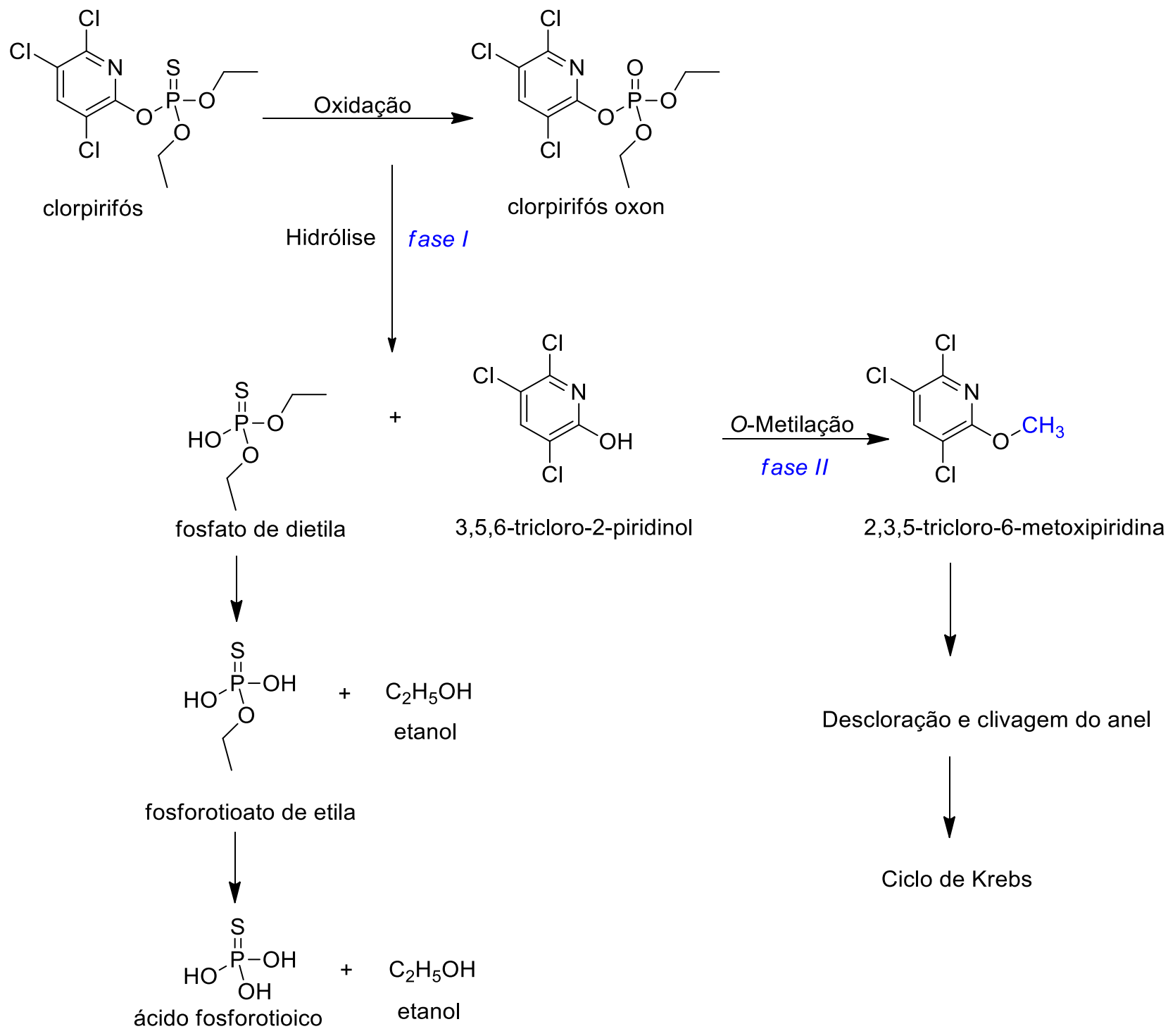

Fonte: Adaptado de ELIZABETH M.J.; JISHA M.S.; Chlorpyrifos: pollution and remediation, Environmental

Chemistry Letters, Springer International Publishing Switzerland, review, v. 13, p. 269-291, $2015 .{ }^{123}$ 
A Figura 21 ilustra o sítio ativo metal-depente da enzima fosfotriesterase que é responsável pela hidrólise, reação de fase I do pesticida clorpirifós, onde as esferas negras no centro da ilustração representam os átomos de zinco.

Figura 21. Representação de resíduos de aminoácidos: ácido aspártico, histidina e lisina coordenados com $\mathrm{Zn}^{2+}$ no sítio ativo da enzima fosfotriesterase.

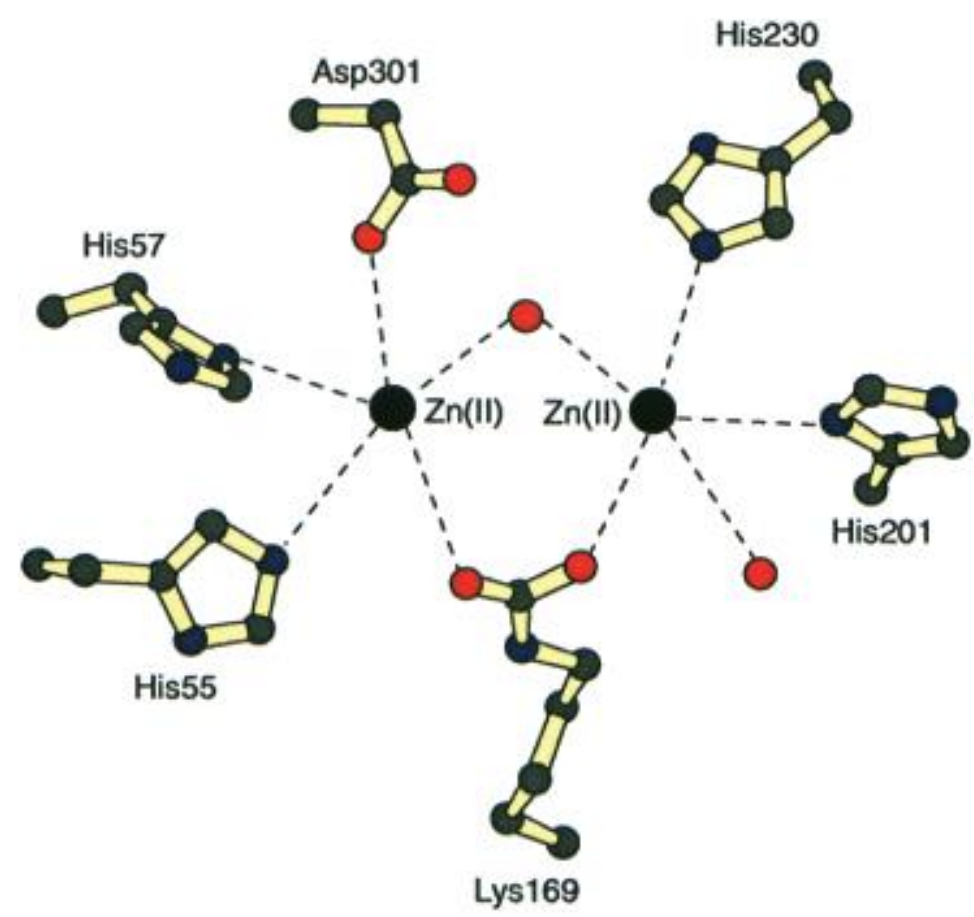

Fonte: BRAJESH K. SINGH.; ALLAN WALKER. Microbial degradation of organophosphorus compounds.

FEMS Microbiology Reviews v. 30, p. 428-471, 2006. ${ }^{57}$

Em sistemas biológicos, a metilação é catalisada por enzimas metiltranferases, tais metilações podem estar envolvidas na modificação de metais tóxicos, regulação de expressão gênica, regulação de funções de proteínas e no metabolismo de RNA. ${ }^{111}$

A metilação refere-se mais especificamente à substituição de um átomo de hidrogênio pelo grupo metila. ${ }^{111}$

A metilação é uma reação química utilizada em todos os ramos do metabolismo. Estas transformações controlam diversos processos biológicos, tais como sinalização celular e a biossíntese de metabólitos complexos. Estas reações são mais frequentemente catalisadas por enzimas metiltransferases (MTs), por vezes referidas como (trans) metilases, que contam com o co-substrato $S$-adenosil-L-metionina (SAM) como um doador de elétrons. O subproduto de metilação é $S$-adenosil-L-homocisteína (SAH). ${ }^{158}$ 
Enzimas metiltransferases participam na biossíntese e modificação de moléculas bioativas do metabolismo secundário e todas as metiltransferases são classificadas de acordo com o seu substrato, onde os átomos que aceitam o grupo metila, geralmente são $\mathrm{O}(54 \%), \mathrm{N}$ $(23 \%)$ e C $(18 \%) .{ }^{158}$ As enzimas metil transferases mais abundantes são $O$-dirigidas e conhecidas como orto-metiltransferases (OMTs). ${ }^{158}$

A metilação de oxigênio ( $O$-metilação), nitrogênio $(N$-metilação) e o carbono $(C$ metilação) são processos fundamentais para todos os organismos e em plantas, os padrões de $O$-metilação de pequenas moléculas poli-hidroxilados são cruciais para fins de regulação, estrutural e funcional, incluindo a proteção contra o fotoenvelhecimento UV. ${ }^{158,159}$

Árvores de álamo (Populus sp.) codificam 26 moléculas diferentes de ortometiltransferases, enquanto apenas duas enzimas orto-metiltransferases são encontradas em seres humanos, a enzima catecol orto-metiltransferase (COMT) e $N$-acetil-serotonina ortometiltransferase (NOMT). ${ }^{158}$ As enzimas metiltransferases podem servir como reguladores, modificando a reatividade de vários xenobióticos tóxicos para seres humanos. ${ }^{119}$

A Figura 22 ilustra a estrutura tridimensional das enzimas chalcona $O$-metiltransferase (ChOMT) e isoflavona $O$-metiltransferase (IOMT) e as Figuras 23 e 24 ilustram o mecanismo enzimático das enzimas (ChOMT) e (IOMT) que são enzimas metiltransferases envolvidas no metabolismo secundário de vegetais. As duas enzimas possuem no sítio ativo, o cofator $S$ adenosil-L-metionina (SAM) que após transferir o grupo metila contido em sua estrutura molecular para o substrato a ser metilado, há a formação do subproduto de metilação $S$ adenosil-L-homocisteína (SAH).

O mecanismo de reação é baseado sobre as estruturas das enzimas chalcona $O$ metiltransferase e isoflavona $O$-metiltransferase. A metilação prossegue mais provavelmente através de desprotonação via base assistida do grupo hidroxila do substrato, seguido por um ataque nucleofílico do ânion fenolato recém-formado do substrato sobre o grupo metila reativo da $S$-adenosil-L-metionina. ${ }^{159}$

$\mathrm{Na}$ enzima chalcona $O$-metiltransferase, a desprotonação do grupo hidroxila do anel aromático do composto (E)-1-(2,4-diidroxifenil)-3-(4-hidroxifenil)prop-2-en-1-ona ocorre no centro ativo da enzima por dois resíduos de aminoácidos, ácido glutâmico (Glu 337) e histidina (His 278). Posteriormente, ocorre o ataque nuclofílico do ânion hidroxila ao grupo metila da $S$-adenosil-L-metionina. Como o enxofre de $S$-adenosil-L-metionina é carregado positivamente, o processo de transmetilação é facilitado e levando a formação do subproduto de Metilação, o $S$-adenosil-L-homocisteína. ${ }^{159}$ 
O processo catalítico da enzima isoflavona $O$-metiltransferase prossegue através de um mecanismo similar ao da enzima chalcona $O$-metiltransferase, o resíduo de aminoácido histidina (His 257) serve como a base responsável pela desprotonação do grupo hidroxila no anel aromático do composto 7-hdroxi-3-(4-hidroxifenil)-4H-cromen-4-ona. Da mesma forma que a enzima chalcona $O$-metiltransferase, os resíduos de aminoácidos, ácido aspártico (Asp 288) e ácido glutâmico (Glu 318), restringem estericamente o resíduo de aminoácido histidina (His 257) a posicionar seu nitrogênio através de ligação de hidrogênio com o ácido glutâmico número 318 para em seguida atacar o ânion fenolato do flavonoide 7-hidroxi-3-(4hidroxifenil)-4H-cromen-4-ona e que, posteriormente, ataca o grupo metila da $S$-adenosil-Lmetionina que é transformada ao final da reação de metilação em $S$-adenosil-L-homocisteína (Figuras 23 e 24). ${ }^{159}$ 
Figura 22. Representação estrututal das enzimas chalcona $O$-metiltranferase (ChOMT) e isoflavona $O$ metiltransferase (IOMT) e compostos catalizados pelas respectivas enzimas.

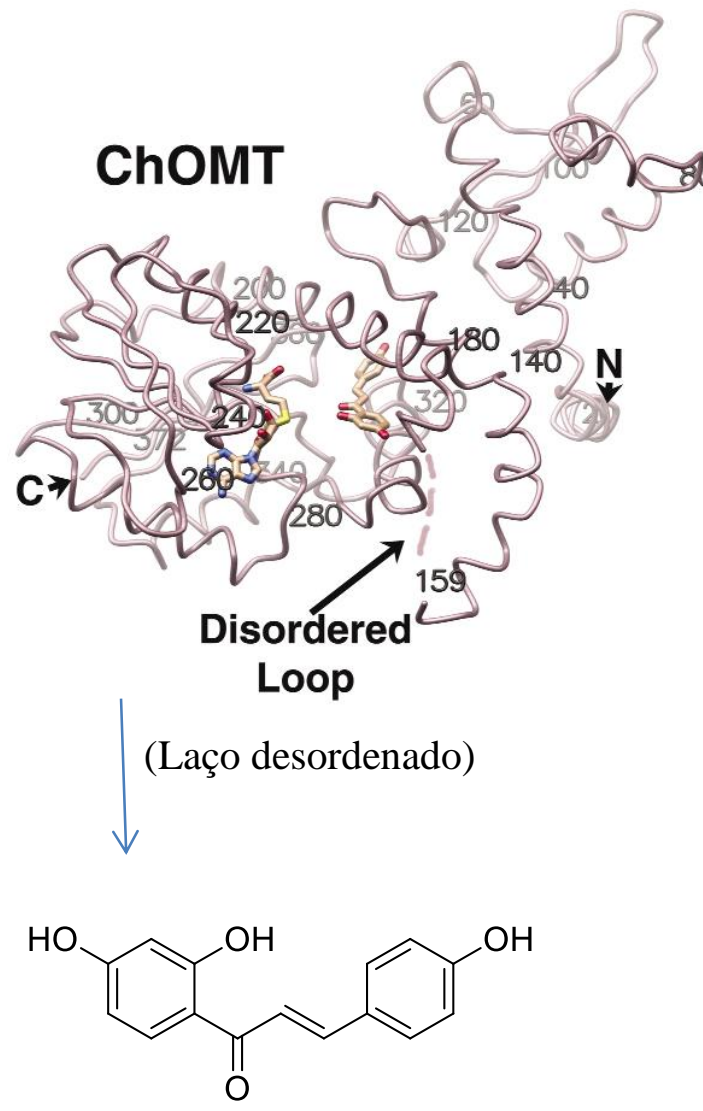

$(E)$-1-(2,4-diidroxifenil)-3(4-hidroxifenil)prop-2-en-1-ona

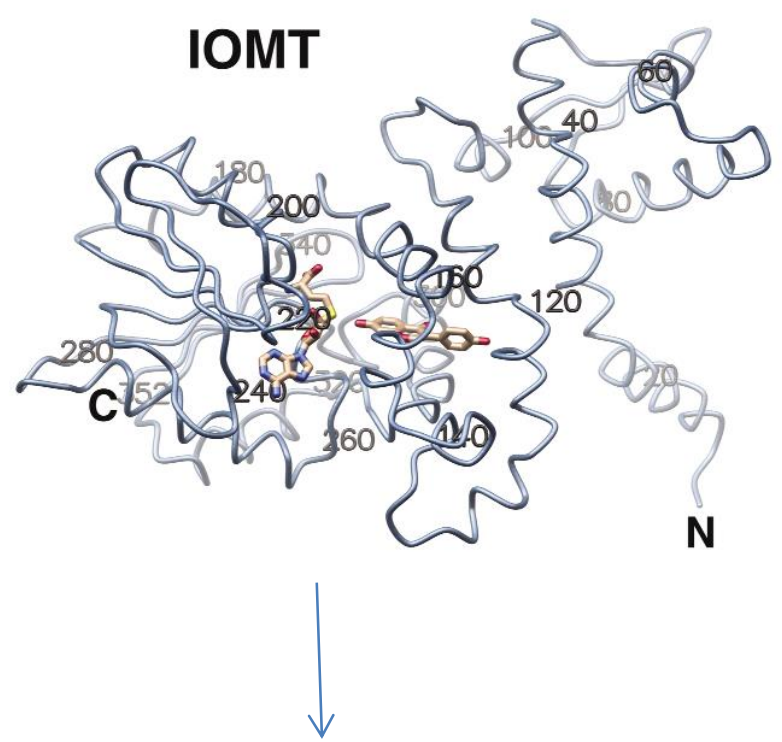<smiles>O=c1c(-c2ccc(O)cc2)coc2cc(O)ccc12</smiles>

7-hdroxi-3-(4-hidroxifenil)-4H-cromen-4-ona

Fonte: ZUBIETA, C.; HE, X.Z.; DIXON, R.A.; NOEL, J.P. Structures of two natural product methyltransferases reveal the basis for substrate specificity in plant $O$-methyltransferases, Nature Structural Biology, v. 8, n. 3, p. 271-279, 2001. ${ }^{159}$ 
Figura 23. Mecanismo enzimático de biometilação da chalcona (E)-1-(2,4diidroxifenil)-3-(4-hidroxifenil)prop2-en-1-ona para (E)-1-(4-diidroxi-2-metoxifenil)-3-(4-hiroxifenil)pro-2-em-1-ona pela enzima chalcona $O$ metiltranferase (ChOMT).

A

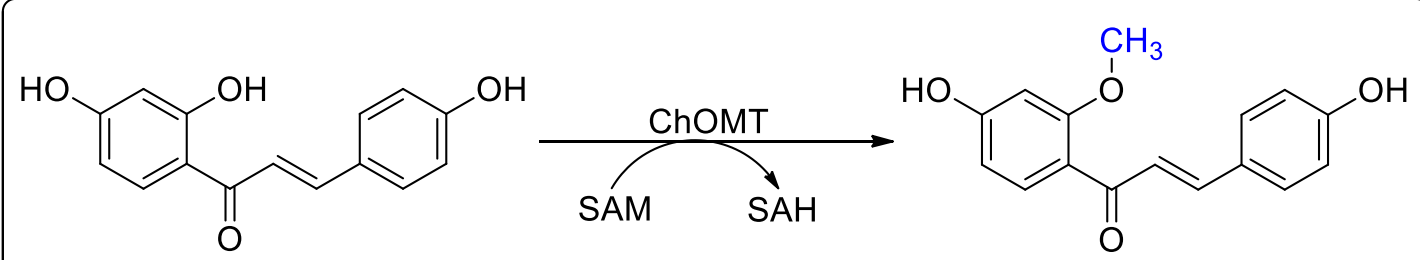

$(E)-1-(2,4-$ diidroxifenil)-3-

(E)-1-(4-diidroxi-2-metoxifenil)-3(4-hidroxifenil)prop-2-en-1-ona

(4-hidroxifenil)prop-2-en-1-ona

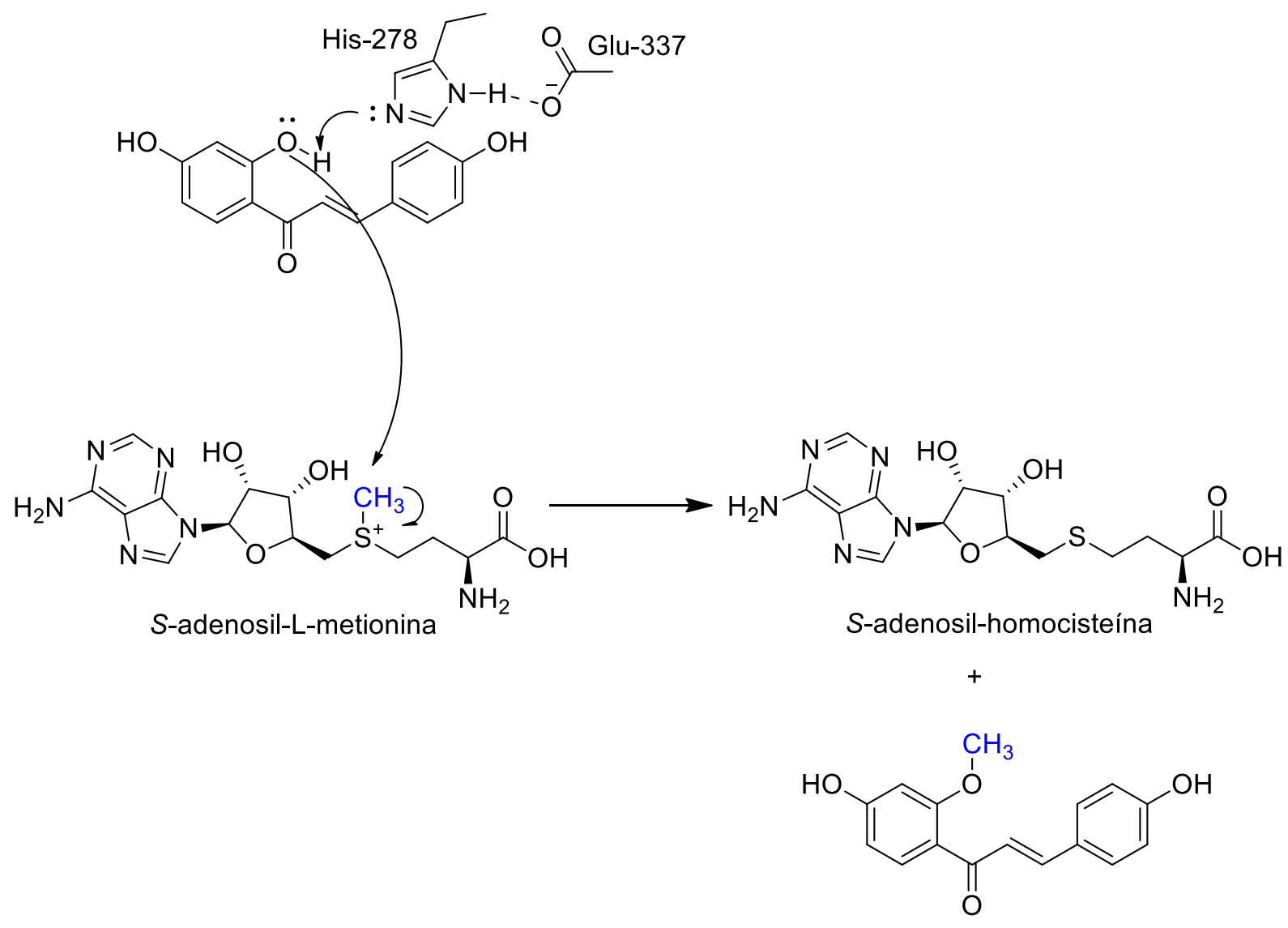

(E)-1-(4-diidroxi-2-metoxifenil)-3(4-hidroxifenil)prop-2-en-1-ona

Fonte: ZUBIETA, C.; HE, X.Z.; DIXON, R.A.; NOEL, J.P. Structures of two natural product methyltransferases reveal the basis for substrate specificity in plant $O$-methyltransferases, Nature Structural Biology, v. 8, n. 3, p. 271-279, 2001. ${ }^{159}$ 
Figura 24. Mecanismo enzimático de biometilação do flavonoide 7-hidroxi-3-(4-hidroxifenil)-4H-cromen-4-ona para 3-(4-hidroxifenil)-7-metoxi-4H-cromen-4-ona pela enzima isoflavona $O$-metiltransferase (IOMT).

B

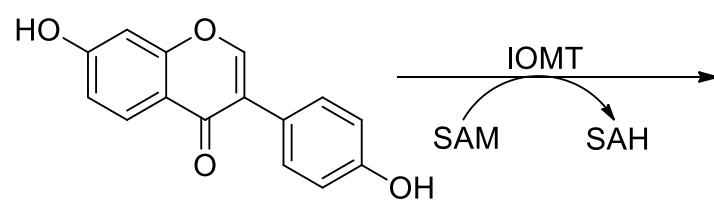<smiles>COc1ccc2c(=O)c(-c3ccc(O)cc3)coc2c1</smiles>

7-hidroxi-3-(4-hidroxifenil)-4H-cromen-4-ona 3-(4-hidroxifenil)-7-metoxi-4H-cromen-4-ona

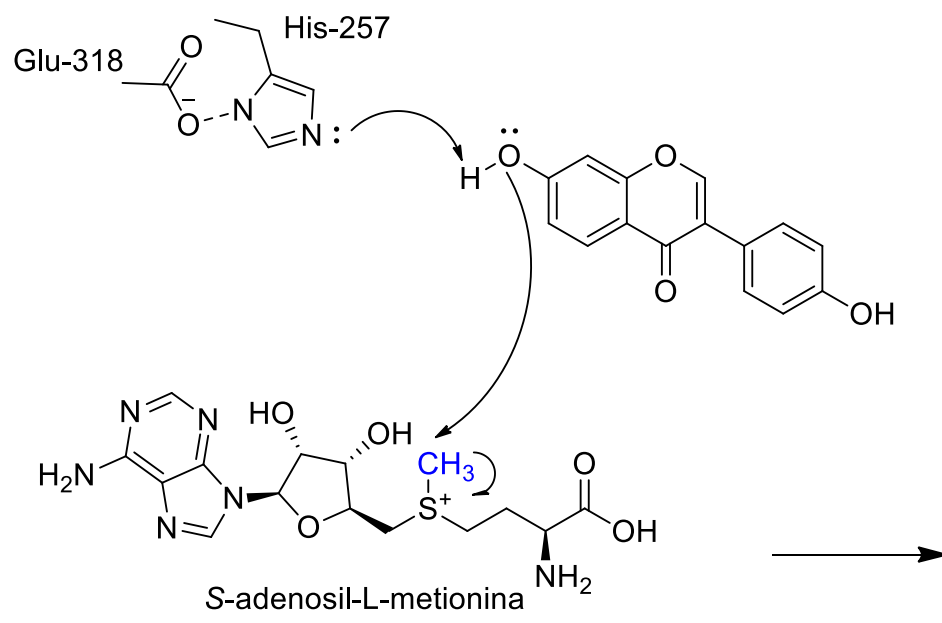<smiles>COc1ccc2c(=O)c(-c3ccc(O)cc3)coc2c1</smiles>

3-(4-hidroxifenil)-7-metoxi-4H-cromen-4-ona

Fonte: ZUBIETA, C.; HE, X.Z.; DIXON, R.A.; NOEL, J.P. Structures of two natural product methyltransferases reveal the basis for substrate specificity in plant $O$-methyltransferases, Nature Structural Biology, v. 8, n. 3, p. 271-279, 2001. ${ }^{159}$

Enzimas orto-metiltransferases tendem a ser regioespecíficas, mas algumas enzimas, tais como as envolvidas na biossíntese dos flavonoides e fenilpropanoide em organismos fotossintéticos, são menos seletivas, capazes de metilações sequenciais do mesmo substrato.

A Figura 25 ilustra a grande variedade de produtos naturais que são submetidos à metilação por enzimas orto-metiltransferases. 
Figura 25. Diversidade química de produtos naturais que podem ser biometilados por enzimas metiltransferases. As hidroxilas com círculos pontilhados representam os locais de possíveis metilações.<smiles>OCCCCCCCCCOc1ccccc1O</smiles>

catecol<smiles>O=C(O)c1ccccc1O</smiles>

ácido salicílico

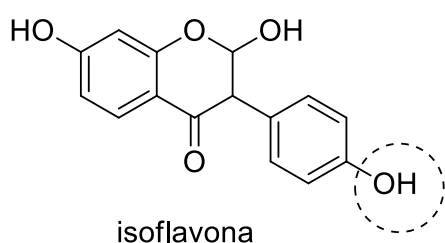
isoflavona<smiles>O=C1C=C(c2ccccc2)CCCCCCCC1</smiles>

chalcona<smiles>O=c1c(O)c(-c2ccc(O)c(O)c2)oc2cc(O)c(O)cc12</smiles>
quecertina<smiles>O=c1cc(-c2ccccc2)oc2cc(O)c(O)cc12</smiles>

6,7-diidroxiflavona

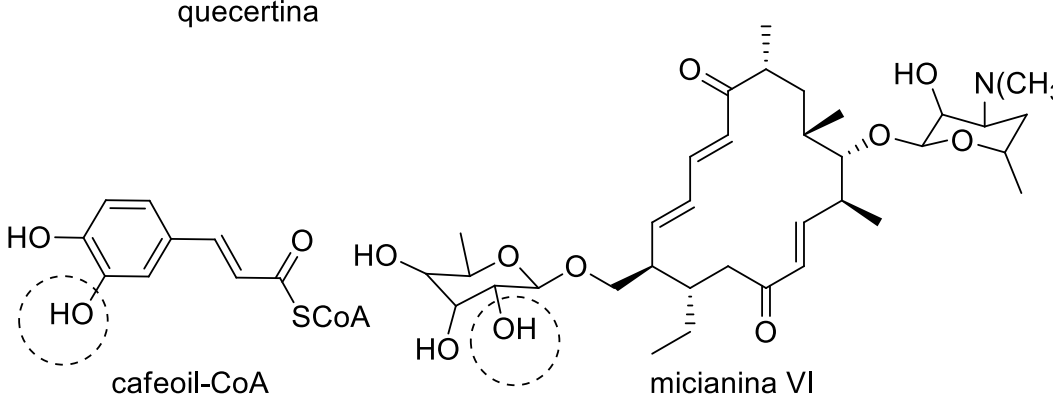
ácido cinâmico 3,4,5 triidroxi<smiles>Cc1cc(O)cc2c(C(=O)O)c(O)ccc12</smiles>
ácido 2,7-diidroxi-5-metil-1-naftoico

Fonte: LISCOMBE, D.K.; LOUIE, G.V.; NOEL, J.P.; Review: Architectures, mechanisms and molecular evolution of natural product methyltransferases, The Royal Society of Chemistry, ed. 29, p. 1238-1250, 2012. 158

A Figura 26 ilustra a diversidade química de substratos que podem ser catalisados por metiltranferases contendo átomos de $\mathrm{N}, \mathrm{C}$ e $\mathrm{S}$. Os grupos que estão com círculos pontilhados representam os locais de possíveis metilações. 
Figura 26. Diversidade química de produtos naturais que podem ser biometilados por enzimas metiltransferases de produtos naturais. Os grupamentos com círculos pontilhados representam os locais de possíveis metilações.<smiles>O=C(O)C1=CC=CC23CCCCC12N=c1ccccc1=N3</smiles>

fenazina-1-carboxílico

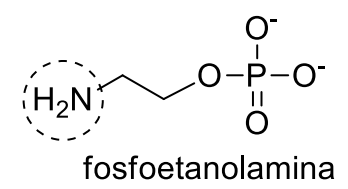<smiles>O=C(O)Cc1ccccc1</smiles>

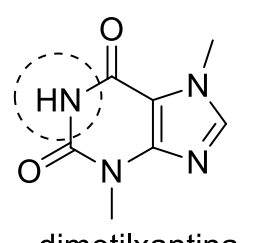

dimetilxantina<smiles></smiles>

6-mercaptopurina<smiles>Oc1ccc([C@@H](O)c2ccccc2)cc1O</smiles>

feniletanolamina
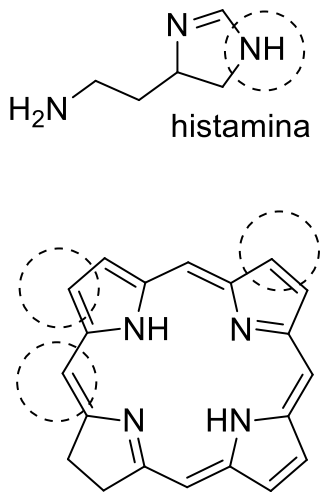

tetrapirrol acaffold<smiles>NC1=NC(C(=O)O)CCC1</smiles>

guaninoacetato<smiles>NC(=O)c1ccc2nc1CCC2</smiles>

Fonte: LISCOMBE, D.K.; LOUIE, G.V.; NOEL, J.P.; Review: Architectures, mechanisms and molecular evolution of natural product methyltransferases, The Royal Society of Chemistry, ed. 29, p. 1238-1250, 2012. 158

A Figura 27 ilustra a ação de enzimas metiltransferases na biotransformação do organoclorado pentaclorofenol. ${ }^{146}$

A principal reação de biotransformação do pentaclorofenol é a metilação, em que os grupos hidroxila $(-\mathrm{OH})$ são substituídos por grupos metoxila $\left(-\mathrm{OCH}_{3}\right)$. Esta via tem sido considerada um mecanismo de desintoxicação em compostos orgânicos recalcitrantes. ${ }^{146}$

O pentacloroanisol é um dos metabólitos intermediários mais frequentemente identificados durante a degradação do pentaclorofenol, o qual é menos tóxico para os fungos da podridão branca do que o pentaclorofenol. ${ }^{146}$

A via de degradação do pentaclofenol inicia-se com uma metilação e a subsequente formação do pentacloroanisol. A segunda reação é uma hidroxilação para formar o 2,3,5,6tetraclorobenzeno-1,4-diol, que em seguida é metilado para gerar tetracloro-1,4dimetoxibenzeno, seguido por reações sucessivas de descloração para formar 2,5-dicloro-1,4dimetoxibenzeno e 2-cloro-1,4-dimetoxibenzeno, respectivamente. Uma série de desmetoxilação, carboxilação, redução e reações de metilação são conduzidas para formar 3,4-dimetoxibenzaldeído, no final da via e a degradação completa do pentaclorofenol com a formação de $\mathrm{CO}_{2}{ }^{146}$ 
Figura 27. Ilustração de biometilação por enzimas metiltransferases e posterior degradação do pentaclorofenol pelo fungo Anthracophyllum discolor.<smiles>Oc1c(Cl)c(Cl)c(Cl)c(Cl)c1Cl</smiles>

pentaclorofenol<smiles>CCOc1c(Cl)c(Cl)c(O)c(Cl)c1Cl</smiles>

2,3,5,6-tetracloro benzeno-1,4-diol<smiles>COc1c(Cl)c(Cl)c(Cl)c(Cl)c1Cl</smiles>

pentacloroanisol<smiles>COc1c(Cl)c(Cl)c(OC)c(Cl)c1Cl</smiles>

tetracloro-1,4-dimetoxibenzeno<smiles>COc1ccc(OC)c(Cl)c1</smiles>

2-cloro-1,4-dimetoxibenzeno<smiles>COc1ccccc1O</smiles>

2-metoxifenol<smiles>COc1ccc(C=O)cc1OC</smiles>

3,4-dimetoxibenzaldeído

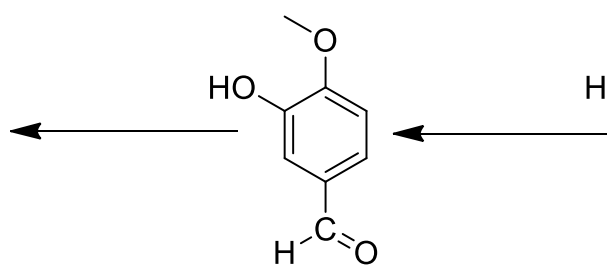

3-hidroxi-4- metoxibenzaldeído<smiles>COc1ccc(C(=O)O)cc1O</smiles>

ácido-3-hidroxi4- metoxibenzoico

Fonte: RUBILAR, O.; FEIJOO, G.; DIEZ, C.; LU-CHAU, T. A.; MOREIRA, M.T.; LEMA, J. M. Biodegradation of pentachlorophenol in soil slurry cultures by Bjerkandera adusta and Anthracophyllum discolor Chemical and Engineering Research, v. 46, p. 6744-6751, $2007 .{ }^{146}$ 
Apesar de já existirem trabalhos na literatura sobre biodegradação de pesticidas organosfosforados por fungos de ambiente marinho, têm-se poucos relatos de estudos para conhecer as rotas de conjugação e biodegradação ou bioacumulação de metabólitos fenólicos provenientes destes pesticidas. No estudo prévio de autoria de Natália Alvarenga da Silva realizado no Grupo de Química Orgânica e Biocatálise (GQOB), coordenado pelo prof. Dr. André Luiz Meleiro Porto, constatou-se que os compostos fenólicos eram consumidos do meio reacional, porém não foram detectados nas análises quais produtos eram formados, onde havia indícios que os compostos fenólicos podiam ter sido bioconjugados.

Assim, a proposta deste trabalho foi de realizar um estudo detalhado das reações de biotransformação de fase I e reações de conjugação de fase II, principalmente metilações em compostos fenólicos derivados de pesticidas organofosforados e outros fenois comuns por fungos do ambiente marinho. Assim realizou-se primeiramente um screening para escolha do melhor fungo para posteriores reações de biotranformação e avaliação do potencial enzimático deste microrganismo frente aos xenobióticos utilizados nesse trabalho.

O conhecimento das rotas de biodegradação destes compostos tóxicos é de interesse ambiental, uma vez que toneladas de pesticidas organofosforados e compostos fenólicos são lançados no meio ambiente. 


\section{OBJETIVOS}

\subsection{Geral}

Estudar as reações de conjugação de fase II nos compostos fenólicos (3,5,6-tricloro-2piridinol, 4-nitrofenol e 4-bromo-2-clorofenol) derivados da hidrólise enzimática (reação de fase I) dos pesticidas organosfosforados (clorpirifós, metil paration e profenofós) e as reações de biotransformação dos compostos fenólicos: fenol, 2-clorofenol, 2-cloro-5-hidroxipiridina, 4-(4-hidroxifenil)ciclo-hexanona, pentaclorofenol e naringenina por enzimas provenientes de fungos de ambiente marinho.

\subsection{Específicos}

a) Realizar um screening em meio de cultura sólido com fungos de ambiente marinho frente aos pesticidas organofosforados (clorpirifós, metil paration e profenofós) para avaliar a resistência destes microrganismos frente à toxicidade dos pesticidas testados para posterior escolha da cepa mais resistente e melhor adaptada aos pesticidas para posteriores reações de biotransformação em meio de cultura líquido;

b) Investigar através de análises cromatográficas, as reações de conjugação de compostos fenólicos provenientes de hidrólises enzimáticas ocasionadas por enzimas provenientes de fungos de ambiente marinho nos pesticidas organofosforados (clorpirifós, metil paration e profenofós);

c) Sintetizar os metabólitos encontrados nas reações de conjugação de fase II para corroborar os resultados encontrados em análises cromatográficas;

d) Analisar e quantificar os produtos formados por reação enzimática por métodos cromatográficos (HPLC e CG-EM); 


\section{METODOLOGIA}

\subsection{Pesticidas organofosforados, compostos fenólicos, reagentes de síntese de metilação,} solventes e meio de cultura

Padrões analíticos dos pesticidas organofosforados: clorpirifós (99\%), metil paration $(99 \%)$ e profenofós $(99 \%)$ foram adquiridos da Fluka ${ }^{\circledR}$.

Padrões analíticos dos compostos fenólicos derivados dos pestidas organofosforados citados acima: 3,5,6-tricloro-2-piridinol (99\%) e 4-nitrofenol (99\%) foram adquiridos da Fluka ${ }^{\circledR}$ e 4-bromo-2-clorofenol (99\%) foi adquirido da Sigma-Aldrich ${ }^{\circledR}$.

Padrões analíticos dos compostos fenólicos: fenol (99\%), 2-cloro-5-hidroxipiridina (99\%), pentaclorofenol $(98 \%)$ e naringenina (95\%) foram adquiridos da Sigma-Aldrich ${ }^{\circledR}$. Os compostos fenólicos 2-clorofenol (99\%) e 4-(4-hidroxifenil)ciclo-hexanona (98\%) foram adquiridos da Fluka ${ }^{\circledR}$.

Reagentes utilizados na síntese de metilação de compostos fenólicos: $\mathrm{K}_{2} \mathrm{CO}_{3}(99 \%)$ (Vetec) e $\mathrm{CH}_{3} \mathrm{I}(99 \%)$ (Sigma Aldrich ${ }^{\circledR}$ ) e acetona (99\%) (Quemis).

Sais utilizados para preparação da água do mar artificial $\left(\mathrm{CaCl}_{2} \cdot 2 \mathrm{H}_{2} \mathrm{O}, \mathrm{MgCl}_{2} \cdot 6 \mathrm{H}_{2} \mathrm{O}\right.$, $\mathrm{KCl}, \mathrm{NaCl}, \mathrm{Na}_{2} \mathrm{HPO}_{4}, \mathrm{Na}_{2} \mathrm{SO}_{4}, \mathrm{NaHCO}_{3}, \mathrm{KBr}, \mathrm{SrCl}_{2} \cdot 6 \mathrm{H}_{2} \mathrm{O}$ e $\mathrm{H}_{3} \mathrm{BO}_{3}$ ) foram adquiridos da Synth, Merck e Vetec.

Solventes: acetato de etila (Synth), acetato de etila grau cromatográfico (Panreac), acetonitrila (Panreac), água Milli-Q (Millipore Corporation ${ }^{\circledR}$ ), dimetilsulfóxido (Synth), hexano grau cromatográfico (Panreac) e isopropanol grau cromatográfico (Panreac).

Meio de cultura para crescimento de microrganismos: extrato de malte (Acumedia) e Agar (Himedia).

\subsection{Fonte dos pesticidas comerciais}

O pesticida clorpirifós foi obtido de Dow AgroSciences com o nome comercial Lorsban 480 BR. O metil paration foi obtido de Agripec com o nome comercial Folisuper 600 BR. O profenofós foi obtido de Syngenta com nome comercial Polytrin 400/40 CE. Os pesticidas comerciais foram doados pelo Prof. Dr. Marcos Roberto de Vasconcelos Lanza (Instituto de Química de São Carlos). 


\subsection{Equipamentos e curvas analíticas para quantificação dos compostos}

\subsubsection{Cromatografia a gás acoplada ao espectrômetro de massas (CG-EM)}

As análises por cromatografia a gás acoplada ao espectrômetro de massas foram realizadas em um aparelho Shimadzu/GC-2010 equipado com auto injetor Shimadzu/AOC5000 e detector de massas (Shimadzu MS2010 plus) com impacto de elétrons (IE, $70 \mathrm{eV}$ ). O forno do cromatógrafo foi equipado com uma coluna de sílica fundida DB-5 (J\&W Scientific, $30 \mathrm{~m} \times 0,25 \mathrm{~mm} \times 0,25 \mu \mathrm{m})$. O gás de arraste foi o hélio a $63 \mathrm{kPa}$.

Para as análises das reações de bioconjugação dos pesticidas organofosforados clorpirifós, metil paration, profenofós e seus compostos fenólicos 3,5,6-tricloro-2-piridinol, 4nitrofenol e 4-bromo-2-clorofenol a temperatura do injetor foi de $250^{\circ} \mathrm{C}$ e a temperatura do detector foi de $270^{\circ} \mathrm{C}$. A temperatura inicial do forno foi de $60^{\circ} \mathrm{C}$, durante 2 min e aumentou até atingir $280^{\circ} \mathrm{C}$ com uma taxa de aquecimento de $6^{\circ} \mathrm{C} / \mathrm{min}$, mantendo esta temperatura durante 10 min., totalizando um tempo total de análise de 45 min. A razão de injeção (split ratio) foi de 1:1. Os analitos foram primeiro analisados no modo SCAN para selecionar os íons e o tempo de retenção para cada composto. Essa metodologia também foi usada para análise dos demais compostos fenólicos e seus respectivos produtos de biotransformação: fenol, anisol, pentaclorofenol, 2-clorofenol, 4-(4-hidroxifenil)ciclo-hexanona, 2-cloro-5hidroxipiridina, e 2-cloro-5-metoxipiridina.

Para as análises do flavonoide naringenina a temperatura do injetor foi de $250^{\circ} \mathrm{C}$ e a temperatura do detector foi de $280^{\circ} \mathrm{C}$. A temperatura inicial do forno foi de $110^{\circ} \mathrm{C}$, durante 2 min e aumentou até atingir $300^{\circ} \mathrm{C}$ com uma taxa de aquecimento de $20^{\circ} \mathrm{C} / \mathrm{min}$, mantendo esta temperatura durante 10 min., totalizando um tempo total de análise de 49,14 min. A razão de injeção (split ratio) foi de 1:1. O analito foi primeiro analisado no modo SCAN para selecionar os íons e o tempo de retenção do composto.

A Tabela 2 mostra os tempos de retenção e os íons moleculares para cada pesticida organofosforado, compostos fenólicos derivados dos pesticidas, produto de conjugação e demais fenois. 
Tabela 2. Dados de tempos de retenção e íons moleculares dos POs e seus respectivos fenois, produtos de conjugação e demais compostos fenólicos obitdos por análise em CG-EM, (IE, 70 eV).

\begin{tabular}{|c|c|c|}
\hline POs, compostos fenólicos e produtos metilados & $\begin{array}{c}\text { Tempo de retenção } \\
\text { (min) }\end{array}$ & $\begin{array}{c}\text { Íon molecular } \\
\left(\mathrm{M}^{+}\right)\end{array}$ \\
\hline Clorpirifós & 28,600 & 349 \\
\hline Metil paration & 27,180 & 263 \\
\hline Profenofós & 31,816 & 372 \\
\hline 3,5,6-Tricloro-2-piridinol & 19,233 & 197 \\
\hline 4-Nitrofenol & 20,650 & 139 \\
\hline 4-Bromo-2-clorofenol & 14,620 & 208 \\
\hline 2,3,5-Tricloro-6-metoxipiridina & 16,900 & 211 \\
\hline 1-Metoxi-4-nitrobenzeno & 17,700 & 153 \\
\hline 4-Bromo-2-cloro-1-metoxibenzeno & 17,360 & 222 \\
\hline 2-Clorofenol & 7,970 & 128 \\
\hline 1-Cloro-2-metoxibenzeno & 11,350 & 142 \\
\hline 4-(4-Hidroxifenil)ciclo-hexanona & 27,366 & 190 \\
\hline 4-(4-Hidroxiciclo-hexil) fenol & 27,200 & 192 \\
\hline 2-Cloro-5-hidroxipiridina & 16,140 & 129 \\
\hline 2-Cloro-5-metoxipiridina & 12,960 & 143 \\
\hline Naringenina & 28,874 & 272 \\
\hline 5,7-dimetoxi-2-(4-metoxifenil)croman-4-ona & 29,831 & 314 \\
\hline Chalcona tetrametilada & 24,780 & 328 \\
\hline Pentaclorofenol & 24,780 & 266 \\
\hline Pentacloroanisol & 24,000 & 280 \\
\hline Fenol & 7,640 & 94 \\
\hline Anisol & 6,330 & 108 \\
\hline
\end{tabular}

Fonte: Autoria própria. 


\subsubsection{Cromatografia líquida de alta eficiência (CLAE-UV)}

As análises por CLAE-UV foram realizadas em aparelho da marca Shimadzu modelo Prominence, equipado com bomba LC-20AT, detector SPD-M20A (UV/VIS), degaseificador DGU-20A 3 , central de controle CBM-20AV, injetor automático Sil-20A e forno CTO 20-A.

Somente o flavonoide naringenina, seus metabólitos e os pesticidas organofosforados (clorpirifós, metil paration, profenofós) com seus respectivos compostos fenólicos $(3,5,6-$ tricloro-2-piridinol, 4-nitrofenol, 4-bromo-2-clorofenol) e seus produtos de conjugação foram analizados e quantificados por CLAE-UV.

Para o clorpirifós e 3,5,6-tricloro-2-piridinol, empregou-se a fase móvel no modo isocrático com acetonitrila grau cromatográfico/água MQ (55:90), fluxo de 0,8 $\mathrm{mL} / \mathrm{min}$ e como fase estacionária coluna C18 CLC-ODS(M) $(0,46$ x $25 \mathrm{~cm})$ da marca Shimadzu ${ }^{\circledR}$. A temperatura do forno foi de $40^{\circ} \mathrm{C}$, o tempo de análise foi de $35 \mathrm{~min}$ e o comprimento de onda de detecção foi de $290 \mathrm{~nm}$. Os tempos de retenção para clorpirifós e 3,5,6-tricloro-2-piridinol, foram de 28,5 e 7,5 min, respectivamente.

Para o metil paration e 4-nitrofenol, empregou-se a fase móvel no modo isocrático com acetonitrila grau cromatográfico/água MQ (30:90), fluxo de 0,8 $\mathrm{mL} / \mathrm{min}$. e como fase estacionária coluna C18 CLC-ODS(M) $(0.46$ x $25 \mathrm{~cm})$ da marca Shimadzu ${ }^{\circledR}$. A temperatura do forno foi de $40^{\circ} \mathrm{C}$, o tempo de análise de 35 min e o comprimento de onda de detecção foi de $310 \mathrm{~nm}$. Os tempos de retenção para metil paration e 4-nitrofenol foram de 26,5 e 9,6 min, respectivamente.

Para o profenofós e 4-bromo-2-clorofenol, empregou-se a fase móvel no modo isocrático com acetonitrila grau cromatográfico/água MQ (45:90), fluxo de 0,8 $\mathrm{mL} / \mathrm{min}$. e como fase estacionária coluna C18 CLC-ODS(M) $(0.46 \times 25 \mathrm{~cm})$ da marca Shimadzu ${ }^{\circledR}$. A temperatura do forno foi de $40^{\circ} \mathrm{C}$, o tempo de análise de 35 min e o comprimento de onda de detecção de $210 \mathrm{~nm}$. Os tempos de retenção para profenofós e 4-bromo-2-clorofenol foram de 28,6 e 13,9 min, respectivamente.

Para a naringenina e seus metabólitos, empregou-se a fase móvel no modo isocrático com hexano grau cromatográfico/isopropanol grau cromatográfico (85:15), fluxo de 0,5 $\mathrm{mL} / \mathrm{min}$ e como fase estacionária coluna CHIRALPAK OD-H $(0.46$ × $25 \mathrm{~cm})$ da marca DAICEL CHEMICAL INDUSTRIES, LTDA. A temperatura do forno foi de $40^{\circ} \mathrm{C}$, o tempo de análise de 50 min e o comprimento de onda de detecção de $300 \mathrm{~nm}$. Os tempos de retenção para a naringenina foram de 30,1 $\min$ ( $R$-naringenina) e 38,7 min ( $S$-naringenina), por ser um composto que apresenta quiralidade. 
A Tabela 3 mostra os tempos de retenção e os gradientes da fase móvel para cada pesticida organofosforado, compostos fenólicos derivados dos pesticidas e o flavonoide naringenina por cromatografia líquida de alta eficiência em coluna C18 e coluna quiral.

Tabela 3. Tempos de retenção e gradientes da fase móvel para as análises em CLAE-UV utilizando coluna C18 e coluna quiral para o flavonoide naringenina.

\begin{tabular}{lccc}
\hline \multicolumn{1}{c}{ POs e compostos fenólicos } & Tempo (min) & Acetonitrila (\%) & Água (\%) \\
\hline Clorpirifós & 27,3 & 55 & 90 \\
Metil paration & 26,5 & 30 & 90 \\
Profenofós & 26,6 & 45 & 90 \\
3,5,6-Tricloro-2-piridinol & 7,5 & 55 & 90 \\
4-Nitrofenol & 9,6 & 30 & 90 \\
4-Bromo-2-clorofenol & 13,9 & 45 & 90 \\
Flavonoide & Tempo (min) & 85 & Isopropanol (\%) \\
Naringenina & 30,1 e 38,7 & 15 \\
\hline
\end{tabular}

\subsection{Curvas analíticas para a quantificação dos pesticidas e seus metabólitos pela técnica de padronização externa (CLAE-UV)}

A curva analítica é representada pela relação matemática entre o sinal da área e as concentrações conhecidas do analito. A linearidade da curva pode ser determinada através da regressão linear, que irá fornecer uma equação da reta e um coeficiente de correlação. Este coeficiente é um parâmetro que permite uma estimativa da qualidade da curva obtida, sendo que valores mais próximos de 1 demonstram uma menor dispersão do conjunto de pontos experimentais. ${ }^{125,126}$ Foram obtidas curvas analíticas utilizando o método de padrão externo para cada um dos compostos analisados, utilizando a equação de regressão linear, ilustrada na Figura 28. 
Figura 28. Regressão linear utilizada para obtenção da equação da reta e coeficiente de correlação.

$$
\mathrm{c}=\mathrm{Ax}+\mathrm{B}
$$

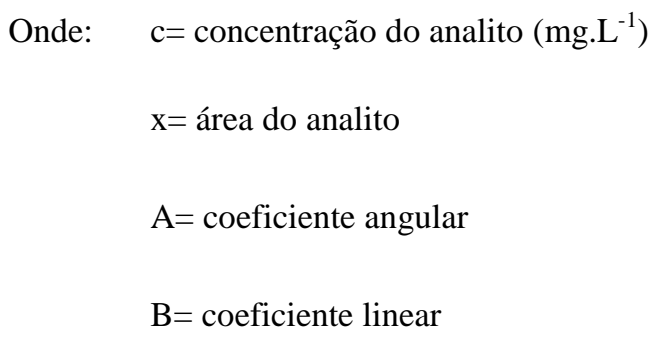

Fonte: RIBANI, M.; BOTTOLI, C. B. G.; COLlinS, C. H.; JARDIM, I.; MELO, L. F. C. Validação em métodos cromatográficos e eletroforéticos. Química Nova, v. 27, p. 771-780, 2004. ${ }^{125}$

Para os pesticidas clorpirifós, metil paration, profenofós e seus respectivos produtos de hidrólise, os fenois 3,5,6-tricloro-2-piridinol, 4-nitrofenol e 4-bromo-2-clorofenol foram preparadas curvas analíticas através da técnica de padronização externa. O método de padronização externa compara a área da substância a ser quantificada na amostra com as áreas obtidas com soluções de concentrações conhecidas preparadas a partir de um padrão. Preparam-se soluções da substância a ser quantificada em diversas concentrações; obtém-se o cromatograma correspondente a cada uma delas e, em um gráfico, relacionam-se as áreas obtidas com as concentrações. Utilizando este gráfico ou a equação da curva resultante, podese calcular a concentração desta substância na amostra a partir da área da substância obtida no cromatograma resultante de injeção separada. ${ }^{125}$

A recomendação da ANVISA é um valor de coeficiente de correlação igual a 0,96 e do INMETRO um valor acima de 0,90. Assim, os coeficientes de correlação obtidos para as seis curvas analíticas utilizadas nesse trabalho, foram obtidos dentro dos parâmetros estabelecidos pela literatura. ${ }^{125}$ 


\subsubsection{Preparo das soluções de estoque e solução de trabalho para obtenção das curvas analíticas para o clorpirifós e 3,5,6-tricloro-2-piridinol (CLAE-UV)}

\subsubsection{Preparo de soluções estoques de $5000 \mathrm{mg} . \mathrm{L}^{-1}$}

Solução de clorpirifós: Em um balão volumétrico de $10 \mathrm{~mL}$ foram solubilizados $50 \mathrm{mg}$ (14,26 mmol) do padrão analítico de clorpirifós em acetonitrila grau cromatográfico.

Solução de 3,5,6-tricloro-2-piridinol: Em um balão volumétrico de $10 \mathrm{~mL}$ foram solubilizados $50 \mathrm{mg}(25,20 \mathrm{mmol})$ do padrão analítico de 3,5,6-tricloro-2-piridinol em acetonitrila grau cromatográfico.

3.4.1.2 Preparo das soluções de trabalho para obtenção de curva analítica pela técnica de padronização externa

As soluções de trabalho foram preparadas em balões volumétricos de $5 \mathrm{~mL}$ a partir das soluções estoques de $5000 \mathrm{mg} . \mathrm{L}^{-1}$ utilizando como solvente acetonitrila grau cromatográfico. Cinco diferentes concentrações de clorpirifós e do metabólito 3,5,6-tricloro-2-piridinol, foram preparadas em 20, 165, 310, 455 e $600 \mathrm{mg} \cdot \mathrm{L}^{-1}$.

Tabela 4. Dados para obtenção da curva analítica para o clorpirifós e 3,5,6-tricloro-2-piridinol pela técnica de padronização externa.

\begin{tabular}{ccc}
\hline $\begin{array}{c}\text { Concentração da solução de } \\
\text { trabalho }\left(\mathrm{mg}_{\mathrm{L}} \mathrm{L}^{-1}\right)\end{array}$ & Volume de clorpirifós $(\mu \mathrm{L})$ & $\begin{array}{c}\text { Volume de 3,5,6-tricloro-2- } \\
\text { piridinol }(\mu \mathrm{L})\end{array}$ \\
\hline 20 & 100 & 100 \\
165 & 825 & 825 \\
310 & 1550 & 1550 \\
455 & 2275 & 2275 \\
600 & 3000 & 3000 \\
\hline
\end{tabular}

As soluções de trabalho foram analisadas por cromatografia líquida de alta eficiência (CLAE-UV) em coluna C18. Foram realizadas análises em triplicatas em todas as concentrações utilizadas.

\subsubsection{Preparo das soluções de estoque e solução de trabalho para obtenção das curvas} analíticas para o metil paration e 4-nitrofenol (CLAE-UV)

\subsubsection{Preparo de soluções estoques de $5000 \mathrm{mg} . \mathrm{L}^{-1}$}

Solução de metil paration: Em um balão volumétrico de $10 \mathrm{~mL}$ foram solubilizados 50 mg $(19,00 \mathrm{mmol})$ de padrão analítico de metil paration em acetonitrila grau cromatográfico. 
Solução de 4-nitrofenol: Em um balão volumétrico de $10 \mathrm{~mL}$ foram solubilizados $50 \mathrm{mg}$ (35,94 mmol) de padrão analítico de 4-nitrofenol em acetonitrila grau cromatográfico.

3.4.2.2 Preparo das soluções de trabalho para obtenção de curva analítica pela técnica de padronização externa

As soluções de trabalho foram preparadas em balões volumétricos de $5 \mathrm{~mL}$ a partir das soluções estoques de $5000 \mathrm{mg} . \mathrm{L}^{-1}$ utilizando como solvente acetonitrila grau cromatográfico. Cinco diferentes concentrações de metil paration e do metabólito 4-nitrofenol foram preparadas em 20, 165, 310, 455 e $600 \mathrm{mg} . \mathrm{L}^{-1}$.

Tabela 5. Dados para obtenção da curva analítica para o metil paration e 4-nitrofenol pela técnica de padronização externa.

\begin{tabular}{ccc}
\hline $\begin{array}{c}\text { Concentração da solução de } \\
\text { trabalho }\left(\mathrm{mg.L}^{-1}\right)\end{array}$ & Volume de metil paration $(\mu \mathrm{L})$ & Volume de 4-nitrofenol $(\mu \mathrm{L})$ \\
\hline 20 & 100 & 100 \\
165 & 825 & 825 \\
310 & 1550 & 1550 \\
455 & 2275 & 2275 \\
600 & 3000 & 3000 \\
\hline
\end{tabular}

As soluções de trabalho foram analisadas por cromatografia líquida de alta eficiência (CLAE-UV) em coluna C18. Foram realizadas análises em triplicatas em todas as concentrações utilizadas.

\subsubsection{Preparo das soluções de estoque e solução de trabalho para obtenção das curvas analíticas para o profenofós e 4-bromo-2-clorofenol (CLAE-UV)}

\subsubsection{Preparo de soluções estoques de $5000 \mathrm{mg} . \mathrm{L}^{-1}$}

Solução de profenofós: em um balão volumétrico de $10 \mathrm{~mL}$ foram solubilizados $50 \mathrm{mg}$ do padrão analítico de profenofós em acetonitrila grau cromatográfico.

Solução de 4-bromo-2-clorofenol: em um balão de volumétrico $10 \mathrm{~mL}$ foram solubilizados $50 \mathrm{mg}(2,41 \mathrm{mmol})$ de padrão analítico 4-bromo-2-clorofenol em acetonitrila grau cromatográfico.

3.4.3.2 Preparo das soluções de trabalho para obtenção de curva analítica pela técnica de padronização externa

As soluções de trabalho foram preparadas em balões volumétricos de $5 \mathrm{~mL}$ a partir das soluções estoques de $500 \mathrm{mg} . \mathrm{L}^{-1}$, utilizando como solvente acetonitrila grau cromatográfico. 
Cinco diferentes concentrações de profenofós e do metabólito 4-bromo-2-clorofenol foram preparadas em 20, 165, 310, 455 e $600 \mathrm{mg} . \mathrm{L}^{-1}$.

Tabela 6. Dados para obtenção da curva analítica para o profenofós e 4-bromo-2-clorofenol pela técnica de padronização externa.

\begin{tabular}{ccc}
\hline $\begin{array}{c}\text { Concentração da } \\
\text { solução de trabalho } \\
\left(\mathrm{mg}^{-1} \mathrm{~L}^{-1}\right)\end{array}$ & Volume de profenofós $(\mu \mathrm{L})$ & Volume de 4-bromo-2-clorofenol $(\mu \mathrm{L})$ \\
\hline 20 & 100 & 100 \\
165 & 825 & 825 \\
310 & 1550 & 1550 \\
455 & 2275 & 2275 \\
600 & 3000 & 3000 \\
\hline
\end{tabular}

As soluções de trabalho foram analisadas por cromatografia líquida de alta eficiência (CLAE-UV) em coluna C18. Foram realizadas análises em triplicatas em todas as concentrações utilizadas.

\subsubsection{Curvas analíticas para a determinação da concentração do pesticida clorpirifós e seu metabólito 3,5,6-tricloro-2-piridinol através da técnica de padronização externa (CLAE-UV)}

Foram desenvolvidos métodos para as análises do clorpirifós e seu metabólito 3,5,6tricloro-2-piridinol através da técnica da padronização externa por CLAE-UV em coluna C18. A curva analítica foi realizada para o pesticida clorpirifós nas concentrações de 20, 165, 310, 455 e $600 \mathrm{mg} . \mathrm{L}^{-1}$ (Figura 29). Para a quantificação do pesticida obteve-se a equação da reta $\mathrm{Y}$ $=1297,6 \mathrm{X}+36896$ e coeficiente de correlação $\mathrm{R}^{2}=0,9936$. 
Figura 29. Curva analítica obtida por CLAE-UV para o pesticida clorpirifós para a faixa de concentração entre 20-600 mg. $\mathrm{L}^{-1}$.

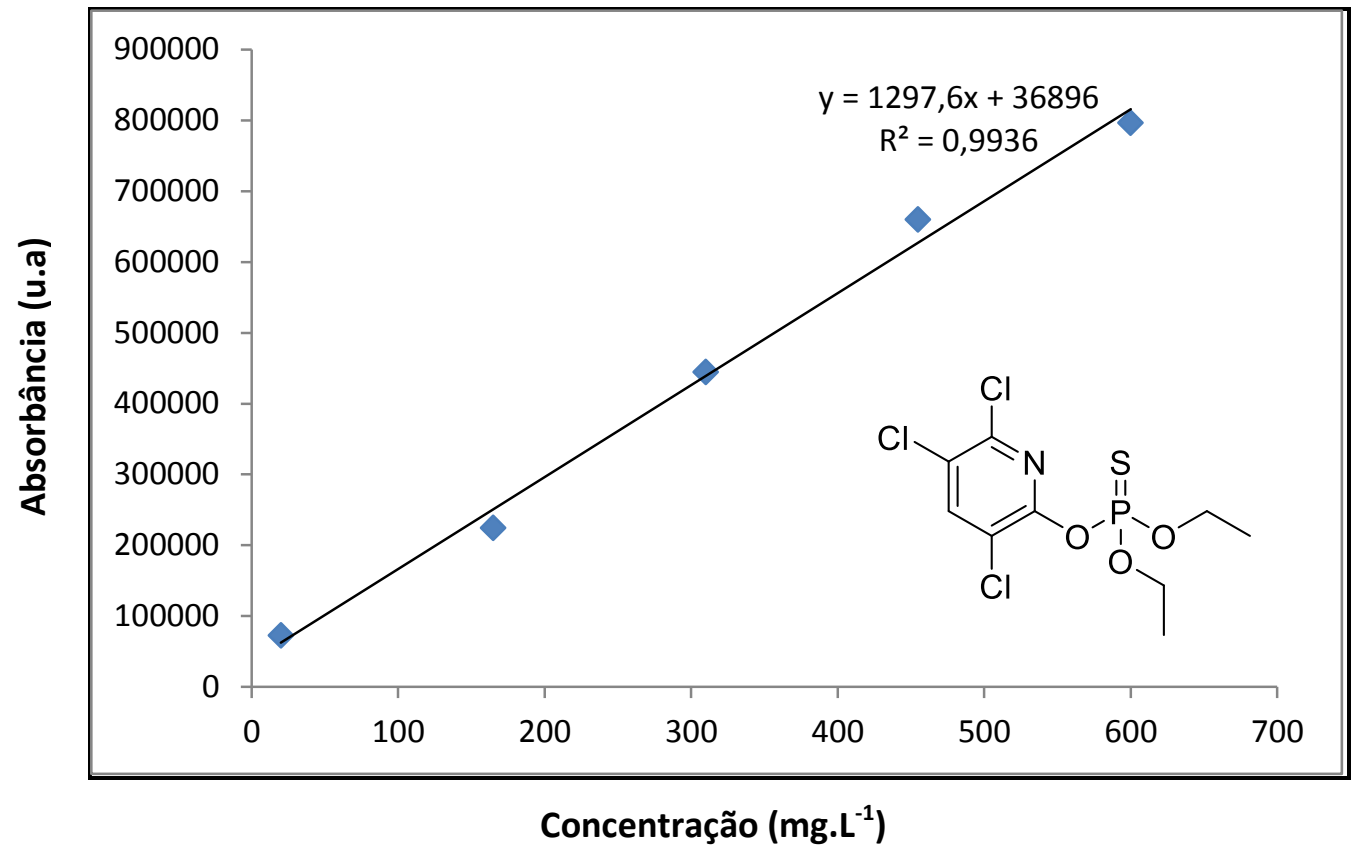

Curva analítica para o composto fenólico 3,5,6-tricloro-2-piridinol nas concentrações de 20, 165, 310, 455 e 600 mg.L ${ }^{-1}$ (Figura 30). Para a quantificação do metabólito 3,5,6-tricloro2-piridinol obteve-se a equação da reta $\mathrm{Y}=26903 \mathrm{X}+1 \mathrm{E}+06$ e coeficiente de correlação $\mathrm{R}^{2}$ $=0,9904$.

Figura 30. Curva analítica obtida por CLAE-UV para o composto fenólico 3,5,6-tricloro-2-piridinol para a faixa de concentração entre 20-600 mg. $\mathrm{L}^{-1}$.

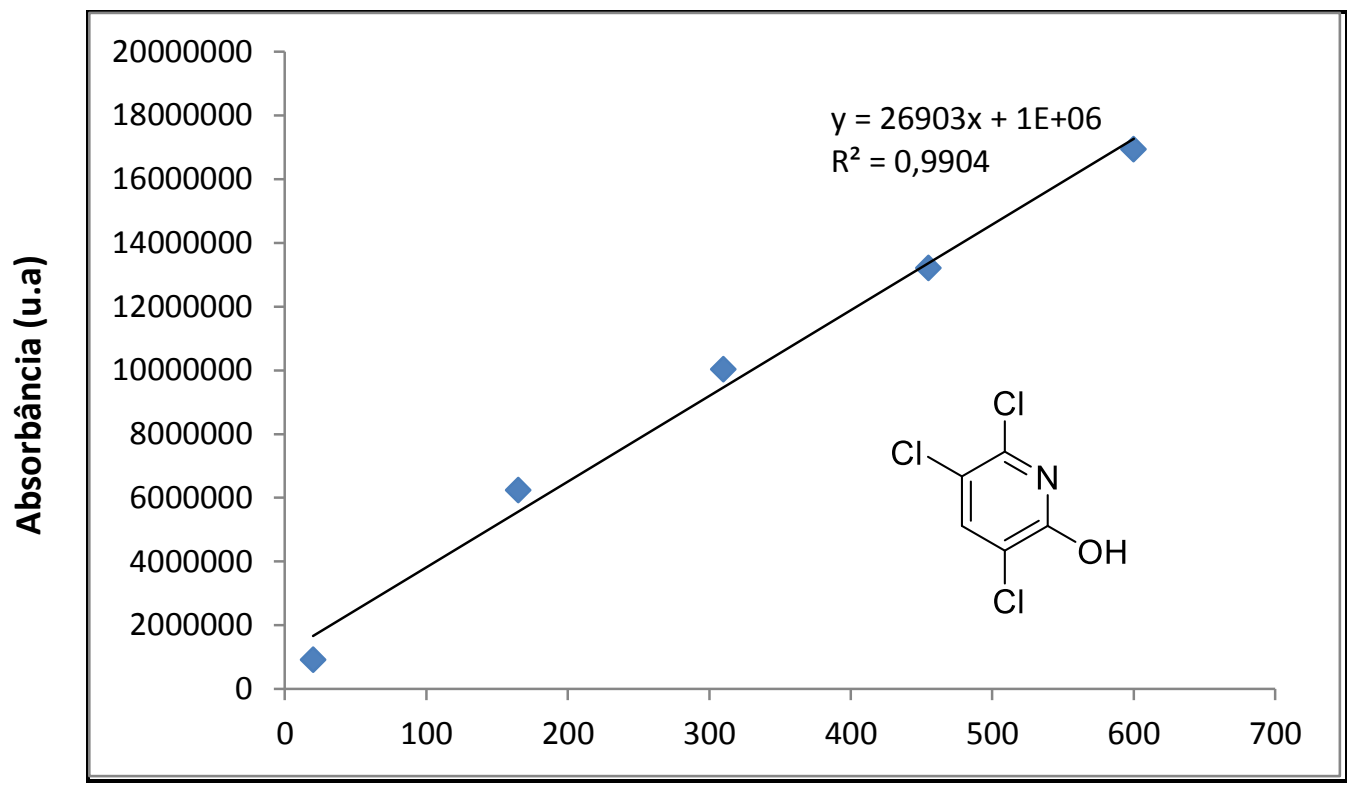




\subsubsection{Curvas analíticas para a determinação da concentração do pesticida metil paration} e seu metabólito 4-nitrofenol através da técnica de padronização externa (CLAE-UV)

Foram desenvolvidos métodos para as análises do metil paration e seu metabólito 4nitrofenol através da técnica da padronização externa por CLAE-UV em coluna C18. A curva analítica foi realizada para o pesticida metil paration nas concentrações de 20, 165, 310, 455 e $600 \mathrm{mg} . \mathrm{L}^{-1}$ (Figura 31). Para a quantificação do pesticida obteve-se a equação da reta $\mathrm{Y}=$ $2264,4 X+184134$ e coeficiente de correlação $R^{2}=0,9949$.

Figura 31. Curva analítica obtida por CLAE-UV para o pesticida metil paration para a faixa de concentração entre $20-600 \mathrm{mg} \cdot \mathrm{L}^{-1}$.

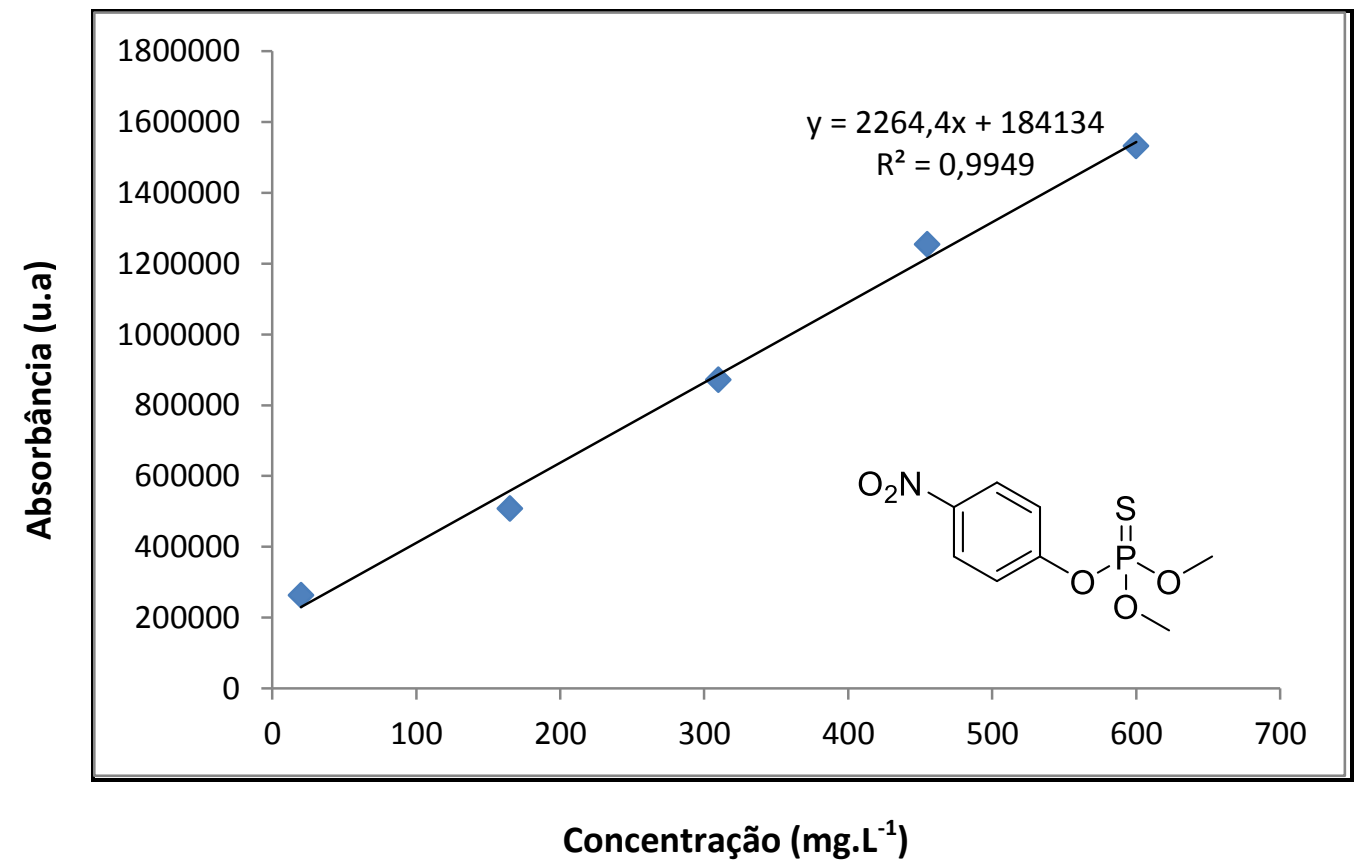


Curva analítica para o composto fenólico 4-nitrofenol nas concentrações de 20, 165, 310, 455 e 600 mg.L ${ }^{-1}$ (Figura 32). Para a quantificação do metabólito 4-nitrofenol obteve-se a equação da reta $\mathrm{Y}=67672 \mathrm{X}+3 \mathrm{E}+06$ e coeficiente de correlação $\mathrm{R}^{2}=0,9871$.

Figura 32. Curva analítica obtida por CLAE-UV para o composto fenólico 4-nitrofenol para a faixa de concentração entre 20-600 mg. $\mathrm{L}^{-1}$.

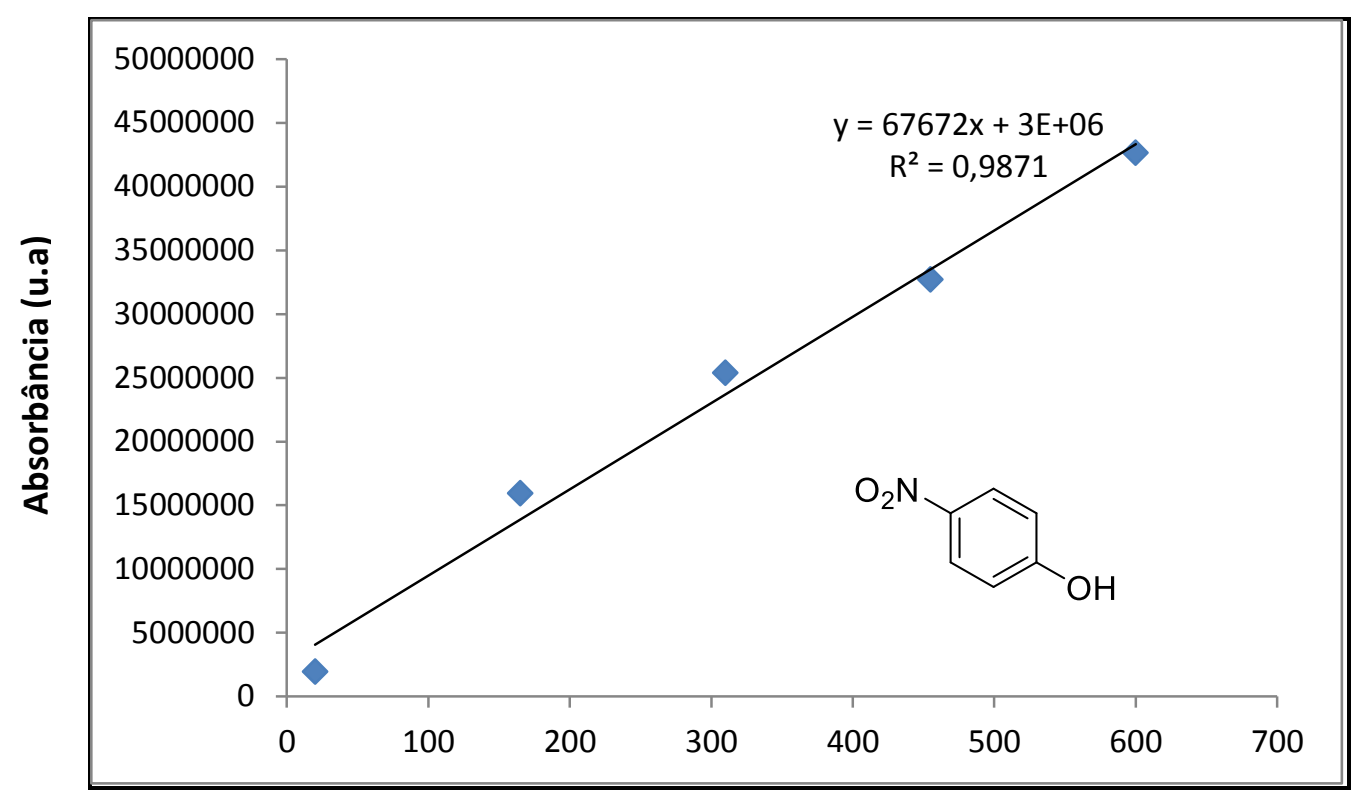

Concentração (mg. $\mathrm{L}^{-1}$ ) 


\subsubsection{Curvas analíticas para a determinação da concentração do pesticida profenofós e} seu metabólito 4-bromo-2-clorofenol através da técnica de padronização externa (CLAE-UV)

Foram desenvolvidos métodos para as análises do profenofós e seu metabólito 4-bromo2-clorofenol através da técnica da padronização externa por CLAE-UV em coluna C18. A curva analítica foi realizada para o pesticida profenofós nas concentrações de 20, 165, 310, 455 e 600 mg. L $^{-1}$ (Figura 33). Para a quantificação do pesticida obteve-se a equação da reta $Y$ $=2702 X+141309$ e coeficiente de correlação $\mathrm{R}^{2}=0,9959$.

Figura 33. Curva analítica obtida por CLAE-UV para o pesticida profenofós para a faixa de concentração entre 20-600 mg. $\mathrm{L}^{-1}$.

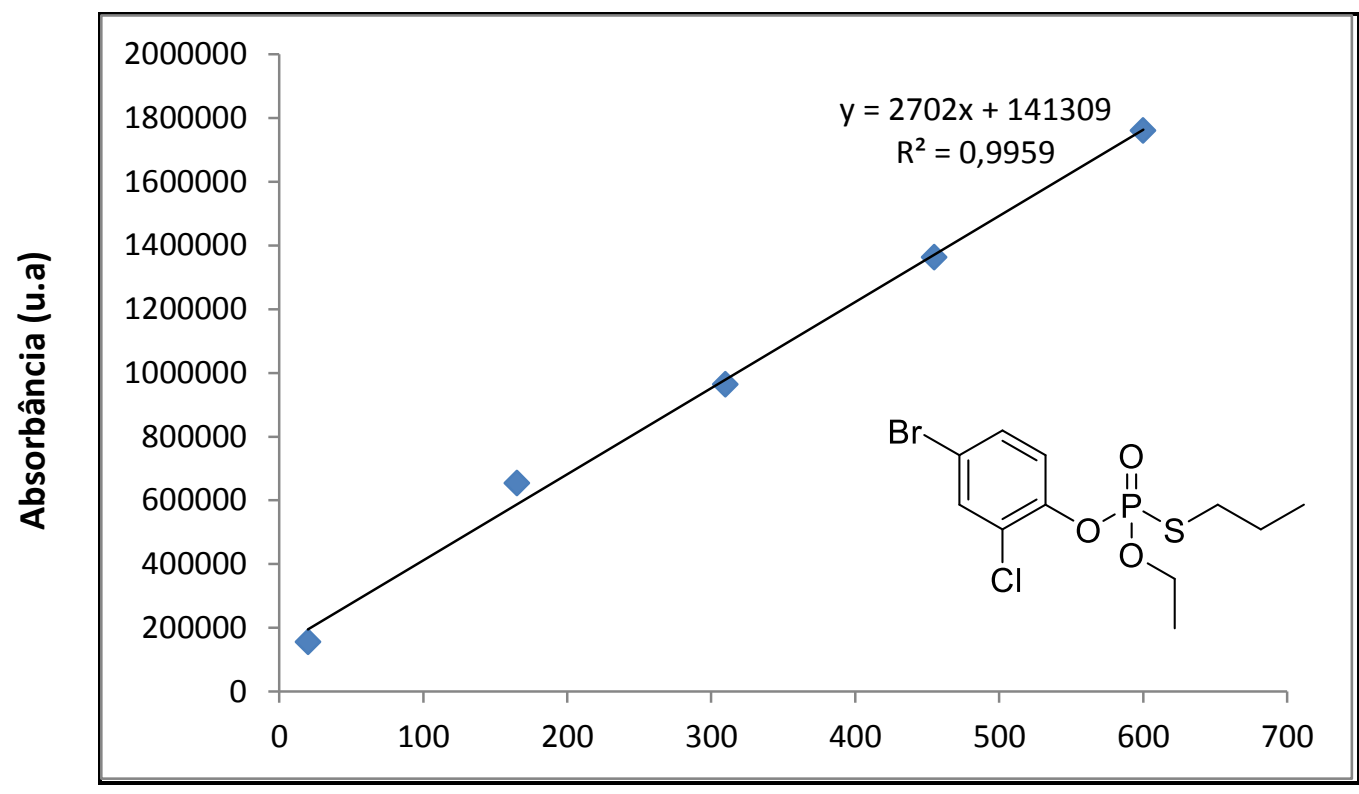

Concentração (mg. $\left.\mathrm{L}^{-1}\right)$ 
Curva analítica para o composto fenólico 4-bromo-2-clorofenol nas concentrações de 20, 165, 310, 455 e $600 \mathrm{mg} . \mathrm{L}^{-1}$ (Figura 34). Para a quantificação do metabólito 4-bromo-2clorofenol obteve-se a equação da reta $\mathrm{Y}=9064,5 \mathrm{X}-33661$ e coeficiente de correlação $\mathrm{R}^{2}=$ $0,9997$.

Figura 34. Curva analítica obtida por CLAE-UV para o composto fenólico 4-bromo-2-clorofenol para a faixa de concentração entre $20-600 \mathrm{mg} \cdot \mathrm{L}^{-1}$.

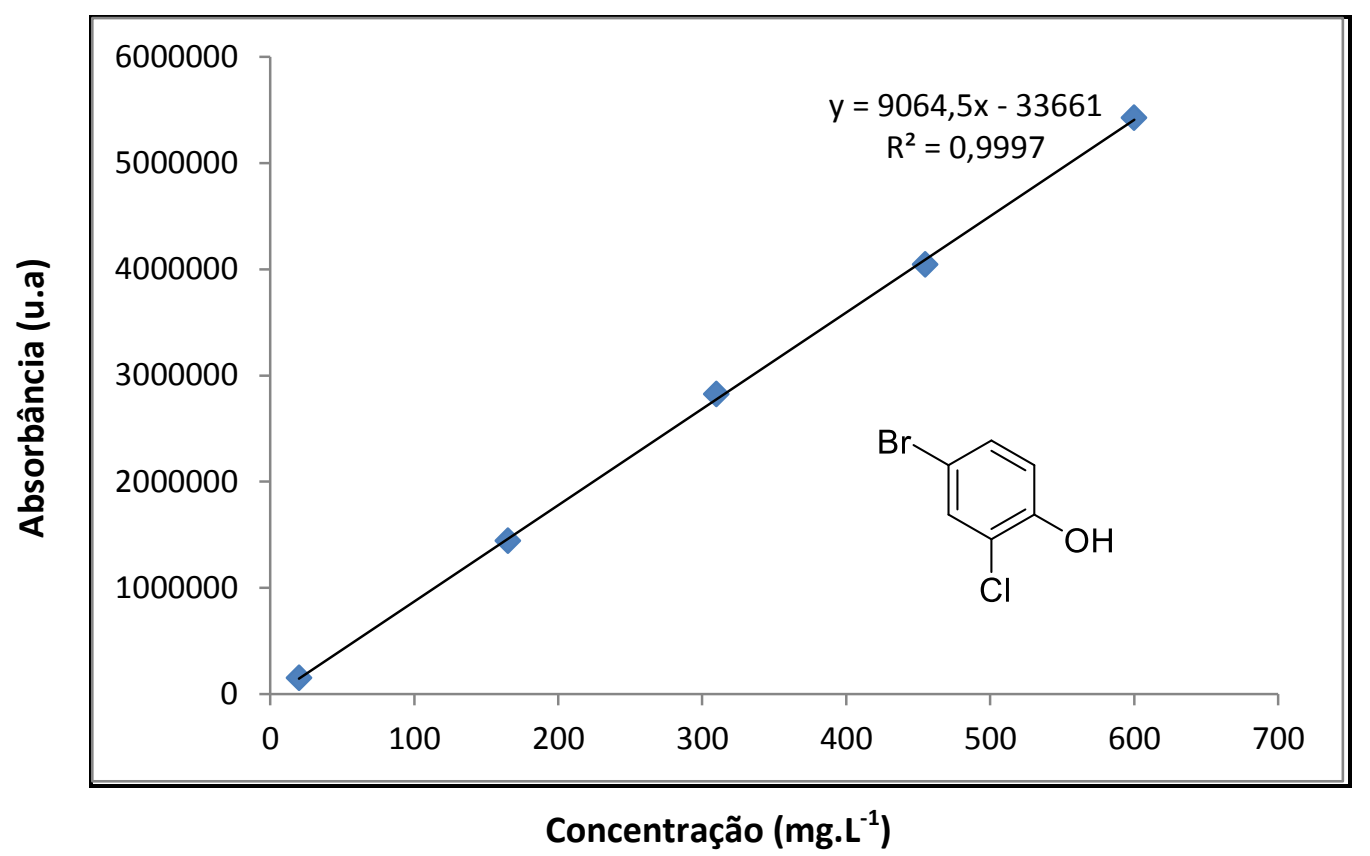

\subsection{Avaliação da concentração dos ingredientes ativos dos pesticidas nas amostras comerciais}

Para análise a quantificação dos ingredientes ativos presentes nas amostras de trabalho e posterior uso nas reações de biotransformação, fez-se necessário à análise por (CLAE-UV) para quantificação da concentração dos ingredientes ativos dos pesticidas clorpirifós, metil paration e profenofós nas amostras comerciais. Para determinação do volume necessário dos pesticidas organofosforados para reações com concentração de $50 \mathrm{mg} \cdot \mathrm{L}^{-1}$.

\subsubsection{Clorpirifós}

Em um balão volumétrico de $25 \mathrm{~mL}$ foram solubilizados $2 \mu \mathrm{L}$ do pesticida comercial clorpirifós em acetonitrila grau cromatográfico. Foram preparadas amostras em duplicatas seguindo esta descrição, duas alíquotas de $1 \mathrm{~mL}$ de cada duplicata foram transferidas para 
vials de $1,5 \mathrm{~mL}$ e analisadas por cromatografia líquida de alta eficiência (CLAE-UV) em coluna C18 CLC-ODS(M) OD-H $(0.46$ x $25 \mathrm{~cm})$ da marca Shimadzu®.

A composição do pesticida clorpirifós comercialmente chamado Lorsban $480 \mathrm{BR}$, de acordo com Dow Agrosciences ${ }^{\circledR} .127$

Clorpirifós: $480 \mathrm{~g} / \mathrm{L}(48 \% \mathrm{~m} / \mathrm{v})$.

Ingredientes inertes: $669 \mathrm{~g} / \mathrm{L}(66,9 \% \mathrm{~m} / \mathrm{v})$.

O volume utilizado nas análises foi de $2 \mu \mathrm{L}$ do pesticida clorpirifós diluído em $25 \mathrm{~mL}$ de acetonitrila (Tabela 7).

Tabela 7. Análise em duplicata com $2 \mu \mathrm{L}$ de clorpirifós para determinação da concentração do pesticida na amostra comercial de Lorsban $480 \mathrm{BR}$.

\begin{tabular}{ccc}
\hline & \multicolumn{2}{c}{ Concentração do ingrediente ativo (mg.L ${ }^{-1}$ ) } \\
\hline Análise & Amostra 1 & Amostra 2 \\
$1^{\mathrm{a}}$ & 47 & 45 \\
$2^{\mathrm{a}}$ & 48 & 49 \\
\hline
\end{tabular}

Após quantifição das análises nas duplicatas e considerando que a amostra foi diluída em $25 \mathrm{~mL}$ de acetonitrila, para obter uma concentração final de $50 \mathrm{mg} . \mathrm{L}^{-1}$. Para as reações de biotransformação foi necessário a adição de $10,3 \mu \mathrm{L}\left(0,41 \mathrm{mmol}, 50 \mathrm{mg} \cdot \mathrm{L}^{-1}\right)$ do pesticida clorpirifós, diluídos em $100 \mathrm{~mL}$ de meio de cultura líquido de malte a $2 \%$.

\subsubsection{Metil paration}

Em um balão volumétrico de $25 \mathrm{~mL}$ foram diluídos $2 \mu \mathrm{L}$ do pesticida comercial metil paration em acetonitrila grau cromatográfico. Posteriormente foram preparadas amostras em duplicatas seguindo esta descrição, duas alíquotas de $1 \mathrm{~mL}$ de cada duplicata foram transferidas para vials de 1,5 mL para posterior análise e quantificação por cromatografia líquida de alta eficiência (CLAE-UV) em coluna C18 CLC-ODS(M) OD-H (0.46 x 25 cm) da marca Shimadzu®.

A composição do pesticida metil paration comercialmente chamado Folisuper $600 \mathrm{BR}$, de acordo com Agripec $^{\circledR} .128$

Metil paration: $600 \mathrm{~g} / \mathrm{L}(60 \% \mathrm{~m} / \mathrm{v})$.

Ingredientes inertes: $528 \mathrm{~g} / \mathrm{L}(52,8 \% \mathrm{~m} / \mathrm{v})$.

$\mathrm{O}$ volume utilizado nas análises foi de $2 \mu \mathrm{L}$ do pesticida metil paration diluído em $25 \mathrm{~mL}$ de acetonitrila (Tabela 8). 
Tabela 8. Análise em duplicata com $2 \mu \mathrm{L}$ de metil paration para determinação da concentração do pesticida na amostra comercial de Folisuper 600 BR.

\begin{tabular}{ccc}
\hline & \multicolumn{2}{c}{ Concentração do ingrediente ativo (mg.L $\left.{ }^{-1}\right)$} \\
\hline Análise & Amostra 1 & Amostra 2 \\
$1^{\mathrm{a}}$ & 52 & 48 \\
$2^{\mathrm{a}}$ & 51 & 52 \\
\hline
\end{tabular}

Após a quantificação das análises nas duplicatas e considerando que a amostra foi diluída em $25 \mathrm{~mL}$ de acetonitrila, para obter uma concentração final de $50 \mathrm{mg} . \mathrm{L}^{-1}$. Para as reações de biotransformação foi necessários a adição de $5,5 \mu \mathrm{L}\left(0,28 \mathrm{mmol}, 50 \mathrm{mg} \cdot \mathrm{L}^{-1}\right)$ do pesticida metil paration diluídos em $100 \mathrm{~mL}$ de meio de cultura líquido de malte a $2 \%$.

\subsubsection{Profenofós}

Em um balão volumétrico de $25 \mathrm{~mL}$ foram diluídos $2 \mu \mathrm{L}$ do pesticida comercial profenofós em acetonitrila grau cromatográfico. Foram preparadas amostras em duplicatas seguindo esta descrição, duas alíquotas de $1 \mathrm{~mL}$ de cada duplicata foram transferidas para vials de 1,5 mL para posterior análise e quantificação em cromatografia líquida de alta eficiência (CLAE-UV) em coluna C18 CLC-ODS(M) OD-H $(0.46 \times 25 \mathrm{~cm})$ da marca Shimadzu®.

A composição do pesticida profenofós comercialmente chamado Polytrin, de acordo com Syngenta ${ }^{\circledR} .129$

Ingredientes inertes: $652 \mathrm{~g} / \mathrm{L}(65,2 \% \mathrm{~m} / \mathrm{v})$.

Profenofós: $400 \mathrm{~g} / \mathrm{L}(40 \% \mathrm{~m} / \mathrm{v})$.

Cipermetrina: $40 \mathrm{~g} / \mathrm{L}(4 \% \mathrm{~m} / \mathrm{v})$.

O volume utilizado nas análises foi de $2 \mu \mathrm{L}$ do pesticida profenofós diluídos em $25 \mathrm{~mL}$ de acetonitrila (Tabela 9).

Tabela 9. Análise em duplicata com $20 \mu \mathrm{L}$ de profenofós para determinação da concentração do pesticida na amostra comercial de Polytrin 400/40 CE.

\begin{tabular}{ccc}
\hline & \multicolumn{2}{c}{ Concentração do ingrediente ativo (ppm) } \\
\hline Análise & Amostra 1 & Amostra 2 \\
$1^{\mathrm{a}}$ & 52 & 51 \\
$2^{\mathrm{a}}$ & 54 & 53 \\
\hline
\end{tabular}


Após a quantificação das análises nas duplicatas e considerando que a amostra foi diluída em $25 \mathrm{~mL}$ de acetonitrila, para obter uma concentração final de $50 \mathrm{mg} . \mathrm{L}^{-1}$. Para as reações de biotransformação foi necessários a adição de $18,5 \mu \mathrm{L}\left(0,72 \mathrm{mmol}, 50 \mathrm{mg} \cdot \mathrm{L}^{-1}\right)$ do pesticida profenofós diluídos em $100 \mathrm{~mL}$ de meio de cultura líquido de malte a $2 \%$.

\subsubsection{Procedimento geral de metilação sintética}

A Figura 35 ilustra a equação química para a metilação do pentaclorofenol e o mecanismo com $\mathrm{K}_{2} \mathrm{CO}_{3}$ e $\mathrm{CH}_{3} \mathrm{I}$.

Figura 35. Reação de metilação do pentaclorofenol.
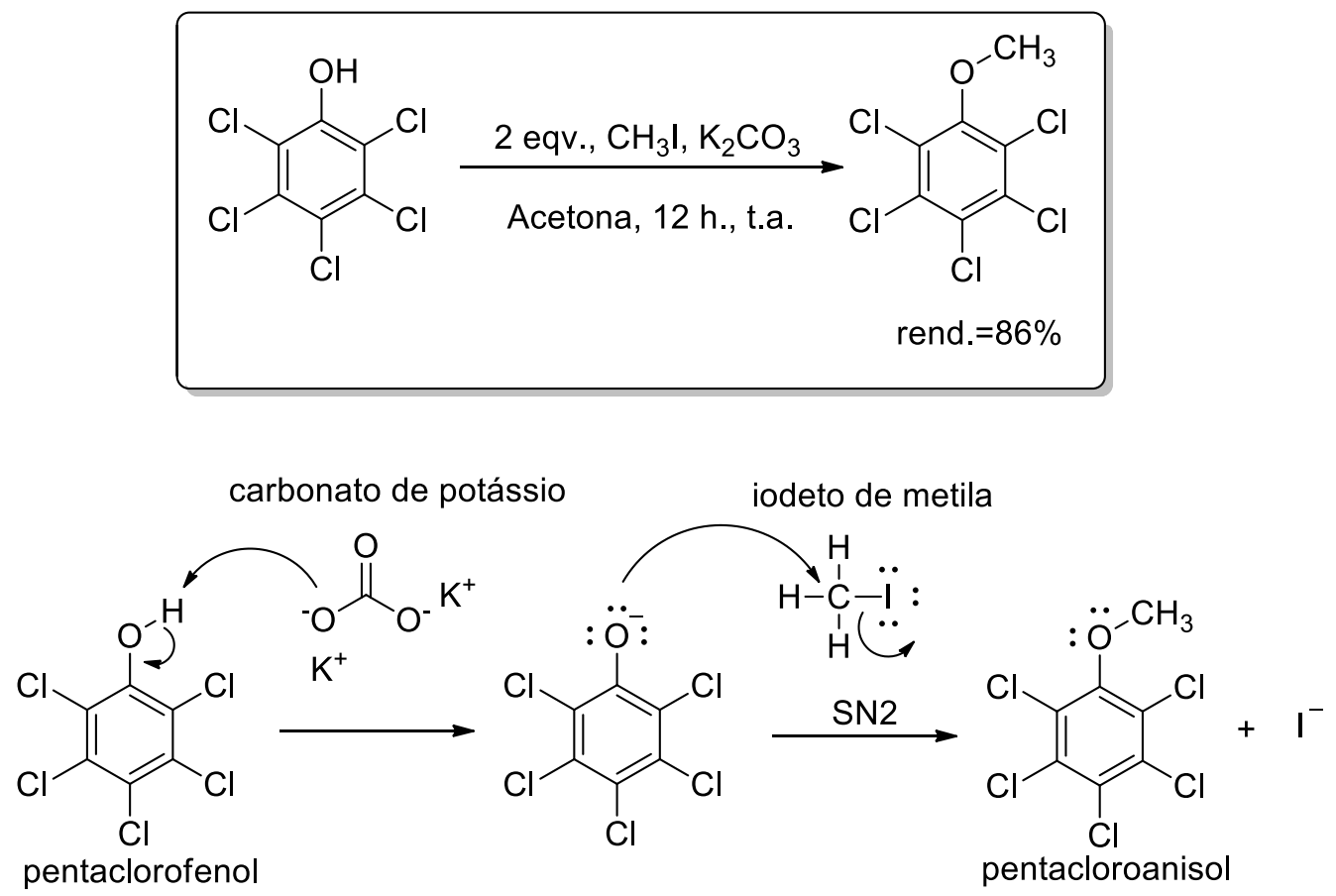

Fonte: Autoria própria.

Procedimento geral de metilação: Em um balão de $100 \mathrm{~mL}$ adicionou 1,0 mmol do pentaclorofenol $(0,265 \mathrm{~g}), 2 \mathrm{mmol}$ de $\mathrm{K}_{2} \mathrm{CO}_{3}(0,276 \mathrm{~g})$ em $20 \mathrm{~mL}$ de acetona e 2,0 mmol de iodeto de metila $(0,284 \mathrm{~g})$. A reação permaneceu à temperatura ambiente em agitação por 24 h. Em seguida realizou-se a extração com $10 \mathrm{~mL}$ da solução saturada de $\mathrm{NaCl}, 5 \mathrm{~mL}$ de $\mathrm{HCl}$ $(1 \% \mathrm{v} / \mathrm{v})$ e acetato de etila $(3 \times 50 \mathrm{~mL})$. O produto metilado foi purificado por cromatografia em coluna utilizando sílica gel, $n$-hexano/acetato de etila (9:1). Foi obtido um sólido branco em $86 \%$ de rendimento $(0,2117 \mathrm{~g})$ o qual foi caracterizado por CG-EM e RMN de ${ }^{1} \mathrm{H} \mathrm{e}{ }^{13} \mathrm{C}$.

O composto fenólico pentaclorofenol foi metilado originando o composto metoxilado pentacloroanisol. 
Esta metodologia de síntese clássica foi utilizada para os demais compostos fenólicos usados nesse trabalho, que foram sintetizados para fins de comparação e caracterização com compostos fenólicos biometilados por enzimas metiltranferases provenientes do fungo de ambiente marinho A. sydowii CBMAI 935.

A Tabela 10 mostra os compostos fenólicos que foram metilados, através de metodologia de síntese clássica e seus respectivos produtos de reação com seus devidos rendimentos.

Tabela 10. Compostos fenólicos que foram metilados, através de metodologia de síntese clássica e seus respectivos produtos de reação com seus devidos rendimentos.

\begin{tabular}{lcc}
\hline Compostos fenólicos & Produtos metilados & Rendimento \\
& & $(\%)$ \\
\hline 3,5,6-Tricloro-2-piridinol & 2,3,5-Tricloro-6-metoxipiridina & 72 \\
4-Bromo-2-clorofenol & 4-Bromo-2-cloro-1-metoxibenzeno & 88 \\
4-Nitrofenol & 1-Metoxi-4-nitrobenzeno & 82 \\
Fenol & Anisol & 85 \\
Pentaclorofenol & Pentacloroanisol & 86 \\
2-Clorofenol & 1-Cloro-2-metoxibenzeno & 82 \\
2-Cloro-5-metoxipiridina & 2-Cloro-5-metoxipiridina & 84 \\
Naringenina & Naringenina trimetilada & 80 \\
\hline
\end{tabular}




\subsubsection{Cromatografia em coluna (CC) utilizando sílica gel}

As cromatografias em coluna (CC) foram realizadas utilizando sílica gel flash de alto grau de pureza, tamanho de poro de $60 \AA$, 220-440 mesh, tamanho de partícula 35-75 $\mu \mathrm{m}$ da Across e cromatofolhas de sílica gel $60 \mathrm{~F}_{254}$ da Sorbent Technologies. Na cromatografia em camada delgada (CCD) as cromatofolhas foram reveladas com soluções de anisaldeído (100 $\mathrm{mL}$ de ácido acético, $1 \mathrm{~mL}$ de anisaldeído e $1 \mathrm{~mL}$ de ácido fosfórico) ou de vanilina (135 $\mathrm{mL}$ $\mathrm{H}_{2} \mathrm{O}$ destilada, $30 \mathrm{~mL}$ de $\mathrm{H}_{2} \mathrm{SO}_{4}, 35 \mathrm{~mL}$ de $\mathrm{CH}_{3} \mathrm{OH}$ e 3,0 g de vanilina).

Para as fases móveis foram determinadas as misturas mais adequadas em cada situação.

\subsubsection{Espectroscopia de ressonância magnética nuclear (RMN)}

Os espectros de RMN ${ }^{1} \mathrm{H}$ e RMN ${ }^{13} \mathrm{C}$ foram obtidos em dois espectrômetros da marca Agilent Technologies-modelo 400 Premium Shielded operando nas frequências de $400 \mathrm{MHz}$, e Agilent Techonologies-modelo 500 Premium Shielded operando nas frequências de 500 MHz. Os solventes utilizados nas análises foram clorofórmio deuterado $\left(\mathrm{CDCl}_{3}\right)$ e dimetilsulfóxido per-deuterado (DMSO- $d_{6}$ ), os deslocamentos químicos $(\delta)$ foram expressos em partes por milhão (ppm) em relação ao padrão interno tetrametilsilano (TMS).

O número de hidrogênios foi deduzido pela integral relativa e a constante de acoplamento (J) foi expressa em Hertz (Hz).

As análises foram realizadas junto à Central de Análises Químicas Instrumentais (CAQI) do Instituto de Química de São Carlos (IQSC).

\subsubsection{Outros equipamentos}

Balança analítica modelo AY-220 da marca Shimadzu, pHmetro modelo 8010 da marca Qualxtron, autoclave vertical modelo Phoenix, cabine de fluxo laminar marca Veco, vortex Motion da Logen Scientific, centrífuga da Hermle Z 200 A, rota-evaporadores Fisaton e Tecnal T-210 equipados com bomba de vácuo TE-058 e refrigeração Tecnal Modelo TE2005, agitadores rotativos modelo Tecnal TE-421, Superohm G-25 ou SI-600R da Analítica, Câmara de Neubauer (Neubauer Improved Bright-line) da marca HBG. 


\subsection{Microrganismos}

A coleta de organismos de ambiente marinho foi realizada pelo Grupo de Química Orgânica de Sistemas Biológicos (QOSBio-IQSC/USP) com a coordenação do Prof. Dr. Roberto Gomes de Souza Berlinck e o isolamento dos fungos foi realizado pelo Grupo de Pesquisa do Laboratório de Ecologia de Microrganismos Aquáticos (Profa. Dra. Mirna Helena Regali Seleghim, (GPLEMA-UFSCar).

As cepas fúngicas de Aspergillus sydowii CBMAI 934, Penicillium raistrickii CBMAI 931 e A. sydowii CBMAI 935 foram isoladas da esponja Chelonaplysilla erecta. P. raistrickii CBMAI 1235, P. decaturense CBMAI 1234 e A. sydowii CBMAI 1241 foram isoladas da esponja Dragmacidon reticulata. Trichoderma sp. CBMAI 932 foi isolada da esponja Geodia corticostylifera. Os fungos foram identificados e depositados na Coleção Brasileira de Microrganismos de Meio Ambiente e Indústria (CBMAI).

O Grupo de pesquisa do laboratório de Química Orgânica e Biocatálise possuem todas as cepas preservadas as quais foram reativadas e utilizadas nas reações de biotransformação.

A reativação das cepas preservados foram realizadas pela técnica do grupo de Química Orgânica e Biocatálise MSc. Marília Cardoso Milanetto Peret.

\subsubsection{Crescimento dos microrganismos}

\subsubsection{Sais necessários para o preparo da água do mar artificial}

Para um litro de água do mar artificial: $\mathrm{CaCl}_{2} \cdot 2 \mathrm{H}_{2} \mathrm{O}(1,36 \mathrm{~g}), \mathrm{MgCl}_{2} \cdot 6 \mathrm{H}_{2} \mathrm{O}(9,68 \mathrm{~g}), \mathrm{KCl}$ $(0,61 \mathrm{~g}), \mathrm{NaCl}$ (30 g), $\mathrm{Na}_{2} \mathrm{HPO}_{4}(0,014 \mathrm{mg}), \mathrm{Na}_{2} \mathrm{SO}_{4}(3,47 \mathrm{~g}), \mathrm{NaHCO}_{3}(0,17 \mathrm{~g}), \mathrm{KBr}(100$ $\mathrm{mg}), \mathrm{SrCl}_{2} \cdot 6 \mathrm{H}_{2} \mathrm{O}(40 \mathrm{mg}), \mathrm{H}_{3} \mathrm{BO}_{3}(30 \mathrm{mg})$.

\subsubsection{Composição e preparo do meio de cultura para o cultivo de microrganismos}

i) Meio líquido de malte 2\%: Em um frasco Becker de $2 \mathrm{~L}$ foram adicionados $1 \mathrm{~L}$ de água do mar artificial e $20 \mathrm{~g}$ de extrato de malte. A solução foi submetida à agitação magnética e o pH foi ajustado para 7,0 com uma solução de $\mathrm{HCl} 1 \mathrm{M}$ ou KOH $1 \mathrm{M}$.

ii) Meio sólido de malte 2\%: Em um frasco Becker de $2 \mathrm{~L}$ foram adicionados $1 \mathrm{~L}$ de água do mar artificial, $20 \mathrm{~g}$ de extrato de malte e $20 \mathrm{~g}$ de Agar. A solução foi submetida à agitação magnética e o pH foi ajustado para 5,0 com uma solução de $\mathrm{HCl} 1 \mathrm{M}$ ou KOH 1 M.

iii) Esterilização dos meios de cultura e preservação das cepas fúngicas: Os meios de cultura foram submetidos à esterilização em autoclave por $20 \min \left(121^{\circ} \mathrm{C}, 1,5 \mathrm{kPa}\right)$. Em uma câmara de fluxo laminar previamente esterilizada com luz ultravioleta e solução de álcool $70 \%$, os meios de cultura foram vertidos em placas de Petri. 
As placas com meio sólido de extrato de malte $2 \%$ foram utilizadas para a preservação das culturas puras dos fungos para repiques posteriores em meios líquidos frente aos estudos de biotransformação dos pesticidas e compostos fenólicos. Após o cultivo em estufa até observação de um bom crescimento de cada microrganismo as cepas foram estocadas em refrigeração a $4^{\circ} \mathrm{C}$ e os repiques para manutenção destas foram realizados a cada três meses.

3.6.2 Seleção dos fungos em meio de cultura sólido de malte $2 \%$ e Agar frente aos pesticidas clorpirifós, metil paration e profenofós

Inicialmente foi realizado um screening com os fungos Aspergillus sydowii CBMAI 934, Penicillium raistrickii CBMAI 931, A. sydowii CBMAI 935, P. raistrickii CBMAI 1235, P. decaturense CBMAI 1234, A. sydowii CBMAI 1241 e Trichoderma sp. CBMAI 932 na presença e ausência dos pesticidas, e em diferentes concentrações de pesticidas. Para cada fungo, foram preparadas dez placas, uma na ausência do pesticida (placa controle) e as demais com três contrações para cada pesticida testado, sendo: 96 mg. $\mathrm{L}^{-1}, 192 \mathrm{mg} . \mathrm{L}^{-1}$ e $288 \mathrm{mg} . \mathrm{L}^{-1}$ para o pesticida clorpirifós, $120 \mathrm{mg} . \mathrm{L}^{-1}, 240 \mathrm{mg} . \mathrm{L}^{-1}$ e $360 \mathrm{mg} . \mathrm{L}^{-1}$ para o pesticida metil paration e $80 \mathrm{mg} . \mathrm{L}^{-1}, 160 \mathrm{mg} . \mathrm{L}^{-1}$ e $240 \mathrm{mg} . \mathrm{L}^{-1}$ para o pesticida profenofós. Após a esterilização do meio, este foi resfriado até $40-50^{\circ} \mathrm{C}$. Foram adicionados em cada placa de Perti, três volumes diluídos em dimetilsulfoxido $(5 \mu \mathrm{L}$ de pesticida/100 $\mu \mathrm{L}$ de DMSO, $10 \mu \mathrm{L}$ de pesticida/200 $\mu \mathrm{L}$ de DMSO e $15 \mu \mathrm{L}$ de pesticida/ $300 \mu \mathrm{L}$ de DMSO) dos pesticidas com as devidas concentrações citadas acima. Com o meio sólido à temperatura ambiente foram realizados os repiques, transferindo-se com o auxílio de uma agulha de inoculação os esporos e micélios dos fungos previamente cultivados em placas de Petri com extrato de malte $2 \%$ que forneceram as culturas puras. Os repiques foram realizados em cinco pontos diferentes da placa de Petri. A placa permaneceu em estufa a uma temperatura de $35^{\circ} \mathrm{C}$ por 10 dias, observando-se o crescimento dos fungos na placa controle e nas placas com cada pesticida durante este período. Estes ensaios foram realizados em duplicatas para cada um dos pesticidas utilizados.

\subsubsection{Padronização dos inóculos dos fungos filamentosos pela técnica de suspensão de esporos para as reações com os pesticidas clorpirifós, metil paration e profenofós}

3.6.3.1 Preparo dos tubos inclinados em meio de cultura sólido de malte 2\% e Agar para o crescimento dos fungos

Para cada fungo (Aspergillus sydowii CBMAI 934, Penicillium raistrickii CBMAI 931, A. sydowii CBMAI 935, P. raistrickii CBMAI 1235, P. decaturense CBMAI 1234, A. sydowii 
CBMAI 1241 e Trichoderma sp. CBMAI 932) testados separadamente pelos pesticidas clorpirifós, metil paration e profenofós foram preparados 14 tubos de ensaio contendo o meio de cultura de malte $2 \%$ na presença do pesticida comercial. Individualmente após a esterilização de $120 \mathrm{~mL}$ de meio, este foi resfriado até $30-35^{\circ} \mathrm{C}$ e foram adicionados os pesticidas comerciais nos volumes de $(12,3 \mu \mathrm{L}$ para clorpirifós, $10,5 \mu \mathrm{L}$ para metil paration e 12,5 $\mu \mathrm{L}$ para profenofós) com uma concentração final de $50 \mathrm{mg} . \mathrm{L}^{-1}$. Foram vertidos aproximadamente $10 \mathrm{~mL}$ de meio de cultura em cada tubo de ensaio. Ainda com o meio de cultura quente e líquido, os tubos foram apoiados em suportes, de modo que, em temperatura ambiente o meio de cultura, já sólido, ficasse inclinado no tubo de ensaio.

Com o meio sólido à temperatura ambiente foram realizados os repiques transferindo-se com o auxílio de uma agulha de inoculação os esporos e micélios dos fungos previamente cultivados em placas de Petri com extrato de malte $2 \%$ que forneceram as culturas puras. Os repiques foram realizados na forma de "estrias" pelo meio de cultura nos tubos de ensaio. Os tubos permaneceram em estufa a uma temperatura de $35^{\circ} \mathrm{C}$ por sete dias e, em seguida, foi feita a preparação das amostras para contagem dos esporos.

\subsubsection{Preparo da suspensão de esporos}

A preparação da suspenção de esporos foi realizada individualmente para cada fungo, na presença de clorpirifós, metil paration e profenofós. Cada tubo de ensaio contendo os fungos previamente cultivados na presença do pesticida comercial foram adicionados $5 \mathrm{~mL}$ de solução previamente estelizada de Tween 80 (0,5\%). Com o auxílio de uma agulha de inoculação os esporos e micélios do fungo foram coletados do meio de cultura sólido e foram transferidos para a solução de Tween 80 . As soluções de Tween 80 contendo os esporos e micélios foram transferidas para um único frasco Erlenmeyer de $250 \mathrm{~mL}$ contendo agitador magnético.

A suspenção de esporos foi agitada e em seguida filtrada em um sistema de funil de filtração simples, contendo lã de vidro, acoplado a frascos de penicilina de $10 \mathrm{~mL}$. Em cada frasco de penicilina foram adicionados $5 \mathrm{~mL}$ da solução filtrada e $5 \mathrm{~mL}$ de água destilada esterilizada. Os frascos foram submetidos à centrifugação em centrífuga da marca Hermle Z 200 A à temperatura ambiente $(10 \mathrm{~min}, 4600 \mathrm{~g})$ em seguida a fase líquida foi descartada. A etapa de lavagem com água destilada esterilizada, seguida por centrifugação foi realizada quatro vezes até a remoção completa do Tween 80 da solução de esporos. 


\subsubsection{Contagem dos esporos na suspensão}

Com o auxílio de uma micropipeta a suspensão de esporos foi transferida para uma câmara de Neubauer (Neubauer Improved Bright-line) da marca HBG e, em seguida, coberta com uma lamínula. A contagem foi feita em Microscópio Óptico da marca Zeiss modelo Primo-Star no Laboratório do Grupo de Microbiologia Microbiana coordenado pela Prof ${ }^{\mathrm{a}}$. Dra Márcia Nitschke do Institudo de Química de São Carlos-IQSC. Para garantir a confiabilidade dos dados, a contagem foi realizada em quadrados pré-estipulados para todas as cepas fúngicas. A câmara de Neubauer é dividida em dois blocos (bloco A e bloco B) com 25 quadrados cada bloco. As contagens foram feitas em 25 quadrados do bloco central da câmara A e em 25 quadrados do bloco central da câmara B contendo a suspensão de esporos, totalizando 50 quadrados contados para cada fungo (Figura 36).

Figura 36. Esquema de ampliação dos blocos de uma câmara de Neubauer.

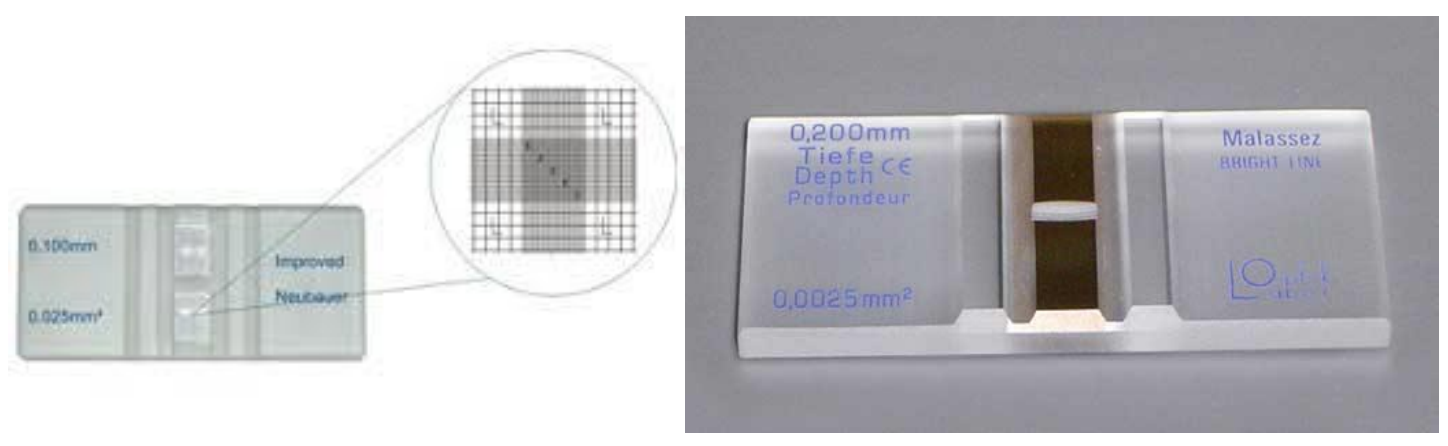

Fonte: FIORI, D. Diagnóstico histológico: reconhecimento dos órgãos por sua estrutura microscópica. Rio de Janeiro: Guanabara Kogan, 1960. 749 p. ${ }^{130}$

Posteriormente foi calculada a densidade celular na suspenção de esporos contada que foi baseada no volume dos quadrados da câmara. O volume de qualquer um dos blocos, A ou B é de $0,1 \mathrm{~mm}^{3}$ e de cada quadrado dos blocos é de $0,004 \mathrm{~mm}^{3}$. A densidade (expressa em células/mL) obtida através da contagem nos blocos pode ser calculada de acordo com a equação para o cálculo de densidade de esporos ilustradada na Figura $37 .{ }^{130}$

Figura 37. Equação para o cálculo da densidade de esporos na solução.

$$
\mathrm{D}=\frac{\mathrm{n}^{\mathrm{o}} \text { de esporos contados }}{\mathrm{Nq} \times 4 \times 10^{-6}}
$$

Onde,

$\mathrm{Nq}=$ números de quadrados contados nas duas câmaras

$4 \times 10^{-6}=$ volume da amostra sobre a área do quadrado $\left(0,004 \mathrm{~mm}^{3}\right)$ expressa em $\mathrm{mL}\left(\mathrm{cm}^{3}\right) .{ }^{130}$ 
A Figura 38 ilustra as etapas de preparação da suspenção de esporos para a posterior contagem na câmara de Neubauer com auxílio de microscópio óptico.

Figura 38. Fluxograma das etapas de preparação da suspensão de esporos.

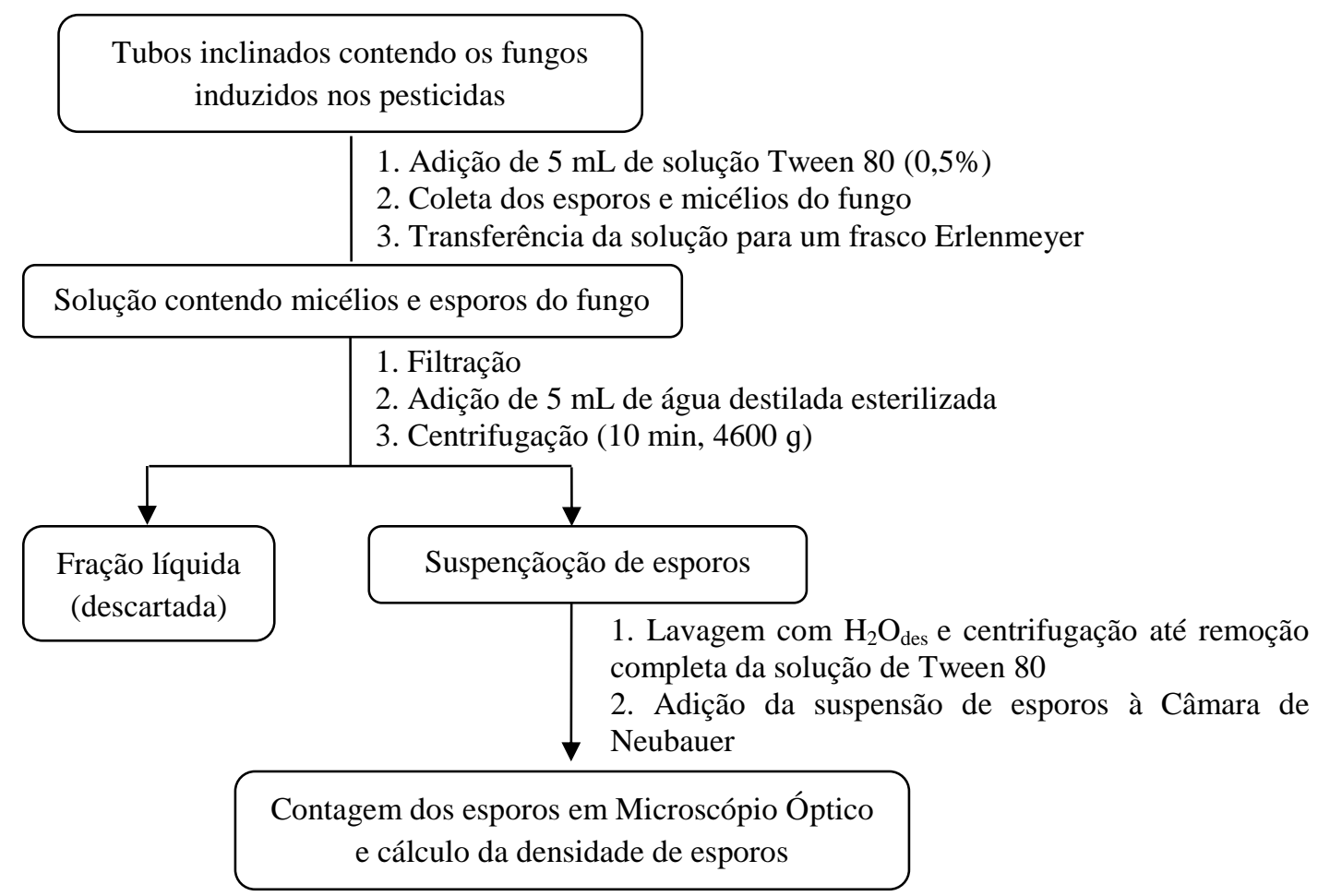

\subsection{Reações de biotransformação de clorpirifós, metil paration e profenofós}

\subsubsection{Reações de biotransformação entre os pesticidas comerciais clorpirifós, metil} paration e profenofós pelo fungo de ambiente marinho A. sydowii CBMAI 935

Para cada pesticida foram preparados nove frascos Erlenmeyer contendo cada um 100 $\mathrm{mL}$ de meio de cultura líquido de malte $2 \%(\mathrm{pH} \mathrm{7,0)}$ previamente esterilizados em autoclave, para realização dos inóculos do fungo A. sydowii CBMAI 935. Com o auxílio de uma micropipeta foi adicionado uma suspensão de esporos com volume $(140 \mu \mathrm{L})$ do A. sydowii CBMAI 935.

Após o inóculo do fungo. Os frascos Erlenmeyer foram mantidos em agitação orbital $\left(130 \mathrm{rpm}, 32^{\circ} \mathrm{C}\right)$ para promover o crescimento dos fungos durante 4 dias. Após este período foram adicionados separadamente os volumes de $10,3 \mu \mathrm{L}\left(0,41 \mathrm{mmol}, 50 \mathrm{mg} . \mathrm{L}^{-1}\right)$ do pesticida clorpirifós; $5,5 \mu \mathrm{L}\left(0,28 \mathrm{mmol}, 50 \mathrm{mg} . \mathrm{L}^{-1}\right)$ do pesticida metil paration e 18,5 $\mu \mathrm{L}(0,72 \mathrm{mmol}$, $\left.50 \mathrm{mg} . \mathrm{L}^{-1}\right)$ do pesticida profenofós. Os frascos foram novamente mantidos em agitação orbital $\left(130 \mathrm{~g}, 32^{\circ} \mathrm{C}\right)$ durante 10,20 e 30 dias. 
Os experimentos foram interrompidos em 10, 20 e 30 dias de reação. Todas as reações foram realizadas em triplicatas e três reações de controle (crescimento do fungo na ausência do pescitida). Em seguida, os micélios foram filtrados em funil de Buchner, promovendo a separação do caldo enzimático das células úmidas. As células úmidas foram adicionadas em um frasco Erlenmeyer contendo $15 \mathrm{~mL}$ de água destilada e $15 \mathrm{~mL}$ de acetato de etila, e então, foram submetidas à agitação magnética durante 30 min à temperatura ambiente.

$\mathrm{O}$ meio reacional foi acidificado com $\mathrm{HCl}(1 \mathrm{~mol} / \mathrm{L})$ para $\mathrm{pH} 6,0$ e em seguida foi extraído com acetato de etila $(3 \times 25 \mathrm{~mL})$. Posteriormente foi adicionado $\mathrm{Na}_{2} \mathrm{SO}_{4}$ anidro, filtrado e evaporado o solvente. O resíduo (ou extrato) obtido foi ressuspenso em acetato de etila e transferido para balões volumétricos de $10 \mathrm{~mL}$, um balão volumétrico com amostra da extração do caldo enzimático e outra com amostra da extração da fase micelial foram posteriormente transferidas para vials de 1,5 mL. As amostras do caldo enzimático e da fase micelial foram submetidas às análises por CLAE-UV e CG-EM.

As células úmidas foram colocadas em estufa para secagem $\left(32^{\circ} \mathrm{C}, 24 \mathrm{~h}\right)$ e posteriormente pesadas.

A Figura 39 ilustra as etapas envolvidas nas reações de biotransformação entre os pesticidas comerciais clorpirifós, metil paration e profenofós. 
Figura 39. Fluxograma das etapas de preparação e extração da fase micelial e caldo enzimático das reações com o fungo A. sydowii CBMAI 935 para os pesticidas clorpirifós, metil paration e profenofós (extração dos micélios e caldo enzimático separadamente).

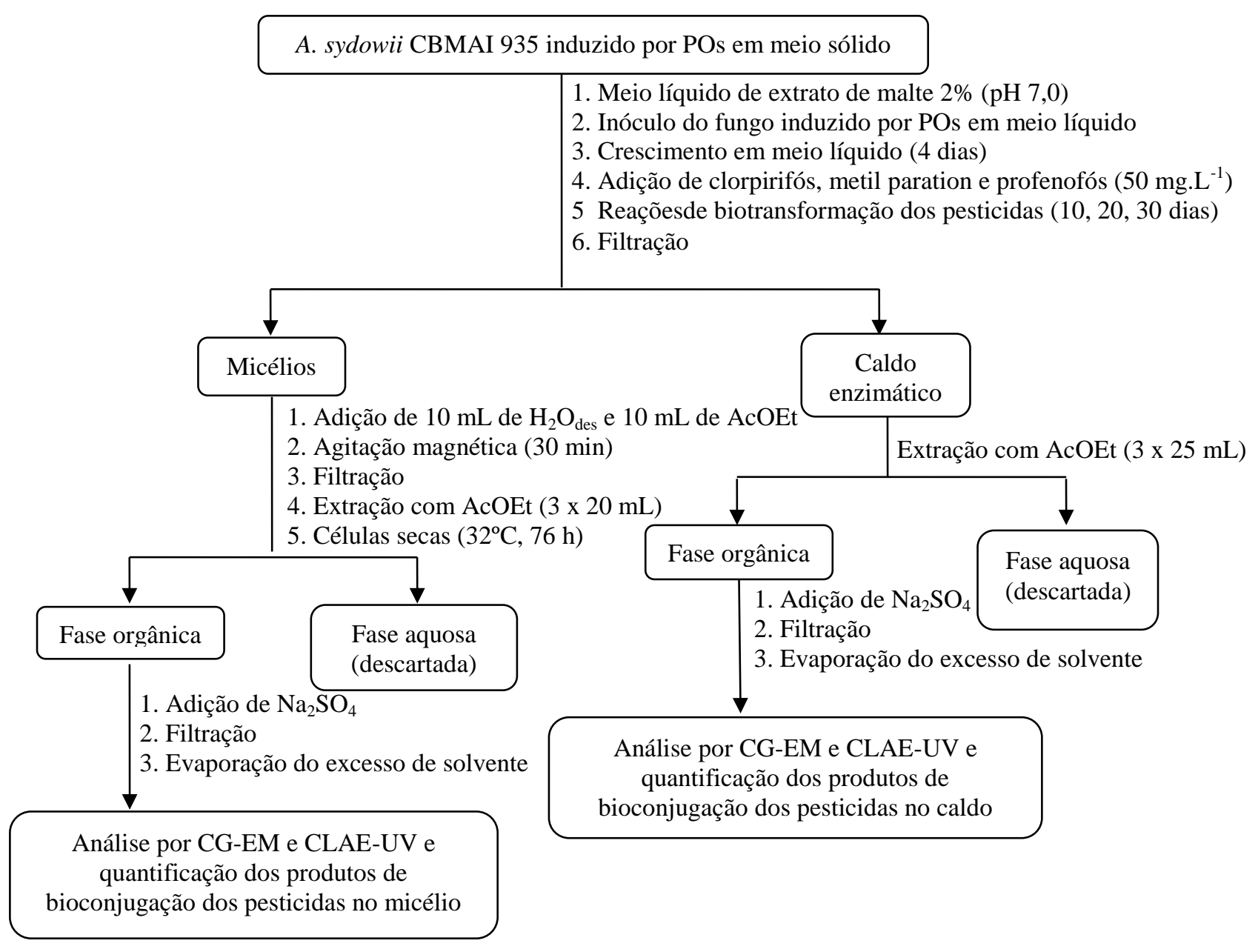

3.7.1.1 Controle da reação para os pesticidas comerciais clorpirifós, metil paration e profenofós (estabilidade dos pesticidas)

Para cada pesticida foram preparados dois frascos Erlenmeyer contendo $100 \mathrm{~mL}$ de meio de cultura líquido de malte $2 \%$ em $\mathrm{pH} 7,0$. Após o meio de cultura esterilizado ser resfriado até $30-35^{\circ} \mathrm{C}$, foram adicionados os volumes de $10,3 \mu \mathrm{L}\left(0,41 \mathrm{mmol}, 50 \mathrm{mg} \cdot \mathrm{L}^{-1}\right)$ do pesticida clorpirifós, $5,5 \mu \mathrm{L}\left(0,28 \mathrm{mmol}, 50 \mathrm{mg} \cdot \mathrm{L}^{-1}\right)$ do pesticida metil paration e $18,5 \mu \mathrm{L}(0,72 \mathrm{mmol}$, $\left.50 \mathrm{mg} \cdot \mathrm{L}^{-1}\right)$ do pesticida profenofós. Os frascos foram mantidos em agitação orbital $(130 \mathrm{~g}$, $\left.32^{\circ} \mathrm{C}\right)$.

Após 10 dias de reação os experimentos foram extraídos. As extrações procederam de acordo com as extrações descritas na Figura 39, não sendo necessária a etapa da filtração já que esta reação não continha o fungo. As amostras foram submetidas às análises por CG-EM. 


\subsubsection{Controle das reações para o fungo A. sydowii CBMAI 935(ausência de pesticida)}

Para cada pesticida foram preparados três frascos Erlenmeyer contendo $100 \mathrm{~mL}$ de meio de cultura líquido de malte $2 \%$ em $\mathrm{pH} 7,0$ seguindo os mesmos procedimentos descritos na Figura 39, no entanto, não foram adicionados os pesticidas. Foram feitas extrações após 10, 20 e 30 dias de reação e as amostras foram submetidas às análises por CG-EM.

\subsubsection{Reações de biotransformação entre os compostos fenólicos 3,5,6-tricloro-2- piridinol, 4-nitrofenol, 4-bromo-2-clorofenol com o fungo de ambiente marinho A. sydowii CBMAI 935}

Para cada composto fenólico: 3,5,6-tricloro-2-piridinol, 4-nitrofenol, 4-bromo-2clorofenol foram preparados nove frascos Erlenmeyer contendo $100 \mathrm{~mL}$ de meio de cultura líquido de malte $2 \%(\mathrm{pH} \mathrm{7)}$, previamente esterilizados em autoclave para realização dos inóculos do fungo A.sydowii CBMAI 935. Com o auxílio de uma de uma micropipeta foi adicionado uma suspensão de esporos $(140 \mu \mathrm{L})$ do A. sydowii CBMAI 935.

Após o inóculo do fungo, os frascos Erlenmeyer foram mantidos em agitação orbital (130 $\mathrm{rpm}, 32^{\circ} \mathrm{C}$ ) para promover o crescimento dos fungos durante 4 dias. Após este período foram adicionados uma concentração de $50 \mathrm{mg} . \mathrm{L}^{-1}$ para cada composto fenólico testado.

Os frascos foram novamente mantidos em agitação orbitalar $\left(130 \mathrm{rpm}, 32^{\circ} \mathrm{C}\right)$ por 10,20 e 30 dias para as reações de biotransformação com os compostos fenólicos derivados dos pesticidas organofosforados (3,5,6-tricloro-2-piridinol, 4-nitrofenol e 4-bromo-2-clorofenol).

Os experimentos para os compostos fenólicos derivados dos pesticidas foram interrompidos com 10, 20 e 30 dias de reação. Todas as reações foram realizadas em triplicatas e três reações de controle (crescimento do fungo na ausência do pescitida). Em seguida, os micélios foram filtrados em funil de Buchner, promovendo a separação do caldo enzimático das células úmidas. As células úmidas foram adicionadas em um frasco Erlenmeyer contendo $15 \mathrm{~mL}$ de água destilada e $15 \mathrm{~mL}$ de acetato de etila, e então, foram submetidas à agitação magnética durante 30 min.

$\mathrm{O}$ meio reacional foi acidificado com $\mathrm{HCl}(1 \mathrm{~mol} / \mathrm{L})$ para $\mathrm{pH}$ 6,0 e em seguida foi extraído com acetato de etila ( $3 \times 25 \mathrm{~mL}$ ), adicionado $\mathrm{Na}_{2} \mathrm{SO}_{4}$ anidro, filtrado e evaporado o solvente. O resíduo (ou extrato) obtido foi ressuspenso em acetato de etila e transferido para um balão volumétrico de $10 \mathrm{~mL}$. As amostras do caldo enzimático e da fase micelial foram submetidas às análises por CLAE e CG-EM. 
As células úmidas foram colocadas em estufa para secagem $\left(32^{\circ} \mathrm{C}, 76 \mathrm{~h}\right)$ e posteriormente pesadas.

A Figura 40 ilustra as etapas de preparação e extração da fase micelial e caldo enzimático das reações com Aspegillus sydowii CBMAI 935 com o 3,5,6-tricloro-2-piridinol, 4-nitrofenol, 4-bromo-2-clorofenol.

Figura 40. Fluxograma das etapas de preparação e extração da fase micelial e caldo enzimático das reações com A. sydowii CBMAI 935 e 3,5,6-tricloro-2-piridinol, 4-nitrofenol, 4-bromo-2-clorofenol (extração dos micélios e caldo enzimático separadamente).

A. sydowii CBMAI 935 induzido por compostos fenólicos em meio sólido

1. Meio líquido de extrato de malte $2 \%(\mathrm{pH} \mathrm{7,0)}$

2. Inóculo do fungo induzido por compostos fenólicos em meio líquido

3. Crescimento em meio líquido (4 dias)

4. Adição de fenois $\left(50 \mathrm{mg} . \mathrm{L}^{-1}\right)$

5. Reações de biometilação com compostos fenólicos (10, 20, 30 d)

6.Filtração

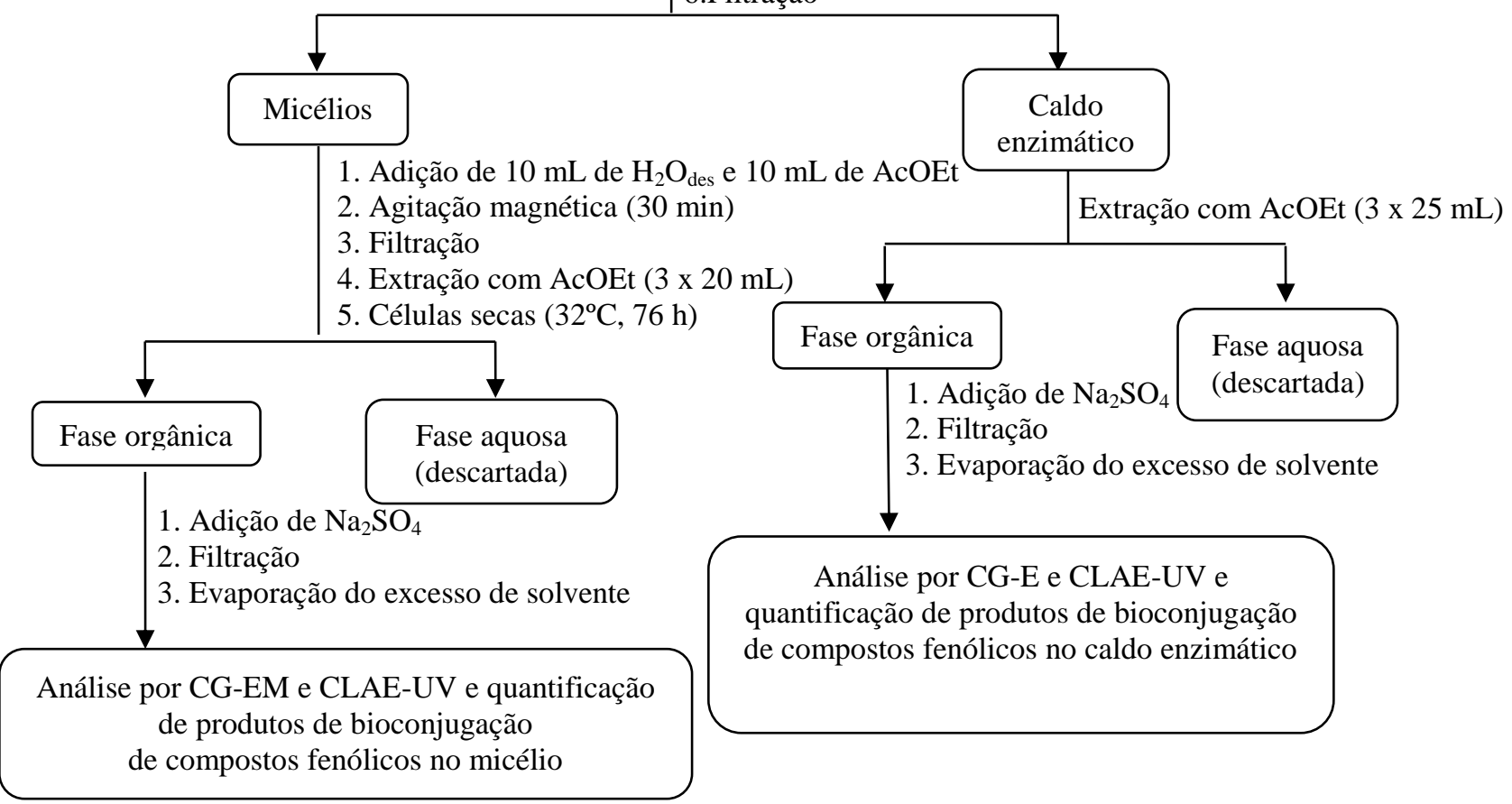


3.7.2.1 Controle das reações para os compostos fenólicos derivados dos pesticidas organofosforados (estabilidade dos compostos fenólicos)

Para cada composto fenólico: 3,5,6-tricloro-2-piridinol, 4-nitrofenol, 4-bromo-2clorofenol foram preparados 2 frascos Erlenmeyer contendo $100 \mathrm{~mL}$ de meio de cultura líquido de malte $2 \%$ em pH 7,0. Após o meio de cultura ser esterilizado foi resfriado até 30$35^{\circ} \mathrm{C}$, foram adicionados $5 \mathrm{mg}\left(0,25 \mathrm{mmol}, 50 \mathrm{mg} . \mathrm{L}^{-1}\right)$ do composto fenólico 3,5,6-tricloro-2piridinol, $5 \mathrm{mg}$ (0,36 mmol, $\left.50 \mathrm{mg} . \mathrm{L}^{-1}\right)$ do composto 4-nitrofenol e $5 \mathrm{mg} . \mathrm{L}^{-1}$ (0,24 mmol, 50 $\left.\mathrm{mg} . \mathrm{L}^{-1}\right)$ do composto 4-bromo-2-clorofenol.

Após 10 dias de reação os experimentos foram extraídos. As extrações procederam de acordo com as extrações descritas na Figura 40, não sendo necessária a etapa da filtração já que esta reação não continha o fungo. As amostras foram submetidas às análises por CG-EM. 3.7.2.2 Controle das reações para o fungo A. sydowii CBMAI 935 (ausência de compostos fenólicos)

Foram preparados 3 frascos Erlenmeyer contendo $100 \mathrm{~mL}$ de meio de cultura líquido de malte $2 \%$ em $\mathrm{pH}$ 7,0 seguindo os mesmos procedimentos descritos na Figura 40. No entanto, não foram adicionados os compostos fenólicos. Foram feitas extrações após 10, 20 e 30 dias de reação. As amostras foram submetidas às análises por CG-EM.

\subsubsection{Reações de biotransformação entre os compostos fenólicos (fenol, 2-clorofenol, 2-} cloro-5-hidroxipiridina, 4-(4-hidroxifenil)ciclo-hexanona, pentaclorofenol e naringenina) com o fungo de ambiente marinho A. sydowii CBMAI 935

Para cada composto fenólico: fenol, 2-clorofenol, 2-cloro-5-hidroxipiridina, 4-(4hidroxifenil)ciclo-hexanona, pentaclorofenol e naringenina foram preparados 9 frascos Erlenmeyer contendo $100 \mathrm{~mL}$ de meio de cultura líquido de malte $2 \%(\mathrm{pH} 7,0)$ previamente esterilizados em autoclave para realização dos inóculos do fungo A.sydowii CBMAI 935. Com o auxílio de uma de uma micropipeta foi adicionado uma suspensão de esporos (140 $\mu \mathrm{L})$ do A. sydowii CBMAI 935.

Após o inóculo do fungo os frascos Erlenmeyer foram mantidos em agitação orbital (130 $\mathrm{rpm}, 32^{\circ} \mathrm{C}$ ) para promover o crescimento dos fungos durante 4 dias. Após este período foram adicionados uma concentração de $50 \mathrm{mg} . \mathrm{L}^{-1}$ para cada composto fenólico testado Os frascos foram novamente mantidos em agitação orbitalar $\left(130 \mathrm{rpm}, 32^{\circ} \mathrm{C}\right)$ por 10 dias para as reações de biotransformação com os compostos fenólicos. 
Os experimentos para os compostos fenólicos foram interrompidos com 10 dias de reação. Todas as reações foram realizadas em triplicatas e três reações de controle (crescimento do fungo na ausência do pescitida). Em seguida, os micélios foram filtrados em funil de Buchner, promovendo a separação do caldo enzimático das células úmidas. As células úmidas foram adicionadas em um frasco Erlenmeyer contendo $15 \mathrm{~mL}$ de água destilada e $15 \mathrm{~mL}$ de acetato de etila, e então, foram submetidas à agitação magnética durante $30 \min$

$\mathrm{O}$ meio reacional foi acidificado com $\mathrm{HCl}(1 \mathrm{~mol} / \mathrm{L})$ para $\mathrm{pH} 6,0$ e em seguida foi extraído com acetato de etila $(3 \times 25 \mathrm{~mL})$, adicionado $\mathrm{Na}_{2} \mathrm{SO}_{4}$ anidro, filtrado e evaporado o solvente. O resíduo (ou extrato) obtido foi ressuspenso em acetato de etila e transferido para um balão volumétrico de $10 \mathrm{~mL}$. As amostras do caldo enzimático e da fase micelial foram submetidas às análises por CG-EM.

As células úmidas foram colocadas em estufa para secagem $\left(32^{\circ} \mathrm{C}, 76 \mathrm{~h}\right)$ e posteriormente pesadas.

A Figura 41 ilustra as etapas de preparação e extração da fase micelial e caldo enzimático das reações com Aspegillus sydowii CBMAI 935 com o fenol, 2-clorofenol, 2-cloro-5hidroxipiridina, 4-(4-hidroxifenil)ciclo-hexanona, pentaclorofenol e naringenina (extração dos micélios e caldo enzimático separadamente). 
Figura 41. Fluxograma das etapas de preparação e extração da fase micelial e caldo enzimático das reações com A. sydowii CBMAI 935 com o fenol, 2-clorofenol, 2-cloro-5-hidroxipiridina, 4-(4-hidroxifenil)ciclo-hexanona, pentaclorofenol e naringenina (extração dos micélios e caldo enzimático separadamente).

A. sydowii CBMAI 935 induzido por compostos fenólicos em meio sólido

1. Meio líquido de extrato de malte $2 \%(\mathrm{pH} 7)$

2. Inóculo do fungo induzido por compostos fenólicos em meio líquido

3. Crescimento em meio líquido (4 dias)

4. Adição de fenois $\left(50 \mathrm{mg} . \mathrm{L}^{-1}\right)$

5 Reaçõesde biometilação com compostos fenólicos (10 d)

6. Filtração

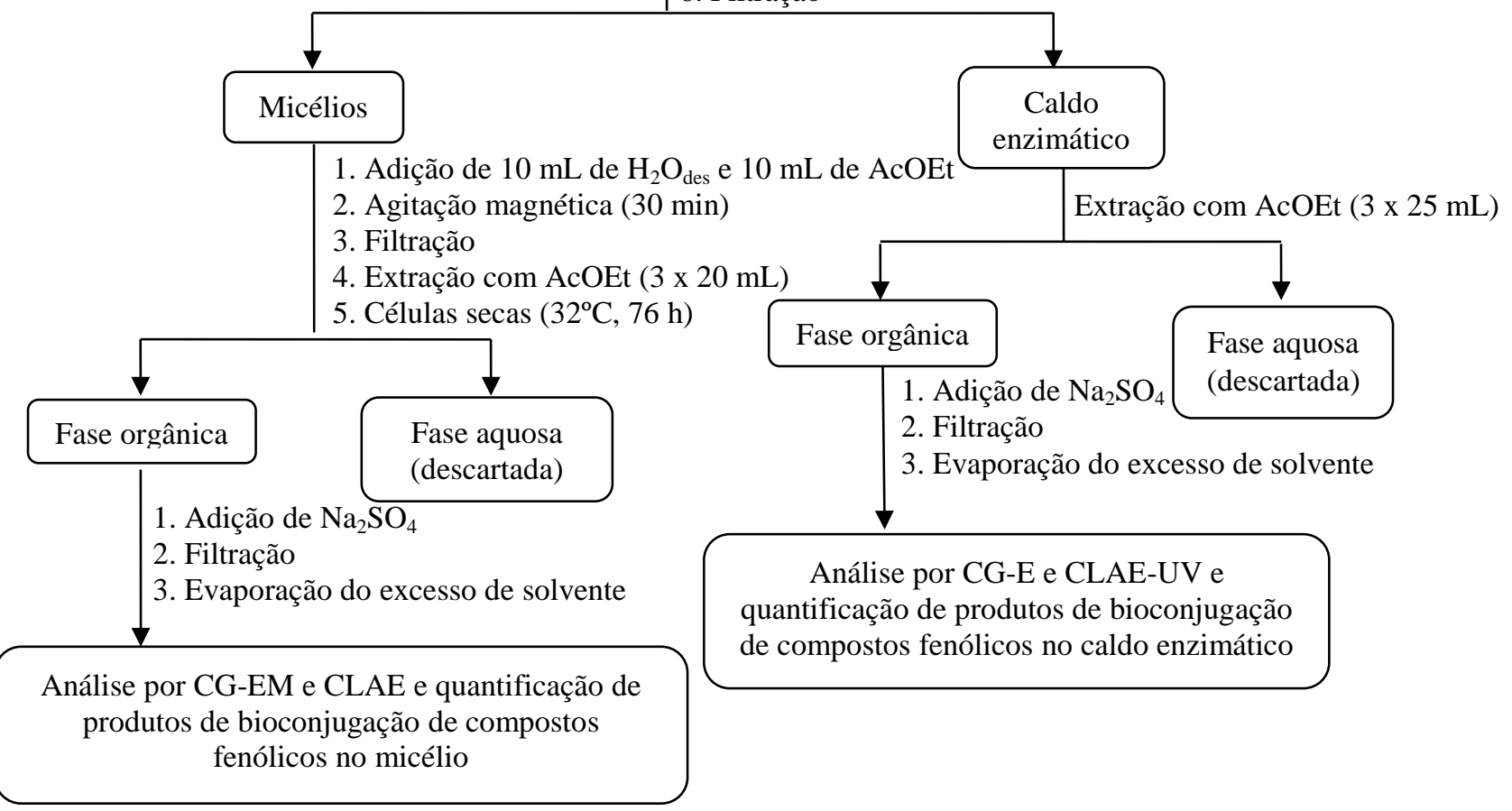

3.7.3.1 Controle das reações para os compostos fenólicos testados (estabilidade dos compostos fenólicos)

Para cada composto fenólico: fenol, 2-clorofenol, 2-cloro-5-hidroxipiridina, 4-(4hidroxifenil)ciclo-hexanona, pentaclorofenol e naringenina foram preparados 2 frascos Erlenmeyer contendo $100 \mathrm{~mL}$ de meio de cultura líquido de malte $2 \%$ em pH 7,0. Após o meio de cultura ser esterilizado foi resfriado entre $30-35^{\circ} \mathrm{C}$ e em seguida foram adicionados $50 \mathrm{mg} . \mathrm{L}^{-1}$ de cada composto fenólico testado.

Após 10 dias de reação os experimentos foram extraídos. As extrações procederam de acordo com as extrações descritas na Figura 41, não sendo necessária a etapa da filtração já que esta reação não continha o fungo. As amostras foram submetidas às análises por CG-EM. 
3.7.3.2 Controle das reações para o fungo A. sydowii CBMAI 935 (ausência de compostos fenólicos)

Foram preparados três frascos Erlenmeyer contendo $100 \mathrm{~mL}$ de meio de cultura líquido de malte $2 \%$ em $\mathrm{pH} 7,0$ seguindo os mesmos procedimentos descritos na Figura 41. No entanto, não foram adicionados os compostos fenólicos. Posteriormente foram feitas extrações após 10 dias de reaçãoe em seguida as amostras foram submetidas às análises qualitativas por CG-EM. 


\section{RESULTADOS E DISCUSSÃO}

\subsection{Seleção dos fungos em meio de cultura sólido de malte $2 \%$ e Ágar frente aos pesticidas comerciais clorpirifós, metil paration e profenofós}

Inicialmente foi realizado um screening com sete fungos: Aspergillus sydowii CBMAI 934, Penicillium raistrickii CBMAI 931, A. sydowii CBMAI 935 que foram isolados da esponja marinha Chelonaplysilla erecta, $P$. raistrickii CBMAI 1235, P. decaturense CBMAI 1234, A. sydowii CBMAI 1241 que foram isolados da esponja marinha Dragmacidon reticulata e o fungo Trichoderma sp. CBMAI 932 que foi isolado da esponja marinha Geodia corticostylifera.

Os sete fungos selecionados foram repicados em meio de cultura sólido de malte $2 \%$ e agar na presença dos pesticidas comerciais organofosforados clorpirifós, metil paration e profenofós. Posteriormente os sete fungos selecionados, foram repicados em meio de cultura sólido de malte $2 \%$ e agar contendo os compostos fenólicos (3,5,6-tricloro piridinol, 4nitrofenol e 4-bromo-2-clorofenol) derivados da hidólise dos pesticidas e os compostos: fenol, 2-clorofenol, 2-cloro-5-hidroxipiridina, 4-(4-hidroxifenil)ciclo-hexanona, pentaclorofenol e naringenina. Essa metodologia usada para os pesticidas e os fenóis teve objetivo de avaliar o crescimento dos fungos na presença destes xenobióticos.

Os fungos foram cultivados no meio de cultura sódido de malte $2 \%$ e Agar em $\mathrm{pH} 5$, que é um valor ótimo para o cultivo da maioria dos fungos, sendo que o $\mathrm{pH}$ ideal pode variar de 4 a 6. Estes valores de $\mathrm{pH}$ favorecem o crescimento dos fungos e inibem o crescimento da maioria das bactérias, já que o cultivo bacteriano é ideal em valores de $\mathrm{pH}$ mais elevados. ${ }^{131}$

O potencial dos fungos para biodegradar os pesticidas foi avaliado pela comparação entre o crescimento das colônias fúngicas em placas de Petri com diferentes concentrações de pesticidas com aqueles cultivados em placa de Petri controle (ausência de pesticida). As quantidades de pesticidas empregadas nas triagens foram inicialmente utilizadas, com o objetivo de analisar qualitativamente o desenvolvimento dos fungos. Na literatura não há uma relação definida da concentração de pesticida que deve ser utilizada em um estudo de biodegradação. Podendo variar muito de acordo com os pesticidas, condições e microrganismos utilizados. ${ }^{74}$

Através das informações fornecidas pelos fabricantes, as concentrações estimadas para os pesticidas comerciais utilizados em meio sólido estão sumarizadas na Tabela 11. 
Tabela 11. Concentrações de pesticidas organofosforados nas placas de Petri para avaliação do crescimento de fungos de ambiente marinho em meio de cultura sólido de malte 2\% e Agar.

\begin{tabular}{lcccc}
\hline \multicolumn{1}{c}{ Pesticida } & $\begin{array}{c}\text { Concentração estabelecida } \\
\text { pelo fornecedor }(\mathrm{g} / \mathrm{L})\end{array}$ & \multicolumn{3}{c}{$\begin{array}{c}\text { Concentração de pesticida (ppm) estimada em meio } \\
\text { sólido por placa de Petri }\end{array}$} \\
\hline Clorpirifós & 480 & $5 \mu \mathrm{L}$ & $10 \mu \mathrm{L}$ & $15 \mu \mathrm{L}$ \\
Metil paration & 600 & 96 & 192 & 288 \\
Profenofós & 400 & 120 & 240 & 360 \\
\hline
\end{tabular}

Os halos de crescimento foram mensurados nas placas de Petri durante 10 dias de cultivo nas condições de temperatura e $\mathrm{pH}\left(32^{\circ} \mathrm{C}, \mathrm{pH}\right.$ 5). Em geral as cepas fúngicas apresentaram um bom desenvolvimento nas placas de Petri controle (ausência de pesticida), demonstrando que o meio de cultura sólido de malte $2 \%$ e Agar foi ideal para o crescimento destes microrganismos, fornecendo os nutrientes necessários para o crescimento fúngico.

Para crescerem e desenvolver-sem os fungos necessitam de uma variedade de elementos químicos inorgânicos e orgânicos como nutrientes. O carbono é um dos elementos mais importantes para o crescimento microbiano, fornecendo energia para o crescimento celular e servindo como unidade básica para obtenção do material celular. O nitrogênio também é essencial aos organismos, bem como outros elementos (hidrogênio, oxigênio e fósforo). ${ }^{131,74}$

Assim, o crescimento dos fungos na presença dos pesticidas ou de compostos fenólicos pode ser um indicativo de que pode ocorrer uma metabolização do pesticida como um mecanismo de defesa dos microrganismos eliminando estes xenobióticos, ou até mesmo possam utilizar estes pesticidas como fontes de nutrientes para o crescimento dos fungos, já que os pesticidas organofosforados em geral, apresentam carbono, oxigênio, enxofre, nitrogênio e fósforo.

Para cada fungo foram preparadas quatro placas de Petri, uma na ausência do pesticida (placa controle) e as demais, com diferentes concentrações de pesticida comercial. Após a esterilização do meio, este foi resfriado a aproximadamente $30-35^{\circ} \mathrm{C}$ e foi adicionado o pesticida nos volumes de $5 \mu \mathrm{L}$ de pesticida ou composto fenólico diluído em $100 \mu \mathrm{L}$ de DMSO, $10 \mu \mathrm{L}$ de pesticida ou composto fenólico diluído em $200 \mu \mathrm{L}$ de DMSO e $15 \mu \mathrm{L}$ de pesticida ou composto fenólico diluído em $300 \mu \mathrm{L}$ de DMSO em cada placa. Com o meio sólido à temperatura ambiente foram realizados os repiques, transferindo-se com o auxílio de uma agulha de inoculação os esporos e micélios dos fungos previamente cultivados em placas de Petri com extrato de malte $2 \%$ e Agar a partir das culturas puras. Os repiques foram realizados em cinco pontos diferentes das placas de Petri. As placas permaneceram em estufa a uma temperatura de $32{ }^{\circ} \mathrm{C}$ por até 10 dias observando-se e mensurando-se o halo de 
crescimento (raio e diâmetro) dos fungos na placa controle e nas placas com cada pesticida durante este período estipulado.

Houve destaque para o fungo do ambiente marinho A. sydowii CBMAI 935 que durante 10 dias apresentou grande crescimento micelial e preencheu toda a placa de Petri com as três volumes diferentes dos pesticidas avaliados. Assim o fungo pode apresentar alta resistência em diferentes concentrações e consequentemente em variados níveis de toxicidade dos pesticidas organofosforados metil paration, profenofós e clorpirifós, bem como nos possíveis metabólitos fenólicos que podem ter sido formados durante os períodos de 10, 20 e 30 dias de reação de biotransformação. Enquanto, os demais fungos apresentaram crescimentos distintos em diferentes concentrações dos pesticidas. Mas, todos foram satisfatórios para estudos de biodegradação.

\subsubsection{Clorpirifós}

A Figura 42 e a Tabela 12 mostram a avaliação de crescimento em meio de cultura sólido de malte 2\% e Agar do fungo de ambiente marinho P. raistrickii CBMAI 931 frente ao pesticida comercial clorpirifós nos volumes de $5 \mu \mathrm{L}$ de pesticida/100 $\mu \mathrm{L}$ de DMSO, $10 \mu \mathrm{L}$ de pesticida/200 $\mu \mathrm{L}$ de DMSO e $15 \mu \mathrm{L}$ de pesticida/ $300 \mu \mathrm{L}$ de DMSO durante 10 dias de crescimento em condições padrões $\mathrm{pH}\left(32^{\circ} \mathrm{C}, \mathrm{pH} 5,0\right)$.

Figura 42. Cultivo do fungo P. raistrickii CBMAI 931 na ausência de clorpirifós (placa controle) e com 5, 10 e $15 \mu \mathrm{L}$ de clorpirifós/placa. (A) 5 dias de cultivo e (B) 10 dias de cultivo.

A

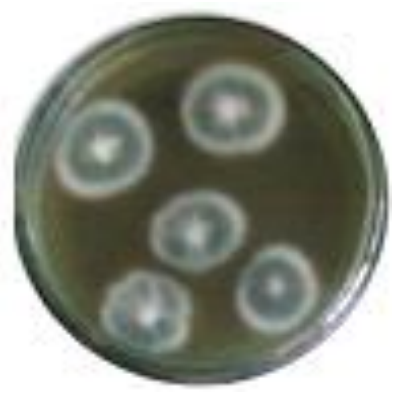

B

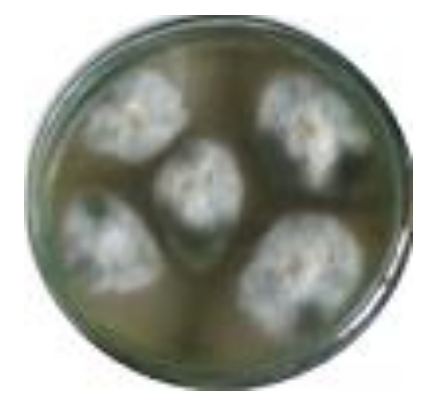

placa de Petri controle
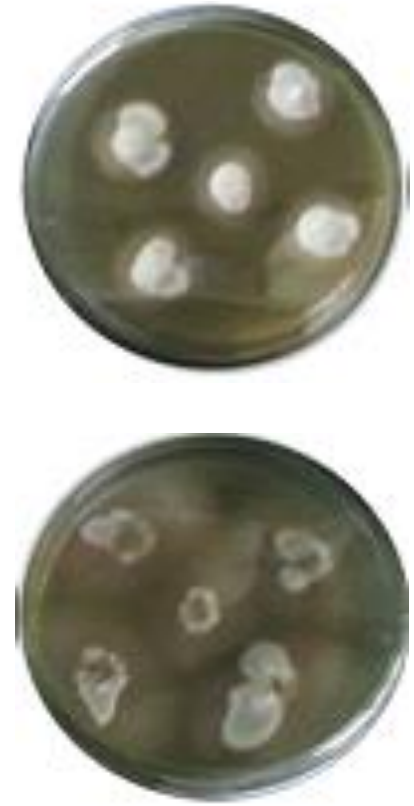

$5 \mu \mathrm{L}$ pesticida/DMSO
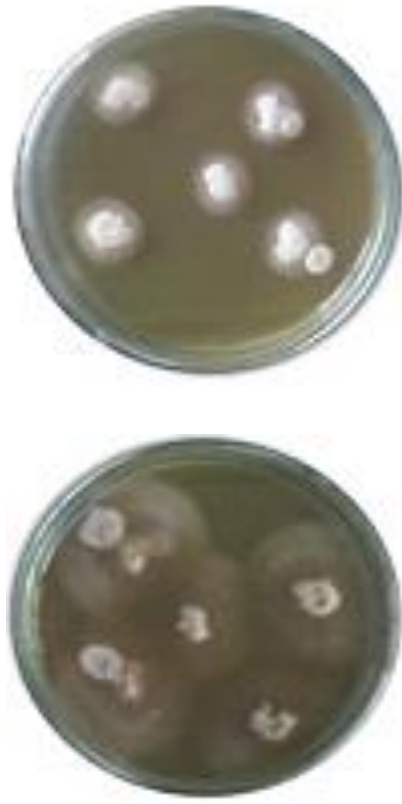

$10 \mu \mathrm{L}$ pesticida/DMSO
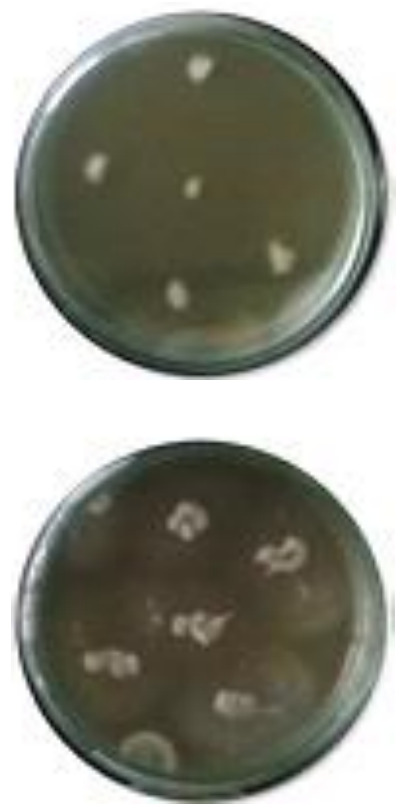

$15 \mu \mathrm{L}$ pesticida/DMSO 
Tabela 12. Avaliação do halo de crescimento em meio de cultura sólido malte $2 \%$ e Agar do fungo de ambiente marinho P. raistrickii CBMAI 931 frente ao pesticida comercial clorpirifós nos volumes de $5 \mu \mathrm{L}$ de pesticida/100 $\mu \mathrm{L}$ de DMSO, $10 \mu \mathrm{L}$ de pesticida/200 $\mu \mathrm{L}$ de DMSO e $15 \mu \mathrm{L}$ de pesticida/ $300 \mu \mathrm{L}$ de DMSO durante 10 dias em condições padrões $\left(32^{\circ} \mathrm{C}, \mathrm{pH} 5,0\right)$.

\begin{tabular}{|c|c|c|c|c|}
\hline \multirow{2}{*}{$\begin{array}{l}\text { Tempo de crescimento } \\
\text { do fungo } \\
\text { P. raistrickii } \\
\text { CBMAI } 931\end{array}$} & \multicolumn{4}{|c|}{ Medida do halo de crescimento $(\mathrm{cm})$} \\
\hline & Placa controle & $\begin{array}{l}5 \mu \mathrm{L} \text { pesticida/ } \\
100 \mu \mathrm{L} \text { DMSO }\end{array}$ & $\begin{array}{l}10 \mu \mathrm{L} \text { pesticida/ } \\
200 \mu \mathrm{L} \text { DMSO }\end{array}$ & $\begin{array}{l}15 \mu \mathrm{L} \text { pesticida/ } \\
300 \mu \mathrm{L} \text { DMSO }\end{array}$ \\
\hline $1^{\circ}$ dia & $1,2 \times 2,0$ & $1,0 \times 1,2$ & $0,8 \times 1,0$ & $0,6 \times 1,0$ \\
\hline $2^{\circ}$ dia & $2,0 \times 2,2$ & $1,3 \times 2,0$ & $1,0 \times 1,5$ & $0,6 \times 1,2$ \\
\hline $3^{\circ}$ dia & $2,2 \times 2,5$ & $1,7 \times 2,2$ & $1,3 \times 1,7$ & $0,8 \times 1,3$ \\
\hline $4^{\circ}$ dia & $2,5 \times 2,5$ & $1,9 \times 2,2$ & $1,4 \times 1,8$ & $1,0 \times 1,3$ \\
\hline $5^{\circ}$ dia & $3,4 \times 3,0$ & $2,2 \times 2,5$ & $1,6 \times 1,8$ & $1,2 \times 1,4$ \\
\hline $6^{\circ} \mathrm{dia}$ & $3,8 \times 3,4$ & $2,5 \times 2,7$ & $2,3 \times 2,5$ & $2,6 \times 2,7$ \\
\hline $7^{\circ}$ dia & $4,2 \times 4,5$ & $2,8 \times 3,0$ & $3,7 \times 3,2$ & $3,2 \times 3,5$ \\
\hline $8^{\circ}$ dia & $5,3 \times 6,2$ & $3,5 \times 3,4$ & $4,3 \times 4,8$ & $3,2 \times 3,5$ \\
\hline $9^{\circ} \mathrm{dia}$ & $6,8 \times 6,5$ & $4,5 \times 4,2$ & $4,3 \times 4,8$ & $3,2 \times 3,5$ \\
\hline $10^{\circ} \mathrm{dia}$ & $6,8 \times 6,5$ & $5,5 \times 4,5$ & $4,3 \times 4,8$ & $3,2 \times 3,5$ \\
\hline
\end{tabular}

Embora as colônias não crescessem de forma uniforme nas placas de Petri, devido o fungo ser esporulante, ficaram evidentes maiores colônias na presença de menor volume do pesticida por placa de Petri. Houve crescimento satisfatório do fungo nas placas de Petri controle (ausência do pesticida) com crescimento estabilizado a partir do $9^{\circ}$ ao $10^{\circ}$ dia, mostrados na Tabela 12.

No volume de $5 \mu \mathrm{L}$ do clorpirifós houve crescimento satisfatório do fungo e estabilizando-se a partir do $9^{\circ}$ dia. Já nos volumes $10 \mu \mathrm{L}$ e $15 \mu \mathrm{L}$ do pesticida, o crescimento foi bem similar, inclusive com a mudança de cor do micélio que nas placas de Petri controle apresentou uma tonalidade verde escura. Nos volumes de $10 \mu \mathrm{L}$ e $15 \mu \mathrm{L}$ do pesticida clorpirifós, a cor predominante foi branca e o crescimento do fungo estabilizou-se a partir do $8^{\circ}$ dia para aconcentração de $10 \mu \mathrm{L}$ e $7^{\circ}$ dia para o volume de $15 \mu \mathrm{L}$, com medidas de crescimento radial mostradas na Tabela 12. 
A Figura 43 e a Tabela 13 mostram a avaliação de crescimento em meio de cultura sólido malte $2 \%$ e Agar do fungo de ambiente marinho Trichoderma sp. CBMAI 932 frente ao pesticida comercial clorpirifós nos volumes de $5 \mu \mathrm{L}$ de pesticida/100 $\mu \mathrm{L}$ de DMSO, $10 \mu \mathrm{L}$ de pesticida/200 $\mu \mathrm{L}$ de DMSO e $15 \mu \mathrm{L}$ de pesticida/ $300 \mu \mathrm{L}$ de DMSO durante 10 dias de crescimento em condições padrões $\mathrm{pH}\left(32^{\circ} \mathrm{C}, \mathrm{pH} 5,0\right)$.

Figura 43. Cultivo do fungo Trichoderma sp. CBMAI 932 na ausência de clorpirifós (placa controle) e com 5, 10 e $15 \mu \mathrm{L}$ de clorpirifós/placa. (A) 5 dias de cultivo e (B) 10 dias de cultivo.

A
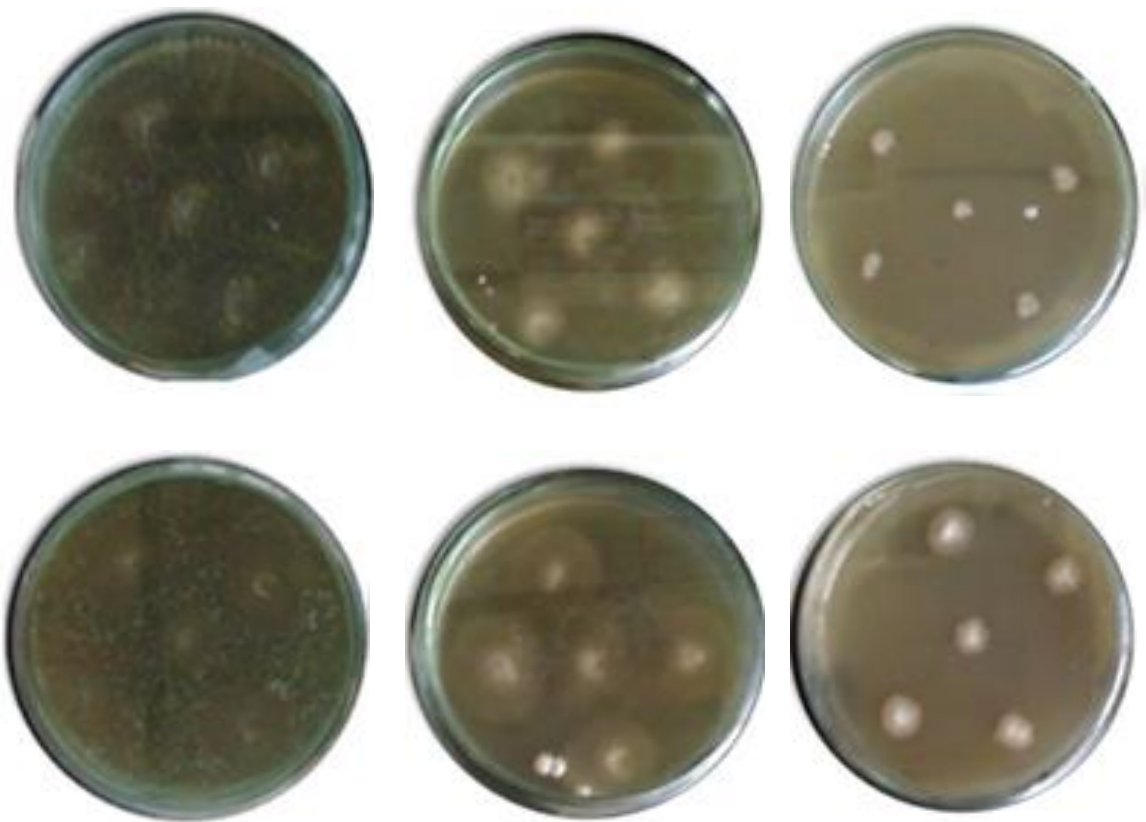

placa de Petri controle
$5 \mu \mathrm{L}$ pesticida/DMSO
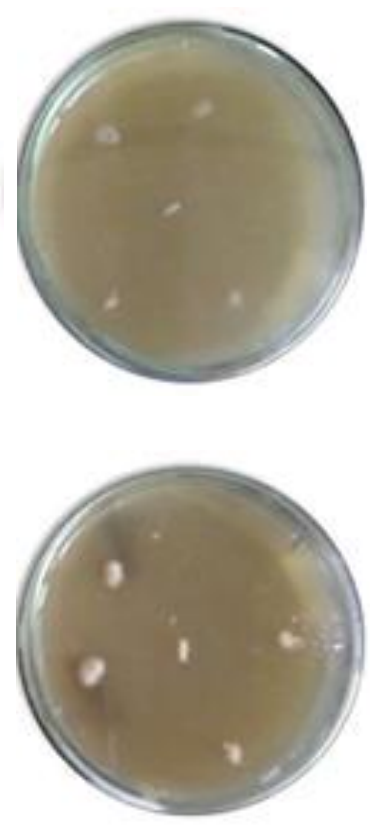

$15 \mu \mathrm{L}$ pesticida/DMSO 
Tabela 13. Avaliação do halo de crescimento em meio de cultura sólido malte $2 \%$ e Agar do fungo de ambiente marinho Trichoderma sp. CBMAI 932 frente ao pesticida comercial clorpirifós nos volumes de $5 \mu \mathrm{L}$ de pesticida/100 $\mu \mathrm{L}$ de DMSO, $10 \mu \mathrm{L}$ de pesticida/200 $\mu \mathrm{L}$ de DMSO e $15 \mu \mathrm{L}$ de pesticida/ $300 \mu \mathrm{L}$ de DMSO durante 10 dias em condições padrões $\left(32^{\circ} \mathrm{C}, \mathrm{pH} 5,0\right)$.

\begin{tabular}{ccccc}
\hline $\begin{array}{l}\text { Tempo de crescimento } \\
\text { do fungo }\end{array}$ & \multicolumn{3}{c}{ Medida do halo de crescimento $(\mathrm{cm})$} \\
\hline $\begin{array}{c}\text { Trichoderma sp. } \\
\text { CBMAI } 932\end{array}$ & Placa controle & $\begin{array}{c}5 \mu \mathrm{L} \text { pesticida/ } \\
100 \mu \mathrm{L} \text { DMSO }\end{array}$ & $\begin{array}{c}10 \mu \mathrm{L} \text { pesticida/ } \\
200 \mu \mathrm{L} \text { DMSO }\end{array}$ & $\begin{array}{c}15 \mu \mathrm{L} \text { pesticida/ } \\
300 \mathrm{~L} \text { DMSO }\end{array}$ \\
$1^{\circ}$ dia & $3,2 \times 3,0$ & $2,0 \times 2,6$ & $0,6 \times 0,8$ & $0,3 \times 0,3$ \\
$2^{\circ}$ dia & $3,8 \times 3,5$ & $3,3 \times 2,8$ & $1,0 \times 1,5$ & $0,6 \times 1,2$ \\
$3^{\circ}$ dia & $5,2 \times 4,5$ & $3,7 \times 3,2$ & $1,3 \times 1,7$ & $1,0 \times 1,3$ \\
$4^{\circ}$ dia & $6,5 \times 5,5$ & $4,9 \times 3,9$ & $1,4 \times 1,8$ & $1,0 \times 1,3$ \\
$5^{\circ}$ dia & $7,4 \times 7,0$ & $5,2 \times 4,5$ & $1,6 \times 1,8$ & $1,0 \times 1,3$ \\
$6^{\circ}$ dia & Toda a placa & $6,5 \times 6,7$ & $2,3 \times 2,5$ & $1,0 \times 1,3$ \\
$7^{\circ}$ dia & Toda a placa & Toda a placa & $2,3 \times 2,5$ & $1,0 \times 1,3$ \\
$8^{\circ}$ dia & Toda a placa & Toda a placa & $2,3 \times 2,5$ & $1,0 \times 1,3$ \\
\hline $9^{\circ}$ dia & Toda a placa & Toda a placa & $2,3 \times 2,5$ & $1,0 \times 1,3$ \\
\hline $0^{\circ}$ dia & Toda a placa & Toda a placa & $2,3 \times 2,5$ & \\
\hline
\end{tabular}

Como pode ser observado nas placas de Petri da Figura 43 houve crescimento satisfatório do fungo Trichoderma sp. CBMAI 932 nas placas Petri controle (ausência do pesticida), com crescimento micelial que preencheu toda a placa de Petri a partir do $6^{\circ}$ dia como mostrado na Tabela 13.

No volume de $5 \mu \mathrm{L}$ de clorpirifós ocorreu o contrário do que se era esperado, pois com a inserção do pesticida houve um crescimento significativo do fungo que preencheu toda placa de Petri a partir do $7^{\circ}$ dia. Isso ocorreu, pois segundo a literatura, o pesticida em baixos volumes pode também ser uma fonte de nutrientes. ${ }^{74}$ Já nos volumes $10 \mu \mathrm{L}$ e $15 \mu \mathrm{L}$ do pesticida o crescimento foi bem similar e pouco significativo devido aos volumes maiores do pesticida, no qual teve seu crescimento estabilizado a partir do $6^{\circ}$ dia para $10 \mu \mathrm{L}$ e no $4^{\circ}$ dia para $15 \mu \mathrm{L}$, com medidas de crescimento micelial mostrados na Tabela 13. 
A Figura 44 e a Tabela 14 mostram a avaliação de crescimento em meio de cultura sólido malte $2 \%$ e Agar do fungo de ambiente marinho A. sydowii CBMAI 934 frente ao pesticida comercial clorpirifós nos volumes de $5 \mu \mathrm{L}$ de pesticida/100 $\mu \mathrm{L}$ de DMSO, $10 \mu \mathrm{L}$ de pesticida/200 $\mu \mathrm{L}$ de DMSO e $15 \mu \mathrm{L}$ de pesticida/ $300 \mu \mathrm{L}$ de DMSO durante 10 dias de crescimento em condições padrões $\mathrm{pH}\left(32^{\circ} \mathrm{C}, \mathrm{pH} 5,0\right)$.

Figura 44. Cultivo do fungo A. sydowii CBMAI 934 na ausência de clorpirifós (placa controle) e com 5, 10 e 15 $\mu \mathrm{L}$ de clorpirifós/placa. (A) 5 dias de cultivo e (B) 10 dias de cultivo.

A
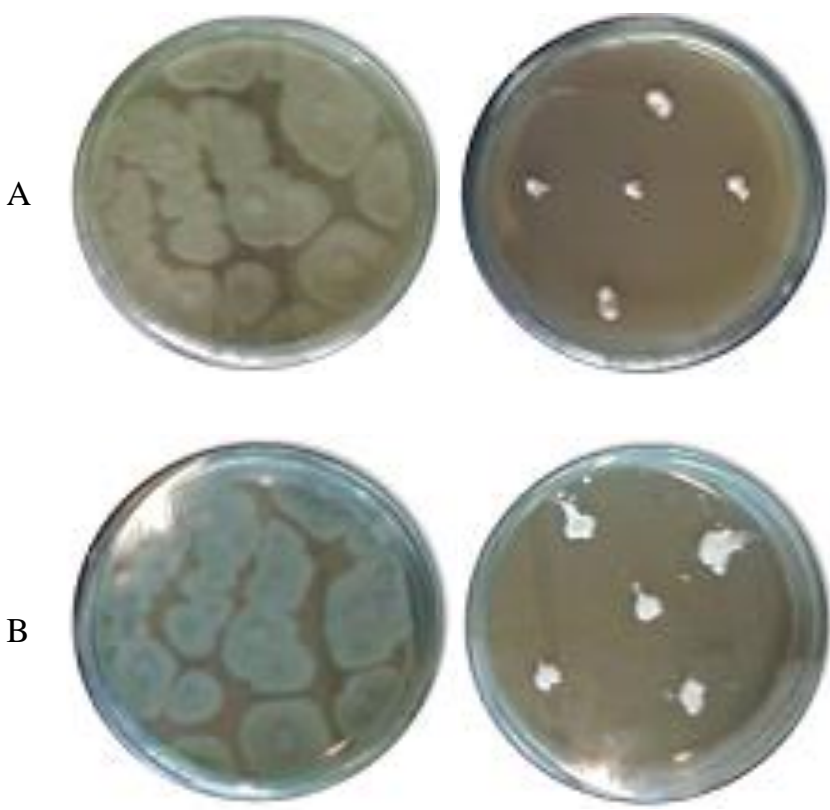

placa de Petri controle

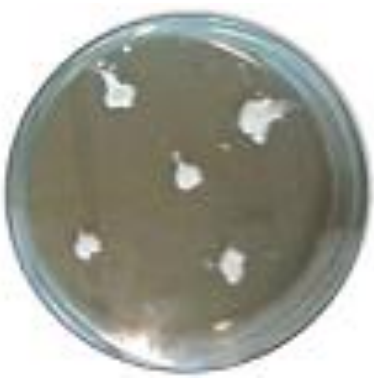

$5 \mu \mathrm{L}$ pesticida/DMSO
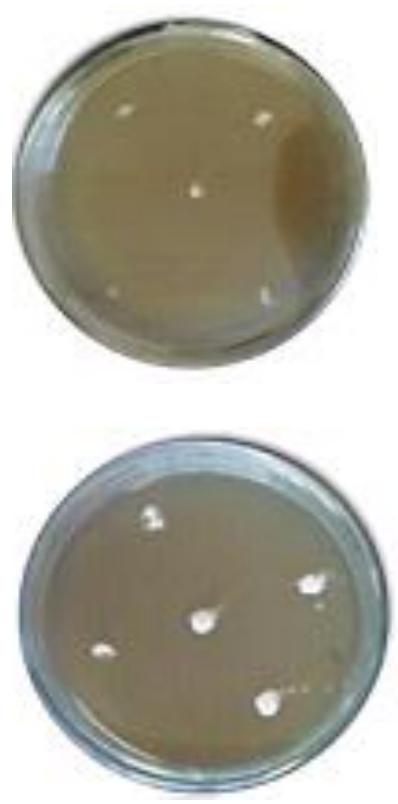

$10 \mu \mathrm{L}$ pesticida/DMSO
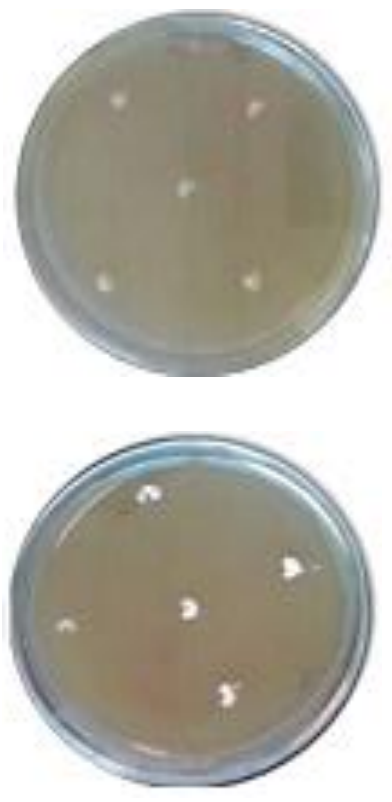

$15 \mu \mathrm{L}$ pesticida/DMSO 
Tabela 14. Avaliação do halo de crescimento em meio de cultura sólido malte $2 \%$ e Ágar do fungo de ambiente marinho A. sydowii CBMAI 934 frente ao pesticida comercial clorpirifós nos volumes de $5 \mu \mathrm{L}$ de pesticida/100 $\mu \mathrm{L}$ de DMSO, $10 \mu \mathrm{L}$ de pesticida/200 $\mu \mathrm{L}$ de DMSO e $15 \mu \mathrm{L}$ de pesticida/ $300 \mu \mathrm{L}$ de DMSO durante 10 dias em condições padrões $\left(32^{\circ} \mathrm{C}, \mathrm{pH} 5,0\right)$.

\begin{tabular}{ccccc}
\hline $\begin{array}{l}\text { Tempo de crescimento } \\
\text { do fungo }\end{array}$ & \multicolumn{3}{l}{ Medida do halo de crescimento $(\mathrm{cm})$} \\
\hline $\begin{array}{c}\text { Aspergillus sydowii } \\
\text { CBMAI } 934\end{array}$ & Placa controle & $\begin{array}{c}5 \mu \mathrm{L} \text { pesticida/ } \\
100 \mu \mathrm{L} \text { DMSO }\end{array}$ & $\begin{array}{c}10 \mu \mathrm{L} \text { pesticida/ } \\
200 \mu \mathrm{L} \text { DMSO }\end{array}$ & $\begin{array}{c}15 \mu \mathrm{L} \text { pesticida/ } \\
300 \mathrm{~L} \text { DMSO }\end{array}$ \\
$1^{\circ}$ dia & $2,2 \times 2,0$ & $0,2 \times 0,3$ & $0,1 \times 0,1$ & $0,1 \times 0,2$ \\
$2^{\circ}$ dia & $2,8 \times 2,5$ & $0,6 \times 1,2$ & $0,2 \times 0,8$ & $0,6 \times 0,5$ \\
$3^{\circ}$ dia & $3,2 \times 4,5$ & $0,8 \times 1,3$ & $0,8 \times 1,0$ & $1,0 \times 1,0$ \\
$4^{\circ}$ dia & $4,5 \times 5,5$ & $1,0 \times 1,2$ & $1,0 \times 1,0$ & $1,0 \times 1,3$ \\
$5^{\circ}$ dia & $6,4 \times 7,0$ & $1,1 \times 1,3$ & $1,0 \times 1,0$ & $1,2 \times 1,3$ \\
$6^{\circ}$ dia & $6,4 \times 7,0$ & $1,3 \times 1,4$ & $1,0 \times 1,0$ & $1,2 \times 1,3$ \\
$7^{\circ}$ dia & $6,4 \times 7,0$ & $1,3 \times 1,4$ & $1,0 \times 1,3$ & $1,2 \times 1,3$ \\
$8^{\circ}$ dia & $6,4 \times 7,0$ & $1,3 \times 1,4$ & $1,0 \times 1,3$ & $1,2 \times 1,3$ \\
\hline $9^{\circ}$ dia & $6,4 \times 7,0$ & $1,3 \times 1,4$ & $1,0 \times 1,3$ & $1,2 \times 1,3$ \\
\hline $0^{\circ}$ dia & $6,4 \times 7,0$ & $1,3 \times 1,4$ & $1,0 \times 1,3$ & \\
\hline
\end{tabular}

Como pode ser observado nas placas de Petri da Figura 44 houve crescimento satisfatório do fungo nas placas Petri controle (ausência do pesticida), com crescimento estabilizado a partir do $5^{\circ}$ dia e visível mudança de cor verde claro para verde escuro do micélio do fungo $A$. sydowii CBMAI 934.

No volume de $5 \mu \mathrm{L}$ do clorpirifós houve um crescimento pouco significativo do halo micelial do fungo que estabilizou a partir do $6^{\circ}$ dia. Já nos volumes de $10 \mu \mathrm{L}$ e $15 \mu \mathrm{L}$ do pesticida, o crescimento foi bem similar e pouco significativo devido aos volumes maiores do pesticida, no qual teve seu crescimento cessado a partir do $7^{\circ}$ dia para $10 \mu \mathrm{L}$ e $6^{\circ}$ dia para 15 $\mu \mathrm{L}$ do pesticida clorpirifós, com dados de crescimento micelial mostrados na Tabela 14. 
A Figura 45 e a Tabela 15 mostram a avaliação de crescimento em meio de cultura sólido malte $2 \%$ e Agar do fungo de ambiente marinho A. sydowii CBMAI 935 frente ao pesticida comercial clorpirifós nos volumes de $5 \mu \mathrm{L}$ de pesticida/100 $\mu \mathrm{L}$ de DMSO, $10 \mu \mathrm{L}$ de pesticida/200 $\mu \mathrm{L}$ de DMSO e $15 \mu \mathrm{L}$ de pesticida/ $300 \mu \mathrm{L}$ de DMSO durante 10 dias de crescimento em condições padrões $\mathrm{pH}\left(32^{\circ} \mathrm{C}, \mathrm{pH} 5,0\right)$.

Figura 45. Cultivo do fungo A. sydowii CBMAI 935 na ausência de clorpirifós (placa controle) e com 5, 10 e 15 $\mu \mathrm{L}$ de clorpirifós/placa. (A) 5 dias de cultivo e (B) 10 dias de cultivo.

A
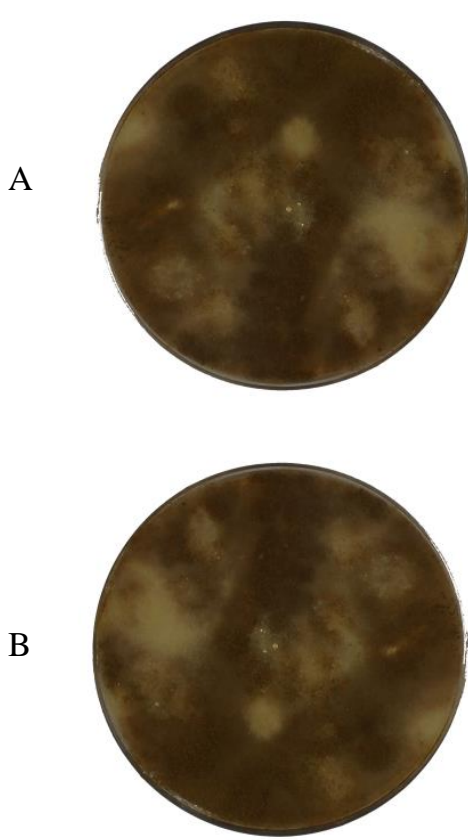

placa de Petri controle
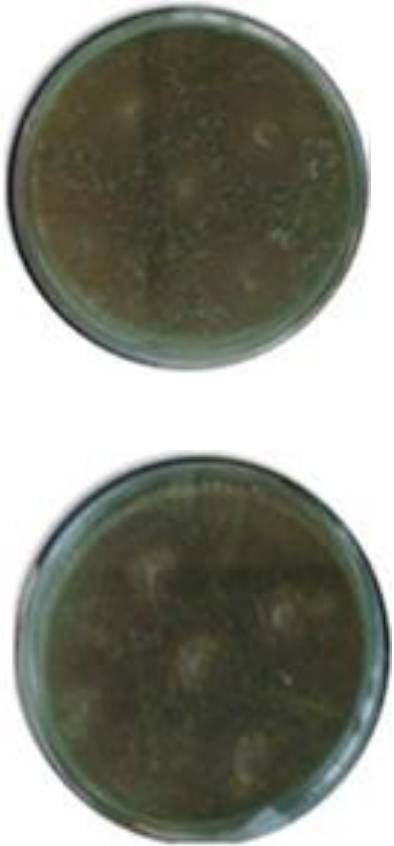

$5 \mu \mathrm{L}$ pesticida/DMSO
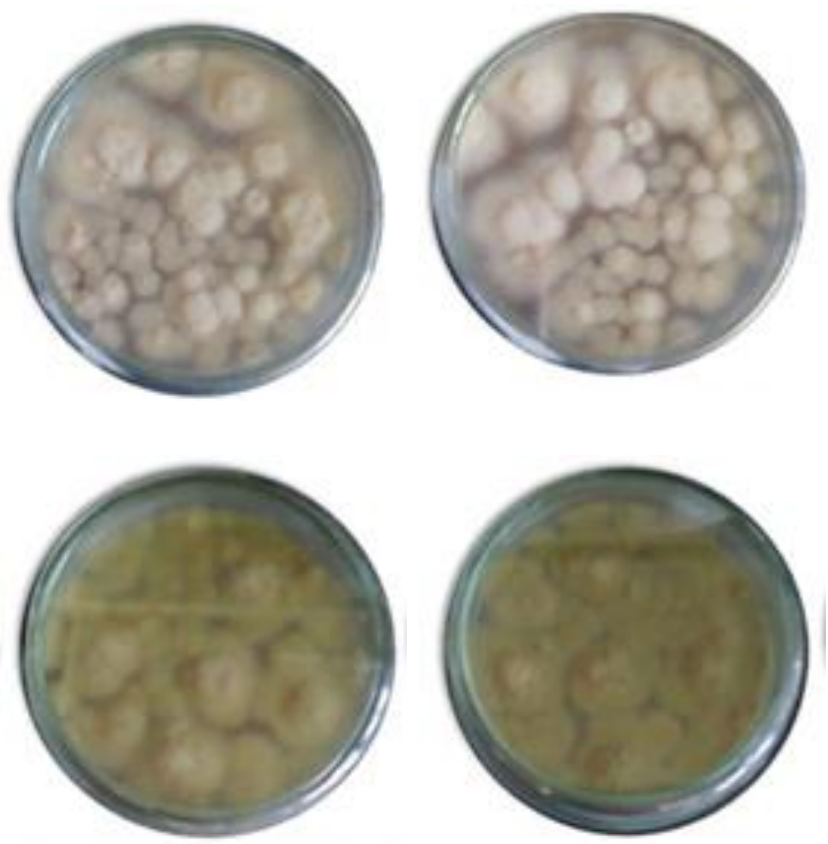

$10 \mu \mathrm{L}$ pesticida/DMSO

$15 \mu \mathrm{L}$ pesticida/DMSO 
Tabela 15. Avaliação do halo de crescimento em meio de cultura sólido malte $2 \%$ e Agar do fungo de ambiente marinho A. sydowii CBMAI 935 frente ao pesticida comercial clorpirifós nos volumes de $5 \mu \mathrm{L}$ de pesticida/100 $\mu \mathrm{L}$ de DMSO, $10 \mu \mathrm{L}$ de pesticida/200 $\mu \mathrm{L}$ de DMSO e $15 \mu \mathrm{L}$ de pesticida/ $300 \mu \mathrm{L}$ de DMSO durante 10 dias em condições padrões $\left(32^{\circ} \mathrm{C}, \mathrm{pH} 5,0\right)$.

\begin{tabular}{|c|c|c|c|c|}
\hline \multirow{2}{*}{$\begin{array}{l}\text { Tempo de crescimento } \\
\text { do fungo } \\
\text { Aspergillus sydowii } \\
\text { CBMAI } 935\end{array}$} & \multicolumn{4}{|c|}{ Medida do halo de crescimento $(\mathrm{cm})$} \\
\hline & Placa controle & $\begin{array}{l}5 \mu \mathrm{L} \text { pesticida/ } \\
100 \mu \mathrm{L} \text { DMSO }\end{array}$ & $\begin{array}{l}10 \mu \mathrm{L} \text { pesticida/ } \\
200 \mu \mathrm{L} \text { DMSO }\end{array}$ & $\begin{array}{l}15 \mu \mathrm{L} \text { pesticida/ } \\
300 \mu \mathrm{L} \text { DMSO }\end{array}$ \\
\hline $1^{\circ}$ dia & $4,2 \times 4,0$ & $4,0 \times 3,8$ & $3,5 \times 3,0$ & $3,2 \times 3,0$ \\
\hline $2^{\circ}$ dia & $5,8 \times 4,5$ & $4,8 \times 4,0$ & $4,5 \times 4,2$ & $3,8 \times 3,5$ \\
\hline $3^{\circ} \mathrm{dia}$ & $6,2 \times 5,5$ & $5,2 \times 5,0$ & $4,8 \times 4,5$ & $4,2 \times 4,0$ \\
\hline $4^{\circ}$ dia & $6,9 \times 6,5$ & $5,9 \times 5,4$ & $5,3 \times 4,7$ & $4,9 \times 4,5$ \\
\hline $5^{\circ}$ dia & Toda a placa & $6,5 \times 6,2$ & $6,0 \times 5,1$ & $5,2 \times 5,3$ \\
\hline $6^{\circ} \mathrm{dia}$ & Toda a placa & Toda a placa & $6,7 \times 6,5$ & $5,6 \times 5,7$ \\
\hline $7^{\circ}$ dia & Toda a placa & Toda a placa & Toda a placa & $6,2 \times 6,3$ \\
\hline $8^{\circ}$ dia & Toda a placa & Toda a placa & Toda a placa & Toda a placa \\
\hline $9^{\circ} \mathrm{dia}$ & Toda a placa & Toda a placa & Toda a placa & Toda a placa \\
\hline $10^{\circ} \mathrm{dia}$ & Toda a placa & Toda a placa & Toda a placa & Toda a placa \\
\hline
\end{tabular}

Como pode ser observado nas placas de Petri da Figura 33 houve crescimento satisfatório do fungo A. sydowii CBMAI 935 nas placas Petri controle (ausência do pesticida) com preenchimento da placa de Petri a partir do $5^{\circ}$ dia com dados de crescimento, mostrados na Tabela 15.

No volume de $5 \mu \mathrm{L}$ do clorpirifós houve crescimento satisfatório do halo micelial do fungo que preencheu toda a placa de Petri a partir do $6^{\circ}$ dia com visível mudança na coloração em comparação com o controle, passando do verde escuro para um tom rosado. Nos volumes de $10 \mu \mathrm{L}$ e $15 \mu \mathrm{L}$ do pesticida, o crescimento foi bastante satisfatório devido a altos volumes do pesticida a partir do $7^{\circ}$ dia houve preenchimento total da placa de Petri para o volume de $10 \mu \mathrm{L}$ do pesticida clorpirifós e preenchimento total da placa de Petri a partir do $6^{\circ}$ dia para o volume de $15 \mu \mathrm{L}$ do pesticida, com dados de crescimento mostrados na Tabela 15. 
A Figura 46 e a Tabela 16 mostram a avaliação do halo de crescimento em meio de cultura sólido malte 2\% e Agar do fungo de ambiente marinho P. decaturense CBMAI 1234 frente ao pesticida comercial clorpirifós nos volumes de $5 \mu \mathrm{L}$ de pesticida/100 $\mu \mathrm{L}$ de DMSO, $10 \mu \mathrm{L}$ de pesticida/200 $\mu \mathrm{L}$ de DMSO e $15 \mu \mathrm{L}$ de pesticida/ $300 \mu \mathrm{L}$ de DMSO durante 10 dias de crescimento em condições padrões $\mathrm{pH}\left(32^{\circ} \mathrm{C}, \mathrm{pH} 5,0\right)$.

Figura 46. Cultivo do fungo $P$. decaturense CBMAI 1234 na ausência de clorpirifós (placa controle) e com 5, 10 e $15 \mu \mathrm{L}$ de clorpirifós/placa. (A) 5 dias de cultivo e (B) 10 dias de cultivo.

A

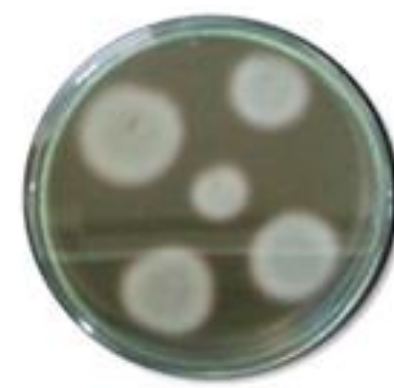

B

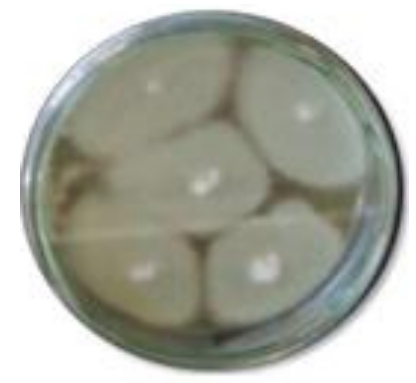

placa de Petri controle
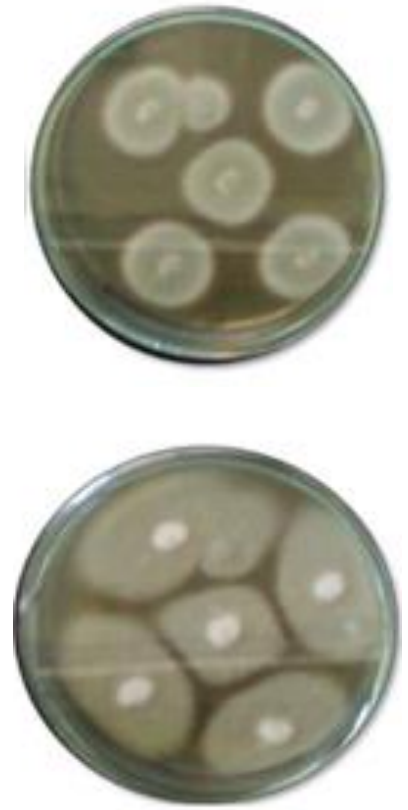

$5 \mu \mathrm{L}$ pesticida/DMSO
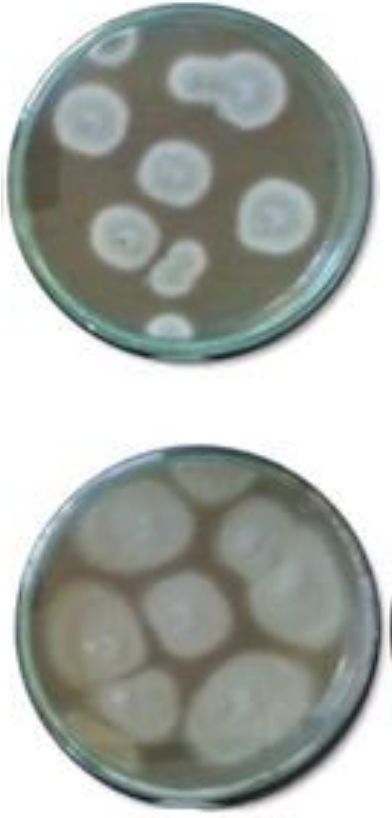

$10 \mu \mathrm{L}$ pesticida/DMSO
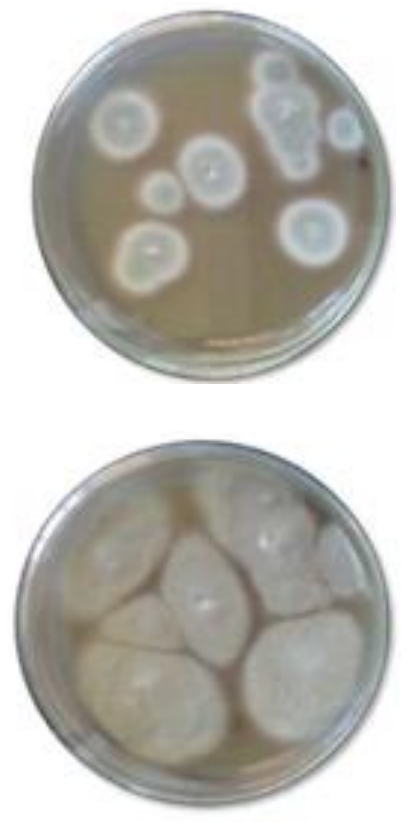

$15 \mu \mathrm{L}$ pesticida/DMSO 
Tabela 16. Avaliação do halo de crescimento em meio de cultura sólido malte $2 \%$ e Agar do fungo de ambiente marinho $P$. decaturense CBMAI 1234 frente ao padrão comercial do pesticida clorpirifós nos volumes de $5 \mu \mathrm{L}$ de pesticida/100 $\mu \mathrm{L}$ de DMSO, $10 \mu \mathrm{L}$ de pesticida/200 $\mu \mathrm{L}$ de DMSO e $15 \mu \mathrm{L}$ de pesticida/ $300 \mu \mathrm{L}$ de DMSO durante 10 dias em condições padrões $\left(32^{\circ} \mathrm{C}, \mathrm{pH} 5,0\right)$.

\begin{tabular}{ccccc}
\hline $\begin{array}{l}\text { Tempo de crescimento } \\
\text { do fungo }\end{array}$ & \multicolumn{3}{l}{ Medida do halo de crescimento $(\mathrm{cm})$} \\
\hline $\begin{array}{c}\text { Penicillium decaturense } \\
\text { CBMAI } 1234\end{array}$ & Placa controle & $\begin{array}{c}5 \mu \mathrm{L} \text { pesticida/ } \\
100 \mu \mathrm{L} \text { DMSO }\end{array}$ & $\begin{array}{c}10 \mu \mathrm{L} \text { pesticida/ } \\
200 \mu \mathrm{L} \text { DMSO }\end{array}$ & $\begin{array}{c}15 \mu \mathrm{L} \text { pesticida/ } \\
300 \mathrm{~L} \text { DMSO }\end{array}$ \\
$1^{\circ}$ dia & $2,6 \times 2,5$ & $2,0 \times 2,3$ & $2,4 \times 2,3$ & $2,2 \times 2,0$ \\
$2^{\circ}$ dia & $2,8 \times 2,5$ & $2,6 \times 2,3$ & $2,5 \times 2,0$ & $2,8 \times 2,7$ \\
$3^{\circ}$ dia & $3,2 \times 4,5$ & $3,0 \times 3,2$ & $3,2 \times 3,5$ & $3,0 \times 3,5$ \\
$4^{\circ}$ dia & $4,5 \times 5,5$ & $3,5 \times 4,5$ & $3,5 \times 5,5$ & $3,4 \times 4,0$ \\
$5^{\circ}$ dia & $6,4 \times 7,0$ & $4,4 \times 5,0$ & $4,9 \times 5,8$ & $4,7 \times 4,5$ \\
$6^{\circ}$ dia & $6,9 \times 7,2$ & $5,0 \times 5,2$ & $5,3 \times 5,2$ & $5,2 \times 5,5$ \\
$7^{\circ}$ dia & $7,2 \times 7,5$ & $5,6 \times 5,5$ & $5,3 \times 5,5$ & $6,4 \times 7,5$ \\
$8^{\circ}$ dia & $7,4 \times 7,8$ & $6,4 \times 7,8$ & $5,7 \times 5,8$ & $7,4 \times 8,0$ \\
\hline $9^{\circ}$ dia & $8,4 \times 8,0$ & $7,4 \times 8,2$ & $6,4 \times 6,7$ & $8,7 \times 8,3$ \\
\hline $0^{\circ}$ dia & $9,0 \times 8,3$ & $8,0 \times 8,7$ & $7,8 \times 7,3$ & \\
\hline
\end{tabular}

Como pode ser observado nas placas de Petri da Figura 46 houve crescimento satisfatório do fungo $P$. decaturense CBMAI 1234 nas placas Petri controle (ausência do pesticida).

$\mathrm{Na}$ concentração $5 \mu \mathrm{L}$ do pesticida clorpirifós houve crescimento similar ao controle do fungo.

Nos volumes de $10 \mu \mathrm{L}$ e $15 \mu \mathrm{L}$ do pesticida, o crescimento foi similar mas não houve inibição do crescimento do halo micelial apesar dos volumes serem maiores quando comparados com o crescimento da placa de Petri controle.

Os dados de crescimento da placa de Petri controle e dos diferentes volumes de pesticida com o fungo $P$. decaturense CBMAI 1234 são mostrados na Tabela 16. 
A Figura 47 e a Tabela 17 mostram a avaliação de crescimento em meio de cultura sólido malte $2 \%$ e Agar do fungo de ambiente marinho P. raistrickii CBMAI 1235 frente ao pesticida comercial clorpirifós nos volumes de $5 \mu \mathrm{L}$ de pesticida/100 $\mu \mathrm{L}$ de DMSO, $10 \mu \mathrm{L}$ de pesticida/200 $\mu \mathrm{L}$ de DMSO e $15 \mu \mathrm{L}$ de pesticida/ $300 \mu \mathrm{L}$ de DMSO durante 10 dias de crescimento em condições padrões $\mathrm{pH}\left(32^{\circ} \mathrm{C}, \mathrm{pH} 5,0\right)$.

Figura 47. Cultivo do fungo P. raistrickii CBMAI 1235 na ausência de clorpirifós (placa controle) e com 5, 10 e $15 \mu \mathrm{L}$ de clorpirifós/placa. (A) 5 dias de cultivo e (B) 10 dias de cultivo.

A

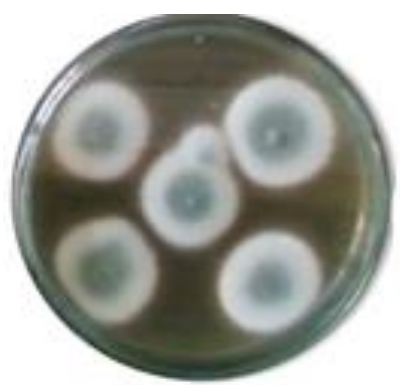

B

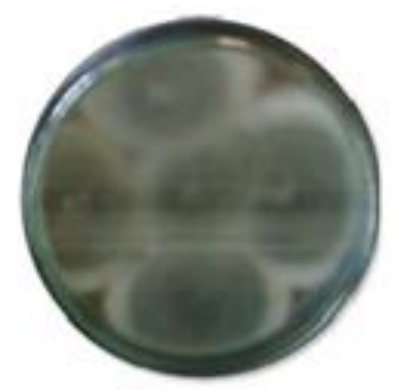

placa de Petri controle
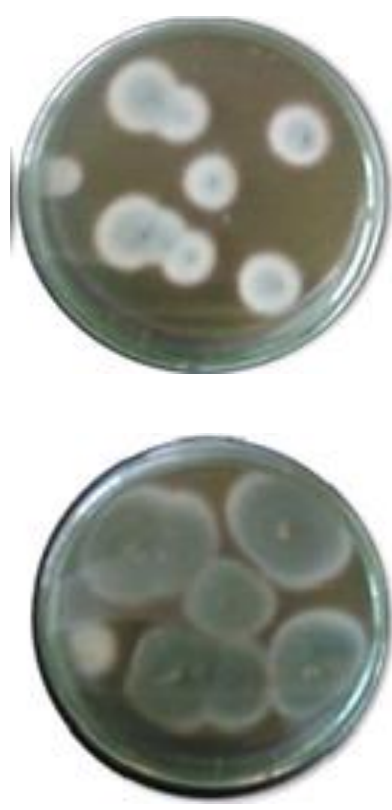

$5 \mu \mathrm{L}$ pesticida/DMSO
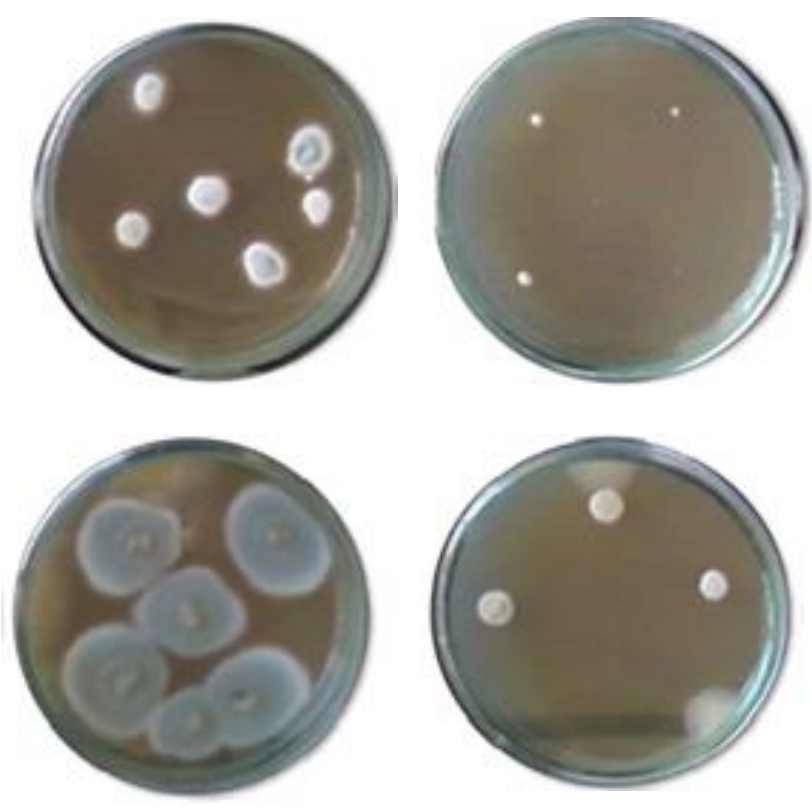

$10 \mu \mathrm{L}$ pesticida/DMSO

$15 \mu \mathrm{L}$ pesticida/DMSO 
Tabela 17. Avaliação do halo de crescimento em meio de cultura sólido malte $2 \%$ e Agar do fungo de ambiente marinho P. raistrickii CBMAI 1235 frente ao padrão comercial do pesticida clorpirifós nos volumes de $5 \mu \mathrm{L}$ de pesticida/100 $\mu \mathrm{L}$ de DMSO, $10 \mu \mathrm{L}$ de pesticida/200 $\mu \mathrm{L}$ de DMSO e $15 \mu \mathrm{L}$ de pesticida/ $300 \mu \mathrm{L}$ de DMSO durante 10 dias em condições padrões $\left(32^{\circ} \mathrm{C}, \mathrm{pH} 5,0\right)$.

\begin{tabular}{ccccc}
\hline $\begin{array}{l}\text { Tempo de crescimento } \\
\text { do fungo }\end{array}$ & \multicolumn{3}{l}{ Medida do halo de crescimento $(\mathrm{cm})$} \\
\hline $\begin{array}{c}\text { Penicillium raistrickii } \\
\text { CBMAI } 1235\end{array}$ & Placa controle & $\begin{array}{c}5 \mu \mathrm{L} \text { pesticida/ } \\
100 \mu \mathrm{L} \text { DMSO }\end{array}$ & $\begin{array}{c}10 \mu \mathrm{L} \text { pesticida/ } \\
200 \mu \mathrm{L} \text { DMSO }\end{array}$ & $\begin{array}{c}15 \mu \mathrm{L} \text { pesticida/ } \\
300 \mu \mathrm{L} \text { DSO }\end{array}$ \\
$1^{\circ}$ dia & $3,6 \times 3,5$ & $3,5 \times 2,5$ & $2,0 \times 2,0$ & $0,1 \times 0,2$ \\
$2^{\circ}$ dia & $3,8 \times 3,8$ & $3,0 \times 2,5$ & $2,8 \times 2,5$ & $0,6 \times 0,5$ \\
$3^{\circ}$ dia & $4,2 \times 4,5$ & $3,2 \times 3,5$ & $2,8 \times 2,6$ & $1,0 \times 1,0$ \\
$4^{\circ}$ dia & $4,5 \times 5,5$ & $3,5 \times 3,8$ & $2,9 \times 2,8$ & $1,0 \times 1,3$ \\
$5^{\circ}$ dia & $5,4 \times 7,0$ & $4,4 \times 4,0$ & $3,0 \times 3,0$ & $1,2 \times 1,3$ \\
$6^{\circ}$ dia & $6,5 \times 7,5$ & $5,9 \times 4,2$ & $3,2 \times 3,2$ & $1,2 \times 1,3$ \\
$7^{\circ}$ dia & $7,8 \times 7,5$ & $6,2 \times 5,5$ & $3,8 \times 3,5$ & $1,2 \times 1,3$ \\
$8^{\circ}$ dia & $8,4 \times 7,8$ & $6,4 \times 5,8$ & $4,4 \times 4,8$ & $1,2 \times 1,3$ \\
\hline $9^{\circ}$ dia & $8,6 \times 8,0$ & $7,4 \times 6,0$ & $5,4 \times 6,0$ & $1,2 \times 1,3$ \\
\hline $0^{\circ}$ dia & $9,0 \times 8,7$ & $8,0 \times 7,3$ & $6,0 \times 6,3$ & \\
\hline
\end{tabular}

Como pode ser observado nas placas de Petri da Figura 47 houve crescimento satisfatório do fungo Penicillium raistrickii CBMAI 1235 nas placas Petri controle (ausência do pesticida) com visível mudança de cor do micélio do fungo passando do branco acinzentado para verde escuro na presença do pesticida.

No volume de $5 \mu \mathrm{L}$ do clorpirifós houve crescimento similar ao controle, praticamente não houve inibição do crescimento do halo micelial do fungo. No volume de $10 \mu \mathrm{L}$ o crescimento foi satisfatório em comparação com a placa controle e apesar do volume de pesticida ser mais elevado enquanto no volume de $15 \mu \mathrm{L}$ do pesticida, o crescimento foi pouco evidente devido às concentrações maiores do pesticida, no qual teve seu crescimento estabilizado a partir do $6^{\circ}$ dia como mostrado nos dados de medidas de crescimento na Tabela 17. 
A Figura 48 e a Tabela 18 mostram a avaliação do halo de crescimento em meio de cultura sólido malte 2\% e Agar do fungo de ambiente marinho A. sydowii CBMAI 1241 frente ao pesicida comercial clorpirifós nos volumes de $5 \mu \mathrm{L}$ de pesticida/100 $\mu \mathrm{L}$ de DMSO, $10 \mu \mathrm{L}$ de pesticida/200 $\mu \mathrm{L}$ de DMSO e $15 \mu \mathrm{L}$ de pesticida/ $300 \mu \mathrm{L}$ de DMSO durante 10 dias de crescimento em condições padrões $\mathrm{pH}\left(32^{\circ} \mathrm{C}, \mathrm{pH} 5,0\right)$.

Figura 48. Cultivo do fungo A. sydowii CBMAI 1241 na ausência de clorpirifós (placa controle) e com 5, 10 e $15 \mu \mathrm{L}$ de clorpirifós/placa. (A) 5 dias de cultivo e (B) 10 dias de cultivo.

A
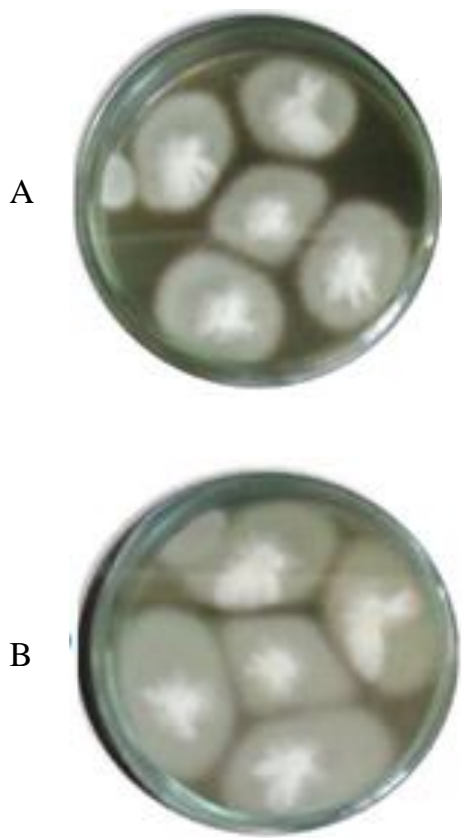

placa de Petri controle
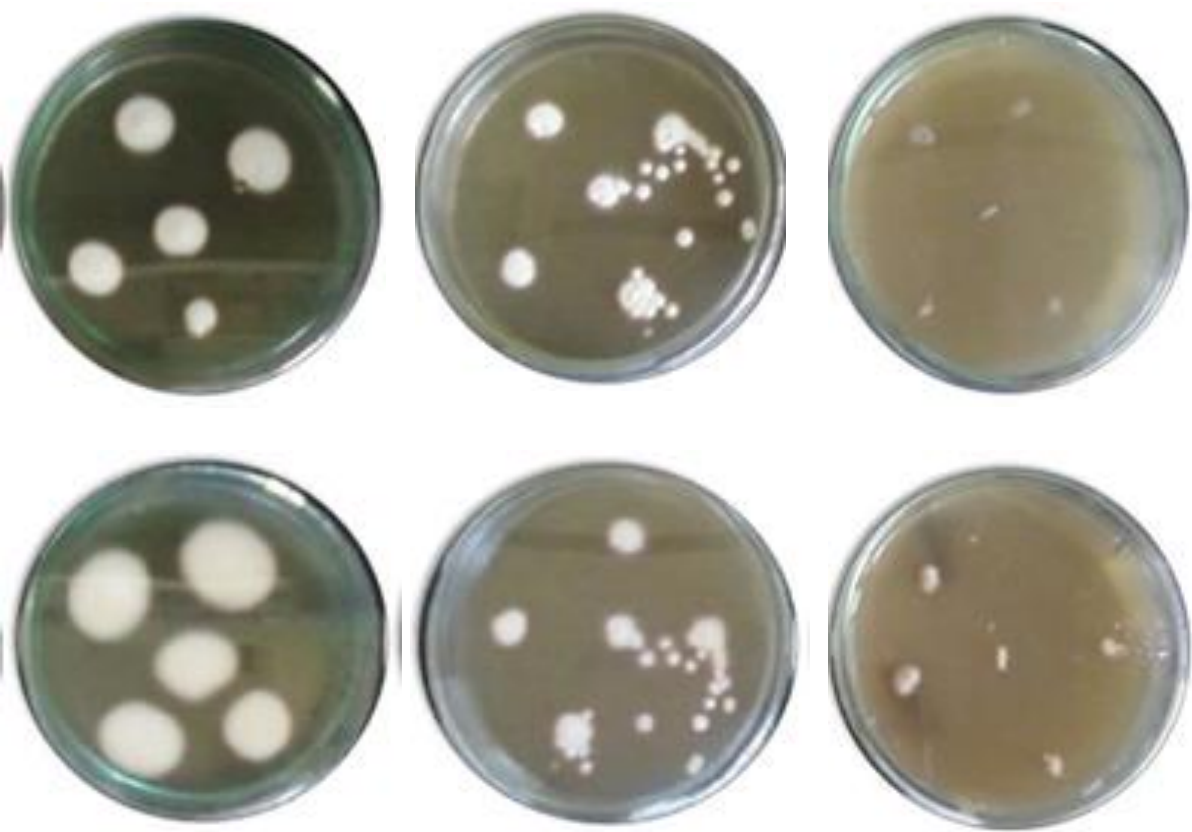

$5 \mu \mathrm{L}$ pesticida/DMSO

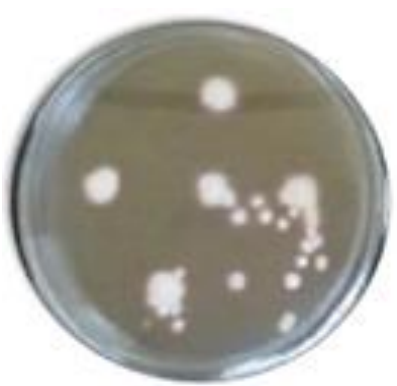

$10 \mu \mathrm{L}$ pesticida/DMSO

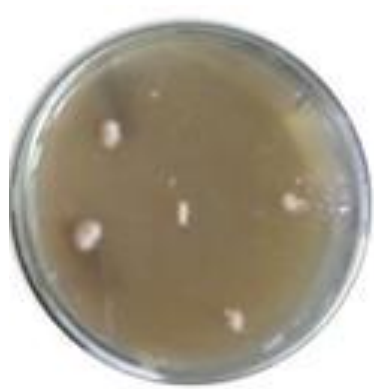

$15 \mu \mathrm{L}$ pesticida/DMSO 
Tabela 18. Avaliação do halo de crescimento em meio de cultura sólido malte $2 \%$ e Agar do fungo de ambiente marinho Aspergillus sydowii CBMAI 1241 frente ao pesticda comercial clorpirifós nos volumes de $5 \mu \mathrm{L}$ de pesticida/100 $\mu \mathrm{L}$ de DMSO, $10 \mu \mathrm{L}$ de pesticida/200 $\mu \mathrm{L}$ de DMSO e $15 \mu \mathrm{L}$ de pesticida/ $300 \mu \mathrm{L}$ de DMSO durante 10 dias em condições padrões $\left(32^{\circ} \mathrm{C}, \mathrm{pH} 5,0\right)$.

\begin{tabular}{|c|c|c|c|c|}
\hline \multirow{2}{*}{$\begin{array}{l}\text { Tempo de crescimento } \\
\text { do fungo } \\
\text { Aspergillus sydowii } \\
\text { CBMAI } 1241\end{array}$} & \multicolumn{4}{|c|}{ Medida do halo de crescimento $(\mathrm{cm})$} \\
\hline & Placa controle & $\begin{array}{l}5 \mu \mathrm{L} \text { pesticida/ } \\
100 \mu \mathrm{L} \text { DMSO }\end{array}$ & $\begin{array}{l}10 \mu \mathrm{L} \text { pesticida/ } \\
200 \mu \mathrm{L} \text { DMSO }\end{array}$ & $\begin{array}{l}15 \mu \mathrm{L} \text { pesticida/ } \\
300 \mu \mathrm{L} \text { DMSO }\end{array}$ \\
\hline $1^{\circ}$ dia & $3,4 \times 3,0$ & $2,5 \times 2,0$ & $0,3 \times 0,5$ & $0,1 \times 0,2$ \\
\hline $2^{\circ}$ dia & $3,8 \times 3,5$ & $2,5 \times 2,2$ & $0,6 \times 0,6$ & $0,6 \times 0,5$ \\
\hline $3^{\circ}$ dia & $4,2 \times 4,0$ & $2,8 \times 2,5$ & $0,8 \times 0,9$ & $0,8 \times 0,7$ \\
\hline $4^{\circ}$ dia & $4,8 \times 5,5$ & $3,0 \times 3,0$ & $1,2 \times 1,5$ & $1,0 \times 1,0$ \\
\hline $5^{\circ}$ dia & $5,2 \times 6,0$ & $3,2 \times 3,0$ & $1,5 \times 1,8$ & $1,2 \times 1,2$ \\
\hline $6^{\circ} \mathrm{dia}$ & $6,0 \times 6,5$ & $3,9 \times 3,2$ & $1,8 \times 2,3$ & $1,3 \times 1,3$ \\
\hline $7^{\circ}$ dia & $7,2 \times 7,5$ & $4,2 \times 3,5$ & $2,2 \times 2,3$ & $1,3 \times 1,3$ \\
\hline $8^{\circ}$ dia & $7,4 \times 7,8$ & $4,4 \times 3,8$ & $2,2 \times 2,3$ & $1,3 \times 1,3$ \\
\hline $9^{\circ} \mathrm{dia}$ & $8,0 \times 8,6$ & $4,4 \times 4,0$ & $2,2 \times 2,3$ & $1,3 \times 1,3$ \\
\hline $10^{\circ} \mathrm{dia}$ & $8,8 \times 9,0$ & $4,6 \times 4,3$ & $2,2 \times 2,3$ & $1,3 \times 1,3$ \\
\hline
\end{tabular}

Como pode ser observado nas placas de Petri da Figura 48 houve crescimento satisfatório do fungo A. sydowii CBMAI 1241 nas placas Petri controle (ausência do pesticida). No volume de $5 \mu \mathrm{L}$ do clorpirifós houve crescimento do halo micelial satisfatório quando comparado com a placa controle.

Nos volumes de $10 \mu \mathrm{L}$ e $15 \mu \mathrm{L}$ do pesticida o crescimento foi bem similar e pouco evidente devido às altas concentrações do pesticida, no qual o fungo teve seu crescimento estabilzado a partir do $7^{\circ}$ dia para o volume de $10 \mu \mathrm{L}$ e $6^{\circ}$ dia para o volume de $15 \mu \mathrm{L}$, com os dados de crescimento mostrados na Tabela 18. 
Como mostrados anteriormente foram estimados os halos de crescimento médios das colônias fúngicas nas placas, tanto na ausência de pesticida quanto na presença do padrão comercial do pesticida clorpirifós. Como pode ser observado nas placas de Petri (Figuras 39 a 45), com dez dias de crescimento do halo micelial, os fungos: A. sydowii CBMAI 934, P. raistrickii CBMAI 931, A. sydowii CBMAI 935, P. raistrickii CBMAI 1235, P. decaturense CBMAI 1234, A. sydowii CBMAI 1241 e Trichoderma sp. CBMAI 932 apresentaram um bom desenvolvimento nas placas controle (ausência do pesticida). Já nas concentrações de 5 $\mu \mathrm{L}, 10 \mu \mathrm{L}$ e $15 \mu \mathrm{L}$ do padrão comercial do pesticida clorpirifós o crescimento foi satisfatório para todos os fungos avaliados, exceto para o fungo A. sydowii CBMAI 935, mostrando que este apresentou maior crescimento do halo micelial frente a diferentes concentrações do pesticida clorpirifós quando comparado aos demais fungos avaliados nesses estudos.

No caso das colônias que não apresentaram um crescimento radial circular, os halos de crescimento foram medidos entre as extremidades mais distantes. Nestes experimentos em meio de cultura sólido de Malte a $2 \%$ e Ágar o importante foi avaliar o crescimento dos fungos na superfície da placa para detectar a presença ou ausência do crescimento microbiano. A medida dos halos, portanto, não apresentou finalidade quantitativa e foi feita para avaliar a capacidade de crescimento dos fungos para posteriormente realizar as reações em meio líquido e quantificar os produtos detectados na biodegradação.

Observou-se que a cepa do fungo Aspergillus sydowii CBMAI 935 apresentou o melhor crescimento nas três concentrações do padrão comercial do pesticida clorpirifós. Em comparação com a placa controle, praticamente não houve inibição do crescimento deste fungo. Estes resultados podem indicar que o fungo é resistente em concentrações mais elevadas do pesticida organofosforado, sugerindo uma potencial capacidade para adaptar-se e até mesmo biodegradar o clorpirifós.

Devido ao elevado número de experimentos e a similaridade quanto à forma de descrevêlos e apresentá-los, as Figuras das placas de Petri e as Tabelas com os dados de crescimento dos fungos testados na triagem frente aos padrões comerciais dos pesticidas metil paration e profenofós foram mantidas no Apêndice da dissertação. 


\subsection{Reações de biotransformação dos pesticidas organofosforados e de compostos} fenólicos em meio de cultura líquido de malte $2 \%$ em 10, 20 e 30 dias pelo fungo de ambiente marinho A. sydowii CBMAI 935

Vários pontos relevantes devem ser discutidos anteriormente às reações de biotransformações em meio de cultura líquido de malte $2 \%$ :

a) Os fungos utilizados para os inóculos adicionados ao meio de cultura líquido de malte $2 \%$ nas reações de biotransformação foram repicados em placas de Petri e em tubos de ensaio contendo uma concentração de $50 \mathrm{mg} . \mathrm{L}^{-1}$ para os pesticidas orgafosforados (clorpirifós, metil paration, clorpirifós) e os compostos fenólicos (3,5,6-tricloro-2-piridinol, 4-nitrofenol e 4bromo-2-clorofenol, fenol, 2-clorofenol, 2-cloro-5-hidroxipiridina, 4-(4-hidroxifenil)ciclohexanona, pentaclorofenol e naringenina) para que houvesse a indução da produção das enzimas. A indução de enzimas é um processo que ocorre na transcrição dos genes. A transcrição corresponde à primeira etapa no fluxo de informação biológica, e por esta razão, neste ponto a expressão gênica é afetada de maneira relativamente fácil. Na indução enzimática, uma enzima é sintetizada somente quando o seu substrato encontra-se presente na amostra. Assim, para que o microrganismo já contenha as enzimas expressas quando inoculados em meio de cultura líquido. ${ }^{74,132}$

b) $\mathrm{O} \mathrm{pH}$ do meio de cultura líquido foi ajustado para $\mathrm{pH} \mathrm{7,0} \mathrm{devido} \mathrm{aos} \mathrm{relatos} \mathrm{na}$ literatura indicarem que em geral as enzimas esterases, que são responsáveis pela reação de biotransformação (hidrólise) dos pesticidas organofosforados apresentam uma melhor atividade catalítica nas faixas de $\mathrm{pH}$ neutro a levemente básico. Valores de $\mathrm{pH}$ muito ácidos ou muito básicos, favorecem a hidrólise expontânea destes pesticidas.

c) A hidrólise dos pesticidas organofosforados no ambiente (ausência de enzimas) também é influenciado pelo $\mathrm{pH}$, sendo que quanto mais alcalino o meio, mais favorável será a hidrólise. ${ }^{74,133}$

d) As extrações das reações de biotransformação foram realizadas em triplicatas com o volume total de $100 \mathrm{~mL}$ de cada reação contida em frasco Erlenmeyer de $250 \mathrm{~mL}$, pois para quantificar os metabólitos gerados é importante que seja feita a extração completa de todo o sistema. Os fungos, assim como as bactérias, absorvem os nutrientes, e esta adsorção de compostos é auxiliada por enzimas secretadas no meio, transportando ou metabolizando as moléculas orgânicas para que estas sejam transferidas para fora das células. ${ }^{74,134}$ Assim, a extração utilizando agitador magnético foi usada para romper a parede celular do fungo e para extrair tanto o pesticida que eventualmente esteva no interior das células (já que esta extração 
consistiu no rompimento das células) quanto aos compostos que deviam estar aderidos na superfície da membrana destas células.

e) Para otimizar o método de inoculação dos fungos para a biotransformação dos pesticidas organofosforados e os compostostos fenólicos foram preparadas suspensões de esporos. Porém, mesmo com a padronização do inóculo, os resultados obtidos quando as reações são realizadas em triplicatas podem apresentar algumas variações, já que o crescimento do fungo pode ocorrer de maneira distinta em cada frasco e vários fatores podem afetar este desenvolvimento, como a agitação orbitalar, temperatura, tipo de formação das colônias, variação de $\mathrm{pH}$ de acordo com o crescimento dos microrganismos, etc.

f) Anteriormente às etapas de extrações líquido-líquido $\left(\mathrm{H}_{2} \mathrm{O}\right.$ e $\left.\mathrm{AcOEt} \backslash 1: 1\right)$ o meio foi acidificado para pH 6,0 para que ocorresse uma extração mais eficiente dos metabólitos referentes aos pesticidas orgafosforados, os compostos fenólicos ou seus derivados. Ajustes no $\mathrm{pH}$ podem aumentar a eficiência da extração, uma vez que tanto o equilíbrio de dissociação quanto a solubilidade de ácidos e bases são diretamente afetados pelo pH da amostra $^{74,135} \mathrm{Em} \mathrm{pH} \mathrm{7,0} \mathrm{estes} \mathrm{compostos} \mathrm{podem,} \mathrm{eventualmente,} \mathrm{estarem} \mathrm{em} \mathrm{sua} \mathrm{forma}$ neutra na solução, não sendo adequadamente extraídos pela técnica de extração líquidolíquido. 


\subsubsection{Reações de biotransformação do pesticida organofosforado clorpirifós em 10, 20 e} 30 dias pelo fungo de ambiente marinho $A$. sydowii CBMAI 935

\subsubsection{Avaliação da biotransformação do clorpirifós em 10 dias de reação com o fungo}

\section{A. sydowii CBMAI 935}

Em 10 dias de reação de biotransformação do pesticida comercial clorpirifós com o fungo de ambiente marinho Aspergillus sydowii CBMAI 935 foram separados o caldo enzimático e o micélio do fungo e posteriormente submetidos às análises por CG-EM. Os cromatogramas das reações foram comparados com os cromatogramas da reação do controle biótico no qual o fungo A. sydowii CBMAI 935 cresceu por 10, 20 e 30 dias na ausência do pesticida clorpirifós. Também foram feitas comparações com os cromatogramas das reações de controle abiótico no qual se utilizou o padrão comercial do pesticida clorpirifós em meio de cultura líquido de malte 2\% na ausência do fungo A. sydowii CBMAI 935 em 10, 20 e 30 dias de reação. Posteriormente foram feitas comparações com os cromatogramas do padrão analítico do pesticida clorpirifós e padrão analítico e padrão sintético dos metabólitos obtidos durante os 10, 20 e 30 dias de reação de biotransformação.

Este mesmo modelo de discussão foi realizado para 20 e 30 dias de reação.

A Figura 49 mostra a sobreposição dos cromatogramas das extrações do caldo enzimático (cor vermelha) e do micélio (cor preta) com o fungo A. sydowii CBMAI 935 na ausência do composto fenólico 3,5,6-tricloro-2-piridinol (reação de controle biótico) em 10 dias de reação e a Figura 50 mostra os mesmos cromatogramas, porém separados. Cromatograma (a) Extração do caldo enzimático e cromatograma (b) Extração do micélio. 
Figura 49. Cromatograma obtido por CG-EM das extrações do micélio (cor preta) e do caldo enzimático (cor vermelha) com o fungo A. sydowii CBMAI 935 na ausência do pesticida clorpirifós (reação controle) durante 10 dias.

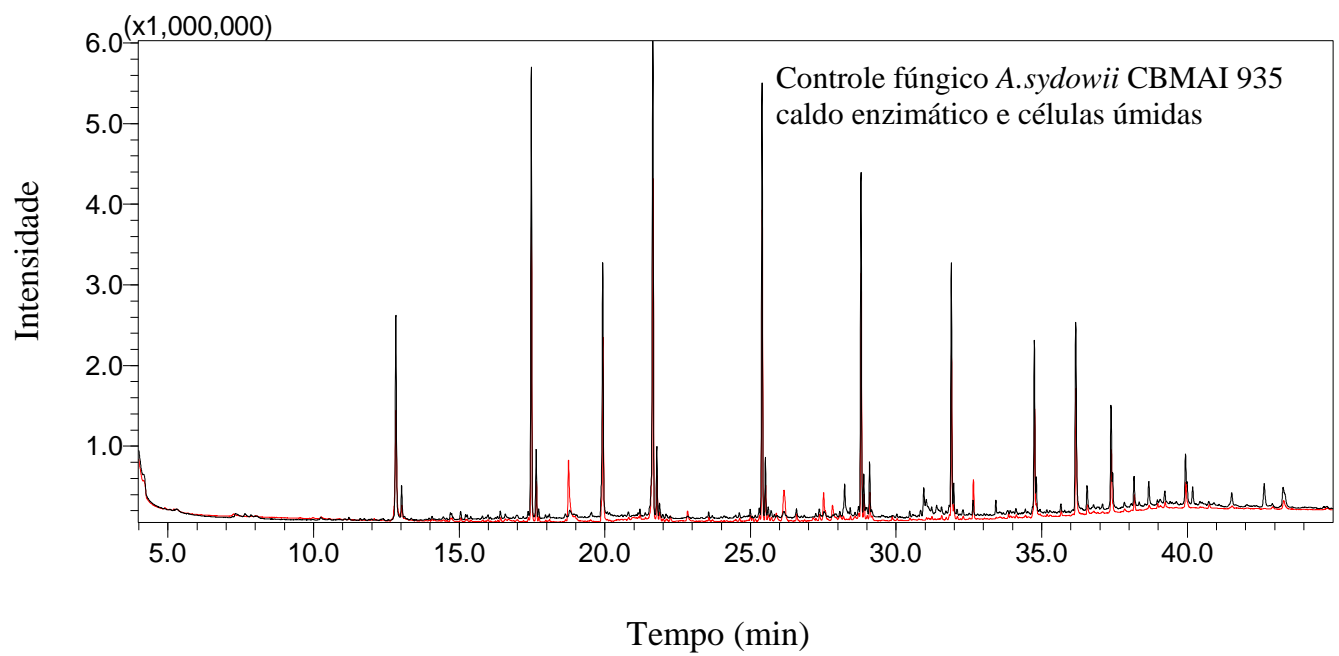

Condições de análise CG-EM: $\mathrm{T}_{\mathrm{i}}=60^{\circ} \mathrm{C}, 2 \mathrm{~min} ; \mathrm{T}_{\mathrm{f}}=280^{\circ} \mathrm{C}, 6 \mathrm{~min} ; \mathrm{r}=6^{\circ} \mathrm{C} / \mathrm{min}, \mathrm{t}_{\mathrm{c}}=45 \mathrm{mim}$.

Coluna capilar DB-5 da J\&W Scientific (30 m x 0,25 mm x 0,25 $\mu \mathrm{m})$.

Figura 50. Cromatogramas obtidos por CG-EM das extrações das células úmidas e do caldo enzimático do fungo A. sydowii CBMAI 935 na ausência do pesticida clorpirifós (reação controle) durante 10 dias. (a) extração do caldo enzimático e (b) extração das células úmidas.

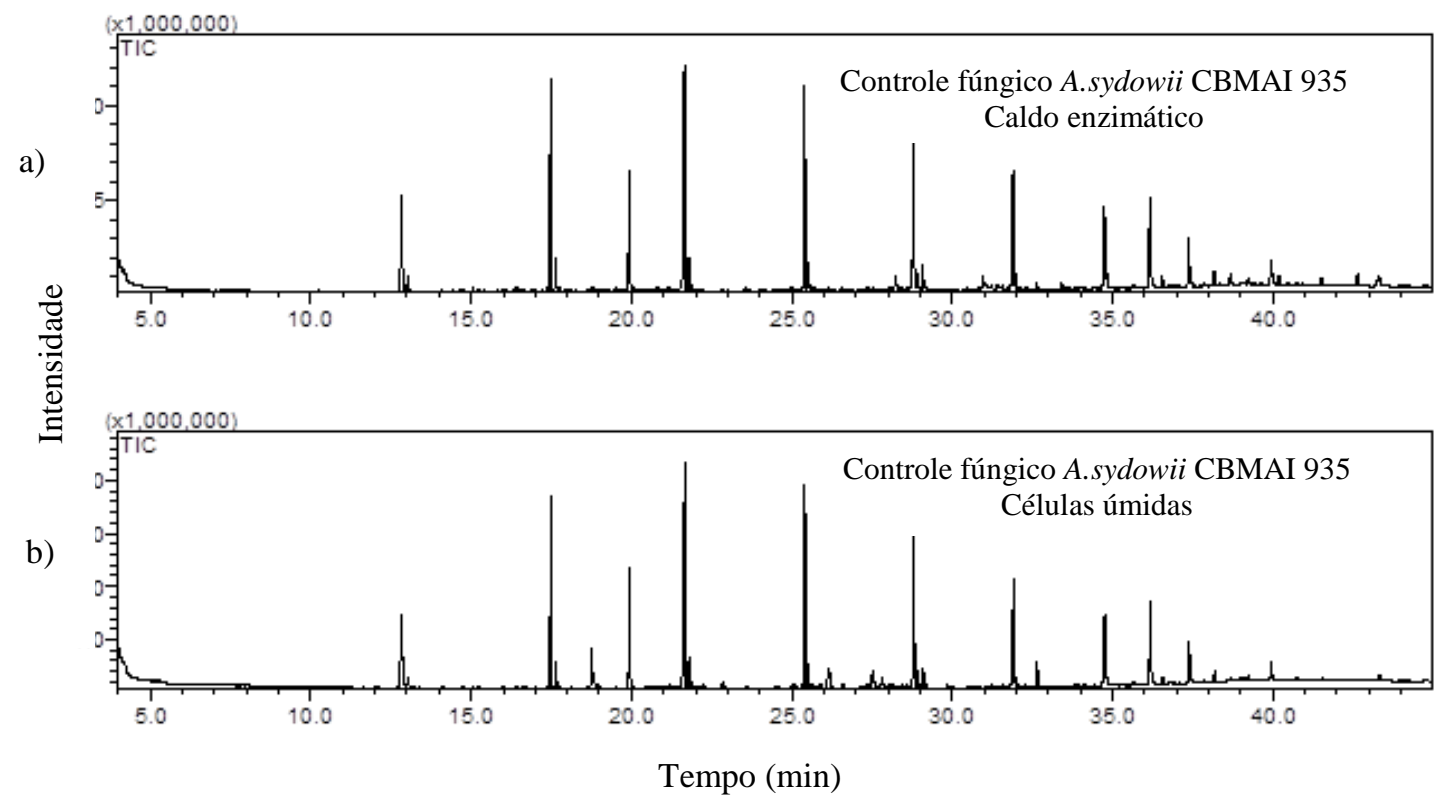

Condições de análise CG-EM: $\mathrm{T}_{\mathrm{i}}=60^{\circ} \mathrm{C}, 2 \mathrm{~min} ; \mathrm{T}_{\mathrm{f}}=280^{\circ} \mathrm{C}, 6 \mathrm{~min} ; \mathrm{r}=6^{\circ} \mathrm{C} / \mathrm{min}, \mathrm{t}_{\mathrm{c}}=45 \mathrm{mim}$.

Coluna capilar DB-5 da J\&W Scientific (30 m x 0,25 mm x 0,25 $\mu \mathrm{m})$. 
Os cromatogramas obtidos por CG-EM das reações em triplicatas com o fungo A. sydowii CBMAI 935 na ausência do pesticida clorpirifós em 10 dias de reação, apresentaram semelhanças quanto à presença de metabólitos provenientes do fungo. O cromatograma com a extração do caldo enzimático apresentou menor intensidade qualitativa dos sinais quando comparado com o cromatograma da extração do micélio (Figuras 49 e 50). É importante frisar que os experimentos também foram realizados para 20 e 30 dias de crescimento micelial na ausência de xenobióticos, onde não houve diferença significativa de intensidade dos sinais dos metabólitos produzidos naturalmente pelo fungo. Os cromatogramas de controle biótico para 20 e 30 dias são mostrados no Apêndice da dissertação.

O crescimento do fungo variou para cada experimento, outros fatores podem ter causado a diferença entre a intensidade dos sinais dos metabólitos. Deve-se também considerar que embora as reações sejam realizadas em triplicatas, elas ocorrem de formas independentes e, portanto, são reações únicas. Ressaltando que o mais importante foi a observação dos metabólitos gerados naturalmente pelo fungo A. sydowii CBMAI 935 para posterior comparação de metabólitos formados por ação enzimática do fungo na presença de xenobióticos como o pesticida comercial clorpirifós e os demais xenobióticos utilizados neste trabalho.

Este mesmo protocolo foi realizado para as reações de biotransformação dos pesticidas organosfosforados metil paration e profenofós e os compostos fenólicos 3,5,6 tricloro-2piridinol, derivado da hidrólise do pesticida clorpirifós, 4-nitrofenol, derivado da hidrólise do pesticida metil paration e 4-bromo-2-clorofenol, derivado da hidrólise do pesticida profenofós e os demais compostos fenólicos biotransformados pelo fungo de ambiente marinho $A$. sydowii CBMAI 935.

A Figura 51 mostra a sobreposição do cromatograma obtido por CG-EM da reação de controle biótico (cor vermelha) e o cromatograma da reação pesticida clorpirifós (cor preta) na concentração de $50 \mathrm{mg} . \mathrm{L}^{-1}$ em 10 dias de reação de biotransformação com o fungo $A$. sydowii CBMAI 935. Os cromatogramas foram sobrepostos para a comparação qualitativa das intensidades dos sinais dos metabólitos formados naturalmente pelo fungo e os metabólitos formados por ação enzimática do fungo e o pesticida comercial clorpirifós. 
Figura 51. Cromatograma obtido por CG-EM das reações de controle do fungo A. sydowii CBMAI 935 e o pesticida clorpirifós durante 10 dias.

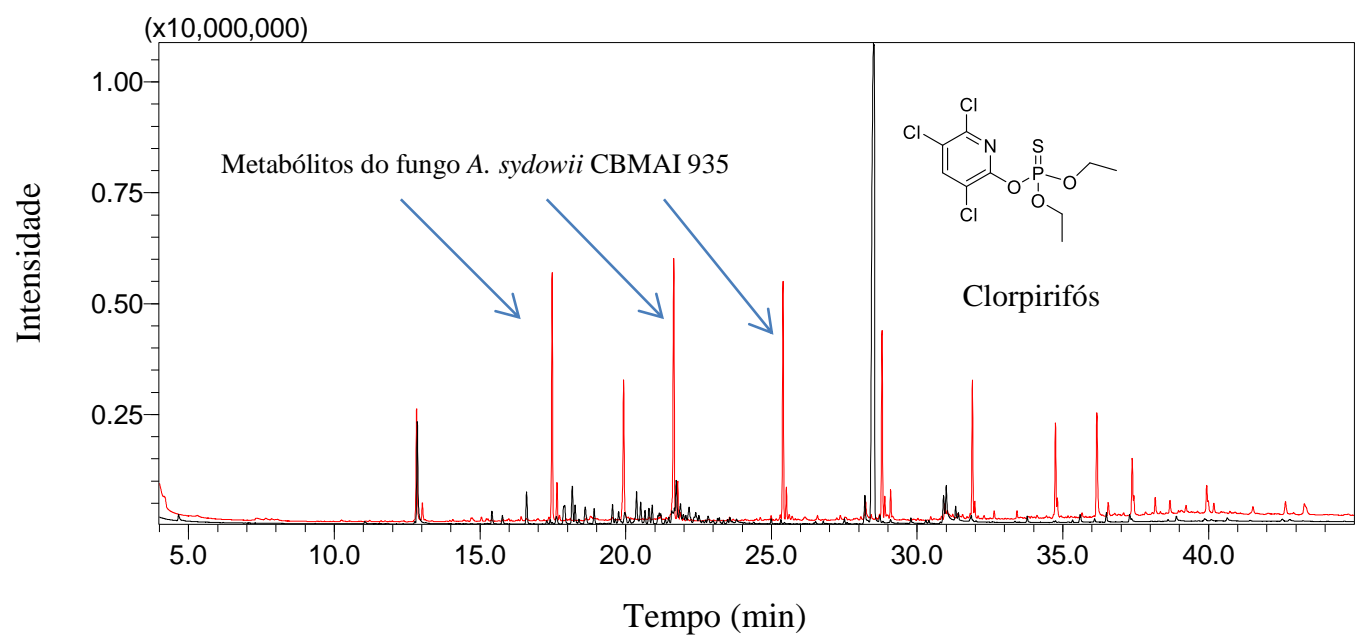

Condições de análise CG-EM: $\mathrm{T}_{\mathrm{i}}=60^{\circ} \mathrm{C}, 2 \mathrm{~min} ; \mathrm{T}_{\mathrm{f}}=280^{\circ} \mathrm{C}, 6 \mathrm{~min} ; \mathrm{r}=6^{\circ} \mathrm{C} / \mathrm{min}, \mathrm{t}_{\mathrm{c}}=45 \mathrm{mim}$. Coluna capilar DB-5 da J\&W Scientific (30 m x 0,25 mm x 0,25 $\mu \mathrm{m}$ ).

A Figura 52 mostra o cromatograma obtido por CG-EM da reação de controle abiótico. Neste caso utilizou-se o pesticida comercial clorpirifós em meio de cultura líquido de malte 2\% na ausência do fungo A. sydowii CBMAI 935 durante 10 dias de reação, para verificar se o mesmo era estável nas condições utilizadas $\left(32^{\circ} \mathrm{C}, \mathrm{pH} 7,0\right)$. O pesticida comercial clorpirifós apresentou o sinal no tempo de retenção em 28,600 minutos, houve também a presença de compostos nos tempos de retenção entre 12 a 37 minutos. Esses compostos estavam contidos no pesticida comercial clorpirifós, bem como, substâncias presente no meio de cultura. Sendo que o pesticida em condições abióticas apresentou a molécula intacta, sem metabólitos de degradação.

Figura 52. Cromatograma obtido por CG-EM da reação de controle abiótico do pesticida clorpirifós na ausência do fungo A. sydowii CBMAI 935 durante 10 dias.

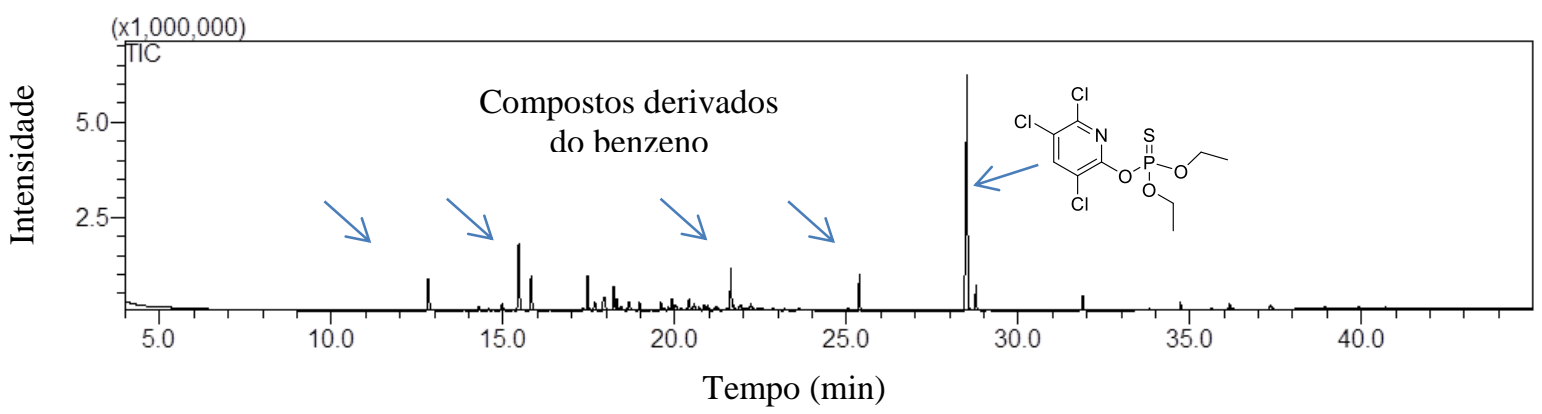

Condições de análise CG-EM: $\mathrm{T}_{\mathrm{i}}=60^{\circ} \mathrm{C}, 2 \mathrm{~min} ; \mathrm{T}_{\mathrm{f}}=280^{\circ} \mathrm{C}, 6 \mathrm{~min} ; \mathrm{r}=6^{\circ} \mathrm{C} / \mathrm{min}, \mathrm{t}_{\mathrm{c}}=45 \mathrm{mim}$.

Coluna capilar DB-5 da J\&W Scientific (30 m x 0,25 mm x 0,25 $\mu \mathrm{m}$ ). 
As Figuras 53 e 54 mostram o cromatograma e o espectro de massas $(70 \mathrm{eV})$ obtidos por CG-EM do padrão analítico do pesticida clorpirifós que tem o seu sinal no tempo de retenção em 28,600 minutos.

Figura 53. Cromatograma obtido por CG-EM do padrão analítico do pesticida clorpirifós.

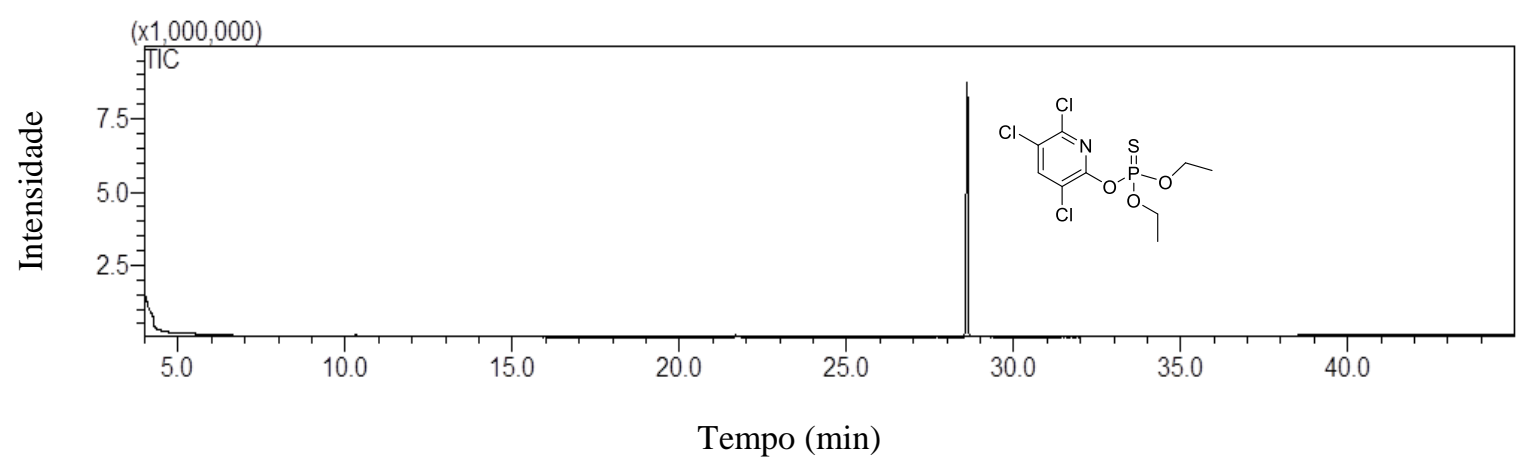

Condições de análise CG-EM: $\mathrm{T}_{\mathrm{i}}=60^{\circ} \mathrm{C}, 2 \mathrm{~min} ; \mathrm{T}_{\mathrm{f}}=280^{\circ} \mathrm{C}, 6 \mathrm{~min} ; \mathrm{r}=6^{\circ} \mathrm{C} / \mathrm{min}, \mathrm{t}_{\mathrm{c}}=45 \mathrm{mim}$.

Coluna capilar DB-5 da J\&W Scientific (30 m x 0,25 mm x 0,25 $\mu \mathrm{m})$.

Figura 54. Espectro de massas obtido por CG-EM $(70 \mathrm{eV})$ para o padrão analítico do pesticida clorpirifós.

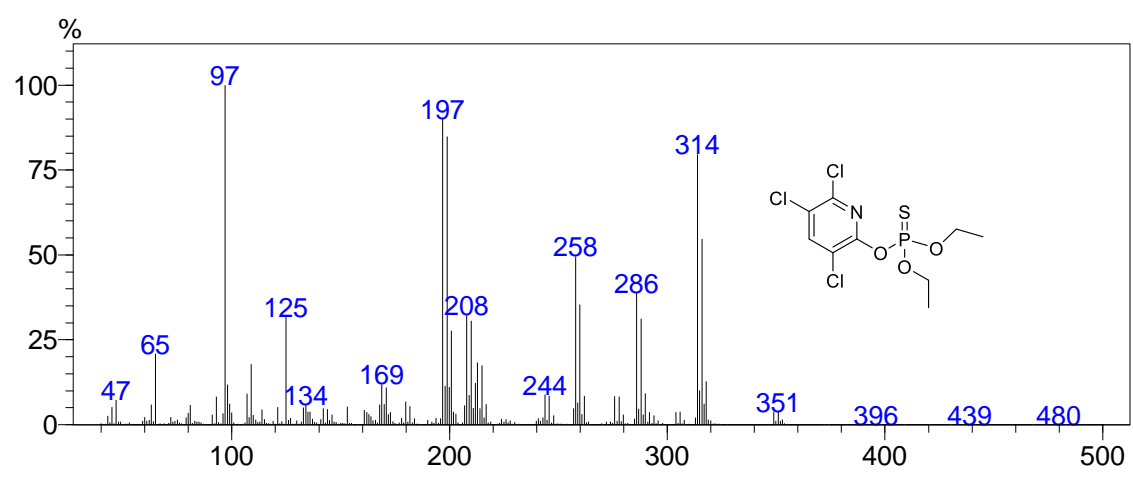

A Figura 55 mostra a sobreposição dos cromatogramas obtidos por CG-EM das extrações do caldo enzimático (cor vermelha) e do micélio (cor preta) com o fungo A. sydowii CBMAI 935 na presença de $50 \mathrm{mg} . \mathrm{L}^{-1}$ do pesticida comercial clorpirifós em 10 dias de reação e a Figura 56 mostra os mesmos cromatogramas, porém separados. Cromatograma (a) Extração do caldo enzimático e cromatograma (b) Extração do micélio.

Durante esse período foi observado qualitativamente uma maior intensidade dos sinais do pesticida no caldo enzimático em comparação com o micélio. Foram encontrados sinais de compostos possivelmente aromáticos que não foram formados naturalmente pelo fungo. Esses compostos já se encontravam no pesticida comercial como foi mostrado no cromatograma da reação de controle abiótico na Figura 52. 
Figura 55. Cromatograma obtido por CG-EM das extrações do micélio e do caldo enzimático do fungo $A$. sydowii CBMAI 935 na presença do pesticida comercial clorpirifós durante 10 dias.

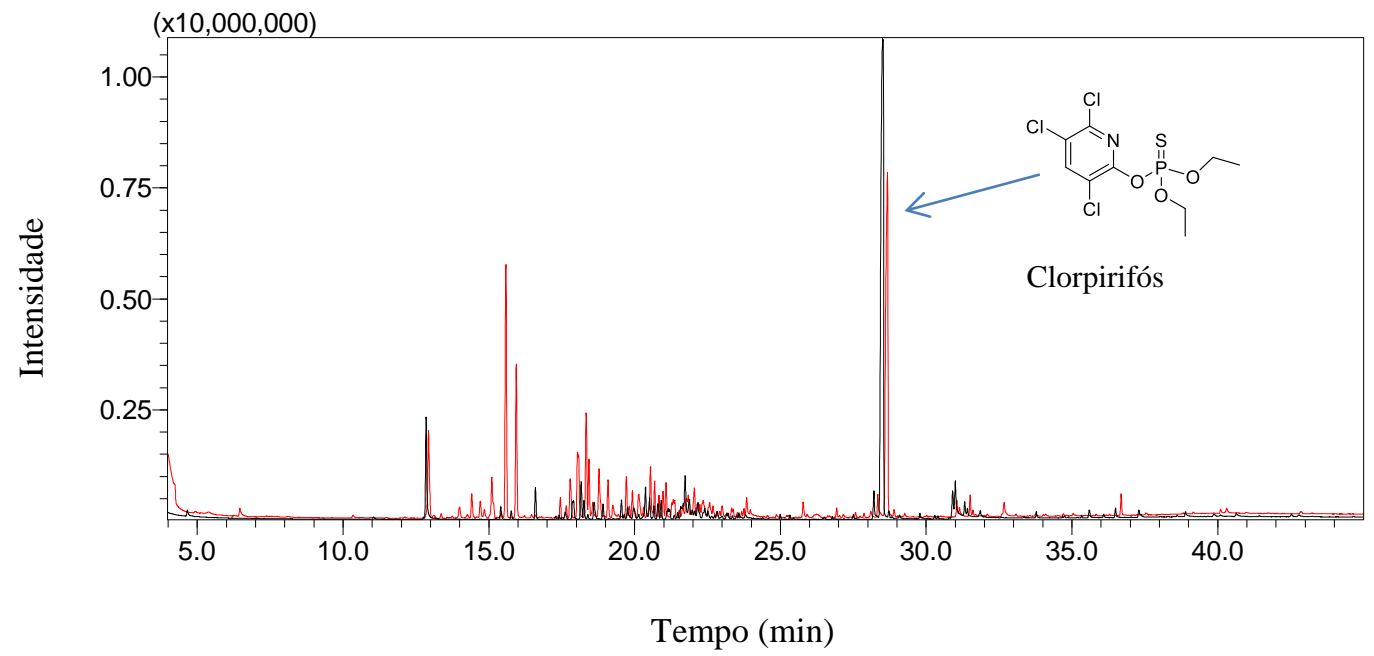

Condições de análise CG-EM: $\mathrm{T}_{\mathrm{i}}=60^{\circ} \mathrm{C}, 2 \mathrm{~min} ; \mathrm{T}_{\mathrm{f}}=280^{\circ} \mathrm{C}, 6 \mathrm{~min} ; \mathrm{r}=6^{\circ} \mathrm{C} / \mathrm{min}, \mathrm{t}_{\mathrm{c}}=45 \mathrm{mim}$.

Coluna capilar DB-5 da J\&W Scientific (30 m x 0,25 mm x 0,25 $\mu \mathrm{m})$.

Figura 56. Cromatogramas obtidos por CG-EM das extrações do micélio e do caldo enzimático do fungo $A$. sydowii CBMAI 935 na presença do pesticida comercial clorpirifós durante 10 dias. (a) Extração do caldo enzimático e (b) Extração do micélio.

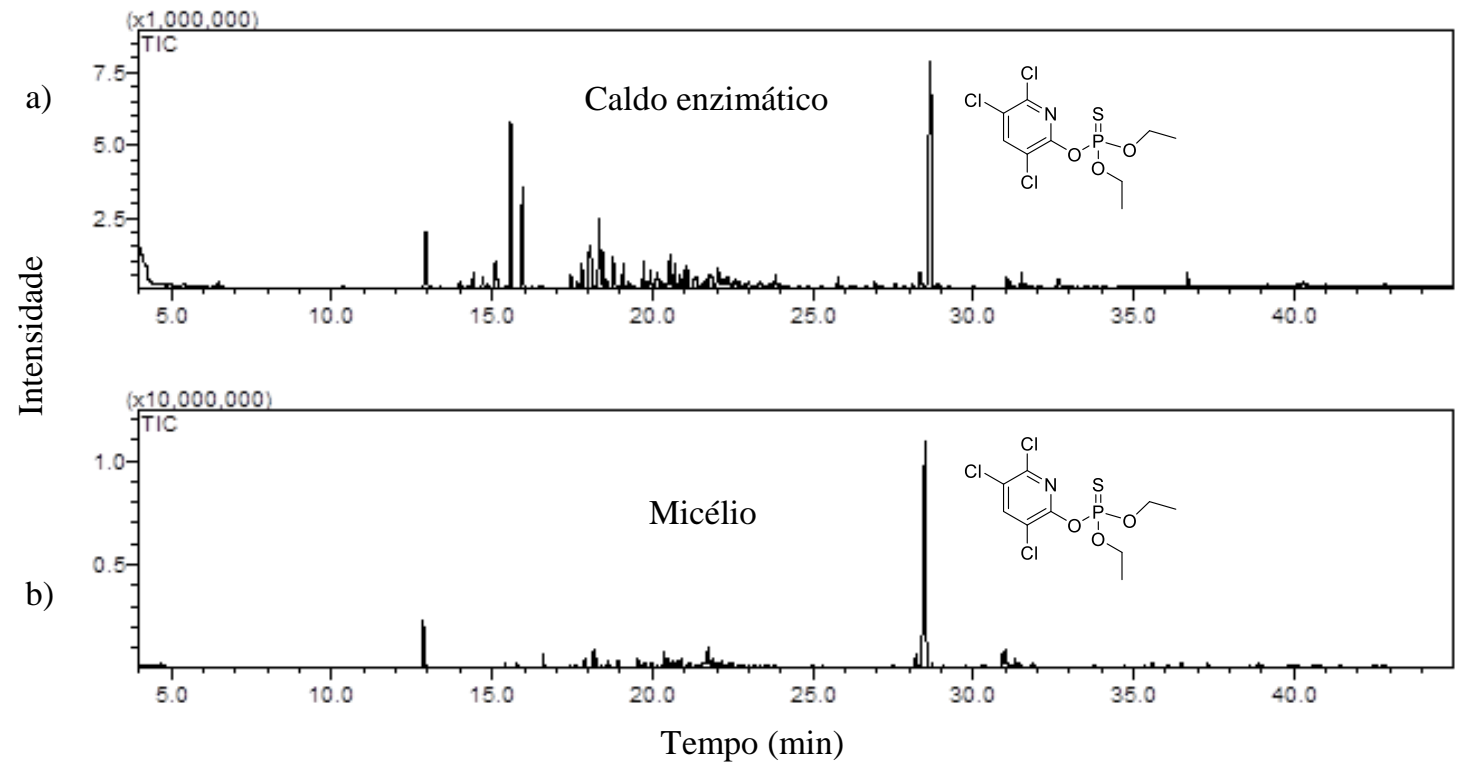

Condições de análise CG-EM: $\mathrm{T}_{\mathrm{i}}=60^{\circ} \mathrm{C}, 2 \mathrm{~min} ; \mathrm{T}_{\mathrm{f}}=280^{\circ} \mathrm{C}, 6 \mathrm{~min} ; \mathrm{r}=6^{\circ} \mathrm{C} / \mathrm{min}, \mathrm{t}_{\mathrm{c}}=45 \mathrm{mim}$.

Coluna capilar DB-5 da J\&W Scientific (30 m x 0,25 mm x 0,25 $\mu \mathrm{m})$. 
As Figuras 57 e 58 mostram os cromatogramas obtidos por CG-EM das extrações do caldo enzimático e extrações do micélio das reações de biotransformação do pesticida comercial clorpirifós pelo fungo A. sydowii CBMAI 935 durante 10 dias.

Nos cromatogramas das extrações do caldo enzimático e do micélio observou-se a obtenção de vários metabólitos provenientes de biotransformação do clorpirifós como a presença dos metabólitos 3,5,6-tricloro-2-piridinol gerado pela ação de enzimas fosfotriesterases responsáveis pela reação de hidrólise (fase I) do pesticida clorpirifós e os metabólitos 2,3,5-tricloro-6-metoxipiridina, 3,5,6-tricloro-1-metil-2-piridinona e ditiofosfato de tetraetila formados por ação de enzimas metiltransferases e etiltransferares responsáveis pela transferência dos grupos metila e etila nos metabólitos aceptores do 3,5,6-tricloro-2piridinol e gerando os metabólitos conjugados, característicos de reações de fase II. O sinal do pesticida comercial clorpirifós foi detectado no tempo de retenção em 28,600 minutos. Coincidindo, neste caso, como seria esperado com os tempos de retenção do padrão analítico do pesticida.

Figura 57. Cromatograma obtido por CG-EM das extrações do caldo enzimático do fungo A. sydowii CBMAI 935 na presença do pesticida comercial clorpirifós durante 10 dias.

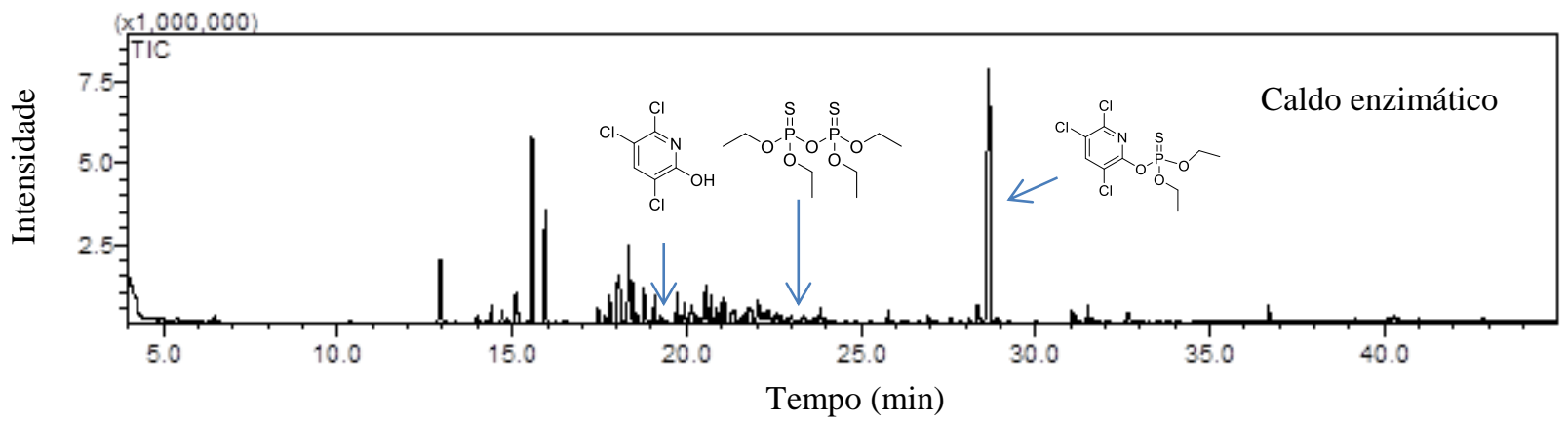

Condições de análise CG-EM: $T_{i}=60^{\circ} \mathrm{C}, 2 \mathrm{~min} ; \mathrm{T}_{\mathrm{f}}=280^{\circ} \mathrm{C}, 6 \mathrm{~min} ; \mathrm{r}=6^{\circ} \mathrm{C} / \mathrm{min}, \mathrm{t}_{\mathrm{c}}=45 \mathrm{mim}$.

Coluna capilar DB-5 da J\&W Scientific (30 $\mathrm{m}$ x 0,25 mm x 0,25 $\mu \mathrm{m})$. 
Figura 58. Cromatograma obtido por CG-EM das extrações do micélio do fungo A. sydowii CBMAI 935 na presença do pesticida comercial clorpirifós durante 10 dias.

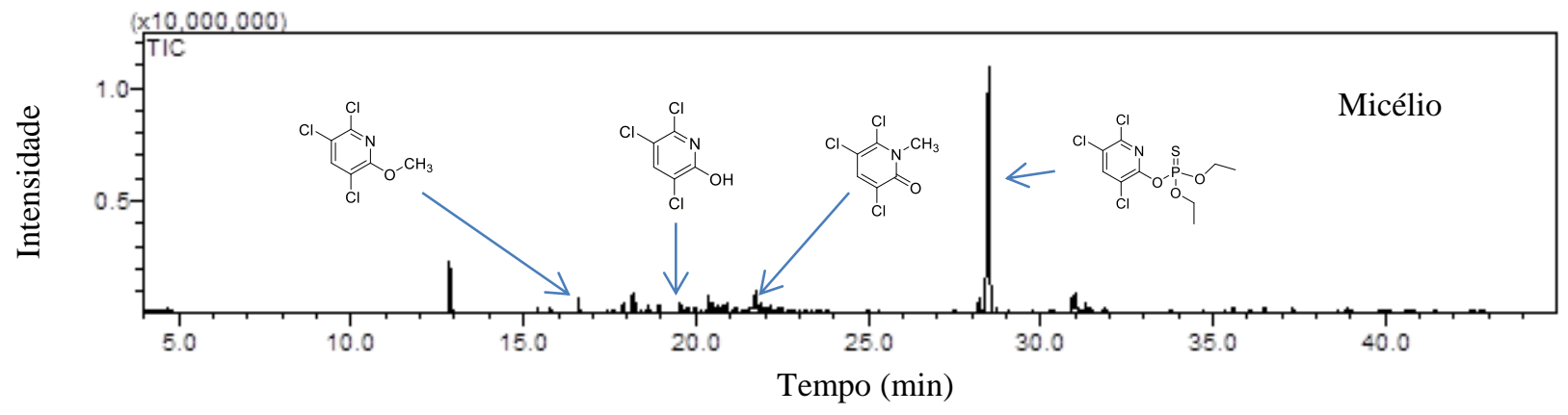

Condições de análise CG-EM: $\mathrm{T}_{\mathrm{i}}=60^{\circ} \mathrm{C}, 2 \mathrm{~min} ; \mathrm{T}_{\mathrm{f}}=280^{\circ} \mathrm{C}, 6 \mathrm{~min} ; \mathrm{r}=6^{\circ} \mathrm{C} / \mathrm{min}, \mathrm{t}_{\mathrm{c}}=45 \mathrm{mim}$. Coluna capilar DB-5 da J\&W Scientific (30 m x 0,25 mm x 0,25 $\mu \mathrm{m})$.

A Figura 59 mostra as ampliações dos cromatogramas mostrados nas Figuras 57 e 58 para melhor visualização dos sinais dos metabólitos 3,5,6-tricloro-2-piridinol, 2,3,5-tricloro6-metoxipiridina, 3,5,6-tricloro-1-metil-2-piridinona e ácido ditiofosfórico formados nas reações com o fungo Aspergillus sydowii CBMAI 935 na presença do pesticida comercial clorpirifós, durante 10 dias.

Cromatograma (a) Sinal do metabólito 2,3,5-tricloro-6-metoxipiridina, cromatograma (b) Sinal do metabólito 3,5,6-tricloro-2-piridinol, cromatograma (c) Sinal do metabólito 3,5,6tricloro-1-metil-2-piridinona e cromatograma (d) Sinal do metabólito ditiofosfato de tetraetila. 
Figura 59. Ampliações dos cromatogramas obtidos por CG-EM das extrações do micélio e caldo enzimático do fungo A. sydowii CBMAI 935 na presença do pesticida clorpirifós durante 10 dias.
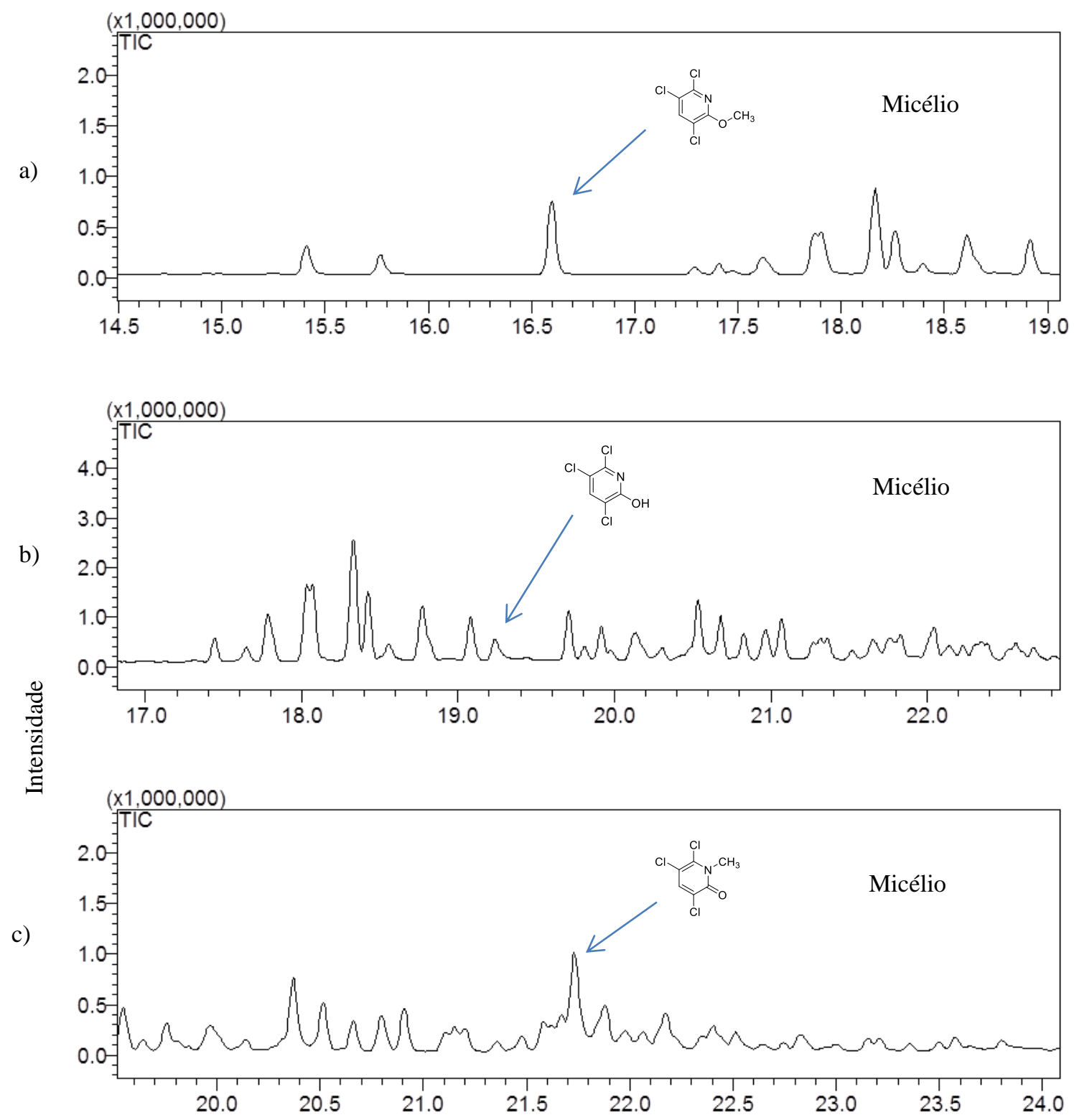

d)

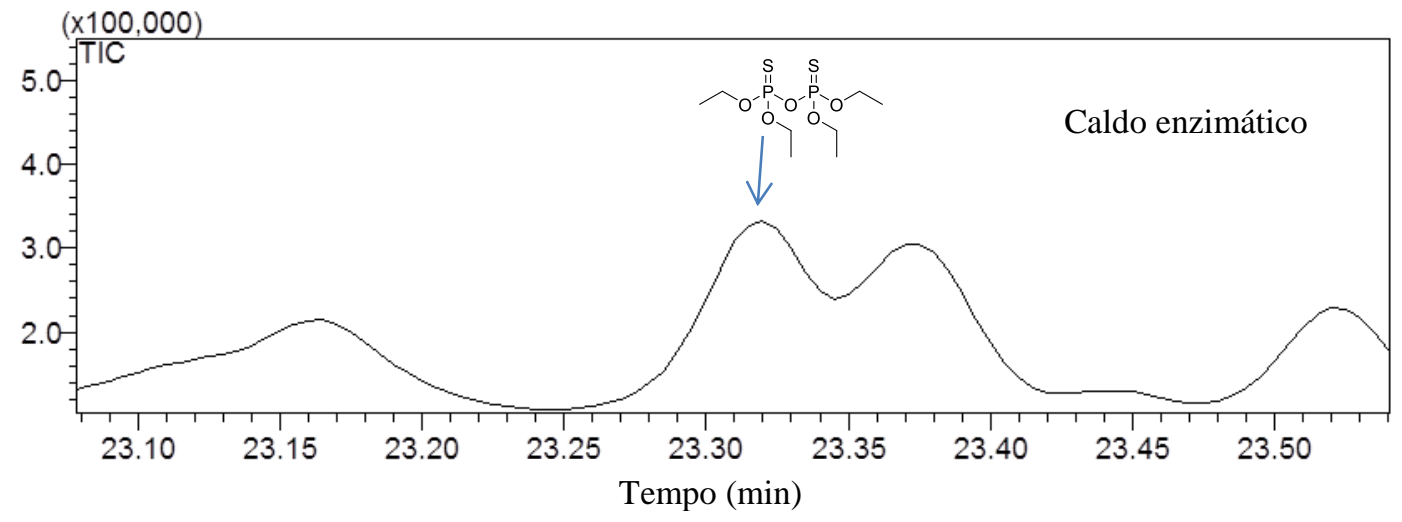

Condições de análise CG-EM: $T_{i}=60^{\circ} \mathrm{C}, 2 \mathrm{~min} ; \mathrm{T}_{\mathrm{f}}=280^{\circ} \mathrm{C}, 6 \mathrm{~min} ; \mathrm{r}=6^{\circ} \mathrm{C} / \mathrm{min}, \mathrm{t}_{\mathrm{c}}=45 \mathrm{mim}$.

Coluna capilar DB-5 da J\&W Scientific ( $30 \mathrm{~m}$ x 0,25 mm x 0,25 $\mu \mathrm{m}$ ). 
O Esquema 1 mostra as possíveis reações de fase I e fase II (biotransformação e bioconjugação) do pesticida comercial clorpirifós por reações enzimáticas do fungo de ambiente marinho Aspergillus sydowii CBMAI 935. O Esquema 1 foi proposto a partir dos compostos identificados nos cromatogramas obtidos por CG-EM das extrações do micélio e do caldo emzimático do fungo A. sydowii CBMAI 935 na presença do pesticida comercial clorpirifós durante 10 dias.

Esquema 1. Proposta de reações e metabólitos de biotransformação de fase I e de faseII do pesticida comercial clorpirifós pelo fungo A. sydowii CBMAI 935 durante 10 dias.<smiles>CCOP(=S)(OCC)Oc1nc(Cl)c(Cl)cc1Cl</smiles>

Clorpirifós<smiles>CCOC(=O)OC(C)C</smiles><smiles>Oc1nc(Cl)c(Cl)cc1Cl</smiles>

3,5,6-tricloro-2-piridinol

$$
\downarrow \begin{gathered}
\text { Conjugação } \\
\text { (Metiltransferases) } \\
\text { Fase II }
\end{gathered}
$$<smiles>COc1nc(Cl)c(Cl)cc1Cl</smiles>

Isomerização

2,5,6-tricloro-6-metoxipiridina<smiles>CCOP(O)(=S)OCC</smiles>

fosforotioato de 0,0 -dietila<smiles>CCOP(=S)(OCC)OP(=S)(OCC)OCC</smiles>

ditilfosfato de tetraetila

Fonte: Autoria própria

3,5,6-tricloro-1-metil-2-piridinona 
A Figura 60 mostra o cromatograma obtido por CG-EM das extrações do caldo enzimático para o pesticida comercial clorpirifós com o fungo de ambiente marinho $A$. sydowii CBMAI 935 em 10 dias de reação de biotransformação. O cromatograma da Figura 60 foi obtido a partir da Figura 57, selecionando apenas o sinal do composto com tempo de retenção em 28,600 minutos.

O sinal, o tempo de retenção e o espectro de massas do pesticida encontrados na reação foram comparados com o padrão analítico do clorpirifós (Figuras 50 e 51). Os quais foram idênticos, confirmando a identidade do composto na amostra comercial que foi utilizada nas reações de biotransformação.

Figura 60. Cromatograma selecionado do pesticida comercial clorpirifós obtido por CG-EM das extrações do caldo enzimático do fungo A. sydowii CBMAI 935 em 10 dias de reação de biotransformação.

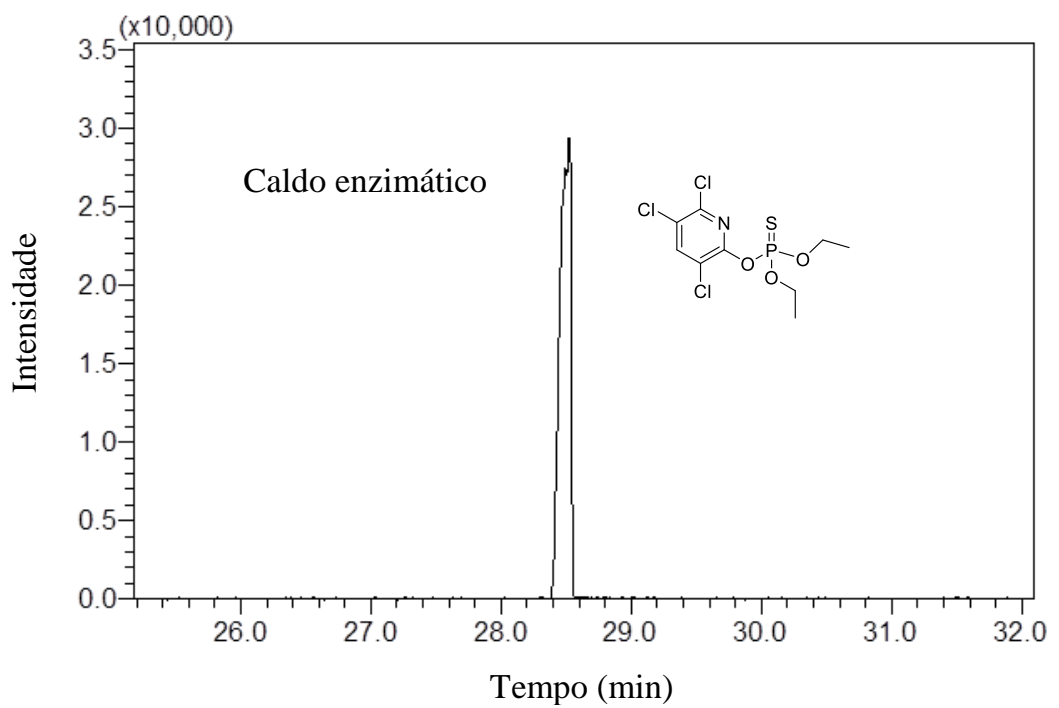

Condições de análise CG-EM: $\mathrm{T}_{\mathrm{i}}=60^{\circ} \mathrm{C}, 2 \mathrm{~min} ; \mathrm{T}_{\mathrm{f}}=280^{\circ} \mathrm{C}, 6 \mathrm{~min} ; \mathrm{r}=6^{\circ} \mathrm{C} / \mathrm{min}, \mathrm{t}_{\mathrm{c}}=45 \mathrm{mim}$.

Coluna capilar DB-5 da J\&W Scientific (30 m x 0,25 mm x 0,25 $\mu \mathrm{m}$ ). 
A Figura 61 mostra o espectro de massas do pesticida comercial clorpirifós obtido da reação de biotransformação com fungo A. sydowii CBMAI 935. O espectro de massas apresenta um amplo padrão de fragmentação. A presença de substituintes que se fragmentam com facilidade, faz com que o pico do íon molecular $\mathrm{m} / \mathrm{z} 351$ (1) fique pouco intenso e os picos dos fragmentos relativamente mais intensos. ${ }^{74,136} \mathrm{O}$ fragmento $(\mathbf{2}), \mathrm{m} / \mathrm{z}, 314$, pode ser resultante da fragmentação do clorpirifós através da perda de um átomo de cloro e um átomo de hidrogênio. Picos com M-1 e M+1 são comuns nesta técnica de ionização. A presença de dois átomos de cloro na molécula faz com que a abundância relativa dos picos $\mathbf{M}, \mathrm{M}+2 \mathrm{(m} / \mathrm{z}$ 316) e $\mathrm{M}+4(\mathrm{~m} / \mathrm{z} 318)$ sejam de 43 e $10 \%$, respectivamente.

Já o fragmento com $\mathrm{m} / \mathrm{z} 197$ (3), corresponde ao 3,5,6-tricloro-2-piridinol. A presença dos três átomos de cloro na molécula faz com que a abundância relativa dos picos $M, M+2 \mathrm{e}$ M+4 seja de 20, 22 e 10\%, respectivamente. Assim para a fragmentação do clorpirifós, o pico base com $\mathrm{m} / z 97$ (4), pode ser resultado de uma série de fragmentações da porção fosforotioato do pesticida. O espectro descrito foi comparado com o espectro de massas do padrão analítico do pesticida clorpirifós (Figura 54), os quais foram idênticos, confirmando a identidade do composto na amostra comercial que foi utilizada nas reações de biotransformação com o fungo A.sydowii CBMAI 935.

Figura 61. Espectro de massas obtido por CG-EM $(70 \mathrm{eV})$ para o pesticida comercial clorpirifós das extrações do micélio do fungo A. sydowii CBMAI em 10 dias.

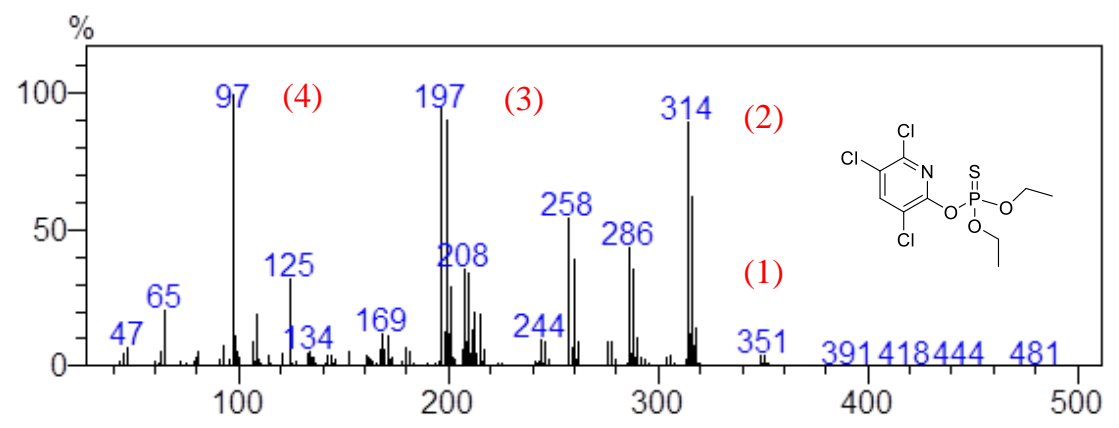


O Esquema 2 mostra a proposta de fragmentação para o pesticida comercial clorpirifós obtido por CG-EM das extrações do micélio com o fungo de ambiente marinho A. sydowii CBMAI 935 em 10 dias de reação de biotransformação.

Esquema 2. Proposta de fragmentação para o pesticida comercial clorpirifós.

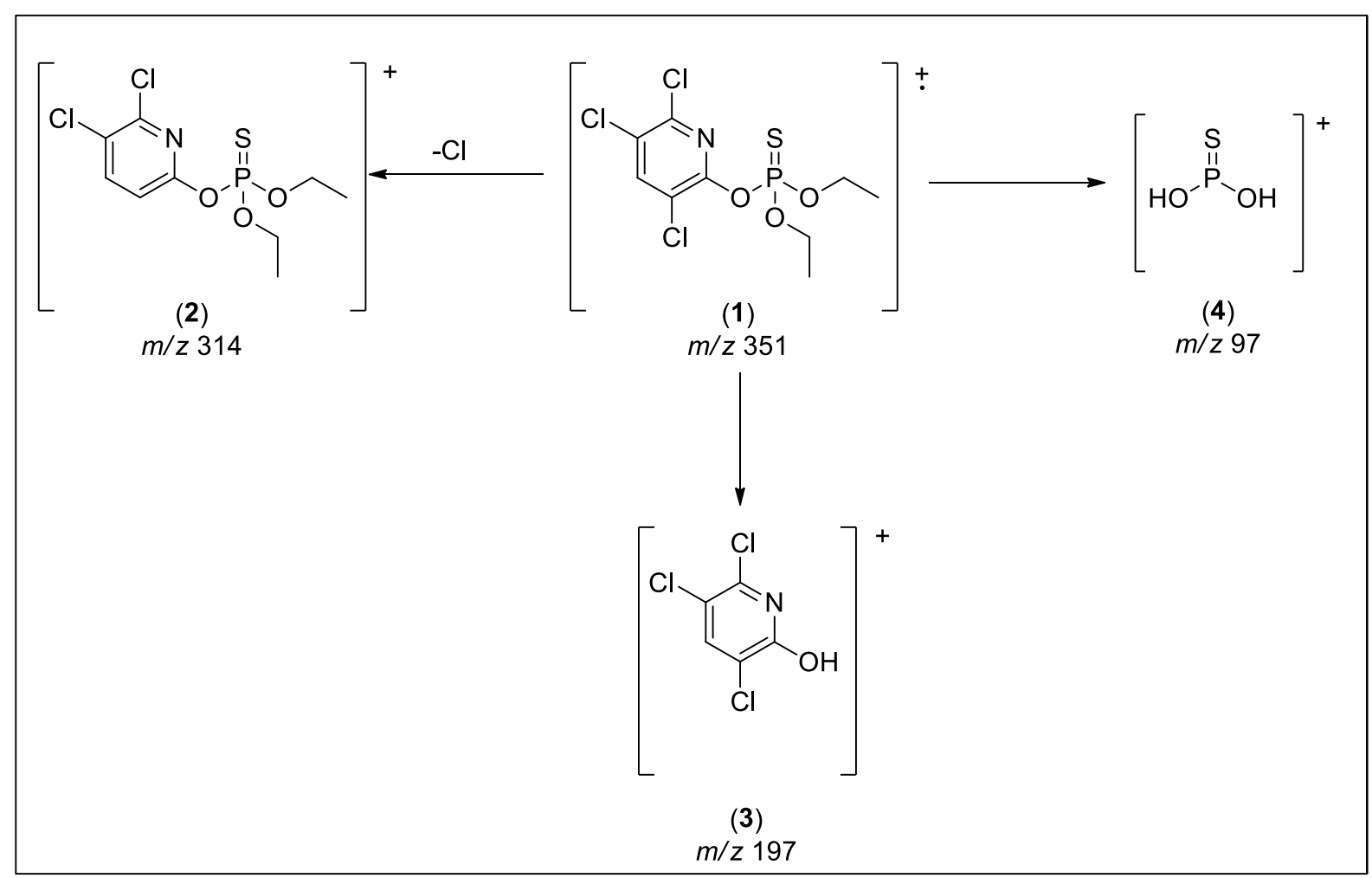

Fonte: Autoria própria.

A Figura 62 mostra o cromatograma obtido por CG-EM das extrações do micélio para o composto fenólico 3,5,6-tricloro-2-piridinol oriundo da hidrólise enzimática do pesticida comercial clorpirifós pelo fungo de ambiente marinho A. sydowii CBMAI 935 em 10 dias de reação de biotransformação. O cromatograma da Figura 62 foi obtido a partir da Figura 58, selecionando apenas o sinal do composto 3,5,6-tricloro-2-piridinol com tempo de retenção em 19,233 minutos.

Por apresentar maior solubilidade em água comparado ao clorpirifós, o 3,5,6-tricloro-2piridinol pode ser um marcador da contaminação deste pesticida, já que este pode ser mais facilmente transportado no ambiente. Uma vez no meio, o 3,5,6-tricloro-2-piridinol pode causar contaminações tanto no solo quanto em corpos hídricos. Na presença de fungos, o 3,5,6-tricloro-2-piridinol não somente é resistente frente a biodegradação, como pode também limitar a biodegradação do clorpirifós, já que que apresenta atividade anti-microbiana. ${ }^{74,138}$ 
O sinal e o tempo de retenção do composto 3,5,6-tricloro-2-piridinol encontrado na reação foram comparados com o padrão analítico do 3,5,6-tricloro-2-piridinol os quais foram idênticos, confirmando a identidade do composto (Figuras 64 e 65).

Figura 62. Cromatograma selecionado do metabólito 3,5,6-tricloro-2-piridinol obtido por CG-EM das extrações do micélio do fungo A. sydowii CBMAI 935 na presença do pesticida comercial clorpirifós durante 10 dias.

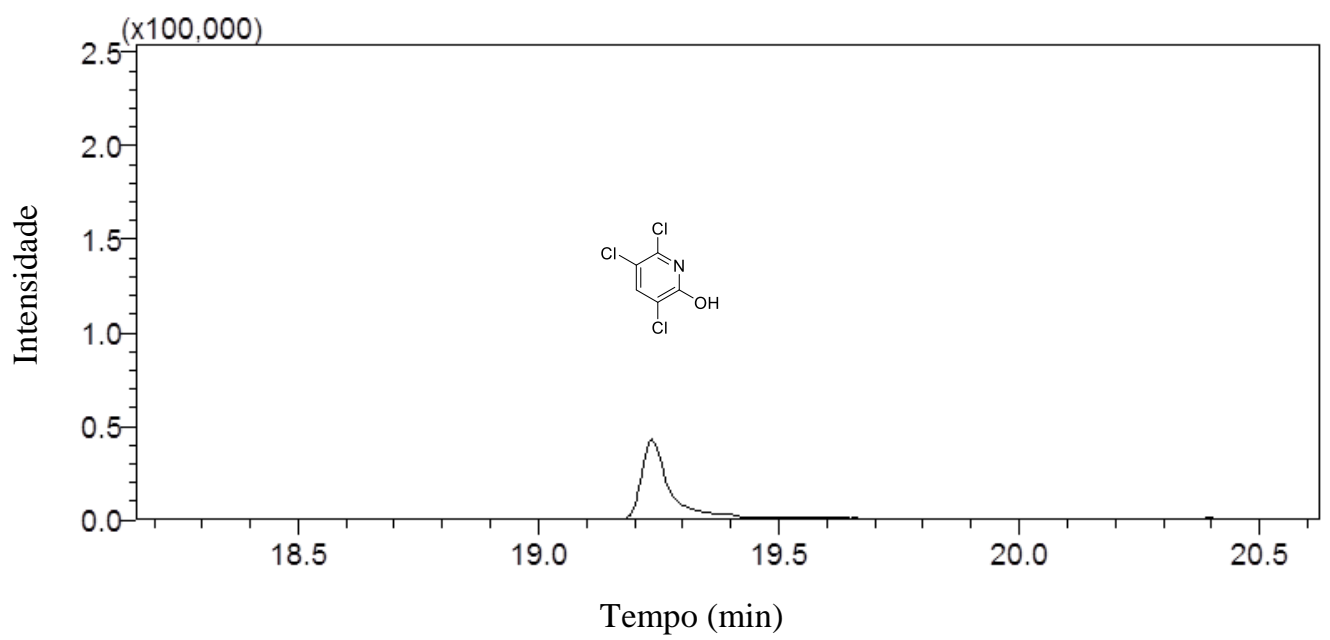

Condições de análise CG-EM: $\mathrm{T}_{\mathrm{i}}=60^{\circ} \mathrm{C}, 2 \mathrm{~min} ; \mathrm{T}_{\mathrm{f}}=280^{\circ} \mathrm{C}, 6 \mathrm{~min} ; \mathrm{r}=6^{\circ} \mathrm{C} / \mathrm{min}, \mathrm{t}_{\mathrm{c}}=45 \mathrm{mim}$. Coluna capilar DB-5 da J\&W Scientific (30 m x 0,25 mm x 0,25 $\mu \mathrm{m}$ ).

A Figura 63 mostra o espectro de massas obtido por CG-EM do composto fenólico 3,5,6tricloro-2-piridinol obtido da reação de biotransformação do pesticida comercial clorpirifós com fungo A. sydowii CBMAI 935. O espectro de massas apresentou o íon molecular como pico base com $m / z 197$ (1). A presença dos três átomos de cloro na molécula faz com que a abundância relativa dos picos $\mathrm{M}, \mathrm{M}+2, \mathrm{M}+4$ e $\mathrm{M}+6$ seja de 100, 96, 30 e 4\%, respectivamente. Como é característico para os fenois, há a perda de CO (M-28) com intensidade de 95\%, resultando no fragmento com $\mathrm{m} / \mathrm{z} 169$ (2), seguindo o padrão de abundância para os picos $M, M+2, M+4$ e $M+6$. Uma subsequente fragmentação pode produzir o fragmento com $\mathrm{m} / z 134$ (3), com perda de hidrogênio e um átomo de cloro $(\mathrm{HCl})$.

O espectro relatado foi comparado com o espectro de massas do padrão analítico do composto fenólico 3,5,6-tricloro-2-piridinol, mostrando semelhanças que comprovam a estrutura deste metabólito. 
Figura 63. Espectro de massas obtido por CG-EM $(70 \mathrm{eV})$ para o metabólito 3,5,6-tricloro-2-piridinol frente a reação de biotransformação do pesticida comercial clorpirifós com o fungo A. sydowii CBMAI 935 durante 10 dias.

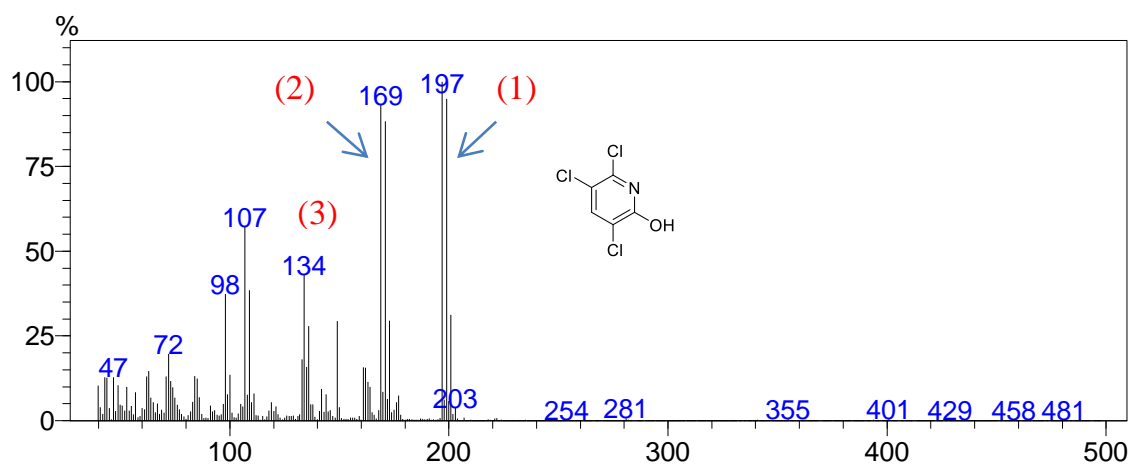

O Esquema 3 mostra a proposta de fragmentação para o metabólito 3,5,6-tricloro-2piridinol obtido por CG-EM das extrações do micélio frente a reação de biotransformação do pesticida comercial clorpirifós com o fungo de ambiente marinho A. sydowii CBMAI 935 em 10 dias de reação de biotransformação.

Esquema 3. Proposta de fragmentação para o metabólito 3,5,6-tricloro-2-piridinol.

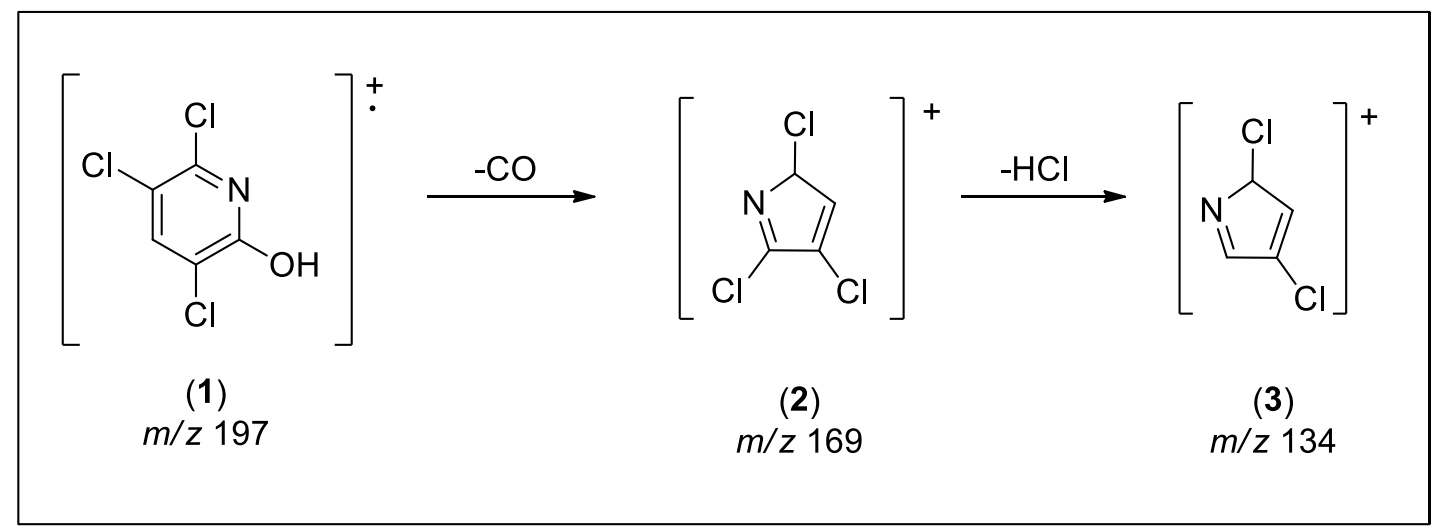

Fonte: Adaptado de SILVA, N.A. Biodegradação dos pesticidas clorpirifós, metil paration e profenofós por fungos de origem marinha. 159f. Dissertação (Mestrado em Química)-Universidade São Paulo-USP. São Carlos, 2013. ${ }^{74}$ 
As Figuras 64 e 65 mostram o cromatograma e o espectro de massas do padrão analítico do composto fenólico 3,5,6-tricloro-2-piridinol que tem o seu pico no tempo de retenção em 19,233 minutos.

Figura 64. Cromatograma obtido por CG-EM do padrão analítico do 3,5,6-tricloro-2-piridinol.

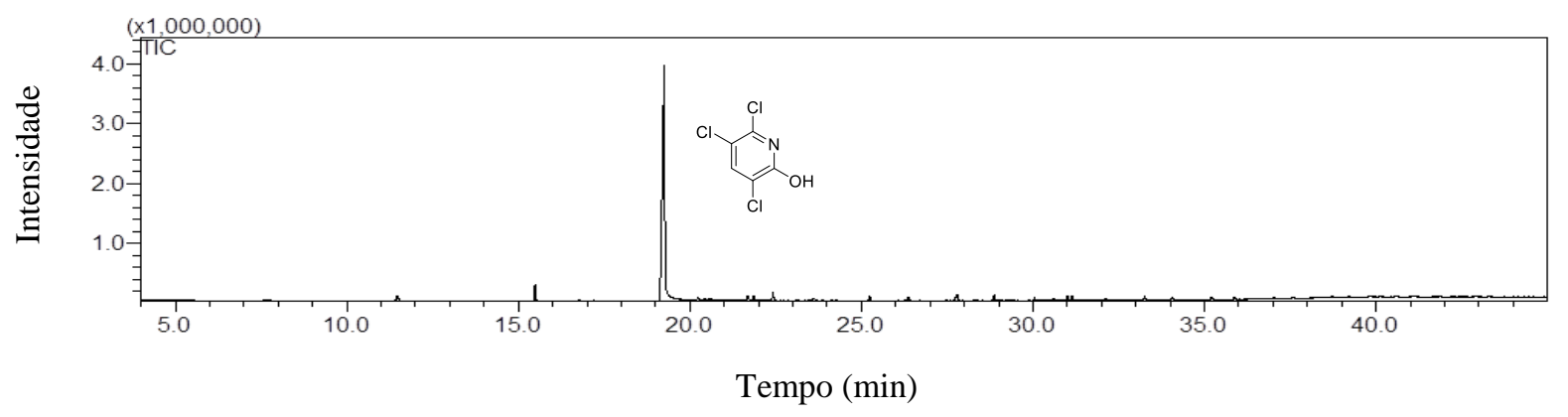

Condições de análise CG-EM: $\mathrm{T}_{\mathrm{i}}=60^{\circ} \mathrm{C}, 2 \mathrm{~min} ; \mathrm{T}_{\mathrm{f}}=280^{\circ} \mathrm{C}, 6 \mathrm{~min} ; \mathrm{r}=6^{\circ} \mathrm{C} / \mathrm{min}, \mathrm{t}_{\mathrm{c}}=45 \mathrm{mim}$.

Coluna capilar DB-5 da J\&W Scientific (30 m x 0,25 mm x 0,25 $\mu \mathrm{m})$.

Figura 65. Espectro de massas obtido por CG-EM (70 eV) para o padrão analítico do 3,5,6-tricloro-2-piridinol.

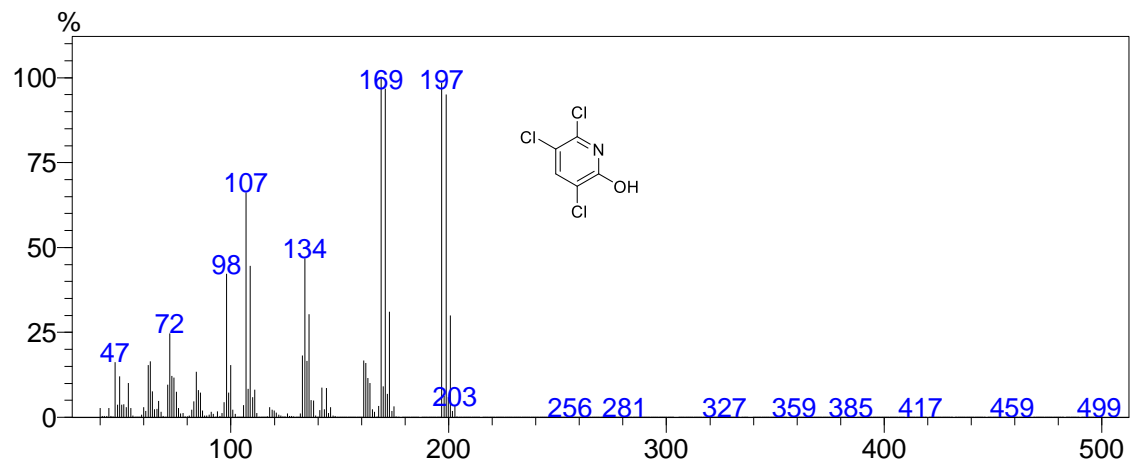


A Figura 66 mostra o cromatograma selecionado obtido por CG-EM do metabólito 2,3,5tricloro-6-metoxipiridina oriundo da metilação enzimática (reação de fase II) do composto fenólico 3,5,6-tricloro-2-piridinol, gerado a partir da hidrólise enzimática do pesticida comercial clorpirifós (reação de fase I) com o fungo de ambiente marinho A. sydowii CBMAI 935 durante 10 dias de reação de biotransformação.

O cromatograma da Figura 63 foi obtido a partir da Figura 55, selecionando apenas o sinal do metabólito 2,3,5-tricloro-6-metoxipiridina com tempo de retenção em 16,900 minutos. O sinal e o tempo de retenção do metabólito encontrado na reação foram comparados com o padrão sintético do 2,3,5-tricloro-6-metoxipiridina os quais foram idênticos, confirmando a identidade do composto (Figuras 68 e 69).

O metabólito 2,3,5-tricloro-6-metoxipiridina foi isolado por coluna de bancada e posteriormente caracterizado por espectroscopia de RMN (Espectros no Apêndice da dissetação).

Figura 66. Cromatograma selecionado obtido por CG-EM do metabólito 2,3,5-tricloro-6-metoxipiridina das extrações do micélio do fungo A. sydowii CBMAI 935 na presença do pesticida comercial clorpirifós durante 10 dias.

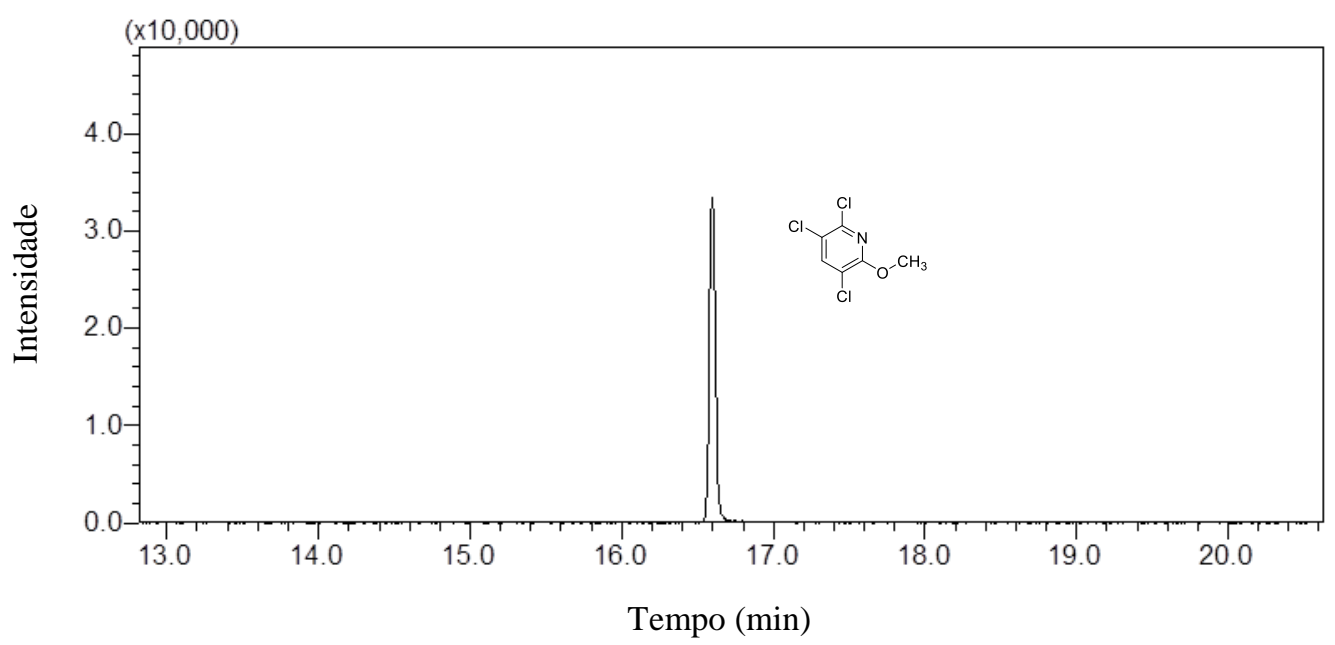

Condições de análise CG-EM: $\mathrm{T}_{\mathrm{i}}=60^{\circ} \mathrm{C}, 2 \mathrm{~min} ; \mathrm{T}_{\mathrm{f}}=280^{\circ} \mathrm{C}, 6 \mathrm{~min} ; \mathrm{r}=6^{\circ} \mathrm{C} / \mathrm{min}, \mathrm{t}_{\mathrm{c}}=45 \mathrm{mim}$. Coluna capilar DB-5 da J\&W Scientific (30 $\mathrm{m}$ x 0,25 mm x 0,25 $\mu \mathrm{m}$ ). 
A Figura 67 mostra o espectro de massas do metabólito 2,3,5-tricloro-6-metoxipiridina obtido da reação de biotransformação do pesticida comercial clorpirifós com fungo A. sydowii CBMAI 935 durante 10 dias. O espectro de massas para metabólito apresenta o íon molecular, com $m / z 211$ (1). A presença dos três átomos de cloro na molécula faz com que a abundância relativa dos picos $\mathrm{M}, \mathrm{M}+2, \mathrm{M}+4$ e $\mathrm{M}+6$ seja de 100, 96, 30 e 6\%, respectivamente. Como característico para os fenois, há a perda de CO (M-28) com intensidade de 100\%, resultando no fragmento e pico base com $\mathrm{m} / z 182$ (2), seguindo o padrão de abundância para os picos $\mathrm{M}$, M+2, M+4 e M+6. Uma subsequente fragmentação pode produzir o fragmento com $\mathrm{m} / z 168$ (3), com perda da metila e um átomo de cloro. O espectro relatado foi comparado com o espectro de massas do padrão sintético do composto 2,3,5-tricloro-6-metoxipiridina confirmando a identidade do composto.

Figura 67. Espectro de massas obtido por CG-EM (70 eV) para o metabólito 2,3,5-tricloro-6-metoxipiridina das extrações do micélio do fungo A. sydowii CBMAI 935 na presença do pesticida comercial clorpirifós durante 10 dias.

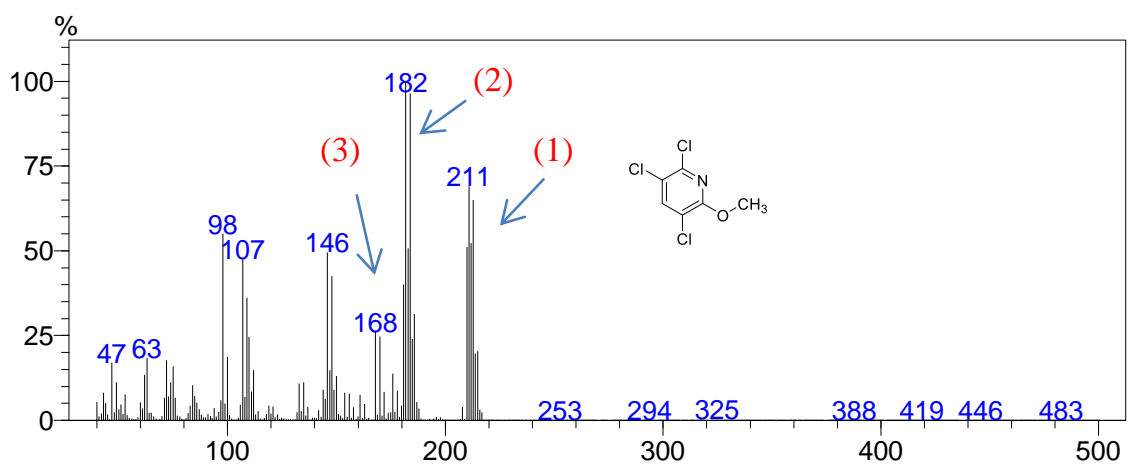

O Esquema 4 mostra a proposta de fragmentação para o composto 2,3,5-tricloro-6metoxipiridina obtido por CG-EM das extrações do micélio com o fungo de ambiente marinho A. sydowii CBMAI 935 em 10 dias de reação de biotransformação. 
Esquema 4. Proposta de fragmentação para o metabólito 2,3,5-tricloro-6-metoxipiridina.

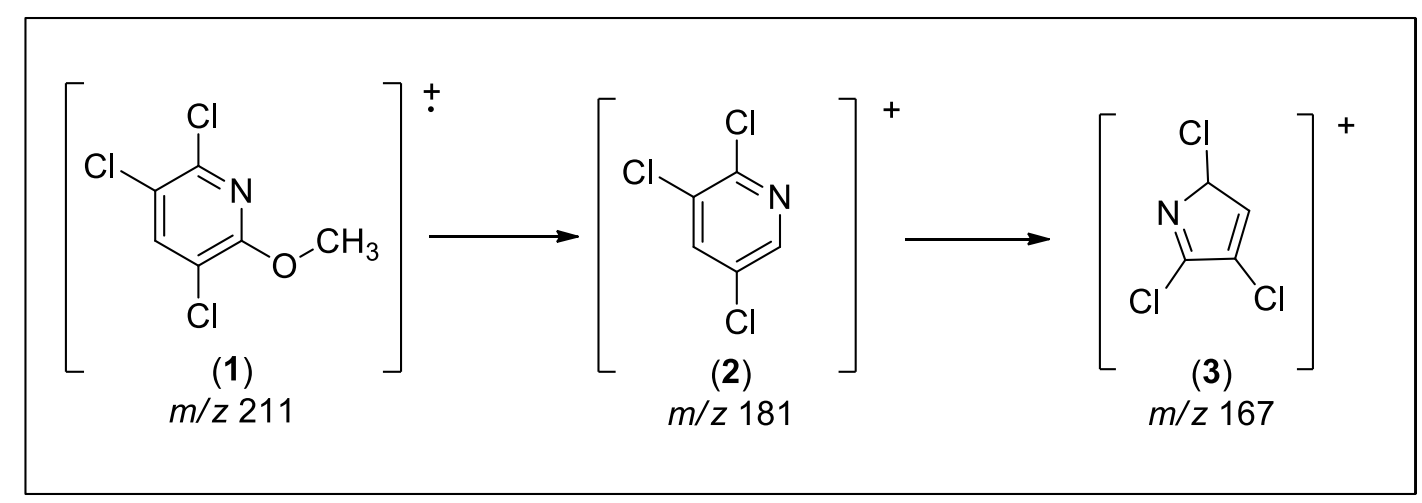

Fonte: Autoria própria.

As Figuras 68 e 69 mostram o cromatograma e o espectro de massas do padrão sintético do metabólito 2,3,5-tricloro-6-metoxipiridina que tem o seu pico no tempo de retenção em 16,900 minutos.

Figura 68. Cromatograma obtido por CG-EM do padrão sintético do 2,3,5-tricloro-6-metoxipiridina.

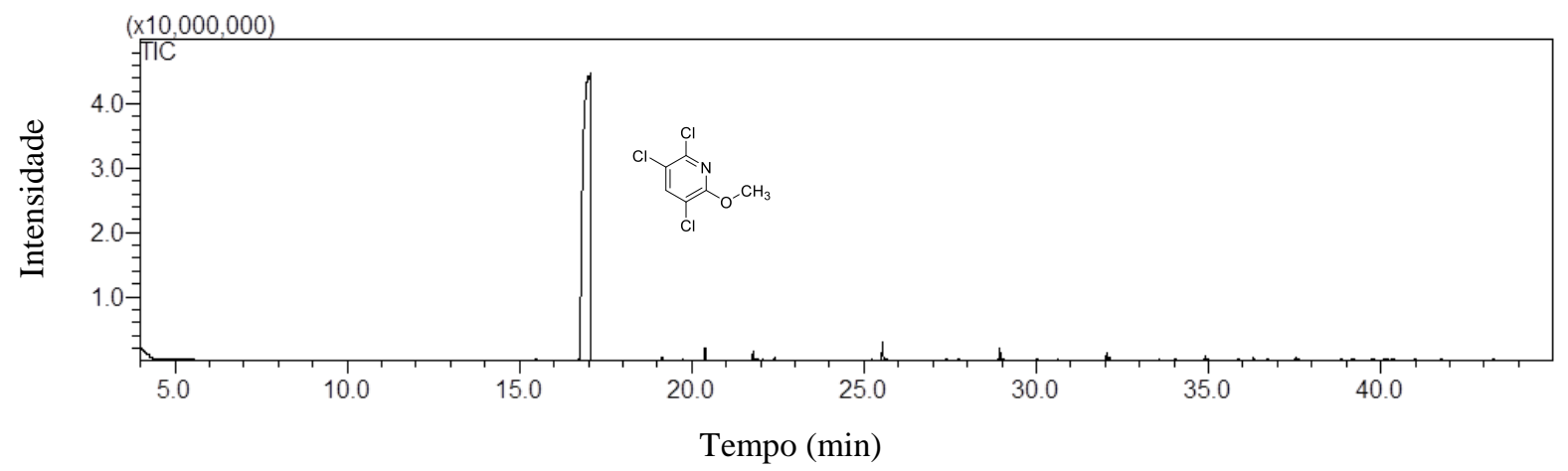

Condições de análise CG-EM: $\mathrm{T}_{\mathrm{i}}=60^{\circ} \mathrm{C}, 2 \mathrm{~min} ; \mathrm{T}_{\mathrm{f}}=280^{\circ} \mathrm{C}, 6 \mathrm{~min} ; \mathrm{r}=6^{\circ} \mathrm{C} / \mathrm{min}, \mathrm{t}_{\mathrm{c}}=45 \mathrm{mim}$.

Coluna capilar DB-5 da J\&W Scientific (30 $\mathrm{m}$ x 0,25 mm x 0,25 $\mu \mathrm{m})$.

Figura 69. Espectro de massas obtido por CG-EM $(70 \mathrm{eV})$ do padrão sintético do 2,3,5-tricloro-6metoxipiridina.

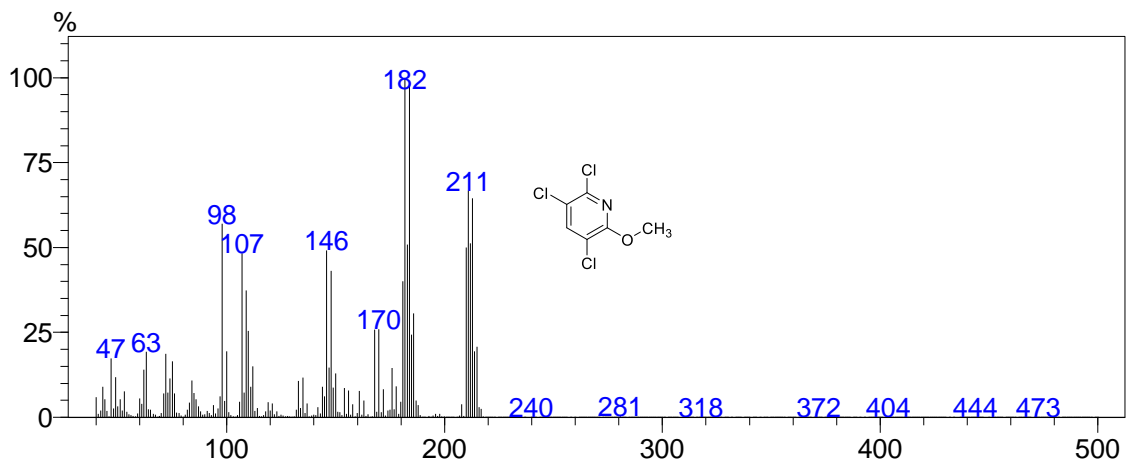


A Figura 70 mostra o cromatograma selecionado obtido por CG-EM do metabólito 3,5,6tricloro-1-metil-2-piridinona, oriundo da metilação enzimática (reação de fase II) e posterior isomerização do composto fenólico 3,5,6-tricloro-2-piridinol, gerado a partir da hidrólise enzimática do pesticida comercial clorpirifós (reação de fase I) com o fungo de ambiente marinho A. sydowii CBMAI 935 durante 10 dias de reação de biotransformação.

O cromatograma da Figura 67 foi obtido a partir da Figura 55, selecionando apenas o sinal do composto 3,5,6-tricloro-1-metil-2-piridinona com tempo de retenção em 21,730 minutos.

O espectro de massas obtido por CG-EM (70 eV) do metabólito 3,5,6-tricloro-1-metil-2piridinona apresentou uma similaridade de $92 \%$ comparado com o padrão das bibliotecas (NIST O5 LIB, NIST 05 s LIB, NIST 21 LIB, NIST 107 e WILEY 8 LIB) do espectrômetro de massas.

O metabólito 3,5,6-tricloro-1-metil-2-piridinona foi isolado por coluna de bancada e posteriormente caracterizado por espectroscopia de RMN (Espectros no Apêndice da dissertação).

Figura 70. Cromatograma selecionado obtido por CG-EM do metabólito 3,5,6-tricloro-1-metil-2-piridinona das extrações do micélio do fungo A. sydowii CBMAI 935 na presença do pesticida comercial clorpirifós durante 10 dias.

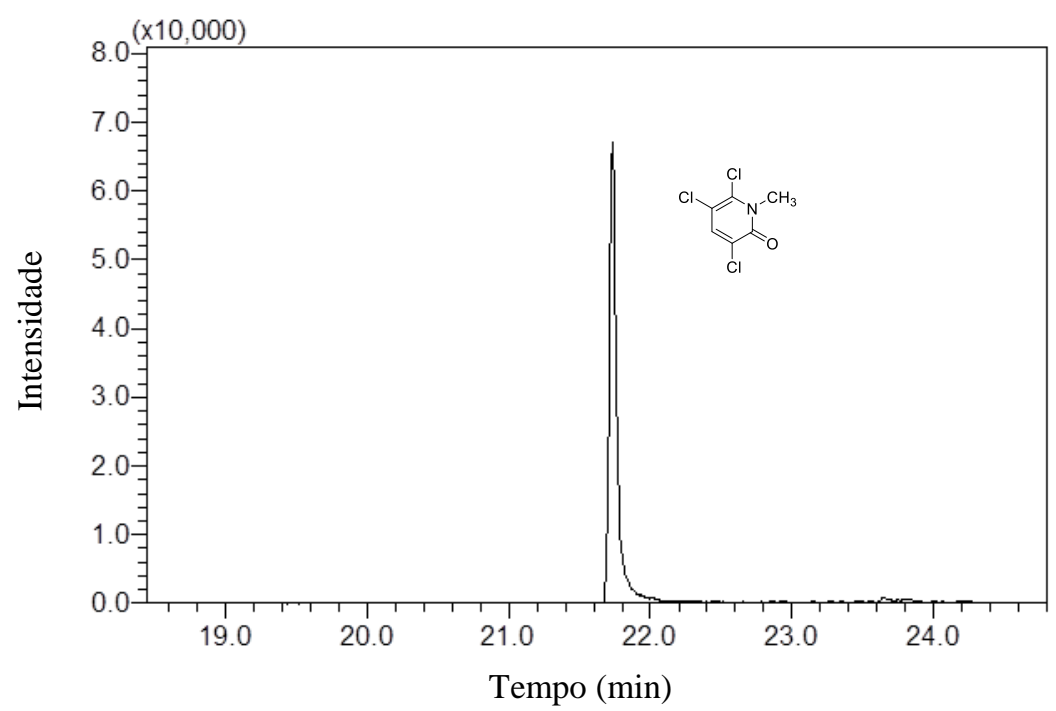

Condições de análise CG-EM: $\mathrm{T}_{\mathrm{i}}=60^{\circ} \mathrm{C}, 2 \mathrm{~min} ; \mathrm{T}_{\mathrm{f}}=280^{\circ} \mathrm{C}, 6 \mathrm{~min} ; \mathrm{r}=6^{\circ} \mathrm{C} / \mathrm{min}, \mathrm{t}_{\mathrm{c}}=45 \mathrm{mim}$.

Coluna capilar DB-5 da J\&W Scientific ( $30 \mathrm{~m}$ x 0,25 mm x 0,25 $\mu \mathrm{m}$ ). 
A Figura 71 mostra o espectro de massas do metabólito 3,5,6-tricloro-1-metil-2piridinona obtido da reação de biotransformação do pesticida comercial clorpirifós com fungo A. sydowii CBMAI 935 durante 10 dias. O espectro de massas para metabólito apresentou o íon molecular com $m / z, 211$ (1). A presença dos três átomos de cloro na molécula faz com que a abundância relativa dos picos $M, M+2, M+4$ e $M+6$ seja de 100, 96, 30 e 6\%, respectivamente. Como característico para os fenois, há a perda de CO (M-28) com intensidade de 100\%, resultando no fragmento e pico base com $\mathrm{m} / z 107$ (2). Uma subsequente fragmentação pode produzir o fragmento com $m / z 148(3)$.

Figura 71. Espectro de massas obtido por CG-EM $(70 \mathrm{eV})$ para o metabólito 3,5,6-tricloro-1-metil-2-piridinona das extrações do micélio do fungo A. sydowii CBMAI 935 na presença do pesticida comercial clorpirifós durante 10 dias.

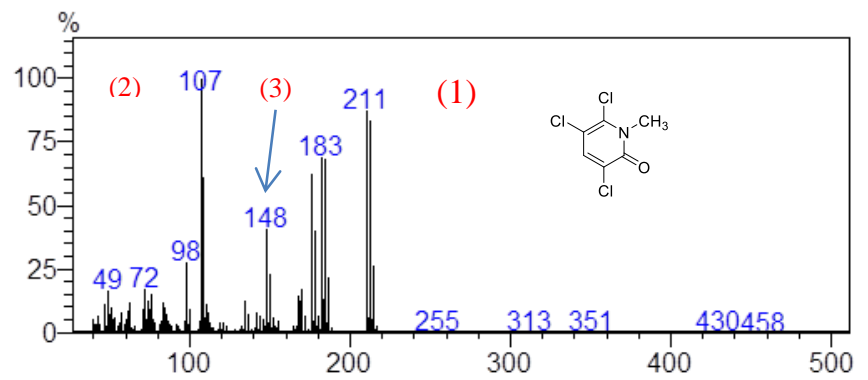

O Esquema 5 mostra a proposta de fragmentação para o composto 3,5,6-tricloro-1-metil2-piridinona obtido por CG-EM das extrações do micélio com o fungo de ambiente marinho A. sydowii CBMAI 935 em 10 dias de reação de biotransformação.

Esquema 5. Proposta de fragmentação para o metabólito 3,5,6-tricloro-1-metil-2-piridinona.

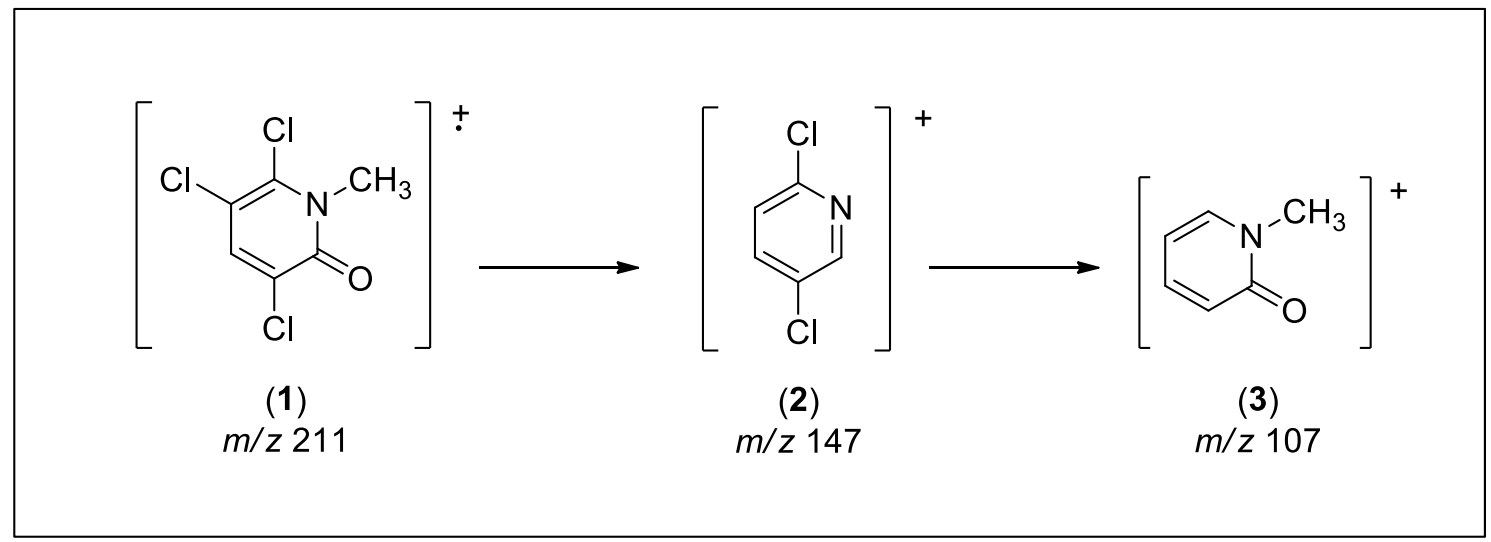

Fonte: Autoria própria. 
A Figura 72 mostra o cromatograma selecionado obtido por CG-EM do metabólito ditiofosfato de tetraetila oriundo da esterificação enzimática do composto fosforotioato de $O, O$-dietila, gerado a partir da hidrólise enzimática do pesticida comercial clorpirifós (reação de fase I) com o fungo de ambiente marinho A. sydowii CBMAI 935 durante 10 dias de reação de biotransformação.

O cromatograma da Figura 72 foi obtido a partir da Figura 58, selecionando apenas o sinal do metabólito ácido ditiofosfórico com tempo de retenção em 23,300 minutos.

O espectro de massas obtido por CG-EM $(70 \mathrm{eV})$ do metabólito ditiofosfato de tetraetila apresentou uma similaridade de $87 \%$ comparado com o padrão das bibliotecas (NIST O5 LIB, NIST 05 s LIB, NIST 21 LIB, NIST 107 e WILEY 8 LIB) do espectrômetro de massas.

Figura 72. Cromatograma selecionado obtido por CG-EM do metabólito ditiofosfato de tetraetila das extrações do micélio do fungo A. sydowii CBMAI 935 na presença do pesticida comercial do pesticida clorpirifós durante 10 dias.

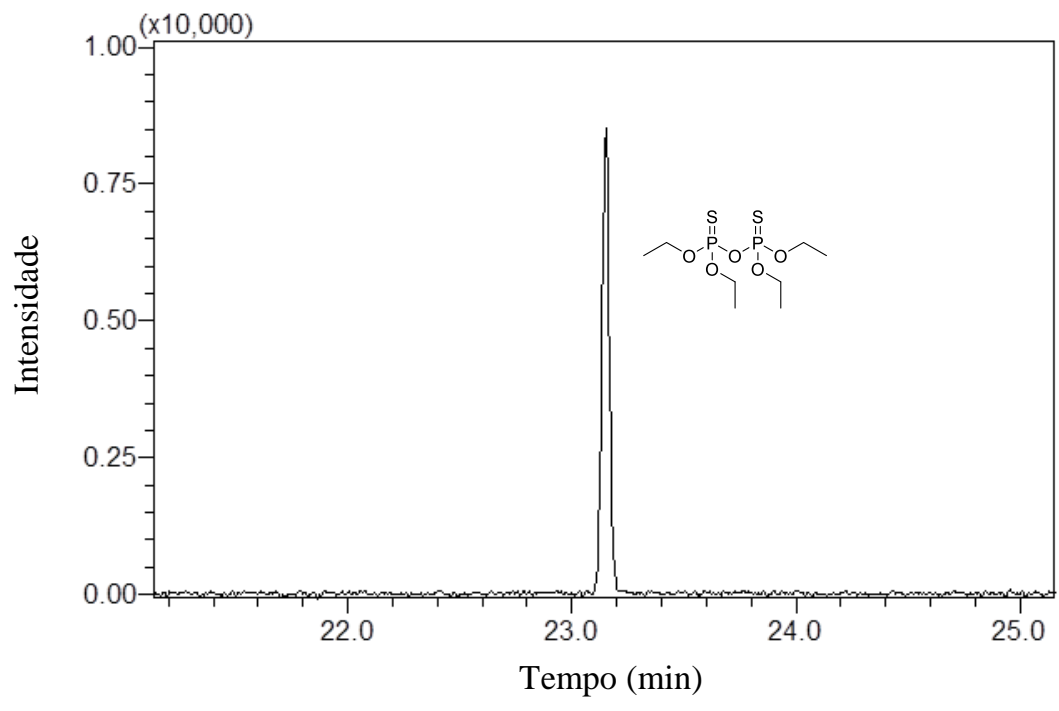

Condições de análise CG-EM: $\mathrm{T}_{\mathrm{i}}=60^{\circ} \mathrm{C}, 2 \mathrm{~min} ; \mathrm{T}_{\mathrm{f}}=280^{\circ} \mathrm{C}, 6 \mathrm{~min} ; \mathrm{r}=6^{\circ} \mathrm{C} / \mathrm{min}, \mathrm{t}_{\mathrm{c}}=45 \mathrm{mim}$. Coluna capilar DB-5 da J\&W Scientific (30 $\mathrm{m}$ x 0,25 mm x 0,25 $\mu \mathrm{m})$. 
A Figura 73 mostra o espectro de massas do metabólito ditiofosfato de tetraetila obtido da reação de biotransformação do pesticida comercial clorpirifós com fungo A. sydowii CBMAI 935 durante 10 dias. O espectro de massas para metabólito apresentou o íon molecular e pico base com $m / z 322$ (1). Com a perda de um grupo etila obtém-se o fragmento com $\mathrm{m} / \mathrm{z}, 294$ (2) e uma subsequente fragmentação pode produzir o fragmento com $\mathrm{m} / z .169$ (3).

Figura 73. Espectro de massas obtido por CG-EM $(70 \mathrm{eV})$ para o metabólito ditiofosfato de tetraetila das extrações do micélio do fungo A. sydowii CBMAI 935 na presença do pesticida comercial clorpirifós durante 10 dias.

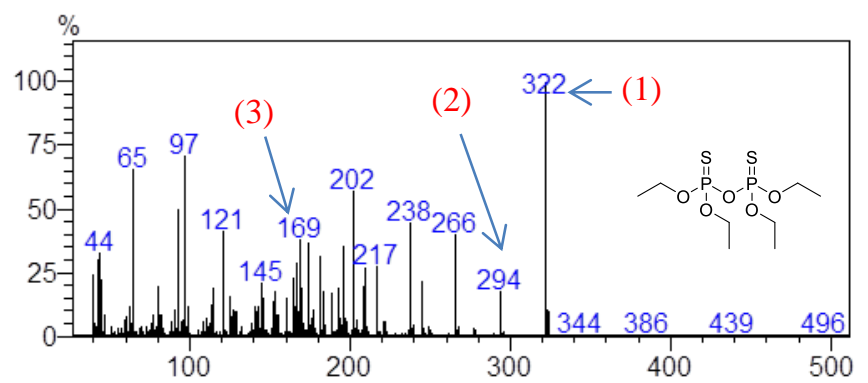

O Esquema 6 mostra a proposta de fragmentação para o composto ditiofosfato de tetraetila obtido por CG-EM das extrações do micélio com o fungo de ambiente marinho $A$. sydowii CBMAI 935 em 10 dias de reação de biotransformação.

Esquema 6. Proposta de fragmentação para o metabólito ditiofosfato de tetraetila.

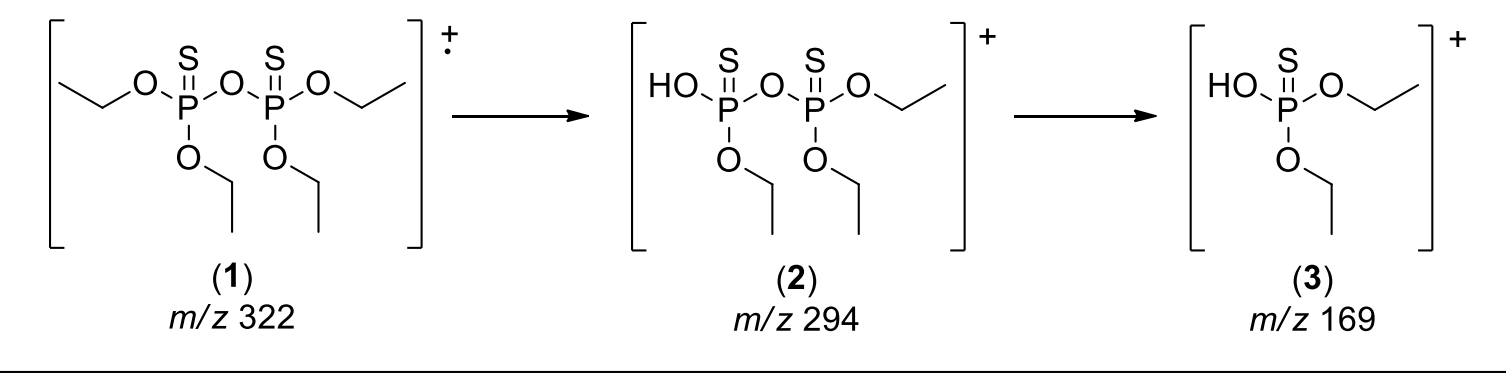

Fonte: Autoria própria. 


\subsubsection{Avaliação da biotransformação do clorpirifós em 20 dias de reação com o fungo}

\section{A. sydowii CBMAI 935}

A Figura 74 mostra o cromatograma obtido por CG-EM das extrações do caldo enzimático para o pesticida comercial clorpirifós com o fungo de ambiente marinho $A$. sydowii CBMAI 935 em 20 dias de reação de biotransformação.

O sinal do composto com tempo de retenção em 28,600 minutos e o espectro de massas do pesticida clorpirifós, encontrados na reação foram comparados com o padrão analítico (Figuras 53 e 54) do clorpirifós. Os quais foram idênticos, confirmando a identidade do composto na amostra comercial que foi utilizada nas reações de biotransformação.

Figura 74. Cromatograma selecionado do pesticida comercial clorpirifós obtido por CG-EM das extrações do caldo enzimático do fungo A. sydowii CBMAI 935 em 20 dias de reação de biotransformação.

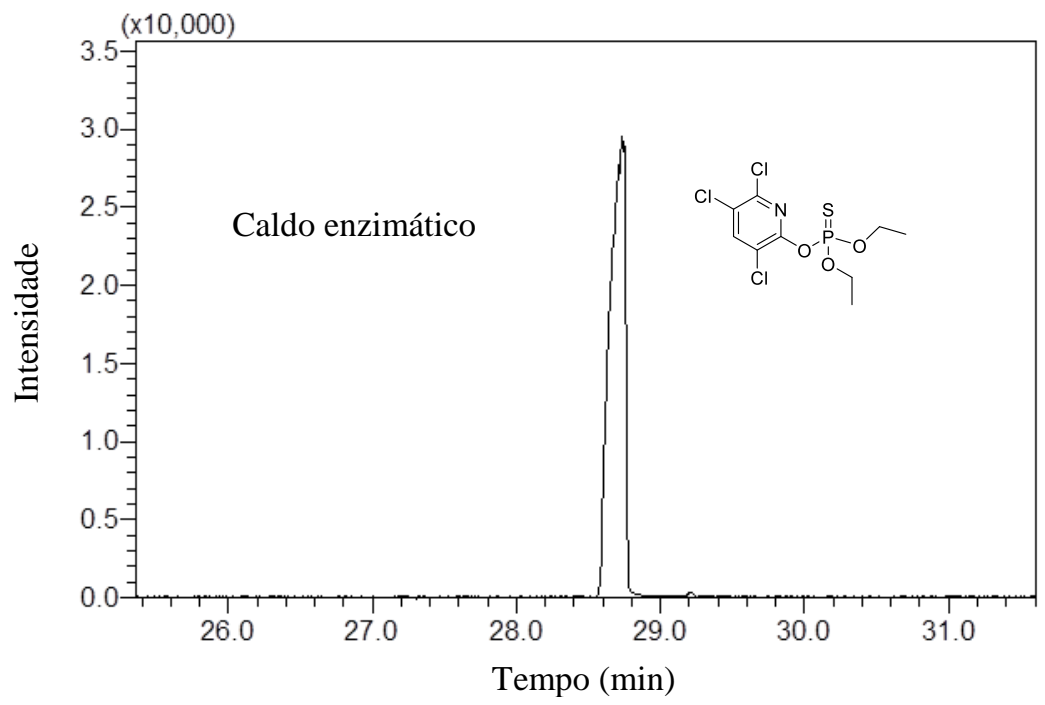

Condições de análise CG-EM: $\mathrm{T}_{\mathrm{i}}=60^{\circ} \mathrm{C}, 2 \mathrm{~min} ; \mathrm{T}_{\mathrm{f}}=280^{\circ} \mathrm{C}, 6 \mathrm{~min} ; \mathrm{r}=6^{\circ} \mathrm{C} / \mathrm{min}, \mathrm{t}_{\mathrm{c}}=45 \mathrm{mim}$.

Coluna capilar DB-5 da J\&W Scientific (30 m x 0,25 mm x 0,25 $\mu \mathrm{m}$ ).

A Figura 75 mostra o espectro de massas do pesticida comercial clorpirifós obtido da reação de biotransformação com fungo A. sydowii CBMAI 935 em 20 dias de reação. 
Figura 75. Espectro de massas obtido por CG-EM $(70 \mathrm{eV})$ para o pesticida comercial clorpirifós das extrações do micélio do fungo A. sydowii CBMAI em 20 dias.

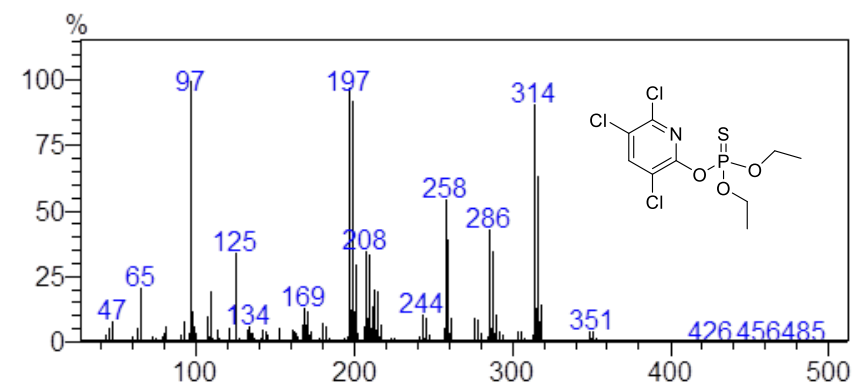

A Figura 76 mostra o cromatograma selecionado obtido por CG-EM das extrações do micélio para o composto fenólico 3,5,6-tricloro-2-piridinol oriundo da hidrólise enzimática do pesticida comercial clorpirifós pelo fungo de ambiente marinho A. sydowii CBMAI 935 em 20 dias de reação de biotransformação.

Figura 76. Cromatograma selecionado do metabólito 3,5,6-tricloro-2-piridinol obtido por CG-EM das extrações do micélio do fungo A. sydowii CBMAI 935 na presença do pesticida comercial clorpirifós durante 20 dias.

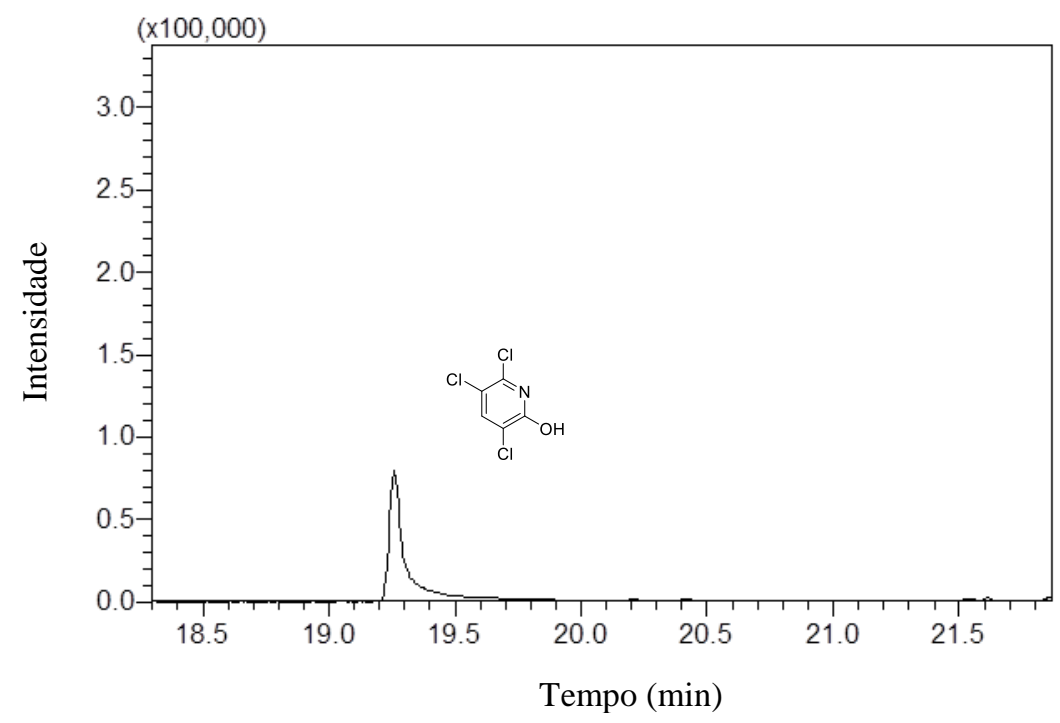

Condições de análise CG-EM: $\mathrm{T}_{\mathrm{i}}=60^{\circ} \mathrm{C}, 2 \mathrm{~min} ; \mathrm{T}_{\mathrm{f}}=280^{\circ} \mathrm{C}, 6 \mathrm{~min} ; \mathrm{r}=6^{\circ} \mathrm{C} / \mathrm{min}, \mathrm{t}_{\mathrm{c}}=45 \mathrm{mim}$.

Coluna capilar DB-5 da J\&W Scientific (30 m x 0,25 mm x 0,25 $\mu \mathrm{m})$.

A Figura 77 mostra o espectro de massas obtido por CG-EM do composto fenólico 3,5,6tricloro-2-piridinol obtido da reação de biotransformação do pesticida comercial clorpirifós com fungo A. sydowii CBMAI 935 em 20 dias de reação. 
Figura 77. Espectro de massas obtido por CG-EM (70 eV) para o metabólito 3,5,6-tricloro-2-piridinol frente a reação de biotransformação do pesticida comercial clorpirifós com o fungo A. sydowii CBMAI 935 durante 20 dias.

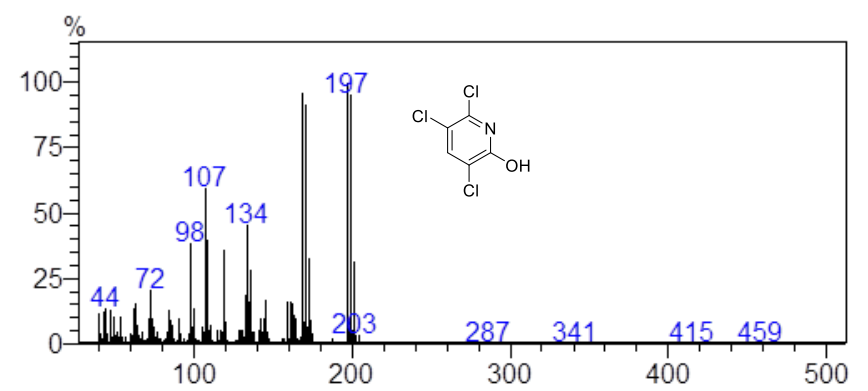

A Figura 78 mostra o cromatograma selecionado obtido por CG-EM do metabólito 2,3,5tricloro-6-metoxipiridina oriundo da metilação enzimática (reação de fase II) do composto fenólico 3,5,6-tricloro-2-piridinol, gerado a partir da hidrólise enzimática do pesticida comercial clorpirifós (reação de fase I) com o fungo de ambiente marinho A. sydowii CBMAI 935 durante 20 dias de reação de biotransformação.

Figura 78. Cromatograma selecionado obtido por CG-EM do metabólito 2,3,5-tricloro-6-metoxipiridina das extrações do micélio do fungo A. sydowii CBMAI 935 na presença do pesticida comercial clorpirifós durante 20 dias.

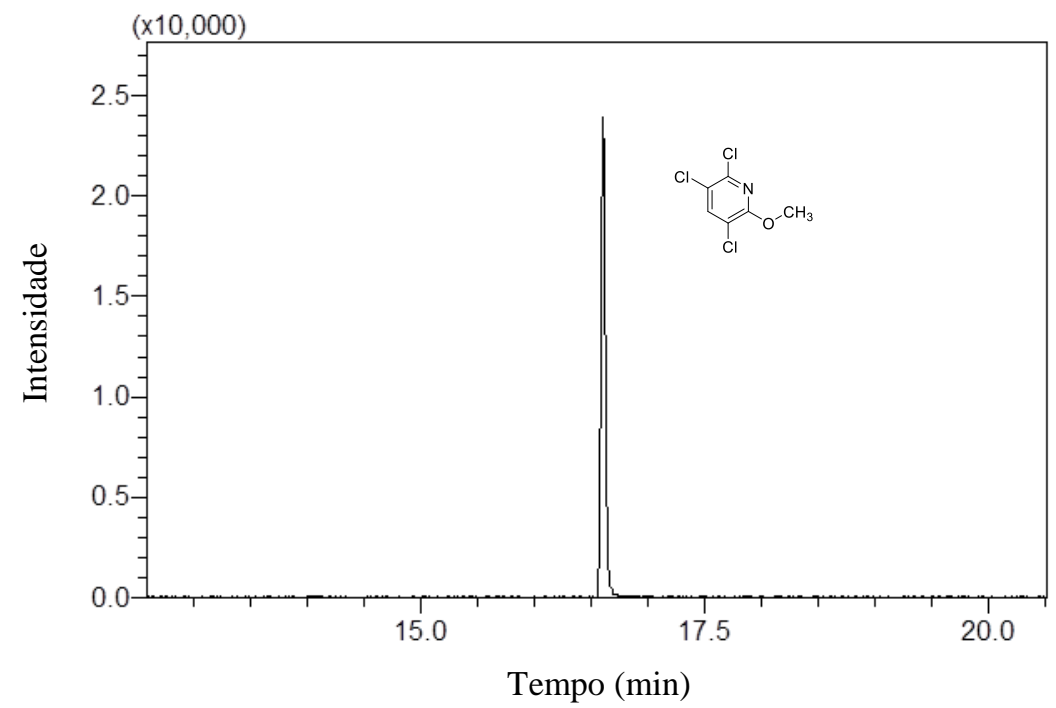

Condições de análise CG-EM: $\mathrm{T}_{\mathrm{i}}=60^{\circ} \mathrm{C}, 2 \mathrm{~min} ; \mathrm{T}_{\mathrm{f}}=280^{\circ} \mathrm{C}, 6 \mathrm{~min} ; \mathrm{r}=6^{\circ} \mathrm{C} / \mathrm{min}, \mathrm{t}_{\mathrm{c}}=45 \mathrm{mim}$.

Coluna capilar DB-5 da J\&W Scientific (30 m x 0,25 mm x 0,25 $\mu \mathrm{m})$. 
A Figura 79 mostra o espectro de massas do metabólito 2,3,5-tricloro-6-metoxipiridina obtido da reação de biotransformação do pesticida comercial clorpirifós com fungo A. sydowii CBMAI 935 durante 20 dias.

Figura 79. Espectro de massas obtido por CG-EM (70 eV) para o metabólito 2,3,5-tricloro-6-metoxipiridina das extrações do micélio do fungo A. sydowii CBMAI 935 na presença do pesticida comercial clorpirifós durante 20 dias.

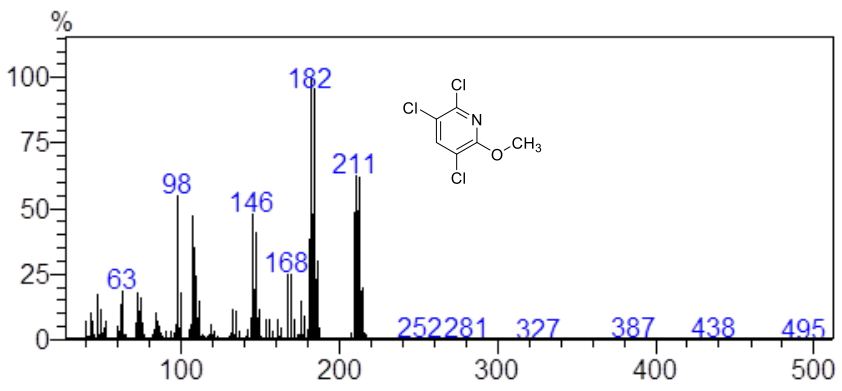

A Figura 80 mostra o cromatograma selecionado obtido por CG-EM do metabólito 3,5,6tricloro-1-metil-2-piridinona, oriundo da metilação enzimática (reação de fase II) e isomerização do composto fenólico 3,5,6-tricloro-2-piridinol, gerado a partir da hidrólise enzimática do pesticida comercial clorpirifós (reação de fase I) com o fungo de ambiente marinho A. sydowii CBMAI 935 durante 20 dias de reação de biotransformação.

Figura 80. Cromatograma selecionado obtido por CG-EM do metabólito 3,5,6-tricloro-1-metil-2-piridinona das extrações do micélio do fungo A. sydowii CBMAI 935 na presença do pesticida comercial clorpirifós durante 20 dias.

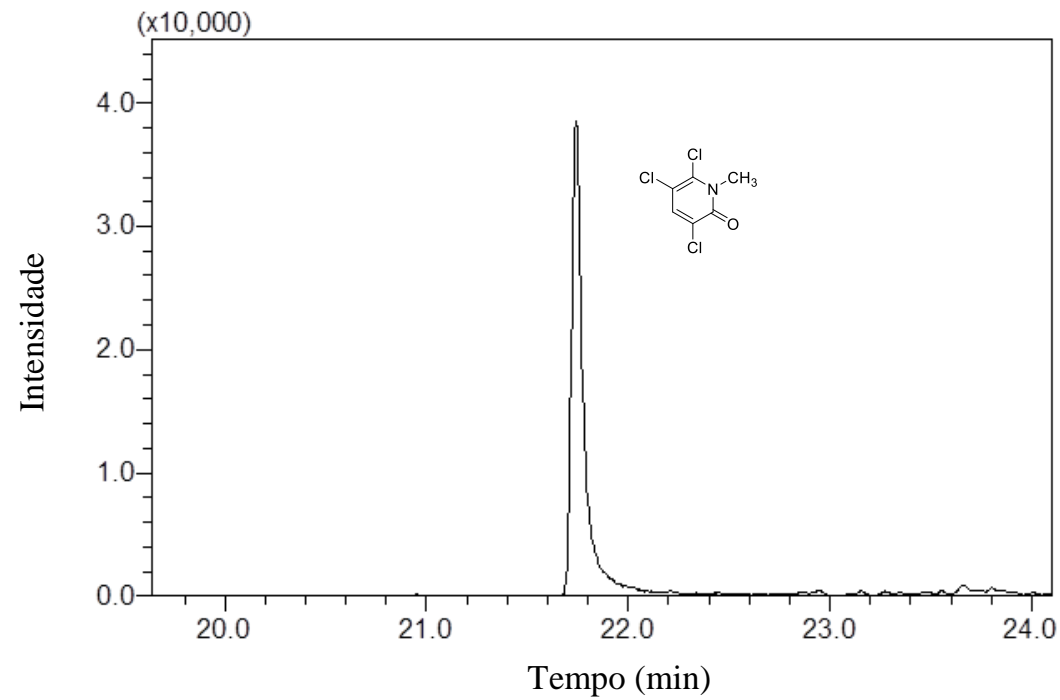

Condições de análise CG-EM: $\mathrm{T}_{\mathrm{i}}=60^{\circ} \mathrm{C}, 2 \mathrm{~min} ; \mathrm{T}_{\mathrm{f}}=280^{\circ} \mathrm{C}, 6 \mathrm{~min} ; \mathrm{r}=6^{\circ} \mathrm{C} / \mathrm{min}, \mathrm{t}_{\mathrm{c}}=45 \mathrm{mim}$.

Coluna capilar DB-5 da J\&W Scientific (30 m x 0,25 mm x 0,25 $\mu \mathrm{m}$ ). 
A Figura 81 mostra o espectro de massas do metabólito 3,5,6-tricloro-1-metil-2piridinona obtido da reação de biotransformação do pesticida comercial clorpirifós com fungo A. sydowii CBMAI 935 durante 20 dias.

Figura 81. Espectro de massas obtido por CG-EM (70 eV) para o metabólito 3,5,6-tricloro-1-metil-2-piridinona das extrações do micélio do fungo A. sydowii CBMAI 935 na presença do pesticida comercial clorpirifós durante 20 dias.

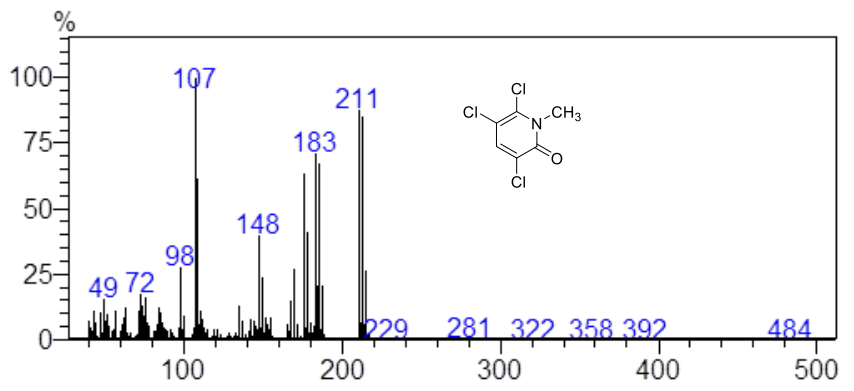

A Figura 82 mostra o cromatograma selecionado obtido por CG-EM do metabólito tetraetilditiofosfato oriundo da esterificação enzimática do composto fosforotioato de $O, O$ dietila, gerado a partir da hidrólise enzimática do pesticida comercial clorpirifós (reação de fase I) com o fungo de ambiente marinho A. sydowii CBMAI 935 durante 20 dias de reação de biotransformação.

Figura 82. Cromatograma selecionado obtido por CG-EM do metabólito ditiofosfato de tetraetila das extrações do micélio do fungo A. sydowii CBMAI 935 na presença do pesticida comercial clorpirifós durante 20 dias.

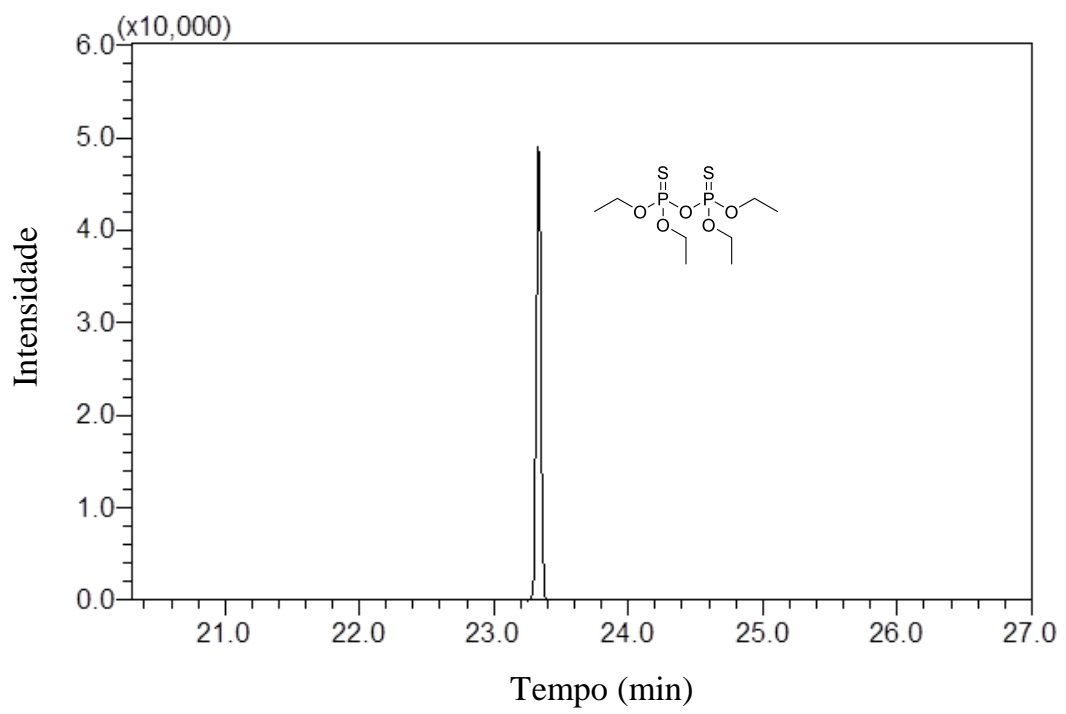

Condições de análise CG-EM: $\mathrm{T}_{\mathrm{i}}=60^{\circ} \mathrm{C}, 2 \mathrm{~min} ; \mathrm{T}_{\mathrm{f}}=280^{\circ} \mathrm{C}, 6 \mathrm{~min} ; \mathrm{r}=6^{\circ} \mathrm{C} / \mathrm{min}, \mathrm{t}_{\mathrm{c}}=45 \mathrm{mim}$.

Coluna capilar DB-5 da J\&W Scientific (30 m x 0,25 mm x 0,25 $\mu \mathrm{m})$. 
A Figura 83 mostra o espectro de massas do metabólito ditiofosfato de tetraetila obtido da reação de biotransformação do pesticida comercial clorpirifós com fungo A. sydowii CBMAI 935 durante 20 dias.

Como observado, a reação em 20 dias forneceu os mesmos produtos de degradação em comparação com 10 dias de reação.

Figura 83. Espectro de massas obtido por CG-EM $(70 \mathrm{eV})$ para o metabólito ditiofosfato de tetraetila das extrações do micélio do fungo A. sydowii CBMAI 935 na presença do pesticida comercial clorpirifós durante 20 dias.

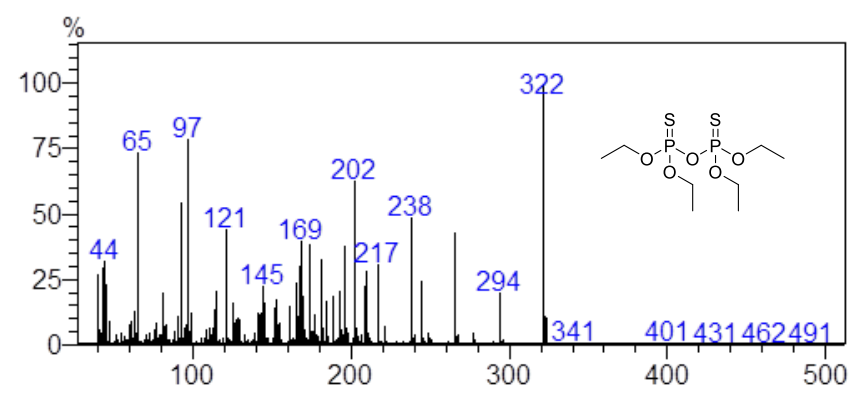

\subsubsection{Avaliação do clorpirifós em 30 dias de reação com o fungo A. sydowii CBMAI 935}

O mesmo comportamento para 30 dias de reação foi observado para 10 e 20 d. Obteve-se as mesmas reações de biotransformação e bioconjugação para o clorpirifós, não cabendo aqui detalhar os resultados uma vez que foram similares aos anteriores. A quantificação dos metabólitos e do pesticida remanescente foi realizada por HPLC (Apêndice).

O Esquema 7 ilustra a proposta dos mecanismos enzimáticos de enzimas fosfotriesterases e $O$-metiltransferases durante 10,20 e 30 dias de reação de biotransformação do pesticida comercial clorpirifós com o fungo de ambiente marinho A. sydowii CBMAI 935.

As enzimas que agem sobre o pesticida comercial clorpirifós catalisam em duas etapas, com reações de biotransformação do pesticida (fase I) e reações de conjugação (fase II).

Na fase I, a biotransformação pode ocorrer por intermédio de enzimas fosfotriesterases, essas enzimas possuem dois íons $\mathrm{Zn}^{2+}$, mas ambos os cátions bivalentes podem ser substituídos por $\mathrm{Cd}^{2+}, \mathrm{Co}^{2+}, \mathrm{Ni}^{2+}$ ou $\mathrm{Mn}^{2+}$, sem perda de atividade catalítica.

O íon metálico pode acelerar a velocidade de hidrólise do pesticida pela coordenação com o átomo de oxigênio do grupo fosforilo. Quando um íon metálico é coordenado a um fosfato, ocorre um aumento do caráter eletrofílico do metal, uma vez que este atua como um catalisador ácido. O estado de transição pode envolver a ligação do substrato ao metal e uma 
distorção do átomo de fósforo central, fazendo com que este se aproxime do grupo hidróxido. O intermediário formado é uma espécie de fósforo pentavalente. ${ }^{74,32}$

Os detalhes mecanísticos da reação enzimática variam de acordo com o sítio ativo da esterase, mas geralmente o íon metálico presente na enzima coordena-se com grupos hidróxidos, favorecendo a hidrólise por meio de catálise básica intramolecular ou coordenando com moléculas de água numa catálise ácida intramolecular. ${ }^{74,32}$

Na fase II, a conjugação ocorre por intermédio de enzimas $O$-metiltransferases, essas enzimas possuem no sítio ativo, o cofator $S$-adenosil-L-metionina (SAM) que após transferir o grupo metila contido em sua estrutura molecular para o substrato a ser metilado, há a formação do subproduto de metilação $S$-adenosil-L-homocisteína (SAH).

Na enzima $O$-metiltransferase, a desprotonação do grupo hidroxila do anel aromático do metabólito 3,5,6-tricloro-2-piridinol ocorre no centro ativo da enzima por dois resíduos de aminoácidos, ácido glutâmico (Glu 337) e histidina (His 278). Posteriormente ocorre o ataque nucleofílico do ânion hidroxila ao grupo metila da $S$-adenosil-L-metionina. Como o enxofre de $S$-adenosil-L-metionina está carregado positivamente, o processo de transmetilação é facilitado e terminando com a formação do subproduto de metilação $S$-adenosil-Lhomocisteína e o composto metilado 2,5,6-tricloro-6-metoxipiridina que posteriormente sofre uma reação de isomerização, formando o composto 3,5,6-tricloro-1-metil-2-piridinona.

Não ficou comprovado nesse estudo se a isomerização do metabólito 2,5,6-tricloro-6metoxipiridina foi enzimática ou não enzimática. 
Esquema 7. Proposta de mecanismos enzimáticos de enzimas fosfotriesterases e $O$-metiltransferases durante 10 , 20 e 30 dias de reação de biotransformação do pesticida comercial clorpirifós com o fungo de ambiente marinho A. sydowii CBMAI 935.<smiles>CCOP(=S)(OCC)Oc1nc(Cl)c(Cl)cc1Cl</smiles>

Clorpirifós

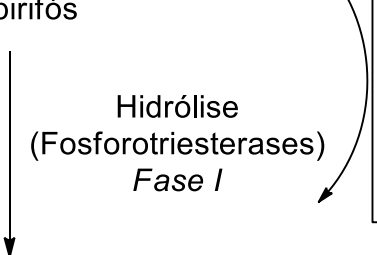<smiles>Oc1nc(Cl)c(Cl)cc1Cl</smiles>

3,5,6-tricloro-2-piridinol

$+$

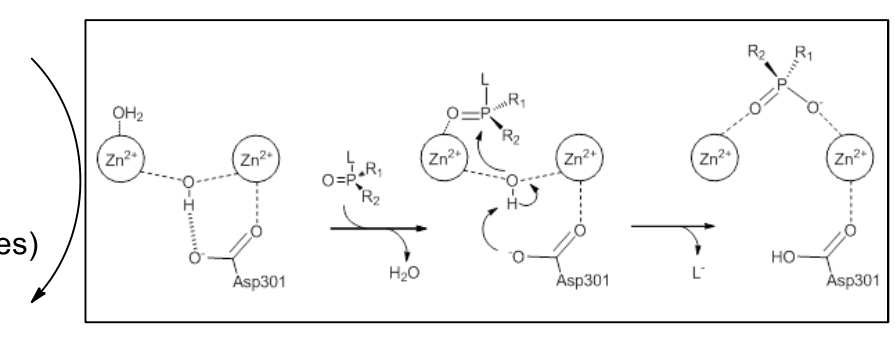<smiles>CCOP(O)(=S)OCC</smiles>

Esterificação<smiles>CCOP(=S)(OCC)OP(=S)(OCC)OCC</smiles>

ditiofosfato de tetraetila

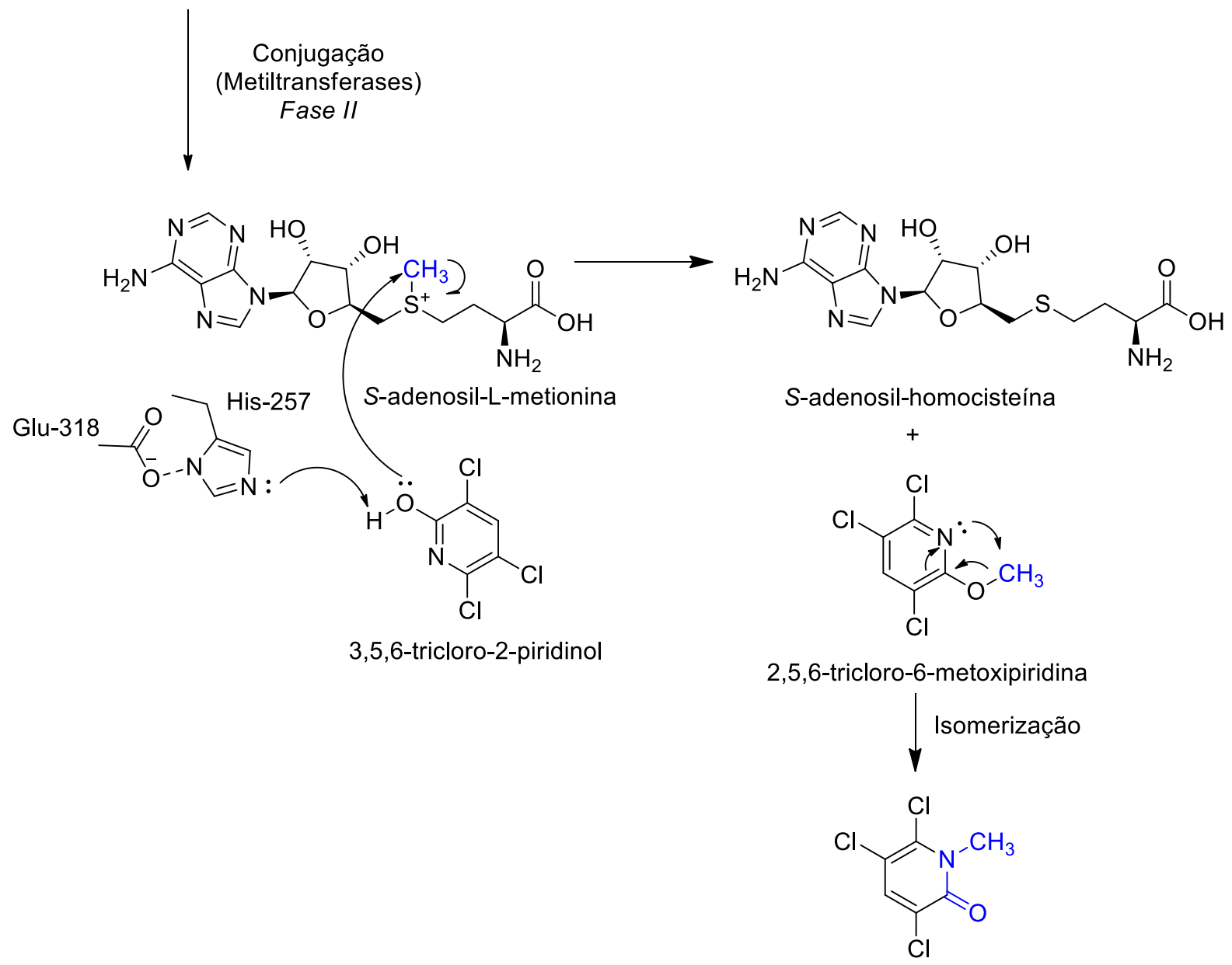

3,5,6-tricloro-1-metil-2-piridinona

Fonte: Autoria própria. 


\subsubsection{Reações de biotransformação do pesticida organofosforado metil paration em 10, 20 e 30 dias pelo fungo de ambiente marinho A. sydowii CBMAI 935}

\subsubsection{Avaliação da biotransformação do metil paration em 10 dias de reação com o fungo A. sydowii CBMAI 935}

Em 10 dias de reação de biotransformação do pesticida organofosforado metil paration com o fungo de ambiente marinho A. sydowii CBMAI 935 foram separados o caldo enzimático e o micélio do fungo e posteriormente submetidos às análises por CG-EM. Os cromatogramas das reações foram comparados com os cromatogramas da reação do controle biótico no qual o fungo A. sydowii CBMAI 935 cresceu por 10 dias na ausência do pesticida. Também foram feitas comparações com os cromatogramas das reações de controle abiótico no qual utilizou-se o pesticida comercial metil paration em meio de cultura líquido de malte $2 \%$ na ausência do fungo em 10, 20 e 30 dias de reação. Posteriormente foram feitas comparações com os cromatogramas do padrão analítico do pesticida metil paration e padrões analíticos dos metabólitos encontrados durante os 10, 20 e 30 dias de reação de biotransformação.

Este mesmo procedimento de discussão foi realizado para 20 e 30 dias de reação.

A Figura 84 mostra a sobreposição dos cromatogramas das extrações do caldo enzimático (cor vermelha) e do micélio (cor preta) com o fungo A. sydowii CBMAI 935 na ausência do pesticida metil paration (reação de controle biótico) em 10 dias de reação e a Figura 92 mostra os mesmos cromatogramas, porém separados. Cromatograma (a) Extração do caldo enzimático e cromatograma (b) Extração do micélio. 
Figura 84. Cromatogramas obtidos por CG-EM das extrações do micélio (cor preta) e do caldo enzimático (cor vermelha) com o fungo A. sydowii CBMAI 935 na ausência do pesticida comercial metil paration (reação de controle biótico) durante 10 dias.

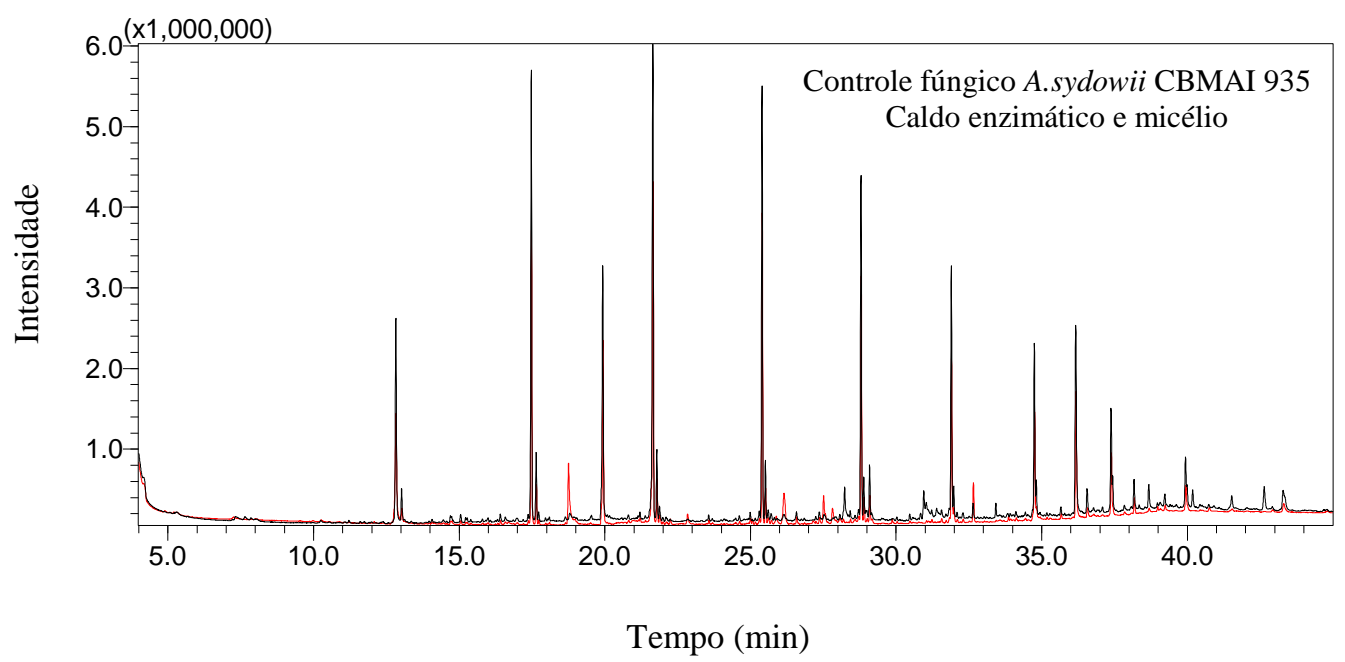

Condições de análise CG-EM: $\mathrm{T}_{\mathrm{i}}=60^{\circ} \mathrm{C}, 2 \mathrm{~min} ; \mathrm{T}_{\mathrm{f}}=280^{\circ} \mathrm{C}, 6 \mathrm{~min} ; \mathrm{r}=6^{\circ} \mathrm{C} / \mathrm{min}, \mathrm{t}_{\mathrm{c}}=45 \mathrm{mim}$.

Coluna capilar DB-5 da J\&W Scientific (30 m x 0,25 mm x 0,25 $\mu \mathrm{m})$.

Figura 85. Cromatogramas obtidos por CG-EM das extrações do micélio e do caldo enzimático do fungo $A$. sydowii CBMAI 935 na ausência do pesticida comercial metil paration (reação de controle biótico) durante 10 dias. (a) Extração do caldo enzimático e (b) Extração do micélio.

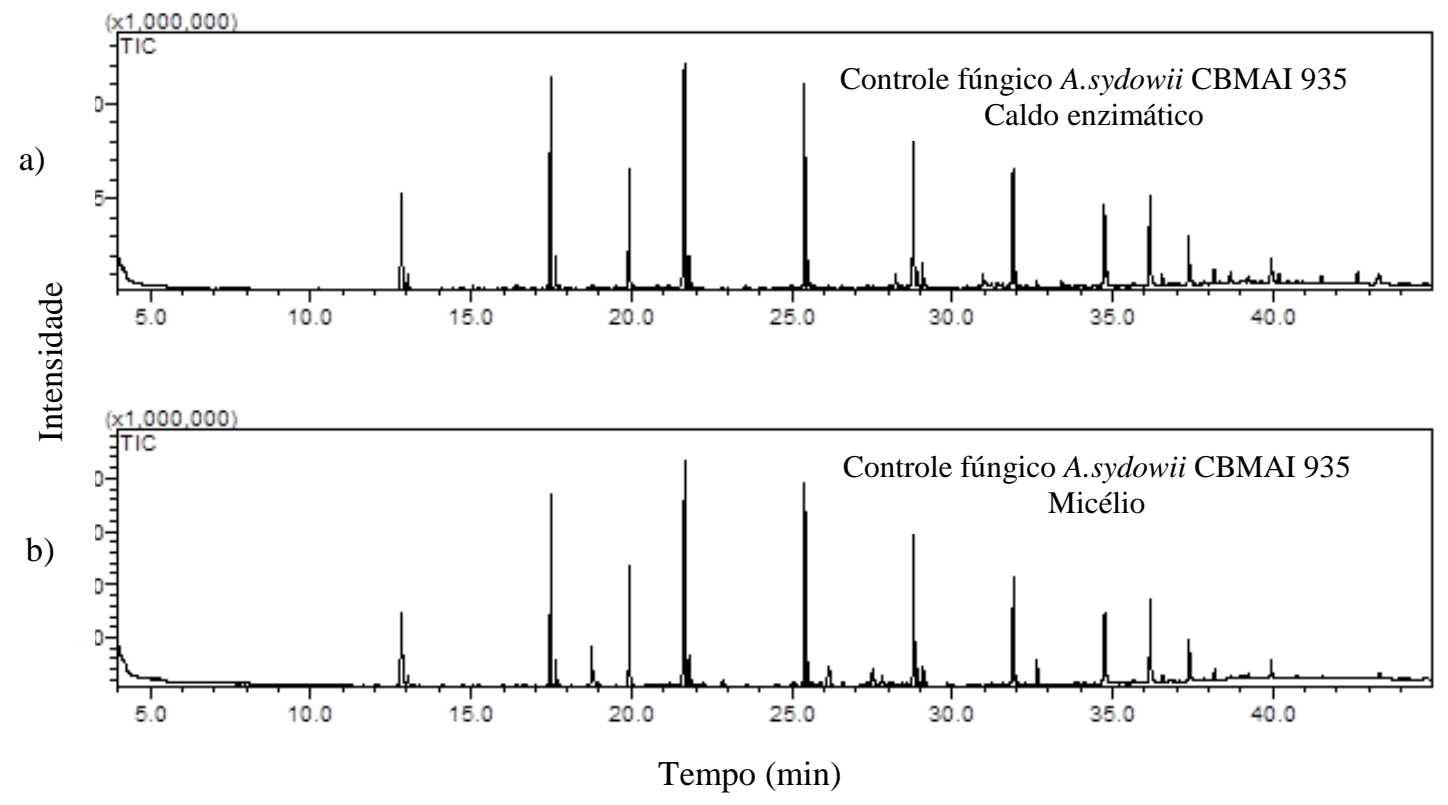

Condições de análise CG-EM: $\mathrm{T}_{\mathrm{i}}=60^{\circ} \mathrm{C}, 2 \mathrm{~min} ; \mathrm{T}_{\mathrm{f}}=280^{\circ} \mathrm{C}, 6 \mathrm{~min} ; \mathrm{r}=6^{\circ} \mathrm{C} / \mathrm{min}, \mathrm{t}_{\mathrm{c}}=45 \mathrm{mim}$.

Coluna capilar DB-5 da J\&W Scientific (30 m x 0,25 mm x 0,25 $\mu \mathrm{m}$ ). 
Os cromatogramas obtidos por CG-EM das reações em duplicatas com o fungo $A$. sydowii CBMAI 935 na ausência do pesticida apresentaram semelhanças quanto à presença de metabólitos, mas a intensidade dos sinais variou qualitativamente nos cromatogramas.

O cromatograma com a extração do caldo enzimático apresentou menor intensidade dos sinais quando comparado com o cromatograma da extração do micélio (Figuras 84 e 85). Como o comportamento do crescimento do fungo pode variar para cada experimento, outros fatores podem ter causado as diferenças entre a intensidade dos sinais analizados. Deve-se também considerar que embora as reações sejam realizadas em duplicatas, elas ocorrem de formas independentes e, portanto, são reações independentes. Ressaltando então que o mais importante neste caso foi a observação dos metabólitos gerados naturalmente pelo fungo $A$. sydowii CBMAI 935 para posterior comparação de metabólitos formados por ação enzimática do fungo na presença de xenobióticos como os pesticidas organofosforados e os demais compostos fenólicos utilizados neste trabalho.

A Figura 86 mostra a sobreposição do cromatograma obtido por CG-EM da reação de controle biótico (cor vermelha) e o cromatograma da reação do pesticida metil paration (cor preta) com concentração de $50 \mathrm{mg} . \mathrm{L}^{-1} \mathrm{em} 10$ dias de reação de biotransformação com o fungo A. sydowii CBMAI 935. Os cromatogramas foram sobrepostos para a comparação qualitativa das intensidades dos sinais dos metabólitos formados naturalmente pelo fungo e os metabólitos formados por ação enzimática do fungo e o pesticida metil paration.

Figura 86. Cromatograma obtido por CG-EM da reação de controle biótico do fungo A. sydowii CBMAI 935 e o pesticida comercial metil paration durante 10 dias.

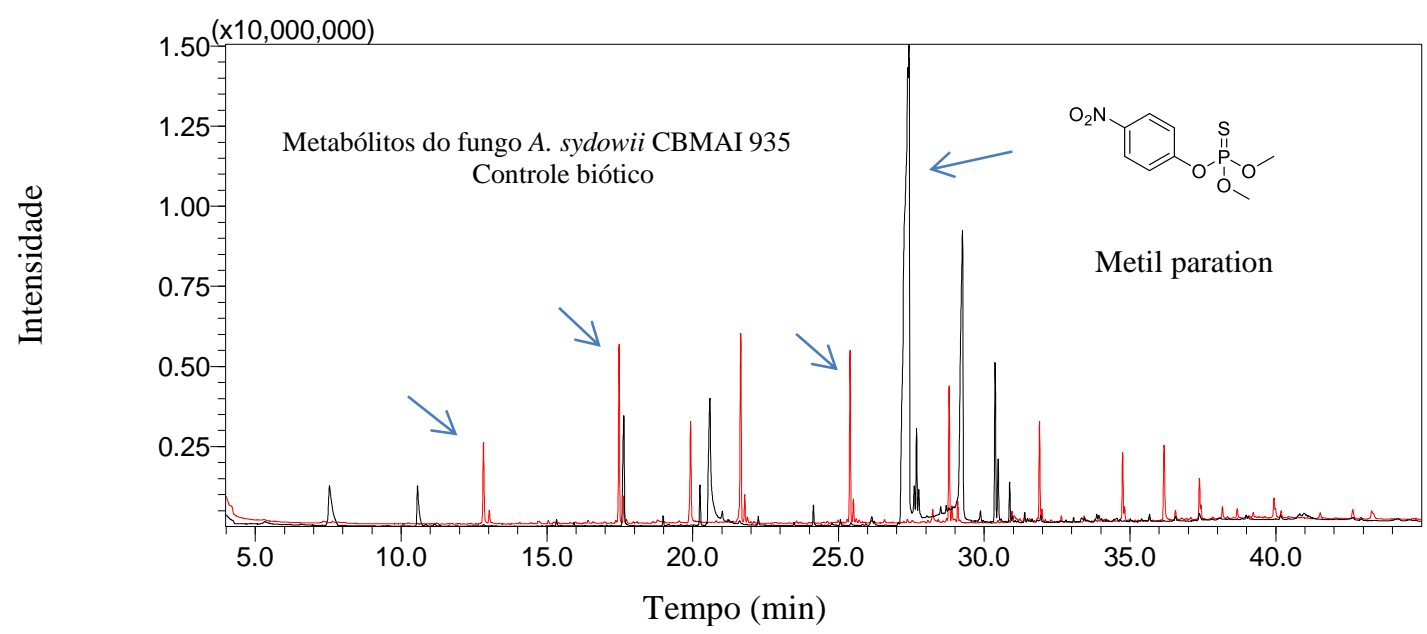

Condições de análise CG-EM: $\mathrm{T}_{\mathrm{i}}=60^{\circ} \mathrm{C}, 2 \mathrm{~min} ; \mathrm{T}_{\mathrm{f}}=280^{\circ} \mathrm{C}, 6 \mathrm{~min} ; \mathrm{r}=6^{\circ} \mathrm{C} / \mathrm{min}, \mathrm{t}_{\mathrm{c}}=45 \mathrm{mim}$.

Coluna capilar DB-5 da J\&W Scientific (30 $\mathrm{m}$ x 0,25 mm x 0,25 $\mu \mathrm{m}$ ). 
A Figura 87 mostra o cromatograma obtido por CG-EM da reação de controle abiótico. Neste caso utilizou-se o pesticida comercial metil paration em meio de cultura líquido de malte $2 \%$ na ausência do fungo A. sydowii CBMAI 935 durante 10 dias de reação, para verificar se o mesmo era estável em condições padrões $\left(32^{\circ} \mathrm{C}, \mathrm{pH} 7\right)$. O pesticida comercial metil paration tem o seu sinal no tempo de retenção em 27,180 minutos. O cromatograma apresenta a molécula do pesticida intacta, sem metabólitos de degradação.

Como pode ser observado na Figura 87 o pesticida comercial metil paration em sua formulação apresenta outros compostos, que segundo o fabricante os mesmos são inertes.

Figura 87. Cromatograma obtido por CG-EM da reação de controle abiótico do pesticida comercial metil paration na ausência do fungo A. sydowii CBMAI 935 durante 10 dias.

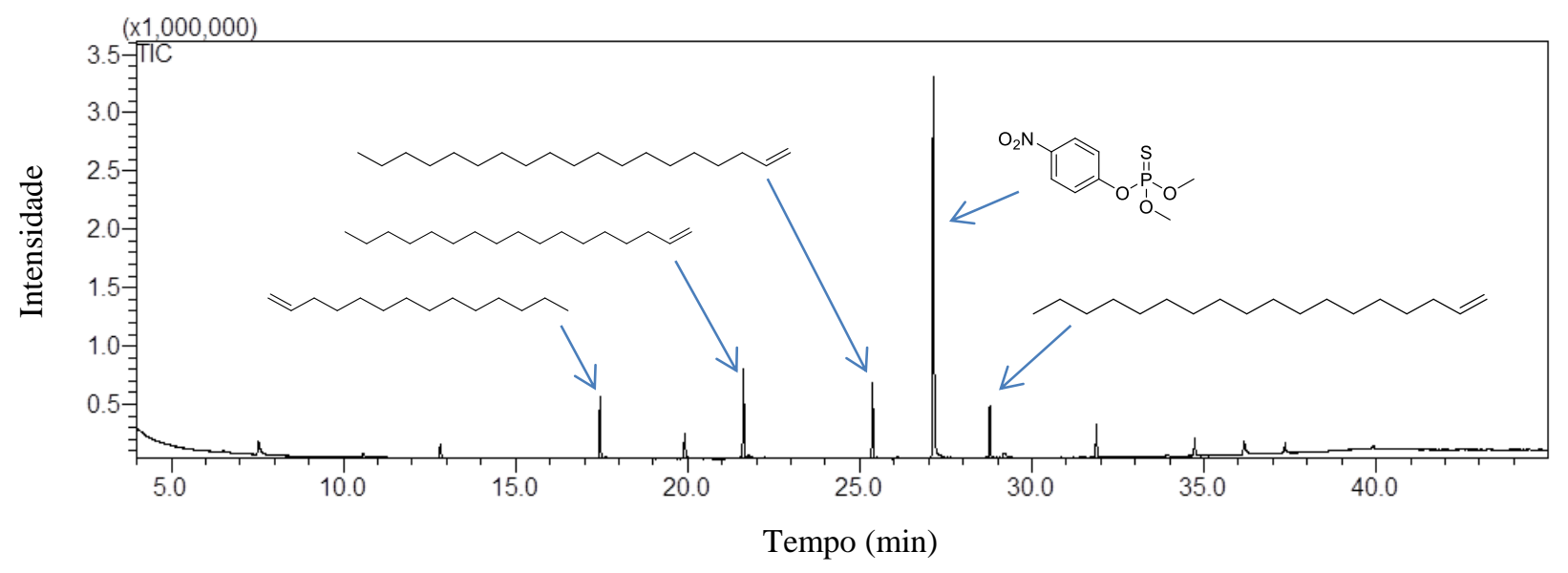

Condições de análise CG-EM: $\mathrm{T}_{\mathrm{i}}=60^{\circ} \mathrm{C}, 2 \mathrm{~min} ; \mathrm{T}_{\mathrm{f}}=280^{\circ} \mathrm{C}, 6 \mathrm{~min} ; \mathrm{r}=6^{\circ} \mathrm{C} / \mathrm{min}, \mathrm{t}_{\mathrm{c}}=45 \mathrm{mim}$. Coluna capilar DB-5 da J\&W Scientific (30 m x 0,25 mm x 0,25 $\mu \mathrm{m}$ ). 
A Figura 88 mostra as ampliações obtidas do cromatograma da Figura 94 para melhor visualização dos sinais dos compostos 1-tetradeceno, 1-heptadeceno, 1-nonadeceno e 1octadeceno que fazem parte da fórmula do pesticida comercial metil paration. Esses compostos, segundo o fabricante, são considerados inertes e representam $52,8 \%$ da composição do pesticida comercial metil paration.

Cromatograma (a) Sinal do composto 1-tetradeceno com tempo de retenção em 17,454 minutos, cromatograma (b) Sinal do composto 1-heptadeceno com tempo de retenção em 21,636 minutos, cromatograma (c) Sinal do composto 1-nonadeceno com tempo de retenção em 25,380 e cromatograma (d) Sinal do composto 1-octadeceno com tempo de retenção em 28,778 minutos.

O espectro de massas obtido por CG-EM $(70 \mathrm{eV})$ do composto 1-tetradeceno apresentou a similaridade de 97\%, o espectro de massas obtido por CG-EM (70 eV) do composto 1heptadeceno apresentou a similaridade de $96 \%$, o espectro de massas obtido por CG-EM (70 eV) do composto 1-nonadeceno apresentou a similaridade de $97 \%$ e o espectro de massas obtido por CG-EM (70 eV) do composto 1-octadeceno apresentou a similaridade de $98 \%$.

Os compostos mostrados no cromatograma da Figura 94 com exceção do pesticida organofosforado metil paration que foi comparado com seu respectivo padrão analítico, foram comparados com os padrões das bibliotecas (NIST O5 LIB, NIST 05 s LIB, NIST 21 LIB, NIST 107 e WILEY 8 LIB) do espectrômetro de massas. 
Figura 88. Ampliações dos cromatogramas selecionados e obtidos por CG-EM da reação de controle abiótico do pesticida comercial metil paration na ausência do fungo A. sydowii CBMAI 935 durante 10 dias.

a)

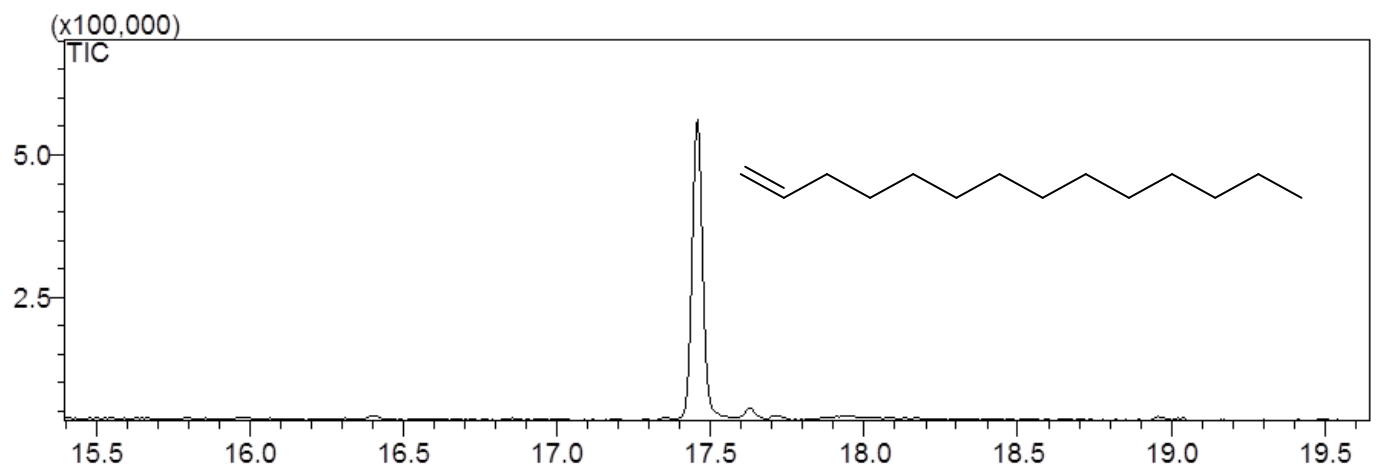

b)

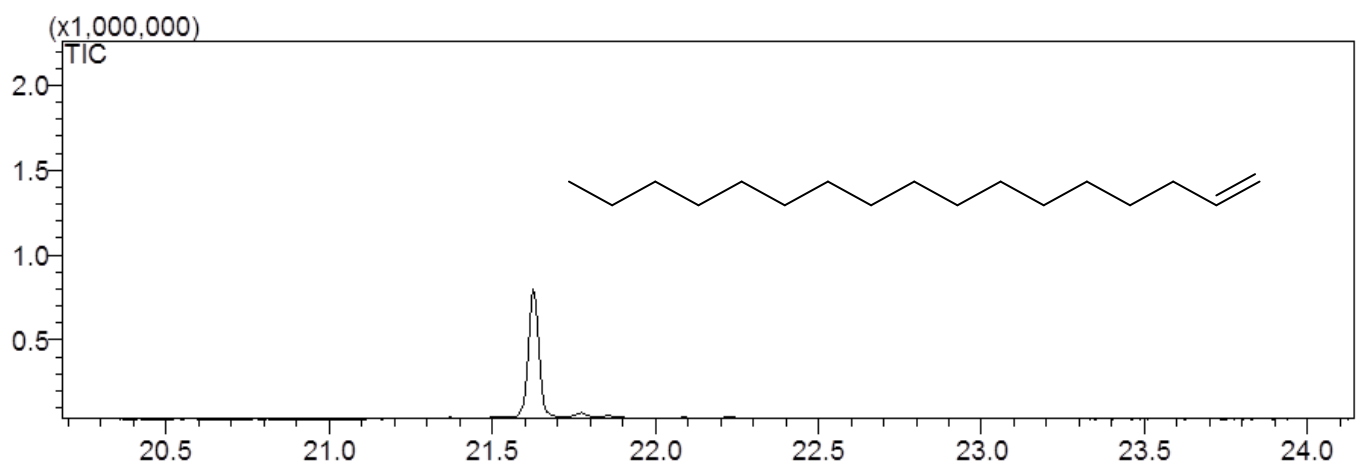

$\frac{0}{\frac{\pi}{0}}$

c)

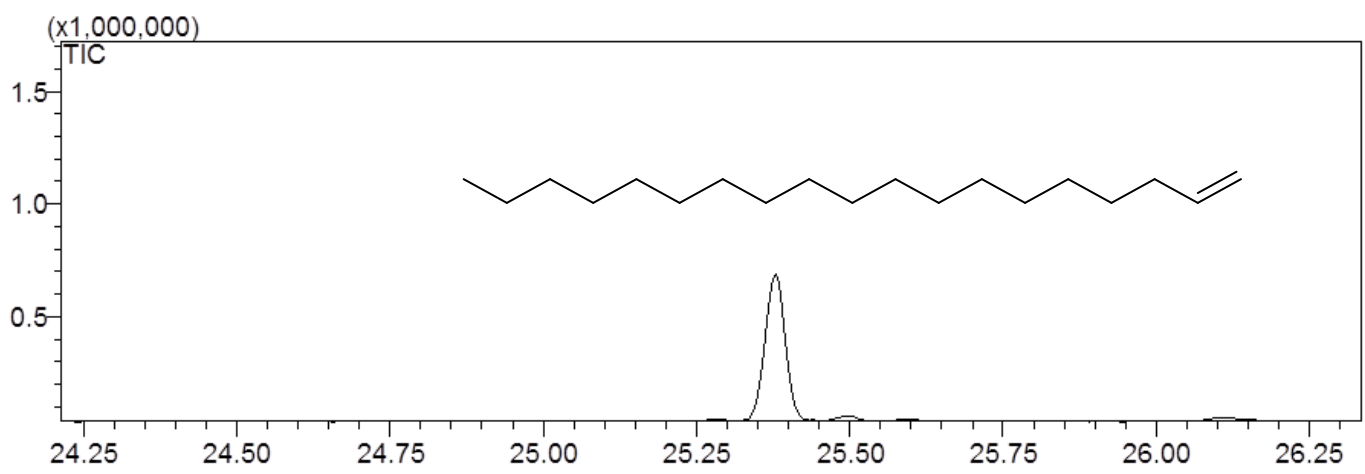

d)

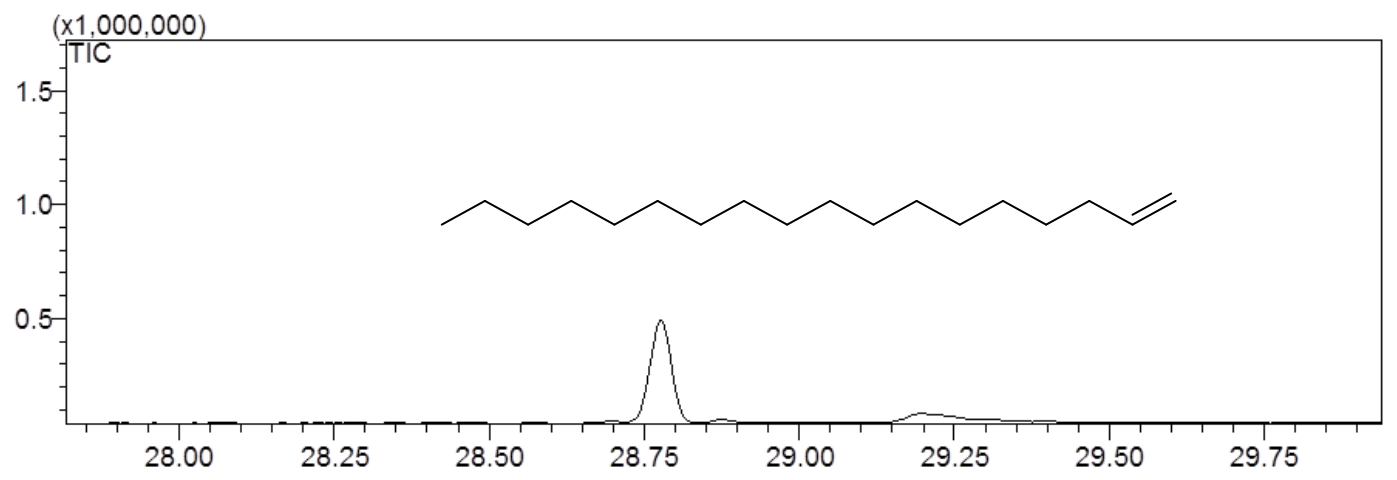

Condições de análise CG-EM: $\mathrm{T}_{\mathrm{i}}=60^{\circ} \mathrm{C}, 2 \mathrm{~min} ; \mathrm{T}_{\mathrm{f}}=280^{\circ} \mathrm{C}, 6 \mathrm{~min} ; \mathrm{r}=6^{\circ} \mathrm{C} / \mathrm{min}, \mathrm{t}_{\mathrm{c}}=45 \mathrm{mim}$.

Coluna capilar DB-5 da J\&W Scientific (30 m x 0,25 mm x 0,25 $\mu \mathrm{m}$ ). 
As Figuras 89 e 90 mostram o cromatograma e o espectro de massas $(70 \mathrm{eV})$ do padrão analítico do pesticida metil paration que tem o seu sinal no tempo de retenção em 27,180 minutos.

Figura 89. Cromatograma obtido por CG-EM do padrão analítico do pesticida metil paration.

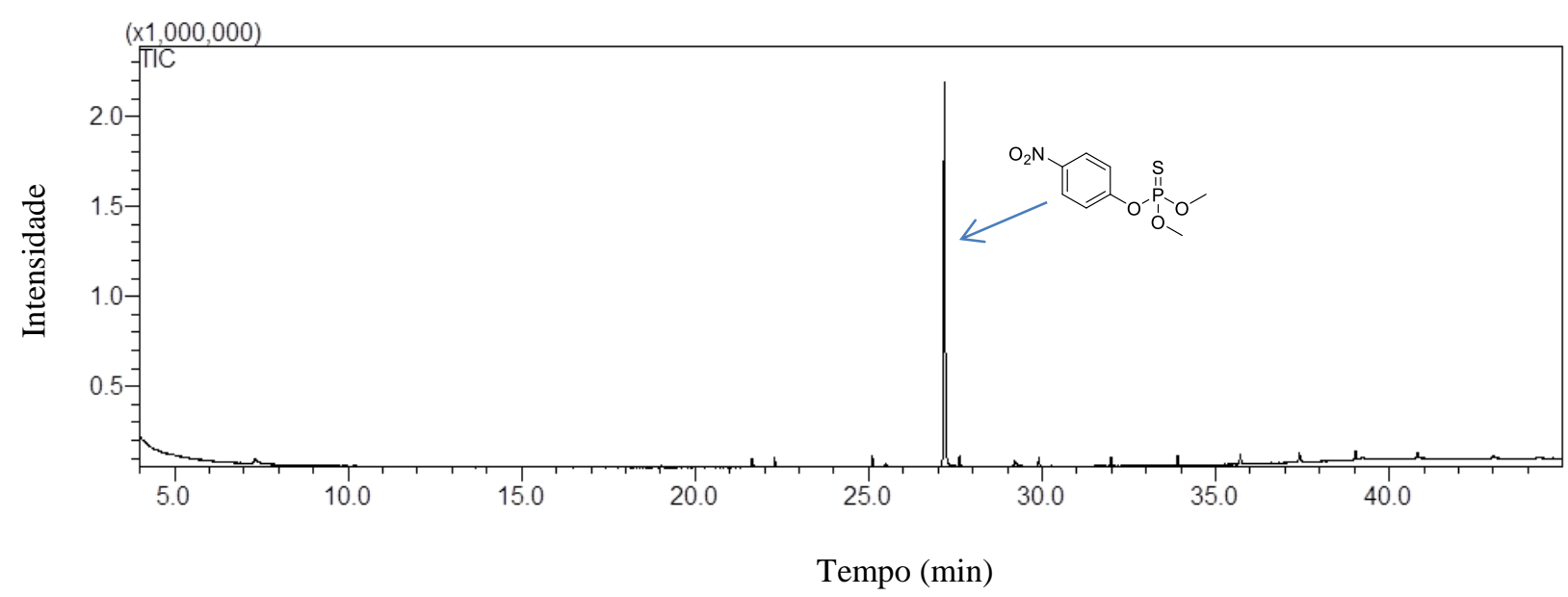

Condições de análise CG-EM: $\mathrm{T}_{\mathrm{i}}=60^{\circ} \mathrm{C}, 2 \mathrm{~min} ; \mathrm{T}_{\mathrm{f}}=280^{\circ} \mathrm{C}, 6 \mathrm{~min} ; \mathrm{r}=6^{\circ} \mathrm{C} / \mathrm{min}, \mathrm{t}_{\mathrm{c}}=45 \mathrm{mim}$.

Coluna capilar DB-5 da J\&W Scientific (30 $\mathrm{m}$ x 0,25 mm x 0,25 $\mu \mathrm{m})$.

Figura 90. Espectro de massas obtido por CG-EM $(70 \mathrm{eV})$ para o padrão analítico do metil paration.

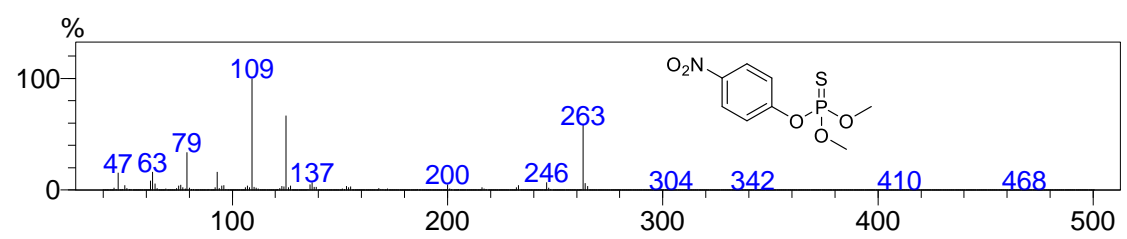

A Figura 91 mostra a sobreposição dos cromatogramas obtidos por CG-EM das extrações do caldo enzimático (cor vermelha) e do micélio (cor preta) com o fungo A. sydowii CBMAI 935 na presença de $50 \mathrm{mg} . \mathrm{L}^{-1}$ do pesticida comercial metil paration em 10 dias de reação e a Figura 92 mostra os mesmos cromatogramas, porém separados. Cromatograma (a) Extração do caldo enzimático e cromatograma (b) Extração do micélio. Durante esse período foi observado qualitativamente uma maior intensidade dos sinais do pesticida no micélio em comparação com o caldo enzimático. 
Figura 91. Cromatograma obtido por CG-EM das extrações do micélio e do caldo enzimático do fungo $A$. sydowii CBMAI 935 na presença do pesticida comercial metil paration durante 10 dias.

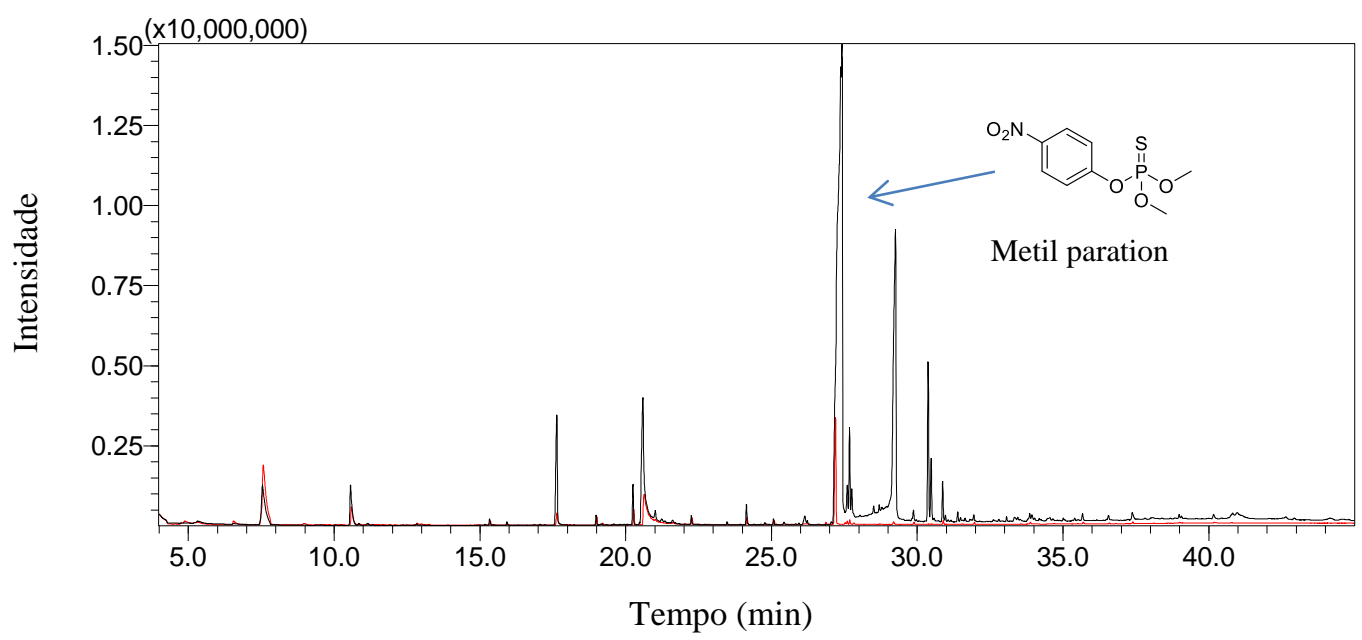

Condições de análise CG-EM: $\mathrm{T}_{\mathrm{i}}=60^{\circ} \mathrm{C}, 2 \mathrm{~min} ; \mathrm{T}_{\mathrm{f}}=280^{\circ} \mathrm{C}, 6 \mathrm{~min} ; \mathrm{r}=6^{\circ} \mathrm{C} / \mathrm{min}, \mathrm{t}_{\mathrm{c}}=45 \mathrm{mim}$.

Coluna capilar DB-5 da J\&W Scientific (30 m x 0,25 mm x 0,25 $\mu \mathrm{m})$.

Figura 92. Cromatogramas obtidos por CG-EM das extrações do micélio e do caldo enzimático do fungo $A$. sydowii CBMAI 935 na presença do pesticida comercial metil paration durante 10 dias. (a) Extração do caldo enzimático e (b) Extração do micélio.

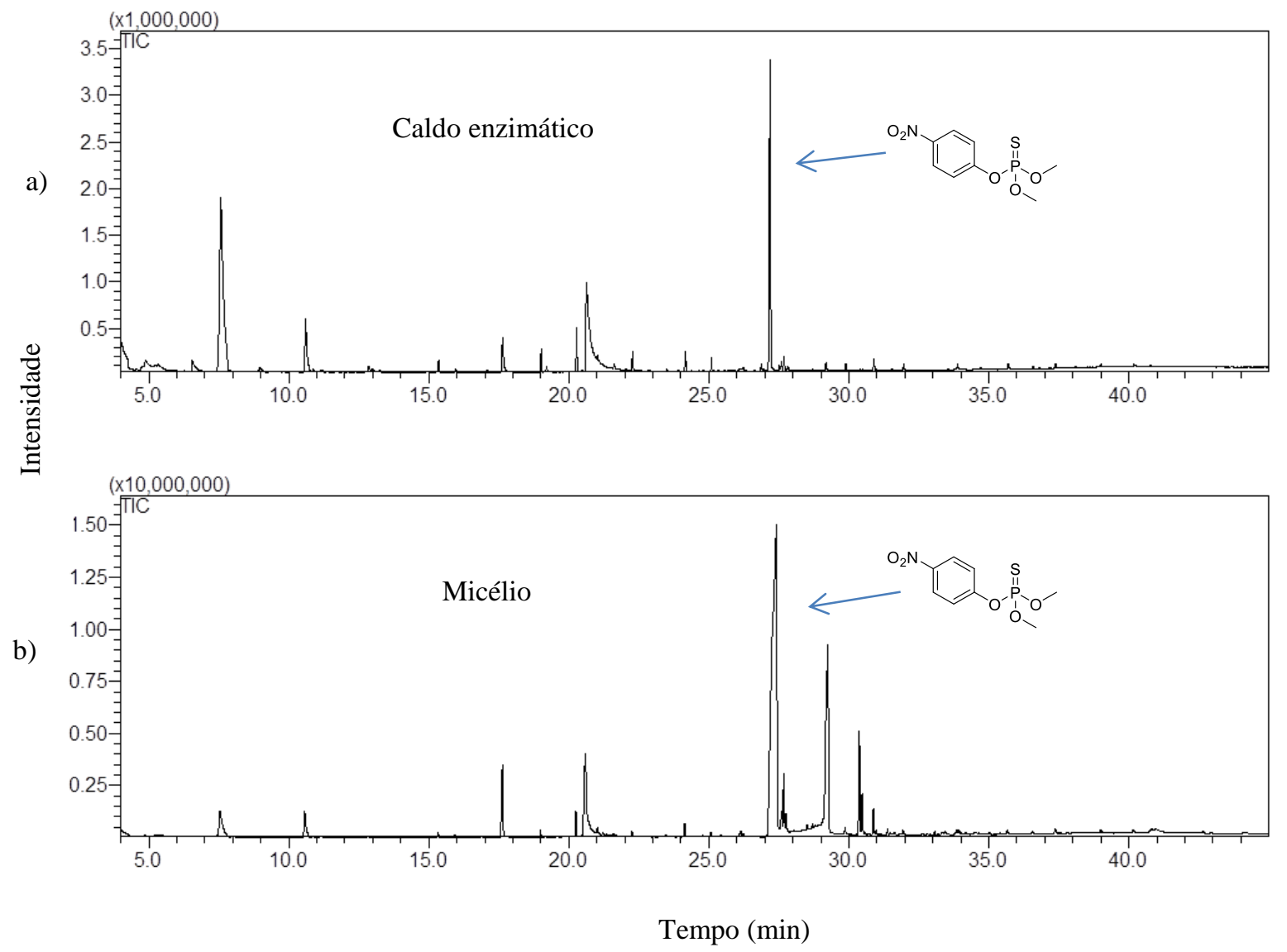

Condições de análise CG-EM: $\mathrm{T}_{\mathrm{i}}=60^{\circ} \mathrm{C}, 2 \mathrm{~min} ; \mathrm{T}_{\mathrm{f}}=280^{\circ} \mathrm{C}, 6 \mathrm{~min} ; \mathrm{r}=6^{\circ} \mathrm{C} / \mathrm{min}, \mathrm{t}_{\mathrm{c}}=45 \mathrm{mim}$.

Coluna capilar DB-5 da J\&W Scientific (30 m x 0,25 mm x 0,25 $\mu \mathrm{m})$. 
A Figuras 93 e 94 mostram os cromatogramas obtidos por CG-EM das extrações do caldo enzimático e extrações do micélio das reações de biotransformação do pesticida comercial metil paration pelo fungo A. sydowii CBMAI 935 durante 10 dias.

No cromatograma da extração do micélio observou-se a obtenção de vários metabólitos provenientes da biotransformação do pesticida comercial metil paration. Foram encontrados metabólitos como o pesticida bioativado para a sua forma mais tóxica, o metil paraoxon e uma estrutura isomérica do pesticida metil paration, juntamente com o metabólito 4-nitrofenol gerado pela ação de enzimas fosfotriesterases responsáveis pela reação de hidrólise (fase I) do pesticida e os metabólitos 1-metoxi-4-nitrobenzeno, $O, O, S$-fosforotioato de trimetila e $O, O, O$ fosforotioato de trimetila gerados por ação de enzimas transferases responsáveis pela transferência do grupo metila nos metabólitos aceptores do 4-nitrofenol, $O, S$-fosforotioato de dimetila e $O, O$-fosforotioato de dimetila, gerando metabólitos conjugados, característicos de reações de fase II. A detecção da bioativação para a forma mais tóxica do pesticida metil paration, ocorreu somente nas reações com o micélio do fungo.

Nas extrações do caldo enzimático foram detectados a presença dos metabólitos de fase I e fase II, com presença do pesticida metil paration. O sinal do pesticida foi detectado no tempo de retenção em 27,180 minutos, coincidindo com os tempos de retenção do padrão analítico e do pesticida comercial.

Figura 93. Cromatograma obtido por CG-EM das extrações do caldo enzimático do fungo A. sydowii CBMAI 935 na presença do pesticida comercial metil paration durante 10 dias.

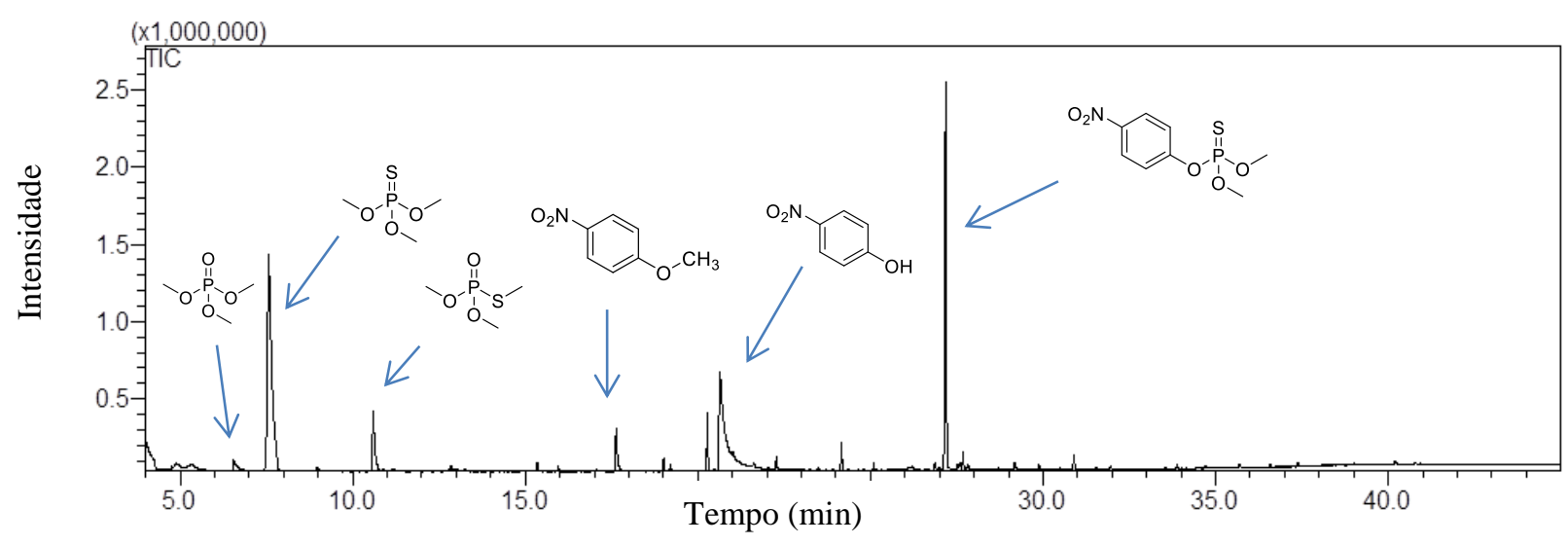

Condições de análise CG-EM: $\mathrm{T}_{\mathrm{i}}=60^{\circ} \mathrm{C}, 2 \mathrm{~min} ; \mathrm{T}_{\mathrm{f}}=280^{\circ} \mathrm{C}, 6 \mathrm{~min} ; \mathrm{r}=6^{\circ} \mathrm{C} / \mathrm{min}, \mathrm{t}_{\mathrm{c}}=45 \mathrm{mim}$.

Coluna capilar DB-5 da J\&W Scientific (30 m x 0,25 mm x 0,25 $\mu \mathrm{m}$ ). 
Figura 94. Cromatograma obtido por CG-EM das extrações do micélio do fungo A. sydowii CBMAI 935 na presença do pesticida comercial metil paration, durante 10 dias.

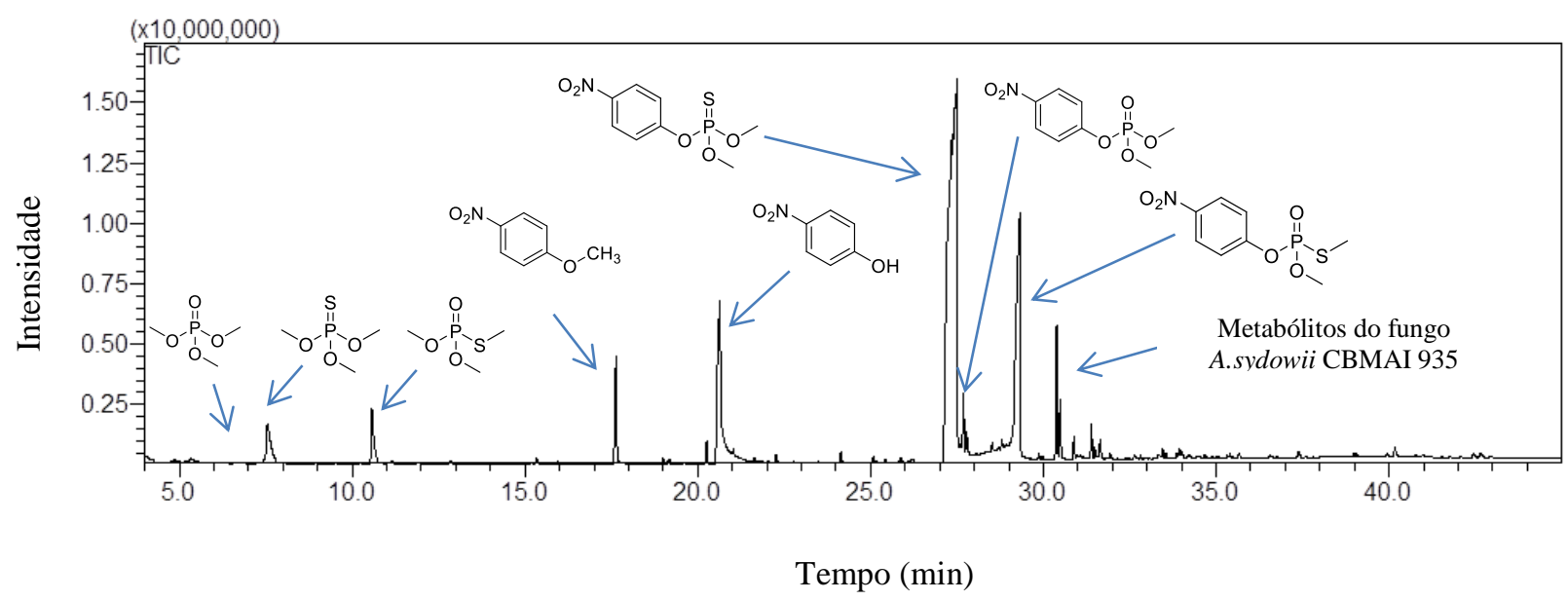

Condições de análise CG-EM: $\mathrm{T}_{\mathrm{i}}=60^{\circ} \mathrm{C}, 2 \mathrm{~min} ; \mathrm{T}_{\mathrm{f}}=280^{\circ} \mathrm{C}, 6 \mathrm{~min} ; \mathrm{r}=6^{\circ} \mathrm{C} / \mathrm{min}, \mathrm{t}_{\mathrm{c}}=45 \mathrm{mim}$.

Coluna capilar DB-5 da J\&W Scientific (30 m x 0,25 mm x 0,25 $\mu \mathrm{m})$.

O Esquema 8 mostra as possíveis reações de fase I e fase II (biotransformação e bioconjugação) do pesticida comercial metil paration por reações enzimáticas do fungo de ambiente marinho A. sydowii CBMAI 935. O Esquema 8 foi proposto a partir dos compostos identificados nos cromatogramas obtidos por CG-EM das extrações do micélio e do caldo emzimático do fungo A. sydowii CBMAI 935 na presença do pesticida metil paration durante 10 dias. 
Esquema 8. Proposta de reações e metabólitos de biotransformação de fase I e de faselI do pesticida comercial metil paration pelo fungo A. sydowii CBMAI 935 durante 10 dias.

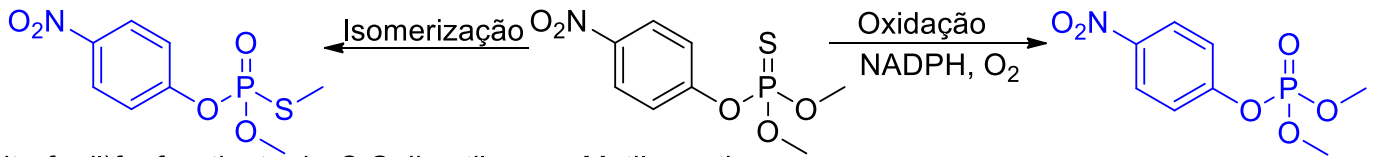

O-(4-nitrofenil)fosforotioato de O,S-dimetila

Metil paration

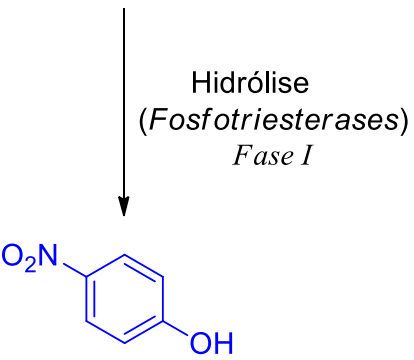

4-nitrofenol<smiles>COP(=O)(O)SC</smiles>

$O, S$-fosforotioato de dimetila<smiles>COc1ccc([N+](=O)[O-])cc1</smiles>

1-metoxi-4-nitrobenzeno<smiles>COP(=O)(OC)SC</smiles>

$\mathrm{O}, \mathrm{O}, \mathrm{S}$-fosforotioato de trimetila

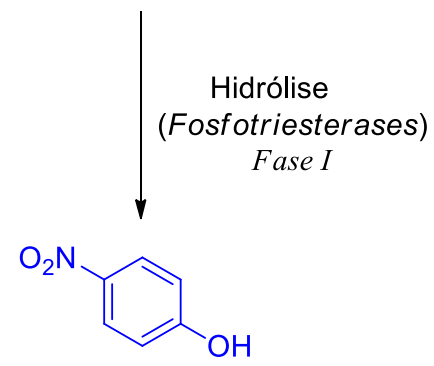

4-nitrofenol<smiles>COP(O)(=S)OC</smiles>

O,O-fosforotioato de dimetila

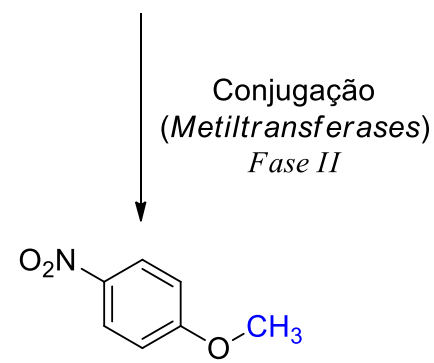

1-metoxi-4-nitrobenzeno<smiles>COP(=S)(OC)OC</smiles>

O,O,O-fosforotioato de trimetila
Metil paraoxon

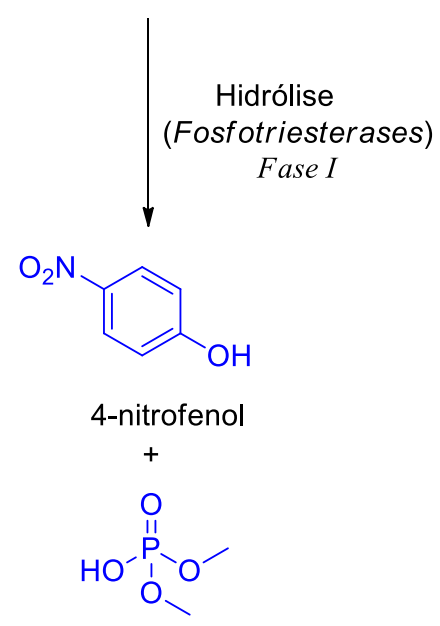

fosfato de dimetila

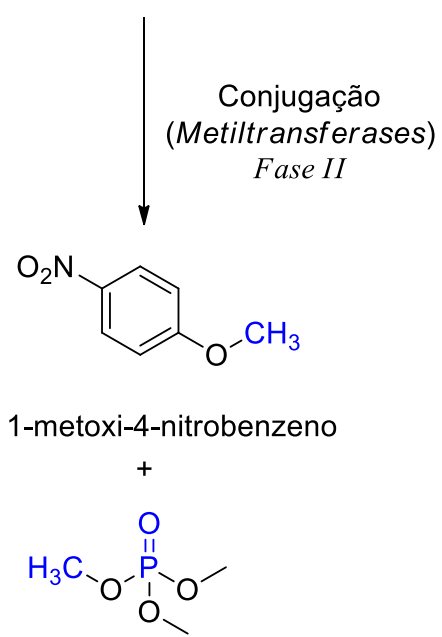

fosfato de trimetila

Fonte: Autoria própria. 
A Figura 95 mostra o cromatograma obtido por CG-EM das extrações do caldo enzimático para o pesticida comercial metil paration com o fungo de ambiente marinho $A$. sydowii CBMAI 935 em 10 dias de reação de biotransformação. E, a Figura 96 mostra o espectro de massas obtido por CG-EM $(70 \mathrm{eV})$ para o metil paration nas extrações do caldo enzimático do fungo A. sydowii CBMAI 935 em 10 dias de reação.

O cromatograma foi obtido a partir da Figura 93, selecionando apenas o sinal do pesticida comercial metil paration com tempo de retenção em 27,180 minutos.

O sinal e o tempo de retenção do pesticida encontrado na reação foram comparados com o padrão analítico (Figuras 89 e 90) do metil paration, os quais foram idênticos, confirmando a identidade do composto na amostra comercial que foi utilizada nas reações de biotransformação.

Figura 95. Cromatograma selecionado do pesticida comercial metil paration obtido por CG-EM das extrações do caldo enzimático do A. sydowii CBMAI 935 em 10 dias de reação de biotransformação.

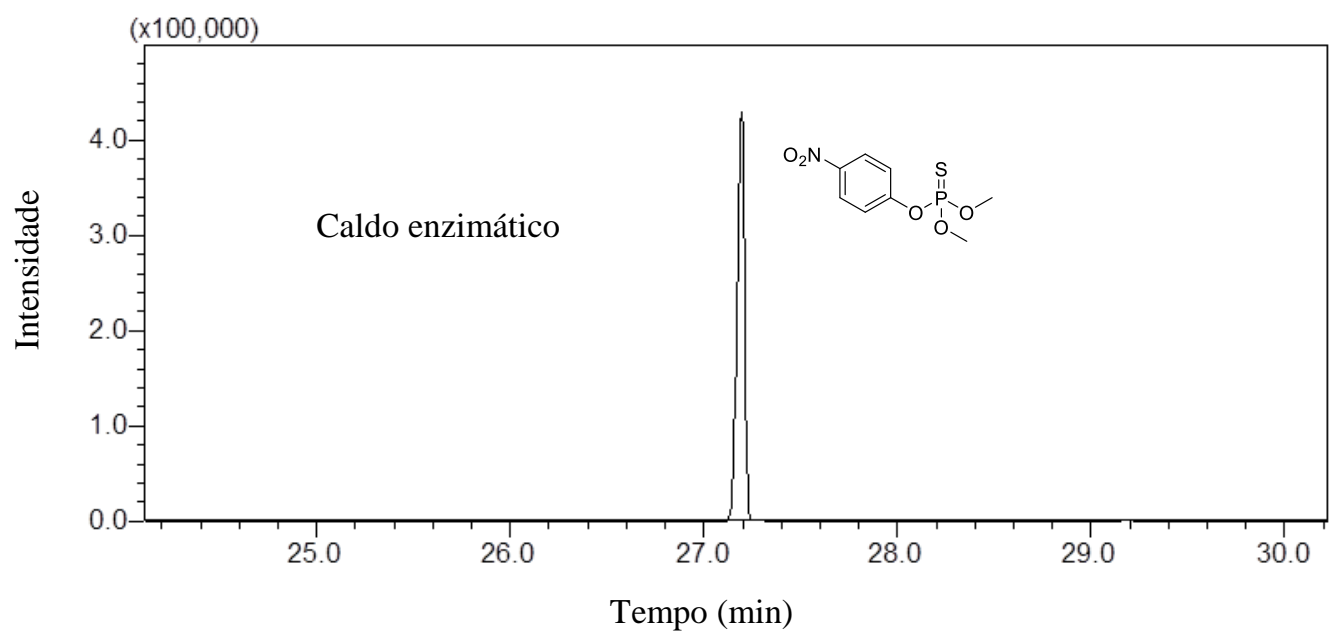

Condições de análise CG-EM: $\mathrm{T}_{\mathrm{i}}=60^{\circ} \mathrm{C}, 2 \mathrm{~min} ; \mathrm{T}_{\mathrm{f}}=280^{\circ} \mathrm{C}, 6 \mathrm{~min} ; \mathrm{r}=6^{\circ} \mathrm{C} / \mathrm{min}, \mathrm{t}_{\mathrm{c}}=45 \mathrm{mim}$.

Coluna capilar DB-5 da J\&W Scientific (30 m x 0,25 mm x 0,25 $\mu \mathrm{m})$.

Figura 96. Espectro de massas obtido por CG-EM $(70 \mathrm{eV})$ para o pesticida comercial metil paration das extrações do caldo enzimático do A. sydowii CBMAI 935 em 10 dias.

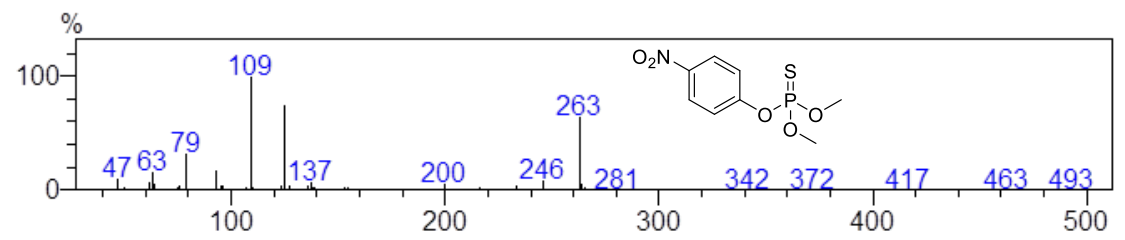


A Figura 97 mostra o cromatograma obtido por CG-EM das extrações do micélio para o o pesticida comercial metil paration com o fungo de ambiente marinho A. sydowii CBMAI 935 em 10 dias de reação de biotransformação.

O cromatograma foi obtido a partir da Figura 94, selecionando apenas o sinal do pesticida com tempo de retenção em 27,180 minutos. O sinal e o tempo de retenção encontrados na reação foram comparados com o padrão analítico (Figuras 89 e 90) do metil paration, os quais foram idênticos, confirmando a identidade do composto na amostra comercial que foi utilizada nas reações de biotransformação.

Figura 97. Cromatograma selecionado do pesticida comercial metil paration obtido por CG-EM das extrações do micélio do A. sydowii CBMAI 935 em 10 dias de reação de biotransformação.

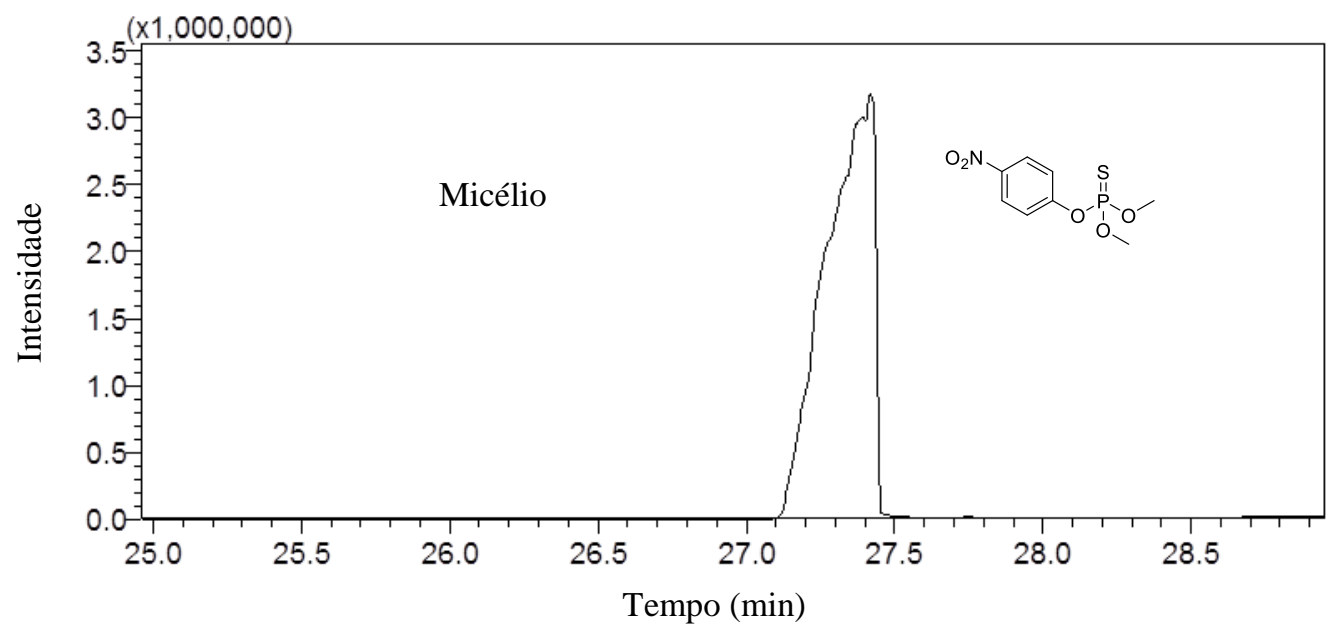

Condições de análise CG-EM: $\mathrm{T}_{\mathrm{i}}=60^{\circ} \mathrm{C}, 2 \mathrm{~min} ; \mathrm{T}_{\mathrm{f}}=280^{\circ} \mathrm{C}, 6 \mathrm{~min} ; \mathrm{r}=6^{\circ} \mathrm{C} / \mathrm{min}, \mathrm{t}_{\mathrm{c}}=45 \mathrm{mim}$. Coluna capilar DB-5 da J\&W Scientific (30 $\mathrm{m}$ x 0,25 mm x 0,25 $\mu \mathrm{m})$.

A Figura 98 mostra o espectro de massas obtido em CG-EM $(70 \mathrm{eV})$ do pesticida comercial metil paration nas extrações do micélio do fungo A. sydowii CBMAI 935 em 10 dias de reação de biotransformação. $\mathrm{O}$ espectro de massas para o metil paration apresentou o íon molecular (1), com $\mathrm{m} / \mathrm{z}$ 263. O pico base (3), com $\mathrm{m} / \mathrm{z}$ 109, pode ser resultante da perda de -CHO (M-29) da porção fenólica. O fragmento de intensidade (2), com $\mathrm{m} / z 125$ pode ser resultado da fragmentação formando a porção fosfonotioato. $O$ espectro descrito foi comparado com o espectro de massas do padrão analítico (Figura 90) do pesticida metil paration os quais foram idênticos, confirmando a identidade do composto na amostra comercial que foi utilizada nas reações de biotransformação. 
Figura 98. Espectro de massas obtido por CG-EM $(70 \mathrm{eV})$ para o pesticida comercial metil paration nas extrações do micélio do A. sydowii CBMAI 935 em 10 dias de reação de biotransformação.

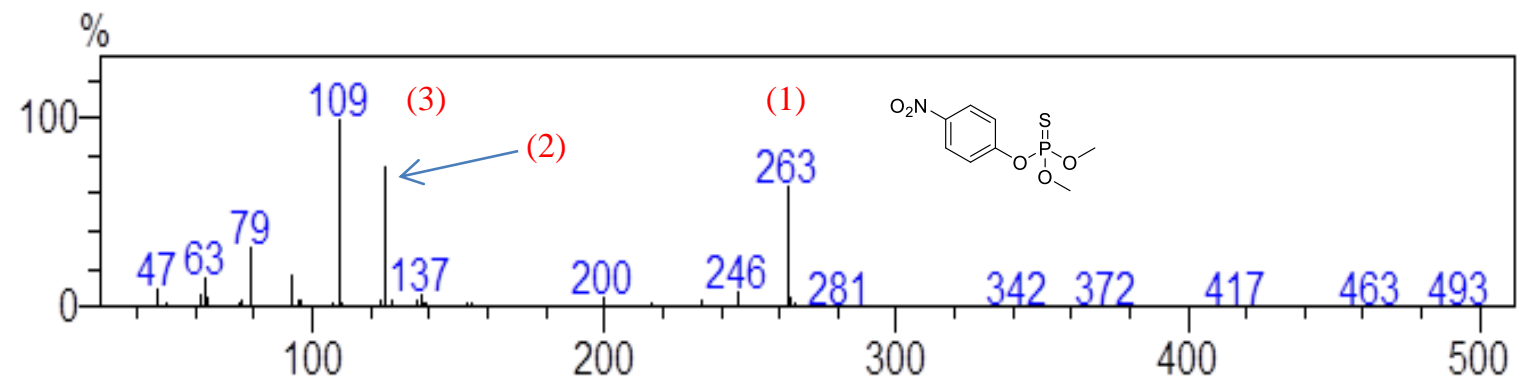

O Esquema 9 mostra a proposta de fragmentação para o pesticida comercial metil paration obtido por CG-EM das extrações do micélio com o fungo de ambiente marinho $A$. sydowii CBMAI 935 em 10 dias de reação de biotransformação.

Esquema 9. Proposta de fragmentação para o pesticida comercial metil paration.

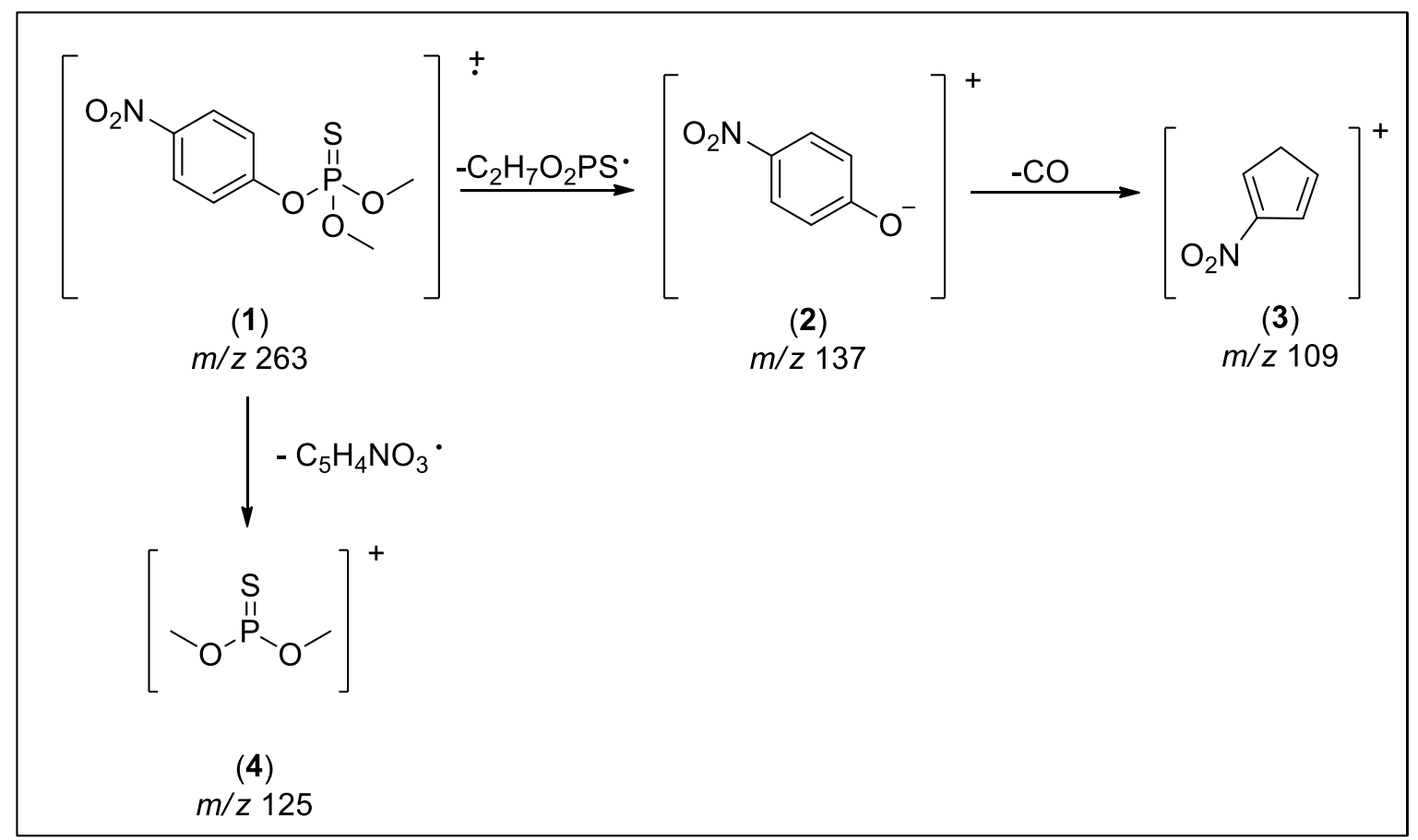

Fonte: Adaptado de SILVA, N.A. Biodegradação dos pesticidas clorpirifós, metil paration e profenofós por fungos de origem marinha. 159f. Dissertação (Mestrado em Química)-Universidade São Paulo-USP. São Carlos, 2013. ${ }^{74}$ 
A Figura 99 mostra o cromatograma obtido por CG-EM das extrações do micélio para o metabólito metil paraoxon que é a forma bioativada e mais tóxica do pesticida metil paration com o fungo de ambiente marinho A. sydowii CBMAI 935 em 10 dias de reação de biotransformação.

O cromatograma foi obtido a partir da Figura 94, selecionando apenas o sinal do metabólito metil paraoxon com tempo de retenção em 27,600 minutos.

$\mathrm{O}$ espectro de massas obtido por CG-EM $(70 \mathrm{eV})$ do metabólito metil paraoxon apresentou uma similaridade de $92 \%$ comparado com o padrão das bibliotecas (NIST O5 LIB, NIST 05 s LIB, NIST 21 LIB, NIST 107 e WILEY 8 LIB) do espectrômetro de massas.

Figura 99. Cromatograma selecionado para o metabólito metil paraoxon obtido por CG-EM das extrações do micélio do A. sydowii CBMAI 935 em 10 dias de reação de biotransformação.

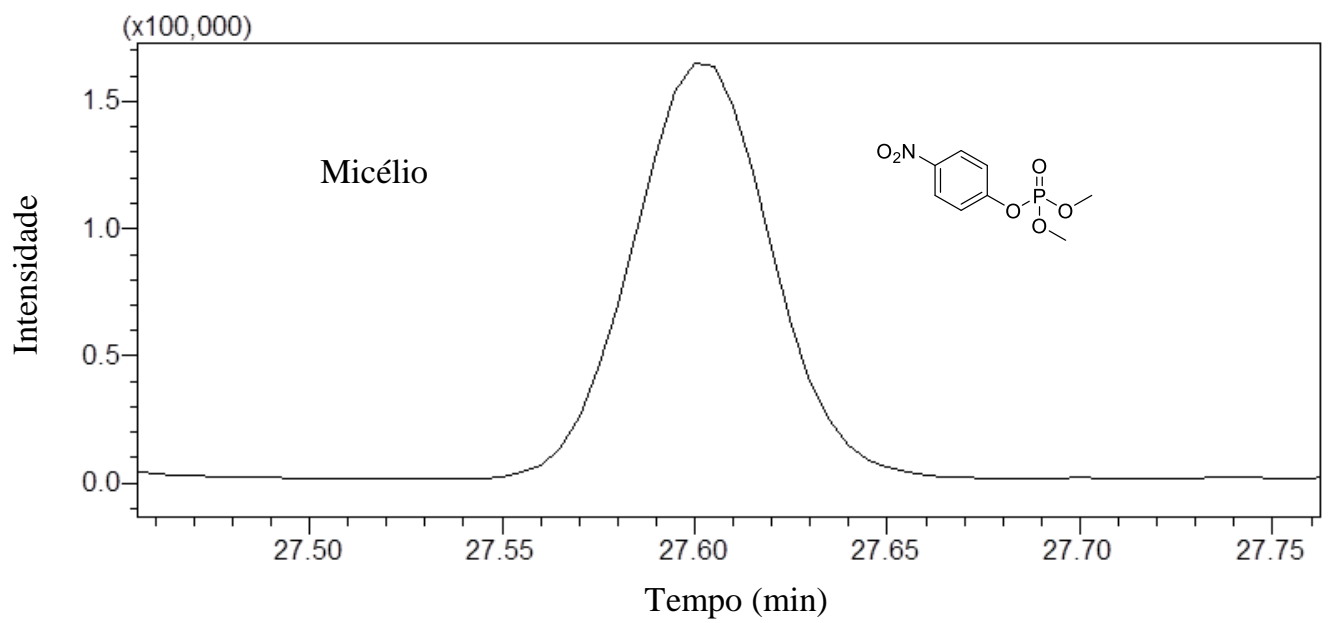

Condições de análise CG-EM: $\mathrm{T}_{\mathrm{i}}=60^{\circ} \mathrm{C}, 2 \mathrm{~min} ; \mathrm{T}_{\mathrm{f}}=280^{\circ} \mathrm{C}, 6 \mathrm{~min} ; \mathrm{r}=6^{\circ} \mathrm{C} / \mathrm{min}, \mathrm{t}_{\mathrm{c}}=45 \mathrm{mim}$. Coluna capilar DB-5 da J\&W Scientific (30 m x 0,25 mm x 0,25 $\mu \mathrm{m})$.

A Figura 100 mostra o espectro de massas obtido em CG-EM (70 eV) para o metabólito metil paraoxon nas extrações do micélio do A. sydowii CBMAI 935 em 10 dias de reação.

Figura 100. Espectro de massas obtido por CG-EM $(70 \mathrm{eV})$ para o metabólito metil paraoxon nas extrações do micélio do A. sydowii CBMAI em 10 dias.

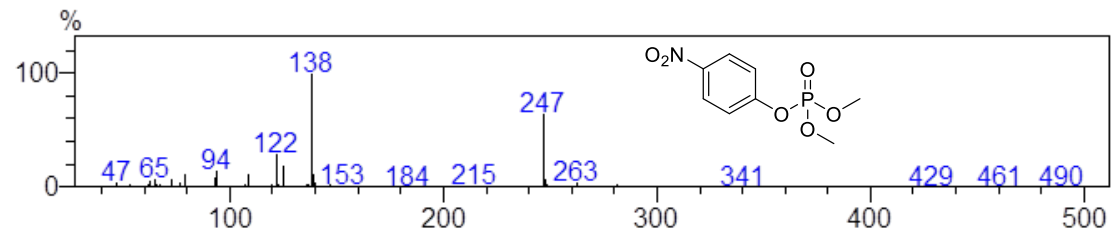


O Esquema 10 mostra a proposta de fragmentação para o metabólito metil paraoxon obtido por CG-EM das extrações do micélio com o fungo de ambiente marinho A. sydowii CBMAI 935 em 10 dias de reação de biotransformação.

Esquema 10. Proposta de fragmentação para o metabólito metil paraoxon.

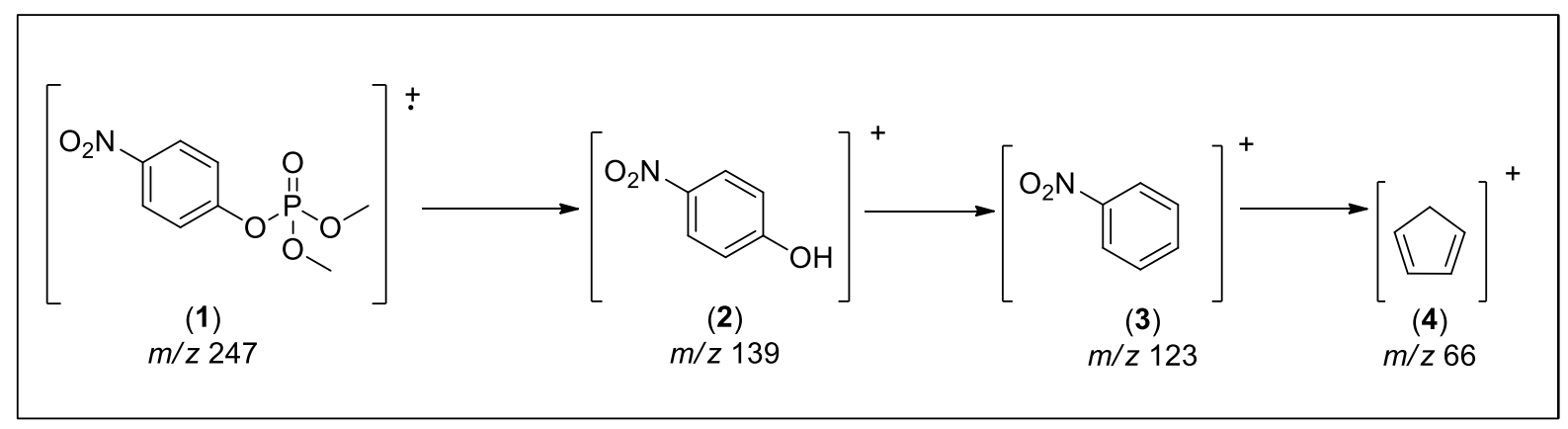

Fonte: Autoria própria.

A Figura 101 mostra o cromatograma obtido por CG-EM das extrações do micélio para o o metabólito $O$-(4-nitrofenil)fosforotioato de $O, S$-dimetila com o fungo de ambiente marinho A. sydowii CBMAI 935 em 10 dias de reação de biotransformação. E, a Figura 102 mostra o espectro de massas obtido em CG-EM $(70 \mathrm{eV})$ para o metabólito $O$-(4nitrofenil)fosforotioato de $O, S$-dimetila nas extrações do micélio do A. sydowii CBMAI 935 em 10 dias de reação.

O cromatograma foi obtido a partir da Figura 94, selecionando apenas o sinal do composto $O$-(4-nitrofenil)fosforotioato de $O, S$-dimetila com tempo de retenção em 29,250 minutos.

O espectro de massas obtido por CG-EM $(70 \mathrm{eV})$ do metabólito $O$-(4nitrofenil)fosforotioato de $O, S$-dimetila apresentou uma similaridade de $90 \%$ comparado com o padrão das bibliotecas (NIST O5 LIB, NIST 05 s LIB, NIST 21 LIB, NIST 107 e WILEY 8 LIB) do espectrômetro de massas. 
Figura 101. Cromatograma selecionado do metabólito $O$-(4-nitrofenil)fosforotioato de $O, S$-dimetila obtido por CG-EM das extrações do micélio do A. sydowii CBMAI 935 em 10 dias de reação de biotransformação.

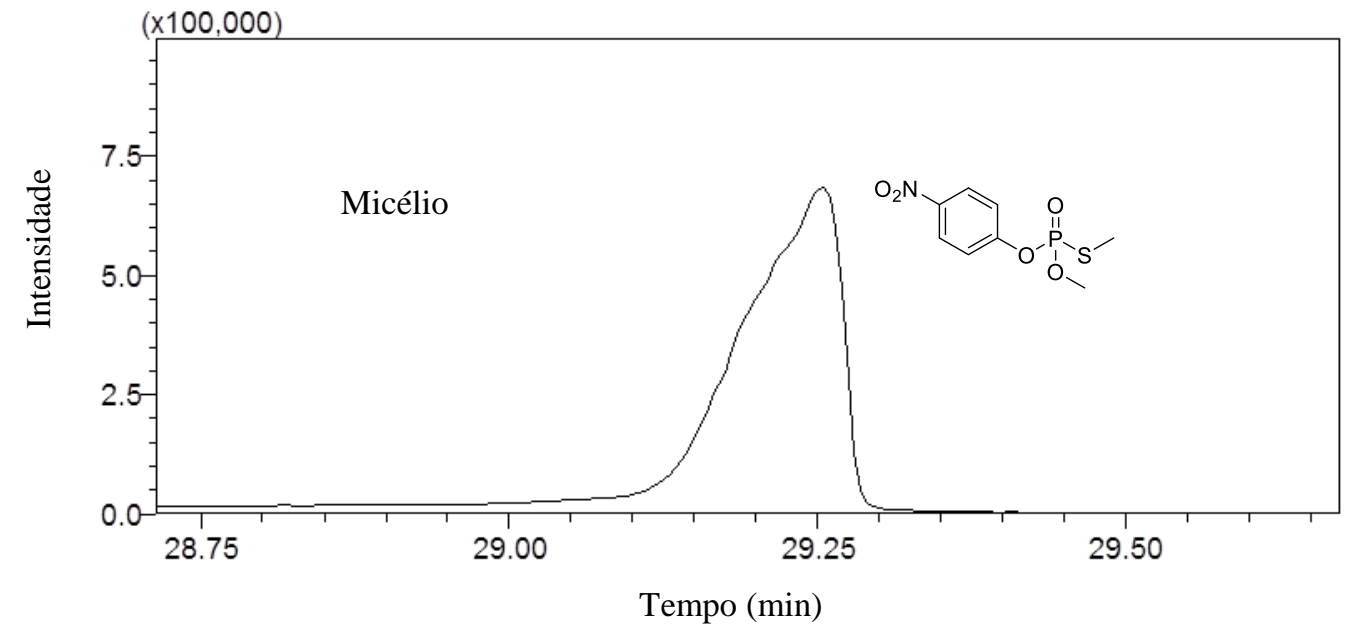

Condições de análise CG-EM: $\mathrm{T}_{\mathrm{i}}=60^{\circ} \mathrm{C}, 2 \mathrm{~min} ; \mathrm{T}_{\mathrm{f}}=280^{\circ} \mathrm{C}, 6 \mathrm{~min} ; \mathrm{r}=6^{\circ} \mathrm{C} / \mathrm{min}, \mathrm{t}_{\mathrm{c}}=45 \mathrm{mim}$. Coluna capilar DB-5 da J\&W Scientific (30 m x 0,25 mm x 0,25 $\mu \mathrm{m})$.

Figura 102. Espectro de massas obtido em CG-EM $(70 \mathrm{eV})$ para o metabólito $O$-(4-nitrofenil)fosforotioato de $O, S$-dimetila nas extrações do micélio do A. sydowii CBMAI em 10 dias.

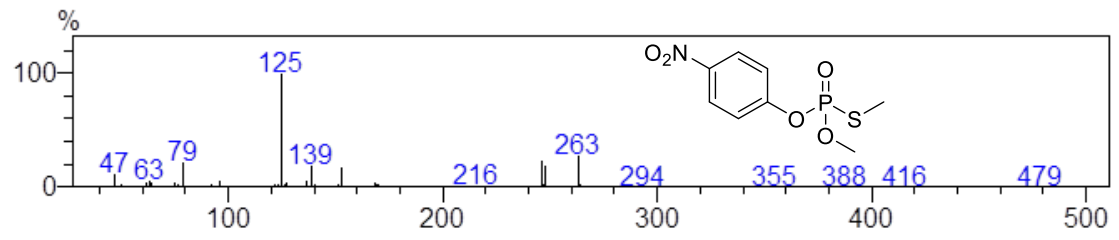

A Figura 103 mostra o cromatograma obtido por CG-EM das extrações do caldo enzimático para o composto fenólico 4-nitrofenol oriundo da hidrólise enzimática do pesticida metil paration pelo fungo de ambiente marinho A. sydowii CBMAI 935 em 10 dias de reação de biotransformação. E, a Figura 104 mostra o espectro de massas obtido em CG-EM (70 eV) para o metabólito 4-nitrofenol das extrações do caldo enzimático do fungo A. sydowii CBMAI 935 na presença do pesticida metil paration, durante 10 dias.

O cromatograma foi obtido a partir da Figura 100, selecionando apenas o sinal do composto com tempo de retenção em 20,650 minutos.

O sinal e o tempo de retenção do composto fenólico encontrados na reação foram comparados com o padrão analítico (Figuras 114 e 115) do 4-nitrofenol, o qual foi idêntico, confirmando a identidade do composto na amostra comercial que foi utilizada nas reações de biotransformação. 
Figura 103. Cromatograma selecionado do metabólito 4-nitrofenol obtido por CG-EM das extrações do caldo enzimático do A. sydowii CBMAI 935 na presença do pesticida comercial metil paration durante 10 dias.

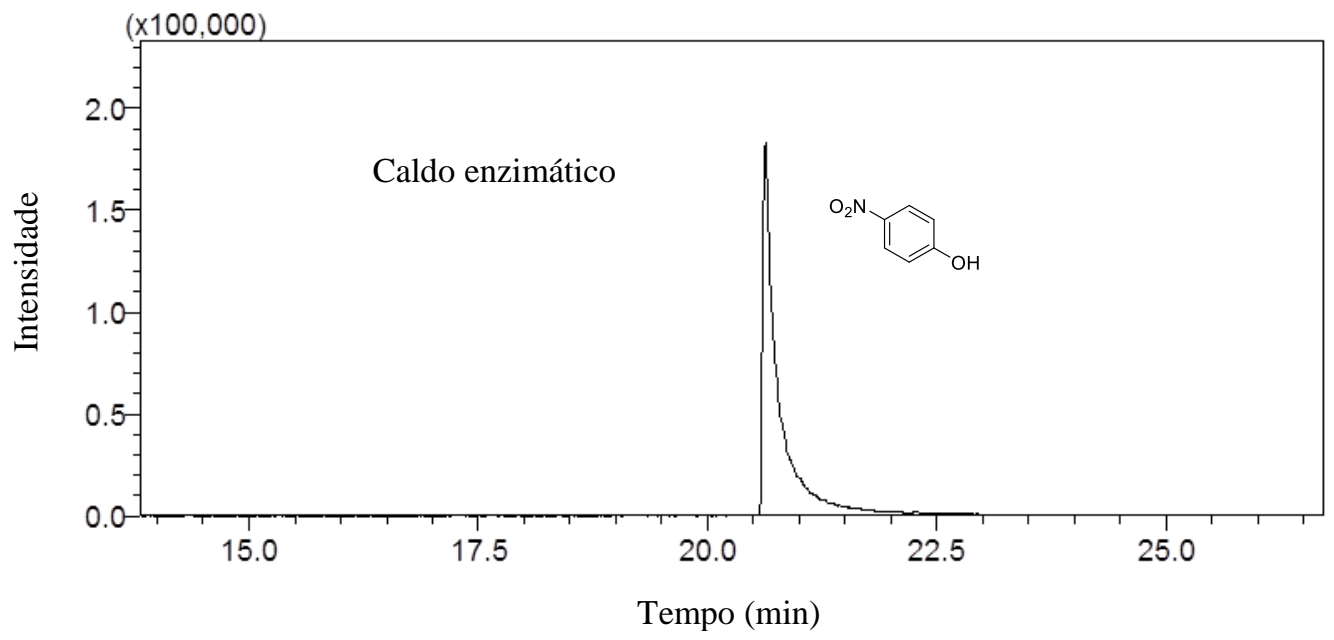

Condições de análise CG-EM: $\mathrm{T}_{\mathrm{i}}=60^{\circ} \mathrm{C}, 2 \mathrm{~min} ; \mathrm{T}_{\mathrm{f}}=280^{\circ} \mathrm{C}, 6 \mathrm{~min} ; \mathrm{r}=6^{\circ} \mathrm{C} / \mathrm{min}, \mathrm{t}_{\mathrm{c}}=45 \mathrm{mim}$. Coluna capilar DB-5 da J\&W Scientific (30 m x 0,25 mm x 0,25 $\mu \mathrm{m})$.

Figura 104. Espectro de massas obtido por CG-EM $(70 \mathrm{eV})$ para o metabólito 4-nitrofenol das extrações do caldo enzimático do A. sydowii CBMAI 935 na presença do pesticida comercial metil paration durante 10 dias.

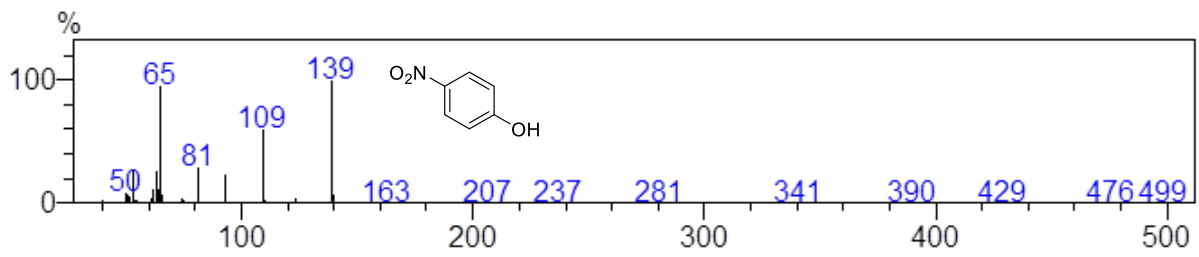

A Figura 105 mostra o cromatograma obtido por CG-EM das extrações do micélio para o composto fenólico 4-nitrofenol oriundo da hidrólise enzimática do pesticida metil paration pelo fungo de ambiente marinho A. sydowii CBMAI 935 em 10 dias de reação de biotransformação. E, a Figura 106 mostra o espectro de massas obtido em CG-EM (70 eV) para o metabólito 4-nitrofenol das extrações do micélio do A. sydowii CBMAI 935 na presença do pesticida metil paration durante 10 dias.

O cromatograma foi obtido a partir da Figura 94, selecionando apenas o sinal do composto com tempo de retenção em 20,650 minutos. O sinal e o tempo de retenção do composto fenólico encontrado na reação de biotransformação das extrações do micélio com o fungo A. sydowii CBMAI 935 em 10 dias foram comparados com o padrão analítico (Figuras 107 e 108) do 4-nitrofenol, os quais foram idênticos, confirmando a identidade do composto na amostra comercial que foi utilizada nas reações de biotransformação. 
Figura 105. Cromatograma selecionado do metabólito 4-nitrofenol obtido por CG-EM das extrações do micélio do A. sydowii CBMAI 935 na presença do pesticida comercial metil paration durante 10 dias.

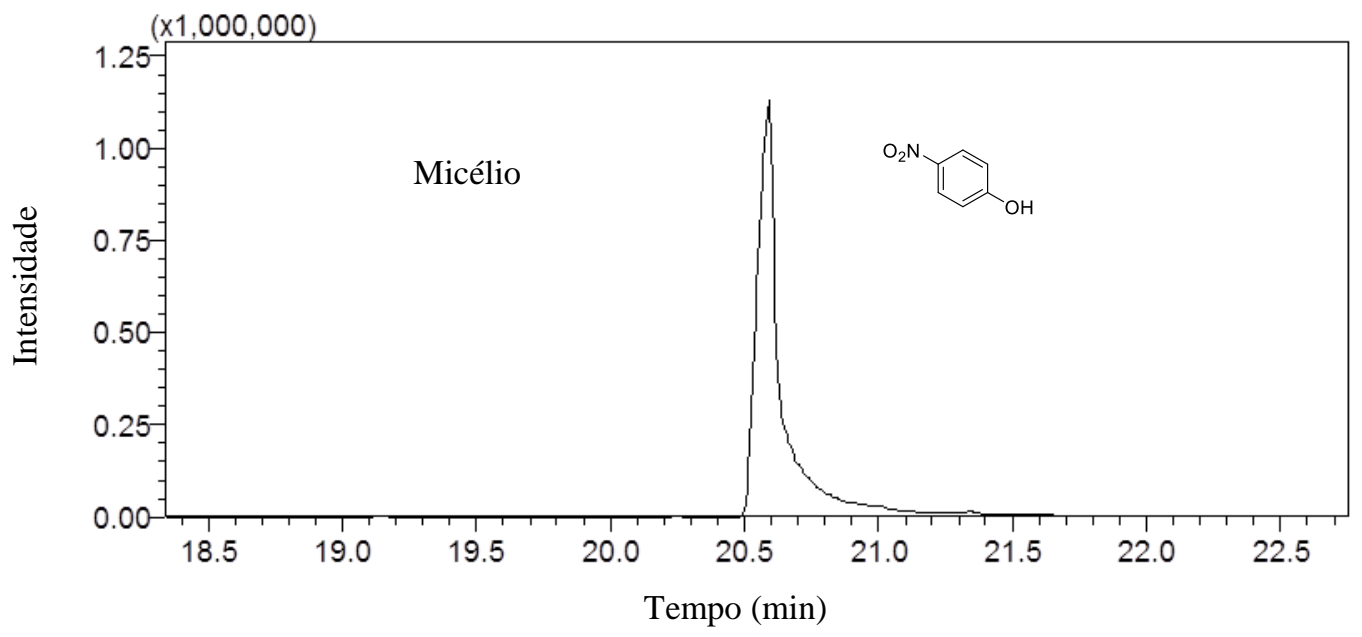

Condições de análise CG-EM: $\mathrm{T}_{\mathrm{i}}=60^{\circ} \mathrm{C}, 2 \mathrm{~min} ; \mathrm{T}_{\mathrm{f}}=280^{\circ} \mathrm{C}, 6 \mathrm{~min} ; \mathrm{r}=6^{\circ} \mathrm{C} / \mathrm{min}, \mathrm{t}_{\mathrm{c}}=45 \mathrm{mim}$.

Coluna capilar DB-5 da J\&W Scientific (30 m x 0,25 mm x 0,25 $\mu \mathrm{m})$.

Figura 106. Espectro de massas obtido por CG-EM (70 eV) para o metabólito 4-nitrofenol das extrações do micélio do A. sydowii CBMAI 935 na presença do pesticida comercial metil paration durante 10 dias.

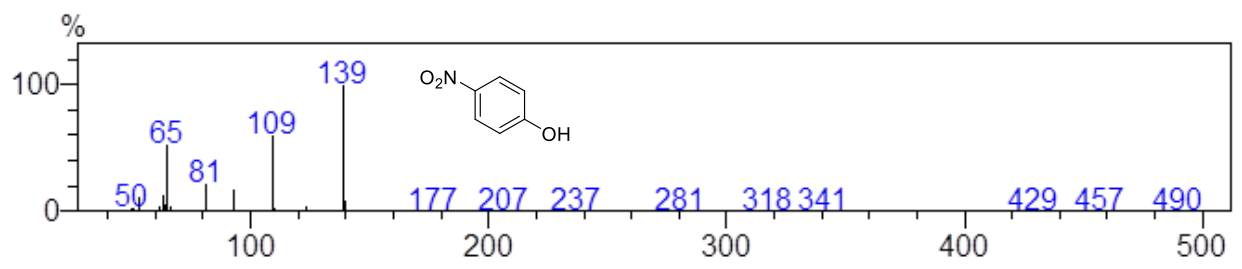

As Figuras 107 e 108 mostram o cromatograma obtido por CG-EM e o espectro de massas do padrão analítico do composto fenólico 4-nitrofenol que tem o seu sinal e tempo de retenção em 20,650 minutos. 
Figura 107. Cromatograma obtido por CG-EM do padrão analítico do 4-nitrofenol.

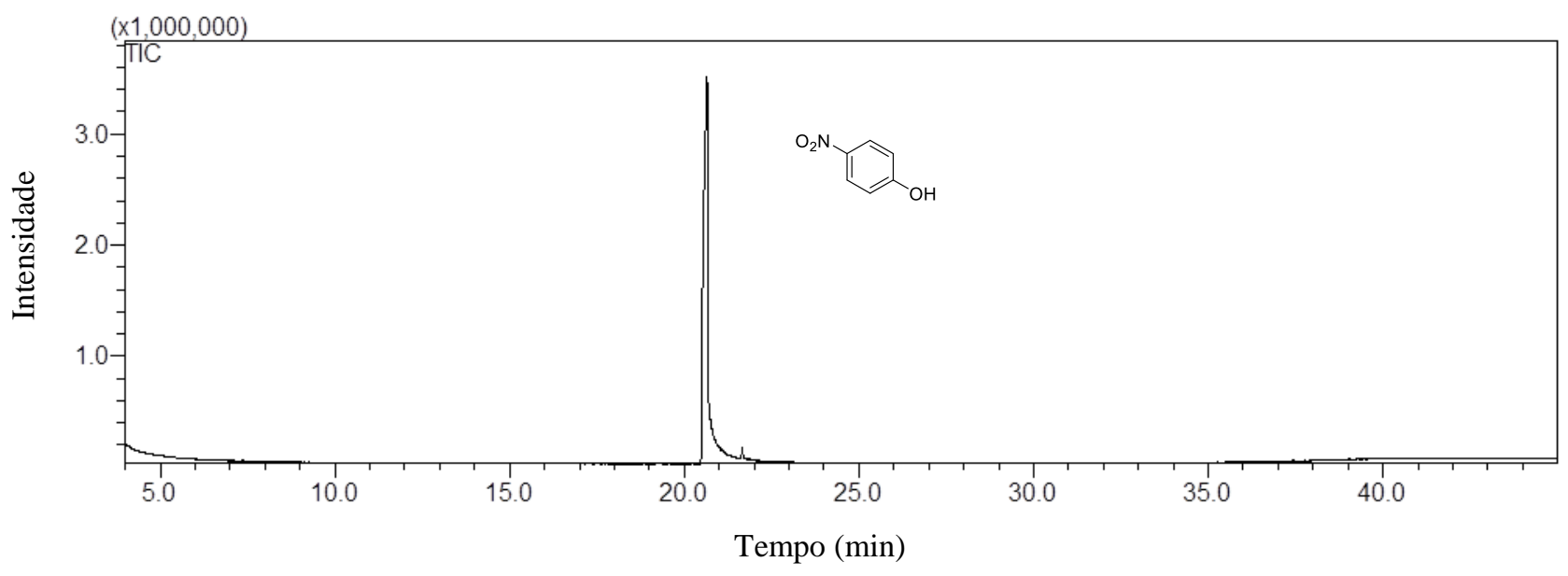

Condições de análise CG-EM: $\mathrm{T}_{\mathrm{i}}=60^{\circ} \mathrm{C}, 2 \mathrm{~min} ; \mathrm{T}_{\mathrm{f}}=280^{\circ} \mathrm{C}, 6 \mathrm{~min} ; \mathrm{r}=6^{\circ} \mathrm{C} / \mathrm{min}, \mathrm{t}_{\mathrm{c}}=45 \mathrm{mim}$. Coluna capilar DB-5 da J\&W Scientific (30 m x 0,25 mm x 0,25 $\mu \mathrm{m})$.

Figura 108. Espectro de massas obtido por CG-EM $(70 \mathrm{eV})$ para o padrão analítico do 4-nitrofenol.

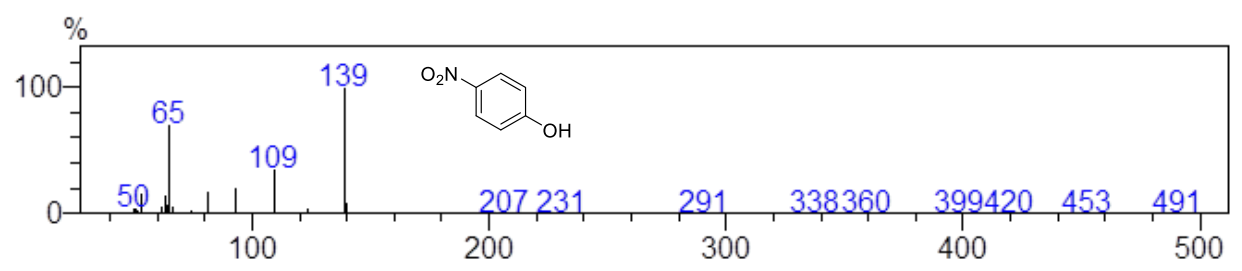

A Figura 109 mostra o espectro de massas obtido em CG-EM (70 eV) do metabólito 4nitrofenol obtido da reação de biotranformação do pesticida comercial metil paration com o fungo A. sydowii CBMAI 935 em 10 dias. O composto fenólico apresentou o íon molecular $\mathrm{m} / z 139$ (1) com intensidade (100\%), sendo este também, o pico base. O fragmento com $\mathrm{m} / \mathrm{z}$ 93 (2) com intensidade de $18 \%$ pode ser resultante da perda do grupo nitro, fornecendo uma molécula de fenol. Em fenois, são usualmente encontrados picos com perda de CHO (M-29), a perda de $\mathrm{CHO}$ e mais um hidrôgenio pode ter resultado no fragmento com $\mathrm{m} / z 109$ (3) com intensidade de 60\%, usualmente os picos resultantes da perda de $\mathrm{CHO}$, podem subsequentemente perder mais um próton, e neste caso juntamente com a perda do grupo nitro, fornecer um fragmento com $\mathrm{m} / \mathrm{z}, 65$ (4) com intensidade de 53\%. O espectro descrito foi comparado com o espectro de massas do padrão analítico do composto fenólico 4-nitrofenol (Figura 108). 
Figura 109. Espectro de massas obtido por CG-EM $(70 \mathrm{eV})$ para o metabólito 4-nitrofenol das extrações do micélio do A. sydowii CBMAI 935 na presença do pesticida comercial metil paration durante 10 dias.

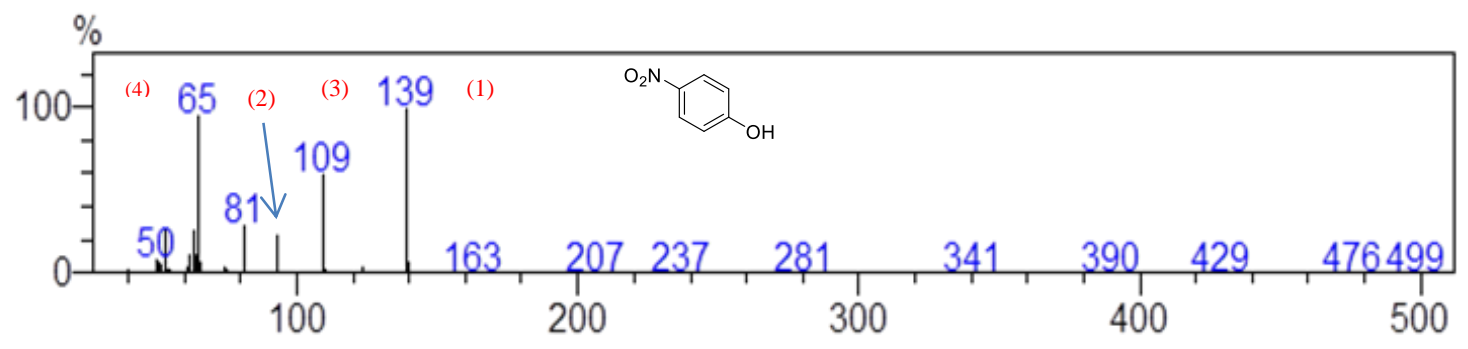

O Esquema 11 mostra a proposta de fragmentação para o composto 4-nitrofenol obtido por CG-EM das extrações do micélio com o fungo de ambiente marinho A. sydowii CBMAI 935 em 10 dias de reação de biotransformação.

Esquema 11. Proposta de fragmentação para o 4-nitrofenol.

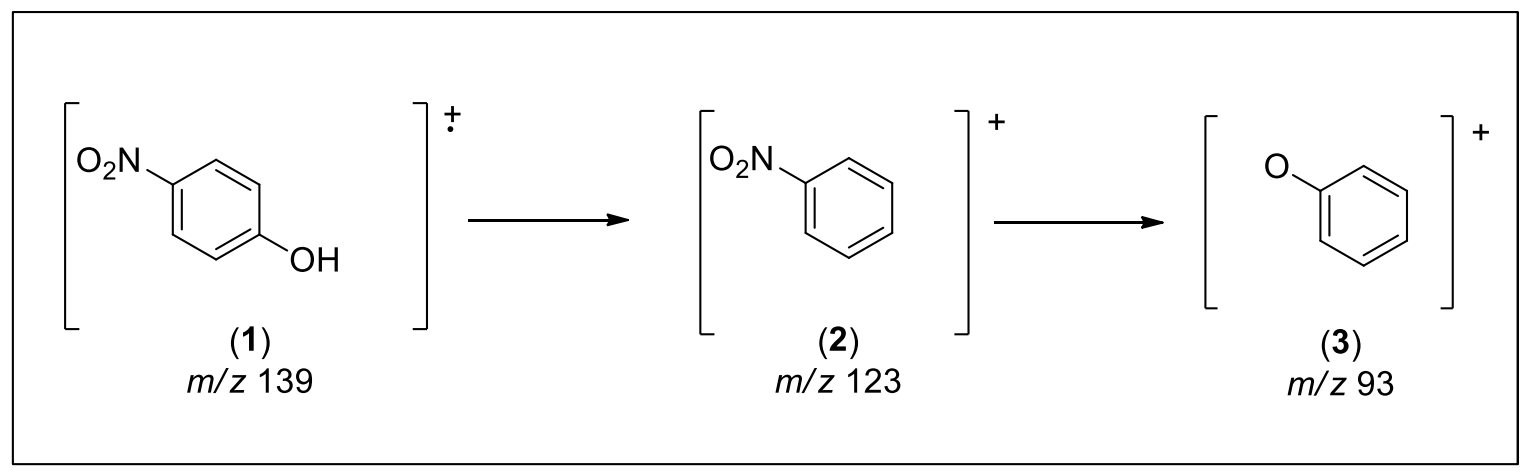

Fonte: Autoria própria.

A Figura 111 mostra o cromatograma obtido por CG-EM das extrações do caldo enzimático para o metabólito 1-metoxi-4-nitrobenzeno oriundo da metilação enzimática do composto fenólico 4-nitrofenol na reação de biotransformação do pesticida comercial metil paration com o fungo A. sydowii CBMAI 935 em 10 dias. E, a Figura 112 mostra o espectro de massas obtido por CG-EM (70 eV) para o metabólito 1-metoxi-4-nitrobenzeno das extrações do caldo enzimático do A. sydowii CBMAI 935 na presença do pesticida metil paration, durante 10 dias.

O cromatograma foi obtido a partir da Figura 93, selecionando apenas o sinal do composto com tempo de retenção em 17,700 minutos.

O sinal e o tempo de retenção do metabólito encontrados na reação foram comparados com o padrão sintético (Figuras 115 e 116) do 1-metoxi-4-nitrobenzeno. Os quais foram 
idênticos, confirmando a identidade do composto na amostra comercial que foi utilizada e encontrada nas reações de biotransformação.

Figura 111. Cromatograma selecionado do metabólito 1-metoxi-4-nitrobenzeno obtido por CG-EM das extrações do caldo enzimático do fungo A. sydowii CBMAI 935 na presença do pesticida comercial metil paration durante 10 dias.

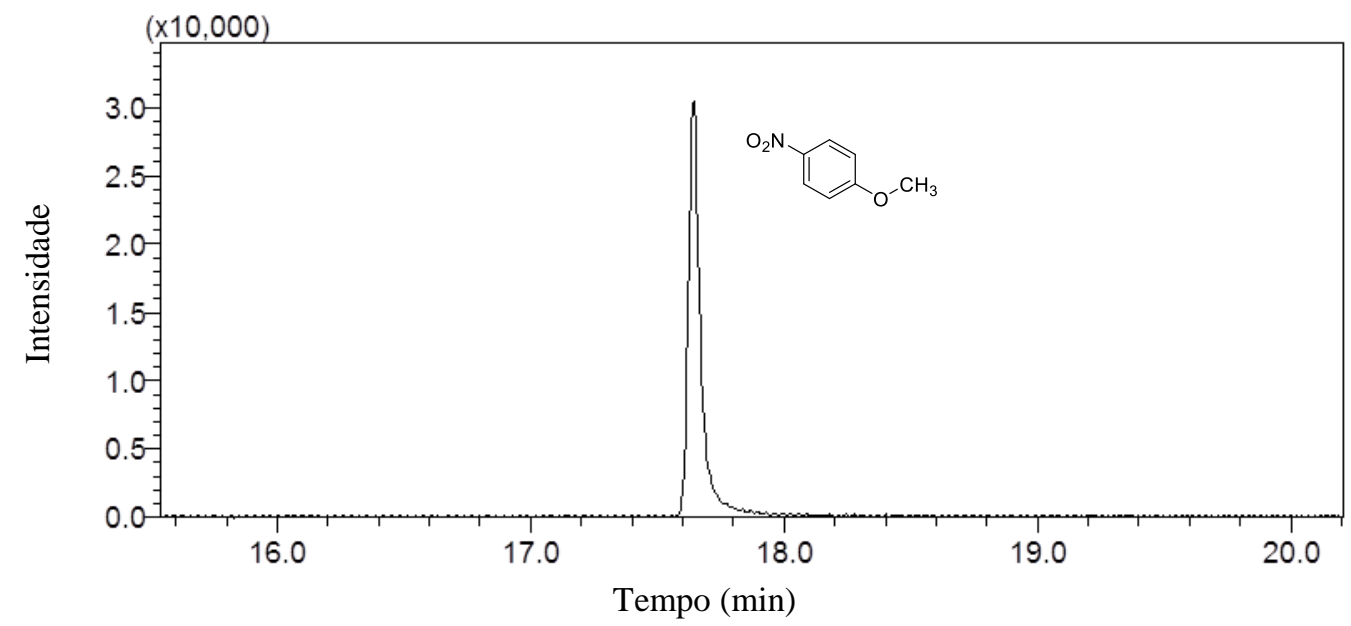

Condições de análise CG-EM: $\mathrm{T}_{\mathrm{i}}=60^{\circ} \mathrm{C}, 2 \mathrm{~min} ; \mathrm{T}_{\mathrm{f}}=280^{\circ} \mathrm{C}, 6 \mathrm{~min} ; \mathrm{r}=6^{\circ} \mathrm{C} / \mathrm{min}, \mathrm{t}_{\mathrm{c}}=45 \mathrm{mim}$. Coluna capilar DB-5 da J\&W Scientific ( $30 \mathrm{~m}$ x 0,25 mm x 0,25 $\mu \mathrm{m}$ ).

Figura 112. Espectro de massas obtido por CG-EM $(70 \mathrm{eV})$ para o metabólito 1-metoxi-4-nitrobenzeno das extrações do caldo enzimático do A. sydowii CBMAI 935 na presença do pesticida comercial metil paration durante 10 dias.

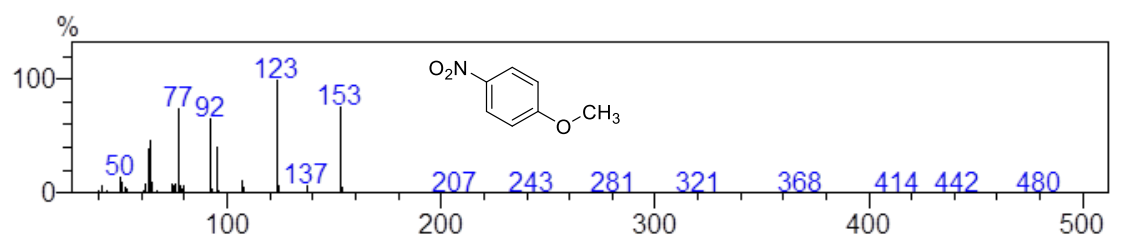

A Figura 113 mostra o cromatograma obtido por CG-EM das extrações do caldo enzimático para o metabólito fosforotioato de $O, O, O$-trimetila com o fungo de ambiente marinho A. sydowii CBMAI 935 em 10 dias de reação de biotransformação. E, a Figura 114 mostra o espectro de massas obtido em CG-EM $(70 \mathrm{eV})$ para o do metabólito fosforotioato de O,O,O-trimetila nas extrações do micélio do A. sydowii CBMAI 935 em 10 dias de reação.

Os cromatogramas foram obtidos a partir da Figura 93, selecionando apenas o sinal do metabólito fosforotioato de $O, O, O$-trimetila com tempo de retenção em 7,570 minutos. 
Figura 113. Cromatograma selecionado do metabólito fosforotioato de $O, O, O$-trimetila obtido por CG-EM das extrações do caldo enzimático do A. sydowii CBMAI 935 em 10 dias de reação de biotransformação do pesticida comercial metil paration.

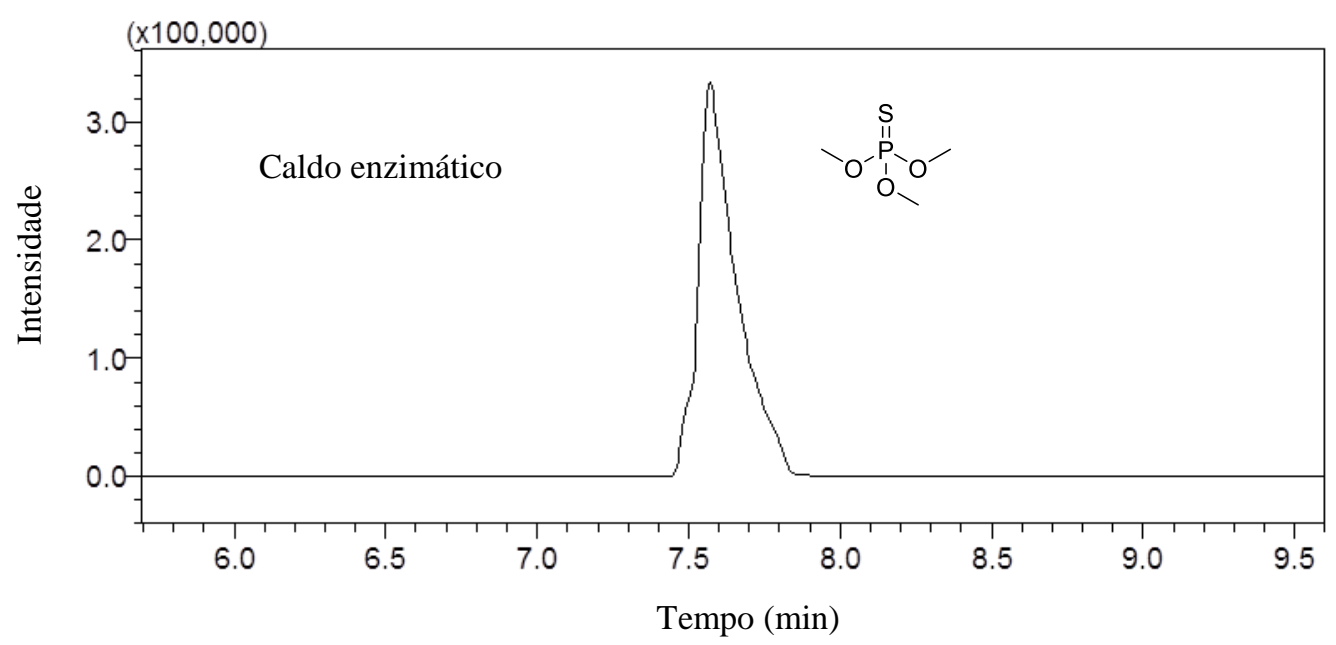

Condições de análise CG-EM: $\mathrm{T}_{\mathrm{i}}=60^{\circ} \mathrm{C}, 2 \mathrm{~min} ; \mathrm{T}_{\mathrm{f}}=280^{\circ} \mathrm{C}, 6 \mathrm{~min} ; \mathrm{r}=6^{\circ} \mathrm{C} / \mathrm{min}, \mathrm{t}_{\mathrm{c}}=45 \mathrm{mim}$. Coluna capilar DB-5 da J\&W Scientific (30 m x 0,25 mm x 0,25 $\mu \mathrm{m})$.

Figura 114. Espectro de massas obtido por CG-EM $(70 \mathrm{eV})$ para o metabólito fosforotioato de $O, O, O$-trimetila nas extrações do caldo enzimático do A. sydowii CBMAI em 10 dias do pesticida comercial metil paration.

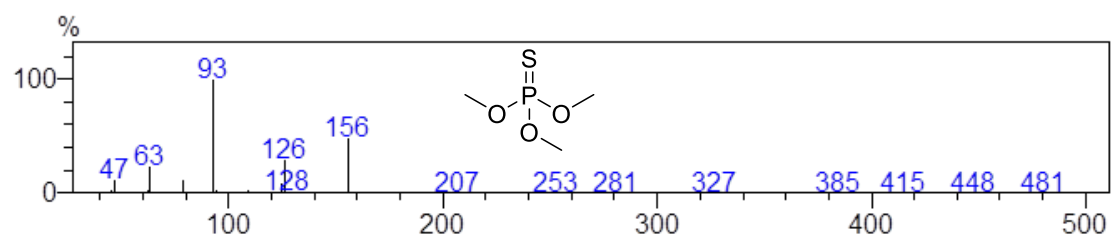

A Figura 115 mostra o cromatograma obtido por CG-EM das extrações do caldo enzimático para o metabólito fosforotioato de $O, O, S$-trimetila com o fungo de ambiente marinho A. sydowii CBMAI 935 em 10 dias de reação de biotransformação. E, a Figura 116 mostra o espectro de massas obtido em CG-EM $(70 \mathrm{eV})$ para o metabólito fosforotioato de O,O,S-trimetila nas extrações do micélio do A. sydowii CBMAI 935 em 10 dias de reação.

O cromatograma foi obtido a partir da Figura 93, selecionando apenas o sinal do metabólito fosforotioato de $O, O, S$-trimetila com o tempo de retenção em 10,600 minutos. 
Figura 115. Cromatograma selecionado do metabólito fosforotioato de $O, O, S$-trimetila obtido por CG-EM das extrações do caldo enzimático do A. sydowii CBMAI 935 em 10 dias de reação de biotransformação do pesticida comercial metil paration.

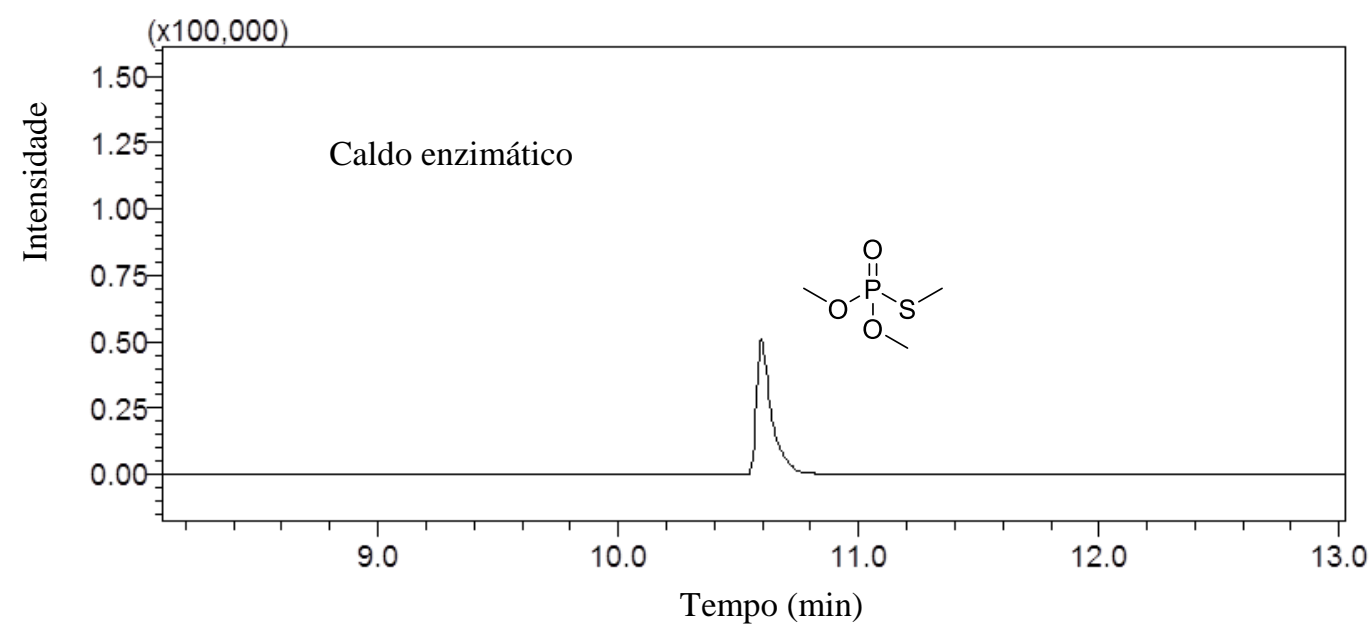

Condições de análise CG-EM: $\mathrm{T}_{\mathrm{i}}=60^{\circ} \mathrm{C}, 2 \mathrm{~min} ; \mathrm{T}_{\mathrm{f}}=280^{\circ} \mathrm{C}, 6 \mathrm{~min} ; \mathrm{r}=6^{\circ} \mathrm{C} / \mathrm{min}, \mathrm{t}_{\mathrm{c}}=45 \mathrm{mim}$.

Coluna capilar DB-5 da J\&W Scientific (30 m x 0,25 mm x 0,25 $\mu \mathrm{m})$.

Figura 116. Espectro de massas obtido em CG-EM $(70 \mathrm{eV})$ para o metabólito fosforotioato de $O, O, S$-trimetila nas extrações do caldo enzimático do A. sydowii CBMAI em 10 dias do pesticida comercial metil paration.

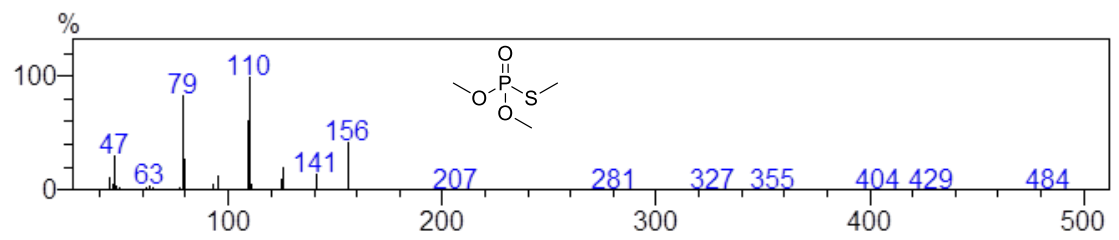




\subsubsection{Avaliação da biotransformação do metil paration em 20 e 30 dias de reação com} o fungo A. sydowii CBMAI 935

O mesmo comportamento para 20 e 30 dias de reação foi observado para 10 d. Obteve-se as mesmas reações de biotransformação e bioconjugação para o metil paration, não cabendo aqui detalhar os resultados uma vez que foram similares aos anteriores.

O Esquema 12 ilustra os mecanismos enzimáticos de enzimas fosfotriesterases e $O$ metiltransferases durante 10,20 e 30 dias de reação de biotransformação do pesticida organofosforado metil paration pesticida comercial com o fungo de ambiente marinho $A$. sydowii CBMAI 935.

Como foi descrito para o pesticida clorpirifós, as enzimas fosfotriesterases e metiltransferases atuam de forma similar para o metil paration. 
Esquema 12. Proposta de mecanismos enzimáticos de enzimas fosfotriesterases e metiltransferases durante 10 , 20 e 30 dias de reação de biotransformação do pesticida comercial metil paration com o fungo de ambiente marinho A. sydowii CBMAI 935.<smiles>COP(=S)(OC)Oc1ccc([N+](=O)[O-])cc1</smiles>

Metil paration
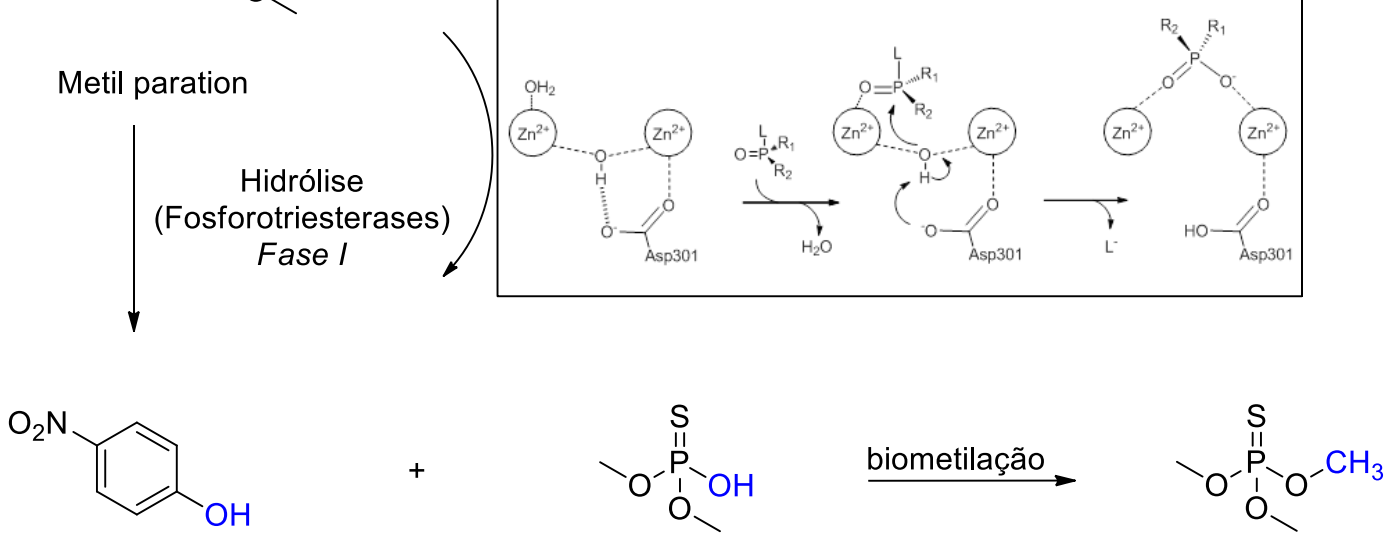

4-nitrofenol fosforotioato de O,O-dimetila O-hidrogênio fosforotioato de O,O,O-trimetila

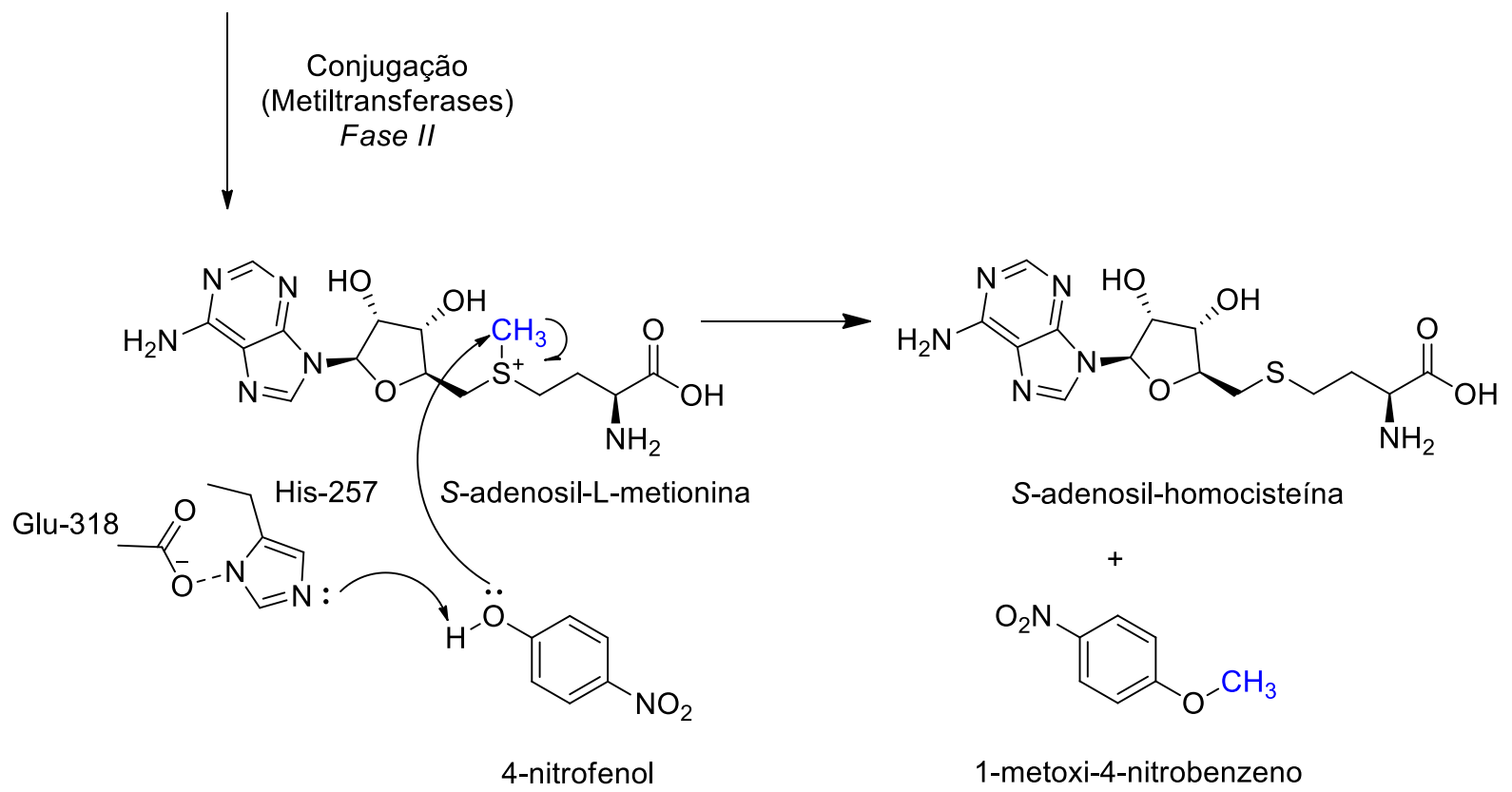

Fonte: Autoria própria. 


\subsubsection{Reações de biotransformação do pesticida organofosforado profenofós em 10, 20 e} 30 dias pelo fungo de ambiente marinho $A$. sydowii CBMAI 935

\subsubsection{Avaliação da biotransformação do profenofós em 10 dias de reação com o fungo}

\section{A. sydowii CBMAI 935}

Em 10 dias de reação de biotransformação do pesticida organofosforado profenofós com o fungo de ambiente marinho A. sydowii CBMAI 935 foram separados o caldo enzimático e o micélio do fungo e posteriormente submetidos às análises por CG-EM. Os cromatogramas das reações foram comparados com os cromatogramas da reação do controle biótico no qual o fungo A. sydowii CBMAI 935 cresceu por 10 dias na ausência do pesticida. Também foram feitas comparações com os cromatogramas das reações de controle abiótico no qual se utilizou o pesticida comercial profenofós em meio de cultura líquido de malte $2 \%$ na ausência do fungo em 10 dias de reação. Posteriormente foram feitas comparações com os cromatogramas dos padrões analíticos do pesticida profenofós e padrões analíticos dos metabólitos obtidos durante os 10 dias de reação de biotransformação.

A Figura 117 mostra a sobreposição dos cromatogramas das extrações do caldo enzimático (cor vermelha) e do micélio (cor preta) com o fungo A. sydowii CBMAI 935 na ausência do pesticida profenofós (reação de controle biótico) em 10 dias de reação e a Figura 118 mostra os mesmos cromatogramas, porém separados. Cromatograma (a) Extração do caldo enzimático e cromatograma (b) Extração do micélio. 
Figura 117. Cromatogramas obtidos por CG-EM das extrações do micélio (cor preta) e do caldo enzimático (cor vermelha) com o fungo A. sydowii CBMAI 935 na ausência do pesticida comercial profenofós (reação de controle biótico) durante 10 dias.

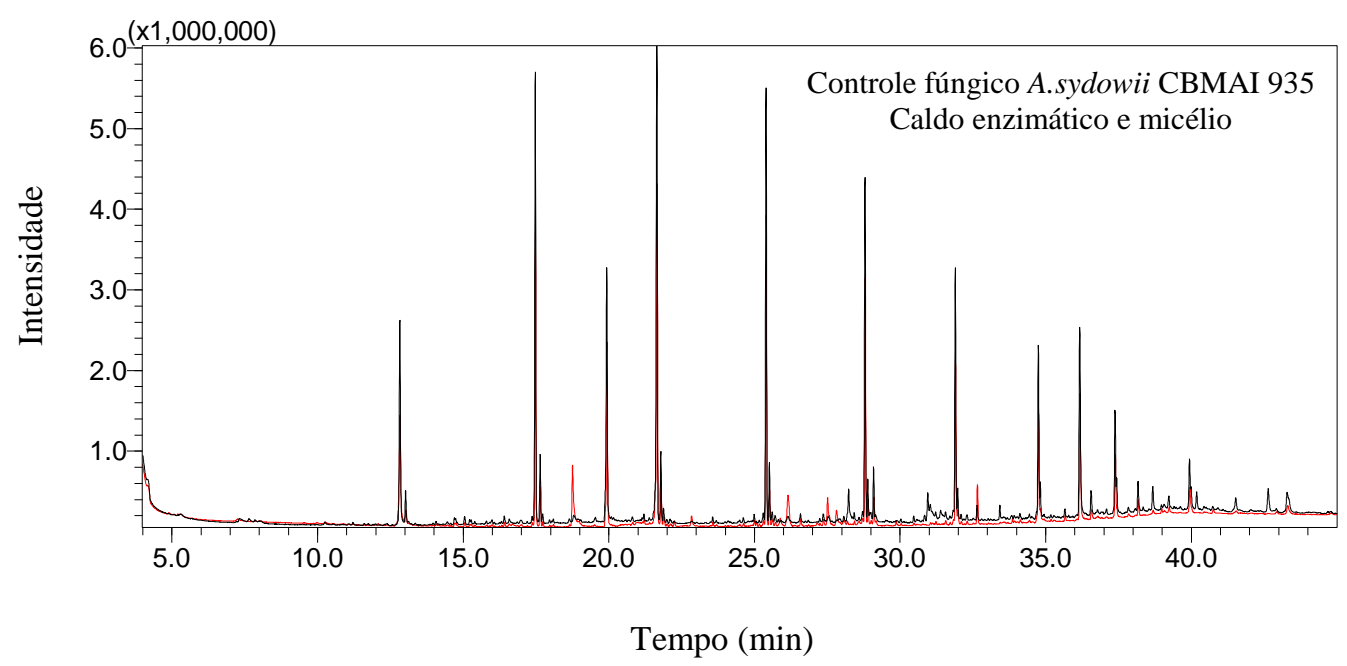

Condições de análise CG-EM: $\mathrm{T}_{\mathrm{i}}=60^{\circ} \mathrm{C}, 2 \mathrm{~min} ; \mathrm{T}_{\mathrm{f}}=280^{\circ} \mathrm{C}, 6 \mathrm{~min} ; \mathrm{r}=6^{\circ} \mathrm{C} / \mathrm{min}, \mathrm{t}_{\mathrm{c}}=45 \mathrm{mim}$.

Coluna capilar DB-5 da J\&W Scientific (30 m x 0,25 mm x 0,25 $\mu \mathrm{m})$.

Figura 118. Cromatogramas obtidos por CG-EM das extrações do micélio e do caldo enzimático do fungo $A$. sydowii CBMAI 935 na ausência do pesticida comercial profenofós (reação de controle biótico) durante 10 dias.

(a) Extração do caldo enzimático e (b) Extração do micélio.

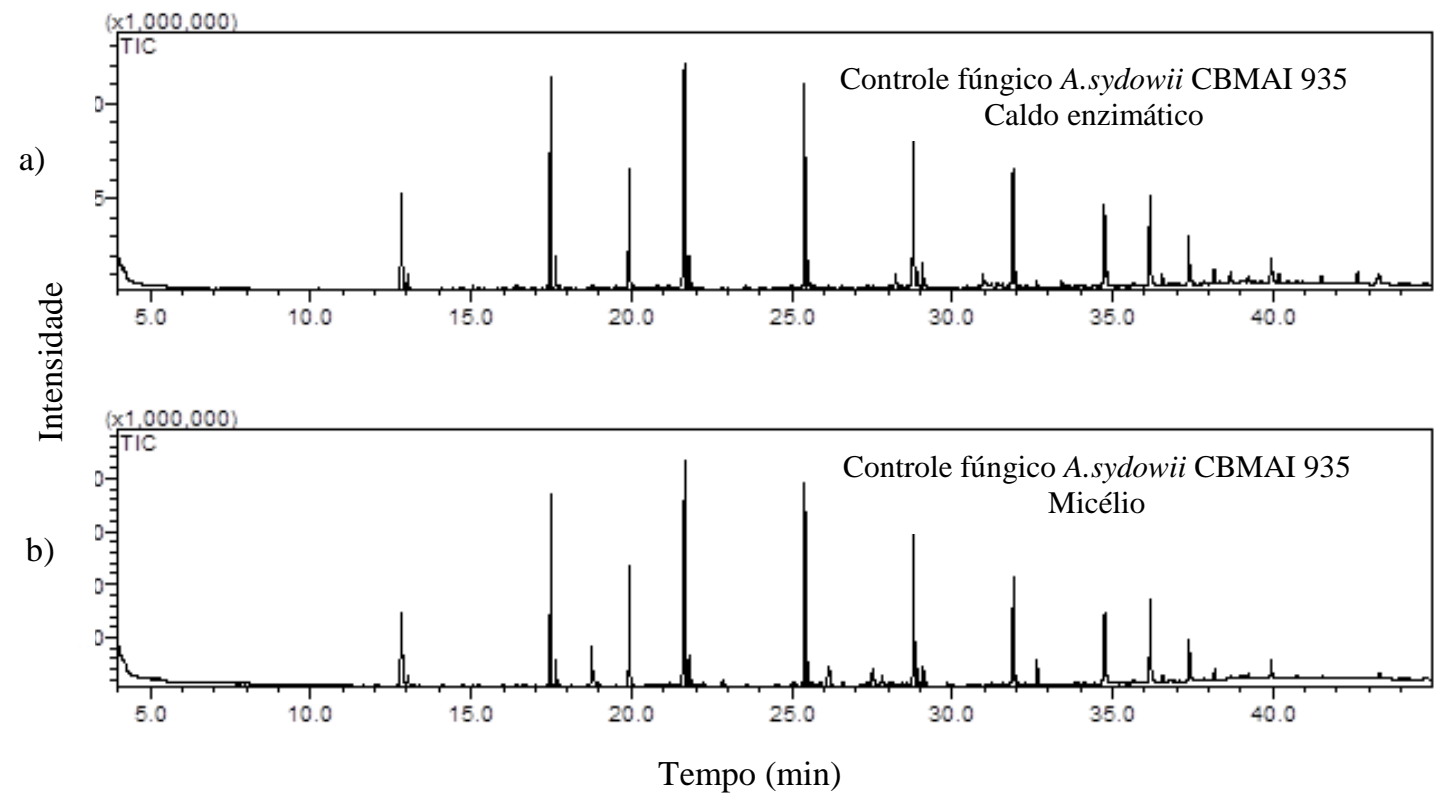

Condições de análise CG-EM: $\mathrm{T}_{\mathrm{i}}=60^{\circ} \mathrm{C}, 2 \mathrm{~min} ; \mathrm{T}_{\mathrm{f}}=280^{\circ} \mathrm{C}, 6 \mathrm{~min} ; \mathrm{r}=6^{\circ} \mathrm{C} / \mathrm{min}, \mathrm{t}_{\mathrm{c}}=45 \mathrm{mim}$.

Coluna capilar DB-5 da J\&W Scientific (30 m x 0,25 mm x 0,25 $\mu \mathrm{m})$. 
Os cromatogramas obtidos por CG-EM das reações em triplicatas com o fungo A. sydowii CBMAI 935 na ausência do pesticida apresentaram semelhanças quanto à presença de metabólitos provenientes do fungo. O cromatograma com a extração do caldo enzimático apresentou menor intensidade qualitativa dos sinais quando comparado com o cromatograma da extração do micélio (Figuras 117 e 118).

A Figura 119 mostra a sobreposição do cromatograma obtido por CG-EM da reação de controle biótico (cor vermelha) e o cromatograma da reação do pesticida profenofós (cor preta) com concentração de $50 \mathrm{mg} . \mathrm{L}^{-1}$ em 10 dias de reação de biotransformação com o fungo A. sydowii CBMAI 935. Os cromatogramas foram sobrepostos para a comparação qualitativa das intensidades dos sinais dos metabólitos formados naturalmente pelo fungo e os metabólitos formados por ação enzimática do fungo e o pesticida profenofós.

Figura 119. Cromatograma obtido por CG-EM da reação de controle biótico do fungo A. sydowii CBMAI 935 e o pesticida comercial profenofós durante 10 dias.

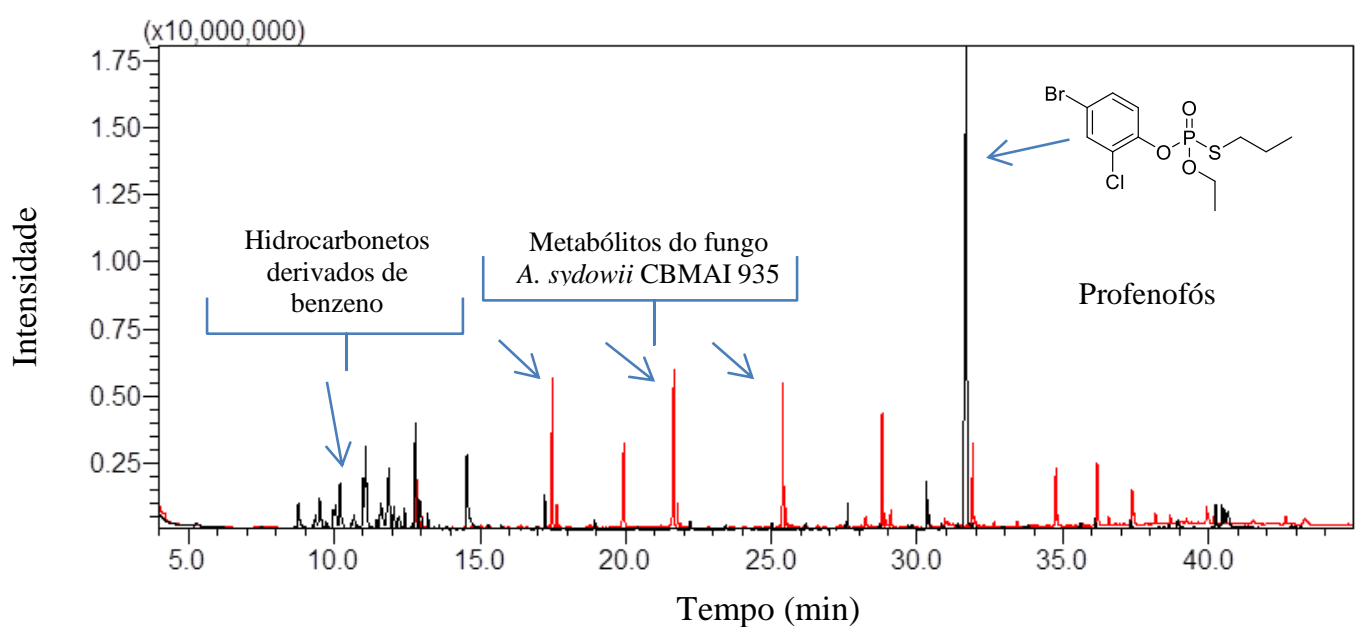

Condições de análise CG-EM: $\mathrm{T}_{\mathrm{i}}=60^{\circ} \mathrm{C}, 2 \mathrm{~min} ; \mathrm{T}_{\mathrm{f}}=280^{\circ} \mathrm{C}, 6 \mathrm{~min} ; \mathrm{r}=6^{\circ} \mathrm{C} / \mathrm{min}, \mathrm{t}_{\mathrm{c}}=45 \mathrm{mim}$.

Coluna capilar DB-5 da J\&W Scientific (30 $\mathrm{m}$ x 0,25 mm x 0,25 $\mu \mathrm{m})$.

A Figura 120 mostra o cromatograma obtido por CG-EM da reação de controle abiótico. Neste caso utilizou-se o pesticida comercial profenofós em meio de cultura líquido de malte 2\% na ausência do fungo A. sydowii CBMAI 935 durante 10 dias de reação, para verificar se o mesmo era estável nas condições utilizadas $\left(32^{\circ} \mathrm{C}, \mathrm{pH} 7\right)$. O pesticida comercial profenofós apresentou o sinal no tempo de retenção em 31,816 minutos. Segundo informações do fabricante, a composição dos ingredientes ativos do pesticida profenofós comercialmente chamado Polytrin, de acordo com Syngenta, ${ }^{\circledR} 129$ possui $652 \mathrm{~g} / \mathrm{L}(65,2 \% \mathrm{~m} / \mathrm{v})$ de ingredientes inertes, $400 \mathrm{~g} / \mathrm{L}(40 \% \mathrm{~m} / \mathrm{v})$ de profenofós e $40 \mathrm{~g} / \mathrm{L}(4 \% \mathrm{~m} / \mathrm{v})$ do piretroide cipermetrina. ${ }^{129}$ 
O cromatograma do controle abiótico mostra que o pesticida comercial profenofós sofreu parcial degradação. Essa informação ficou evidente devido à presença do composto fenólico 4-bromo-2-clorofenol, tendo seu sinal no tempo de retenção em 14,620 minutos. Porém, não foram encontrados metabólitos conjugados que seriam produtos característicos de reações de fase II. Nesse caso específico, o composto 4-bromo-2-clorofenol foi formado devido à reação de hidrólise do pesticida prefenofós. Também foi encontrado o sinal característico no tempo de retenção em 40,677 minutos do piretroide de tipo II (cipermetrina), no qual o mesmo é descrito como ingrediente ativo do pesticida comercial profenofós. Os mecanismos de toxicidade dos piretroides são complexos e se tornam ainda mais complicados quando estes são formulados juntamente com outras classes de pesticidas. ${ }^{139}$

Figura 120. Cromatograma obtido por CG-EM da reação de controle abiótico do pesticida comercial profenofós na ausência do fungo A. sydowii CBMAI 935 durante 10 dias.

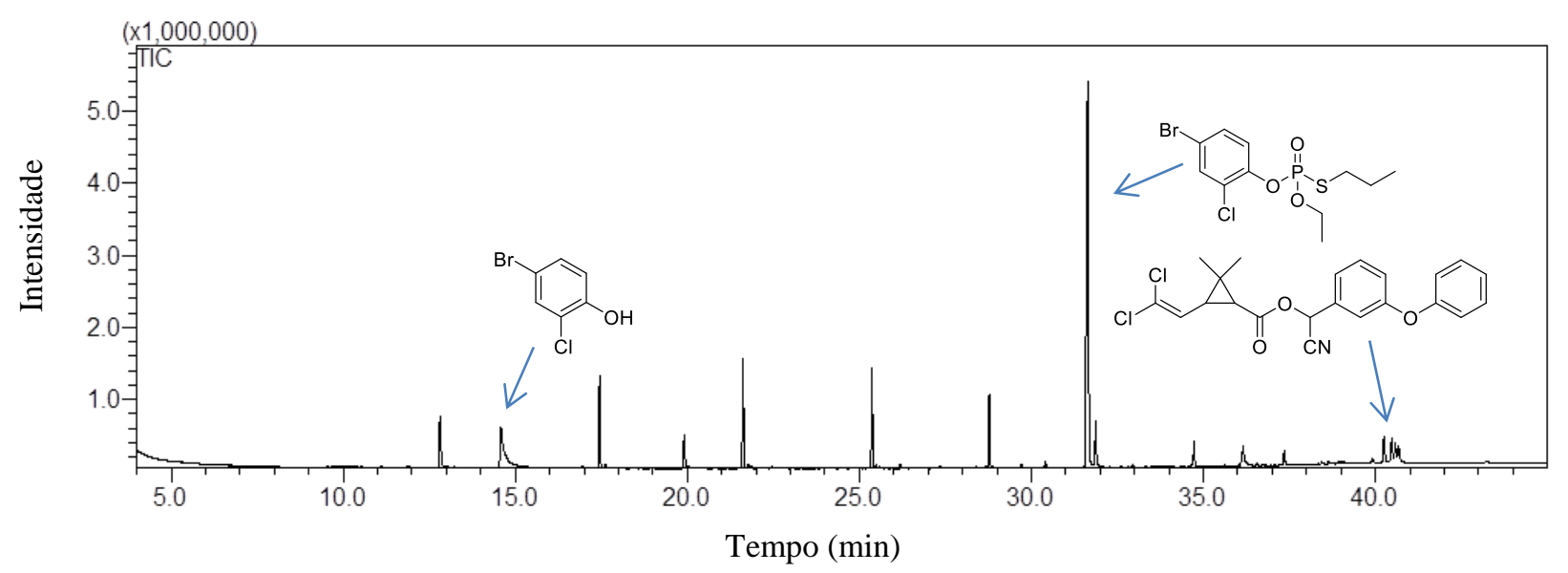

Condições de análise CG-EM: $\mathrm{T}_{\mathrm{i}}=60^{\circ} \mathrm{C}, 2 \mathrm{~min} ; \mathrm{T}_{\mathrm{f}}=280^{\circ} \mathrm{C}, 6 \mathrm{~min} ; \mathrm{r}=6^{\circ} \mathrm{C} / \mathrm{min}, \mathrm{t}_{\mathrm{c}}=45 \mathrm{mim}$.

Coluna capilar DB-5 da J\&W Scientific ( $30 \mathrm{~m}$ x $0,25 \mathrm{~mm}$ x $0,25 \mu \mathrm{m}$ ).

As Figuras 121 e 122 mostram o cromatograma e os espectros de massas (70 eV) obtidos por CG-EM do padrão analítico do pesticida profenofós que tem o seu sinal no tempo de retenção em 31,816 minutos. O cromatograma mostra que o padrão analítico do pesticida profenofós sofreu degradação. Essa informação foi evidente devido à presença do composto fenólico 4-bromo-2-clorofenol, tendo seu sinal característico no tempo de retenção em 14,620 minutos. Porém, não foram encontrados metabólitos conjugados que seriam produtos de reações de fase II. Esses resultados mostram qualitativamente que o pesticida profenofós possui estabilidade moderada. Nos experimentos de controle abiótico (ausência do fungo $A$. sydowii CBMAI 935) com o pesticida comercial profenofós, o mesmo sofreu degradação 
parcial (Figura 120). A diferença entre os dois padrões, está no fato do pesticida comercial profenofós conter o piretroide cipermetrina em sua formulação, enquanto que o padrão analítico possui apenas o pesticida profenofós.

Figura 121. Cromatograma obtido por CG-EM do padrão analítico do pesticida profenofós.

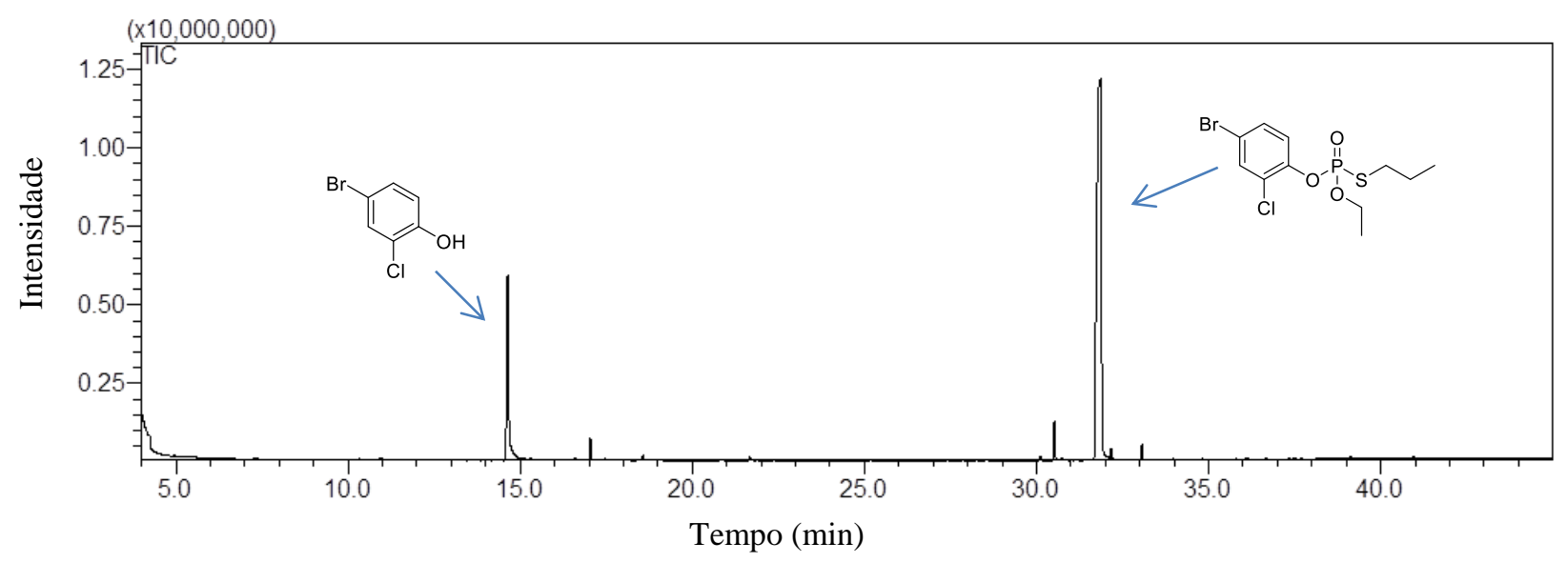

Condições de análise CG-EM: $\mathrm{T}_{\mathrm{i}}=60^{\circ} \mathrm{C}, 2 \mathrm{~min} ; \mathrm{T}_{\mathrm{f}}=280^{\circ} \mathrm{C}, 6 \mathrm{~min} ; \mathrm{r}=6^{\circ} \mathrm{C} / \mathrm{min}, \mathrm{t}_{\mathrm{c}}=45 \mathrm{mim}$.

Coluna capilar DB-5 da J\&W Scientific (30 m x 0,25 mm x 0,25 $\mu \mathrm{m}$ ).

Figura 122. Espectros de massas obtido por CG-EM $(70 \mathrm{eV})$ (a) para o padrão analítico do profenofós e (b) para o metabólito 4-bromo-2-clorofenol.

(a)

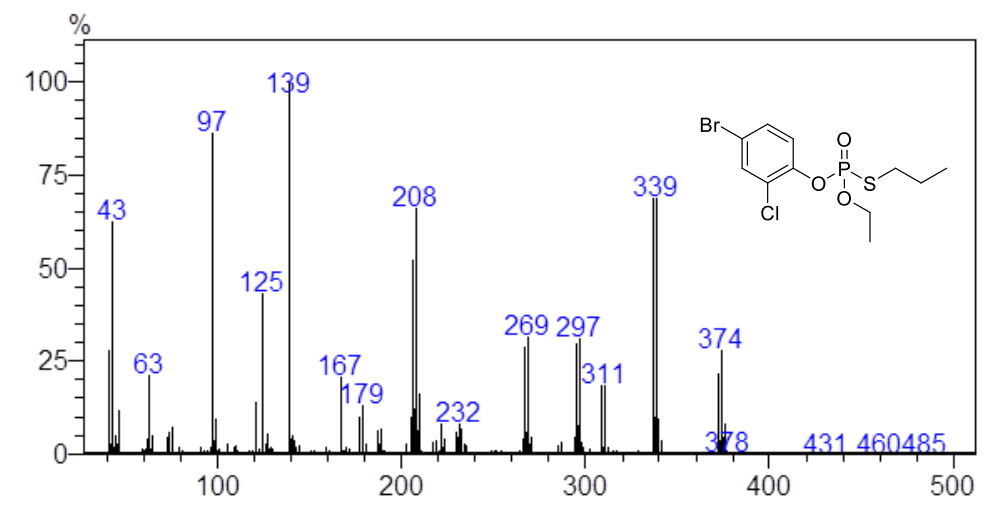

(b)

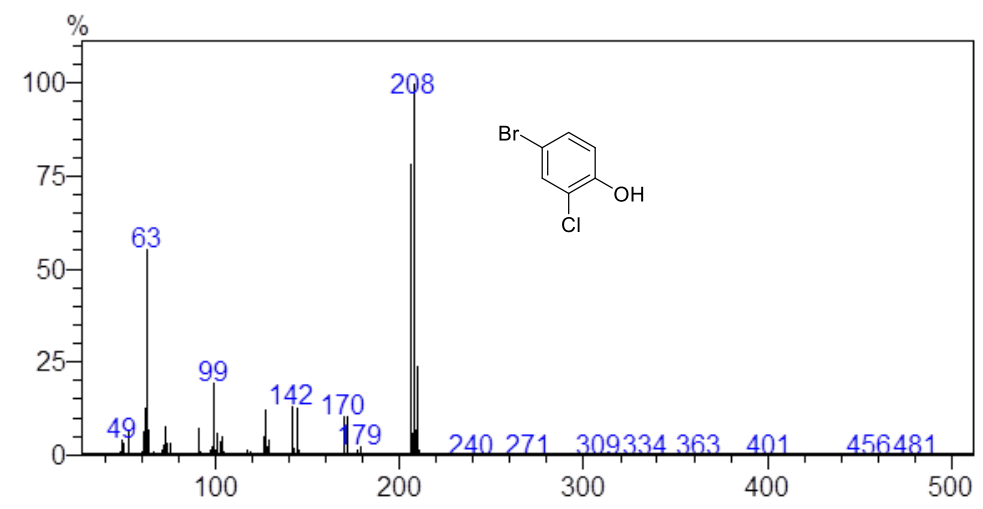


A Figura 123 mostra a sobreposição dos cromatogramas obtidos por CG-EM das extrações do caldo enzimático (cor vermelha) e do micélio (cor preta) com o fungo A. sydowii CBMAI 935 na presença de $50 \mathrm{mg} . \mathrm{L}^{-1}$ do pesticida comercial profenofós em 10 dias de reação e a Figura 124 mostra os mesmos cromatogramas, porém separados. Cromatograma (a) Extração do caldo enzimático e cromatograma (b) Extração do micélio. Durante esse período foi observado qualitativamente uma maior intensidade dos sinais do pesticida no micélio em comparação com o caldo enzimático.

Figura 123. Cromatograma obtido por CG-EM das extrações do micélio e do caldo enzimático do fungo $A$. sydowii CBMAI 935 na presença do pesticida comercial profenofós durante 10 dias.

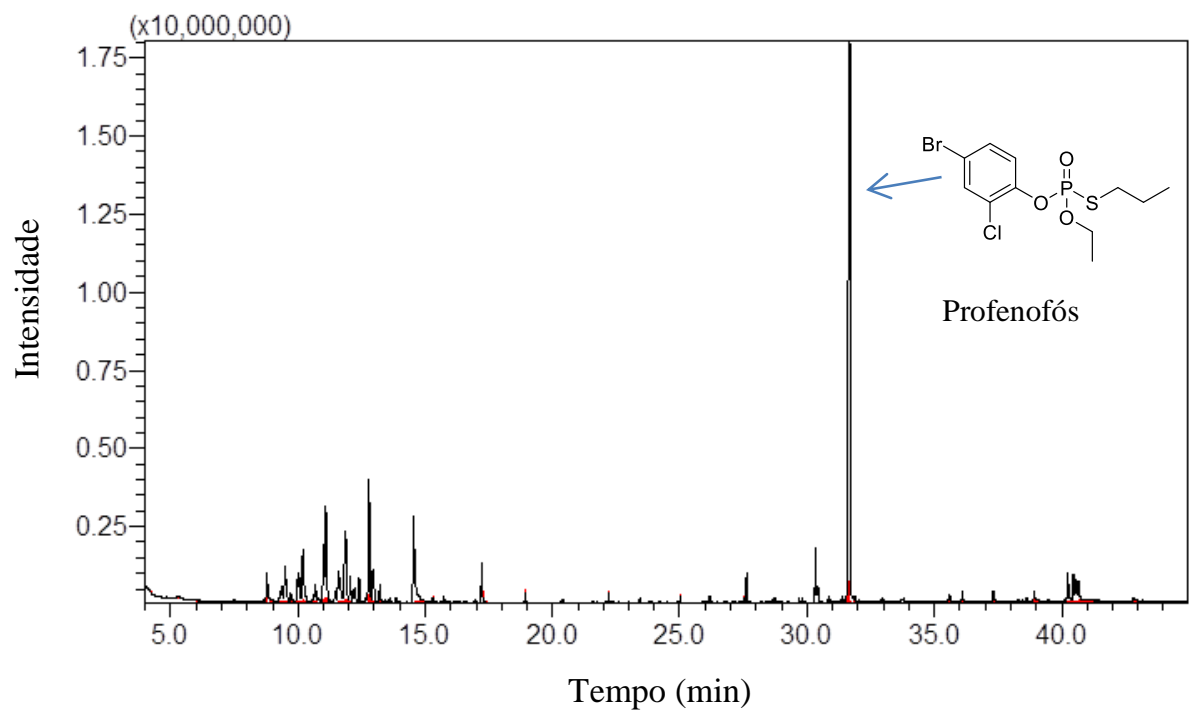

Condições de análise CG-EM: $\mathrm{T}_{\mathrm{i}}=60^{\circ} \mathrm{C}, 2 \mathrm{~min} ; \mathrm{T}_{\mathrm{f}}=280^{\circ} \mathrm{C}, 6 \mathrm{~min} ; \mathrm{r}=6^{\circ} \mathrm{C} / \mathrm{min}, \mathrm{t}_{\mathrm{c}}=45 \mathrm{mim}$. Coluna capilar DB-5 da J\&W Scientific ( $30 \mathrm{~m}$ x 0,25 mm x 0,25 $\mu \mathrm{m}$ ). 
Figura 124. Cromatogramas obtidos por CG-EM das extrações do micélio e do caldo enzimático do fungo $A$. sydowii CBMAI 935 na presença do pesticida comercial profenofós durante 10 dias. (a) Extração do caldo enzimático e (b) Extração do micélio.

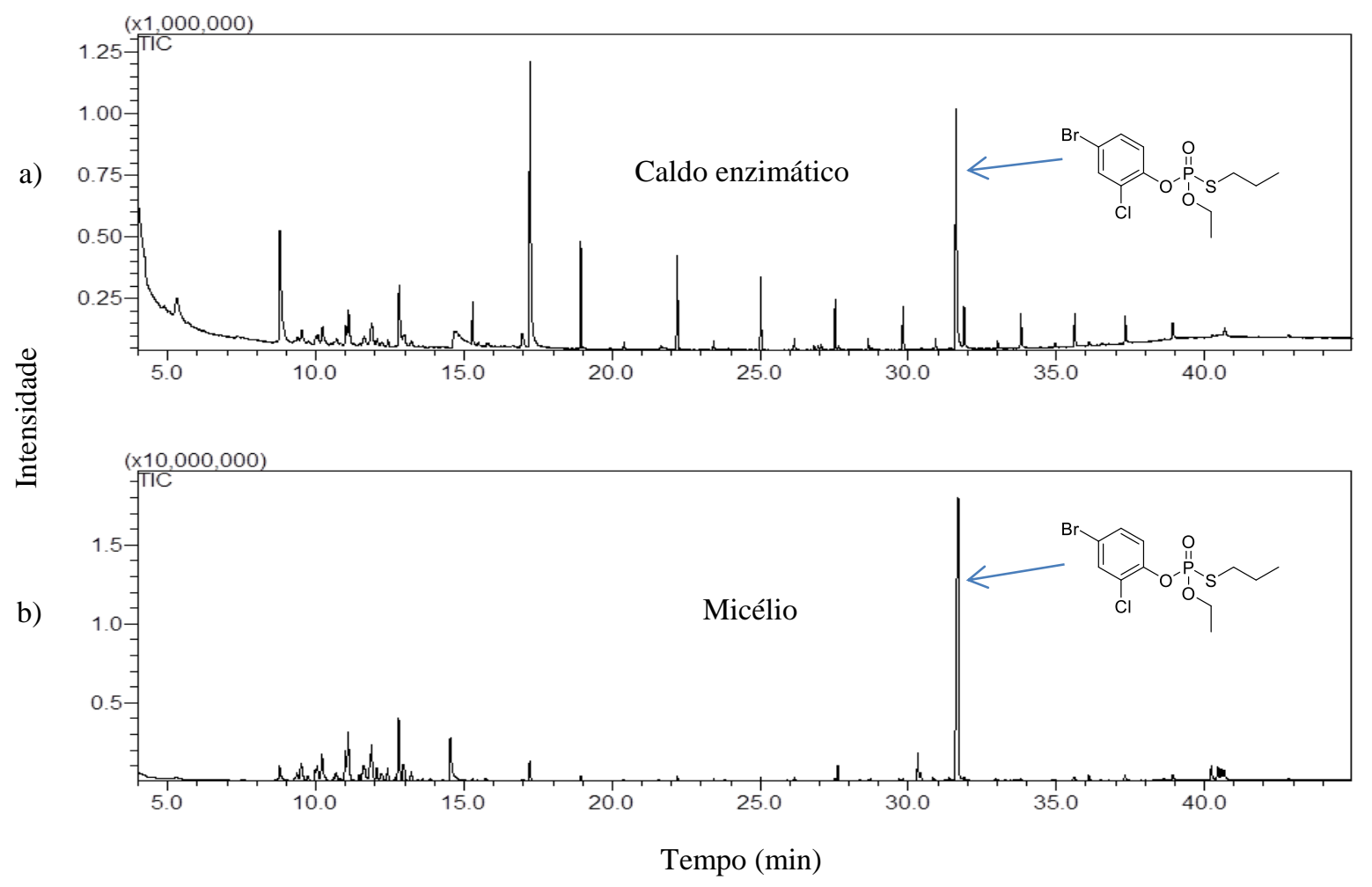

Condições de análise CG-EM: $\mathrm{T}_{\mathrm{i}}=60^{\circ} \mathrm{C}, 2 \mathrm{~min} ; \mathrm{T}_{\mathrm{f}}=280^{\circ} \mathrm{C}, 6 \mathrm{~min} ; \mathrm{r}=6^{\circ} \mathrm{C} / \mathrm{min}, \mathrm{t}_{\mathrm{c}}=45 \mathrm{mim}$. Coluna capilar DB-5 da J\&W Scientific (30 m x 0,25 mm x 0,25 $\mu \mathrm{m})$.

As Figuras 125 e 126 mostram os cromatogramas obtidos por CG-EM das extrações do caldo enzimático e extrações do micélio das reações de biotransformação do pesticida comercial profenofós pelo fungo A. sydowii CBMAI 935 durante 10 dias. Nos cromatogramas das extrações do caldo enzimático e do micélio observou-se a obtenção de vários metabólitos provenientes de biotransformação do pesticida comercial profenofós.

Nos cromatogramas notou-se a presença do profenofós juntamente com o metabólito 4bromo-2-clorofenol gerado pela ação de enzimas fosfotriesterases responsáveis pela reação de hidrólise (fase I) do pesticida e os metabólitos 4-bromo-2-cloro-1-metoxibenzeno e o fosforotioato de $O, O$-dietil-S-propila gerados por ação de enzimas transferases responsáveis pela transferência dos grupos etila e metila nos metabólitos aceptores do 4-bromo-2clorofenol e fosforotioato de $O$-etil-S-propila, gerando os metabólitos conjugados, característicos de reações de fase II.

Nas extrações do caldo enzimático e micélio foram detectados a presença dos metabólitos de fase I e faseII, derivados do pesticida comercial profenofós. Além do pesticida e seus 
metabólitos, foi encontrado nas extrações do micélio o sinal do piretroide cipermetrina e o metabólito 3-fenoxibenzaldeído oriundo da degradação da cipermetrina. O sinal do pesticida comercial profenofós foi detectado no tempo de retenção em 31,816 minutos, coincidindo como seria esperado com os tempos de retenção do padrão analítico do pesticida.

Figura 125. Cromatograma obtido por CG-EM das extrações do caldo enzimático do fungo A. sydowii CBMAI 935 na presença do pesticida comercial profenofós durante 10 dias.

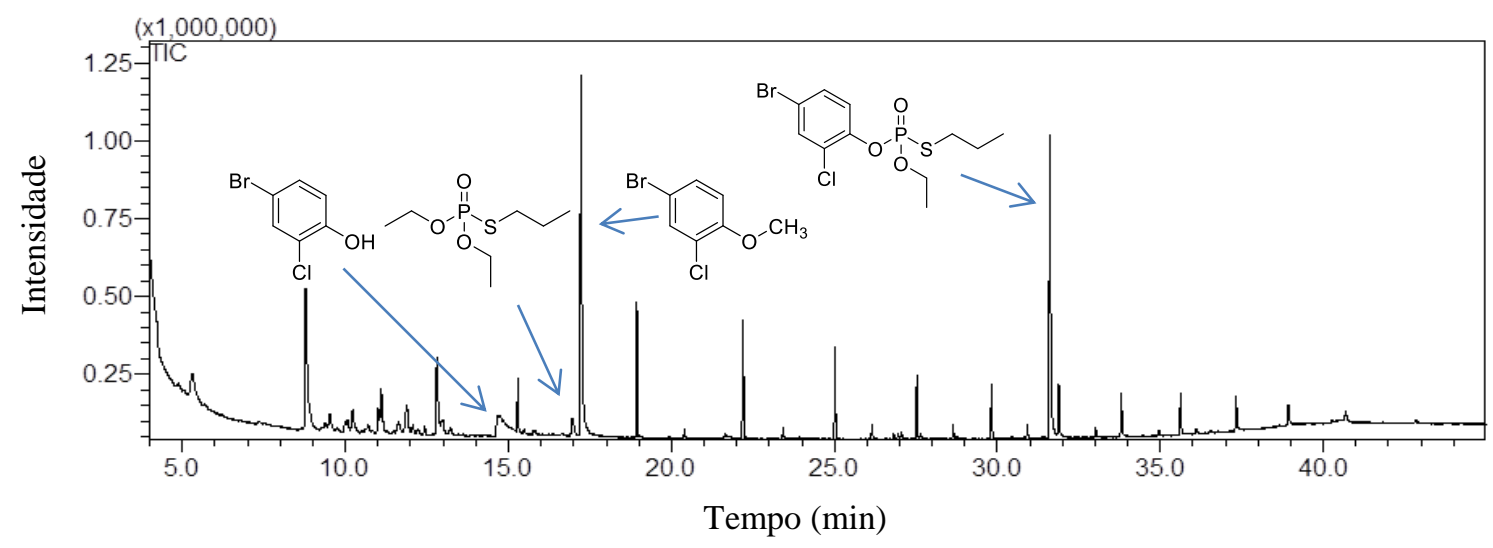

Condições de análise CG-EM: $\mathrm{T}_{\mathrm{i}}=60^{\circ} \mathrm{C}, 2 \mathrm{~min} ; \mathrm{T}_{\mathrm{f}}=280^{\circ} \mathrm{C}, 6 \mathrm{~min} ; \mathrm{r}=6^{\circ} \mathrm{C} / \mathrm{min}, \mathrm{t}_{\mathrm{c}}=45 \mathrm{mim}$.

Coluna capilar DB-5 da J\&W Scientific (30 m x 0,25 mm x 0,25 $\mu \mathrm{m}$ ).

Figura 126. Cromatograma obtido por CG-EM das extrações do micélio do fungo A. sydowii CBMAI 935 na presença do pesticida comercial profenofós durante 10 dias.

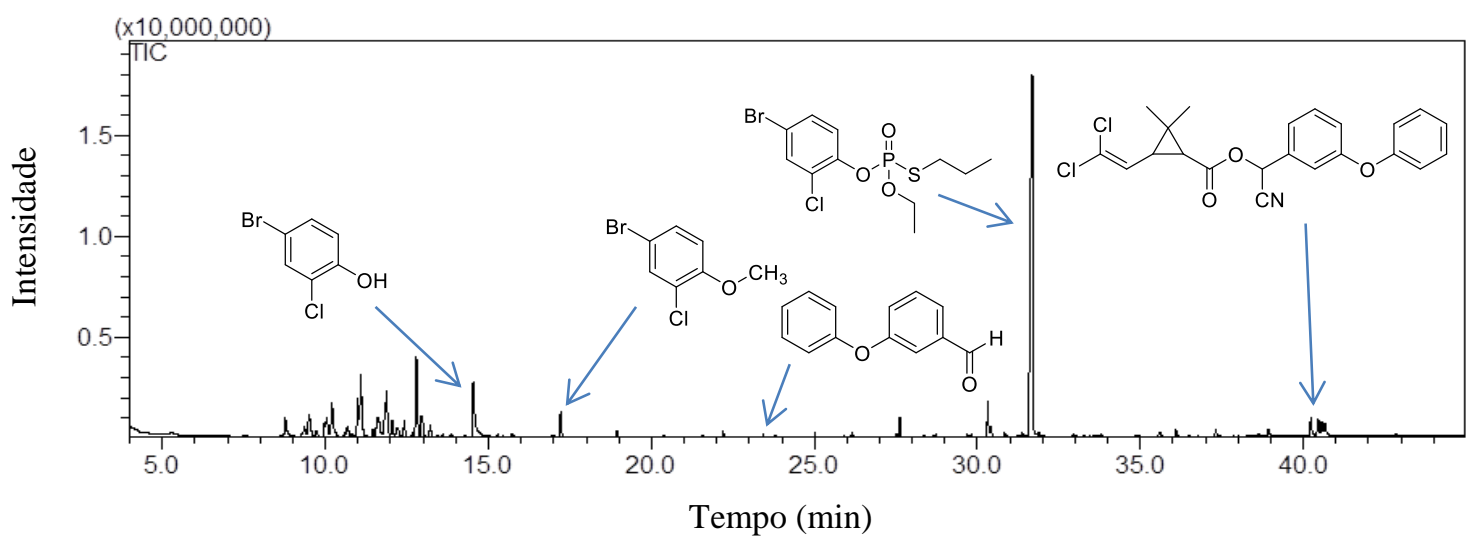

Condições de análise CG-EM: $\mathrm{T}_{\mathrm{i}}=60^{\circ} \mathrm{C}, 2 \mathrm{~min} ; \mathrm{T}_{\mathrm{f}}=280^{\circ} \mathrm{C}, 6 \mathrm{~min} ; \mathrm{r}=6^{\circ} \mathrm{C} / \mathrm{min}, \mathrm{t}_{\mathrm{c}}=45 \mathrm{mim}$.

Coluna capilar DB-5 da J\&W Scientific (30 m x 0,25 mm x 0,25 $\mu \mathrm{m})$.

O Esquema 13 mostra as possíveis reações de fase I e fase II (biotransformação e bioconjugação) do pesticida comercial profenofós por reações enzimáticas do fungo de ambiente marinho A. sydowii CBMAI 935. O Esquema 13 foi proposto a partir dos compostos 
identificados nos cromatogramas obtidos por CG-EM das extrações do micélio e do caldo emzimático do fungo A. sydowii CBMAI 935 na presença do pesticida comercial profenofós durante 10 dias.

Esquema 13. Proposta de reações e metabólitos de biotransformação de fase I e de fase II do pesticida comercial profenofós pelo fungo A. sydowii CBMAI 935 durante 10 dias.<smiles>CCCSP(=O)(OCC)Oc1ccc(Br)cc1Cl</smiles>

Profenofós

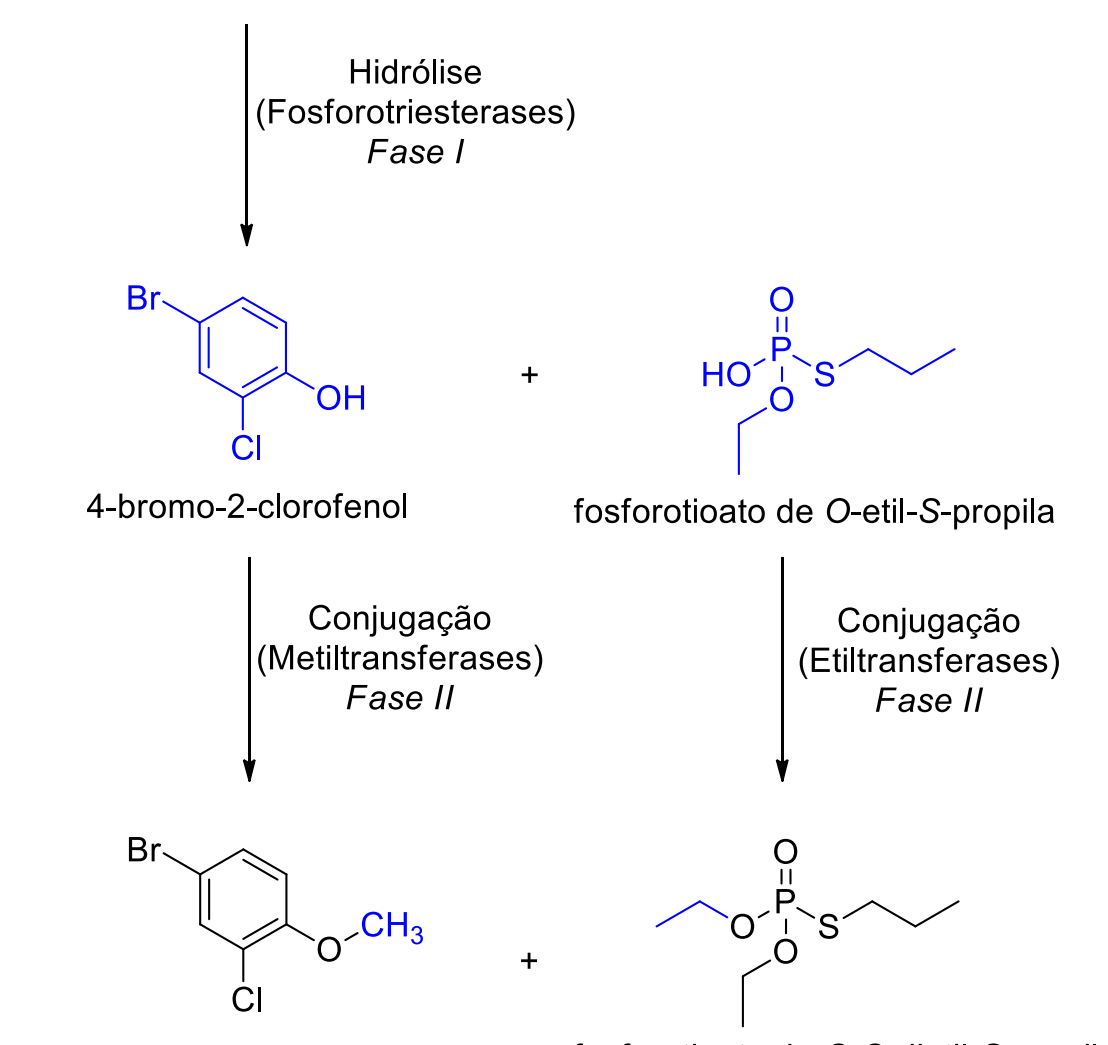

4-bromo-2-cloro-1-metoxibenzeno fosforotioato de O,O-dietil-S-propila

Fonte: Autoria própria 
O Esquema 14 mostra a possível rota de biodegradação do piretroide cipermetrina pelo fungo A. sydowii CBMAI 935. Sendo que este piretroide estava contido na formulação do pesticida comercial profenofós. O Esquema 14 foi proposto a partir do piretroide cipermetrina e seu metabólito 3-fenoxibenzaldeído, identificados nos cromatogramas obtidos por CG-EM das extrações do micélio e do caldo emzimático do fungo A. sydowii CBMAI 935 na presença do pesticida comercial profenofós, durante 10 dias.

Os piretroides são principalmente metabolizados por oxidação e clivagem da ligação éster, os quais são mediados por isoformas de citocromos e carboxilesterases, respectivamente. A resistência aos piretroides devido ao citocromo P450 é geralmente atribuída à super expressão destas enzimas. ${ }^{139,141}$ 
Esquema 14. Possível rota de biodegradação da ciepermetrina por microrganismos.

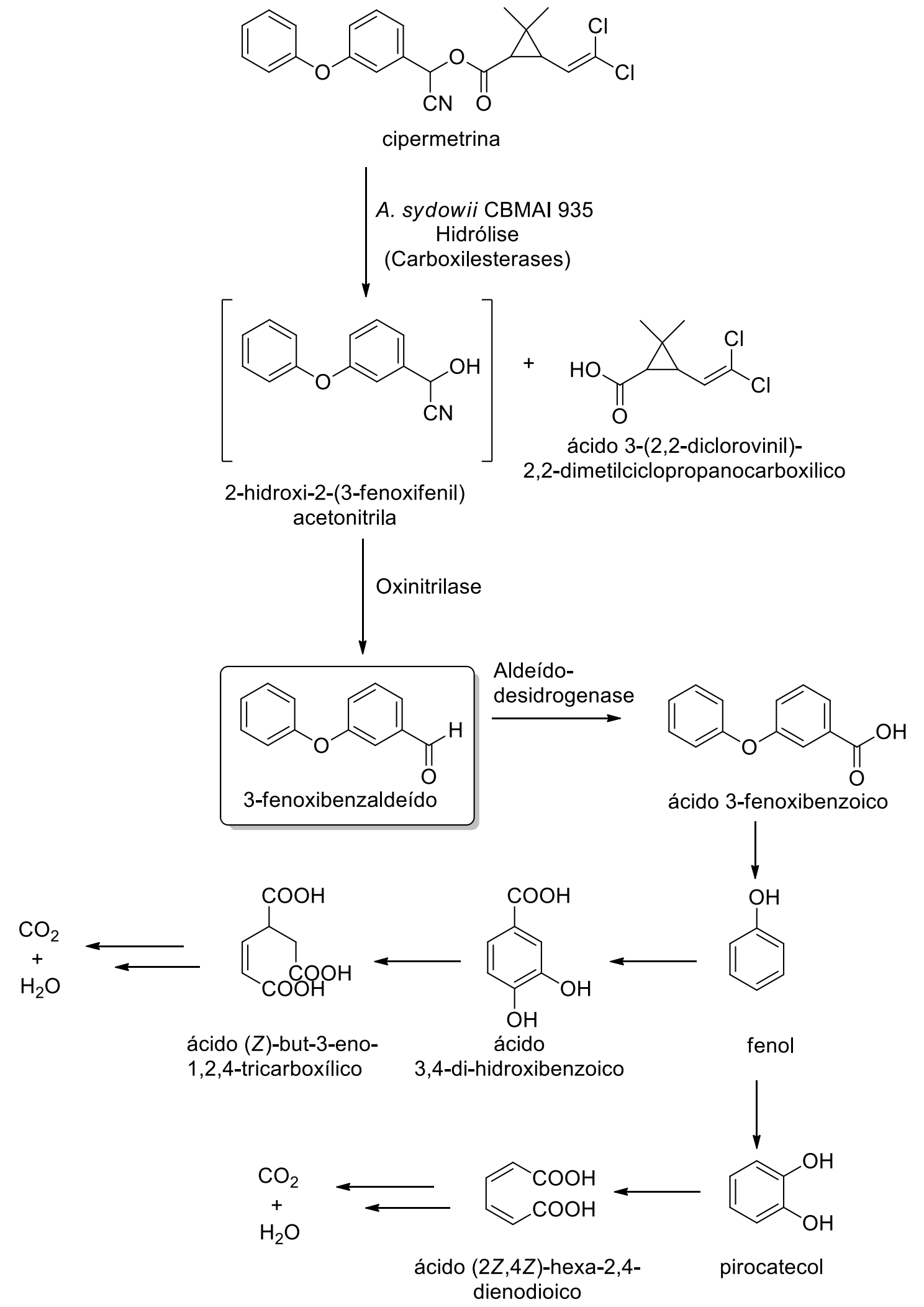

Fonte: Adaptado de TALLUR, P.N.; MEGADI, V.B.; NINNECKAR, H.Z. Biodegradation of cypermetrin by Micrococcus sp. Strain CPN 1. Biodegration, v.19, p. 77-82, 2008. ${ }^{140}$ 
A Figura 127 mostra o cromatograma obtido por CG-EM das extrações do caldo enzimático para o pesticida comercial do pesticida profenofós com o fungo de ambiente marinho A. sydowii CBMAI 935 em 10 dias de reação de biotransformação. E, a Figura 128 mostra o espectro de massas obtido por CG-EM $(70 \mathrm{eV})$ para o profenofós nas extrações do caldo enzimático do fungo A. sydowii CBMAI 935 em 10 dias de reação.

O cromatograma da Figura 127 foi obtido a partir da Figura 125, selecionando apenas o sinal do composto com tempo de retenção em 31,816 minutos.

O sinal, o tempo de retenção e o espectro de massas do pesticida profenofós encontrados na reação foram comparados com o padrão analítico do profenofós, os quais foram idênticos, confirmando a identidade do composto na amostra comercial que foi utilizada nas reações de biotransformação.

Figura 127. Cromatograma selecionado do pesticida comercial profenofós, obtido por CG-EM das extrações do caldo enzimático do fungo A. sydowii CBMAI 935 em 10 dias de reação de biotransformação.

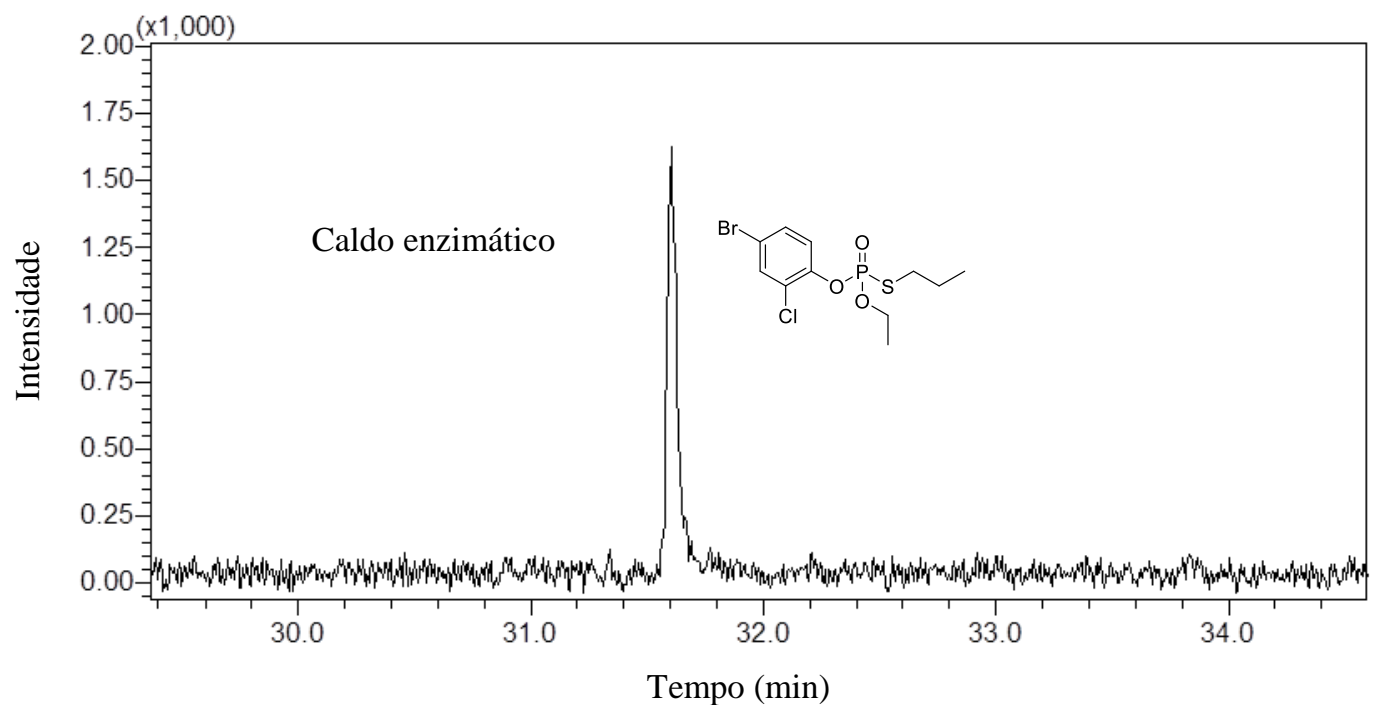

Condições de análise CG-EM: $\mathrm{T}_{\mathrm{i}}=60^{\circ} \mathrm{C}, 2 \mathrm{~min} ; \mathrm{T}_{\mathrm{f}}=280^{\circ} \mathrm{C}, 6 \mathrm{~min} ; \mathrm{r}=6^{\circ} \mathrm{C} / \mathrm{min}, \mathrm{t}_{\mathrm{c}}=45 \mathrm{mim}$.

Coluna capilar DB-5 da J\&W Scientific (30 m x 0,25 mm x 0,25 $\mu \mathrm{m}$ ). 
Figura 128. Espectro de massas obtido por CG-EM $(70 \mathrm{eV})$ para o pesticida comercial profenofós das extrações do caldo enzimático do fungo A. sydowii CBMAI 935 em 10 dias de reação de biotransformação.

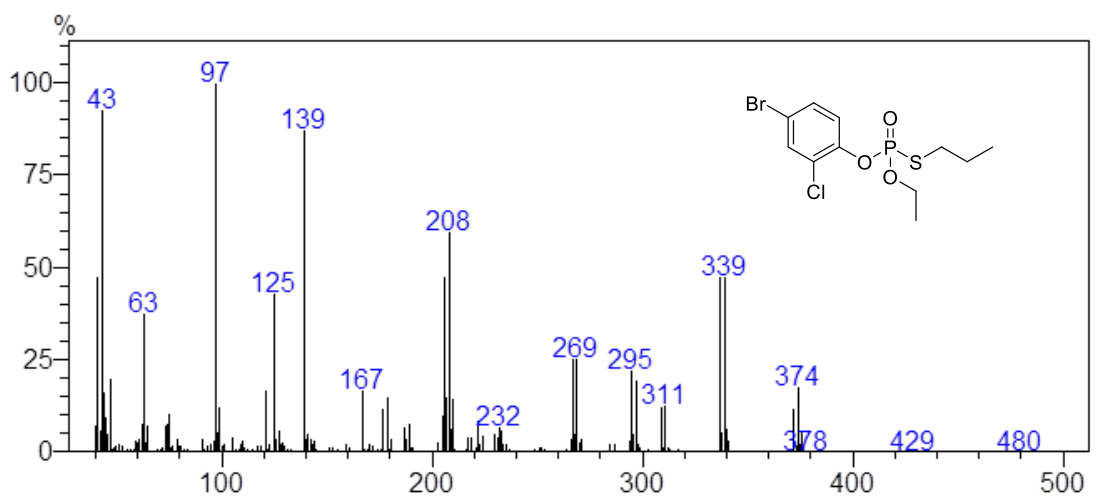

A Figura 129 mostra o cromatograma obtido por CG-EM das extrações do micélio para o pesticida comercial profenofós com o fungo de ambiente marinho A. sydowii CBMAI 935 em 10 dias de reação de biotransformação.

O cromatograma da Figura 129 foi obtido a partir da Figura 126, selecionando apenas o sinal do pesticida com tempo de retenção em 31,816 minutos. O sinal e o tempo de retenção do pesticida encontrados na reação foram comparados com o padrão analítico (Figuras 199 e 200) do profenofós, os quais foram idênticos, confirmando a identidade do composto na amostra comercial que foi utilizada nas reações de biotransformação.

Figura 129. Cromatograma selecionado do pesticida comercial profenofós obtido por CG-EM das extrações do micélio do fungo A. sydowii CBMAI 935 em 10 dias de reação de biotransformação.

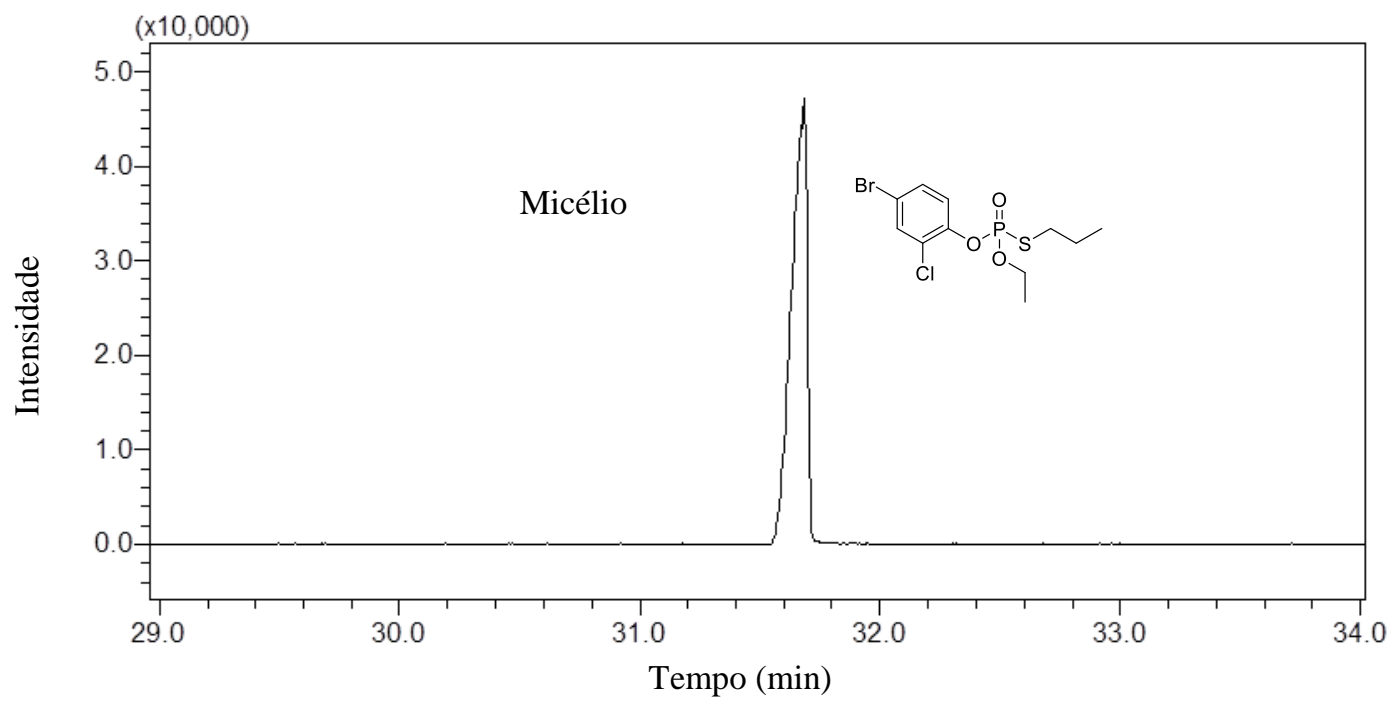

Condições de análise CG-EM: $\mathrm{T}_{\mathrm{i}}=60^{\circ} \mathrm{C}, 2 \mathrm{~min} ; \mathrm{T}_{\mathrm{f}}=280^{\circ} \mathrm{C}, 6 \mathrm{~min} ; \mathrm{r}=6^{\circ} \mathrm{C} / \mathrm{min}, \mathrm{t}_{\mathrm{c}}=45 \mathrm{mim}$.

Coluna capilar DB-5 da J\&W Scientific (30 m x 0,25 mm x 0,25 $\mu \mathrm{m}$ ). 
A Figura 130 mostra o espectro de massas obtido por CG-EM $(70 \mathrm{eV})$ do pesticida comercial profenofós nas extrações do micélio do fungo A. sydowii CBMAI 935 em 10 dias de reação de biotransformação. O íon molecular no espectro de massas do profenofós foi identificado com $\mathrm{m} / \mathrm{z} 374$ e intensidade de $30 \%$ (1). O pico com $\mathrm{m} / \mathrm{z}, 295$ e intensidade de $30 \%$ correspondente a molécula do pesticida com perda de um átomo de bromo (2). O fragmento com $m / z 208$ e intensidade de 74\%, que é correspondente ao 4-bromo-2-clorofenol com a saída do grupo $O, O$-dietil- $S$-propila (4). O fragmento com $\mathrm{m} / z, 97$ (3) pode ser correspondente de uma série de fragmentações da porção fosforotioato da molécula de pesticida, resultando em um pico com $100 \%$ de intensidade. O espectro descrito foi comparado com o espectro de massas do padrão analítico (Figura 200) do pesticida profenofós os quais foram idênticos, confirmando a identidade do composto na amostra comercial que foi utilizada nas reações de biotransformação.

Figura 130. Espectro de massas obtido por CG-EM $(70 \mathrm{eV})$ para o pesticida comercial profenofós nas extrações do micélio do fungo A. sydowii CBMAI 935 em 10 dias de reação de biotransformação.

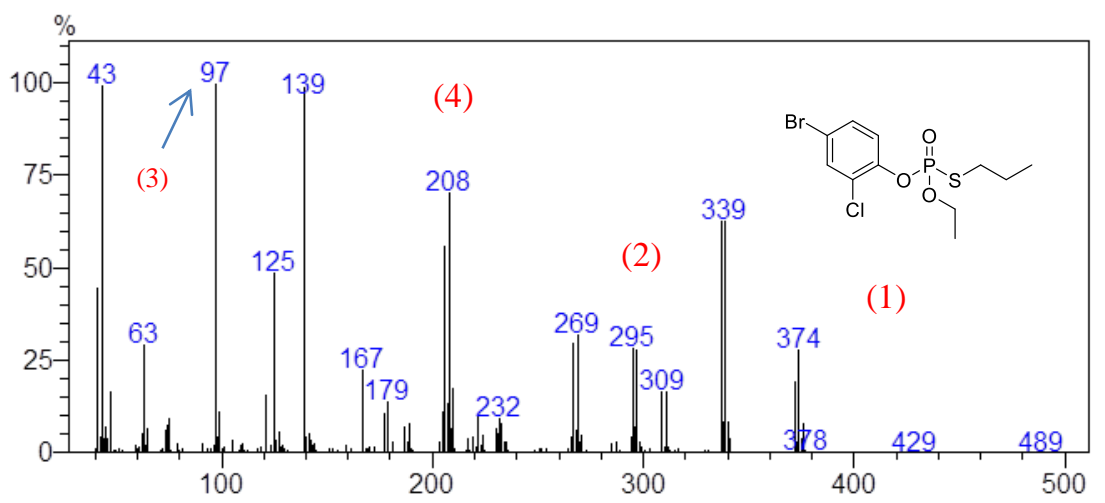

O Esquema 15 mostra a proposta de fragmentação para o profenofós obtido por CG-EM das extrações do micélio com o fungo de ambiente marinho A. sydowii CBMAI 935 em 10 dias de reação de biotransformação. 
Esquema 15. Proposta de fragmentação para o profenofós.

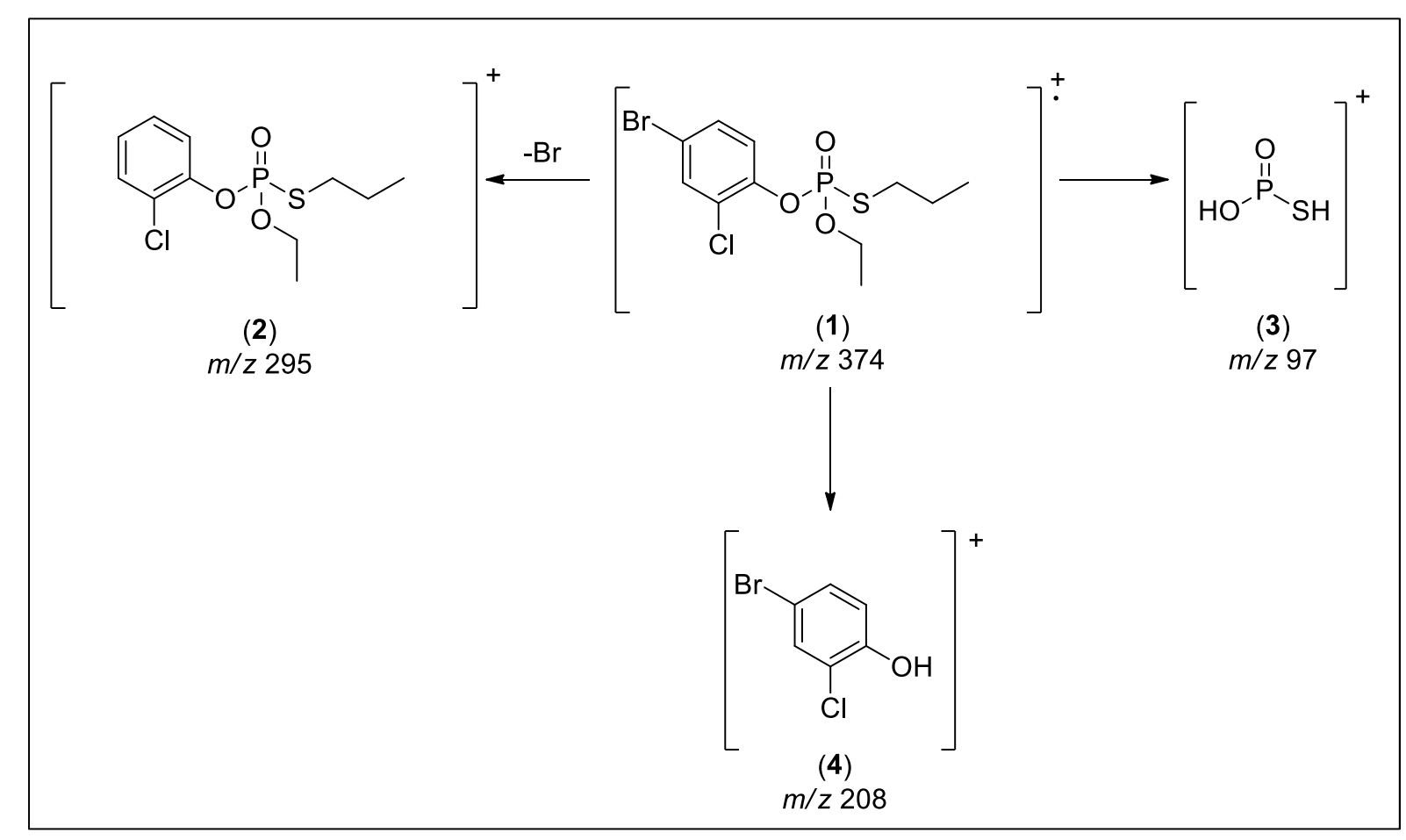

Fonte: Autoria própria.

A Figura 131 mostra o cromatograma obtido por CG-EM das extrações do caldo enzimático para o composto fenólico 4-bromo-2-clorofenol oriundo da hidrólise enzimática do pesticida comercial profenofós pelo fungo de ambiente marinho A. sydowii CBMAI 935 em 10 dias de reação de biotransformação. E, a Figura 132 mostra o espectro de massas obtido em CG-EM (70 eV) para o metabólito 4-bromo-2-clorofenol das extrações do caldo enzimático do A. sydowii CBMAI 935 na presença do pesticida comercial profenofós durante 10 dias.

O cromatograma da Figura 131 foi obtido a partir da Figura 125, selecionando apenas o sinal do composto fenólico 4-bromo-2-clorofenol com tempo de retenção em 14,620 minutos.

O sinal e o tempo de retenção do composto fenólico encontrado na reação foram comparados com o padrão analítico do 4-bromo-2-clorofenol, o qual foi idêntico, confirmando a identidade do composto na amostra comercial que foi utilizada nas reações de biotransformação. 
Figura 131. Cromatograma selecionado do metabólito 4-bromo-2-clorofenol obtido por CG-EM das extrações do caldo enzimático do fungo A. sydowii CBMAI 935 na presença do pesticida comercial profenofós durante 10 dias de reação de biotransformação.

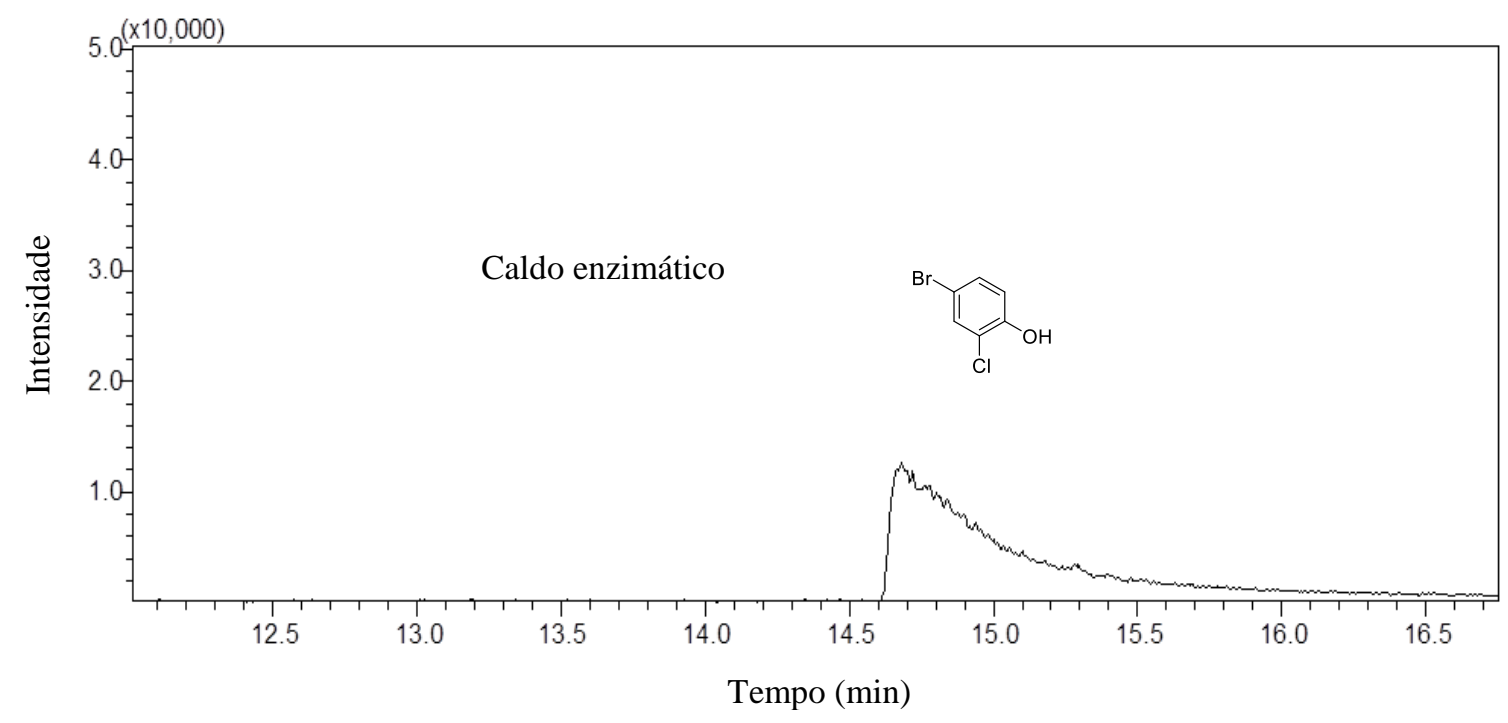

Condições de análise CG-EM: $\mathrm{T}_{\mathrm{i}}=60^{\circ} \mathrm{C}, 2 \mathrm{~min} ; \mathrm{T}_{\mathrm{f}}=280^{\circ} \mathrm{C}, 6 \mathrm{~min} ; \mathrm{r}=6^{\circ} \mathrm{C} / \mathrm{min}, \mathrm{t}_{\mathrm{c}}=45 \mathrm{mim}$.

Coluna capilar DB-5 da J\&W Scientific (30 m x 0,25 mm x 0,25 $\mu \mathrm{m})$.

Figura 132. Espectro de massas obtido por CG-EM $(70 \mathrm{eV})$ para o metabólito 4-bromo-2-clorofenol das extrações do caldo enzimático do fungo A. sydowii CBMAI 935 na presença do pesticida comercial profenofós durante 10 dias de reação de biotransformação.

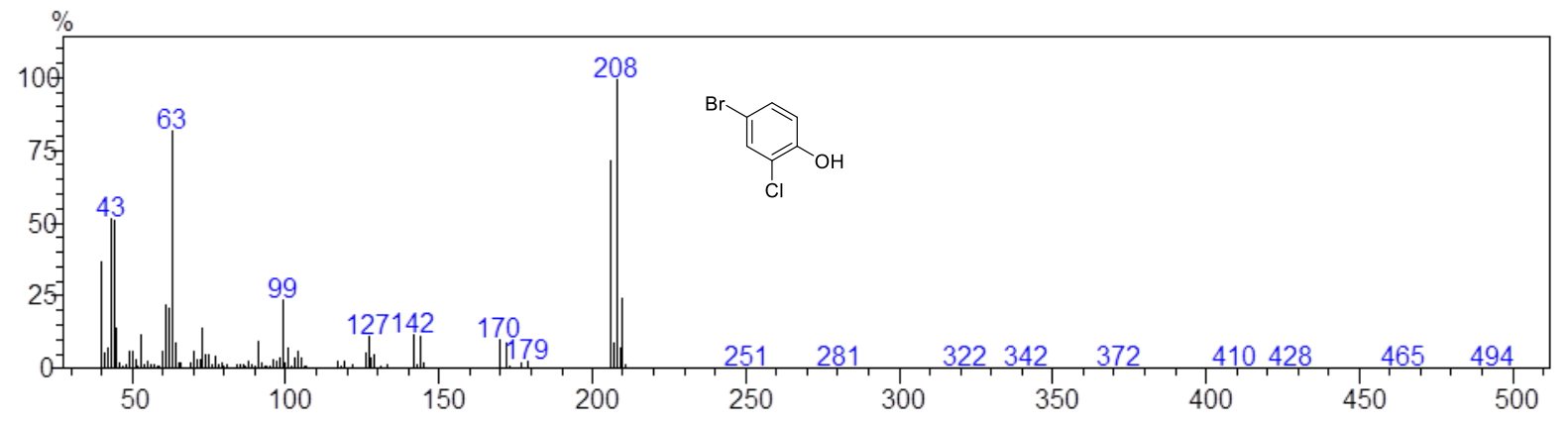


A Figura 133 mostra o espectro de massas obtido em CG-EM (70 eV) do metabólito 4bromo-2-clorofenol obtido da reação de biotranformação do pesticida comercial profenofós com o fungo A. sydowii CBMAI 935 em 10 dias.

O espectro de massas para o 4-bromo-2-clorofenol apresentou o pico do íon molecular intenso, característico de fenois. Com a maior intensidade, o pico do íon molecular foi também o pico base com fragmento de $m / z$ 208. Assim como na fragmentação do profenofós, o pico correspondente ao 4-bromo-2-clorofenol apresentou maior intensidade com $\mathrm{m} / \mathrm{z} 208$ (1), que é correspondente ao pico $\mathrm{M}+2$, com esta molécula apresentando abundâncias relativas dos picos $\mathbf{M}(\mathrm{m} / \mathrm{z}, 206), \mathbf{M}+2$ e $\mathbf{M}+4(\mathrm{~m} / \mathrm{z} 210)$ de aproximadamente 78,100 e 24\%, respectivamente.

A presença de um pico pouco intenso $(8 \%) \mathrm{com} \mathrm{m} / \mathrm{z} 170$ (2) pode representar a perda do átomo de cloro. O fragmento com $\mathrm{m} / \mathrm{z} 63$ (44\%) (3) pode ser resultante da perda de $\mathrm{CHO}$, característica para os fenois. O espectro descrito foi comparado com o espectro de massas do padrão analítico do composto fenólico 4-bromo-2-clorofenol.

Figura 133. Espectro de massas obtido por CG-EM (70 eV) para o metabólito 4-bromo-2-clorofenol das extrações do micélio do fungo A. sydowii CBMAI 935 na presença do pesticida comercial profenofós durante 10 dias de reação de biotransformação.

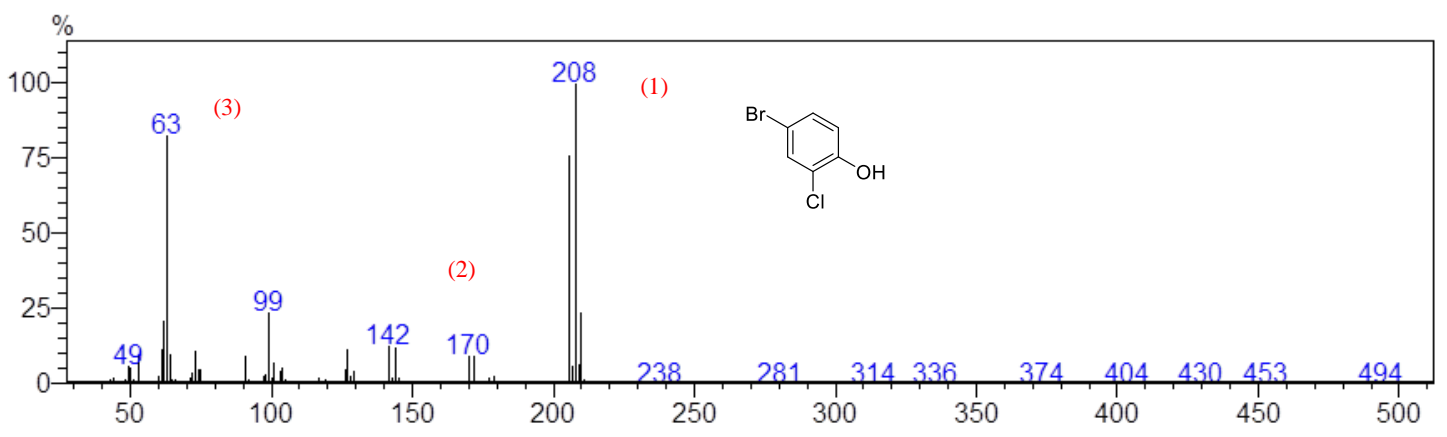

O Esquema 16 mostra a proposta de fragmentação para o 4-bromo-2-clorofenol obtido por CG-EM das extrações do micélio com o fungo de ambiente marinho A. sydowii CBMAI 935 em 10 dias de reação de biotransformação. 
Esquema 16. Proposta de fragmentação para o 4-bromo-2-clorofenol.

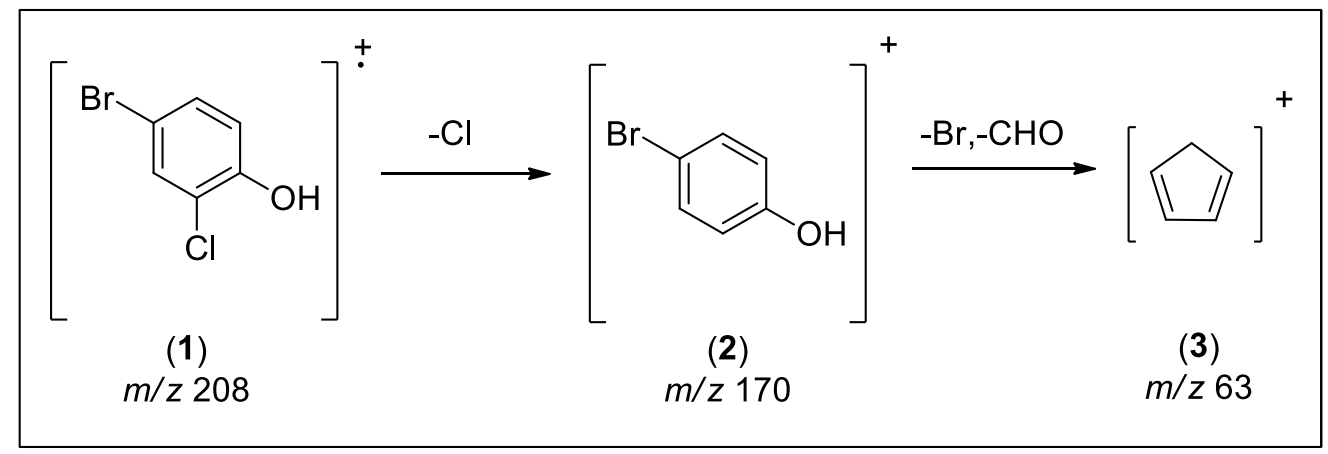

Fonte: Autoria Própria.

A Figura 134 mostra o cromatograma obtido por CG-EM das extrações do caldo enzimático para o metabólito 4-bromo-2-cloro-1-metoxibenzeno oriundo da metilação enzimática do composto fenólico 4-bromo-2-clorofenol na reação de biotransformação do pesticida comercial profenofós com o fungo A. sydowii CBMAI 935 em 10 dias.

O cromatograma da Figura 134 foi obtido a partir da Figura 123, selecionando apenas o sinal do composto com tempo de retenção em 17,360 minutos.

O sinal e o tempo de retenção do metabólito 4-bromo-2-cloro-1-metoxibenzeno encontrado na reação foram comparados com o padrão sintético (Figuras 222 e 223) do 4bromo-2-cloro-1-metoxibenzeno, os quais foram idênticos, confirmando a identidade do composto na amostra comercial que foi utilizada nas reações de biotransformação.

Figura 134. Cromatograma selecionado do metabólito 4-bromo-2-cloro-1-metoxibenzeno obtido por CG-EM das extrações do caldo enzimático do fungo A. sydowii CBMAI 935 na presença do pesticida comercial profenofós durante 10 dias de reação de biotransformação.

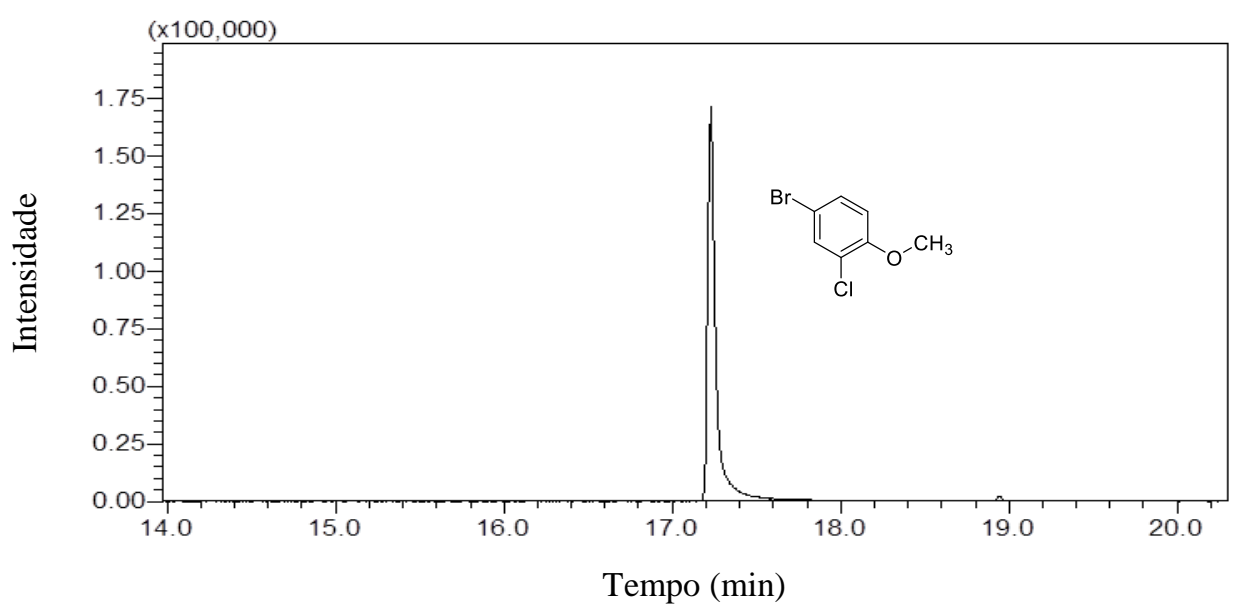

Condições de análise CG-EM: $\mathrm{T}_{\mathrm{i}}=60^{\circ} \mathrm{C}, 2 \mathrm{~min} ; \mathrm{T}_{\mathrm{f}}=280^{\circ} \mathrm{C}, 6 \mathrm{~min} ; \mathrm{r}=6^{\circ} \mathrm{C} / \mathrm{min}, \mathrm{t}_{\mathrm{c}}=45 \mathrm{mim}$.

Coluna capilar DB-5 da J\&W Scientific (30 m x 0,25 mm x 0,25 $\mu \mathrm{m})$. 
A Figura 135 mostra o espectro de massas obtido por CG-EM (70 eV) do metabólito 4bromo-2-cloro-1-metoxibenzeno da reação de biotranformação do pesticida comercial profenofós com o fungo A. sydowii CBMAI 935 em 10 dias. O espectro de massas para o 4bromo-2-cloro-1-metoxibenzeno apresenta o pico do íon molecular intenso. Com a maior intensidade, o pico do íon molecular é também o pico base com fragmento de $m / z 222$ (1). A presença de um pico pouco intenso $(12 \%) \mathrm{em} \mathrm{m} / z 126(2)$ pode representar a perda do átomo de bromo do anel. O fragmento com $\mathrm{m} / z 63$ (44\%) (3) pode ser resultante da perda de CHO, característica para os fenois. O espectro descrito foi comparado com o espectro de massas do padrão sintético do 4-bromo-2-cloro-1-metoxibenzeno.

Figura 135. Espectro de massas obtido em CG-EM (70 eV) para o metabólito 4-bromo-2-cloro-1metoxibenzeno das extrações do micélio do fungo A. sydowii CBMAI 935 na presença do pesticida comercial profenofós durante 10 dias de reação de biotranformação.

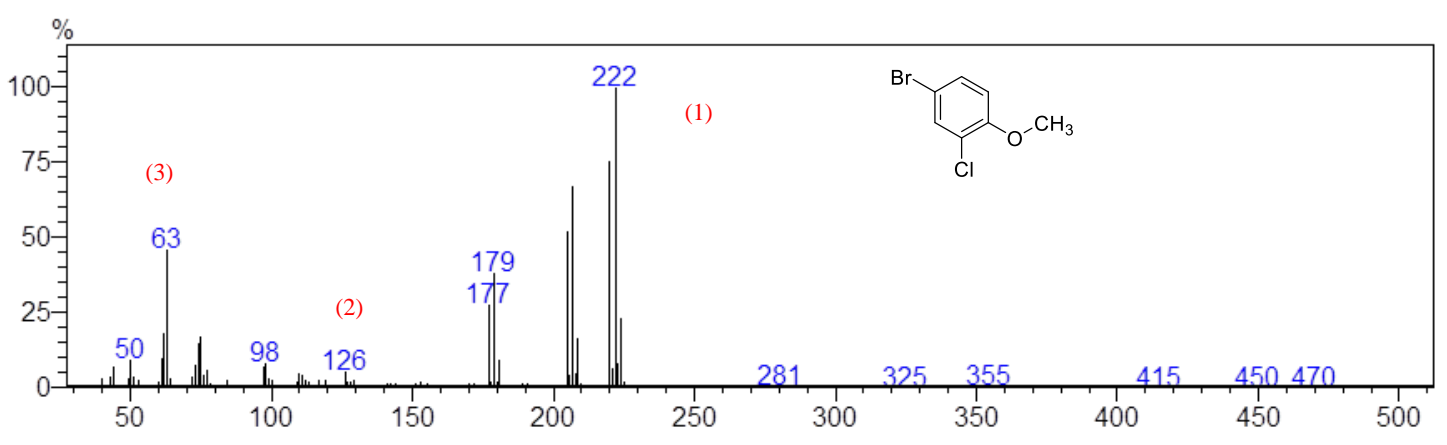

O Esquema 17 mostra a proposta de fragmentação para o 4-bromo-2-cloro-1metoxibenzeno obtido por CG-EM das extrações do micélio com o fungo de ambiente marinho A. sydowii CBMAI 935 em 10 dias de reação de biotransformação.

Esquema 17. Proposta de fragmentação para o 4-bromo-2-cloro-1-metoxibenzeno.

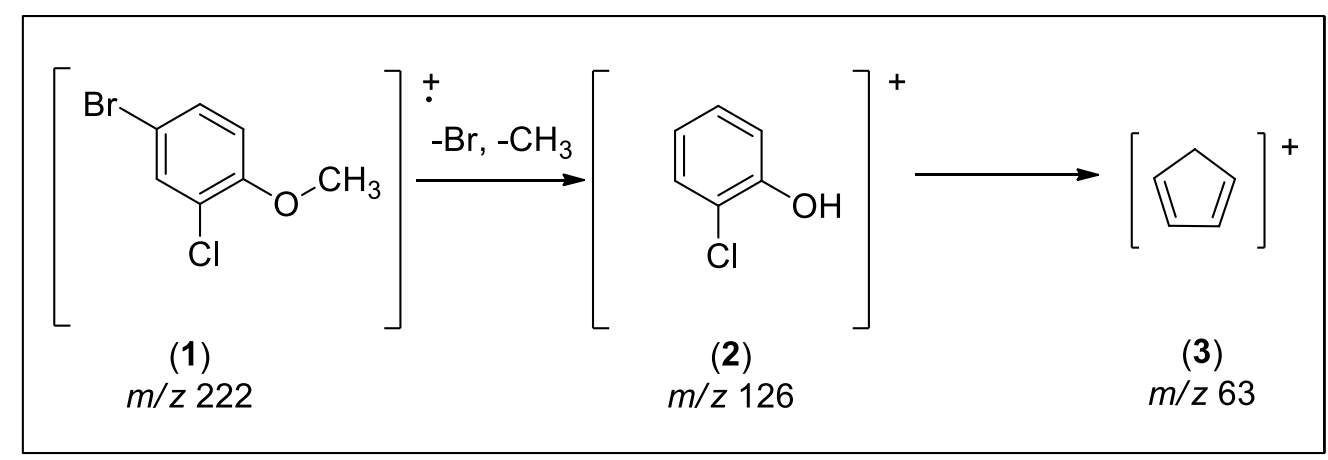

Fonte: Autoria própria. 
A Figura 136 mostra o cromatograma obtido por CG-EM das extrações do caldo enzimático para o metabólito fosforotioato de $O, O$-dietil- $S$-propila oriundo da etilação enzimática do composto aceptor fosforotioato de $O$-etil- $S$-propila na reação de biotransformação do pesticida comercial profenofós com o fungo A. sydowii CBMAI 935 em 10 dias. E, a Figura 137 mostra o espectro de massas obtido por CG-EM (70 eV) para o metabólito etilado fosforotioato de $O, O$-dietil-S-propila das extrações do caldo enzimático do A. sydowii CBMAI 935 na presença do profenofós durante 10 dias.

O cromatograma da Figura 136 foi obtido a partir da Figura 121, selecionando apenas o sinal do composto fosforotioato de $O, O$-dietil-S-propila com tempo de retenção em 16,960 minutos.

O espectro de massas obtido por CG-EM $(70 \mathrm{eV})$ do metabólito de bioetilação fosforotioato de $O, O$-dietil- $S$-propila apresentou uma similaridade de $84 \%$ comparado com o padrão das bibliotecas (NIST O5 LIB, NIST 05 s LIB, NIST 21 LIB, NIST 107 e WILEY 8 LIB) do espectrômetro de massas. As principais fragmentações foram $\mathrm{m} / \mathrm{z} 43$ (pico base), $\mathrm{m} / \mathrm{z}$ 170 com intensidade de $62 \%, \mathrm{~m} / \mathrm{z}, 111 \mathrm{com}$ intensidade de $71 \%$ e o íon molecular $\mathrm{M}^{+} 212$ com intensidade de $12 \%$.

Figura 136. Cromatograma selecionado do metabólito fosforotioato de $O, O$-dietil- $S$-propila obtido por CG-EM das extrações do caldo enzimático do fungo A. sydowii CBMAI 935 com o pesticida comercial profenofós em 10 dias de reação de biotransformação.

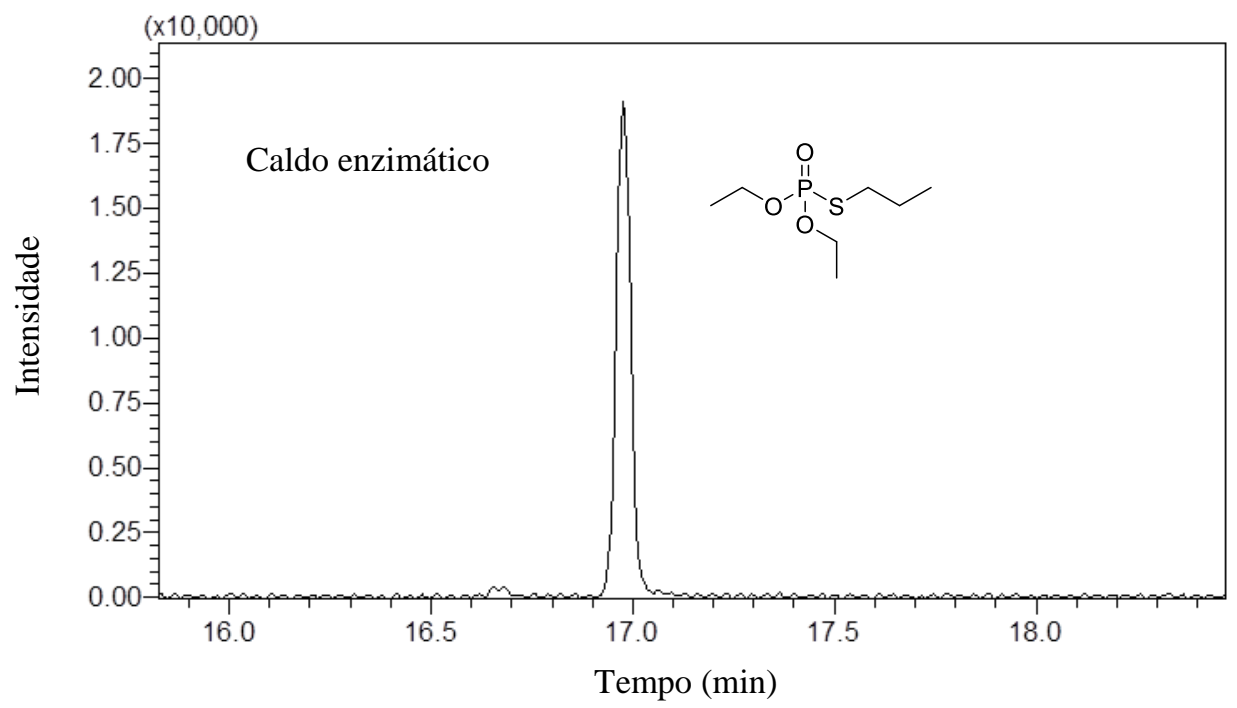

Condições de análise CG-EM: $\mathrm{T}_{\mathrm{i}}=60^{\circ} \mathrm{C}, 2 \mathrm{~min} ; \mathrm{T}_{\mathrm{f}}=280^{\circ} \mathrm{C}, 6 \mathrm{~min} ; \mathrm{r}=6^{\circ} \mathrm{C} / \mathrm{min}, \mathrm{t}_{\mathrm{c}}=45 \mathrm{mim}$. Coluna capilar DB-5 da J\&W Scientific (30 $\mathrm{m}$ x 0,25 mm x 0,25 $\mu \mathrm{m})$. 
Figura 137. Espectro de massas obtido por CG-EM $(70 \mathrm{eV})$ para o metabólito fosforotioato de $O, O$-dietil-Spropila nas extrações do caldo enzimático do fungo A. sydowii CBMAI com o pesticida comercial profenofós em 10 dias de reação de biotransformação.

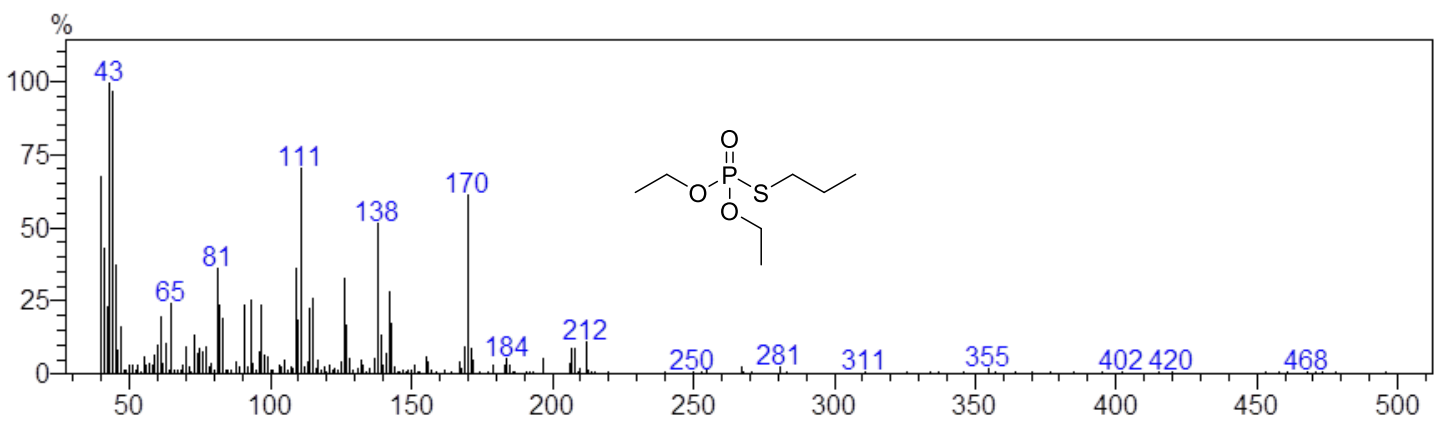

O Esquema 18 mostra a proposta de fragmentação para o metabólito fosforotioato de $O, O$-dietil- $S$-propila obtido por CG-EM das extrações do micélio com o fungo de ambiente marinho A. sydowii CBMAI 935 com o pesticida comercial profenofós em 10 dias de reação de biotransformação.

Esquema 18. Proposta de fragmentação para o metabólito $O, O$-dietil-S-propila.

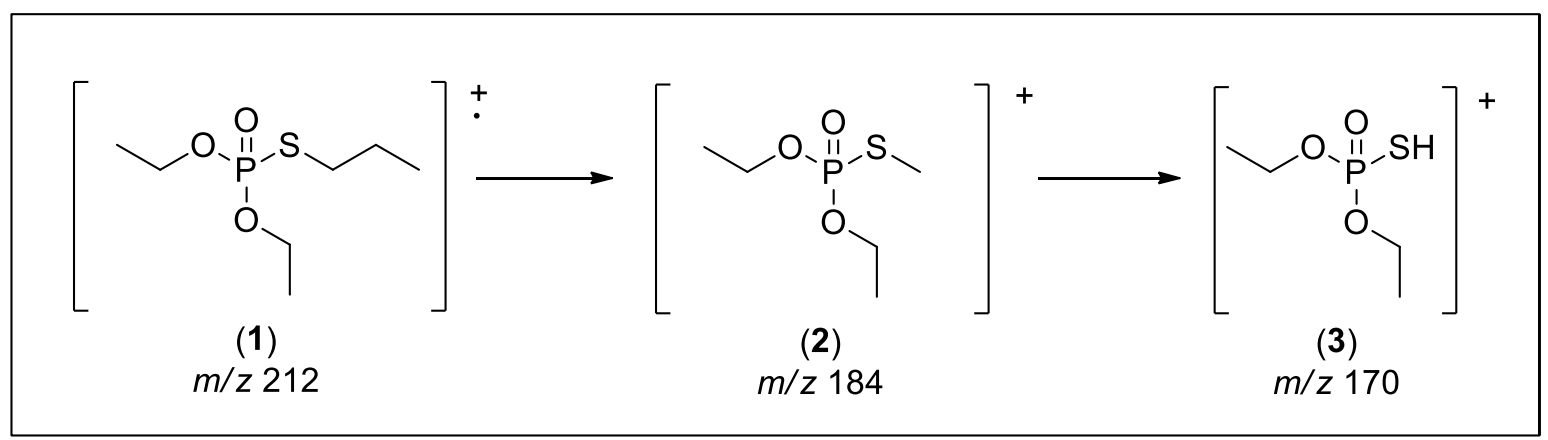

Fonte: Autoria própria.

A Figura 138 mostra o cromatograma obtido por CG-EM das extrações do micélio para o piretroide cipermetrina contido na reação de biotransformação do pesticida comercial profenofós com o fungo A. sydowii CBMAI 935 em 10 dias. E, a Figura 139 mostra o espectro de massas obtido por CG-EM $(70 \mathrm{eV})$ para o piretroide cipermetrina das extrações do micélio do fungo A. sydowii CBMAI 935 na presença do profenofós durante 10 dias.

O cromatograma da Figura 138 foi obtido a partir da Figura 122, selecionando apenas o sinal do piretroide cipermetrina com tempo de retenção em 40,677 minutos. 
O sinal e o tempo de retenção do piretroide cipermetrina encontrado na reação foram comparados com o padrão analítico do piretroide cipermetrina, os quais foram idênticos, confirmando a identidade do composto na amostra comercial que foi utilizada nas reações de biotransformação.

Figura 138. Cromatograma selecionado do piretroide cipermetrina obtido por CG-EM das extrações do micélio do fungo A. sydowii CBMAI 935 com o pesticida comercial profenofós em 10 dias de reação de biotransformação.

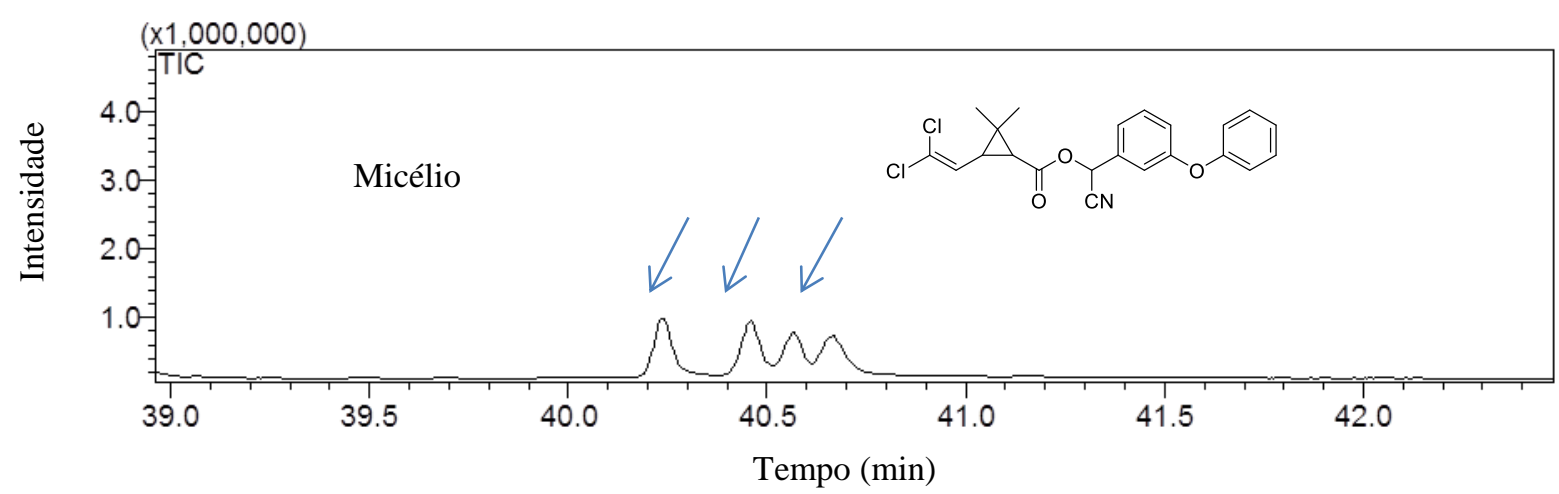

Condições de análise CG-EM: $T_{i}=60^{\circ} \mathrm{C}, 2 \mathrm{~min} ; \mathrm{T}_{\mathrm{f}}=280^{\circ} \mathrm{C}, 6 \mathrm{~min} ; \mathrm{r}=6^{\circ} \mathrm{C} / \mathrm{min}, \mathrm{t}_{\mathrm{c}}=45 \mathrm{mim}$.

Coluna capilar DB-5 da J\&W Scientific ( $30 \mathrm{~m}$ x 0,25 mm x 0,25 $\mu \mathrm{m}$ ).

Figura 139. Espectro de massas obtido por CG-EM $(70 \mathrm{eV})$ para o piretroide cipermetrina nas extrações do micélio do fungo A. sydowii CBMAI com o pesticida comercial profenofós em 10 dias de reação de biotransformação.

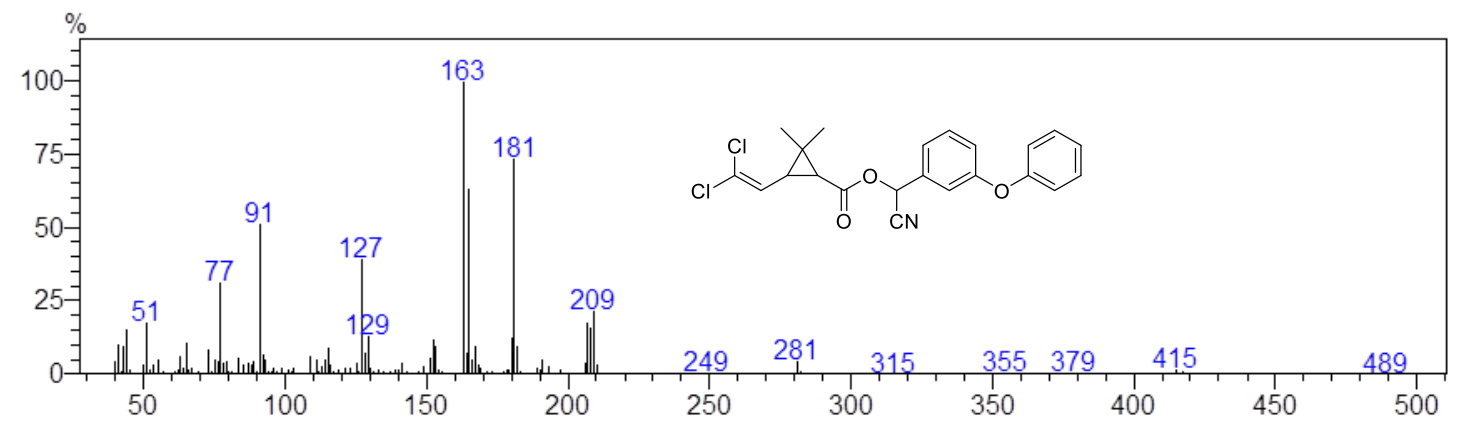


As Figuras 140 e 141 mostram o cromatograma obtido por CG-EM e o espectro de massas do padrão analítico do piretroide cipermetrina que teve o seu sinal e tempo de retenção em 40,677 minutos.

Figura 140. Cromatograma obtido por CG-EM do padrão analítico do piretroide cipermetrina.

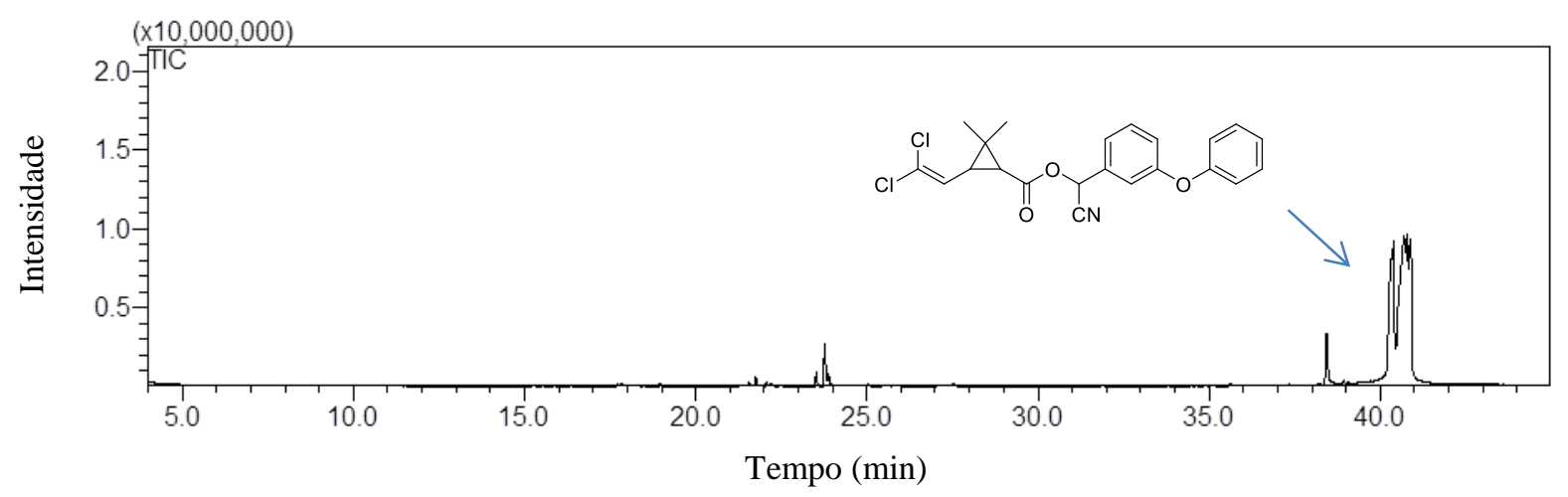

Condições de análise CG-EM: $\mathrm{T}_{\mathrm{i}}=60^{\circ} \mathrm{C}, 2 \mathrm{~min} ; \mathrm{T}_{\mathrm{f}}=280^{\circ} \mathrm{C}, 6 \mathrm{~min} ; \mathrm{r}=6^{\circ} \mathrm{C} / \mathrm{min}, \mathrm{t}_{\mathrm{c}}=45 \mathrm{mim}$.

Coluna capilar DB-5 da J\&W Scientific ( $30 \mathrm{~m} \times 0,25 \mathrm{~mm}$ x 0,25 $\mu \mathrm{m}$ ).

Figura 141. Espectro de massas obtido por CG-EM (70 eV) para o padrão analítico do piretroide cipermetrina.

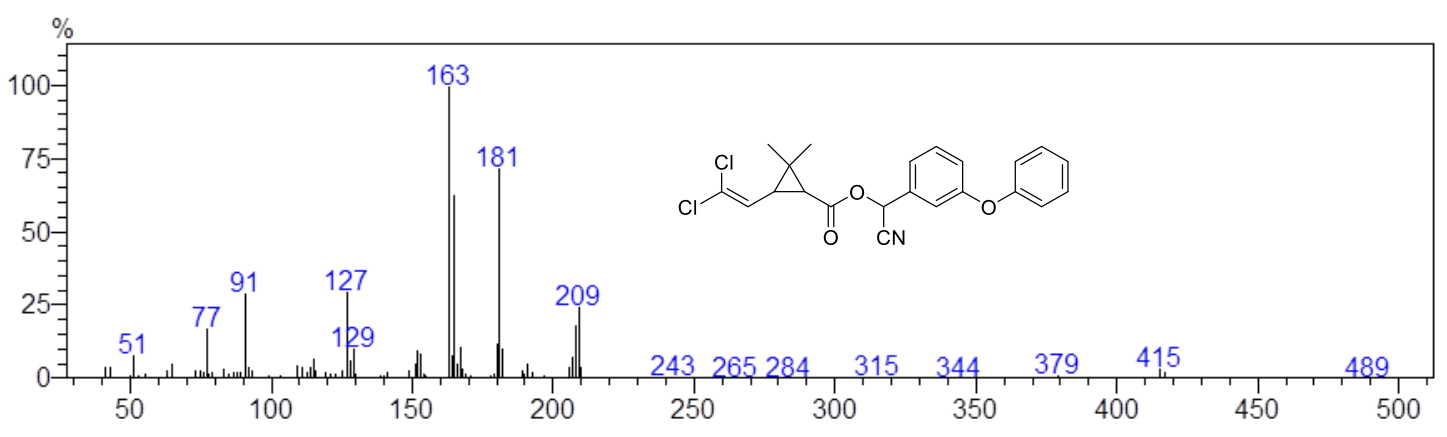

A Figura 142 mostra o cromatograma obtido por CG-EM das extrações do micélio para o metabólito 3-fenoxibenzaldeído oriundo da hidrólise enzimática do piretroide cipermetrina contido na reação de biotransformação do pesticida comercial profenofós com o fungo $A$. sydowii CBMAI 935 em 10 dias. E, a Figura 143 mostra o espectro de massas obtido por CGEM $(70 \mathrm{eV})$ para o metabólito 3-fenoxibenzaldeído das extrações do micélio do fungo $A$. sydowii CBMAI 935 na presença do profenofós durante 10 dias.

O cromatograma da Figura 142 foi obtido a partir da Figura 122, selecionando apenas o sinal do metabólito 3-fenoxibenzaldeído com tempo de retenção em 23,800 minutos.

O sinal e o tempo de retenção do metabólito encontrado na reação foram comparados com o padrão analítico do 3-fenoxibenzaldeído. Os quais foram idênticos, confirmando a 
identidade do composto na amostra comercial que foi utilizada nas reações de biotransformação.

Figura 142. Cromatograma selecionado do metabólito 3-fenoxibenzaldeído obtido por CG-EM das extrações do micélio do fungo A. sydowii CBMAI 935 com o pesticida comercial profenofós em 10 dias de reação de biotransformação.

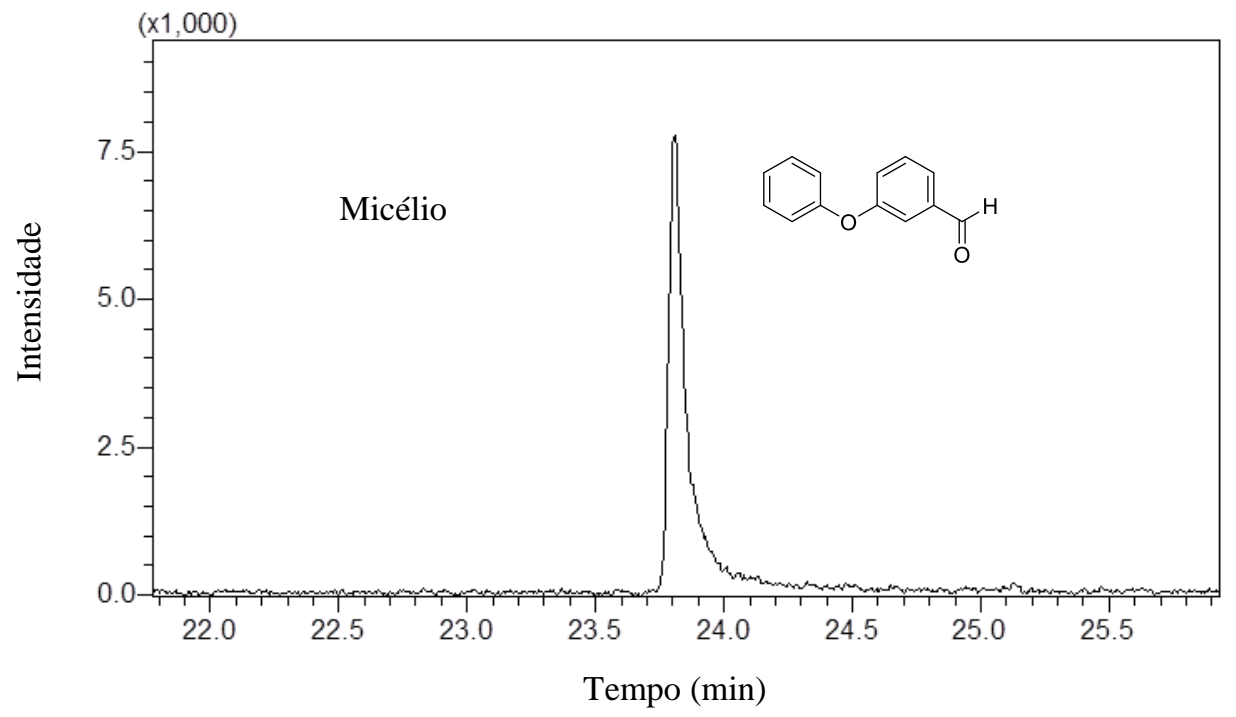

Condições de análise CG-EM: $\mathrm{T}_{\mathrm{i}}=60^{\circ} \mathrm{C}, 2 \mathrm{~min} ; \mathrm{T}_{\mathrm{f}}=280^{\circ} \mathrm{C}, 6 \mathrm{~min} ; \mathrm{r}=6^{\circ} \mathrm{C} / \mathrm{min}, \mathrm{t}_{\mathrm{c}}=45 \mathrm{mim}$.

Coluna capilar DB-5 da J\&W Scientific ( $30 \mathrm{~m}$ x 0,25 mm x 0,25 $\mu \mathrm{m}$ ).

Figura 143. Espectro de massas obtido por CG-EM $(70 \mathrm{eV})$ para o metabólito 3-fenoxibenzaldeído nas extrações do micélio do fungo A. sydowii CBMAI com o pesticida comercial profenofós em 10 dias de reação de biotransformação.

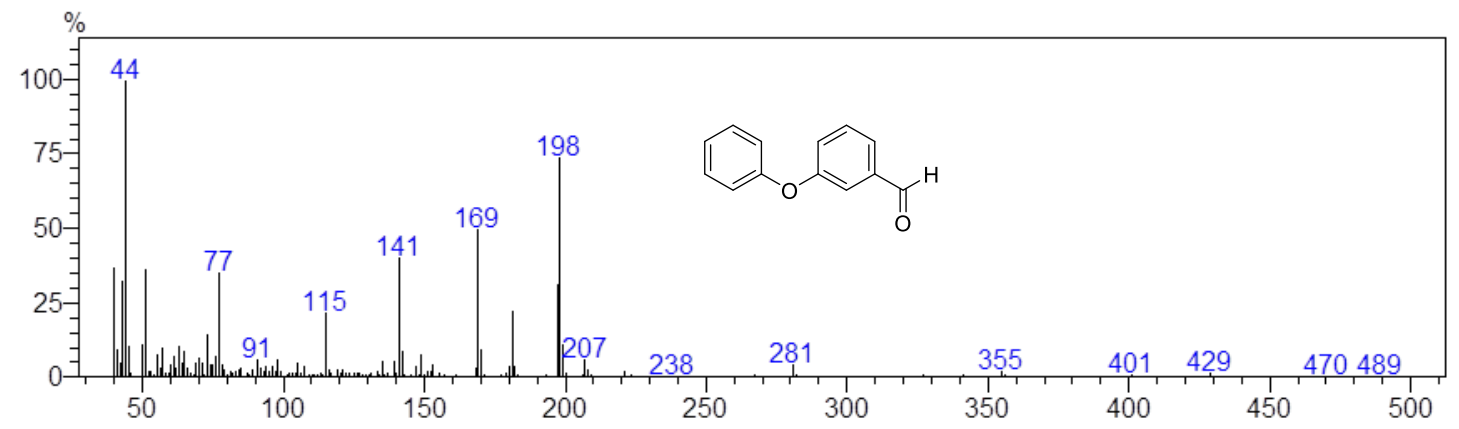




\subsubsection{Avaliação da biotransformação do profenofós em 20 e 30 dias de reação com o} fungo A. sydowii CBMAI 935

O mesmo comportamento para 20 e 30 dias de reação foi observado para 10 d. Obteve-se as mesmas reações de biotransformação e bioconjugação para o profenofós, não cabendo aqui detalhar os resultados uma vez que foram similares aos anteriores.

O Esquema 19 ilustra os mecanismos enzimáticos de enzimas fosfotriesterases e $O$ metiltransferases durante 10, 20 e 30 dias de reação de biotransformação do pesticida comercial metil paration com o fungo de ambiente marinho A. sydowii CBMAI 935.

Como foi descrtito para os pesticidas clorpirifós e metil paration, as enzimas fosfotriesterases e metiltransferases atuam de forma similar para o profenofós. 
Esquema 19. Proposta de mecanismos enzimáticos de enzimas fosfotriesterases e metiltransferases durante 10 , 20 e 30 dias de reação de biotransformação do pesticida comercial profenofós com o fungo de ambiente marinho A. sydowii CBMAI 935.<smiles>CCCSP(=O)(OCC)Oc1ccc(Br)cc1Cl</smiles>

Profenofós $\mid \begin{gathered}\text { Hidrólise } \\ \text { (Fosforotriesterases) } \\ \text { Fase I }\end{gathered}$

$\mathrm{Br}$<smiles>Oc1ccc(I)cc1Cl</smiles>

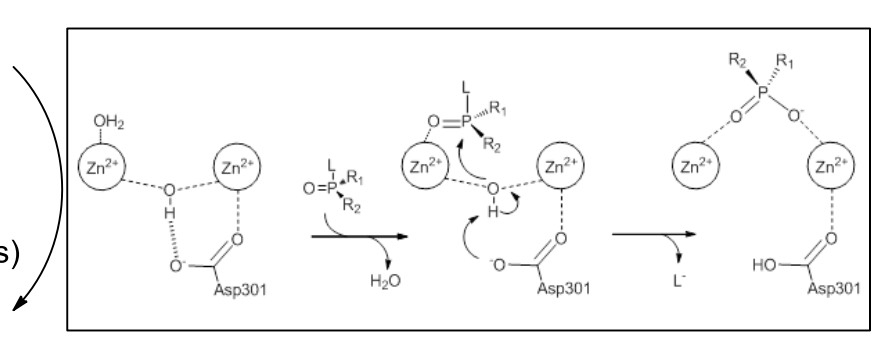<smiles>CCCSP(=O)(O)OCC</smiles>

4-bromo-2-clorofenol

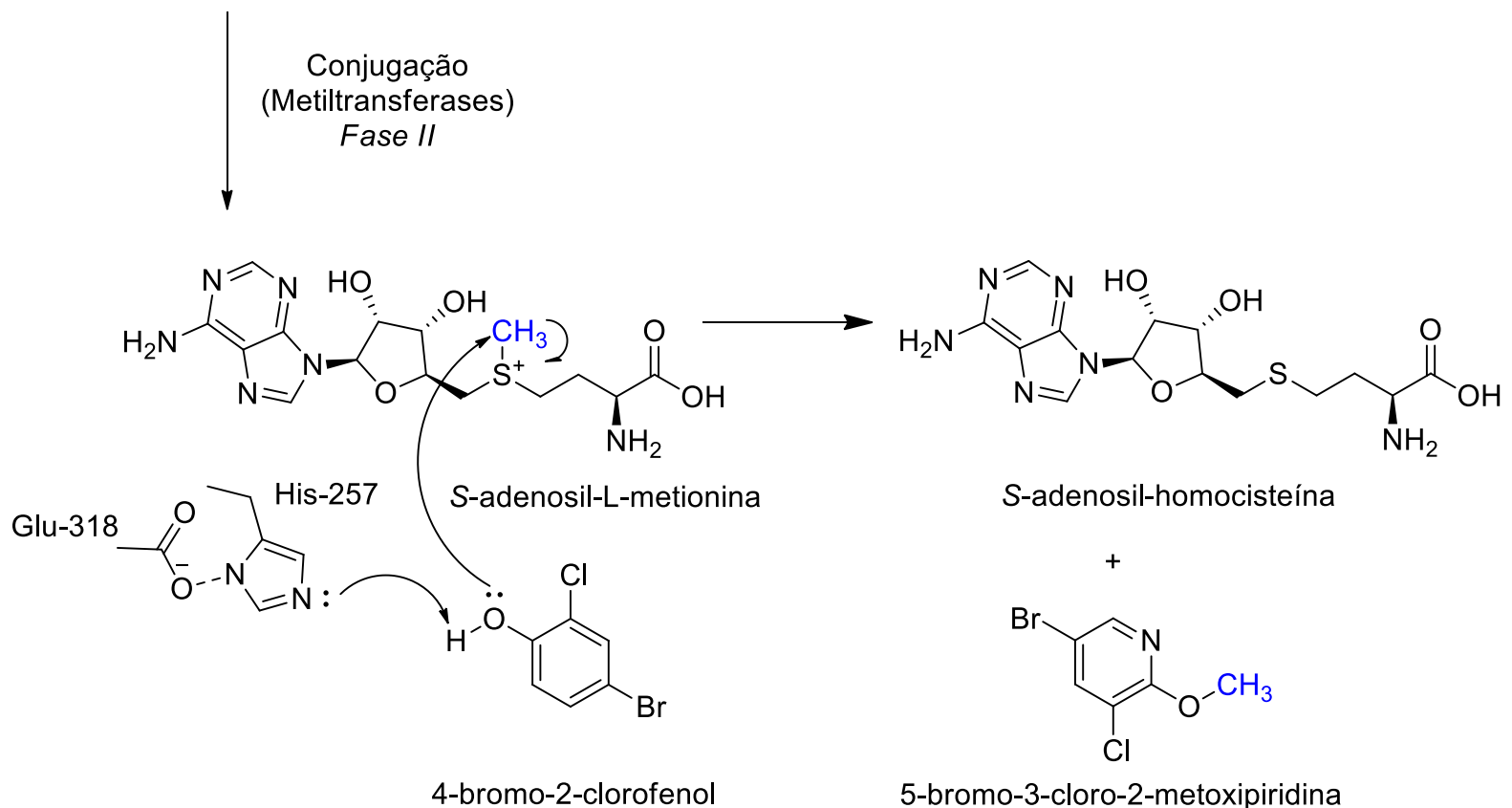

Fonte: Autoria própria. 


\subsubsection{Reações de biotransformação do composto fenólico 3,5,6-tricloro-2-piridinol em 10, 20 e 30 dias pelo fungo de ambiente marinho A. sydowii CBMAI 935}

\subsubsection{Avaliação da biotransformação do composto fenólico 3,5,6-tricloro-2-piridinol em 10 dias de reação com o fungo $A$. sydowii CBMAI 935}

Em 10 dias de reação de biotransformação do composto fenólico 3,5,6-tricloro-2piridinol com o fungo de ambiente marinho A. sydowii CBMAI 935 foram separados o caldo enzimático e o micélio e posteriormente submetidos às análises por CG-EM. Os cromatogramas das reações foram comparados com os cromatogramas da reação do controle biótico no qual o fungo A. sydowii CBMAI 935 cresceu por 10, 20 e 30 dias na ausência do composto fenólico 3,5,6-tricloro-2-piridinol. Também foram feitas comparações com os cromatogramas das reações de controle abiótico no qual se utilizou o padrão analítico do composto fenólico 3,5,6-tricloro-2-piridinol em meio de cultura líquido de malte $2 \%$ na ausência do fungo A. sydowii CBMAI 935 em 10, 20 e 30 dias de reação. Posteriormente foram feitas comparações com os cromatogramas do padrão analítico do composto fenólico 3,5,6-tricloro-2-piridinol e padrão sintético do metabólito 2,3,5-tricloro-6-metoxipiridina obtido durante os 10, 20 e 30 dias de reação de biotransformação. Este mesmo procedimento de caracterização foi realizado para 20 e 30 dias de reação.

A Figura 144 mostra a sobreposição dos cromatogramas das extrações do caldo enzimático (cor vermelha) e do micélio (cor preta) com o fungo A. sydowii CBMAI 935 na ausência do composto fenólico 3,5,6-tricloro-2-piridinol (reação de controle biótico) em 10 dias de reação e a Figura 145 mostra os mesmos cromatogramas, porém separados. Cromatograma (a) Extração do caldo enzimático e cromatograma (b) Extração do micélio. 
Figura 144. Cromatogramas obtidos por CG-EM das extrações do micélio (cor preta) e do caldo enzimático (cor vermelha) com o fungo A. sydowii CBMAI 935 na ausência do composto fenólico 3,5,6-tricloro-2-piridinol (reação de controle biótico) durante 10 dias de reação de biotransformação.

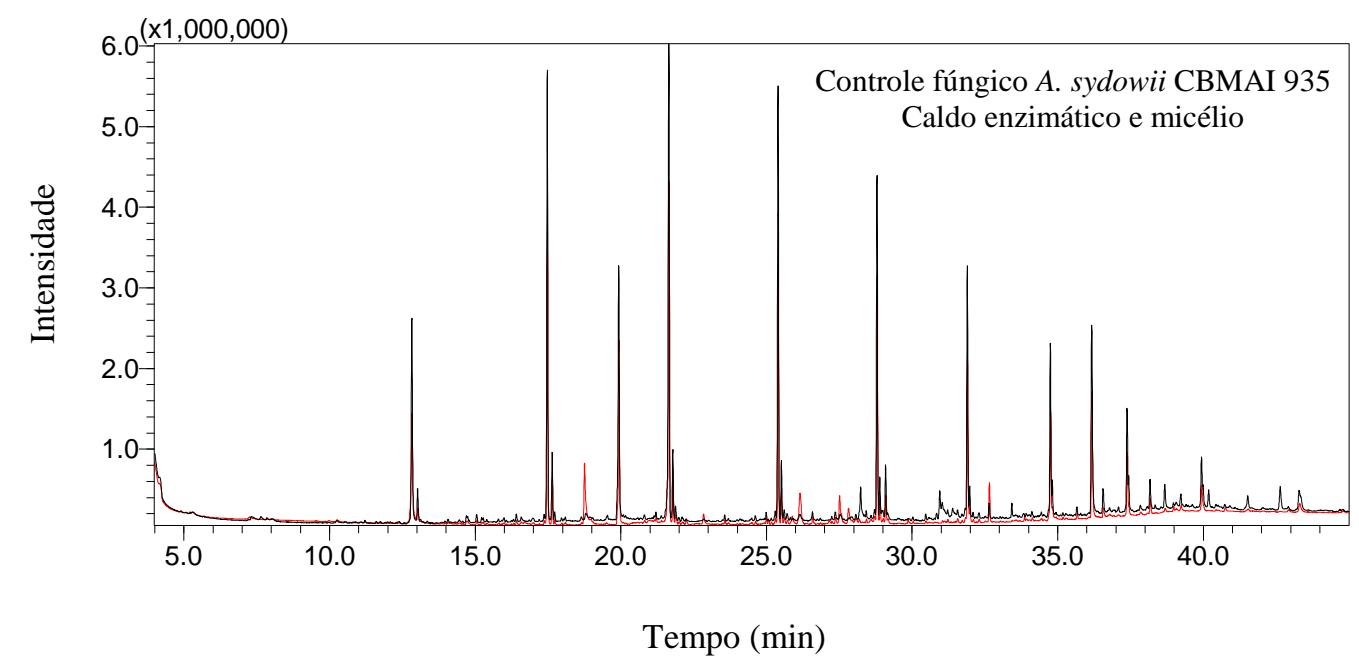

Condições de análise CG-EM: $\mathrm{T}_{\mathrm{i}}=60^{\circ} \mathrm{C}, 2 \mathrm{~min} ; \mathrm{T}_{\mathrm{f}}=280^{\circ} \mathrm{C}, 6 \mathrm{~min} ; \mathrm{r}=6^{\circ} \mathrm{C} / \mathrm{min}, \mathrm{t}_{\mathrm{c}}=45 \mathrm{mim}$.

Coluna capilar DB-5 da J\&W Scientific (30 m x 0,25 mm x 0,25 $\mu \mathrm{m})$.

Figura 145. Cromatogramas obtidos por CG-EM das extrações do micélio e do caldo enzimático do fungo $A$. sydowii CBMAI 935 na ausência do composto fenólico 3,5,6-tricloro-2-piridinol (reação de controle biótico) durante 10 dias. (a) Extração do caldo enzimático e (b) Extração do micélio.

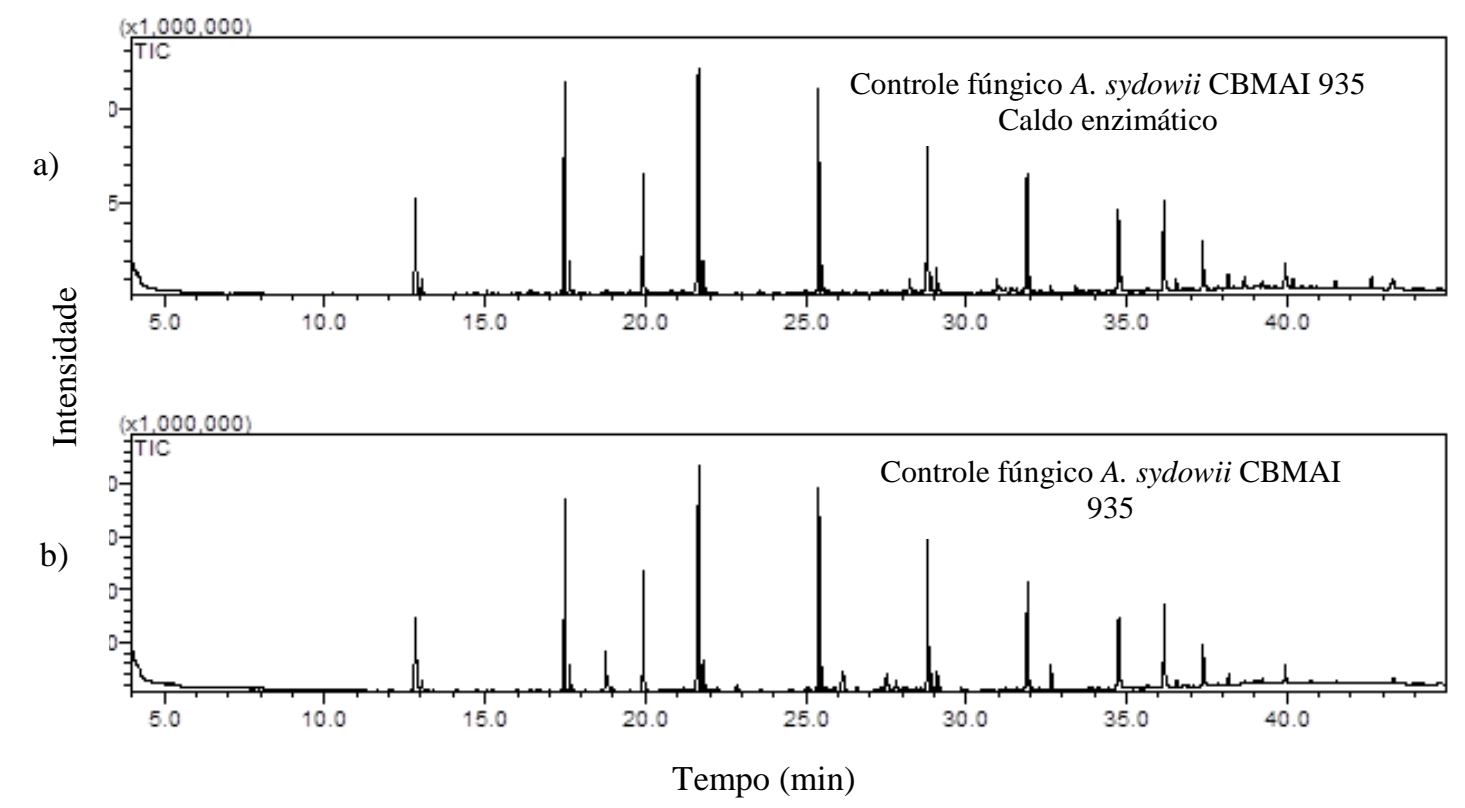

Condições de análise CG-EM: $\mathrm{T}_{\mathrm{i}}=60^{\circ} \mathrm{C}, 2 \mathrm{~min} ; \mathrm{T}_{\mathrm{f}}=280^{\circ} \mathrm{C}, 6 \mathrm{~min} ; \mathrm{r}=6^{\circ} \mathrm{C} / \mathrm{min}, \mathrm{t}_{\mathrm{c}}=45 \mathrm{mim}$.

Coluna capilar DB-5 da J\&W Scientific (30 m x 0,25 mm x 0,25 $\mu \mathrm{m}$ ). 
Os cromatogramas obtidos por CG-EM das reações em triplicatas com o fungo A. sydowii CBMAI 935 na ausência do composto fenólico 3,5,6-tricloro-2-piridinol em 10 dias de reação apresentaram semelhanças quanto à presença de metabólitos provenientes do fungo. $\mathrm{O}$ cromatograma com a extração do caldo enzimático apresentou menor intensidade dos sinais quando comparado com o cromatograma da extração do micélio (Figuras 144 e 145). É importante frisar que os experimentos também foram realizados para 20 e 30 dias de crescimento micelial na ausência de xenobióticos, onde não houve diferença significativa de intensidade dos sinais dos metabólitos produzidos naturalmente pelo fungo. Os cromatogramas de controle biótico pra 20 e 30 dias são mostrados no Apêndice da dissertação.

O crescimento do fungo variou para cada experimento, outros fatores podem ter causado a diferença entre a intensidade dos sinais dos metabólitos como foi discutido anteriormente para os pesticidas organofosforados.

A Figura 146 mostra a sobreposição do cromatograma obtido por CG-EM da reação de controle biótico (cor vermelha) e o cromatograma da reação do composto fenólico 3,5,6tricloro-2-piridinol (cor preta) com concentração de 50 mg. $\mathrm{L}^{-1}$ em 10 dias de reação de biotransformação com o fungo A. sydowii CBMAI 935. Os cromatogramas foram sobrepostos para a comparação qualitativa das intensidades dos sinais dos metabólitos formados naturalmente pelo fungo e os metabólitos formados por ação enzimática do fungo e o composto fenólico 3,5,6-tricloro-2-piridinol.

Figura 146. Cromatogramas obtidos por CG-EM da reação de controle biótico do fungo A. sydowii CBMAI 935 e o composto fenólico 3,5,6-tricloro-2-piridinol em 10 dias de reação de biotransformação.

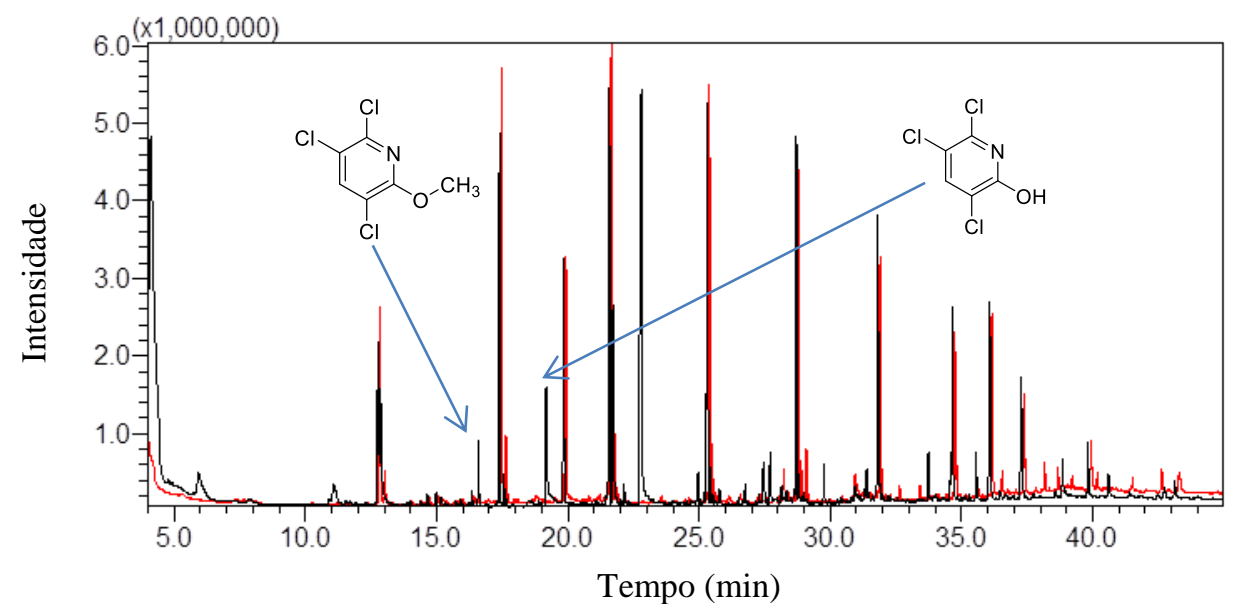

Condições de análise CG-EM: $\mathrm{T}_{\mathrm{i}}=60^{\circ} \mathrm{C}, 2 \mathrm{~min} ; \mathrm{T}_{\mathrm{f}}=280^{\circ} \mathrm{C}, 6 \mathrm{~min} ; \mathrm{r}=6^{\circ} \mathrm{C} / \mathrm{min}, \mathrm{t}_{\mathrm{c}}=45 \mathrm{mim}$.

Coluna capilar DB-5 da J\&W Scientific (30 m x 0,25 mm x 0,25 $\mu \mathrm{m}$ ). 
A Figura 147 mostra o cromatograma obtido por CG-EM da reação de controle abiótico. Neste caso utilizou-se o padrão analítico do composto fenólico 3,5,6-tricloro-2-piridinol em meio de cultura líquido de malte $2 \%$ na ausência do fungo A. sydowii CBMAI 935 durante 10 dias de reação, para verificar se o mesmo era estável nas condições utlizadas $\left(32^{\circ} \mathrm{C}, \mathrm{pH} 7,0\right)$. O padrão analítico do composto fenólico 3,5,6-tricloro-2-piridinol teve o seu sinal no tempo de retenção em 19,233 minutos.

Figura 147. Cromatograma obtido por CG-EM da reação de controle abiótico do composto fenólico 3,5,6tricloro-2-piridinol na ausência do fungo A. sydowii CBMAI 935 durante 10 dias de reação de biotransformação.

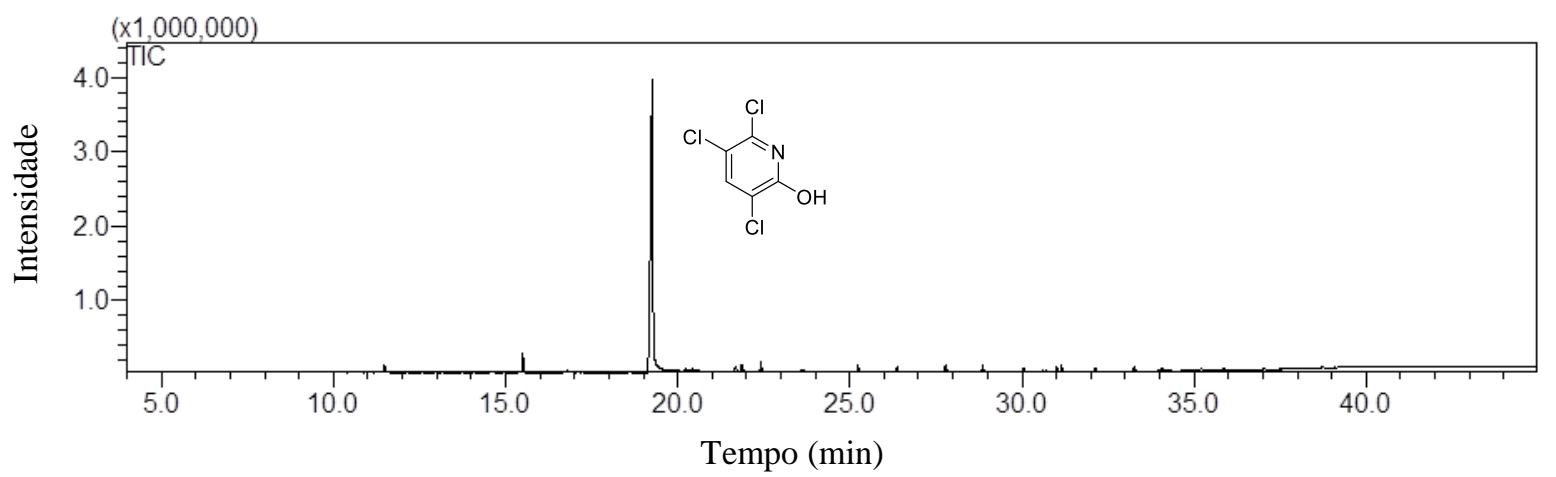

Condições de análise CG-EM: $\mathrm{T}_{\mathrm{i}}=60^{\circ} \mathrm{C}, 2 \mathrm{~min} ; \mathrm{T}_{\mathrm{f}}=280^{\circ} \mathrm{C}, 6 \mathrm{~min} ; \mathrm{r}=6^{\circ} \mathrm{C} / \mathrm{min}, \mathrm{t}_{\mathrm{c}}=45 \mathrm{mim}$. Coluna capilar DB-5 da J\&W Scientific (30 m x 0,25 mm x 0,25 $\mu \mathrm{m}$ ).

A Figura 148 mostra o cromatograma selecionado do composto fenólico 3,5,6-tricloro-2piridinol da extração do micélio. O mesmo foi oriundo da reação de biotransformação com o fungo de ambiente marinho A. sydowii CBMAI 935 durante 10 dias.

O sinal do composto fenólico foi encontrado no cromatograma com o tempo de retenção em 19,233 minutos. O tempo de retenção do composto fenólico encontrado foi comparado com o padrão analítico do composto fenólico 3,5,6-tricloro-2-piridinol, mostrando semelhanças que comprovaram a estrutura deste metabólito. 
Figura 148. Cromatograma obtido por CG-EM e selecionado do composto fenólico 3,5,6-tricloro-2-piridinol da extração do micélio do fungo A. sydowii CBMAI 935 durante 10 dias de reação de biotransformação.

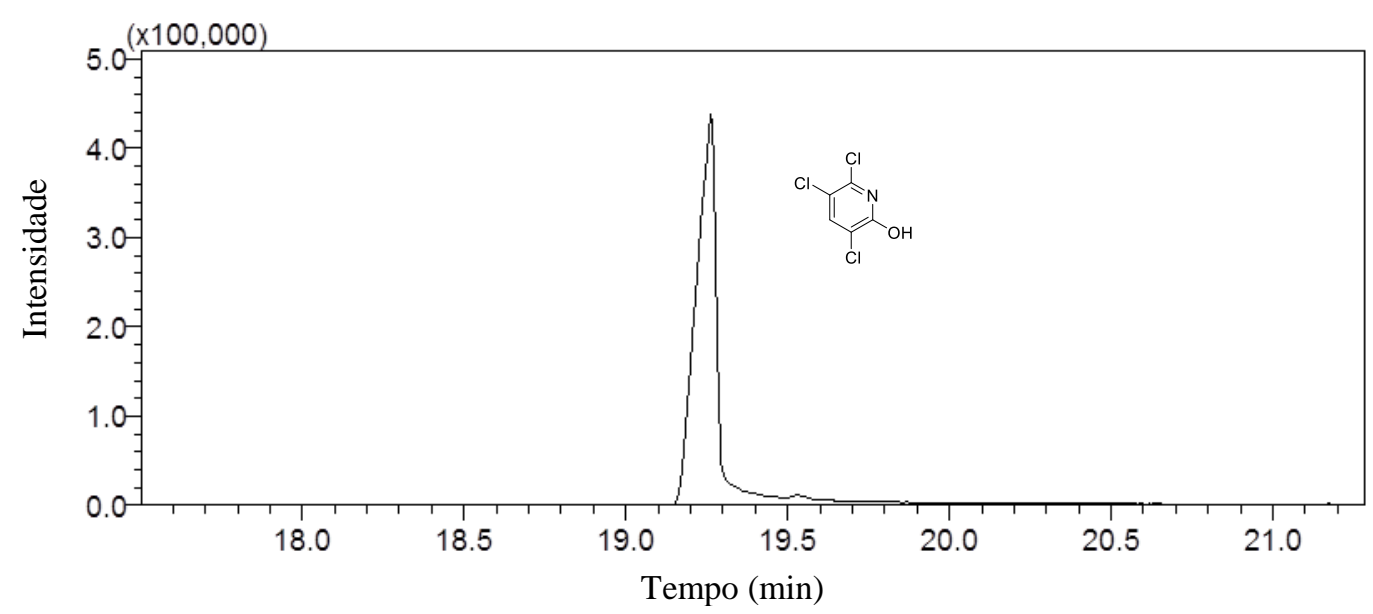

Condições de análise CG-EM: $\mathrm{T}_{\mathrm{i}}=60^{\circ} \mathrm{C}, 2 \mathrm{~min} ; \mathrm{T}_{\mathrm{f}}=280^{\circ} \mathrm{C}, 6 \mathrm{~min} ; \mathrm{r}=6^{\circ} \mathrm{C} / \mathrm{min}, \mathrm{t}_{\mathrm{c}}=45 \mathrm{mim}$. Coluna capilar DB-5 da J\&W Scientific (30 m x 0,25 mm x 0,25 $\mu \mathrm{m})$.

A Figura 149 mostra o espectro de massas obtido por CG-EM do composto fenólico 3,5,6-tricloro-2-piridinol da extração do micélio do fungo A. sydowii CBMAI 935 durante 10 dias. O espectro apresentou o íon molecular com $\mathrm{m} / \mathrm{z} 197$ (1) sendo o mesmo também o pico base. A presença dos três átomos de cloro na molécula faz com que a abundância relativa dos picos M, M+2, M+4 e M+6 seja de 100, 96, 30 e 4\%, respectivamente. Como é característico para os fenois, há a perda de CO (M-28) com intensidade de 95\%, resultando no fragmento com $m / z 169$ (2), seguindo o padrão de abundância para os picos M, M+2, M+4 e M+6. Uma subsequente fragmentação pode produzir o fragmento com $m / z 134$ (3), com perda de hidrogênio e um átomo de cloro.

Figura149. Espectro de massas obtido por CG-EM (70 eV) para o composto fenólico 3,5,6-tricloro-2-piridinol.

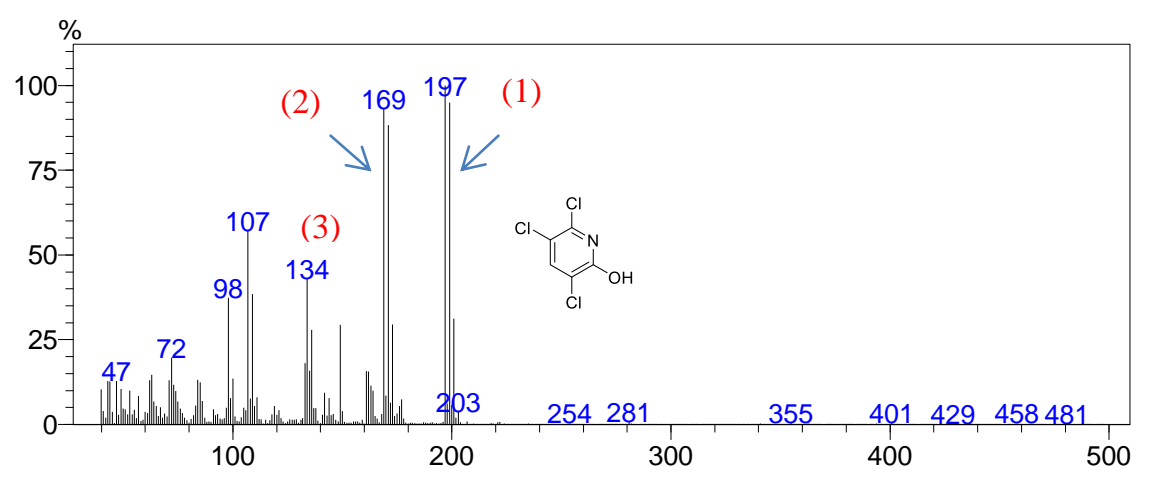


O Esquema 20 mostra a proposta de fragmentação para o composto fenólico 3,5,6tricloro-2-piridinol obtido por CG-EM das extrações do micélio com o fungo de ambiente marinho A. sydowii CBMAI 935 em 10 dias de reação de biotransformação.

Esquema 20. Proposta de fragmentação para o composto 3,5,6-tricloro-2-piridinol.<smiles>Oc1nc(Cl)c(Cl)cc1Cl</smiles>

(1)

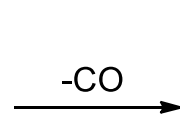

(2)

$m / z 169$<smiles>[3H]C1C=C(Cl)C=N1</smiles>

(3) $m / z 134$

Fonte: Adaptado de SILVA, N.A. Biodegradação dos pesticidas clorpirifós, metil paration e profenofós por fungos de origem marinha. 159f. Dissertação (Mestrado em Química)-Universidade São Paulo-USP. São Carlos, 2013. ${ }^{74}$

A Figura 150 mostra o cromatograma do metabólito 2,3,5-tricloro-6-metoxipiridina oriundo da metilação enzimática do composto fenólico 3,5,6-tricloro-2-piridinol na reação de biotransformação com o fungo de A.sydowii CBMAI 935.

Figura 150. Cromatograma obtido por CG-EM e selecionado do metabólito 2,3,5-tricloro-6-metoxipiridina das extrações do micélio do fungo A. sydowii CBMAI 935 na presença do composto fenólico 3,5,6-tricloro-2piridinol durante 10 dias de reação de biotransformação.

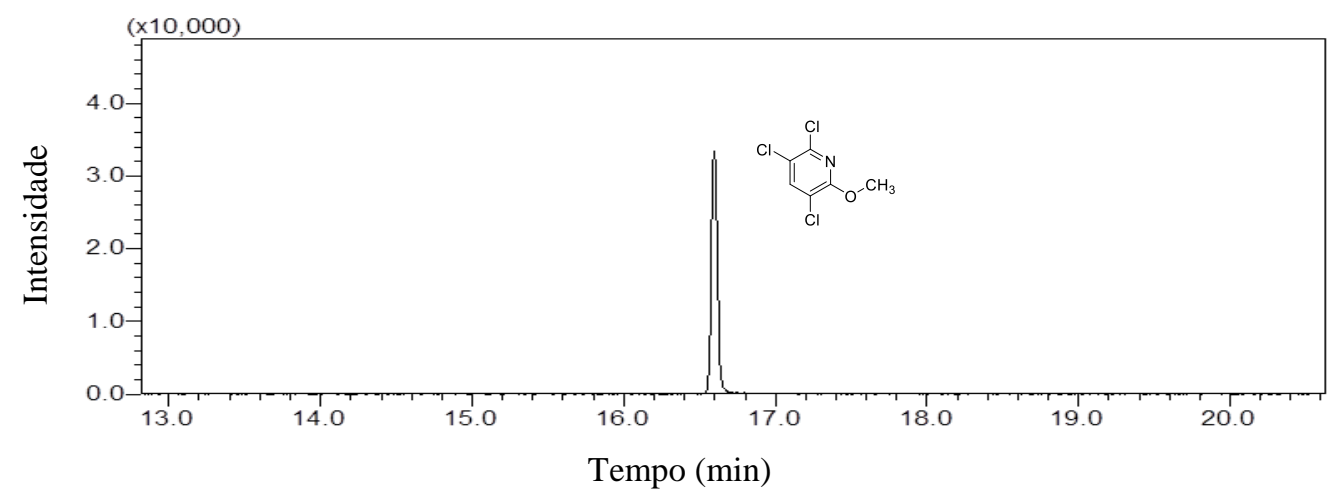

Condições de análise CG-EM: $\mathrm{T}_{\mathrm{i}}=60^{\circ} \mathrm{C}, 2 \mathrm{~min} ; \mathrm{T}_{\mathrm{f}}=280^{\circ} \mathrm{C}, 6 \mathrm{~min} ; \mathrm{r}=6^{\circ} \mathrm{C} / \mathrm{min}, \mathrm{t}_{\mathrm{c}}=45 \mathrm{mim}$.

Coluna capilar DB-5 da J\&W Scientific ( $30 \mathrm{~m}$ x 0,25 mm x 0,25 $\mu \mathrm{m}$ ). 
A Figura 151 mostra o espectro de massas obtido por CG-EM do metabólito 2,3,5tricloro-6-metoxipiridina obtido da reação de biotransformação do composto fenólico 3,5,6tricloro-2-piridinol com fungo A. sydowii CBMAI 935 durante 10 dias. O espectro de massas para metabólito apresentou o íon molecular com $\mathrm{m} / \mathrm{z} 211$ (1) sendo o mesmo também o pico base. A presença dos três átomos de cloro na molécula faz com que a abundância relativa dos picos M, M+2, M+4 e M+6 seja de 100, 96, 30 e 6\%, respectivamente. Como característico para os fenois, há a perda de CO (M-28) com intensidade de $100 \%$, resultando no fragmento e o pico base com $m / z 182$ (2), seguindo o padrão de abundância para os picos $\mathrm{M}, \mathrm{M}+2, \mathrm{M}+4 \mathrm{e}$ M+6. Uma subsequente fragmentação pode produzir o fragmento com $\mathrm{m} / \mathrm{z} 168(3)$, com perda da metila e um átomo de cloro. O espectro relatado foi comparado com o espectro de massas do padrão sintético do composto 2,3,5-tricloro-6-metoxipiridina.

Figura 151. Espectro de massas obtido por CG-EM (70 eV) para o metabólito 2,3,5-tricloro-6-metoxipiridina durante 10 dias de reação de biotransformação.

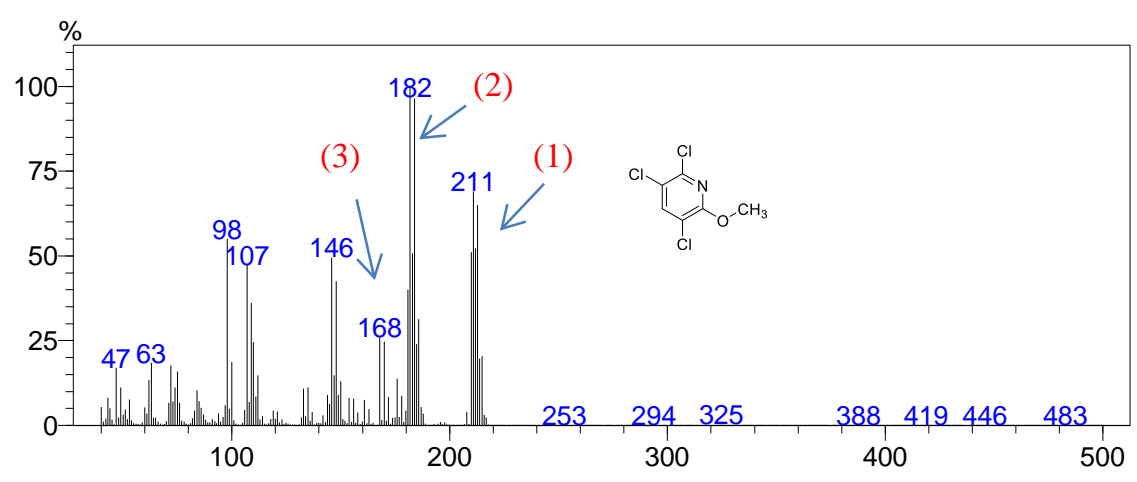

O Esquema 21 mostra a proposta de fragmentação para o composto 2,3,5-tricloro-6metoxipiridina obtido por CG-EM das extrações do micélio com o fungo de ambiente marinho A. sydowii CBMAI 935 em 10 dias de reação de biotransformação.

Esquema 21. Proposta de fragmentação para o composto 2,3,5-tricloro-6-metoxipiridina.

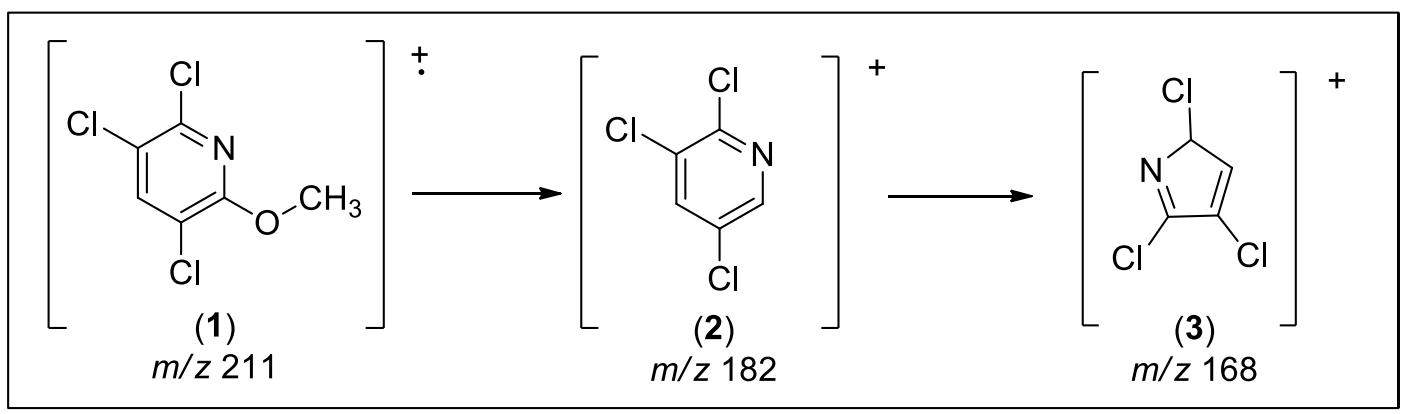

Fonte: Autoria própria. 


\subsubsection{Avaliação da biotransformação do composto fenólico 3,5,6-tricloro-2-piridinol em 20 e 30 dias de reação com o fungo A. sydowii CBMAI 935}

O mesmo comportamento para 20 e 30 dias de reação foi observado para 10 d. Obteve-se as mesmas reações de biotransformação e bioconjugação para o 3,5,6-tricloro-2-piridinol, não cabendo aqui detalhar os resultados uma vez que foram similares aos anteriores.

O Esquema 22 mostra o mecanismo enzimático da reação de biotransformação do composto fenólico 3,5,6-tricloro-2-piridinol pelo fungo de ambiente marinho A. sydowii CBMAI 935. O Esquema 22 foi proposto a partir do metabólito identificado nos cromatogramas obtidos por CG-EM das extrações do micélio e do caldo emzimático do fungo A. sydowii CBMAI 935 na presença do 3,5,6-tricloro-2-piridinol, durante 10, 20 e 30 dias de reação.

Observou-se que em 10, 20 e 30 dias de reação com o fungo de ambiente marinho $A$. sydowii CBMAI 935, o composto 3,5,6-tricloro-2-piridinol foi biotransformado.

Observou-se que a reação com o 3,5,6-tricloro-2-piridinol houve apenas a formação do metabólito 2,3,5-tricloro-6-metoxipiridina. Enquanto na reação de com o pesticida comercial clorpirifós houve a formação dos metabólitos 2,3,5-tricloro-6-metoxipiridina e 3,5,6-tricloro1-metil-2-piridinona (Esquema 7, página 154).

Essas diferenças ocorrem, pois as estruturas moleculares dos dois compostos são diferentes. O pesticida comercial clorpirifós possui um grupo tiofosfato ligado diretamente ao anel aromático enquanto o composto fenólico 3,5,6-tricloro-2-piridinol não possui grupo substituinte ligado ao anel aromático. 
Esquema 22. Proposta de mecanismo enzimático de metiltranferases durante a reação de biotransformação do composto fenólico 3,5,6-tricloro-2-piridinol pelo fungo A. sydowii CBMAI 935 durante 10, 20 e 30 dias de reação.<smiles>Oc1nc(Cl)c(Cl)cc1Cl</smiles>

3,5,6-tricloro-2-piridinol

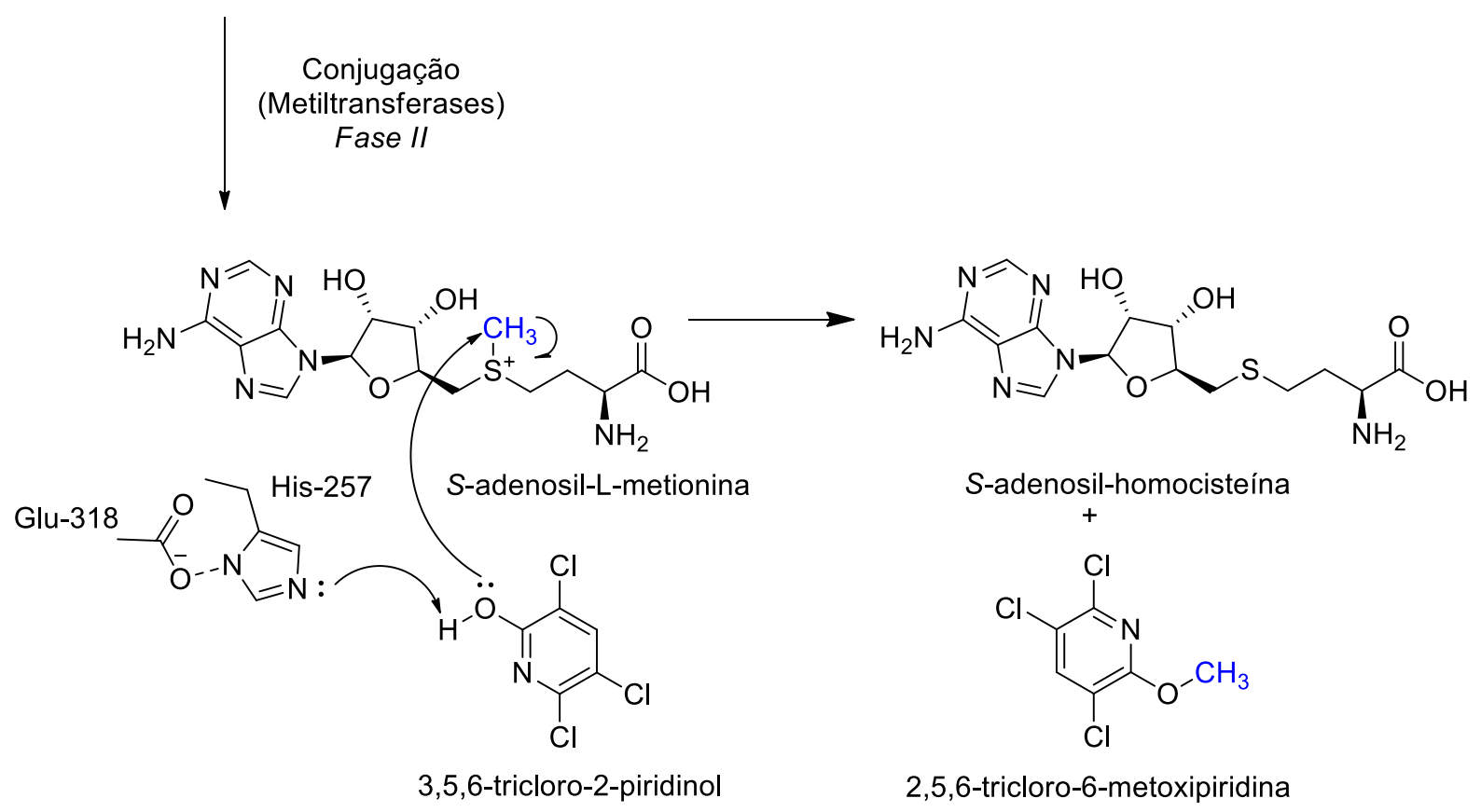

Fonte: Autoria própria. 


\subsubsection{Reações de biotransformação do composto fenólico 4-nitrofenol em 10, 20 e 30 dias pelo fungo de ambiente marinho A. sydowii CBMAI 935}

\subsubsection{Avaliação da biotransformação do composto fenólico 4-nitrofenol em 10 dias de reação com o fungo A. sydowii CBMAI 935}

A Figura 152 mostra a sobreposição dos cromatogramas das extrações do caldo enzimático (cor vermelha) e do micélio (cor preta) com o fungo A. sydowii CBMAI 935 na ausência do composto fenólico 4-nitrofenol (reação de controle biótico) em 10 dias de reação e a Figura 153 mostra os mesmos cromatogramas, porém separados. Cromatograma (a) Extração do caldo enzimático e cromatograma (b) Extração do micélio.

Figura 152. Cromatogramas obtidos por CG-EM das extrações do micélio (cor preta) e do caldo enzimático (cor vermelha) com o fungo A. sydowii CBMAI 935 na ausência do composto fenólico 4-nitrofenol (reação de controle biótico) durante 10 dias de reação de biotransformação.

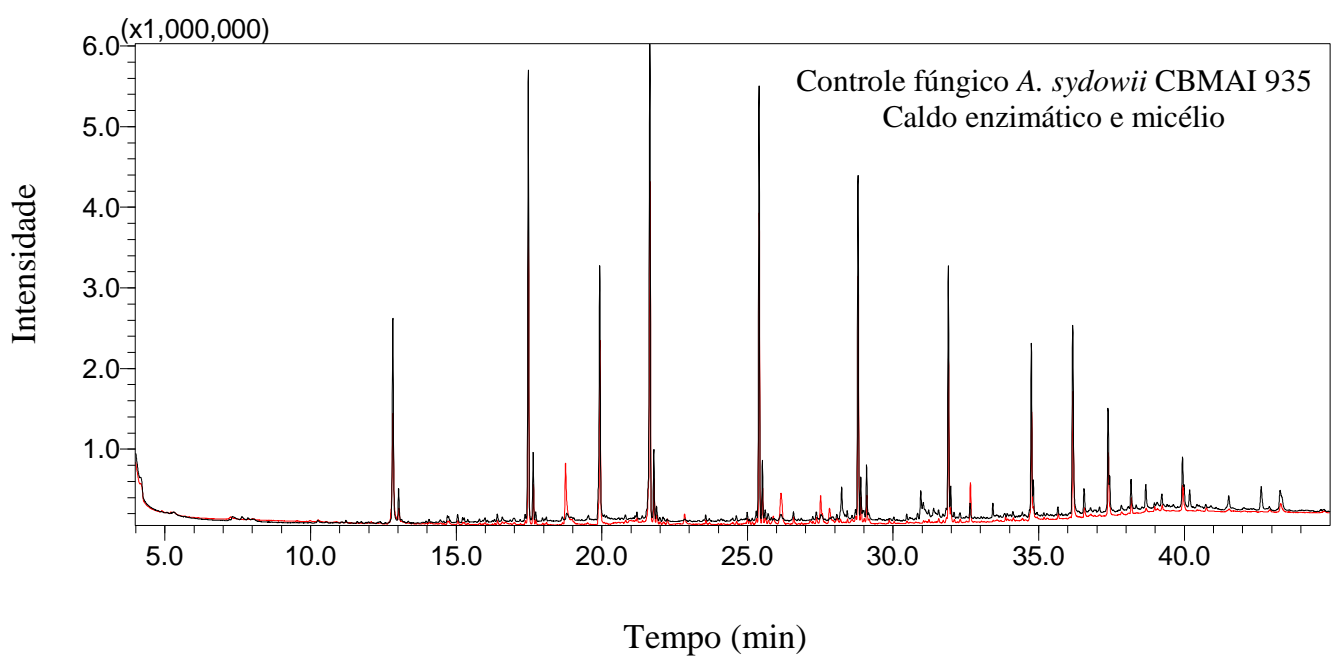

Condições de análise CG-EM: $\mathrm{T}_{\mathrm{i}}=60^{\circ} \mathrm{C}, 2 \mathrm{~min} ; \mathrm{T}_{\mathrm{f}}=280^{\circ} \mathrm{C}, 6 \mathrm{~min} ; \mathrm{r}=6^{\circ} \mathrm{C} / \mathrm{min}, \mathrm{t}_{\mathrm{c}}=45 \mathrm{mim}$.

Coluna capilar DB-5 da J\&W Scientific (30 m x 0,25 mm x 0,25 $\mu \mathrm{m}$ ). 
Figura 153. Cromatogramas obtidos por CG-EM das extrações do micélio e do caldo enzimático do fungo $A$. sydowii CBMAI 935 na ausência do composto fenólico 4-nitrofenol (reação de controle biótico) durante 10 dias.

(a) Extração do caldo enzimático e (b) Extração do micélio.

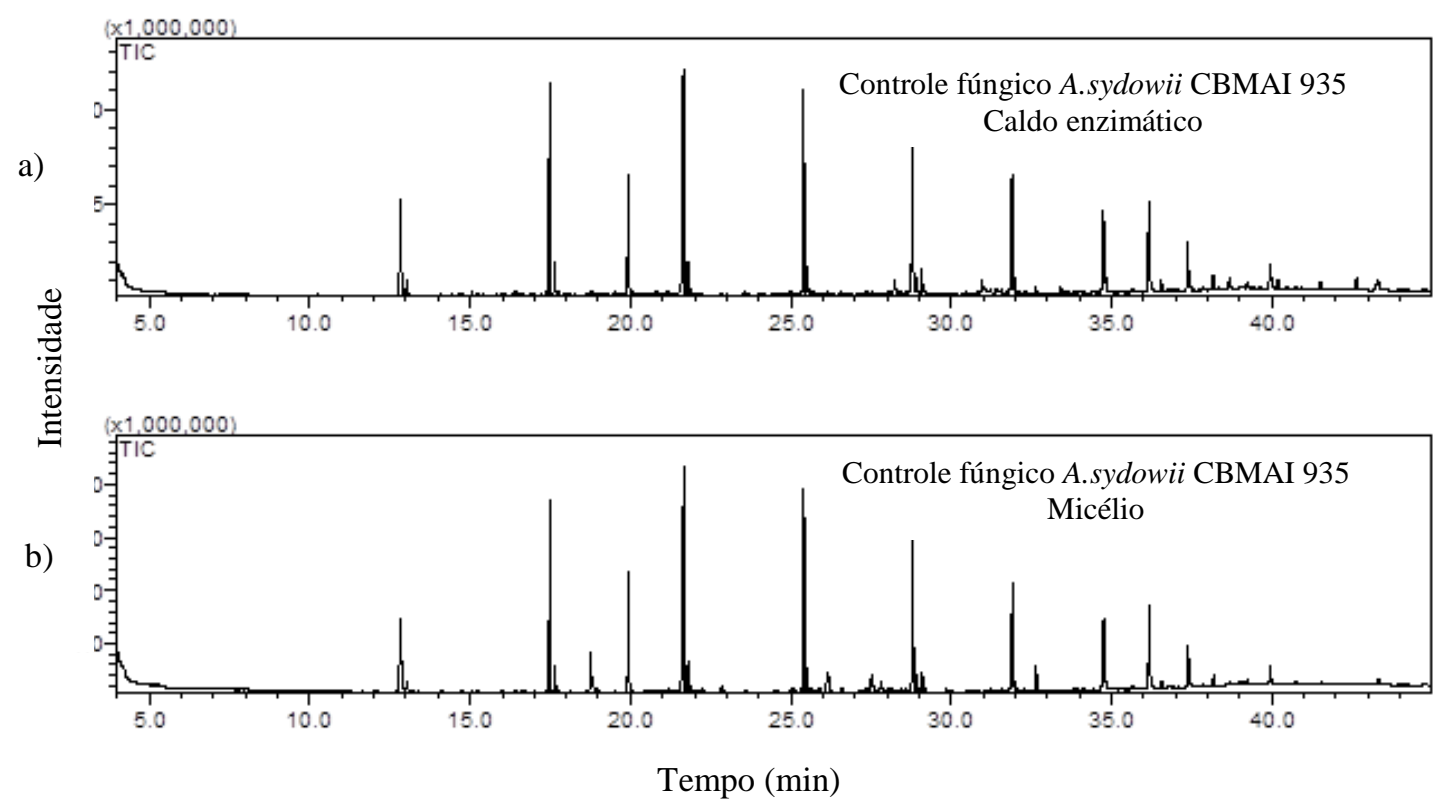

Condições de análise CG-EM: $\mathrm{T}_{\mathrm{i}}=60^{\circ} \mathrm{C}, 2 \mathrm{~min} ; \mathrm{T}_{\mathrm{f}}=280^{\circ} \mathrm{C}, 6 \mathrm{~min} ; \mathrm{r}=6^{\circ} \mathrm{C} / \mathrm{min}, \mathrm{t}_{\mathrm{c}}=45 \mathrm{mim}$.

Coluna capilar DB-5 da J\&W Scientific (30 m x 0,25 mm x 0,25 $\mu \mathrm{m})$.

Os cromatogramas obtidos por CG-EM das reações em triplicatas com o fungo A. sydowii CBMAI 935 na ausência do composto fenólico 4-nitrofenol em 10 dias de reação, apresentaram semelhanças quanto à presença de metabólitos provenientes do fungo. $\mathrm{O}$ cromatograma com a extração do caldo enzimático apresentou menor intensidade qualitativa dos sinais quando comparado com o cromatograma da extração do micélio (Figuras 152 e 153). É importante frisar que os experimentos também foram realizados para 20 e 30 dias de crescimento micelial na ausência de xenobióticos, onde não houve diferença significativa de intensidade dos sinais dos metabólitos produzidos naturalmente pelo fungo. Os cromatogramas de controle biótico pra 20 e 30 dias são mostrados no Apêndice da dissertação.

A Figura 154 mostra a sobreposição do cromatograma obtido por CG-EM da reação de controle biótico (cor vermelha) e o cromatograma da reação do composto fenólico 4nitrofenol (cor preta) com concentração de 50 mg. $\mathrm{L}^{-1}$ em 10 dias de reação de biotransformação com o fungo A. sydowii CBMAI 935. Os cromatogramas estão sobrepostos para a comparação qualitativa das intensidades dos sinais dos metabólitos formados naturalmente pelo fungo e os metabólitos formados por ação enzimática do fungo e o composto fenólico 4-nitrofenol. 
Figura 154. Cromatograma obtido por CG-EM da reação de controle biótico do fungo A. sydowii CBMAI 935 e o composto fenólico 4-nitrofenol em 10 dias de reação de biotransformação.

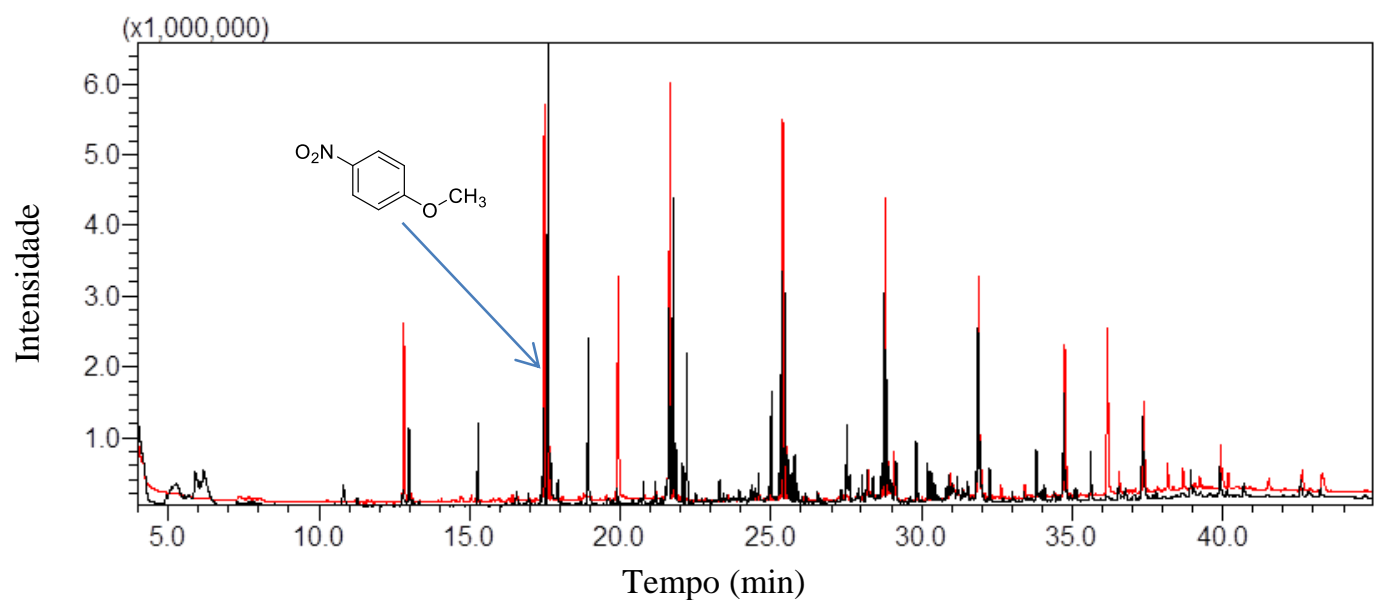

Condições de análise CG-EM: $\mathrm{T}_{\mathrm{i}}=60^{\circ} \mathrm{C}, 2 \mathrm{~min} ; \mathrm{T}_{\mathrm{f}}=280^{\circ} \mathrm{C}, 6 \mathrm{~min} ; \mathrm{r}=6^{\circ} \mathrm{C} / \mathrm{min}, \mathrm{t}_{\mathrm{c}}=45 \mathrm{mim}$.

Coluna capilar DB-5 da J\&W Scientific (30 m x 0,25 mm x 0,25 $\mu \mathrm{m})$.

A Figura 155 mostra o cromatograma obtido por CG-EM da reação de controle abiótico. Neste caso utilizou-se o padrão analítico do composto fenólico 4-nitrofenol em meio de cultura líquido de malte $2 \%$ na ausência do fungo A. sydowii CBMAI 935 durante 10 dias de reação, para verificar se o mesmo era estável nas condições utlizadas $\left(32^{\circ} \mathrm{C}, \mathrm{pH} 7,0\right)$. $\mathrm{O}$ padrão analítico do composto fenólico 4-nitrofenol teve o seu sinal no tempo de retenção em 20,650 minutos.

Figura 155. Cromatograma obtido por CG-EM da reação de controle abiótico do composto fenólico 4-nitrofenol na ausência do fungo A. sydowii CBMAI 935 durante 10 dias de reação de biotransformação.

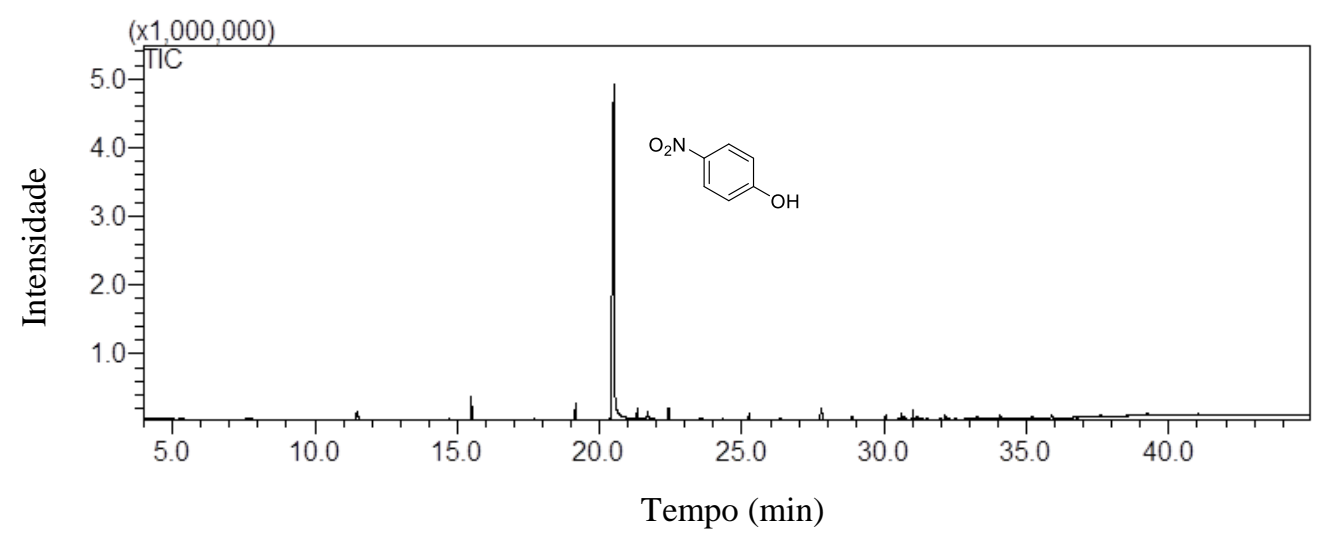

Condições de análise CG-EM: $\mathrm{T}_{\mathrm{i}}=60^{\circ} \mathrm{C}, 2 \mathrm{~min} ; \mathrm{T}_{\mathrm{f}}=280^{\circ} \mathrm{C}, 6 \mathrm{~min} ; \mathrm{r}=6^{\circ} \mathrm{C} / \mathrm{min}, \mathrm{t}_{\mathrm{c}}=45 \mathrm{mim}$.

Coluna capilar DB-5 da J\&W Scientific (30 m x 0,25 mm x 0,25 $\mu \mathrm{m})$. 
A Figura 156 mostra o cromatograma obtido por CG-EM das extrações do micélio para o metabólito 1-metoxi-4-nitrobenzeno oriundo da metilação enzimática do composto fenólico 4nitrofenol na reação de biotranformação com o fungo A. sydowii CBMAI 935 em 10 dias.

O cromatograma foi obtido a partir da Figura 153, selecionando apenas o sinal do composto 1-metoxi-4-nitrobenzeno com tempo de retenção em 17,700 minutos.

O sinal e o tempo de retenção do metabólito encontrados na reação foram comparados com o padrão sintético do 1-metoxi-4-nitrobenzeno, os quais foram idênticos, confirmando a identidade do composto nas reações de biotransformação.

Figura 156. Ampliação do cromatograma do metabólito 1-metoxi-4-nitrobenzeno obtido por CG-EM das extrações do caldo enzimático do fungo A. sydowii CBMAI 935 na presença do composto fenólico 4-nitrofenol durante 10 dias de reação de biotransformação.

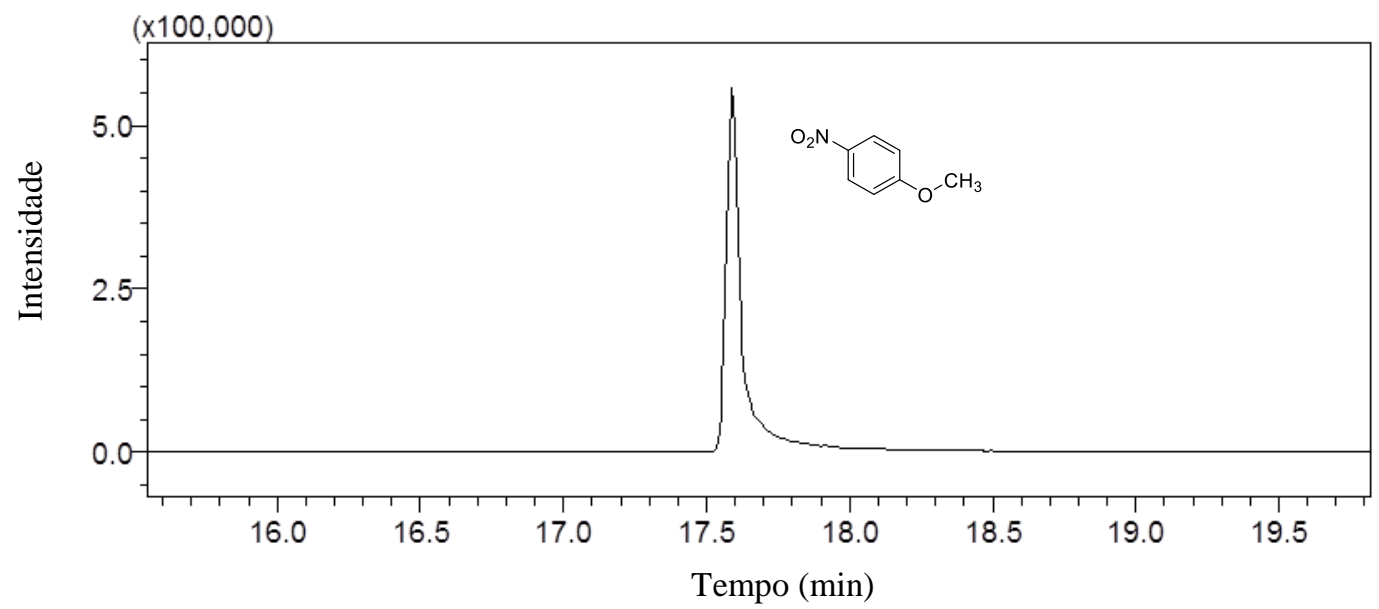

Condições de análise CG-EM: $\mathrm{T}_{\mathrm{i}}=60^{\circ} \mathrm{C}, 2 \mathrm{~min} ; \mathrm{T}_{\mathrm{f}}=280^{\circ} \mathrm{C}, 6 \mathrm{~min} ; \mathrm{r}=6^{\circ} \mathrm{C} / \mathrm{min}, \mathrm{t}_{\mathrm{c}}=45 \mathrm{mim}$. Coluna capilar DB-5 da J\&W Scientific (30 m x 0,25 mm x 0,25 $\mu \mathrm{m})$.

A Figura 157 mostra o espectro de massas obtido por CG-EM (70 eV) do metabólito 1metoxi-4-nitrobenzeno obtido da reação de biotranformação do composto fenólico 4nitrofenol com o fungo A. sydowii CBMAI 935 em 10 dias. O composto fenólico apresentou o íon molecular $m / z 153$ (1) sendo este também o pico base. No fragmento com $\mathrm{m} / z 137$ (2) com intensidade de (8\%), usualmente os picos resultantes da perda de $-\mathrm{CH}_{3}$ e pode subsequentemente perder um próton. O fragmento com $\mathrm{m} / \mathrm{z} 123$ (2) com intensidade de (73\%) pode ser resultante da perda do perda de $-\mathrm{OCH}_{3}$. $\mathrm{O}$ espectro descrito foi comparado com o espectro de massas do padrão sintético do 1-metoxi-4-nitrobenzeno. 
Figura 157. Espectro de massas obtido em CG-EM $(70 \mathrm{eV})$ para o metabólito 1-metoxi-4-nitrobenzeno das extrações do micélio do fungo A. sydowii CBMAI 935 na presença do composto fenólico 4-nitrofenol durante 10 dias de reação de biotransformação.

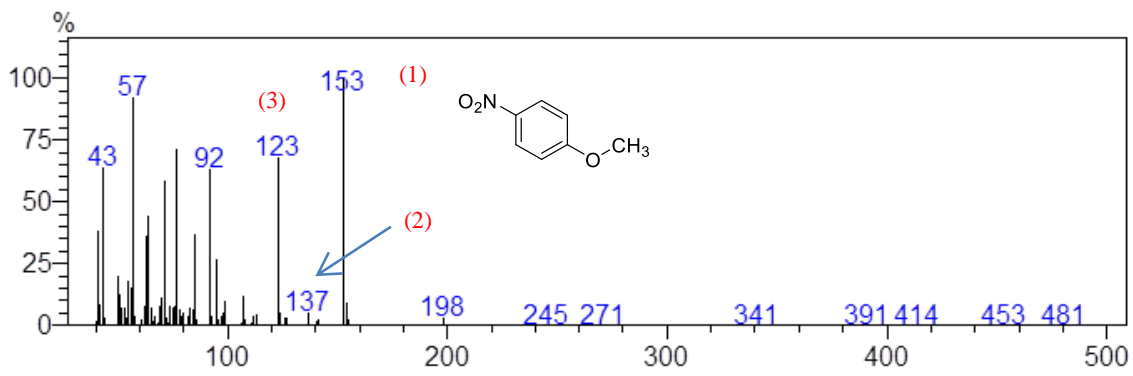

O Esquema 23 mostra a proposta de fragmentação para o composto 1-metoxi-4nitrobenzeno obtido por CG-EM das extrações do micélio com o fungo de ambiente marinho A. sydowii CBMAI 935 em 10 dias de reação de biotransformação.

Esquema 23. Proposta de fragmentação para o composto 1-metoxi-4-nitrobenzeno.

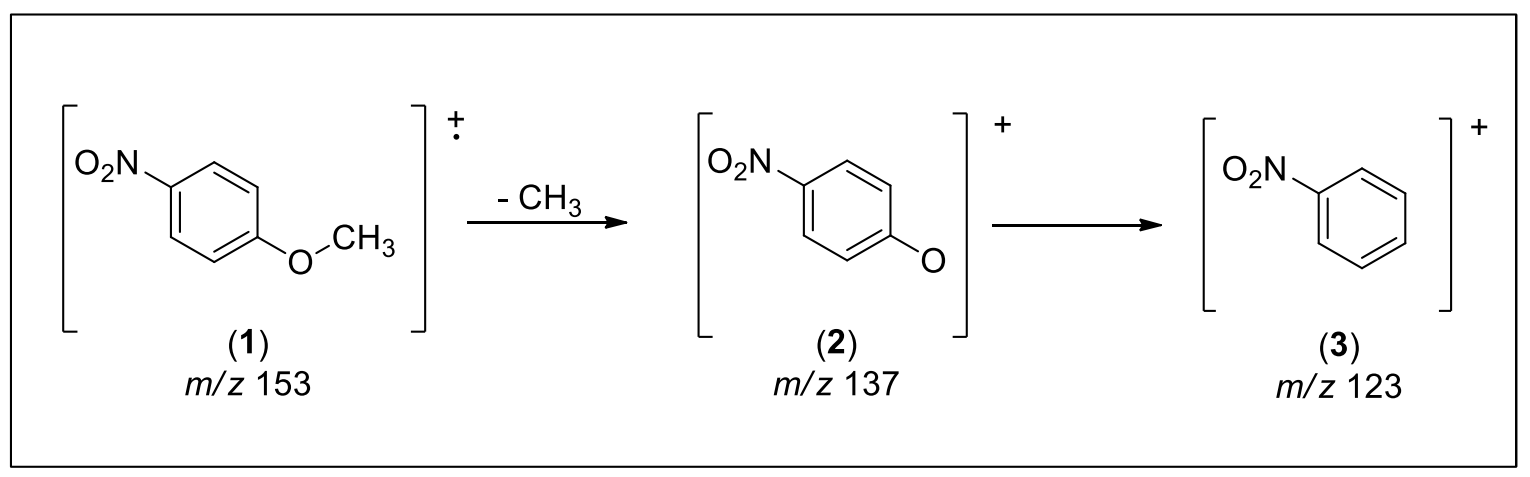

Fonte: Autoria própria.

\subsubsection{Avaliação da biotransformação do composto fenólico 4-nitrofenol em 20 e 30 dias de reação com o fungo $A$. sydowii CBMAI 935}

O mesmo comportamento para 20 e 30 dias de reação foi observado para 10 d. Obteve-se as mesmas reações de biotransformação e bioconjugação para o 4-nitrofenol, não cabendo aqui detalhar os resultados uma vez que foram similares aos anteriores.

O Esquema 24 mostra o mecanismo enzimático da reação de biotransformação do composto fenólico 4-nitrofenol pelo fungo de ambiente marinho A. sydowii CBMAI 935. Esse esquema foi proposto a partir do composto identificado nos cromatogramas obtidos por CG- 
EM das extrações do micélio e do caldo emzimático do fungo A. sydowii CBMAI 935 na presença do 4-nitrofenol, durante 10, 20 e 30 dias de reação.

Fazendo comparações com as reações de biotransformação do pesticida comercial metil paration, notou-se que a reação com o 4-nitrofenol houve a formação do mesmo metabólito de biotransformação o composto 1-metoxi-4-nitrobenzeno e o 4-nitrofenol não foi encontrado nos cromatogramas das reações, indicando que o mesmo foi totalmente biotransformado.

Esquema 24. Proposta de mecanismo enzimático da reação de biotransformação do composto fenólico 4nitrofenol pelo fungo A. sydowii CBMAI 935 durante 10, 20 e 30 dias de reação.<smiles>O=[N+]([O-])c1ccc(O)cc1</smiles>

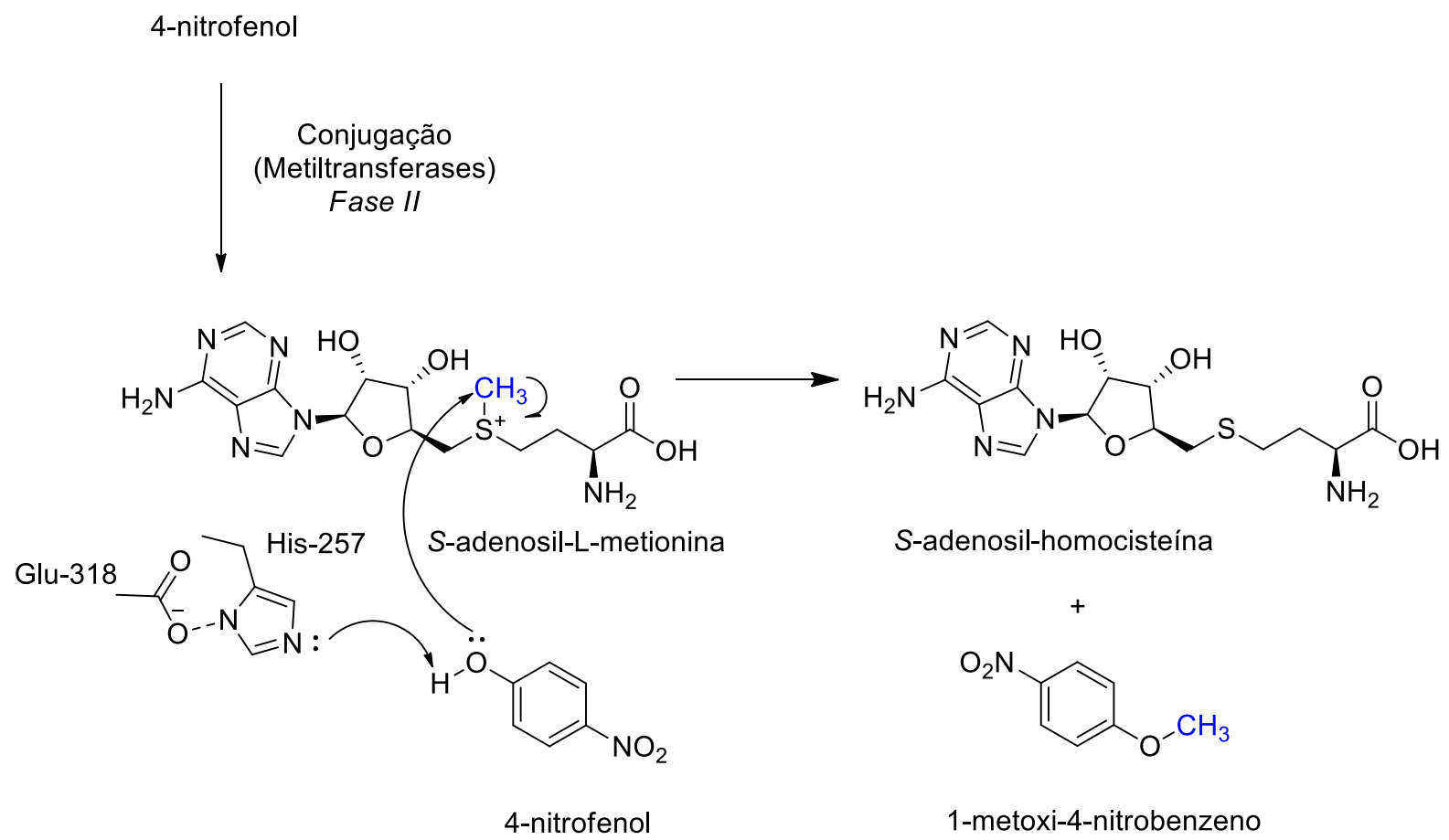

Fonte: Autoria própria. 


\subsubsection{Reações de biotransformação do composto fenólico 4-bromo-2-clorofenol em 10, 20} e 30 dias pelo fungo de ambiente marinho A. sydowii CBMAI 935

\subsubsection{Avaliação da biotransformação do composto fenólico 4-bromo-2-clorofenol em} 10 dias de reação com o fungo $A$. sydowii CBMAI 935

A Figura 158 mostra a sobreposição dos cromatogramas das extrações do caldo enzimático (cor vermelha) e do micélio (cor preta) com o fungo A. sydowii CBMAI 935 na ausência do composto fenólico 4-bromo-2-clorofenol (reação de controle biótico) em 10 dias de reação e a Figura 159 mostra os mesmos cromatogramas, porém separados. Cromatograma (a) Extração do caldo enzimático e (b) Extração do micélio.

Figura 158. Cromatogramas obtidos por CG-EM das extrações do micélio (cor preta) e do caldo enzimático (cor vermelha) com o fungo A. sydowii CBMAI 935 na ausência do composto fenólico 4-bromo-2-clorofenol (reação de controle biótico) durante 10 dias de biotransformação.

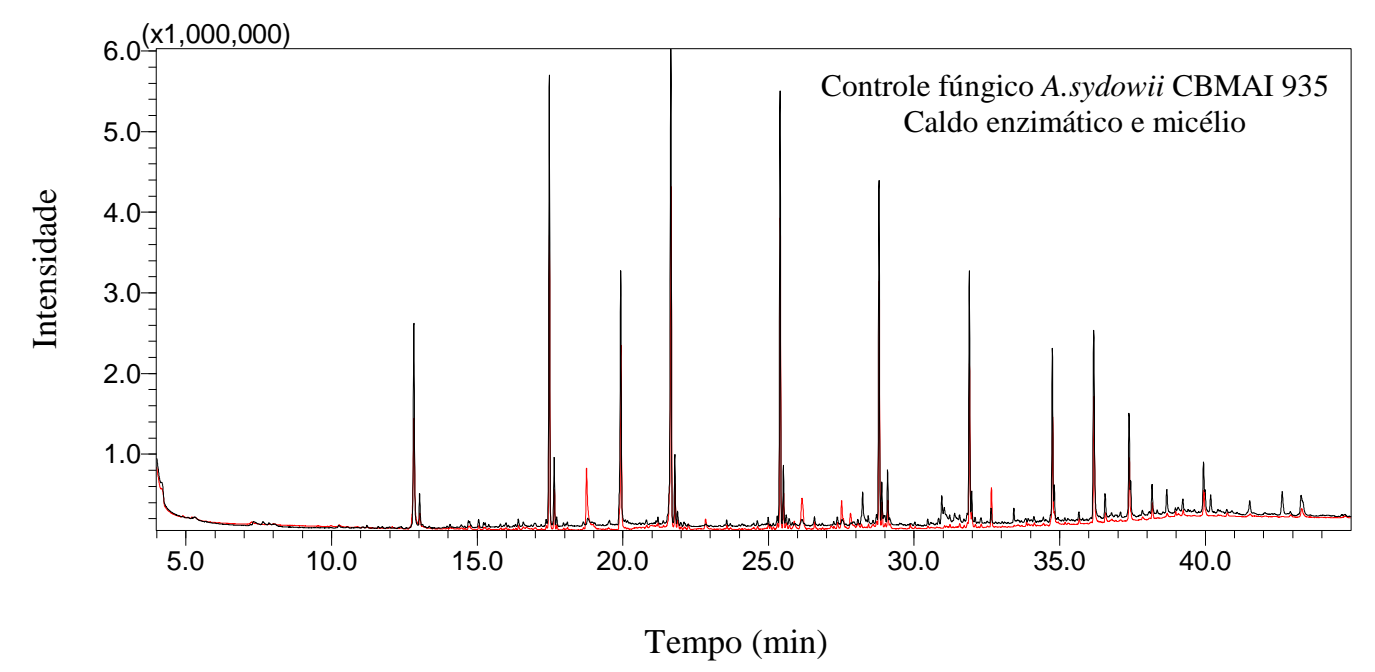

Condições de análise CG-EM: $\mathrm{T}_{\mathrm{i}}=60^{\circ} \mathrm{C}, 2 \mathrm{~min} ; \mathrm{T}_{\mathrm{f}}=280^{\circ} \mathrm{C}, 6 \mathrm{~min} ; \mathrm{r}=6^{\circ} \mathrm{C} / \mathrm{min}, \mathrm{t}_{\mathrm{c}}=45 \mathrm{mim}$.

Coluna capilar DB-5 da J\&W Scientific (30 $\mathrm{m}$ x 0,25 mm x 0,25 $\mu \mathrm{m})$. 
Figura 159. Cromatogramas obtidos por CG-EM das extrações do micélio e do caldo enzimático do fungo $A$. sydowii CBMAI 935 na ausência do composto fenólico 4-bromo-2-clorofenol (reação de controle biótico) durante 10 dias. (a) Extração do caldo enzimático e (b) Extração do micélio.

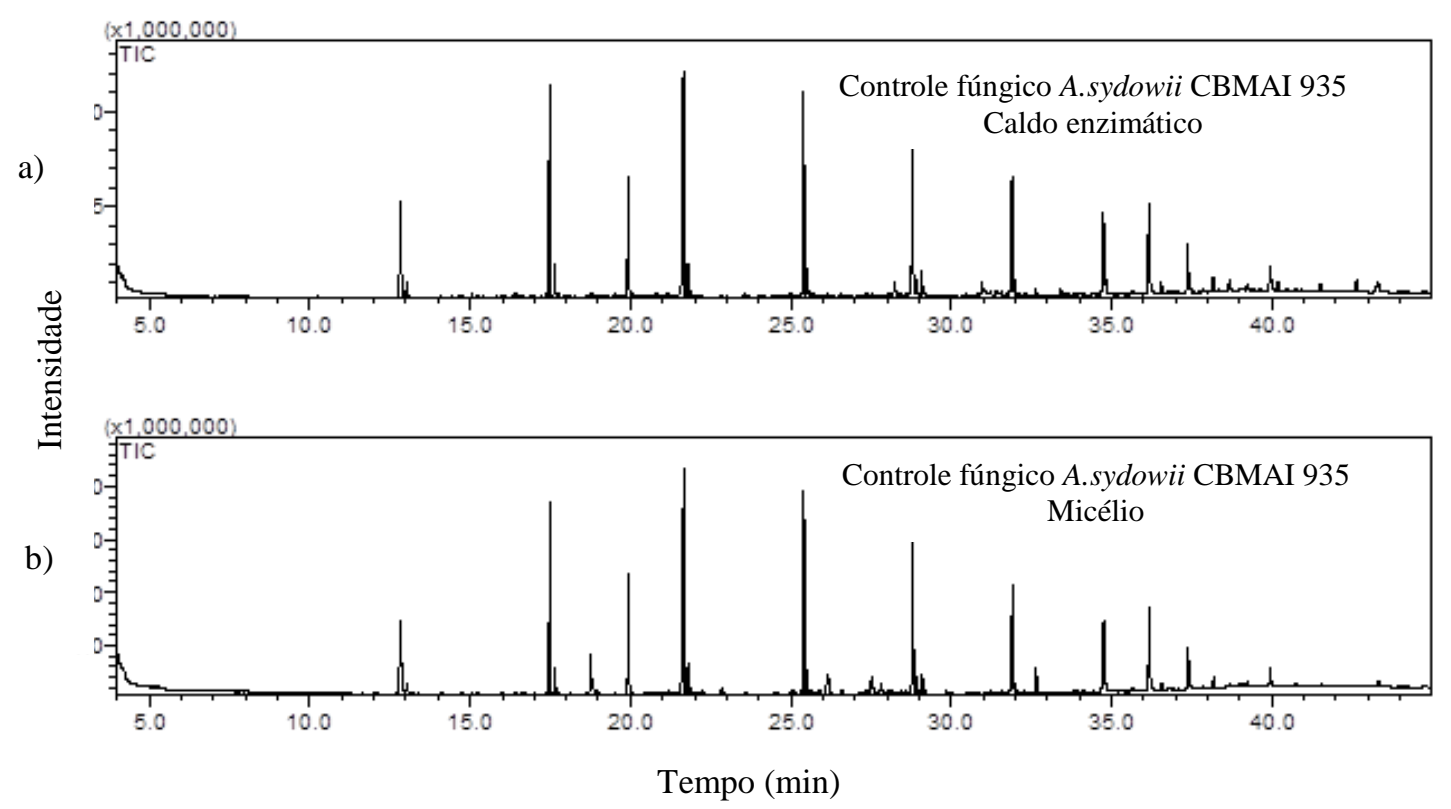

Condições de análise CG-EM: $\mathrm{T}_{\mathrm{i}}=60^{\circ} \mathrm{C}, 2 \mathrm{~min} ; \mathrm{T}_{\mathrm{f}}=280^{\circ} \mathrm{C}, 6 \mathrm{~min} ; \mathrm{r}=6^{\circ} \mathrm{C} / \mathrm{min}, \mathrm{t}_{\mathrm{c}}=45 \mathrm{mim}$.

Coluna capilar DB-5 da J\&W Scientific (30 m x 0,25 mm x 0,25 $\mu \mathrm{m})$.

Os cromatogramas obtidos por CG-EM das reações em triplicatas com o fungo A. sydowii CBMAI 935 na ausência do composto fenólico 4-bromo-2-clorofenol em 10 dias de reação, apresentaram semelhanças quanto à presença de metabólitos provenientes do fungo.

Os cromatogramas de controle biótico pra 20 e 30 dias são mostrados nas páginas de Apêndice da dissertação.

A Figura 160 mostra a sobreposição do cromatograma obtido por CG-EM da reação de controle biótico (cor vermelha) e o cromatograma da reação do composto fenólico 4-bromo-2clorofenol (cor preta) com concentração de 50 mg.L ${ }^{-1}$ em 10 dias de reação de biotransformação com o fungo A. sydowii CBMAI 935. Os cromatogramas estão sobrepostos para a comparação qualitativa das intensidades dos sinais dos metabólitos formados naturalmente pelo fungo e os metabólitos formados por ação enzimática do fungo e o composto fenólico4-bromo-2-clorofenol. 
Figura 160. Cromatograma obtido por CG-EM da reação de controle biótico do fungo A. sydowii CBMAI 935 e o composto fenólico 4-bromo-2-clorofenol em 10 dias de reação de biotransformação.

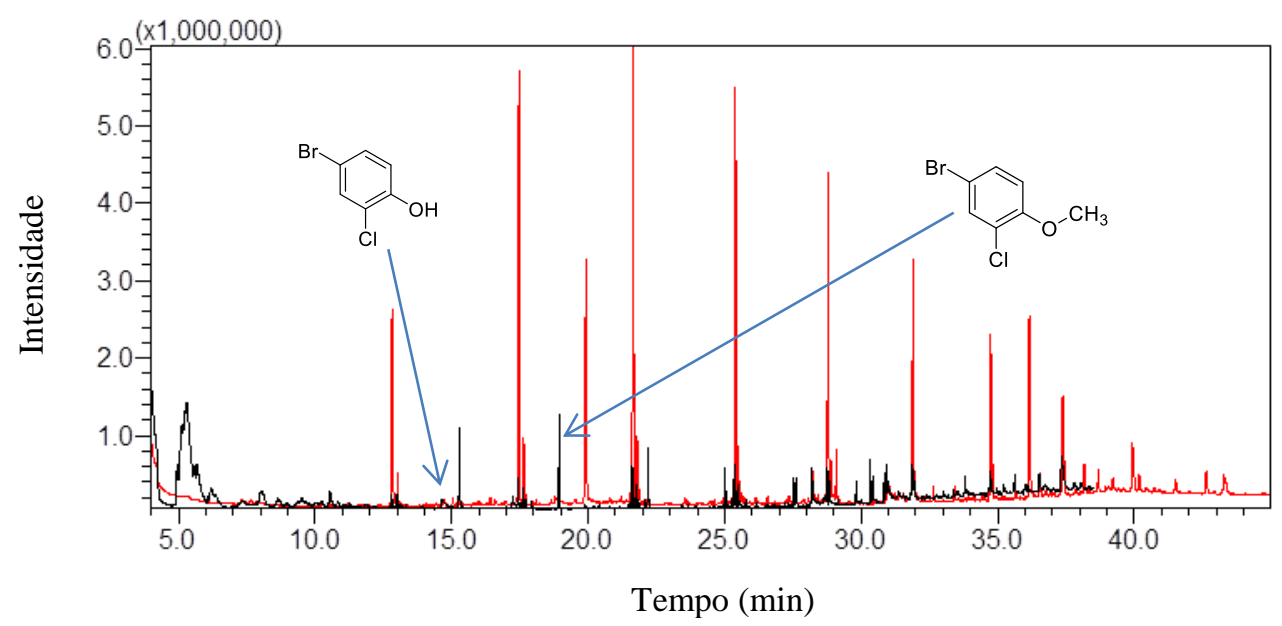

Condições de análise CG-EM: $\mathrm{T}_{\mathrm{i}}=60^{\circ} \mathrm{C}, 2 \mathrm{~min} ; \mathrm{T}_{\mathrm{f}}=280^{\circ} \mathrm{C}, 6 \mathrm{~min} ; \mathrm{r}=6^{\circ} \mathrm{C} / \mathrm{min}, \mathrm{t}_{\mathrm{c}}=45 \mathrm{mim}$. Coluna capilar DB-5 da J\&W Scientific (30 m x 0,25 mm x 0,25 $\mu \mathrm{m})$.

A Figura 161 mostra o cromatograma obtido por CG-EM da reação de controle abiótico. Neste caso utilizou-se o padrão analítico do composto fenólico 4-bromo-2-clorofenol em meio de cultura líquido de malte $2 \%$ na ausência do fungo A. sydowii CBMAI 935 durante 10 dias de reação para verificar se o mesmo foi estável nas condições utlizadas $\left(32^{\circ} \mathrm{C}, \mathrm{pH} 7,0\right)$. O padrão analítico do composto fenólico 4-bromo-2-clorofenol teve o seu sinal no tempo de retenção em 14,620 minutos.

Figura 161. Cromatograma obtido por CG-EM da reação de controle abiótico do composto fenólico 4-bromo-2clorofenol na ausência do fungo A. sydowii CBMAI 935 durante 10 dias de reação de biotransformação.

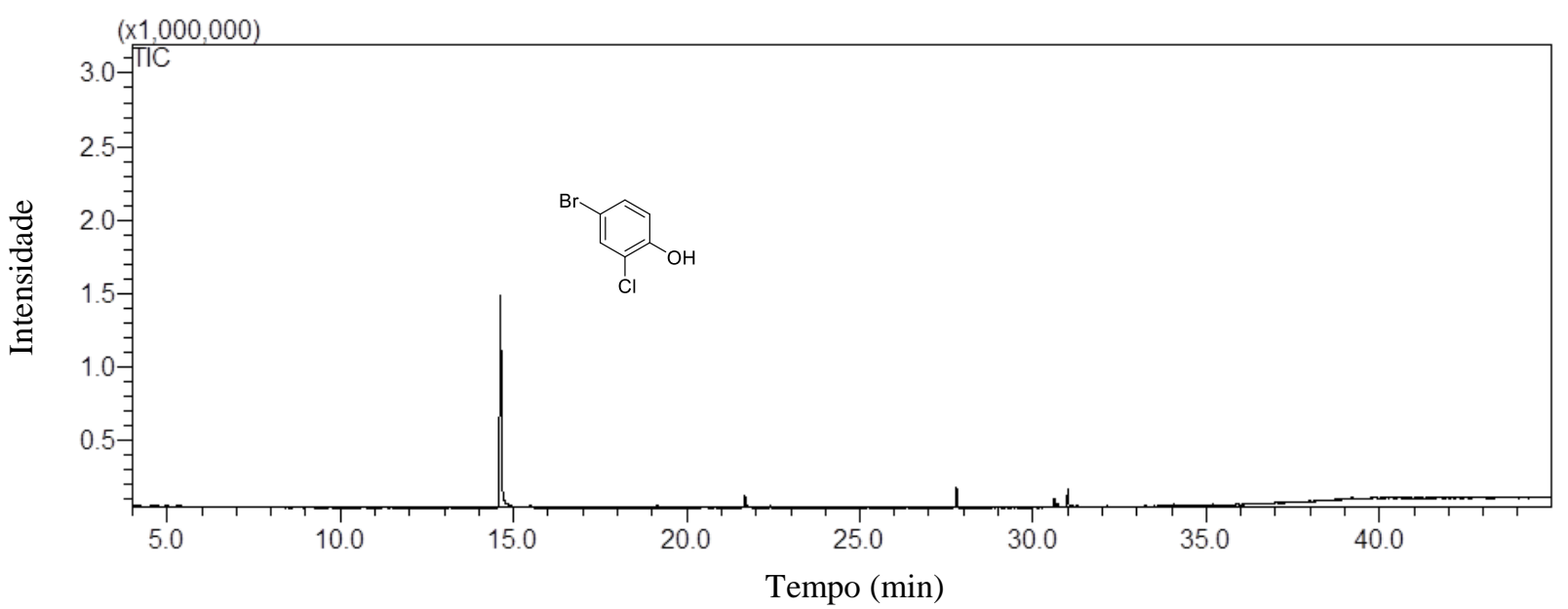

Condições de análise CG-EM: $\mathrm{T}_{\mathrm{i}}=60^{\circ} \mathrm{C}, 2 \mathrm{~min} ; \mathrm{T}_{\mathrm{f}}=280^{\circ} \mathrm{C}, 6 \mathrm{~min} ; \mathrm{r}=6^{\circ} \mathrm{C} / \mathrm{min}, \mathrm{t}_{\mathrm{c}}=45 \mathrm{mim}$.

Coluna capilar DB-5 da J\&W Scientific (30 m x 0,25 mm x 0,25 $\mu \mathrm{m})$. 
A Figura 162 mostra o cromatograma obtido por CG-EM das extrações do micélio para o composto fenólico 4-bromo-2-clorofenol com o fungo de ambiente marinho A. sydowii CBMAI 935 em 10 dias de reação de biotransformação. O cromatograma foi obtido a partir da Figura 160, selecionando apenas o sinal do composto com tempo de retenção em 14,620 minutos. O sinal e o tempo de retenção do composto fenólico encontrado na reação de biotransformação das extrações do micélio com o fungo A. sydowii CBMAI 935 em 10 dias foram comparados com o padrão analítico do 4-bromo-2-clorofenol. Os quais foram idênticos, confirmando a identidade do composto na amostra comercial que foi utilizada nas reações de biotransformação.

Figura 162. Cromatograma selecionado do composto fenólico 4-bromo-2-clorofenol obtido por CG-EM das extrações do micélio do A. sydowii CBMAI 935 durante 10 dias de reação de biotransformação.

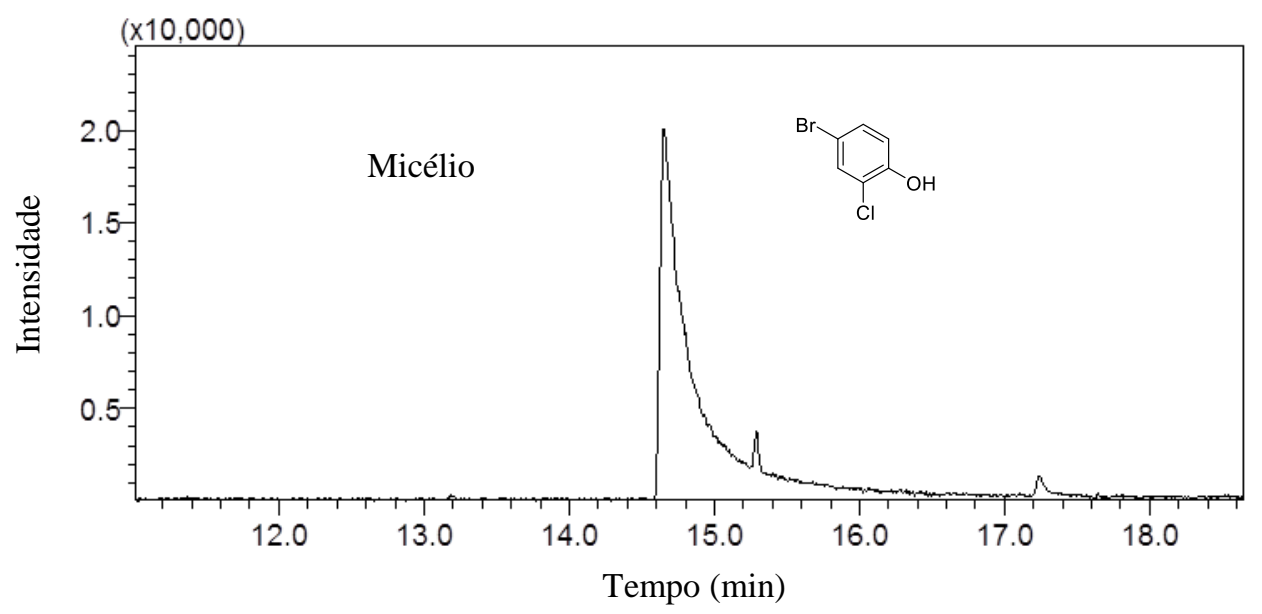

Condições de análise CG-EM: $\mathrm{T}_{\mathrm{i}}=60^{\circ} \mathrm{C}, 2 \mathrm{~min} ; \mathrm{T}_{\mathrm{f}}=280^{\circ} \mathrm{C}, 6 \mathrm{~min} ; \mathrm{r}=6^{\circ} \mathrm{C} / \mathrm{min}, \mathrm{t}_{\mathrm{c}}=45 \mathrm{mim}$. Coluna capilar DB-5 da J\&W Scientific (30 m x 0,25 mm x 0,25 $\mu \mathrm{m})$.

A Figura 163 mostra o espectro de massas obtido em CG-EM (70 eV) do composto fenólico 4-bromo-2-clorofenol com o fungo A. sydowii CBMAI 935 em 10 dias. O espectro de massas para o 4-bromo-2-clorofenol apresenta o pico do íon molecular intenso, característico dos fenois. Com a maior intensidade, o pico do íon molecular é também o pico base com fragmento de $\mathrm{m} / \mathrm{z}$ 208. Assim como na fragmentação do profenofós, o pico correspondente ao 4-bromo-2-clorofenol apresenta maior intensidade em $\mathrm{m} / \mathrm{z} 208$ (1), que é correspondente ao pico $\mathrm{M}+2$, com esta molécula apresentando abundâncias relativas dos picos $\mathbf{M}(\mathrm{m} / \mathrm{z}, 206), \mathbf{M}+2$ e $\mathrm{M}+4(\mathrm{~m} / \mathrm{z}, 210)$ de aproximadamente 78,100 e $24 \%$. A presença de um pico pouco intenso $(8 \%)$ em $\mathrm{m} / z 170$ (2) pode representar a perda do átomo de cloro do fenol. O fragmento com $\mathrm{m} / \mathrm{z} 63$ (44\%) (3) pode ser resultante da perda de CHO, característica para 
os fenois. O espectro descrito foi comparado com o espectro de massas do padrão analítico do composto fenólico 4-bromo-2-clorofenol.

Figura 163. Espectro de massas obtido por CG-EM $(70 \mathrm{eV})$ para o composto fenólico 4-bromo-2-clorofenol das extrações do micélio do fungo A. sydowii CBMAI 935 durante 10 dias de reação de biotransformação.

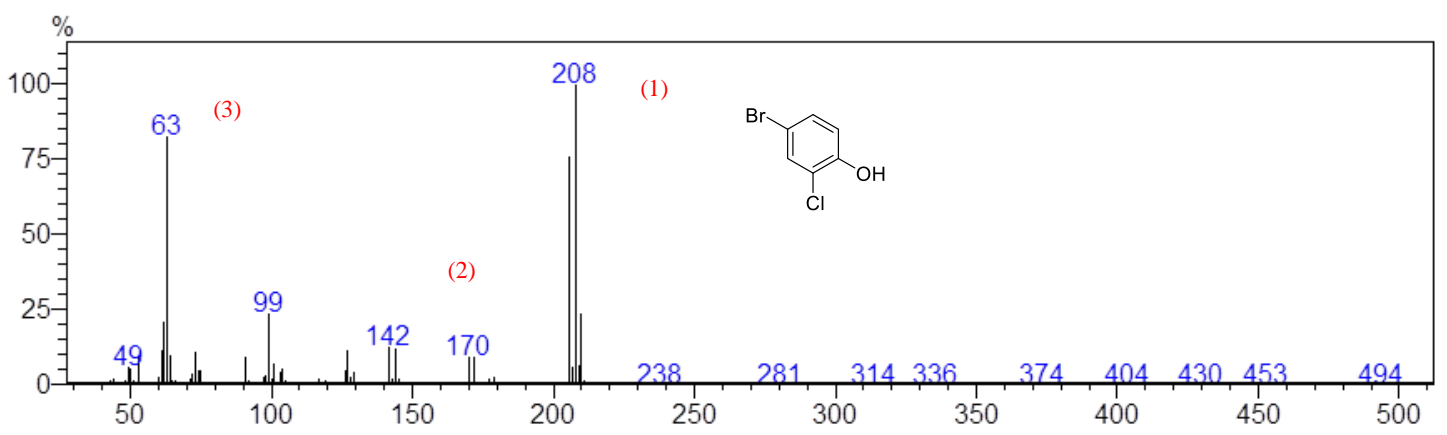

O Esquema 25 mostra a proposta de fragmentação para o 4-bromo-2-clorofenol obtido por CG-EM das extrações do micélio com o fungo de ambiente marinho A. sydowii CBMAI 935 em 10 dias de reação de biotransformação.

Esquema 25. Proposta de fragmentação do composto 4-bromo-2-clorofenol.

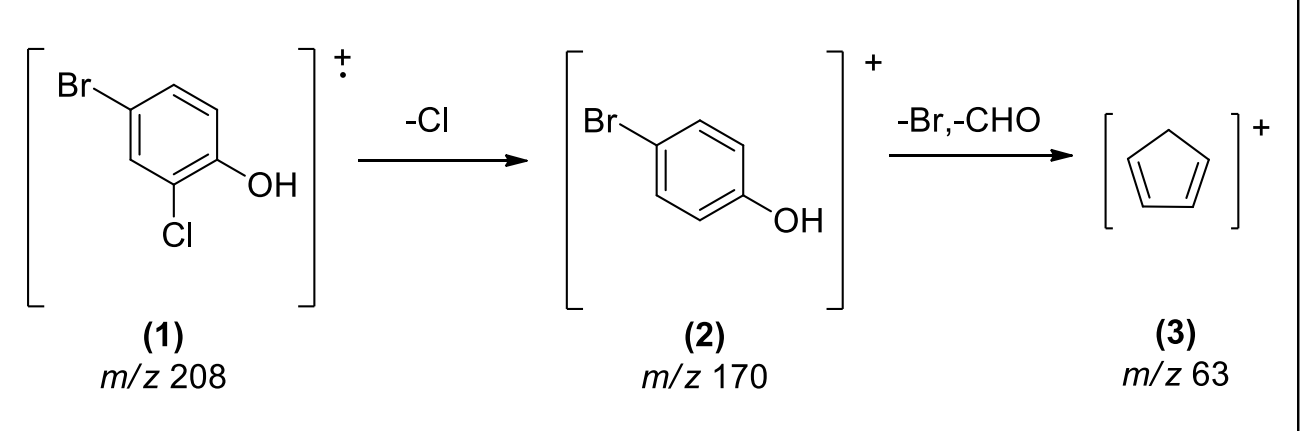

Fonte: Autoria Própria.

A Figura 164 mostra o cromatograma obtido por CG-EM das extrações do micélio para o metabólito 4-bromo-2-cloro-1-metoxibenzeno oriundo da metilação enzimática do composto fenólico 4-bromo-2-clorofenol na reação de biotransformação com o fungo A. sydowii CBMAI 935 em 10 dias. O cromatograma foi obtido a partir da Figura 160 selecionando apenas o sinal do composto com tempo de retenção em 17,360 minutos.

O sinal e o tempo de retenção do metabólito 4-bromo-2-cloro-1-metoxibenzeno encontrado na reação foram comparados com o padrão sintético do 4-bromo-2-cloro-1- 
metoxibenzeno, os quais foram idênticos, confirmando a identidade do composto na amostra comercial que foi utilizada nas reações de biotransformação.

Figura 164. Ampliação do cromatograma do metabólito 4-bromo-2-cloro-1-metoxibenzeno obtido por CG-EM do caldo enzimático do fungo A. sydowii CBMAI 935 durante 10 dias de reação de biotransformação com o composto fenólico 4-bromo-2-clorofenol.

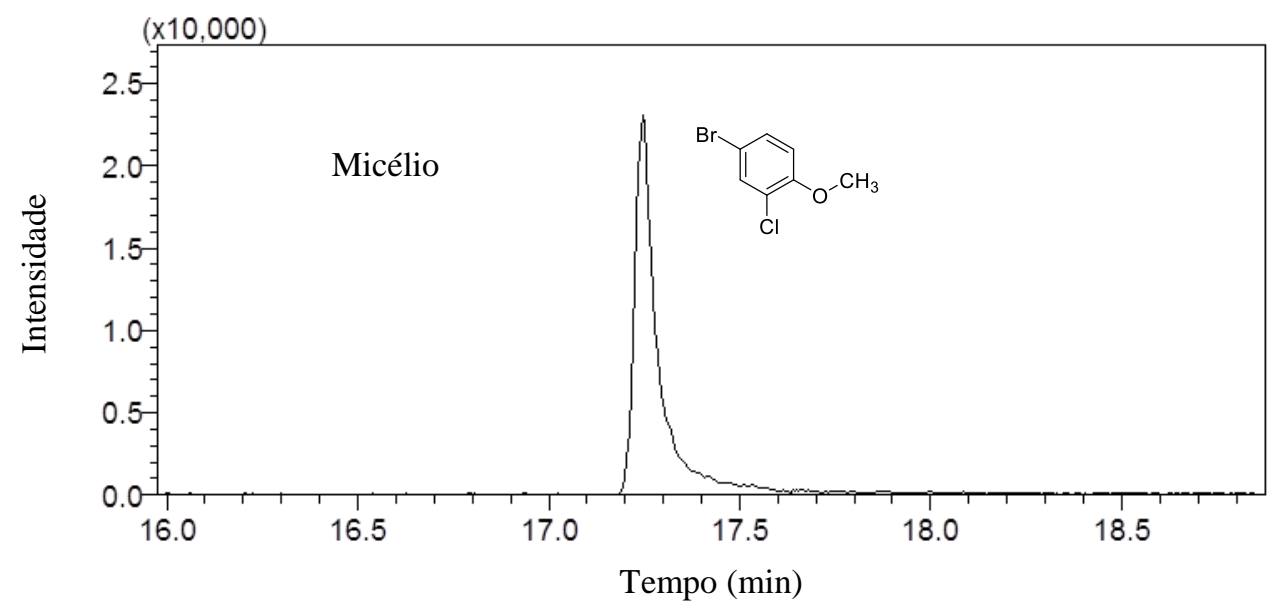

Condições de análise CG-EM: $\mathrm{T}_{\mathrm{i}}=60^{\circ} \mathrm{C}, 2 \mathrm{~min} ; \mathrm{T}_{\mathrm{f}}=280^{\circ} \mathrm{C}, 6 \mathrm{~min} ; \mathrm{r}=6^{\circ} \mathrm{C} / \mathrm{min}, \mathrm{t}_{\mathrm{c}}=45 \mathrm{mim}$. Coluna capilar DB-5 da J\&W Scientific (30 $\mathrm{m}$ x 0,25 mm x 0,25 $\mu \mathrm{m})$.

A Figura 165 mostra o espectro de massas obtido por CG-EM (70 eV) do metabólito 4bromo-2-cloro-1-metoxibenzeno obtido da reação de biotransformação com o fungo $A$. sydowii CBMAI 935 durante 10 dias. O espectro de massas para o 4-bromo-2-cloro-1metoxibenzeno apresenta o pico do íon molecular intenso. Com a maior intensidade, o pico do íon molecular é também o pico base com fragmento de $\mathrm{m} / z 222$ (1). A presença de um pico pouco intenso (12\%) em $\mathrm{m} / z 126$ (2) pode representar a perda do átomo de bromo do anel. O fragmento com $\mathrm{m} / \mathrm{z} 63$ (44\%) (3) pode ser resultante da perda de $\mathrm{CHO}$, característica para os fenois. O espectro descrito foi comparado com o espectro de massas do padrão sintético do 4bromo-2-cloro-1-metoxibenzeno. 
Figura 165. Espectro de massas obtido por CG-EM (70 eV) para o metabólito 4-bromo-2-cloro-1metoxibenzeno das extrações do micélio do A. sydowii CBMAI 935 durante 10 dias de reação de biotransformação.

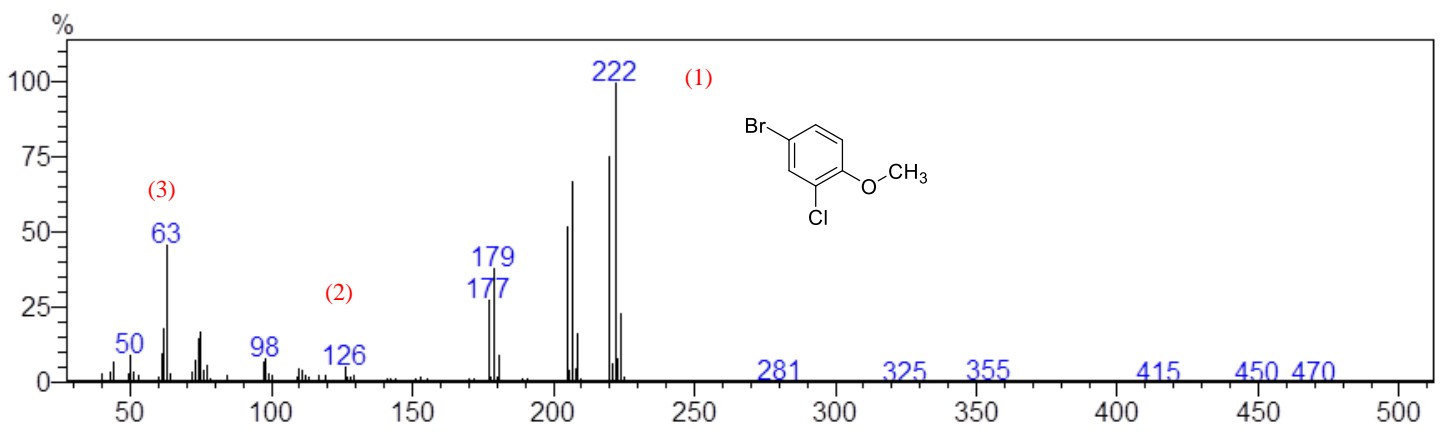

O Esquema 26 mostra a proposta de fragmentação para o 4-bromo-2-cloro-1metoxibenzeno obtido por CG-EM das extrações do micélio com o fungo de ambiente marinho A. sydowii CBMAI 935 em 10 dias de reação de biotransformação.

Esquema 26. Proposta de fragmentação do composto 4-bromo-2-cloro-1-metoxibenzeno.

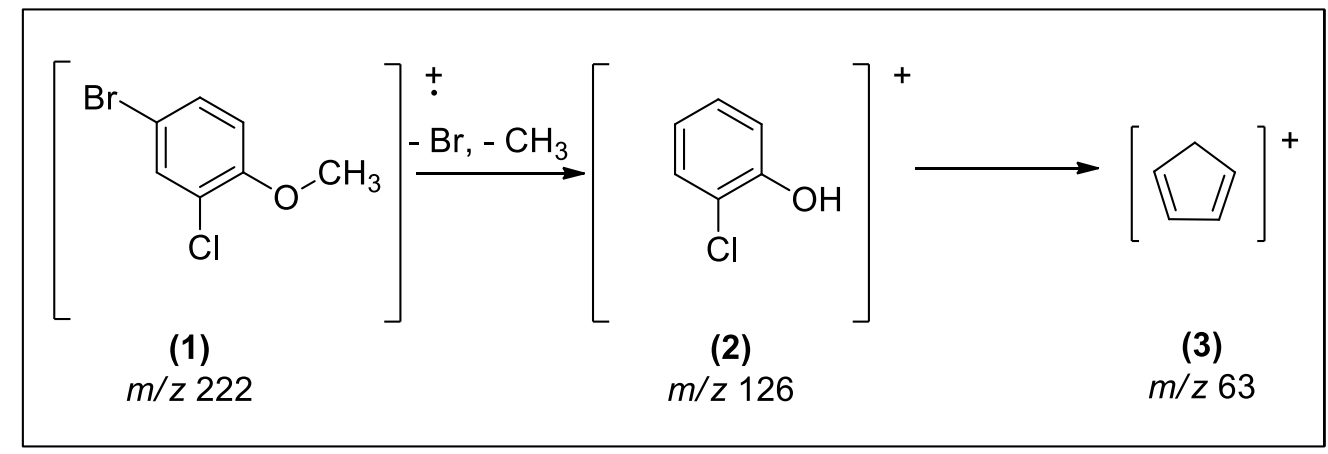

Fonte: Autoria própria.

\subsubsection{Avaliação da biotransformação do composto fenólico 4-bromo-2-clorofenol em 20 e 30 dias de reação com o fungo $A$. sydowii CBMAI 935}

O mesmo comportamento para 20 e 30 dias de reação foi observado para 10 d. Obteve-se as mesmas reações de biotransformação e bioconjugação para o 4-bromo-2-clorofenol, não cabendo aqui detalhar os resultados uma vez que foram similares aos anteriores.

O Esquema 27 mostra o mecanismo enzimático da reação de biotransformação do composto fenólico 4-bromo-2-clorofenol pelo fungo de ambiente marinho A. sydowii CBMAI 935. O Esquema 27 foi proposto a partir do composto identificado nos cromatogramas obtidos por CG-EM das extrações do micélio e do caldo emzimático do fungo A. sydowii CBMAI 935 na presença do 4-bromo-2-clorofenol, durante 10, 20 e 30 dias de reação. 
Fazendo comparações com as reações de biotransformação do pesticida comercial profenofós, notou-se que a reação com o 4-bromo-2-clorofenol houve a formação do mesmo metabólito de biotransformação, ou seja, o composto 4-bromo-2-cloro-1-metoxibenzeno.

Esquema 27. Proposta de mecanismo enzimático da reação de biotransformação do composto fenólico 4-bromo2-clorofenol pelo fungo A. sydowii CBMAI 935 durante 10, 20 e 30 dias de reação.<smiles>Oc1ccc(Br)cc1Cl</smiles>

4-bromo-2-clorofenol

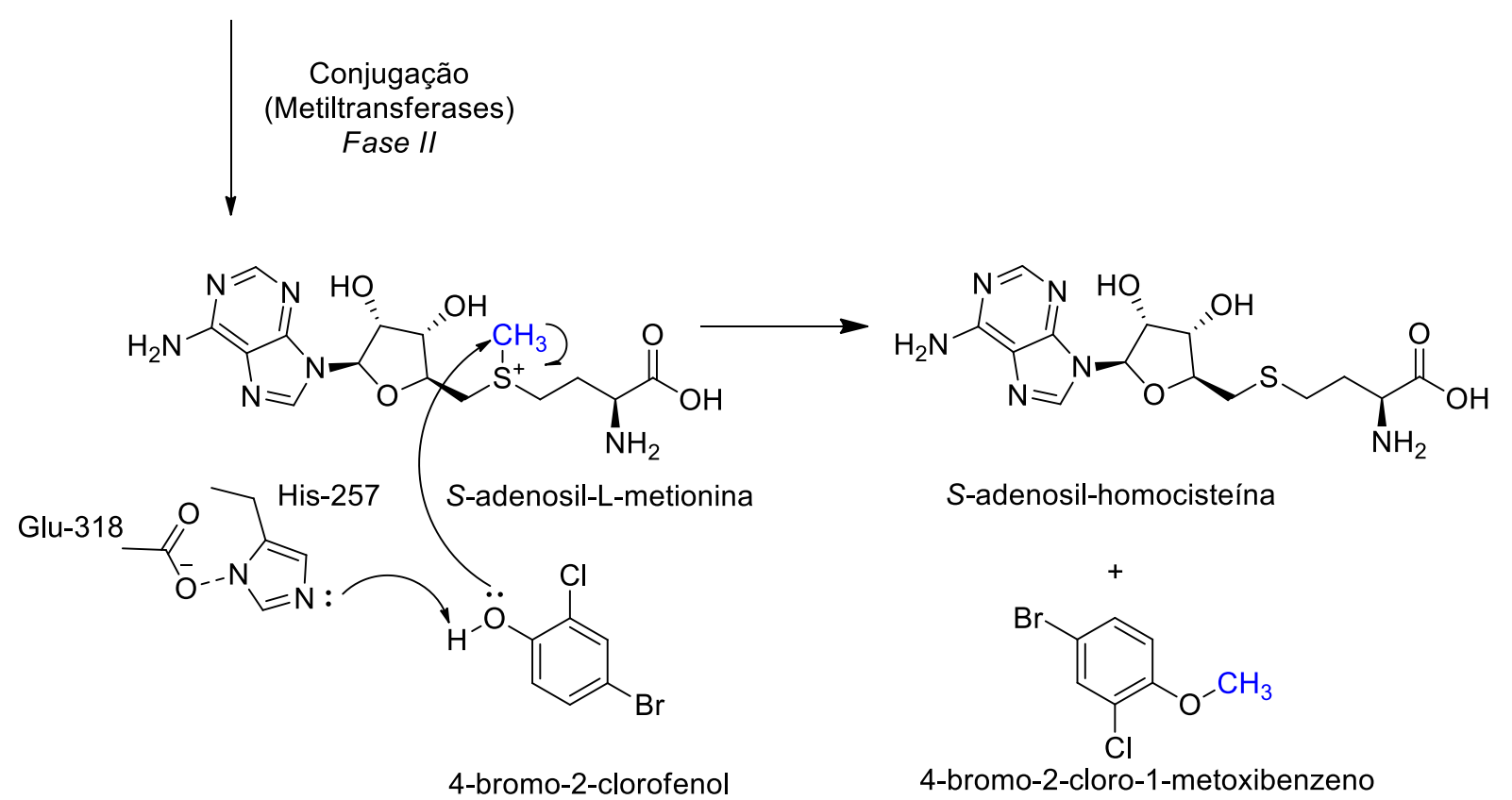

Fonte: Autoria própria. 


\subsubsection{Avaliação da biotransformação dos compostos fenólicos em 10 dias de reação pelo fungo de ambiente marinho $A$. sydowii CBMAI 935}

Devido aos exelentes resultados referentes à biometilação de pesticidas organofosfoforados (clorpirifós, metil paration e profenofós) e seus respectivos compostos fenólicos (3,5,6-tricloro-2-piridinol, 4-nitrofenol e 4-bromo-2-clorofenol) pelo fungo de ambiente marinho Aspergillus sydowii CBMAI 935, foram realizadas reações de biotransformação de outros compostos fenólicos utilizando a mesma metodologia para os pesticidas organofosforados e seus derivados fenólicos.

Os compostos fenólicos 3,5,6-tricloro-2-piridinol, 4-nitrofenol e 4-bromo-2-clorofenol, fenol, 2-clorofenol, 2-cloro-5-hidroxipiridina, 4-(4-hidroxifenil)ciclo-hexanona, pentaclorofenol e naringenina foram avaliados na concentração de $50 \mathrm{mg} . \mathrm{L}^{-1}$ para que houvesse a indução da produção das enzimas do fungo A. sydowii CBMAI 935 e posteriormente analizados por CG-EM. Os mesmos foram comparados com os seus respectivos padrões analíticos e padrões sintéticos caso fossem encontrados metabólitos produtos de biotransformação.

Os padrões sintéticos foram analizados por espectroscopia de ressonância nuclear (RMN) de ${ }^{1} \mathrm{H}$ e ${ }^{13} \mathrm{C}$. Os espectros de RMN dos padrões sintéticos e metabólitos isolados estão no Apêndice da dissertação.

Como os metabólitos de biotransformação gerados por reações enzimáticas provenientes do fungo de ambiente marinho A. sydowii CBMAI 935 e posteriormente analizados por CGEM foram formados nos primeiros 10 dias de reação com o fungo, optou-se por adequar as reações de biotransformação dos compostos fenólicos: fenol, 2-clorofenol, 2-cloro-5hidroxipiridina, 4-(4-hidroxifenil)ciclohexanona, pentaclorofenol e naringenina por 10 dias. Visto que em 10 dias de reação de biotransformação, foi tempo suficiente para a biotransformação dos pesticidas organofosforados e seus derivados fenólicos. 


\subsubsection{Cromatogramas obtidos por CG-EM e cromatogramas obtidos por CLAE-UV} das reações de biotransformação entre o flavonoide naringenina e o fungo de ambiente marinho A. sydowii CBMAI 935 em 10 dias de crescimento em meio de cultura líquido de malte a $2 \%$

Os flavonoides são fenois de ampla distribuição nas plantas. ${ }^{147,148}$ A sua estrutura básica consiste no núcleo flavânico que possui 15 átomos de carbono. As classes de flavonoides são diferenciadas por aneis heterocíclicos adicionais, pelas diversas posições do anel B e pela distribuição dos grupos hidroxila, metila e metoxila. ${ }^{147,149}$

A naringenina, 5,7-di-2-(4-hidroxifenil)croman-4-ona é uma flavanona de ocorrência quase exclusiva em espécies do gênero Citrus. O potencial farmacológico da naringenina tem sido intensamente investigado e a literatura descreve relatos de que a naringenina ajuda no reparo do DNA no câncer de próstata, ${ }^{147,150}$ melhora a resistência à insulina, ${ }^{147,151}$ tem efeito antioxidante $^{147,152}$ e vasodilatador. ${ }^{147,153}$

A Figura 166 ilustra a estrutura química básica dos subtipos de flavonoides mais comuns.

Figura 166. Estrutura química básica dos subtipos de flavonoides mais comuns.

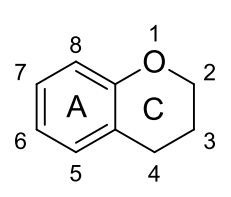

Cromona<smiles>O=C1CC(c2ccccc2)Oc2ccccc21</smiles>

Flavanona<smiles></smiles>

Flavona<smiles>Oc1cc2ccccc2[o+]c1-c1ccccc1</smiles>

Antocianidina

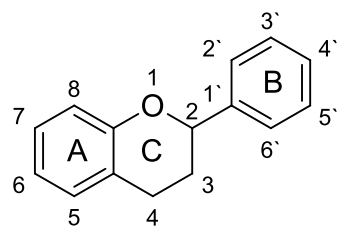

Flavana<smiles>O=C1c2ccccc2OCC1c1ccccc1</smiles>

Isoflavanona<smiles>O=c1c(-c2ccccc2)coc2ccccc12</smiles>

Isoflavona

Chalcona

Fonte: SILVEIRA, J.P. Aplicação do fungo filamentoso Beaveria bassiana spp. na produção de derivado petencialmente vasodilatador e antiproliferativo de naringenina. $74 \mathrm{f}$. Dissertação (Mestrado em Ciências Farmaceuticas)- Universidade Federal de Goiás. Goiânia 2012.

A produção de derivados de naringenina tem sido intensamente pesquisada, prioritariamente com a intenção de melhorar as propriedades biológicas do composto inicial. 147,154

Em 10 dias de reação de biotransformação da naringenina com o fungo de ambiente marinho Aspergillus sydowii CBMAI 935 foram separados o caldo enzimático e o micélio do 
fungo e posteriormente submetidos às análises por CG-EM. Os cromatogramas das reações foram comparados com os cromatogramas da reação do controle biótico no qual o fungo $A$. sydowii CBMAI 935 cresceu por 10 dias na ausência do flavonoide. Também foram feitas comparações com os cromatogramas das reações de controle abiótico no qual se utilizou o padrão analítico do flavonoide naringenina em meio de cultura líquido de malte $2 \%$ na ausência do fungo em 10 dias de reação. Posteriormente foram feitas comparações com os cromatogramas do padrão analítico da naringenina durante os 10 dias de reação de biotransformação.

Para posterior isolamento de metabólitos provenientes de reações enzimáticas com o fungo A. sydowii CBMAI 935 foram preparadas reações em sextoplicata com 50 mg.L $\mathrm{L}^{-1}$ cada, para se obter uma maior quantidade em massa dos metabólitos formados.

Após identificação dos metabólitos 5,7-dimetoxi-2-(4-metoxifenil)cromen-4-ona e (E)-3(4-metoxifenil)-1-(2,4,6-trimetoxifenil)prop-2-en-1-ona por CG-EM, foi feita a separação dos metabólitos por coluna cromatográfica para posterior caracterização por $\mathrm{RMN}{ }^{1} \mathrm{H}$ e ${ }^{13} \mathrm{C}$ e espectrometria de infravermelho contidos no Apêndice.

A Figura 167 mostra a sobreposição dos cromatogramas das extrações do caldo enzimático (cor vermelha) e do micélio (cor preta) com o fungo A. sydowii CBMAI 935 na ausência do flavonoide naringenina (reação de controle biótico) em 10 dias de reação e a Figura 168 mostra os mesmos cromatogramas, porém separados. Cromatograma (a) Extração do caldo enzimático e cromatograma (b) Extração do micélio.

Figura 167. Cromatogramas obtidos por CG-EM das extrações do micélio (cor preta) e do caldo enzimático (cor vermelha) com o fungo A. sydowii CBMAI 935 na ausência do flavonoide naringenina (reação de controle biótico) durante 10 dias.

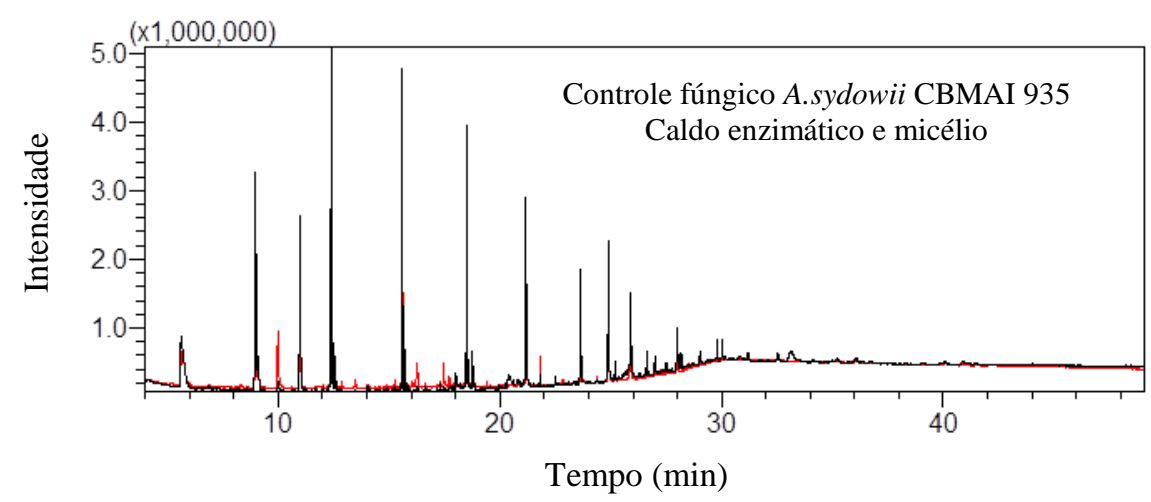

Condições de análise CG-EM: $\mathrm{T}_{\mathrm{i}}=110^{\circ} \mathrm{C}, 2 \mathrm{~min} ; \mathrm{T}_{\mathrm{f}}=300^{\circ} \mathrm{C}, 20 \mathrm{~min} ; \mathrm{r}=7^{\circ} \mathrm{C} / \mathrm{min}, \mathrm{t}_{\mathrm{c}}=50 \mathrm{mim}$.

Coluna capilar DB-5 da J\&W Scientific (30 m x 0,25 mm x 0,25 $\mu \mathrm{m}$ ). 
Figura 168. Cromatogramas obtidos por CG-EM das extrações do micélio e do caldo enzimático do fungo $A$. sydowii CBMAI 935 na ausência do flavonoide naringenina (reação de controle biótico) durante 10 dias. (a) Extração do caldo enzimático e (b) Extração do micélio.

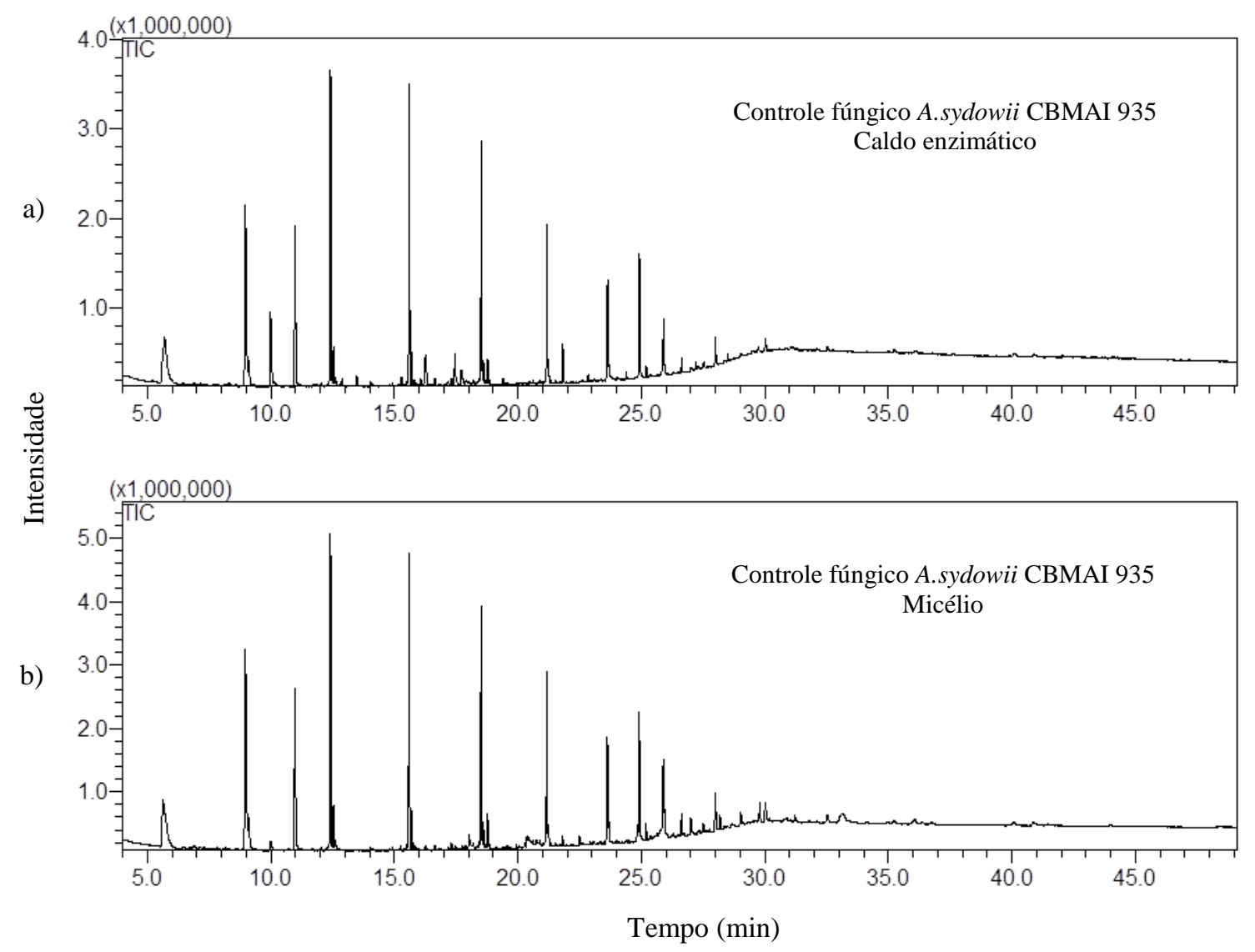

Condições de análise CG-EM: $\mathrm{T}_{\mathrm{i}}=110^{\circ} \mathrm{C}, 2 \mathrm{~min} ; \mathrm{T}_{\mathrm{f}}=300^{\circ} \mathrm{C}, 20 \mathrm{~min} ; \mathrm{r}=7^{\circ} \mathrm{C} / \mathrm{min}, \mathrm{t}_{\mathrm{c}}=50 \mathrm{mim}$. Coluna capilar DB-5 da J\&W Scientific (30 m x 0,25 mm x 0,25 $\mu \mathrm{m})$.

Os cromatogramas obtidos por CG-EM das reações em triplicatas com o fungo A. sydowii CBMAI 935 na ausência do flavonoide naringenina em 10 dias de reação apresentaram semelhanças quanto à presença de metabólitos provenientes do fungo. $\mathrm{O}$ cromatograma com a extração do caldo enzimático apresentou menor intensidade qualitativa dos sinais quando comparado com o cromatograma da extração do micélio (Figuras 167 e 168).

A Figura 169 mostra a sobreposição do cromatograma obtido por CG-EM da reação de controle biótico (cor vermelha) e o cromatograma da reação do flavonoide naringenina (cor preta) com concentração de $50 \mathrm{mg} . \mathrm{L}^{-1}$ em 10 dias de reação de biotransformação com o fungo A. sydowii CBMAI 935. Os cromatogramas estão sobrepostos para a comparação qualitativa das intensidades dos sinais dos metabólitos formados naturalmente pelo fungo e os metabólitos formados por ação enzimática do fungo e o flavonoide naringenina. 
Figura 169. Cromatograma obtido por CG-EM da reação de controle biótico do fungo A. sydowii CBMAI 935 e o flavonoide naringenina em 10 dias de reação de biotransformação.

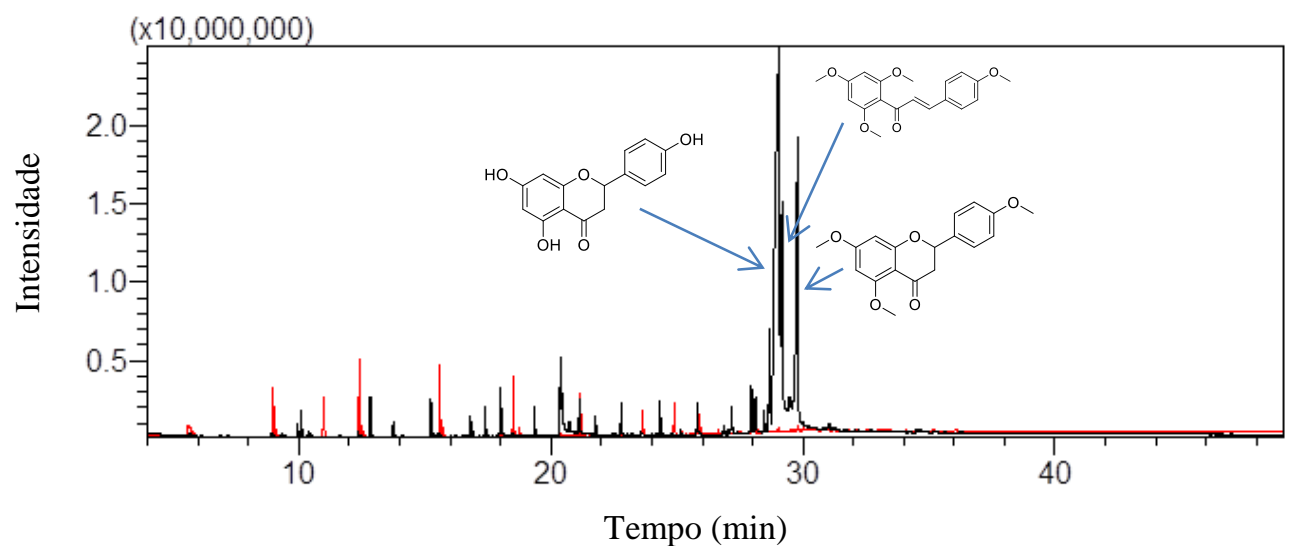

Condições de análise CG-EM: $\mathrm{T}_{\mathrm{i}}=110^{\circ} \mathrm{C}, 2 \mathrm{~min} ; \mathrm{T}_{\mathrm{f}}=300^{\circ} \mathrm{C}, 20 \mathrm{~min} ; \mathrm{r}=7^{\circ} \mathrm{C} / \mathrm{min}, \mathrm{t}_{\mathrm{c}}=50 \mathrm{mim}$. Coluna capilar DB-5 da J\&W Scientific (30 m x 0,25 mm x 0,25 $\mu \mathrm{m})$.

A Figura 170 mostra a ampliação do cromatograma da Figura 171 para melhor visualização dos sinais dos metabólitos 5,7-dimetoxi-2-(4-metoxifenil)cromen-4-ona e (E)-3(4-metoxifenil)-1-(2,4,6-trimetoxifenil)prop-2-en-1-ona.

Figura 170. Ampliação do cromatograma obtido por CG-EM da reação de biotransformação do flavonoide naringenina pelo fungo A. sydowii CBMAI 935 em 10 dias de reação.

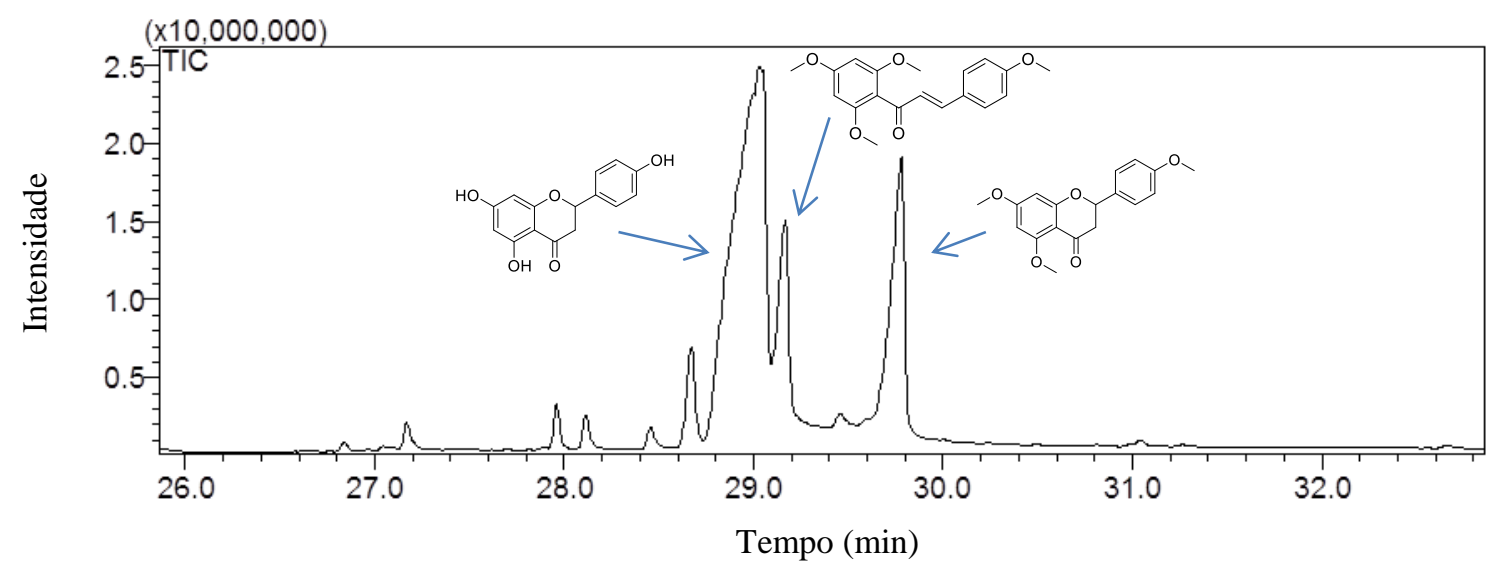

Condições de análise CG-EM: $\mathrm{T}_{\mathrm{i}}=110^{\circ} \mathrm{C}, 2 \mathrm{~min} ; \mathrm{T}_{\mathrm{f}}=300^{\circ} \mathrm{C}, 20 \mathrm{~min} ; \mathrm{r}=7^{\circ} \mathrm{C} / \mathrm{min}, \mathrm{t}_{\mathrm{c}}=50 \mathrm{mim}$. Coluna capilar DB-5 da J\&W Scientific (30 m x 0,25 mm x 0,25 $\mu \mathrm{m})$.

A Figura 171 mostra o cromatograma obtido por CG-EM da reação de controle abiótico. Neste caso utilizou-se o padrão analítico do flavonoide naringenina em meio de cultura líquido de malte $2 \%$ na ausência do fungo A. sydowii CBMAI 935 durante 10 dias de reação, 
para verificar se o mesmo foi estável nas condições utlizadas $\left(32^{\circ} \mathrm{C}, \mathrm{pH} 7\right)$. O padrão analítico do flavonoide naringenina tem o seu sinal no tempo de retenção em 28,874 minutos.

Figura 171. Cromatograma obtido por CG-EM da reação de controle abiótico do flavonoide naringenina na ausência do fungo A. sydowii CBMAI 935 durante 10 dias.

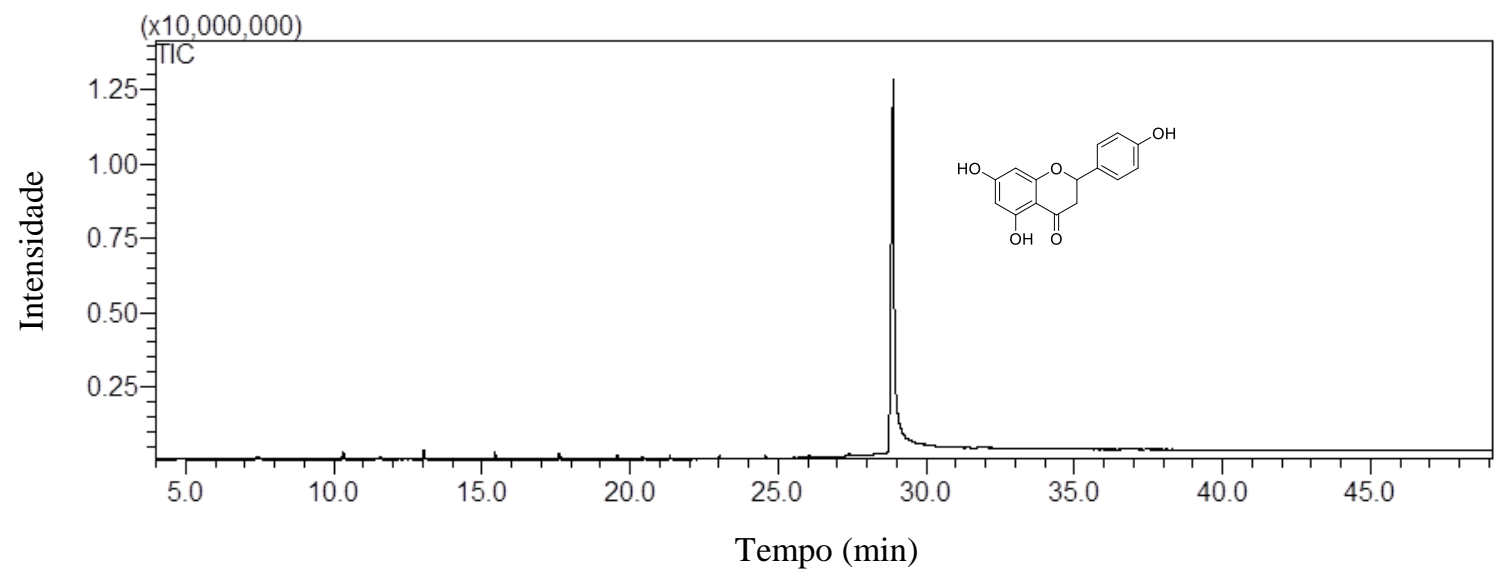

Condições de análise CG-EM: $\mathrm{T}_{\mathrm{i}}=110^{\circ} \mathrm{C}, 2 \mathrm{~min} ; \mathrm{T}_{\mathrm{f}}=300^{\circ} \mathrm{C}, 20 \mathrm{~min} ; \mathrm{r}=7^{\circ} \mathrm{C} / \mathrm{min}, \mathrm{t}_{\mathrm{c}}=50 \mathrm{mim}$.

Coluna capilar DB-5 da J\&W Scientific ( $30 \mathrm{~m}$ x 0,25 mm x 0,25 $\mu \mathrm{m})$.

A Figura 172 mostra o cromatograma obtido por CLAE-UV da reação de controle abiótico. Neste caso utilizou-se o padrão analítico do flavonoide naringenina em meio de cultura líquido de malte $2 \%$ na ausência do fungo A. sydowii CBMAI 935 durante 10 dias. O padrão analítico do flavonoide naringenina devido a sua molécula possuir um centro estereogênico possui dois sinais nos tempos de retenção em 31,145 e 34,123 minutos respectivamente.

Figura 172. Cromatograma obtido por CLAE-UV da reação entre o padrão racêmico da naringenina e o fungo A. sydowii CBMAI 935 em 10 dias de reação. Com sinais nos tempos de retenção em 31, 145 e 34,123 minutos.

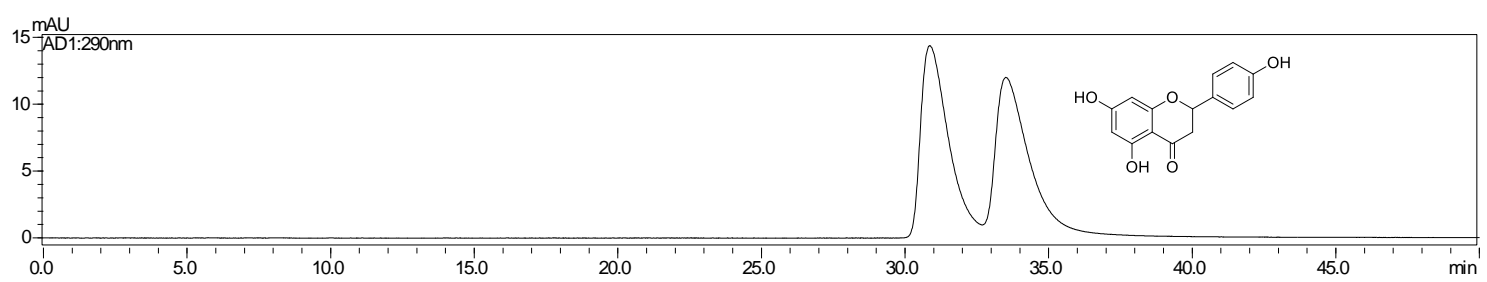

Condições de análise CLAE-UV: Hexano/Isopropanol (85:15); fluxo 1,0 mL/ min; $280 \mathrm{~nm} ; \mathrm{t}_{\mathrm{c}}=50 \mathrm{~min}$ Coluna Daiacel OD-H $(0,46$ x $25 \mathrm{~cm})$ 
A Figura 173 mostra o cromatograma obtido por CG-EM do metabólito 5,7-dimetoxi-2(4-metoxifenil)cromen-4-ona, isolado por coluna de bancada a partir das extrações do caldo enzimático e micélio do fungo de ambiente marinho A. sydowii CBMAI 935 em 10 dias de reação de biotransformação. O metabólito 5,7-dimetoxi-2-(4-metoxifenil)cromen-4-ona apresentou o sinal no tempo de retenção em 29,831 minutos.

Após análise em CG-EM, o composto isolado foi caracterizado por $\mathrm{RMN}{ }^{1} \mathrm{H}$ e ${ }^{13} \mathrm{C}$ e espectrometria no infravermelho IV (Apêndice).

Figura 173. Cromatograma obtido por CG-EM do metabólito 5,7-dimetoxi-2-(4-metoxifenil)cromen-4-ona isolado a partir das reações de biotransformação do flavonoide naringenina com o fungo A. sydowii CBMAI 935 durante 10 dias.

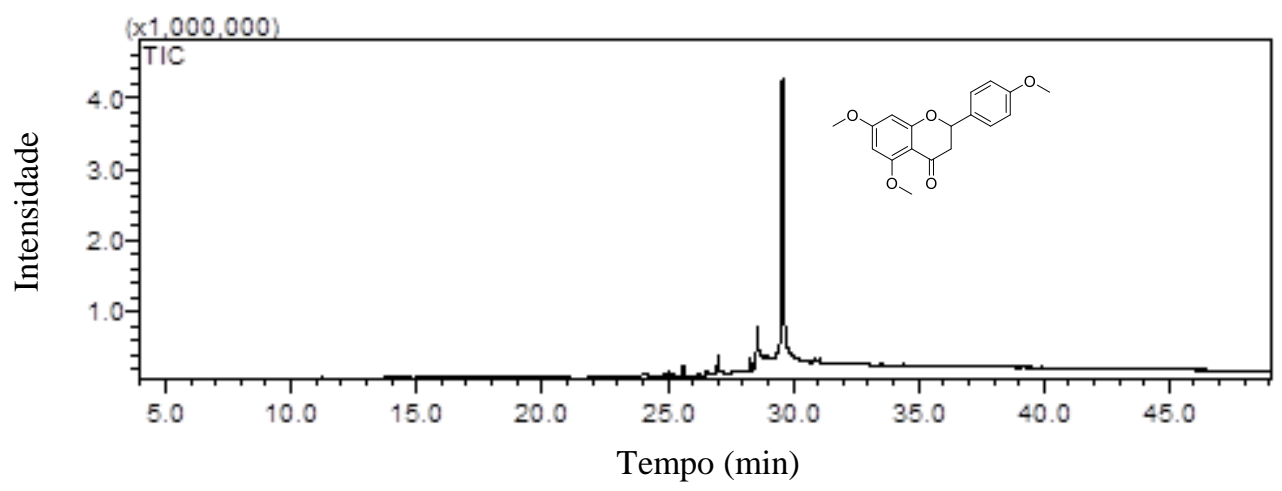

Condições de análise CG-EM: $\mathrm{T}_{\mathrm{i}}=110^{\circ} \mathrm{C}, 2 \mathrm{~min} ; \mathrm{T}_{\mathrm{f}}=300^{\circ} \mathrm{C}, 20 \mathrm{~min} ; \mathrm{r}=7^{\circ} \mathrm{C} / \mathrm{min}, \mathrm{t}_{\mathrm{c}}=50 \mathrm{mim}$. Coluna capilar DB-5 da J\&W Scientific ( $30 \mathrm{~m}$ x 0,25 mm x 0,25 $\mu \mathrm{m}$ ).

A Figura 174 mostra o espectro de massas obtido por CG-EM (70 eV) do metabólito 5,7dimetoxi-2-(4-metoxifenil)cromen-4-ona isolado a partir das reações de biotransformação do flavonoide naringenina com o fungo A. sydowii CBMAI $935 \mathrm{em} 10$ dias.

Figura 174. Espectro de massas obtido por CG-EM (70 eV) para o metabólito 5,7-dimetoxi-2-(4metoxifenil)cromen-4-ona isolado a partir das reações de biotransformação do flavonoide naringenina com o fungo A. sydowii CBMAI 935 durante 10 dias.

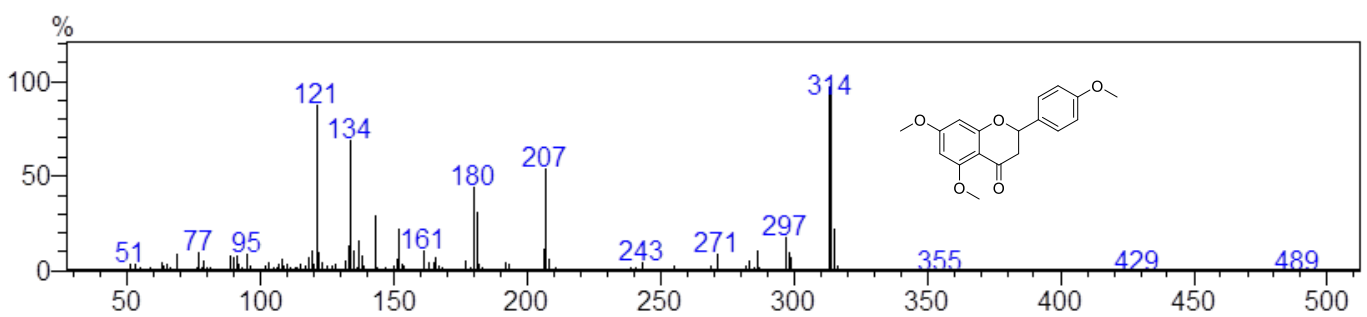


A Figura 175 mostra o cromatograma obtido por CLAE-UV do metabólito 5,7-dimetoxi2-(4-metoxifenil)cromen-4-ona, isolado por coluna de cromatográfica (CC) a partir das extrações do caldo enzimático e micélio do fungo de ambiente marinho A. sydowii CBMAI 935 em 10 dias de reação de biotransformação. O metabólito 5,7-dimetoxi-2-(4metoxifenil)cromen-4-ona devido a sua molécula possuir um centro estereogênico apresentou dois sinais nos tempos de retenção em 27,399 e 33,258 minutos respectivamente.

Figura 175. Cromatograma obtido por CLAE-UV do metabólito 5,7-dimetoxi-2-(4-metoxifenil)croman-4-ona (isolado) e o fungo A. sydowii CBMAI 935 em 10 dias de reação. Com sinais nos tempos de retenção em 27, 399 e 33, 258 minutos.

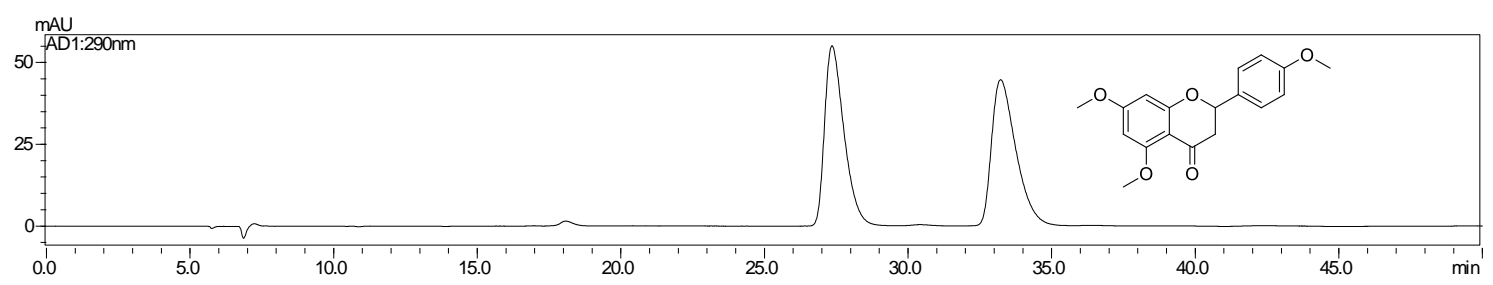

Condições de análise CLAE-UV: Hexano/Isopropanol (85:15); fluxo 1,0 mL/ min; $280 \mathrm{~nm}$; $\mathrm{t}_{\mathrm{c}}=50 \mathrm{~min}$ Coluna Daiacel OD-H $(0,46$ x $25 \mathrm{~cm})$

A Figura 176 mostra os cromatogramas sobrepostos obtidos por CLAE-UV do metabólito 5,7-dimetoxi-2-(4-metoxifenil)cromen-4-ona (cor rosa), isolado por coluna de cromatográfica (CC) a partir das extrações do caldo enzimático e micélio do fungo de ambiente marinho $A$. sydowii CBMAI 935 em 10 dias de reação de biotransformação e o cromatograma da naringenina (cor negra). Os metabólitos estão sobrepostos para fins de comparação dos seus respectivos tempos de retenção já que os dois utilizaram a mesma metodologia de análise.

Figura 176. Cromatogramas sobrepostos obtidos por CLAE-UV do metabólito 5,7-dimetoxi-2-(4metoxifenil)croman-4-ona (isolado) e naringenina com o fungo A. sydowii CBMAI 935 em 10 dias de reação.

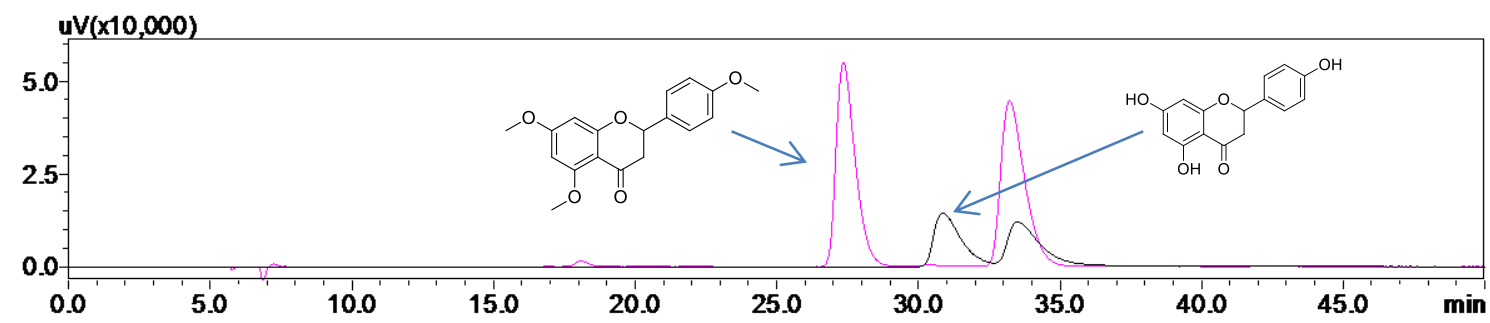

Condições de análise CLAE-UV: Hexano/Isopropanol (85:15); fluxo 1,0 mL/ min; $280 \mathrm{~nm}$; $\mathrm{t}_{\mathrm{c}}=50 \mathrm{~min}$ Coluna Daiacel OD-H $(0,46$ x $25 \mathrm{~cm})$ 
A Figura 177 mostra o cromatograma obtido por CG-EM do metabólito (E)-3-(4metoxifenil)-1-(2,4,6-trimetoxifenil)prop-2-en-1-ona, isolado por coluna de bancada a partir das extrações do caldo enzimático e micélio do fungo de ambiente marinho A. sydowii CBMAI 935 em 10 dias de reação de biotransformação. O metabólito (E)-3-(4-metoxifenil)1-(2,4,6-trimetoxifenil)prop-2-en-1-ona apresentou o sinal no tempo de retenção em 29,233 minutos.

Após análise em CG-EM o composto isolado foi caracterizado por $\mathrm{RMN}{ }^{1} \mathrm{H}$ e ${ }^{13} \mathrm{C}$ e espectrometria no infravermelho IV (Apêndice).

Figura 177. Cromatograma obtido por CG-EM do metabólito (E)-3-(4-metoxifenil)-1-(2,4,6trimetoxifenil)prop-2-en-1-ona isolado a partir das reações de biotransformação do flavonoide naringenina com o fungo A. sydowii CBMAI 935 durante 10 dias.

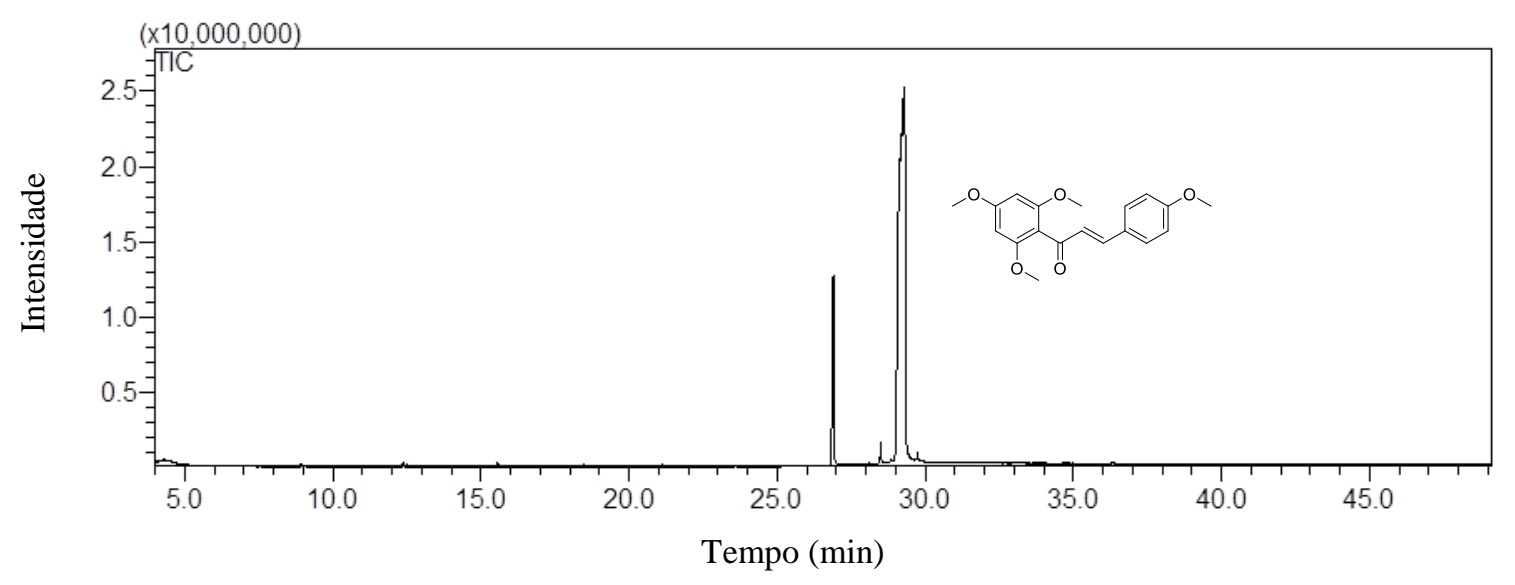

Condições de análise CG-EM: $\mathrm{T}_{\mathrm{i}}=110^{\circ} \mathrm{C}, 2 \mathrm{~min} ; \mathrm{T}_{\mathrm{f}}=300^{\circ} \mathrm{C}, 20 \mathrm{~min} ; \mathrm{r}=7^{\circ} \mathrm{C} / \mathrm{min}, \mathrm{t}_{\mathrm{c}}=50 \mathrm{mim}$.

Coluna capilar DB-5 da J\&W Scientific (30 m x 0,25 mm x 0,25 $\mu \mathrm{m}$ ).

A Figura 178 mostra o espectro de massas obtido em CG-EM (70 eV) do metabólito 5,7dimetoxi-2-(4-metoxifenil)cromen-4-ona isolado a partir das reações de biotransformação do flavonoide naringenaina com o fungo A. sydowii CBMAI 935 em 10 dias.

Figura 178. Espectro de massas obtido por CG-EM (70 eV) para o metabólito (E)-3-(4-metoxifenil)-1-(2,4,6trimetoxifenil)prop-2-en-1-ona isolado a partir das reações de biotransformação do flavonoide naringenina com o fungo A. sydowii CBMAI 935 durante 10 dias.

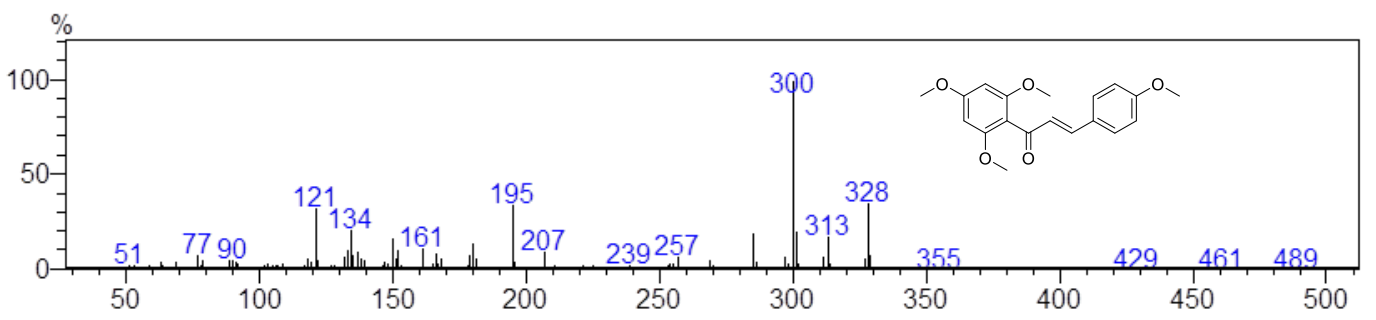


A Figura 179 mostra o cromatograma obtido por CLAE-UV do metabólito (E)-3-(4metoxifenil)-1-(2,4,6-trimetoxifenil)prop-2-en-1-ona, isolado por coluna de cromatográfica (CC) a partir das extrações do caldo enzimático e micélio do fungo de ambiente marinho $A$. sydowii CBMAI 935 em 10 dias de reação de biotransformação. O metabólito (E)-3-(4metoxifenil)-1-(2,4,6-trimetoxifenil)prop-2-en-1-ona apresentou o sinal no tempo de retenção em 30,062 minutos.

Figura 179. Cromatograma obtido por CLAE-UV do metabólito (E)-3-(4-metoxifenil)-1-(2,4,6trimetoxifenil)prop-2-en-1-ona (isolado) com o fungo A. sydowii CBMAI 935 em 10 dias de reação. Com sinal no tempo de retenção em 30, 062 minutos.

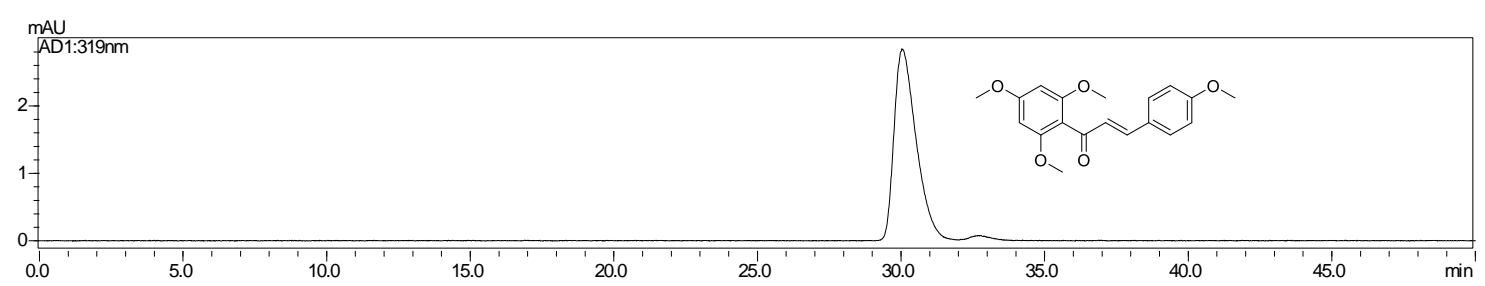

Condições de análise CLAE-UV: Hexano/Isopropanol (85:15); fluxo 1,0 mL/ min; $280 \mathrm{~nm}$; $\mathrm{t}_{\mathrm{c}}=50 \mathrm{~min}$ Coluna Daiacel OD-H $(0,46$ x $25 \mathrm{~cm})$

O Esquema 28 mostra a reação de biotransformação do flavonoide naringenina pelo fungo de ambiente marinho Aspergillus sydowii CBMAI 935. O Esquema 28 foi proposto a partir dos metabólitos 5,7-dimetoxi-2-(4-metoxifenil)cromen-4-ona e (E)-3-(4-metoxifenil)-1(2,4,6-trimetoxifenil)prop-2-en-1-ona, isolados a partir das reações de biotransformação do flavonoide naringenina com o fungo A. sydowii CBMAI 935, durante 10 dias.

Flavononas e chalconas são comumente intercovertidas em meio ácido e alcalino por tautomerismo. ${ }^{152}$

As reações com melhores resultados, foi realizada sem a presença de solução tampão com $\mathrm{pH}$ inicial 7,0, mas que ao final da reação estabilizou-se na faixa de $\mathrm{pH}$ 5,0. Com ação de enzimas metiltransferases do fungo A. sydowii CBMAI 935 houve metilação das hidroxilas contidas no metabólito 5,7-dimetoxi-2-(4-metoxifenil)cromen-4-ona e metilação das hidroxilas contidas no metabólito (E)-3-(4-metoxifenil)-1-(2,4,6-trimetoxifenil)prop-2-en-1ona. 
Esquema 28. Proposta de reação de biotransformação do flavonoide naringenina pelo fungo A. sydowii CBMAI 935 durante 10 dias de reação.<smiles>O=C1CC(c2ccc(O)cc2)Oc2cc(O)cc(O)c21</smiles>

naringenina<smiles>O=C(/C=C/c1ccc(O)cc1)c1c(O)cc(O)cc1O</smiles>

naringenina chalcona<smiles>COc1ccc(C2CC(=O)c3c(OC)cc(OC)cc3O2)cc1</smiles>

5,7-dimetoxi-2-(4-metoxifenil)croman-4-ona<smiles>COc1ccc(/C=C/C(=O)c2c(OC)cc(OC)cc2OC)cc1</smiles>

(E)-3-(4-metoxifenil)-1-(2,4,6-trimetoxifenil) prop-2-en-1-ona

Fonte: Autoria própria.

\subsubsection{Avaliação da biotransformação do composto fenólico pentaclorofenol em 10 dias de reação com o fungo $A$. sydowii CBMAI 935}

O pentaclorofenol causa sérios problemas à saúde humana com efeitos adversos em longo prazo, é carcinogênico, pode causar alterações nos sistemas imunológico e endócrino, danos hepáticos (cirrose hepática e tumores), desordens nervosas, aumenta a suscetibilidade do organismo a infecções, pode causar disfunções no aparelho reprodutivo, nervoso e glandular. 154,155 O pentaclorofenol atua como inibidor da fosforilação oxidativa, processo básico da respiração celular. Portanto, é tóxico a todas as formas de vida e sua alta toxicidade torna-o persistente. ${ }^{154}$

É um pesticida clorofenólico de caráter ácido, constituído de benzeno com cinco átomos de cloro substituídos. Este poluente pertence ao grupo dos hidrocarbonetos halogenados, é altamente resistente à degradação biótica e abiótica, e consequentemente apresenta uma alta 
persistência no meio ambiente. ${ }^{154,156}$ A estabilidade do anel aromático e o alto conteúdo de cloro dessa molécula torna difícil sua degradação. ${ }^{157}$

A Figura 180 mostra a sobreposição do cromatograma obtido por CG-EM da reação de controle biótico (cor vermelha) e o cromatograma da reação do composto fenólico pentaclorofenol (cor preta) com concentração de $50 \mathrm{mg} . \mathrm{L}^{-1}$ em 10 dias de reação de biotransformação com o fungo A. sydowii CBMAI 935. Os cromatogramas foram sobrepostos para a comparação qualitativa das intensidades dos sinais dos metabólitos formados naturalmente pelo fungo e os metabólitos formados por ação enzimática do fungo e o pentaclorofenol.

Figura 180. Cromatograma obtido por CG-EM da reação de controle biótico do fungo A. sydowii CBMAI 935 e o composto fenólico pentaclorofenol em 10 dias de reação de biotransformação.

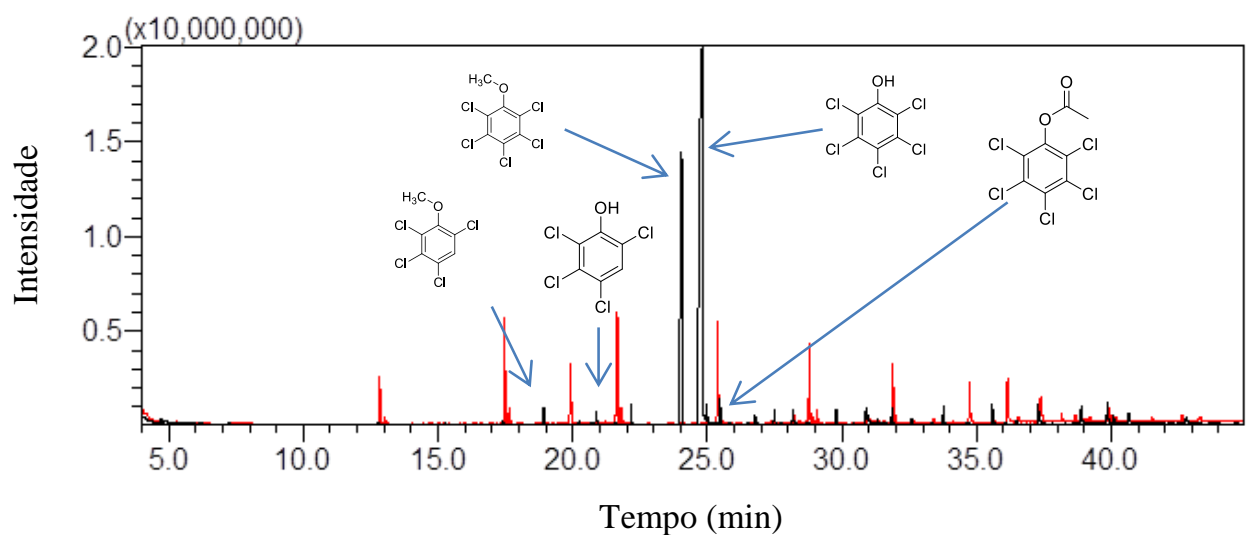

Condições de análise CG-EM: $\mathrm{T}_{\mathrm{i}}=60^{\circ} \mathrm{C}, 2 \mathrm{~min} ; \mathrm{T}_{\mathrm{f}}=280^{\circ} \mathrm{C}, 6 \mathrm{~min} ; \mathrm{r}=6^{\circ} \mathrm{C} / \mathrm{min}, \mathrm{t}_{\mathrm{c}}=45 \mathrm{mim}$. Coluna capilar DB-5 da J\&W Scientific (30 $\mathrm{m}$ x 0,25 mm x 0,25 $\mu \mathrm{m})$.

A Figura 181 mostra as ampliações dos cromatogramas dos metabólitos encontrados e seus respectivos espectros de massas. Esses cromatogramas foram selecionados a partir da Figura 180 para melhor visualização dos sinais dos metabólitos 1,2,3,4,5-pentaclorofenol-6metoxibenzeno, 2,3,4,6-tetraclorofenol, 1,2,3,5-tetracloro-4-metoxibenzeno e acetato de perclorofenila formados nas reações com o fungo A. sydowii CBMAI 935 na presença do composto fenólico pentaclorofenol, durante 10 dias.

Cromatograma (a) Sinal do metabólito 1,2,3,4,5-pentaclorofenol-6-metoxibenzeno, cromatograma (b) Sinal do metabólito 2,3,4,6-tetraclorofenol, cromatograma (c) Sinal do metabólito 1,2,3,5-tetracloro-4-metoxibenzeno e cromatograma (d) Sinal do metabólito acetato de perclorofenila. 
Figura 181. Ampliações dos Cromatograma selecionado e espectros de massas obtidos por CG-EM dos metabólitos gerados a partir das reações de biotransformação do composto fenólico pentaclorofenol com o fungo A. sydowii CBMAI 935 durante 10 dias.

a)

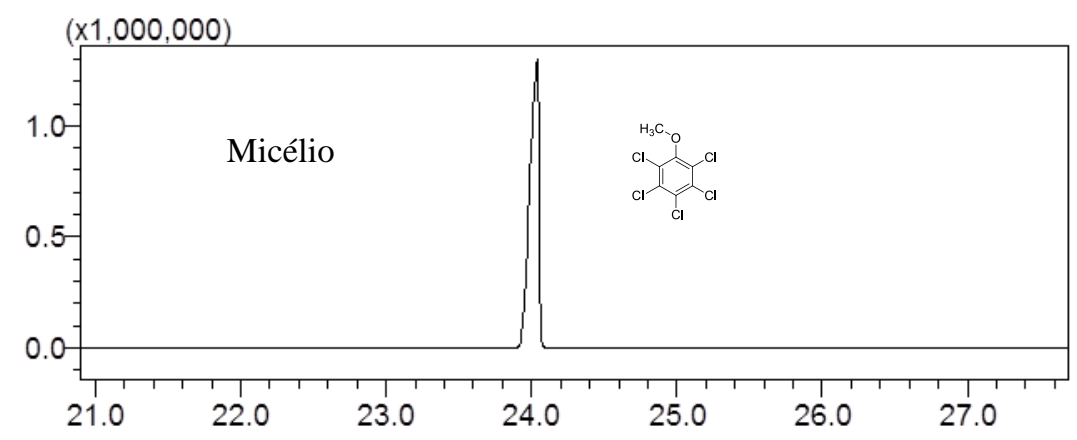

Condições de análise CG-EM: $\mathrm{T}_{\mathrm{i}}=60^{\circ} \mathrm{C}, 2 \mathrm{~min} ; \mathrm{T}_{\mathrm{f}}=280^{\circ} \mathrm{C}, 6 \mathrm{~min} ; \mathrm{r}=6^{\circ} \mathrm{C} / \mathrm{min}, \mathrm{t}_{\mathrm{c}}=45 \mathrm{mim}$.

Coluna capilar DB-5 da J\&W Scientific (30 $\mathrm{m}$ x 0,25 mm x 0,25 $\mu \mathrm{m}$ ).

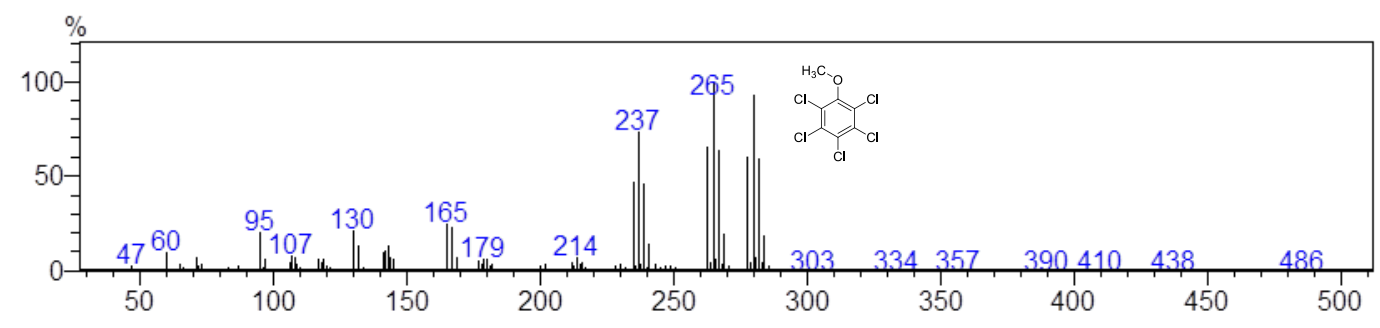

b)

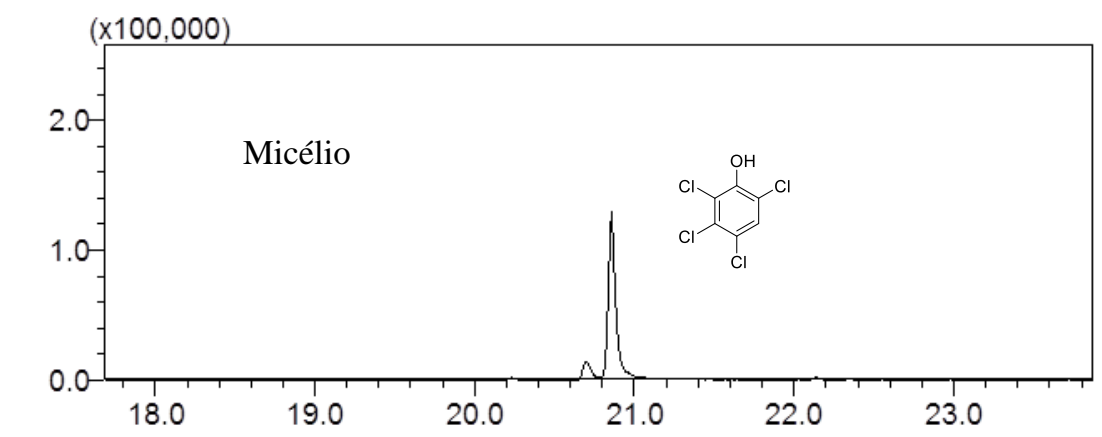

Condições de análise CG-EM: $\mathrm{T}_{\mathrm{i}}=60^{\circ} \mathrm{C}, 2 \mathrm{~min} ; \mathrm{T}_{\mathrm{f}}=280^{\circ} \mathrm{C}, 6 \mathrm{~min} ; \mathrm{r}=6^{\circ} \mathrm{C} / \mathrm{min}, \mathrm{t}_{\mathrm{c}}=45 \mathrm{mim}$.

Coluna capilar DB-5 da J\&W Scientific (30 m x 0,25 mm x 0,25 $\mu \mathrm{m})$.

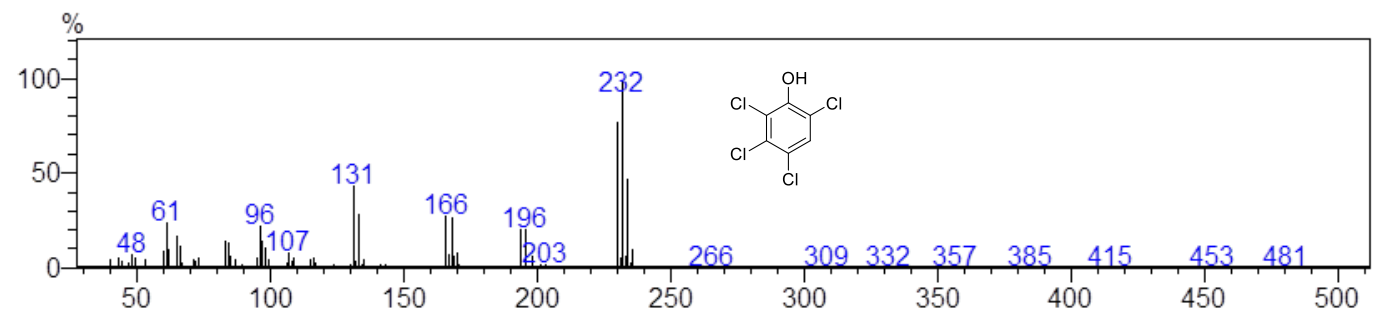




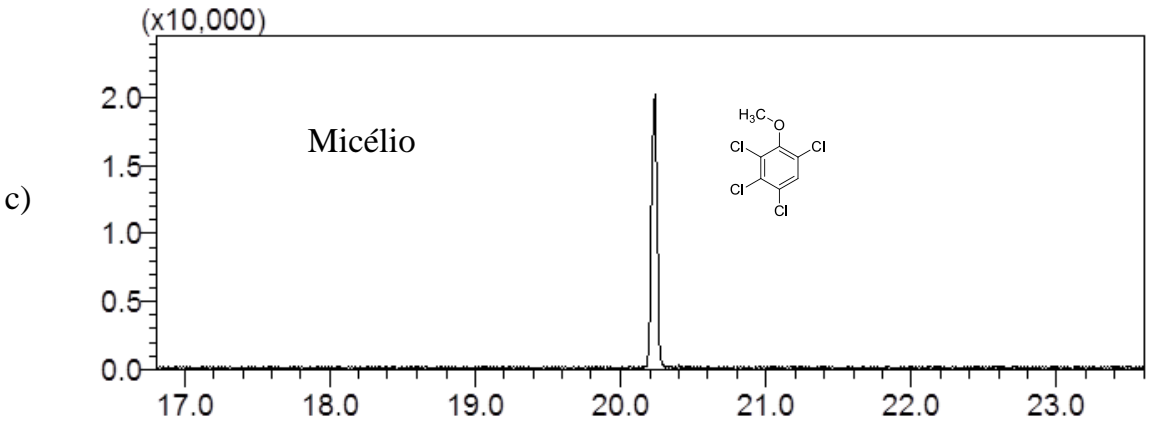

Condições de análise CG-EM: $\mathrm{T}_{\mathrm{i}}=60^{\circ} \mathrm{C}, 2 \mathrm{~min} ; \mathrm{T}_{\mathrm{f}}=280^{\circ} \mathrm{C}, 6 \mathrm{~min} ; \mathrm{r}=6^{\circ} \mathrm{C} / \mathrm{min}, \mathrm{t}_{\mathrm{c}}=45 \mathrm{mim}$. Coluna capilar DB-5 da J\&W Scientific (30 $\mathrm{m}$ x 0,25 mm x 0,25 $\mu \mathrm{m})$.
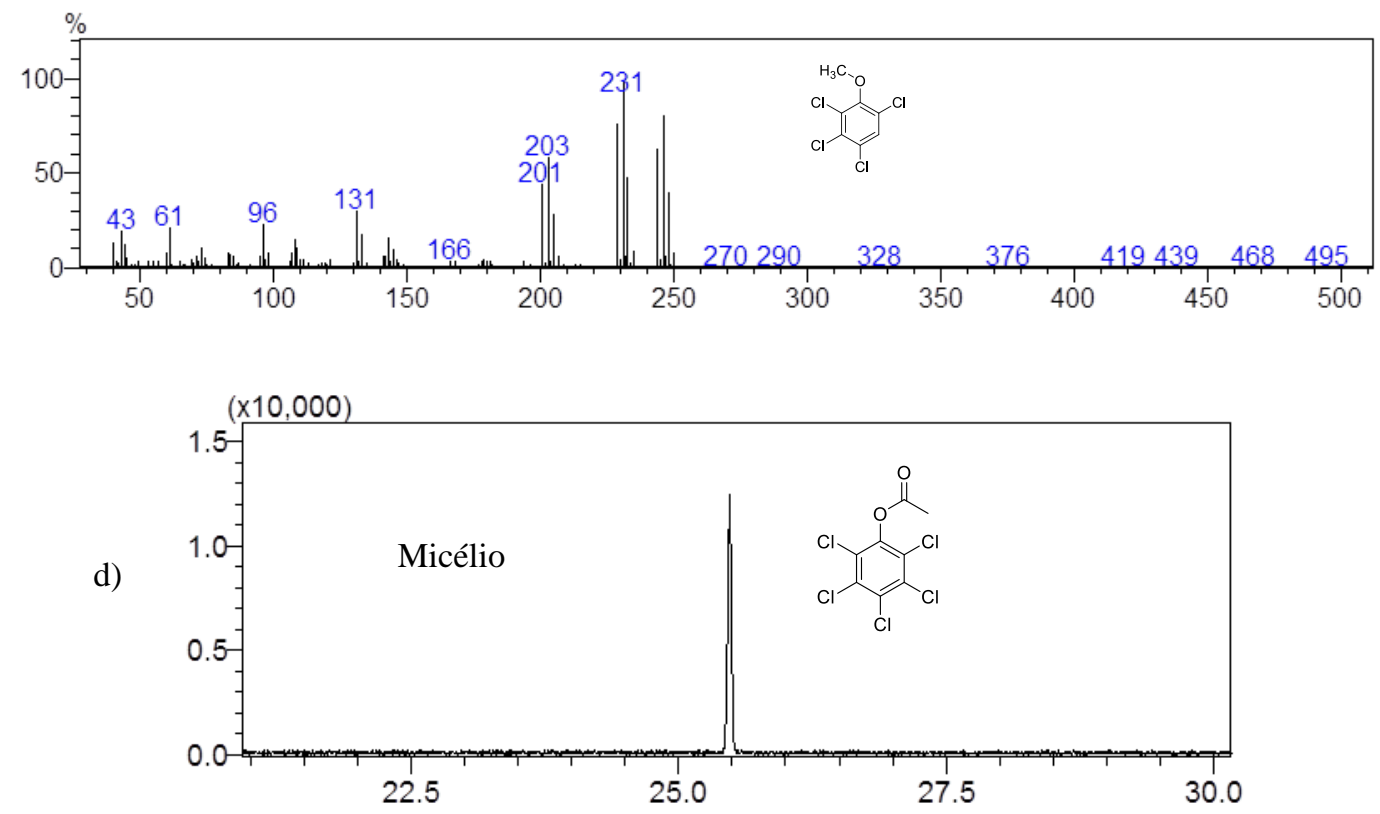

Condições de análise CG-EM: $\mathrm{T}_{\mathrm{i}}=60^{\circ} \mathrm{C}, 2 \mathrm{~min} ; \mathrm{T}_{\mathrm{f}}=280^{\circ} \mathrm{C}, 6 \mathrm{~min} ; \mathrm{r}=6^{\circ} \mathrm{C} / \mathrm{min}, \mathrm{t}_{\mathrm{c}}=45 \mathrm{mim}$. Coluna capilar DB-5 da J\&W Scientific (30 m x 0,25 mm x 0,25 $\mu \mathrm{m}$ ).

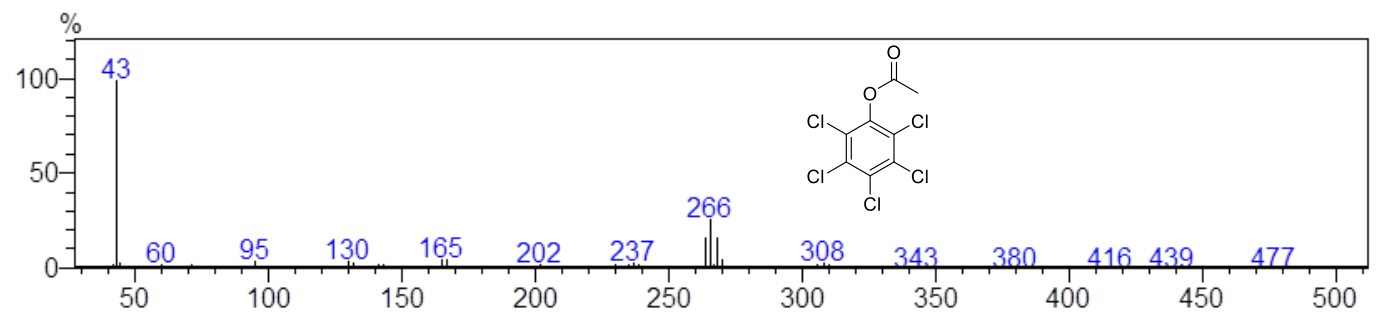


As Figuras 182 e 183 mostram o cromatograma obtido por CG-EM e o espectro de massas do padrão analítico do composto fenólico pentaclorofenol que tem o seu sinal e tempo de retenção em 24,780 minutos.

Figura 182. Cromatograma obtido por CG-EM do padrão analítico do composto fenólico pentaclorofenol.

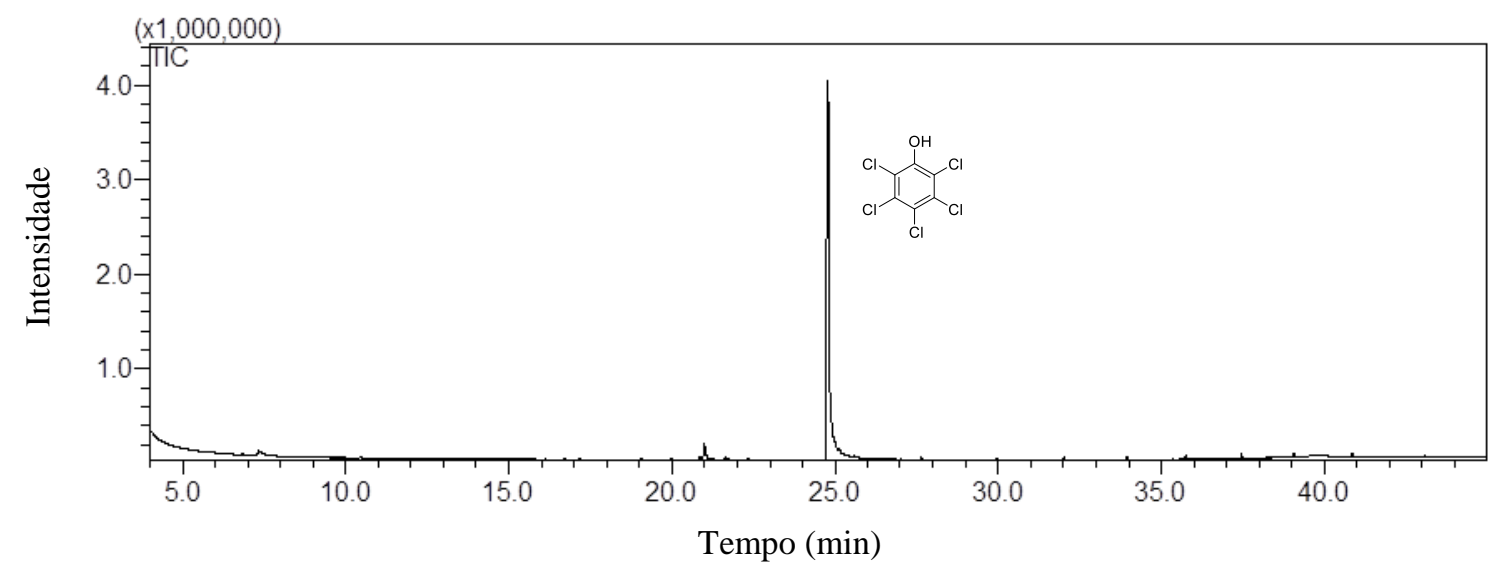

Condições de análise CG-EM: $\mathrm{T}_{\mathrm{i}}=60^{\circ} \mathrm{C}, 2 \mathrm{~min} ; \mathrm{T}_{\mathrm{f}}=280^{\circ} \mathrm{C}, 6 \mathrm{~min} ; \mathrm{r}=6^{\circ} \mathrm{C} / \mathrm{min}, \mathrm{t}_{\mathrm{c}}=45 \mathrm{mim}$.

Coluna capilar DB-5 da J\&W Scientific (30 m x 0,25 mm x 0,25 $\mu \mathrm{m})$.

Figura 183. Espectro de massas obtido por CG-EM $(70 \mathrm{eV})$ para o padrão analítico do composto fenólico pentaclorofenol.

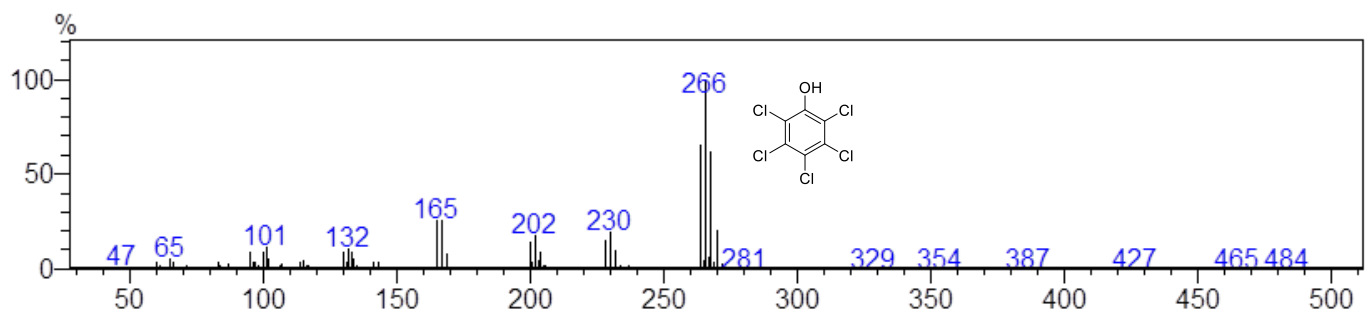

As Figuras 184 e 185 mostram o cromatograma obtido por CG-EM e o espectro de massas do padrão analítico do composto fenólico 2,3,4,6-tetraclorofenol que tem o seu sinal e tempo de retenção em 21,000 minutos. 
Figura 184. Cromatograma obtido por CG-EM do padrão analítico do composto fenólico 2,3,4,6tetraclorofenol.

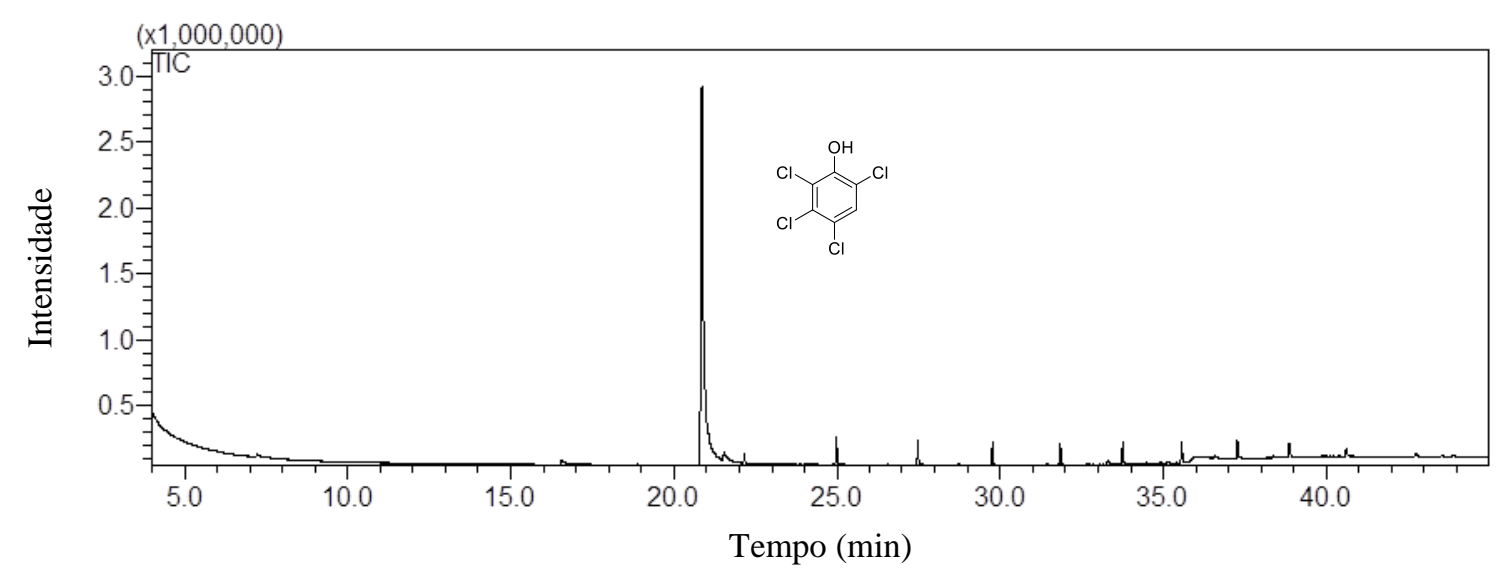

Condições de análise CG-EM: $\mathrm{T}_{\mathrm{i}}=60^{\circ} \mathrm{C}, 2 \mathrm{~min} ; \mathrm{T}_{\mathrm{f}}=280^{\circ} \mathrm{C}, 6 \mathrm{~min} ; \mathrm{r}=6^{\circ} \mathrm{C} / \mathrm{min}, \mathrm{t}_{\mathrm{c}}=45 \mathrm{mim}$.

Coluna capilar DB-5 da J\&W Scientific (30 m x 0,25 mm x 0,25 $\mu \mathrm{m})$.

Figura 185. Espectro de massas obtido por CG-EM $(70 \mathrm{eV})$ para o padrão analítico do composto fenólico 2,3,4,6-tetraclorofenol.

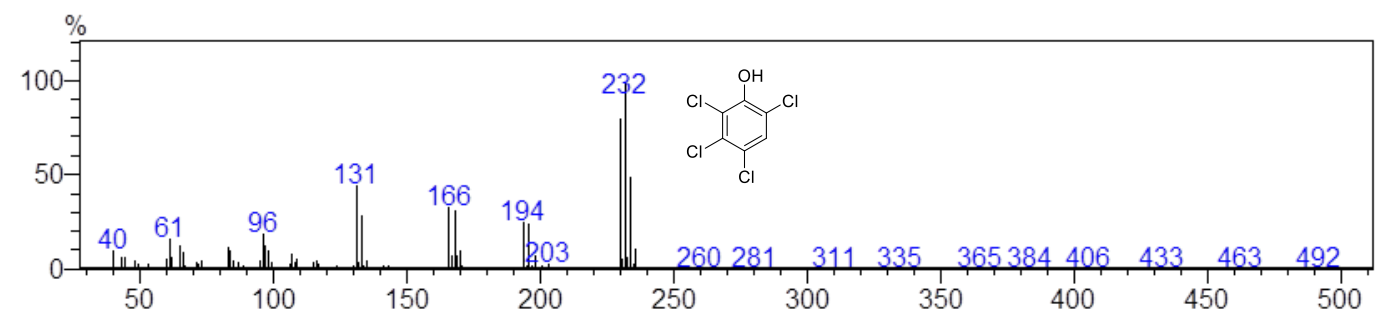

As Figuras 186 e 187 mostram o cromatograma obtido por CG-EM e o espectro de massas do padrão sintético do composto fenólico 1,2,3,4,5-pentaclorofenol-6-metoxibenzeno que tem o seu sinal e tempo de retenção em 24,000 minutos. 
Figura 186. Cromatograma obtido por CG-EM do padrão sintético do composto 1,2,3,4,5-pentaclorofenol-6metoxibenzeno.

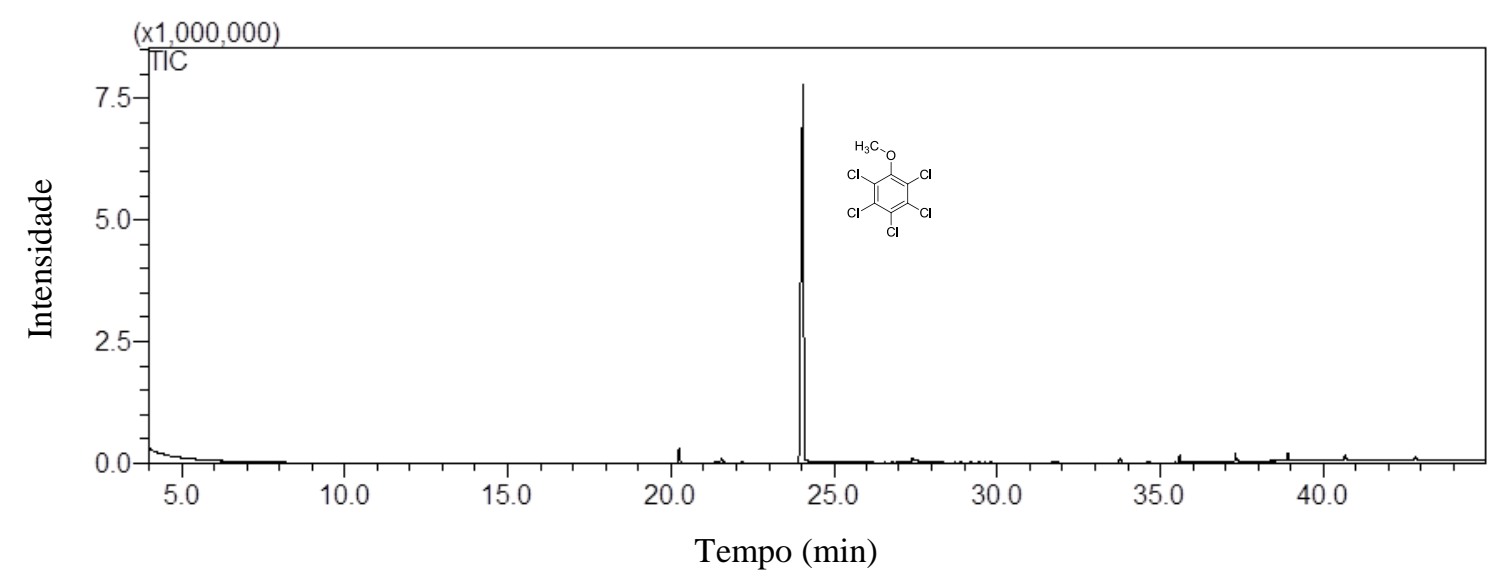

Condições de análise CG-EM: $\mathrm{T}_{\mathrm{i}}=60^{\circ} \mathrm{C}, 2 \mathrm{~min} ; \mathrm{T}_{\mathrm{f}}=280^{\circ} \mathrm{C}, 6 \mathrm{~min} ; \mathrm{r}=6^{\circ} \mathrm{C} / \mathrm{min}, \mathrm{t}_{\mathrm{c}}=45 \mathrm{mim}$. Coluna capilar DB-5 da J\&W Scientific (30 m x 0,25 mm x 0,25 $\mu \mathrm{m})$.

Figura 187. Espectro de massas obtido por CG-EM (70 eV) para o padrão sintético do composto 1,2,3,4,5pentaclorofenol-6-metoxibenzeno.

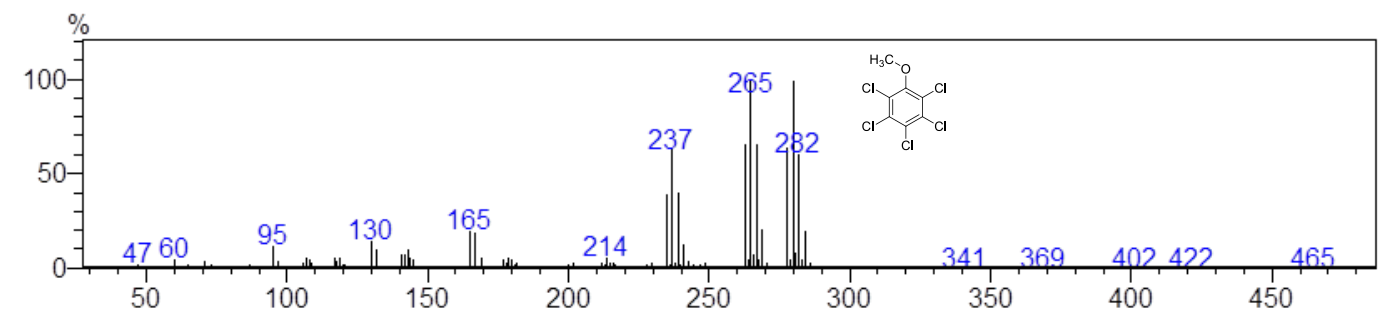

O Esquema 29 mostra a reação de biotransformação do composto fenólico pentaclorofenol pelo fungo de ambiente marinho A. sydowii CBMAI 935. O Esquema 29 foi proposto a partir dos metabólitos 1,2,3,4,5-pentaclorofenol-6-metoxibenzeno, 2,3,4,6tetraclorofenol, 1,2,3,5-tetracloro-4-metoxibenzeno e acetato de perclorofenila, formados a partir das reações de biotransformação do composto fenólico pentaclorofenol com o fungo $A$. sydowii CBMAI 935, durante 10 dias. 
Esquema 29. Proposta de reação de biotransformação do pentaclorofenol pelo fungo A. sydowii CBMAI 935 durante 10 dias de reação.<smiles>CC(C)(C)C1CCCCC1</smiles>

2,3,4,6-tetraclorofenol<smiles>COc1c(Cl)cc(Cl)c(Cl)c1Cl</smiles><smiles>Oc1c(Cl)c(Cl)c(Cl)c(Cl)c1Cl</smiles>
pentaclorofenol<smiles>CC(=O)Oc1c(Cl)c(Cl)c(Cl)c(Cl)c1Cl</smiles><smiles>COc1c(Cl)c(Cl)c(Cl)c(Cl)c1Cl</smiles>

pentaclorofenol anisol

1,2,3,5-tetracloro-4-metoxibenzeno acetato de perclorofenila

Fonte: Autoria própria. 


\subsubsection{Avaliação da biotransformação do composto fenólico hidroxibenzeno em 10 dias de reação com o fungo $A$. sydowii CBMAI 935}

A função orgânica fenol é caracterizada pela presença de uma ou mais hidroxilas ligadas diretamente ao anel aromático. O exemplo mais simples é o fenol, o qual recebe o nome da função, ou ainda ácido carbólico, ou ácido fênico ou hidroxibenzeno, é constituído pela presença de uma hidroxila ligada ao anel aromático, com fórmula molecular de $\mathrm{C}_{6} \mathrm{H}_{5} \mathrm{OH} .{ }^{99}$

Esse composto apresenta-se como um sólido maciço de coloração branca, que tende a modificar sua coloração para rosa quando impuro ou por ação direta da luz. Em tempos prolongados de exposição ao ar atmosférico, absorve água e liquefaz-se. Possui um odor forte, característico e apresenta considerável toxicidade ao homem. ${ }^{99}$

A Figura 188 mostra a sobreposição do cromatograma obtido por CG-EM da reação de controle biótico (cor vermelha) e o cromatograma da reação do composto fenólico hidroxibenzeno (cor preta) com concentração de $50 \mathrm{mg} . \mathrm{L}^{-1}$ em 10 dias de reação de biotransformação com o fungo A. sydowii CBMAI 935. Os cromatogramas estão sobrepostos para a comparação qualitativa das intensidades dos sinais dos metabólitos formados naturalmente pelo fungo e os metabólitos formados por ação enzimática do fungo e o hidroxibenzeno.

Figura 188. Cromatograma obtido por CG-EM da reação de controle biótico do fungo A. sydowii CBMAI 935 e o composto fenólico hidroxibenzeno em 10 dias de reação de biotransformação.

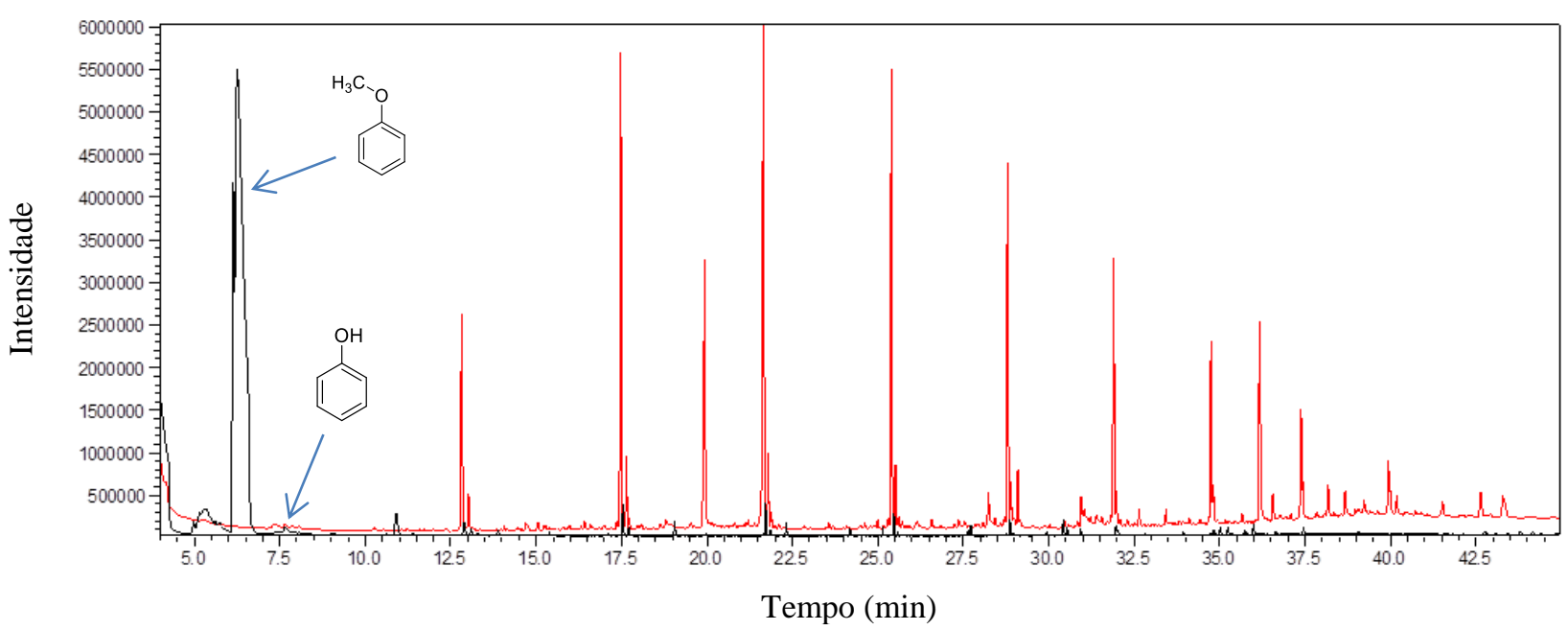

Condições de análise CG-EM: $\mathrm{T}_{\mathrm{i}}=60^{\circ} \mathrm{C}, 2 \mathrm{~min} ; \mathrm{T}_{\mathrm{f}}=280^{\circ} \mathrm{C}, 6 \mathrm{~min} ; \mathrm{r}=6^{\circ} \mathrm{C} / \mathrm{min}, \mathrm{t}_{\mathrm{c}}=45 \mathrm{mim}$.

Coluna capilar DB-5 da J\&W Scientific (30 m x 0,25 mm x 0,25 $\mu \mathrm{m})$. 
As Figuras 189 e 190 mostram o cromatograma obtido por CG-EM e o espectro de massas do padrão analítico do composto fenólico hidroxibenzeno que tem o seu sinal e tempo de retenção em 7,640 minutos.

Figura 189. Cromatograma obtido por CG-EM do padrão analítico do composto fenólico hidroxibenzeno.

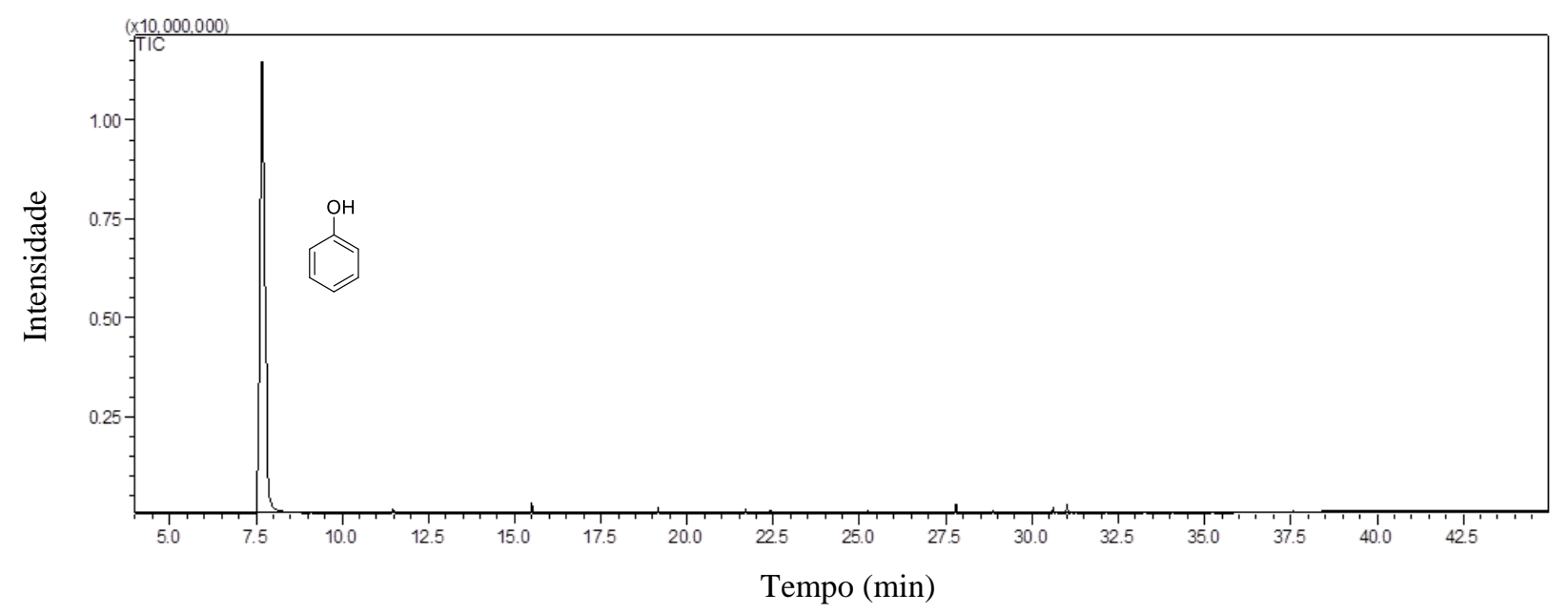

Condições de análise CG-EM: $\mathrm{T}_{\mathrm{i}}=60^{\circ} \mathrm{C}, 2 \mathrm{~min} ; \mathrm{T}_{\mathrm{f}}=280^{\circ} \mathrm{C}, 6 \mathrm{~min} ; \mathrm{r}=6^{\circ} \mathrm{C} / \mathrm{min}, \mathrm{t}_{\mathrm{c}}=45 \mathrm{mim}$.

Coluna capilar DB-5 da J\&W Scientific (30 m x 0,25 mm x 0,25 $\mu \mathrm{m}$ ).

Figura 190. Espectro de massas obtido por CG-EM $(70 \mathrm{eV})$ para o padrão analítico do composto fenólico hidroxibenzeno.

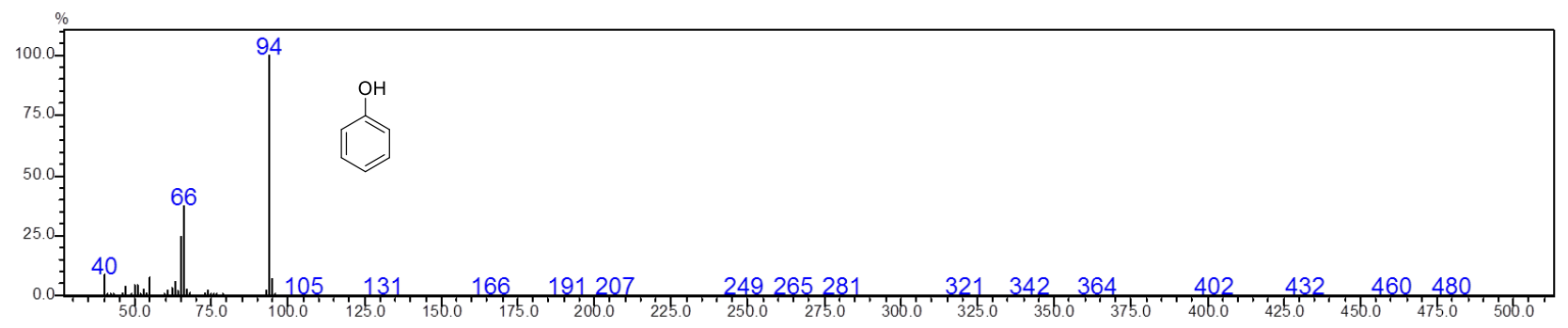


As Figuras 191 e 192 mostram o cromatograma obtido por CG-EM e o espectro de massas do padrão sintético do composto fenólico anisol que tem o seu sinal e tempo de retenção em 6,330 minutos.

Figura 191. Cromatograma obtido por CG-EM do padrão sintético do composto anisol.

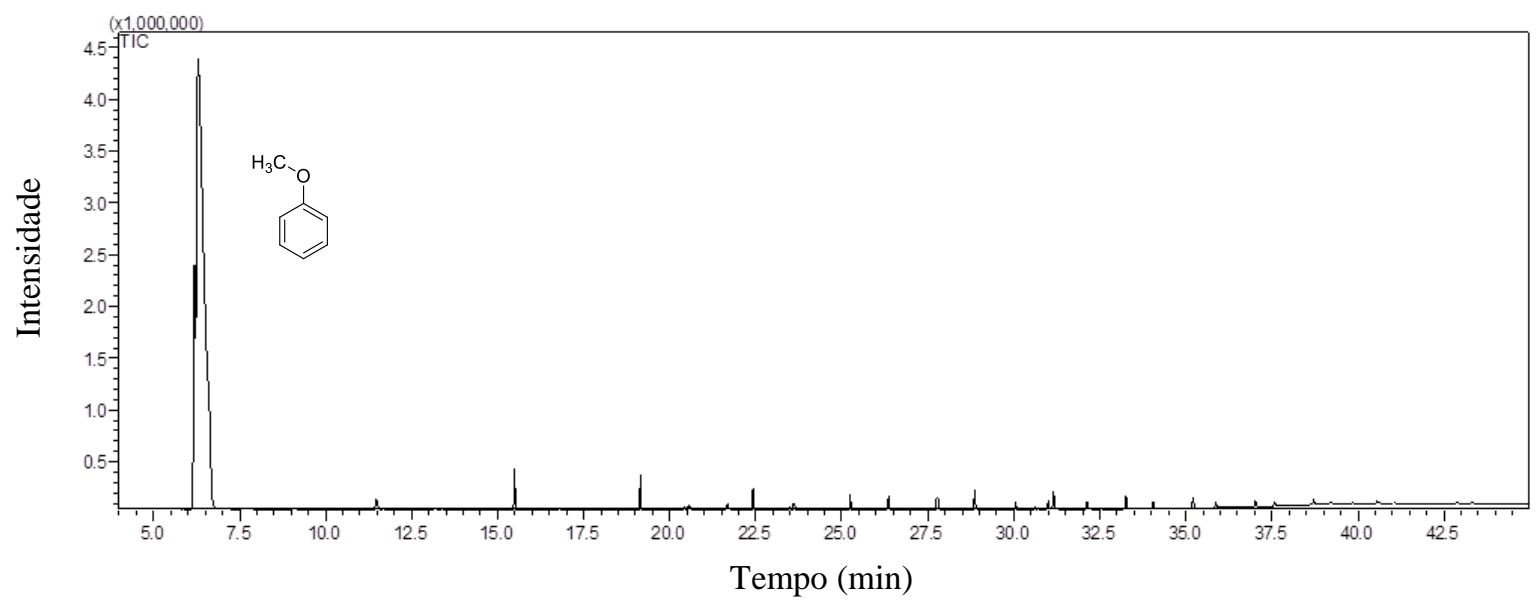

Condições de análise CG-EM: $\mathrm{T}_{\mathrm{i}}=60^{\circ} \mathrm{C}, 2 \mathrm{~min} ; \mathrm{T}_{\mathrm{f}}=280^{\circ} \mathrm{C}, 6 \mathrm{~min} ; \mathrm{r}=6^{\circ} \mathrm{C} / \mathrm{min}, \mathrm{t}_{\mathrm{c}}=45 \mathrm{mim}$.

Coluna capilar DB-5 da J\&W Scientific (30 m x 0,25 mm x 0,25 $\mu \mathrm{m}$ ).

Figura 192. Espectro de massas obtido por CG-EM $(70 \mathrm{eV})$ para o padrão sintético do composto anisol.

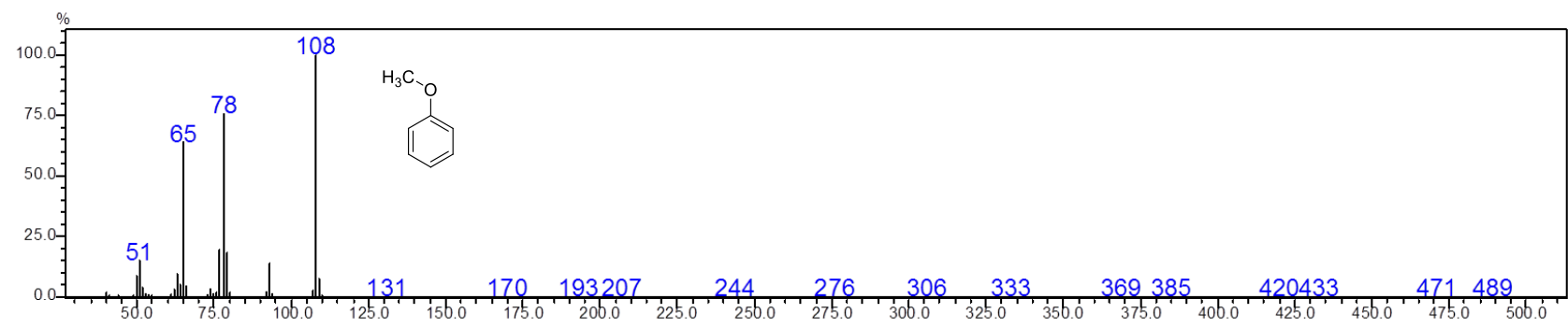

O Esquema 30 mostra a reação de biotransformação do fenólico hidroxibenzeno pelo fungo de ambiente marinho Aspergillus sydowii CBMAI 935. O Esquema 30 foi proposto a partir do metabólito anisol, formado a partir das reações de biotransformação do composto fenólico hidroxibenzeno com o fungo A. sydowii CBMAI 935 durante 10 dias. 
Esquema 30. Proposta de reação de biotransformação do composto fenólico hidroxibenzeno pelo fungo $A$. sydowii CBMAI 935 durante 10 dias de reação.<smiles>Oc1ccccc1</smiles>

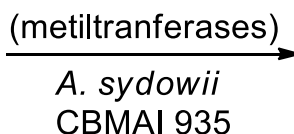

hidroxibenzeno<smiles>COc1ccccc1</smiles>

anisol

Fonte: Autoria própria.

\subsubsection{Avaliação da biotransformação do composto fenólico 2-clorofenol em 10 dias de reação com o fungo A. sydowii CBMAI 935}

A Figura 193 mostra a sobreposição do cromatograma obtido por CG-EM da reação de controle biótico (cor vermelha) e o cromatograma da reação do composto fenólico 2clorofenol (cor preta) com concentração de 50 mg.L ${ }^{-1}$ em 10 dias de reação de biotransformação com o fungo A. sydowii CBMAI 935. Os cromatogramas estão sobrepostos para a comparação qualitativa das intensidades dos sinais dos metabólitos formados naturalmente pelo fungo e os metabólitos formados por ação enzimática do fungo e o 2clorofenol.

Figura 193. Cromatograma obtido por CG-EM da reação de controle biótico do fungo A. sydowii CBMAI 935 e o composto fenólico 2-clorofenol em 10 dias de reação de biotransformação.

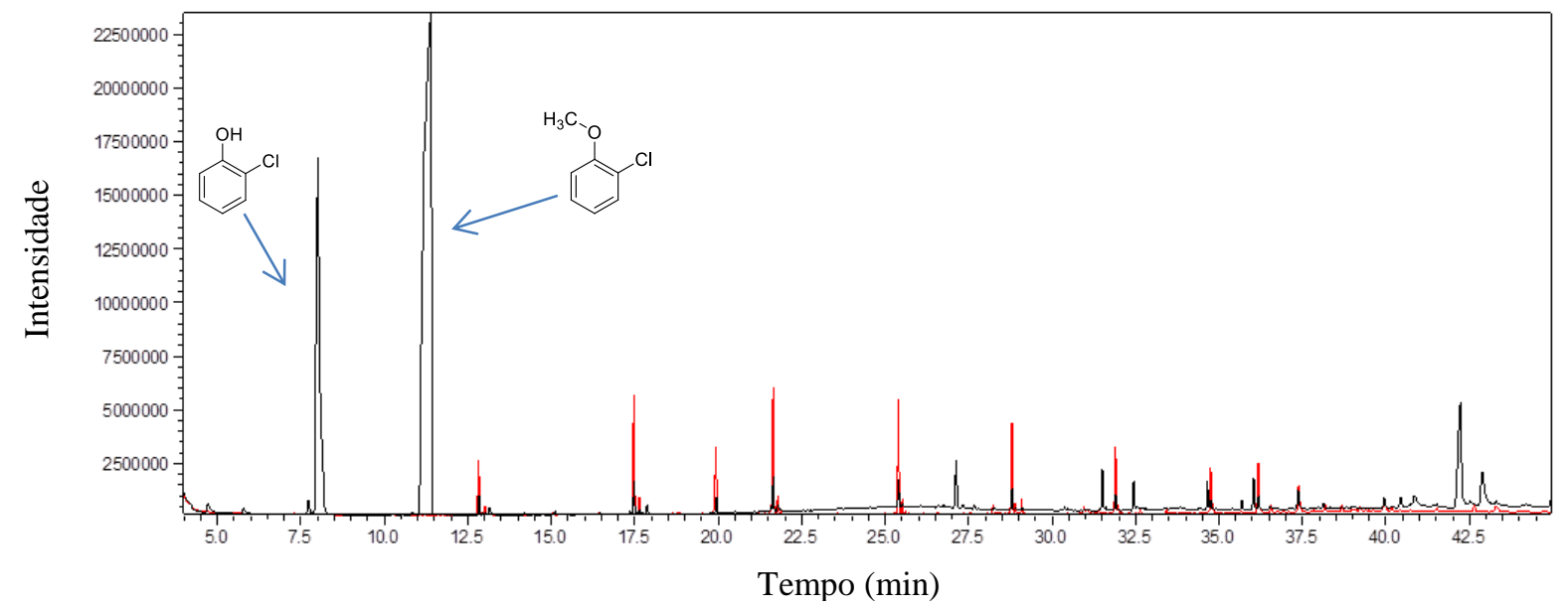

Condições de análise CG-EM: $\mathrm{T}_{\mathrm{i}}=60^{\circ} \mathrm{C}, 2 \mathrm{~min} ; \mathrm{T}_{\mathrm{f}}=280^{\circ} \mathrm{C}, 6 \mathrm{~min} ; \mathrm{r}=6^{\circ} \mathrm{C} / \mathrm{min}, \mathrm{t}_{\mathrm{c}}=45 \mathrm{mim}$.

Coluna capilar DB-5 da J\&W Scientific (30 m x 0,25 mm x 0,25 $\mu \mathrm{m}$ ). 
As Figuras 194 e 195 mostram o cromatograma obtido por CG-EM e o espectro de massas do padrão analítico do composto fenólico 2-clorofenol que tem o seu sinal e tempo de retenção em 8,00 minutos.

Figura 194. Cromatograma obtido por CG-EM do padrão analítico do composto fenólico 2-clorofenol.

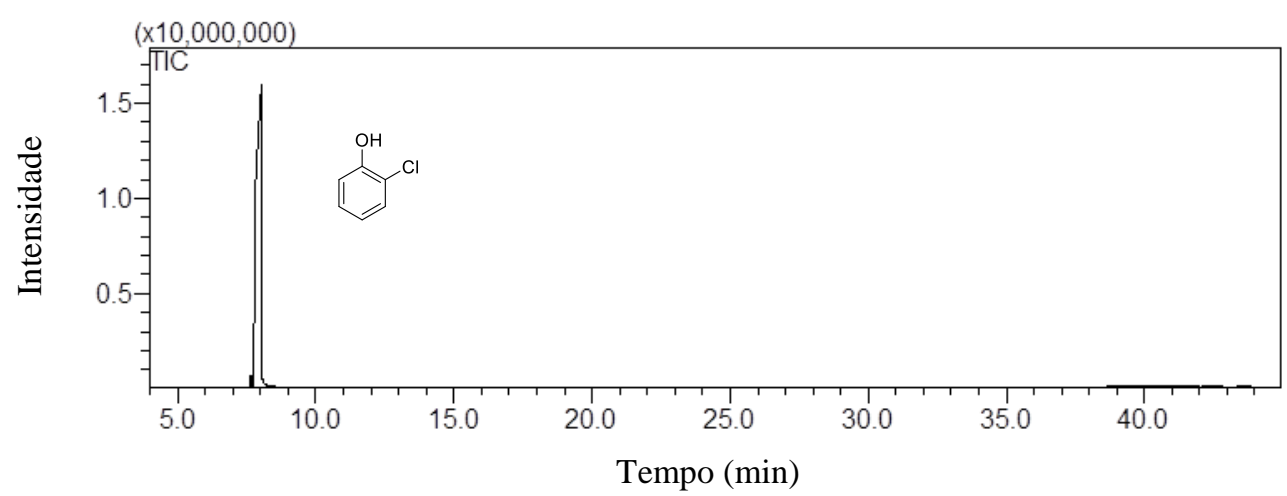

Condições de análise CG-EM: $\mathrm{T}_{\mathrm{i}}=60^{\circ} \mathrm{C}, 2 \mathrm{~min} ; \mathrm{T}_{\mathrm{f}}=280^{\circ} \mathrm{C}, 6 \mathrm{~min} ; \mathrm{r}=6^{\circ} \mathrm{C} / \mathrm{min}, \mathrm{t}_{\mathrm{c}}=45 \mathrm{mim}$. Coluna capilar DB-5 da J\&W Scientific (30 m x 0,25 mm x 0,25 $\mu \mathrm{m})$.

Figura 195. Espectro de massas obtido por CG-EM $(70 \mathrm{eV})$ para o padrão analítico do composto fenólico 2clorofenol.

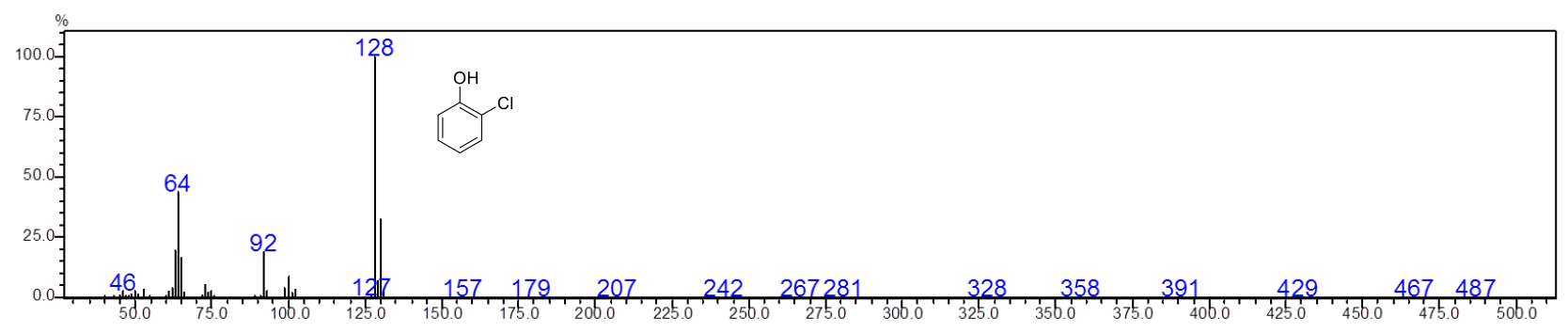


As Figuras 196 e 197 mostram o cromatograma obtido por CG-EM e o espectro de massas do padrão sintético do composto 1-cloro-2-metoxibenzeno que tem o seu sinal e tempo de retenção em 11, 350 minutos.

Figura 196. Cromatograma obtido por CG-EM do padrão sintético do composto 1-cloro-2-metoxibenzeno.

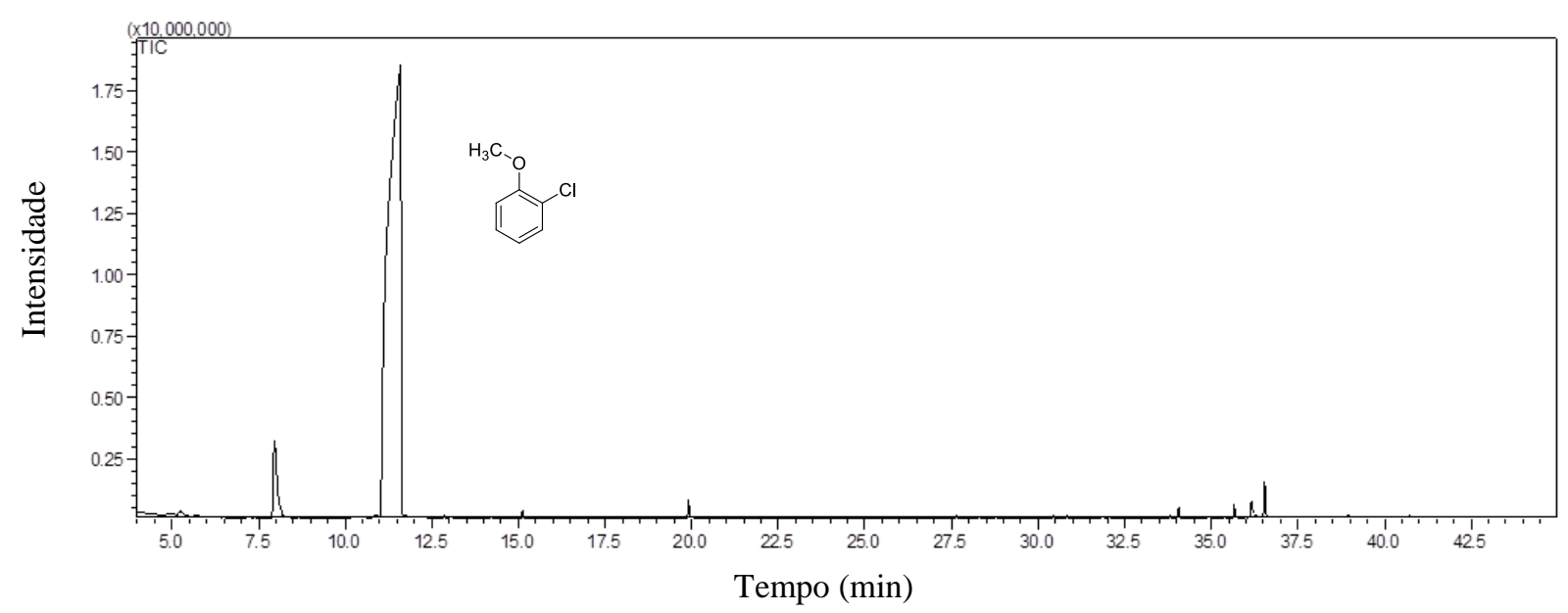

Condições de análise CG-EM: $\mathrm{T}_{\mathrm{i}}=60^{\circ} \mathrm{C}, 2 \mathrm{~min} ; \mathrm{T}_{\mathrm{f}}=280^{\circ} \mathrm{C}, 6 \mathrm{~min} ; \mathrm{r}=6^{\circ} \mathrm{C} / \mathrm{min}, \mathrm{t}_{\mathrm{c}}=45 \mathrm{mim}$.

Coluna capilar DB-5 da J\&W Scientific ( $30 \mathrm{~m}$ x 0,25 mm x 0,25 $\mu \mathrm{m})$.

Figura 197. Espectro de massas obtido por CG-EM (70 eV) para o padrão sintético do composto 1-cloro-2metoxibenzeno.

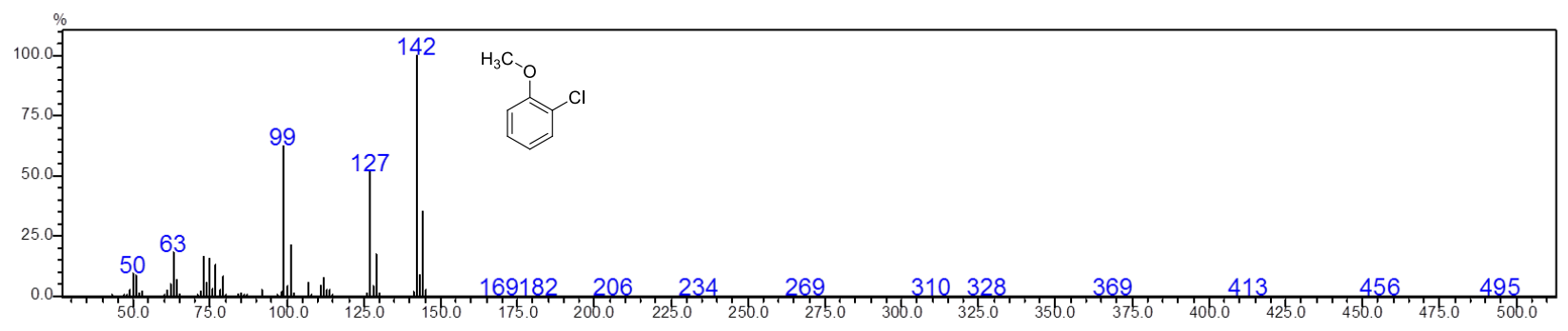

O Esquema 31 mostra a reação de biotransformação do fenólico 2-clorofenol pelo fungo de ambiente marinho Aspergillus sydowii CBMAI 935. O Esquema 31 foi proposto a partir do metabólito 1-cloro-2-metoxibenzeno, formados a partir das reações de biotransformação do composto fenólico 2-clorofenol com o fungo A. sydowii CBMAI 935 durante 10 dias. 
Esquema 31. Proposta de reação de biotransformação do composto fenólico 2-clorofenol pelo fungo A. sydowii CBMAI 935 durante 10 dias de reação.

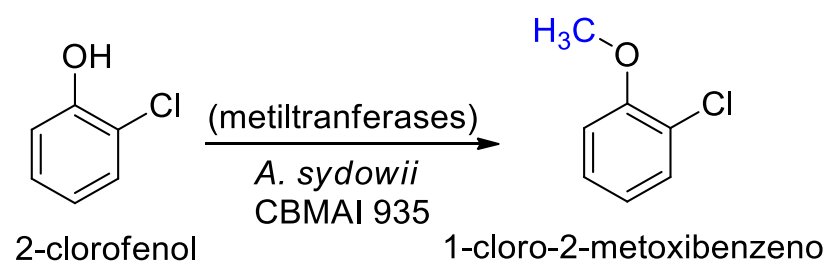

Fonte: Autoria própria.

\subsubsection{Avaliação da biotransformação do composto fenólico 2-cloro-5-hidroxipiridina em 10 dias de reação com o fungo A. sydowii CBMAI 935}

A Figura 198 mostra a sobreposição do cromatograma obtido por CG-EM da reação de controle biótico (cor vermelha) e o cromatograma da reação do composto fenólico 2-cloro-5hidroxipiridina (cor preta) com concentração de 50 mg. $\mathrm{L}^{-1}$ em 10 dias de reação de biotransformação com o fungo A. sydowii CBMAI 935. Os cromatogramas foram sobrepostos para a comparação qualitativa das intensidades dos sinais dos metabólitos formados naturalmente pelo fungo e o metabólito formado por ação enzimática do fungo e o 2-cloro-5hidroxipiridina.

Figura 198. Cromatograma obtido por CG-EM da reação de controle biótico do fungo A. sydowii CBMAI 935 e o composto fenólico 2-cloro-5-hidroxipiridina em 10 dias de reação de biotransformação.

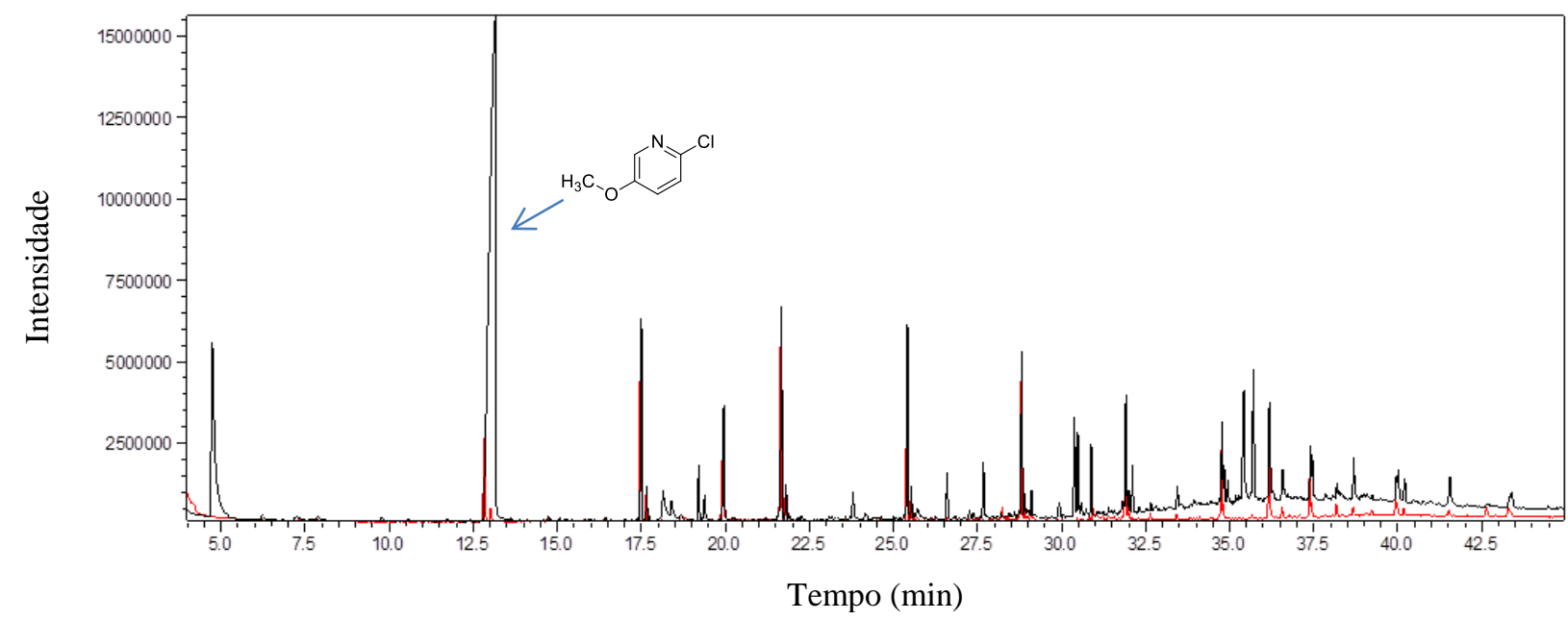

Condições de análise CG-EM: $\mathrm{T}_{\mathrm{i}}=60^{\circ} \mathrm{C}, 2 \mathrm{~min} ; \mathrm{T}_{\mathrm{f}}=280^{\circ} \mathrm{C}, 6 \mathrm{~min} ; \mathrm{r}=6^{\circ} \mathrm{C} / \mathrm{min}, \mathrm{t}_{\mathrm{c}}=45 \mathrm{mim}$.

Coluna capilar DB-5 da J\&W Scientific (30 m x 0,25 mm x 0,25 $\mu \mathrm{m})$. 
As Figuras 199 e 200 mostram o cromatograma obtido por CG-EM e o espectro de massas do padrão analítico do composto fenólico 2-cloro-5-hidroxipiridina que tem o seu sinal e tempo de retenção em 16, 140 minutos.

Figura 199. Cromatograma obtido por CG-EM do padrão analítico do composto fenólico 2-cloro-5hidroxipiridina.

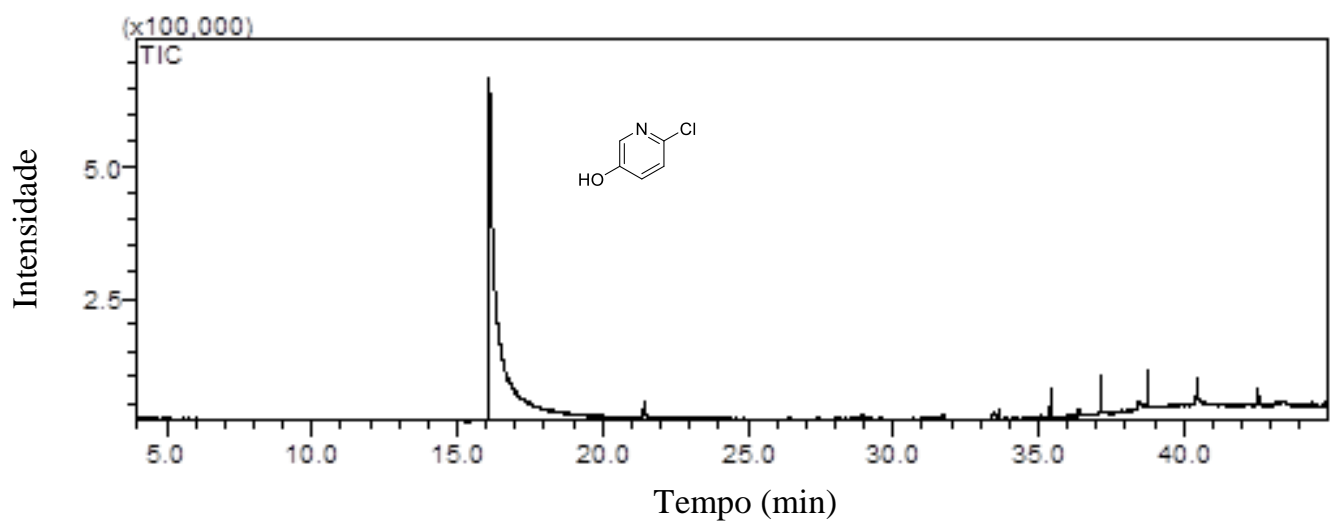

Condições de análise CG-EM: $\mathrm{T}_{\mathrm{i}}=60^{\circ} \mathrm{C}, 2 \mathrm{~min} ; \mathrm{T}_{\mathrm{f}}=280^{\circ} \mathrm{C}, 6 \mathrm{~min} ; \mathrm{r}=6^{\circ} \mathrm{C} / \mathrm{min}, \mathrm{t}_{\mathrm{c}}=45 \mathrm{mim}$. Coluna capilar DB-5 da J\&W Scientific (30 m x 0,25 mm x 0,25 $\mu \mathrm{m})$.

Figura 200. Espectro de massas obtido por CG-EM $(70 \mathrm{eV})$ para o padrão analítico do composto fenólico 2cloro-5-hidroxipiridina.

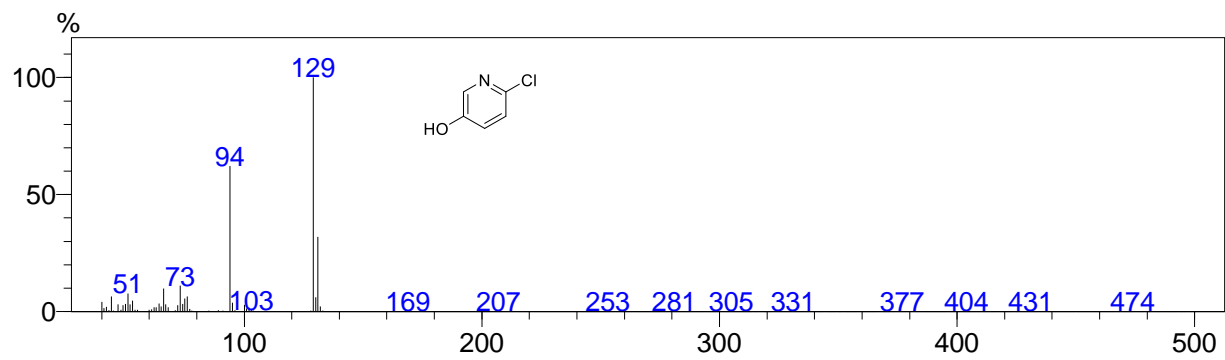


As Figuras 201 e 202 mostram o cromatograma obtido por CG-EM e o espectro de massas do padrão sintético do composto 2-cloro-5-metoxipiridina que tem o seu sinal e tempo de retenção em 12, 960 minutos.

Figura 201. Cromatograma obtido por CG-EM do padrão sintético do composto 2-cloro-5-metoxipiridina.

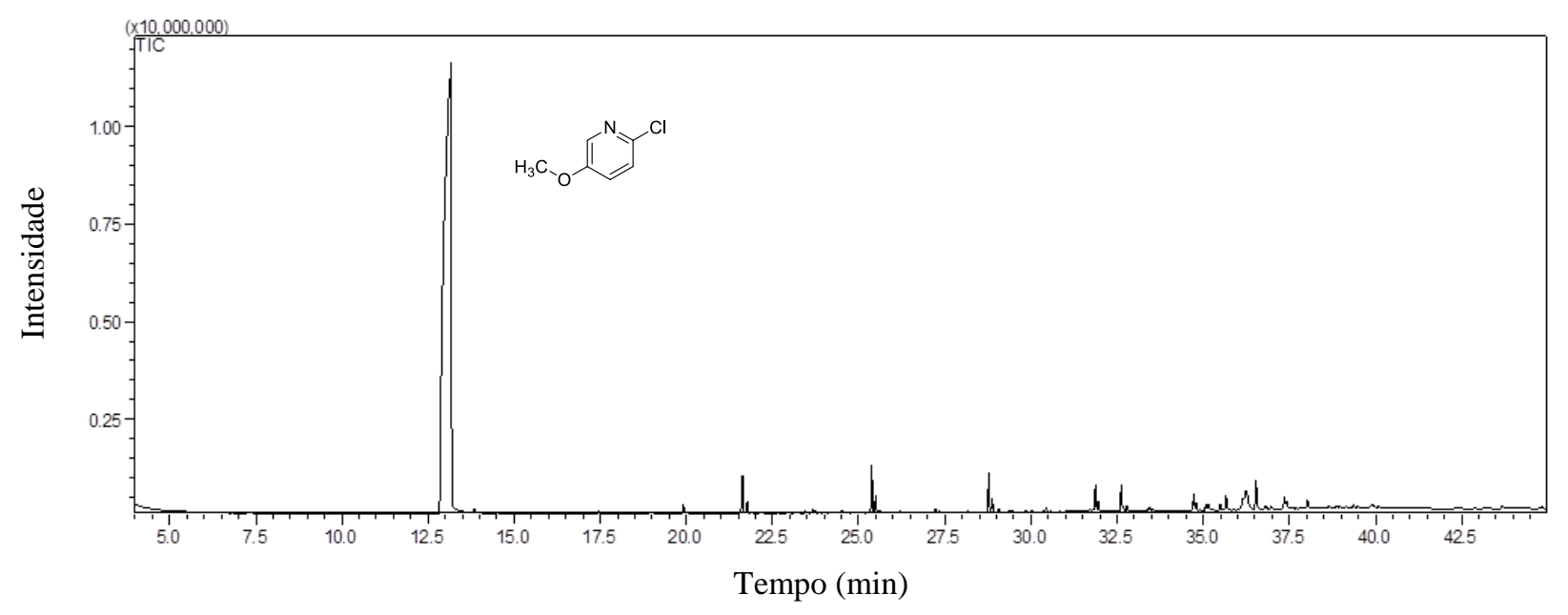

Condições de análise CG-EM: $\mathrm{T}_{\mathrm{i}}=60^{\circ} \mathrm{C}, 2 \mathrm{~min} ; \mathrm{T}_{\mathrm{f}}=280^{\circ} \mathrm{C}, 6 \mathrm{~min} ; \mathrm{r}=6^{\circ} \mathrm{C} / \mathrm{min}, \mathrm{t}_{\mathrm{c}}=45 \mathrm{mim}$.

Coluna capilar DB-5 da J\&W Scientific ( $30 \mathrm{~m}$ x 0,25 mm x 0,25 $\mu \mathrm{m}$ ).

Figura 202. Espectro de massas obtido por CG-EM (70 eV) para o padrão sintético do composto 2-cloro-5metoxipiridina.

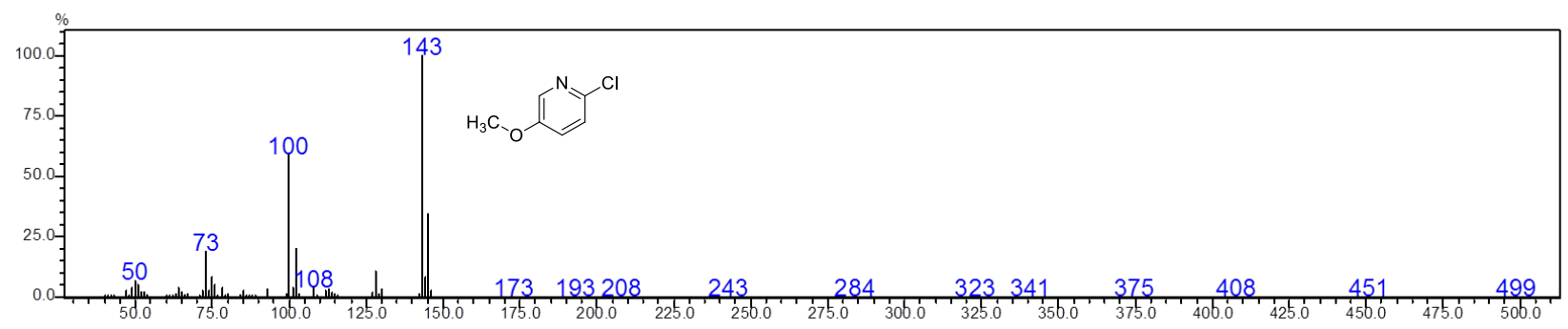

O Esquema 32 mostra a reação de biotransformação do fenólico 2-cloro-5-hidroxipiridina pelo fungo de ambiente marinho Aspergillus sydowii CBMAI 935. O Esquema 32 foi proposto a partir do metabólito 2-cloro-5-metoxipiridina, formado a partir das reações de biotransformação do composto fenólico 2-cloro-5-hidroxipiridina com o fungo A. sydowii CBMAI 935 durante 10 dias. 
Esquema 32. Proposta de reação de biotransformação do 2-cloro-5-hidroxipiridina pelo fungo A. sydowii CBMAI 935 durante 10 dias de reação.

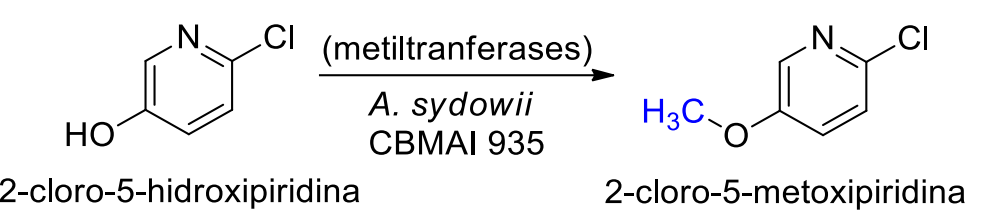

Fonte: Autoria própria.

\subsubsection{Avaliação da biotransformação do composto fenólico 4-(4-hidroxifenil)ciclo- hexanona em 10 dias de reação com o fungo $A$. sydowii CBMAI 935}

A Figura 203 mostra a sobreposição do cromatograma obtido por CG-EM da reação de controle biótico (cor vermelha) e o cromatograma da reação do composto fenólico 4-(4hidroxifenil)ciclo-hexanona (cor preta) com concentração de $50 \mathrm{mg} . \mathrm{L}^{-1}$ em 10 dias de reação de biotransformação com o fungo A. sydowii CBMAI 935. Os cromatogramas estão sobrepostos para a comparação qualitativa das intensidades dos sinais dos metabólitos formados naturalmente pelo fungo e o metabólito formado por ação enzimática do fungo e o 4-(4-hidroxifenil)ciclo-hexanona.

Figura 203. Cromatograma obtido por CG-EM da reação de controle biótico do fungo A. sydowii CBMAI 935 e o composto fenólico 4-(4-hidroxifenil)ciclo-hexanona em 10 dias de reação de biotransformação.

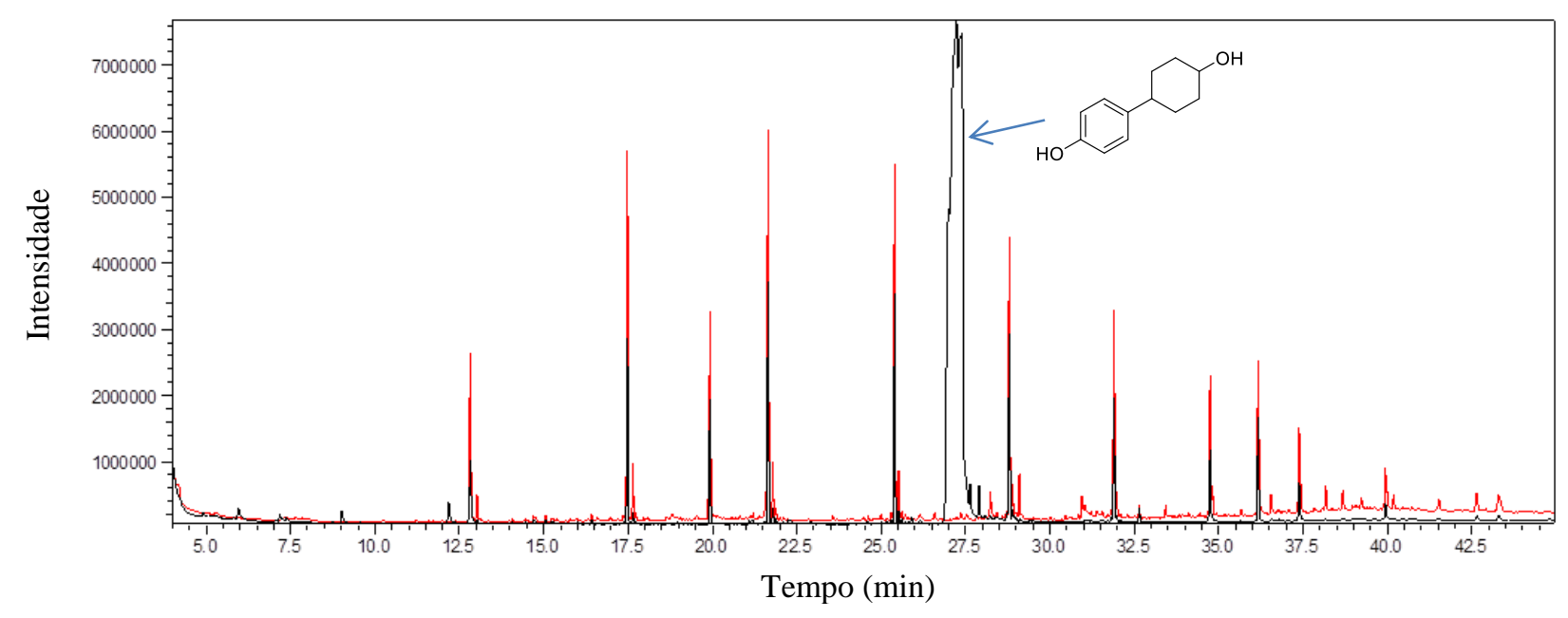

Condições de análise CG-EM: $\mathrm{T}_{\mathrm{i}}=60^{\circ} \mathrm{C}, 2 \mathrm{~min} ; \mathrm{T}_{\mathrm{f}}=280^{\circ} \mathrm{C}, 6 \mathrm{~min} ; \mathrm{r}=6^{\circ} \mathrm{C} / \mathrm{min}, \mathrm{t}_{\mathrm{c}}=45 \mathrm{mim}$.

Coluna capilar DB-5 da J\&W Scientific (30 m x 0,25 mm x 0,25 $\mu \mathrm{m})$. 
As Figuras 204 e 205 mostram o cromatograma obtido por CG-EM e o espectro de massas do padrão analítico do composto fenólico 4-(4-hidroxifenil)ciclo-hexanona que tem o seu sinal e tempo de retenção em 27,366 minutos.

Figura 204. Cromatograma obtido por CG-EM do padrão analítico do composto fenólico 4-(4hidroxifenil)ciclo-hexanona.

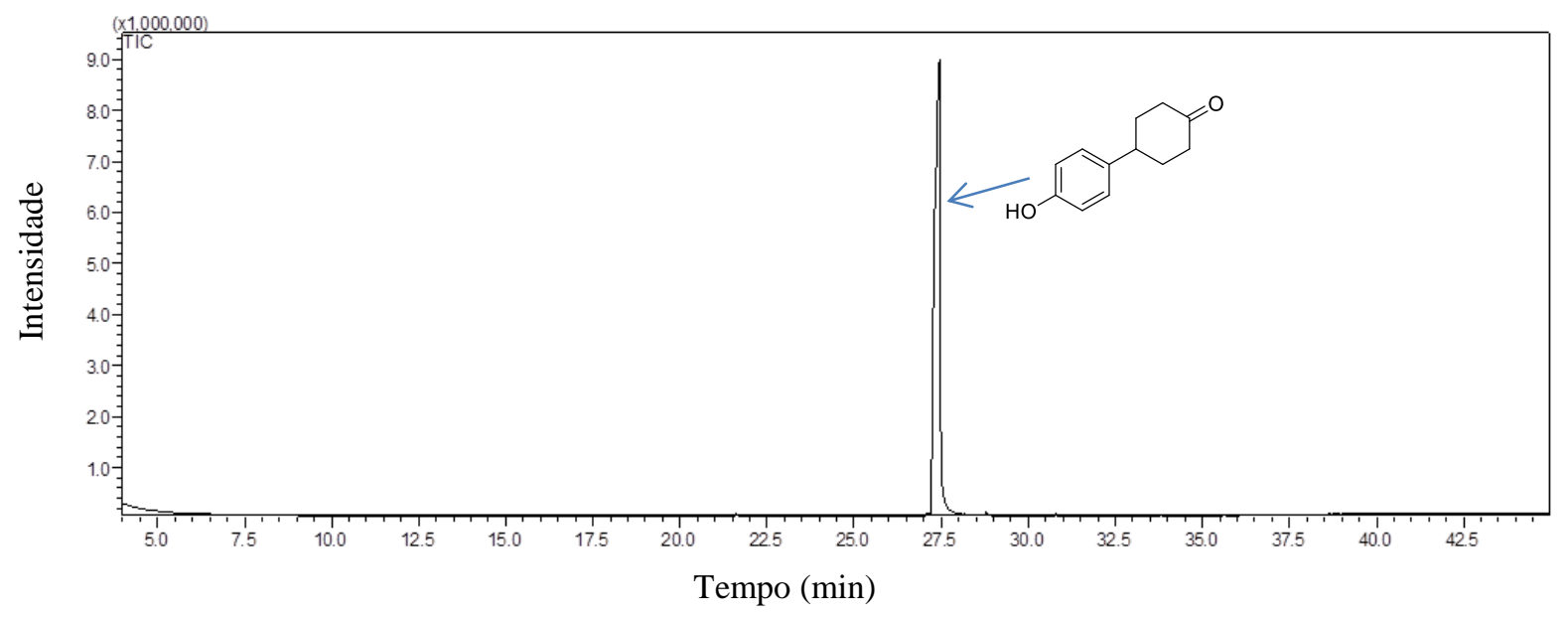

Condições de análise CG-EM: $\mathrm{T}_{\mathrm{i}}=60^{\circ} \mathrm{C}, 2 \mathrm{~min} ; \mathrm{T}_{\mathrm{f}}=280^{\circ} \mathrm{C}, 6 \mathrm{~min} ; \mathrm{r}=6^{\circ} \mathrm{C} / \mathrm{min}, \mathrm{t}_{\mathrm{c}}=45 \mathrm{mim}$.

Coluna capilar DB-5 da J\&W Scientific ( $30 \mathrm{~m}$ x 0,25 mm x 0,25 $\mu \mathrm{m})$.

Figura 205. Espectro de massas obtido por CG-EM $(70 \mathrm{eV})$ para o padrão analítico do composto fenólico 4-(4hidroxifenil)ciclo-hexanona.

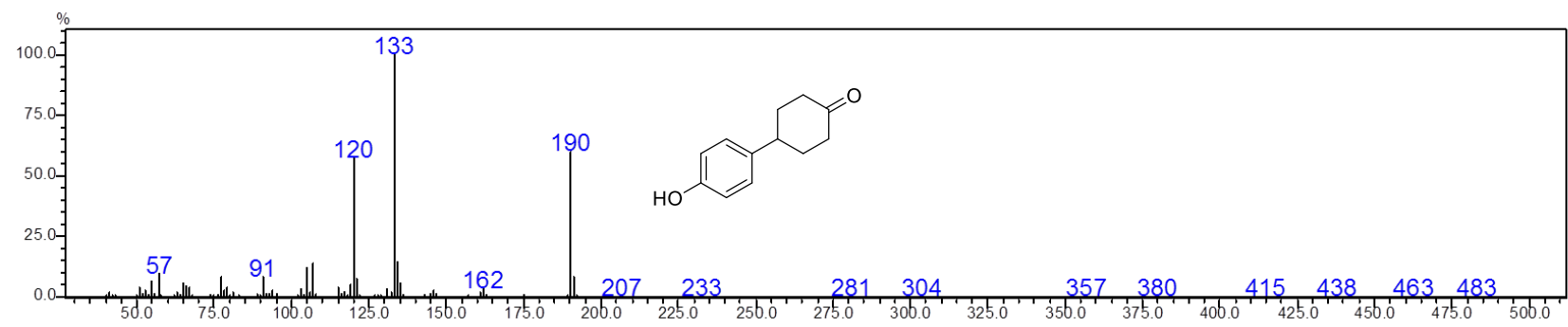


As Figuras 206 e 207 mostram o cromatograma obtido por CG-EM e o espectro de massas do padrão sintético do composto 4-(4-hidroxiciclo-hexil) fenol que tem o seu sinal e tempo de retenção em 27, 200 minutos.

Figura 206. Cromatograma obtido por CG-EM do padrão sintético do composto fenólico 4-(4-hidroxiciclohexil) fenol.

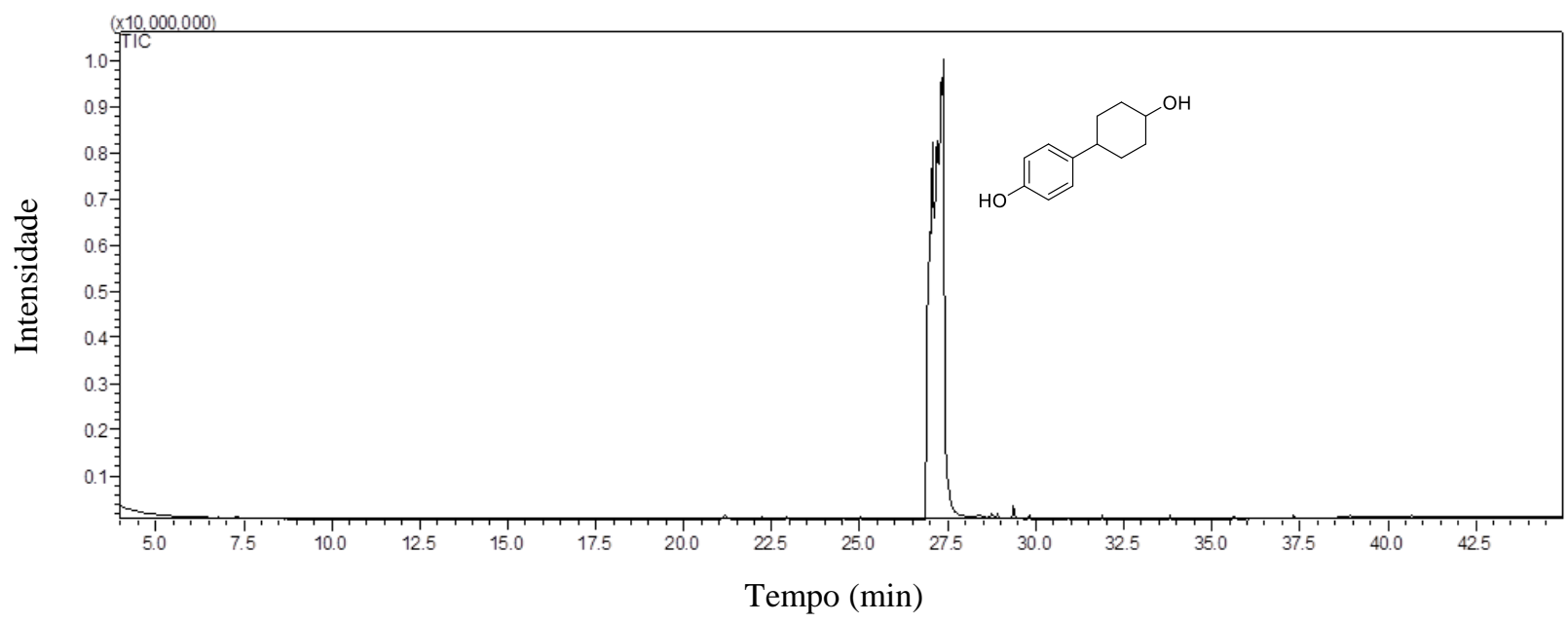

Condições de análise CG-EM: $\mathrm{T}_{\mathrm{i}}=60^{\circ} \mathrm{C}, 2 \mathrm{~min} ; \mathrm{T}_{\mathrm{f}}=280^{\circ} \mathrm{C}, 6 \mathrm{~min} ; \mathrm{r}=6^{\circ} \mathrm{C} / \mathrm{min}, \mathrm{t}_{\mathrm{c}}=45 \mathrm{mim}$. Coluna capilar DB-5 da J\&W Scientific (30 $\mathrm{m}$ x 0,25 mm x 0,25 $\mu \mathrm{m})$.

Figura 207. Espectro de massas obtido por CG-EM $(70 \mathrm{eV})$ para o padrão sintético do composto fenólico 4-(4hidroxiciclo-hexil) fenol.

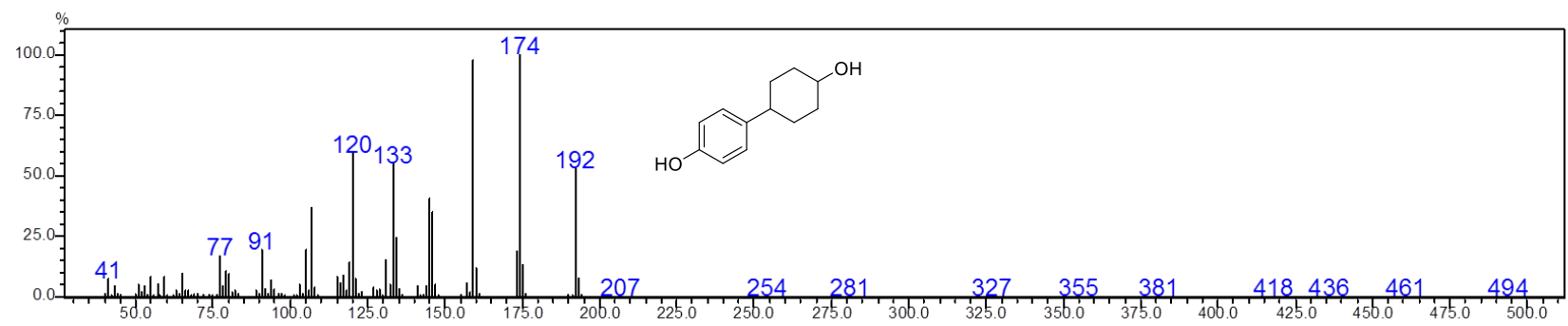

O Esquema 33 mostra a reação de biotransformação do fenol 4-(4-hidroxifenil)ciclohexanona pelo fungo de ambiente marinho Aspergillus sydowii CBMAI 935. O Esquema 33 foi proposto a partir do metabólito 4-(4-hidroxiciclo-hexil) fenol, formado a partir das reações de biotransformação do composto fenólico 4-(4-hidroxifenil)ciclo-hexanona com o fungo $A$. sydowii CBMAI 935, durante 10 dias.

Neste caso não ocorreu a biometilação, mas a redução do grupo carbonílico catalisado por enzimas redutases. 
Esquema 33. Proposta de reação de biotransformação do 4-(4-hidroxifenil)ciclo-hexanona pelo fungo $A$. sydowii CBMAI 935 durante 10 dias de reação.<smiles>O=C1CCC(c2ccc(O)cc2)CC1</smiles>

4-(4-hidroxifenil)ciclo-hexan-1-ona $\underset{\text { (oxido-redutases) }}{\stackrel{\text { sydowii }}{\longrightarrow}}$

A. sydowil CBMAI 935<smiles>Oc1ccc(C2CCC(O)CC2)cc1</smiles>

4-(4-hidroxiciclo-hexil)fenol

Fonte: Autoria própria.

Os compostos fenólicos: pirogalol, 4-aminofenol, 2-hidroxiacetofenona, 2,4 diclorofenol, 3-hidroxi-4-metoxibenzaldeído, 2-hidroxi-6-metoxibenzaldeído, 4-cloro-2,6-diiodofenol, 2,6diiodofenol, 2,6-diiodofenol, 1-(4-hidroxi-3-iodofenil)etan-1-ona, também foram submetidos às reações com o fungo $A$. sydowii CBMAI 935, porém não foram obtidos produtos de biotransformação. 


\section{CONCLUSÃO}

Primeiramente foi realizado um screening em meio de cultura sólido com sete cepas previamente selecionadas de fungos de ambiente marinho frente aos pesticidas organofosforados (clorpirifós, metil paration e profenofós) para avaliar a resistência destes microrganismos frente à toxicidade dos pesticidas.

Após o screening ser realizado, o fungo selecionado para as reações de biotransformação em meio líquido de malte $2 \%$, que melhor adaptou-se na presença dos pesticidas e compostos fenólicos testados nesse trabalho foi o fungo Aspergillus sydowii CBMAI 935 que se mostrou uma possível fonte de enzimas fosfotriestreses e metiltrasferases, uma vez que foi capaz de hidrolisar e metilar os pesticidas organofosforaodos e os demais compostos fenólicos testados neste trabalho.

Todos os metabólitos encontrados nas reações de biotransformação dos xenobióticos com o fungo A. sydowii CBMAI 935 (caldo e micélio) foram comparados com os seus devidos padrões analíticos e sintéticos com o intuito de corroborar os resultados encontrados, onde foi possível sugerir possíveis mecanismos enzimáticos e possíveis rotas de biodegradação para cada xenobiótoco analizado nesse trabalho.

Através deste estudo foi possível sugerir a presença de enzimas fosfotriesterases e enzimas metiltransferases que promoveram a hidrólise e biometilação dos pesticidas e compostos fenólicos testados nesse trabalho. É importante frizar que além de reações de hidrólise e biometilação, o fungo A. sydowii CBMAI 935 mostrou-se bastante versátil, uma vez que foi capaz de realizar outras reações biotransformações além da biometilação, como ocorreu com os compostos fenólicos 4-(4-hidroxifenil)ciclo-hexanona e pentaclorofenol no qual esses dois compostos foram biotransformado através de reações enzimáticas provenientes do fungo de ambiente marinho.

Este trabalho é inovador, uma vez que até o presente momento, não há relatos na literatura de reações de conjugação (biometilação) dos pesticidas organofosforados clorpirifós, metil paration e profenofós na presença de fungos de ambiente marinho.

Aprimoramentos nas metodologias de extração e análises cromatográficas podem futuramente, possibilitar a identificação de outros metabólitos correspondentes às reações de fase I e reações de fase II (conjugação) dos pesticidas testados, possibilitando um melhor estudo das rotas enzimáticas. 


\section{REFERÊNCIAS BIBLIOGRÁFICAS}

1 CONCEIÇÃO, D.M.; DE ANGELIS,D.A.; BIDOIA, E.D. Fungos filamentosos isolados do rio Atibaia, SP e refinaria de petróleo biodegradadores de compostos fenólicos. Arquivo do Instituto de Biociências, São Paulo, v. 72, n. 1, p. 99-106, 2005.

2 AGÊNCIA NACIONAL DE VIGILÂNCIA SANITÁRIA (ANVISA). Estudo traça perfil do mercado de agrotóxicos no Brasil. 2015. Disponível em:

<http://s.anvisa.gov.br/wps/s/r/oFb>. Acesso em: 22 mar. 2016.

3 AZEVEDO, J. L.; ESPÓSITO, E. Fungos: uma introdução à biologia, bioquímica e biotecnologia. $2^{\mathrm{a}}$ ed. Rio Grande do Sul: Educs, 2006. p. 20-45.

4 COUTINHO, C. F. B.; TANIMOTO, S. T.; GALLI, A.; GARBELLINI, G. S.;

TAKAYAMA, M.; AMARAL, R. B.; MAZO, L. H.; AVACA, L. A.; MACHADO, S. A. S. Pesticidas: mecanismo de ação, degradação e toxidez. Pesticidas, v. 15, p. 65-72, 2005.

5 DIEZ, M. Biological aspects involved in the degradation of organic pollutants. Journal of Soil Science and Plant Nutrition, v. 10, n. 3, p. 244-267, 2010.

6 AGÊNCIA NACIONAL DE VIGILÂNCIA SANITÁRIA (ANVISA). Agrotóxicos e toxicologia. Brasília, 2009. Disponível em:

$<$ http://portal.anvisa.gov.br/wps/content/Anvisa+Portal/Anvisa/Inicio/Agrotoxicos+e+Toxicol ogia>. Acesso em: 20 out. 2015.

7 KOUZAYHA, A.; RABAA, A. R.; ISKANDARANI1, M. A.; BEH, D.; BUDZINSKI, H.; JABER1, F. Multiresidue method for determination of 67 pesticides in water samples using solid-phase extraction with centrifugation and gas chromatography- mass spectrometry. American Journal of Analytical Chemistry, v. 3, p. 257-265, 2012.

8 SILVA, C. M. M. S.; MELO, I. S.; FAY, E. F. Biotransformação de agrotóxicos e biorremediação. In: SILVA, C. M. M. S.; FAY, E. F. Agrotóxicos e meio ambiente. Brasília: Embrapa Informação Tecnológica, 2004. p. 145-192.

9 GAVRILESCU, M. Fate of pesticides in the environment and its bioremediation. Engineering in Life Sciences, v. 5, n. 6, p. 497-526, 2005.

10 RIBEIRO, M. L.; LOURENCETTI, C.; POLESE, L.; NAVICKIENE, S.; OLIVEIRA, L. C. Pesticidas: Usos e riscos para o meio ambiente. Holos Environment, v. 8, n. 1, p. 5371, 2008. 
11 BARNARD C.; DABERKOW S.; PADGITT M.; SMITH M. E.; URI N. D. Alternative measures of pesticide use. The Science of the Total Environment, v. 203, p. 229-244, 1997.

12 BARBOSA, L.C.A. Os pesticidas, o homem e o meio ambiente. Minas Gerais: Ed. UFV, 2004. p. 75-90.

13 RATTNER, B. A. History of wildlife toxicology. Ecotoxicology, v. 18, n. 7, p. 773-783, 2009.

14 FREIRE, R. S.; PELEGRINI, R.; KUBOTA, L. T.; DURÁN, N.; PERALTA-ZAMORA, $\mathrm{P}$. Novas tendências para o tratamento de resíduos industriais contendo espécies organocloradas. Química Nova, v. 23, n. 4, p. 504-511, 2000.

15 AGÊNCIA NACIONAL DE VIGILÂNCIA SANITÁRIA (ANVISA). Estudo traça perfil do mercado de agrotóxicos no Brasil. 2015. Disponível em:

<http://s.anvisa.gov.br/wps/s/r/oFb>. Acesso em: 28 maio 2016.

16 SINDICATO NACIONAL DA INDÚSTRIA DE PRODUTOS PARA DEFESA AGRÍCOLA (SINDAG). Investimento em tecnologia produziu safra recorde. Conexão Sindag Especial, v. 8, n. 42, p. 22, 2013.

17 AGÊNCIA NACIONAL DE VIGILÂNCIA SANITÁRIA (ANVISA); UNIVERSIDADE FEDERAL DO PARANÁ (UFPR). Seminário de mercado de agrotóxico e regulação. Brasília, 2012. p. 12-15.

18 MINISTÉRIO DA AGRICULTURA, PECUÁRIA E ABASTECIMENTO. Estatísticas. São Paulo, 2016. Disponível em: <http:// www.agricultura.gov.br/vegetal/estatísticas>. Acesso em: 14 fev. 2016.

19 PEIXOTO, S. C. Estudo da estabilidade a Campo dos Pesticidas Carbofurano e Quincloraque em Água de Lavoura de Arroz Irrigado empregando SPE e HPLCDAD. 2007. 108 f. Dissertação (Mestrado) - Curso de Programa de Pós-graduação em Química, Departamento de Centro de Ciências Naturais e Exatas, Universidade Federal de Santa Maria, Santa Maria, 2007. Cap. 2. Disponível em: $<$ http://cascavel.cpd.ufsm.br/tede/tde_arquivos/6/TDE-2007-11-26T180311Z1033/Publico/SANDRA PEIXOTO.pdf>. Acesso em: 23 out. 2015.

20 VILARINHO, F. Pesticidas. 2011. Disponível em: <http://repositorio.insa.pt/bitstream/10400.18/772/1/Pesticidas 2011.pdf>. Acesso em: 20 out. 2015. 
21 LATORRACA, A. Agrotóxicos utilizados na produção do tomate em Goiânia e Goianápolis e efeitos na saúde humana, Ciências e Saúde, v. 4, n. 19, p. 365-374, 2008.

22 EMBRAPA. Produção de sementes sadias de feijão comum em várzeas tropicais. Embrapa Arroz e Feijão, 2004. Disponível em: $<$ http://sistemasdeproducao.cnptia.embrapa.br/FontesHTML/Feijao/FeijaoVarzeaTropical/agr otoxicos.htm>. Acesso em: 20 out. 2015.

23 QUINTELA, E. D. Produção de sementes sadias de feijão comum em várzeas tropicais. Embrapa Arroz e Feijão, 2004. Disponível em: $<$ http://sistemasdeproducao.cnptia.embrapa.br/FontesHTML/Feijao/FeijaoVarzeaTropical/agr otoxicos.htm>. Acesso em: 20 out. 2015.

24 LEVINE, R.S. Assessment of mortality and morbidity due unitentional pesticide poisonings. Genebra, Organización Mundial de Salud, 1986.

25 DOMÉNECH, X. Quimica ambiental: El impacto ambiental de los residuos. Madrid: Miraguano Ediciones, 1994. p. 254.

26 ORGANIZAÇÃO MUNDIAL DE SAÚDE (OMS), Foro mundial de la salud. Revista Internacional de Desarrollo Sanitario, v.12, n. 3, p.325, 1991.

27 LINS, L.; Brasil é um dos países que mais abusam de agrotóxicos. O Globo, Rio de Janeiro 18 de dez. 1995, p. 16.

28 RACKE, K.D.; SKIDMORE, M.W.; HAMILTON, D.J.; UNSWORTH, J.B.; MIYAMOTO, J.; COHEN, S.Z. Pesticide fate in tropical sils. Pure \& Application Chemystri, v. 69, p. 1449-1371, 1997.

29 AGÊNCIA NACIONAL DE VIGILÂNCIA SANITÁRIA (ANVISA). Lista de alimentos contaminados no ano de 2015. 2015. Disponível em: 〈http://s.anvisa.gov.br/wps/s/r/oFb〉. Acesso em: 28 maio 2016.

30 GAVRILESCU, M. Fate of pesticides in the environment and its bioremediation. Engineering in Life Sciences, v. 5, n. 6, p. 497-526, 2005.

31 FLORES, A. V.; RIBEIRO, J. N.; NEVES, A. A.; QUEIROZ, E. L. R. Organoclorados: Um problema de saúde pública. Ambiente \& Sociedade, v. 7, n. 2, p. 125-143, 2004. 
32 HARAZONO, K.; NAKAMURA, K. Descolorization of mixtures of different reactive textile dyes by the write-rot basidiomycetes Phanerochaete sórdida and inhibitory effect of poly vinyl alcohol. Chemosphere, v, 59, p. 63-68, 2005.

33 SILVA, M.; ESPÓSITO, E. O papel dos fungos na recuperação ambiental. In: ESPÓSITO, E.; AZEVEDO, J.L Fungos: uma introdução à biologia, bioquímica e biotecnologia. Caxias do Sul: Educs, 2004. p. 337-378.

34 STOLZ, A. Basic and applied aspects in the microbial degradation of azo dyes. Appllied Microbiology Biotechnology, v. 80, p. 56-69, 2001.

35 ZANONI, M. V. B.; CARNEIRO, P. A. O descarte dos corantes têxteis. Ciência Hoje, v. 29, p. 61-65, 2001.

36 AZMI, W.; SANI, R. K.; BANERJEE V.C. Biodegradation of triphenylmethane dyes. Enzyme and Microbial Technology, v.22, p.185-191, 1998.

37 DURAN , N. Enzimas lignolíticas. In: ESPÓSITO, E.; AZEVEDO, J.L. Fungos: uma introdução à biologia, bioquímica e biotecnologia, Caxias do Sul: Educs, 2004. p. 215-242.

38 KANEKAR, P. P.; BHADBHADE, B.; DESHPANDE, N. M.; SARNAIK, S.

Biodegradation of organophosphorus pestides. Proceedings of the Indian National Science Academy, v. 1, p. 57-70, 2004.

39 SINGH, B. K.; KUHAD, R. C.; SINGH, A.; LAL, R.; TRIAPTHI, K. K. Biochemical and molecular basis of pesticide degradation by microorganisms. Critical Reviews in Biotechnology, v. 19, p. 197-225, 1999.

40 MARONI, M.; COLOSIO, C.; FERIOLI, A.; FAIT, A. Biological monitoring of pesticide exposure: Toxicology, v. 143, p. 1-118, 2000.

41 SOGORB, M. A.; VILANOVA, E. Enzymes involved in the detoxification of organophosphorus, carbamate and pyrethroid insecticides through hydrolysis. Toxicology Letters, v. 128, n. 1, p. 215-228, 2002.

42 BIGLEY, A. N.; RAUSHEL, F. M. Catalytic mechanisms for phosphotriesterases.

Biochimica et Biophysica Acta (BBA)-Proteins \& Proteomics, v. 1837, n. 1, p. 443-453, 2013. 
43 BLEECKER, J. L. Organophosphate and carbamate poisoning. Handbook of Clinical Neurology, v. 91, p. 401-432, 2008.

44 ALMEIDA T. N. Contaminação por agrotóxicos carbamatos e organofosforados em água para consumo humano de Dourados, MS, 2008 a 2009. 2010. 110 f. Dissertação (Mestrado) - Escola Nacional de Saúde Pública Sergio Arouca, Campo Grande. 2010.

45 MONTEIRO, D. A. Efeito do inseticida organofosforado metil paration (Folisuper 600 Br) sobre biomarcadores do estresse oxidante no teleósteo de água doce matrinxã Brycon cephalus (Günther, 1969) e o papel da suplementação de selênio na dieta. 2006. 163f. Dissertação (Mestrado) Instituto de Química de São Carlos, Universidade de São Paulo, São Carlos-SP. 2006.

46 PORTO, A. L. M. P.; MELGAR, G. Z.; KASEMODEL, M. C.; NITSCHKE, M. Biodegradation of pesticides. In: STOYTCHEVA, M. Pesticides in the modern worldpesticides use and management. Croatia: InTech, 2011. p. 407-438.

47 SANTOS, V. M. R.; DONNICI, C. L.; DACOSTA, J. B. N.; CAIXEIRO, J. M. R. Compostos organofosforados pentavalentes: Histórico, métodos sintéticos de preparação e aplicações como inseticidas e agentes antitumorais. Química Nova, v. 30, n. 1, p. 159-170, 2007.

48 EDWARDS, F. L.; TCHOUNWOU, P. B. Environmental toxicology and health effects associated with methyl parathion exposure-A scientific review. International Journal of Environmental Research and Public Health, v. 2, n. 3, p. 430-441, 2005.

49 RANG, H. P.; DALE, M. M.; RITTER, J. M. Drogas que inibem a cholinesterase. 4a edição, Rio de Janeiro: Guanabara Koogan, 2001. p. 110-115.

50 PATRICK, G. L.; An introduction to medicinal chemistry. London: Oxford, 2001. p. 432.

51 SILMAN, I.; SUSSMAN, J. L. Acetylcholinesterase: "classical" and "non-classical" functions and pharmacology. Current Opinion in Phamacology, v. 5, p. 293, 2005.

52 SUSSMAN, J. L.; HAREL, M.; FROLOW, F.; OEFNER, C.; GOLDMAN, A.; TOKER, L.; SILMAN, I.; Atomic struture of acetylcholinesterase from Torpedo Califórnia: A prototypic acetylcholine-binding protein. Science, v. 253, p. 872, 1991.

53 TAYLOR, P., BROWN, J. H. Acetylcholine basic neurochemistry: molecular, cellular and medical aspects. Philadelphia: LTC, 1999. p. 214-242. 
54 ORDENTLICH, A.; BARAK, D.; SOD-MORIAH, G.; KAPLAN, D.; MIZHARI, D. Stereoselectivity toward VX is determined by interactions with residues of the acyl pocket as well as of the peripheral anionic site of AChE. Biochemistry, v. 43, p. 11255-11265, 2004.

55 SOGORB, M. A.; VILANOVA, E. Enzymes involved in the detoxification of organophosphorus, carbamate and pyrethroid insecticides through hydrolysis. Toxicology Letters, v. 128, n. 1, p. 215-228, 2002.

56 DUYSEN, E. G.; CASHMAN, J. R.; SCHOPFER, L. M.; NACHON, F.; MASSON, P.; LOCKRIDGE, O. Differential sensitivity of plasma carboxylesterase-null mice to parathion, chlorpyrifos and chlorpyrifos oxon, but not to diazinon, dichlorvos,

diisopropylfluorophosphate, cresyl saligenin phosphate, cyclosarin thiocholine, tabun thiocholine, and carbofuran. Chemico-Biological Interactions, v. 195, n. 3, p. 189-198, 2011.

57 BRAJESH K. SINGH.; ALLAN WALKER. Microbial degradation of organophosphorus compounds. FEMS Microbiology Reviews v. 30, p. 428-471, 2006.

58 SIRIPATTANAKUL-RATPUKDI S.; ALISA S. VANGNAI.; PUTTAPORN SANGTHEAN.; SIRINUTTAKAN SINGKIBUT. Profenofos insecticide degradation by novel microbial consortium and isolates enriched from contaminated chili farm soil. Heidelberg: Plenum, 2014. p. 321-328.

59 RAUH, V. A..; GARFINKEL, R.; PERERA, F. P.; ANDREWS, H. F.; HOEPNER, L.; BARR, D. B.; WHITEHEAD, R.; TANG, D.; WHYATT, R. W. Impact of prenatal chlorpyrifos exposure on neurodevelopment in the first 3 years of life among inner-city children. Pediatrics, v.118, n. 6, p. 1845-1859, 2006.

60 APAW DESINFESTAÇÕES S/A. Clorpirifós. 2015. Disponível em: <http:// http://www.apaw.com.br/arquivos/ficha_clorpirifos_480_ce.pdf $>$. Acesso em: 20 out. 2015.

61 HOLIMAH, M.; TAN, Y.A.; ISMAIL, B.S; NASHRIYAH, M. Downward movement of chlorpyrifos in the soil an oil palm platation in Sepang, Selangor, Malaysia. Journal of Oil Palm Research, v. 22, p. 721-728, 2010.

62 EDWARDS, F. L.; TCHOUNWOU, P. B. Environmental toxicology and health effects associated with methyl parathion exposure-a scientific review. International Journal of Environmental. Research and Public Health, v. 2, n. 3, p. 430-441, 2005. 
63 COCKER, J., MASON, H. J., GARFITT, S. J., JONES, K. Biological monitoring of exposure to organophosphate pesticides. Toxicology Letters, v. 134, p. 97-103, 2002.

64 HOLLINGWORTH, R. M. Insecticides biochemistry and physiology. New York: Plenum, 1976. p. 431.

65 AGÊNCIA NACIONAL DE VIGILÂNCIA SANITÁRIA (ANVISA). Monografias: parationa metílica. Brasília, DF, 2002. Disponível em: <URL:

http:anvisa.gov.br/toxicologia/monografias/poe.pdf >. Acesso em: 20 out. 2015.

66 US ENVIRONMENTAL PROTECTION AGENCY. Reregistration eligibility decision for methyl parathion in 1954. 1954. Disponível em:

<http://www.epa.gov/oppsrrd1/REDs/methyl_parathion_red.pdf>. Acesso em: 20 out. 2015.

67 KEPRASERTSUP, C.; UPATHAM, E. S.; SUKHAPANTH, N.; PREMPREE, P. Degradation of methyl parathion in an aqueous medium by soil bacteria. Journal of the Science Society of Thailand, v. 27, p. 261-270, 2001.

68 UNITED NATIONS ENVIRONMENT PROGRAMME; FOOD AND AGRICULTURE ORGANIZATION (UNEP/FAO). Inclusion of chemicals in Annex III of the Rotterdam Convention: Review of notifications of final regulatory actions to ban or severely restrict a chemical: methyl parathion. FAO /RC/CRC.1/19/Add.4. Item 7(f) of 93

the provisional agenda. Geneva, 11-18 February 2005. Disponível em: <http: //www.pic. /int/incs/crc1/s19add4)/English/CRC\%201-19Add4\%20methyl\%20parathion\%20EC.pdf>. Acesso em: 22 out. 2015.

69 AGENCY FOR TOXIC SUBSTANCES AND DISEASE REGISTRY DIVISION. Toxicological profile for methyl parathion. Atlanta, 2001. p. 45-50.

70 ATHANASOPOULOS P. E.; KYRIAKIDIS, N. V.; STAVROPOULOS, P. A study on the environmental degradation of pesticides azinphos methyl and parathion methyl. Journal Environmental Science Health B. v. 39, n. 2 p. 297-309, 2004.

71 CALIFORNIA DEPARTMENT OF PESTICIDE REGULATION. Evaluation of methyl parathion as a toxic air contaminant. Part C. Human Health Assessment, 1999. TAC 9902C. Disponível em: <www.cdpr.ca.gov/docs/emon/pubs/methylpa/exsumoct.pdf〉. Acesso em: 25 out. 2015. 
72 EDWARDS, F. L.; TCHOUNWOU, P. B. Environmental toxicology and health effects associated with methyl parathion exposure-a scientific review. International Journal of Environmental. Research and Public Health, v. 2, n. 3, p. 430-441, 2005.

73 CHAMBERS, J.E.; CHAMBERS, H.W.; SNAWDER, J.E. Target site bioactivation of the neurotoxic organophosphorus insecticide parathion in partially hepatectomized rats. Life Science,v. 48, n. 10, p. 1023-1029, 1991.

74 SILVA, N.A. Biodegradação dos pesticidas clorpirifós, metil paration e profenofós por fungos de origem marinha. 2013. 159 f. Dissertação (Mestrado em Química)-Instituto de Química de São Carlos-Universidade São Paulo, São Carlos, 2013.

75 NORMAN, B.J.; NEAL, R.A. Examination of the metabolism in vitro of parathion (diethyl $p$-nitrophenyl phosphorothionate) by rat lung and brain. Biochemistry

Pharmacology, v. 25, n. 1, p. 37-45, 1976.

76 BUTLER, A.M.; MURRAY, M. Biotransformation of parathion in human liver: participation of CYP3A4 and its inactivation during microsomal parathion oxidation. The Journal of Pharmacology and Expreimental Therapeutics, v. 280, n. 2, p. 966-973, 1997.

77 ALBORES, A.; ORTEGA-MANTILLA, G.; SIERRA-SANTOYO, A.; CEBRIÁN, M.E.; MUÑOZ-SÁNCHEZ, J.L.; CALDERÓN-SALINAS, J.V.; MANNO, M. Cytochrome P450 2B (CYP2B)-mediated activation of methyl-parathion in rat brain extracts. Toxicology Letters, v. 124, n. 1-3, p. 1-10, 2001.

78 NEAL, R.A. Studies of the enzymic mechanism of the metabolism of diethyl 4-nitrophenyl phosphorothionate (parathion) by rat liver microsomes. Biochemistry Journal, v. 105, n. 1, p. 289-297, 1967.

79 TYNDALL, R.L.; DANIEL, J.C. Alterations in uterine and serum esterases in pregnant mammals. Fertil Steril, v. 26, n. 11, p. 1098-1104, 1975.

80 ABEL, E.L.; BAMMLER, T.K.; EATON, D.L. Biotransformation of methyl parathion by glutathione S-transferases. Toxicology Science, v. 79, n. 2, p. 224-232, 2004.

81 ABU-QARE, A.; ABOU-DONIA, M. B. Urinary excretion of metabolites following a single dermal dose of [14C] methyl parathion in pregnant rats. Toxicology, v. 150, p. 119$127,2000$. 
82 DE LIMA, J.S.; BASTOS NETO, J.D.; BASTOS, V.L.; DA CUNHA, J.C.; MORAES, F.F.; FERREIRA M.F.; MOREIRA, J.D.; FARIA, M.V. Methyl parathion activation by a partially purified rat brain fraction. Toxicology Letters, v. 87, n. 1, p. 53-60, 1996.

83 AGÊNCIA NACIONAL DE VIGILÂNCIA SANITÁRIA (ANVISA). Monografias de Agrotóxicos. ANVISA, 2014. Disponível em:

<http://portal.anvisa.gov.br/wps/wcm/connect/a88fd880474576798462d43fbc4c6735/P13Profenof\%C3\%B3s.pdf?MOD=AJPERES>. Acesso em: 12 jan. 2016.

84 ABASS, K.; REPONEN, P.; JALONEN, J.; PELKONEN, O. In vitro metabolism and interaction of profenofos by human, mouse and rat liver preparations. Pesticide Biochemistry and Physiology, v. 87, n. 3, p. 238-247, 2007.

85 MALGHANI, S.; CHATTERJEE, N.; YU, H. X.; LUO, Z. Isolation and identification of profenofos degrading bacteria. Brazilian Journal of Microbiology, v. 40, n. 4, p. 893-900, 2009.

86 GOTOH M. ; SAKATA M.; ENDO T , HAYASHI H.; SENO H.; SUZUKI O.; Profenofos metabolites in human poisoning. Forensic Science International, p. 221-2261, 2000.

87 PETRONILHO, E.C.; PINTO, A.C.; VILLAR, J.D.F. Acetilcolinesterase: Alzheimer e guerra química. Grupo de Química Medicinal, Departamento de Química, Instituto Militar de Engenharia, Universidade Federal do Rio de Janeiro-UFRJ. Revista Militar de Ciência e Tecnologia, p. 03-14, 2011.

88 MATIAS, R.S. Como agem os inseticidas nos insetos. 2014. Disponível em: <http: //matiassinantropicos.blogspot.com.br/>. Acesso em: 25 jan. de 2016.

89 ENVIRONMENTAL PROTECTION AGENCY (EPA) Office of Pesticide Programs. Reregistration eligibility decision for profenofos. 1982. Disponível em: <http://www.epa.gov/profenofos>. Acesso em: 18 fev. 2016.

90 AKERBLOM, N. Agricultural pesticide toxicity to aquatic organisms: a literature review, Research Report $\mathrm{n}^{\circ} 16$ of Department of Environmental Assessmen, Swedish University of Agricultural Sciences, Sweden, 2004.

91 FUKUTO, T. R. Mechanism of action of organophosphorus and carbamate insecticides. Environmental Health Perspectives, v. 87, p. 245-254, 1990. 
92 COSTA, L. G; COLE, T. B; JANSEN, K. L; FURLONG, C. E. Paraoxonase (pon1) and organophosphate toxicity. Amsterdam: Springer. 2008. p. 209-220.

93 CAPPS, T. M.; BARRINGER, V. M.; EBERLE, W. J.; BROWN, D. R.; SANSON, D. R. Identification of a unique glucosylsulfate conjugate metabolite of profenofos in cotton.

Journal of Agricultural and Food Chemistry, v. 44, n. 8, p. 2408-2411, 1996.

94 VASSILEV, N.; BACAM. T.; VASSILEV, A. M. Plant lignocellulose and decomposition by fungy: from nature to industrial use. Mycologist, v. 8, p.113-114,1994.

95 ZANONI, M. V. B.; CARNEIRO, P. A. O descarte dos corantes têxteis. Ciência Hoje, v. 29, p. 61-65, 2001.

96 OLIVEIRA, E.C.; FELIX, J.P.L.; LEITÃO, R.C.; MELO, V.M.M; SANTANELLA, S.T. Degradação e fenois por fungos presentes em águas residuárias de refinarias de petróleo. In: CONGRESSO BRASILEIRO DE ENGENHARIA SANITÁRIA E AMBIENTAL, 23. , 2005. Fortaleza. Anais... Ceará: Associação Brasileira de Engenharia Sanitária e Ambiental, 2005. p. 1-8.

97 SILVA, V.M.; LOPES, W.A.; ANDRADE, J.B; VELOSO, M.C.C.; SANTOS, G.V.; OLIVEIRA, A.S. Brominated phenols as key flavor compounds found in marine organisms. Química Nova, v. 30, p. 629-635, 2007.

98 BRASIL. Ministério do Desenvolvimento Urbano e Meio Ambiente. CONAMA. Resolução $n^{\circ}$ 430, publicada em 13 de maio de 2011. Diário Oficial da União. Brasília, 30 de maio de 2011. Seção 4, p. 5.

99 SOLOMONS,T.W.G.; FRYHLE, C.B. Organic chemistry, 6 ed. Rio de Janeiro: LTC, 1996. v. 2, cap. 21, p. 261-270.

100 SOARES, E.P. Fungos amazônicos com potencial para degradação de polietileno tereftalato-pet. 2012. 126 f. Dissertação (Mestrado em Biotecnologia e Recursos Naturais da Amazônia)-Universidade do Estado do Amazonas, Manaus, 2012.

101 ALI OA, BADAWY MI. Hydrolysis of organophosphate insecticides in aqueous media. Environmental International, v. 7, p. 373-377, 1982. 
102 AHMED RMAH. Chemical and biochemical studies on the residuals of the organophosphorus insecticide (prothiofos) in potato plant. 2007. $220 \mathrm{f}$ (Thesis) Department of Chemistry Faculty of Science Zagazig University, Zagazig University, Egypt 2007. Disponível em: <http://lib.bioinfo.pl/files/theses/thesis_11.pdf.>. Acesso em: 26 de fev. 2016.

103 SILVA, N.A.; BIROLLI, W.G.; SELEGHIM M.H.R.; PORTO, A.L.M. Biodegradation of the organophosphate pesticide profenofos by marine fungi. Applied Bioremediation, v. 7, p. 149-180, 2013.

104 GRACIOSO, L.H. Análise das proteínas expressas em resposta ao fenol em bactérias isoladas da zona industrial de Cubatão-SP. 2012. 43 f. Dissertação (Mestrado em Biotecnologia)-Instituto de Ciências Biomédicas-Universidade de São Paulo, São Paulo, 2012.

105 BENNET, J.W. Mycotecnology: the role of fungi in biotechnology. Journal Biotechnology, v. 66, p. 101-107, 1998.

106 CONCEIÇÃO, D.M.; DE ANGELIS,D.A.; BIDOIA, E.D. Fungos filamentosos isolados de rio Atibaia, SP e refinaria de petróleo biodegradadores de compostos fenólicos. Universidade Estadual Paulista, Instituto de Biociências, Departamento de Bioquímica e Microbiologia, Arquivo do Instituto de Biociências, São Paulo, v. 72, n. 1, p. 99-106, 2005.

107 HARAZONO, K.; NAKAMURA, K. Descolorization of mixtures of different reactive textile dyes by the write-rot basidiomycetes Phanerochaete sordida and inhibitory effect of poly vinyl alcohol. Chemosphere, v. 59, p. 63-68, 2005.

108 PUTZKE, J. ; PUTZKE; M. T. O Reino dos fungos. $2^{\mathrm{a}}$ ed. Rio Grande do Sul:Edunisc, 2004. p. 25-67.

109 MARTINS, L.R. Avaliação do potencial biotecnológico de fungos brasileiros em reações de biotransformação e biorremediação. 2009. $208 \mathrm{f}$. Tese (Doutorado em Ciências)-Departamento de Química-Instituto de Ciências Exatas-Universidade Federal de Minas Gerais, Belo Horizonte 2009.

110 AZEVEDO, J. L., ESPÓSITO, E. Fungos: Uma introdução à biologia, bioquímica e biotecnologia. $2^{\mathrm{a}}$ ed. Rio Grande do Sul: Educs, 2006. p. 35-70.

111 ALLINGER, N. L.; CAVA, M. P.; DE JONGH, D.C.; JOHNSON, C. R.; LEBEL, N.A.; STEVENS,C.L. Química orgânica. Rio de Janeiro: LTC, 1976. p. 961. 
112 HATZIOS K.K. Biotransformations of herbicides in higher plants. Environmental Chemistry, v. 2, p. 141-185, 1991.

113 SOUSA, C. M. M.; SILVA, H. R.; VIEIRA-JR, G. M.; AYRES, M. C. C.; COSTA, C. L. S.; ARAÚJO, D. S.; CAVALCANTE, L. C. D.; BARROS, E. D. S.; ARAÚJO, P. B. M.;

CHAVES, M. S. B. M. H. Fenóis totais e atividade antioxidante de cinco plantas medicinais. Química Nova, v. 30, n. 2, p. 351-355, 2007. Disponível em:< http://dx.doi.org/10.1590/S0100-40422007000200021 >. Acesso em: 14 out. 2015.

114 FORTES, M. E.; ZAPPE, J. A. A química dos agrotóxicos. Química Nova na Escola, v. 34, n. 1, p.10-15, 2012.

115 SELEEM, M.; ALI, M.S.; HUSSAIN, S.; JABBAR, A.; ASHRAF, M.; LEE, Y.S. Marine natural products of fungal origin. Natural Products Reports, v. 24, p. 1142-1152, 2007.

116 GRAVRILESCU, M. Fate of pesticides in the evironment and its biorremetion. Engineering in Life Sciences, v. 5, n. 6, p. 497-526, 2005.

117 REMADEVI, C.; NATH, M.M.; PRASAD, M.G. Mycodegradation of malathion by a soil fungal isolate, Aspergillus niger. International Journal of Basic and Applied Chemical Sciences, v. 2, n. 1, p. 108-115, 2012.

118 DERELANKO, M.J.; HOLLINGER, M.A. Handbook of toxicology. New York: Taylor \& Francis, 2002. v. 1, p. 1440.

119 LISCOMBE, DAVID K.; LOUIE, GORDON V.; NOEL, JOSEPH P. Architectures, mechanisms and molecular evolution of natural product methyltransferases. Natural Product Reports v. 29, p. 1238-1250, 2012.

120 NATIONAL CENTER FOR BIOTCHNOLOGY INFORMATION (NCBI). PNMT phenylethanolamine $N$-methyltransferase. 2005. Disponível em: < http://www.ncbi.nlm.nih.gov/gtr/genes/5409/>. Acesso em: 08 mar. 2016.

121 NATIONAL CENTER FOR BIOTCHNOLOGY INFORMATION (NCBI). HNMT histamine $N$-methyltransferase. 2005. Disponível em < http://www.ncbi.nlm.nih.gov/gtr/genes/3176/>. Acesso em: 08 mar. 2016. 
122 NATIONAL CENTER FOR BIOTCHNOLOGY INFORMATION (NCBI). COMT catechol- $\boldsymbol{O}$-methyltransferase. 2005. Disponível em < http://www.ncbi.nlm.nih.gov/gtr/genes/1312/>. Acesso em: 08 de mar. 2016.

123 ELIZABETH M.J.; JISHA M.S. Chlorpyrifos: pollution and remediation, Environmental Chemistry Letters, v. 13, p. 269-291, 2015.

124 LILJA, TOBIAS; NINA HELDRING; OLA HERMANSON. Like a rolling histone: Epigenetic regulation of neural stem cells and brain development by factors controlling histone acetylation and methylation. Biochimica et Biophysica Acta (BBA), v. 2, p. 23542360, 2013.

125 RIBANI, M.; BOTTOLI, C. B. G.; COLLINS, C. H.; JARDIM, I.; MELO, L. F. C. Validação em métodos cromatográficos e eletroforéticos. Química Nova, v. 27, p. 771-780, 2004.

126 ARAGÃO, N. M.; VELOSO, M. C. C.; ANDRADE, J. B. Validação de métodos cromatográficos de análise - Um experimento de fácil aplicação utilizando cromatografia líquida de alta eficiência (CLAE) e os princípios da "química verde" na determinação de metilxantinas em bebidas. Quimíca Nova, v. 32, n. 9, p. 2476-2481, 2009.

127 MATERIAL SAFETY DATA SHEET (MSDS). Lorsban 480 BR. 2005. Disponível em: $<$ http://www.adapar.pr.gov.br/arquivos/File/defis/DFI/Bulas/Inseticidas/LORSBAN_480_BR. pdf>. Acesso em: 15 mar. 2016.

128 MINISTÉRIO DA AGRICULTURA, PECUÁRIA E ABASTECIMENTO. Folisuper 600 BR. 2005. Disponível em:

<http://www.agricultura.pr.gov.br/arquivos/File/defis/DFI/Bulas/Inseticidas/FOLISUPER_60 0_BR.pdf>. Acesso em: 15 mar. 2016.

129 MINISTÉRIO DA AGRICULTURA, PECUÁRIA E ABASTECIMENTO. Polytrin 400/40 EC. 2005. Disponível em:

<http://www.agricultura.pr.gov.br/arquivos/File/defis/DFI/Bulas/Inseticidas/POLYTRIN4004 0EC.pdf>. Acesso em: 15 mar. 2016.

130 FIORI, D. Diagnóstico histológico: reconhecimento dos órgãos por sua estrutura microscópica. Rio de Janeiro: Guanabara Kogan, 1960. 749 p.

131 PELCZAR, M. J. C., E.C.S.; KRIEG, N.R. Microbiologia. São Paulo: Makron Books, 1997. 524 p. 
132 TORTORA, G. J.; FUNKE, B. R.; CASE, C. L.; JOHNSON, T. R. Microbiology: an introduction. San Francisco: Benjamin Cummings, 2004. 812 p.

133 EIVAZI, F.; TABATABAI, M. Phosphatases in soils. Soil Biology and Biochemistry, v. 9, n. 3, p. 167-172, 1977.

134 ZAMY, C.; MAZELLIER, P.; LEGUBE, B. Analytical and kinetic study of the aqueous hydrolysis of four organophosphorus and two carbamate pesticides. International Journal of Environmental Analytical Chemistry, v. 84, n. 14-15, p. 1059-1068, 2004.

135 MALGHANI, S.; CHATTERJEE, N.; YU, H. X.; LUO, Z. Isolation and identification of profenofos degrading bacteria. Brazilian Journal of Microbiology, v. 40, n. 4, p. 893-900, 2009.

136 SILVERSTEIN, R.; WEBSTER, F. X.; KIEMLE, D. J. Identificação espectrométrica de compostos orgânicos. Rio de Janeiro: LTC, 2006. p. 490.

137 PESTICIDES Database. 3,5,6-trichloro-2-pyridinol. 2008. Disponível em: http://www.pesticideinfo.org/Summary_Chemical.jsp?Rec_Id=PC37647. Acesso em: 25 jan. 2016.

138 ANWAR, S.; LIAQUAT, F.; KHAN, Q. M.; KHALID, Z. M.; IQBAL, S. Biodegradation of chlorpyrifos and its hydrolysis product 3,5,6-trichloro-2-pyridinol by Bacillus pumilus strain C2A1. Journal of Hazardous Materials, v. 168, n. 1, p. 400-405, 2009.

139 BIROLLI, W.G. Biodegradação do pesticida esfanvarelato por fungos de ambiente marinho. 2013. 118f. Dissertação (Mestrado em Química)-Instituto de Química de São Carlos-Universidade São Paulo, São Carlos, 2013.

140 TALLUR, P.N.; MEGADI, V.B.; NINNECKAR, H.Z. Biodegradation of cypermetrin by Micrococcus sp. Strain CPN 1. Biodegration, v.19, p. 77-82, 2008.

141 LEITE, J.V. Avaliação da toxicidade de fenol em sistemas de lodos ativadosutilização do método fed-batch-reator (FBR) modificado. 1997. 120 f. Dissertação (Mestrado)-Escola Politécnica de São Paulo-Universidade de São Paulo, São Paulo, 1997.

142 PASSOS, C.T. Estudo da biodegradação do fenol por uma nova linhagem de Aspesgillus sp. 2006. 84 f. Dissertação (Mestrado em Engenharia de Alimentos)- Fundação Universidade do Rio Grande, Rio Grande Rio Grande do Sul, 2006. 
143 SCHIE, P.M.; YOUNG, L.Y. Biodegradation of phenol: mechanisms and applications, Biorremetion Journal, v. 4, p. 1-18, 2000.

144 MADIGAN, M. T. Biology of microrganisms. San Francisco: Pearson Education, 2012. p. 125-127.

145 ORJUELA, G.L Isolamento de cepas bacterianas degradadoras de hidrocarbonetos. 2016. 107 f. Tese (Doutorado em Microbiologia)- Institudo de biociências, Letras e Ciências Exatas -Universidade Estadual Paulista "Júlio de Mesquita Filho", São José do Rio Preto 2016.

146 RUBILAR, O.; FEIJOO, G.; DIEZ, C.; LU-CHAU, T. A.; MOREIRA, M.T.; LEMA, J. M. Biodegradation of pentachlorophenol in soil slurry Cultures by Bjerkandera adusta and Anthracophyllum discolor, Chemical and Engineering Research, v. 46, p. 6744-6751, 2007.

147 SILVEIRA, J.P. Aplicação do fungo filamentoso Beaveria bassiana spp. Na produção de derivado petencialmente vasodilatador e antiproliferativo de naringenina. $74 \mathrm{f}$.

Dissertação (Mestrado em Ciências Farmaceuticas)- Universidade Federal de Goiás, Goiânia 2012.

148 BREINHOLT. In vitro investigation of cytochrome P450-mediated metabolism of dietary flavonoids. Food and Chemical Toxicology, v. 40, p. 609-616, 2002.

149 DAS, S.; ROSAZZA, J. P. N. Microbial and enzimatic transformations of flavonoids. Journal of Natural Products, v. 69, p. 499-508, 2006.

$150 \mathrm{GAO}, \mathrm{K}$. The citrus flavonoids naringenin stimulates DNA repair in prostate cancer cells. Journal of Nutricional Biochemistry, v. 17, p. 89-95, 2006.

151 HORIBA, T. Naringenin chalcone improves adipocyte functions by enhancing adiponectin production. Molecular and Cellular Endocrinology, v. 323, p. 208-214, 2010.

152 SHIMODA, K. Biotransformation of naringenin by cultured Eucalyptus perriniana cells. Phytochemistry, v. 71, p. 201-205, 2010.

153 AJAY, M.; GILANI, A. H.; MUSTAFA, M. R. Effects of flavonoids on vascular smooth muscle of the isolated rat thoracic aorta. Life Sciences, v.74, p. 603-612, 2003. 
154 IBRAHIM, A. R. S. Sulfation of naringenin by Cunninghamella elegans.

Phytochemistry, v. 53, p. 209-212, 2000.

154 GIMENES, L.J. Biodegradação de pentaclorofenol por Trametes villosa (sw.)

Kreisel: análises bioquímicas e moleculares. 2011. 105 f. Tese (Doutorado em

Biodiversidade Vegetal e Meio Ambiente )-Institudo de Botânica da Secreataria do Meio Ambiente-Universidade de São Paulo, São Paulo 2011.

155 MORALES, I. C.; PAZOS, C. B. Pentaclorofenol: toxicología y riesgos para el ambiente. Madera y Bosques, v. 4, p. 21-37, 1998.

156 SEMPLE, K. T.; REID, B. J.; FERMOR, T. R. Review: Impact of composting strategies on the treatment of soils contaminated with organic pollutants. Environmental Pollution, v. 112, p. 269-283, 2001.

157 MONTIEL, A. M.; FERNÁNDEZ, F.J.; MARCIAL, J.; SORIANO, J.; BARRIOSGONZÁLEZ, J; TOMASINI, A. A fungal phenoloxidase (tyrosinase) involved in pentachlorophenol degradation. Biotechnology Letters, v. 26, p. 1353-1357, 2004.

158 LISCOMBE, D.K.; LOUIE, G.V.; NOEL, J.P. Review: Architectures, mechanisms and molecular evolution of natural product methyltransferases. The Royal Society of Chemistry, v. 29, p. 1238-1250, 2012.

159 ZUBIETA, C.; HE, X.Z.; DIXON, R.A.; NOEL,J.P. Structures of two natural product methyltransferases reveal the basis for substrate specificity in plant $O$-methyltransferases.

Nature Structural Biology, v. 8, n. 3, p. 271-279, 2001.

160 CALDAS, E.D.; SOUZA, L.C.K.R. Avaliação de risco crônico da ingestão de resíduos de pesticidas na dieta brasileira. Journal of Plublic Health, v. 34, n. 5, p. 529-537, 2000.

161 SILVA, R.L. Desenvolvimento de método para determinação de resíduos de pesticidas em alface (Lactuca sativa L.) produzida em sistema convencional. 2010. 85f . Dissertação (Mestrado em Química)- Universidade Federal de Sergipe, São Cristóvão, 2010.

162 GOTOH M.; SAKATA M.; ENDO T , HAYASHI H.; SENO H.; SUZUKI O.; Profenofos metabolites in human poisoning. Forensic Science International, p. 221-2261, 2000 . 


\section{APÊNDICE}

\section{Metil paration}

A Figura 1 e a Tabela 1 mostram a avaliação de crescimento em meio de cultura sólido malte 2\% e Agar do fungo de ambiente marinho P. raistrickii CBMAI 931 frente ao pesticida metil paration nos volumes de $5 \mu \mathrm{L}$ de pesticida/100 $\mu \mathrm{L}$ de DMSO, $10 \mu \mathrm{L}$ de pesticida/200 $\mu \mathrm{L}$ de DMSO e $15 \mu \mathrm{L}$ de pesticida/ $300 \mu \mathrm{L}$ de DMSO durante 10 dias de crescimento em condições padrões $\mathrm{pH}\left(32^{\circ} \mathrm{C}, \mathrm{pH} 5,0\right)$.

Figura 1. Cultivo do fungo P. raistrickii CBMAI 931 na ausência de metil paration (placa controle) e com 5, 10 e $15 \mu \mathrm{L}$ de metil paration/placa. (A) 5 dias de cultivo e (B) 10 dias de cultivo.

A

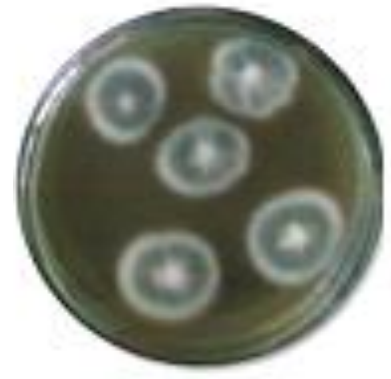

B

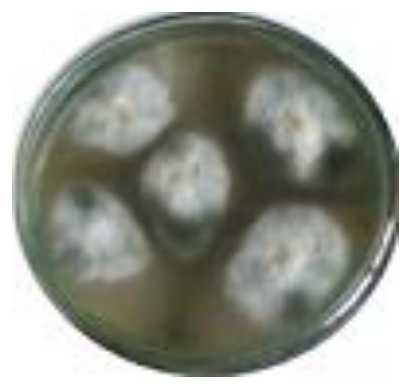

placa de Petri controle
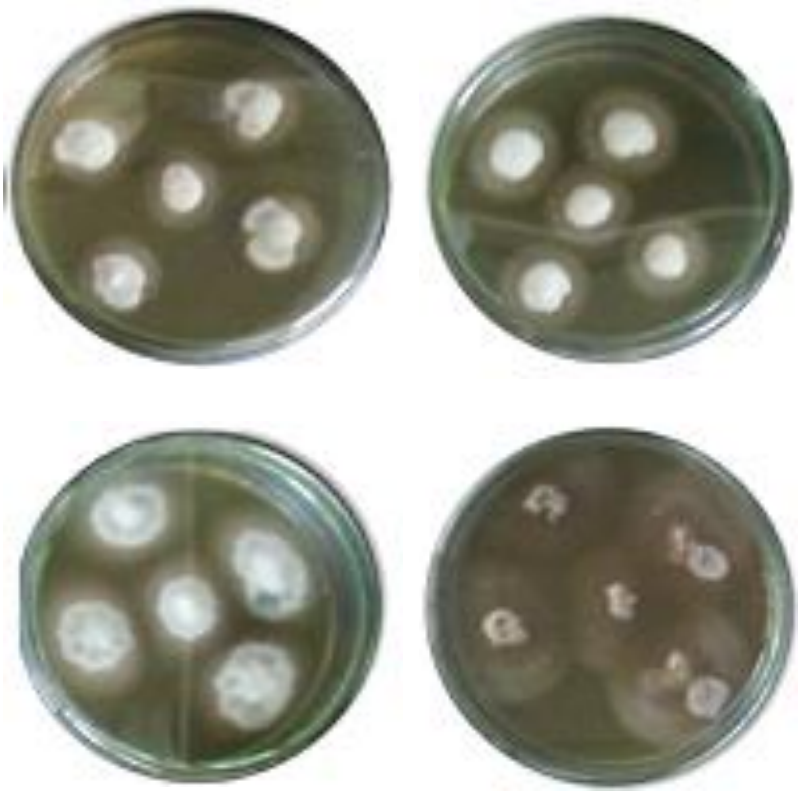

$10 \mu \mathrm{L}$ pesticida/DMSO
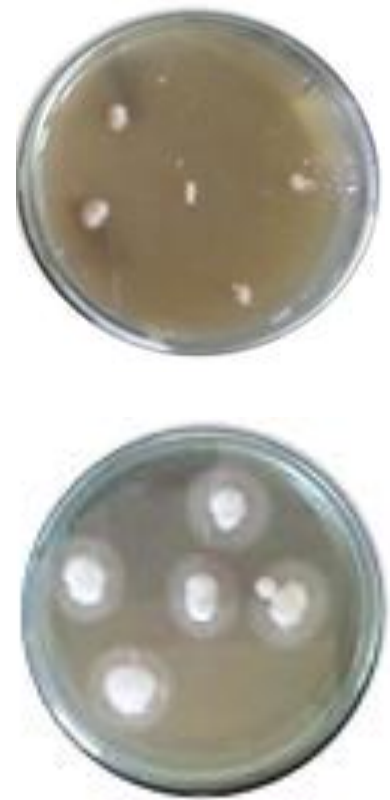

$15 \mu \mathrm{L}$ pesticida/DMSO 
Tabela 1. Avaliação de crescimento em meio de cultura sólido malte $2 \%$ e Agar do fungo de ambiente marinho P. raistrickii CBMAI 931 frente ao pesticida comercial metil paration nos volumes de $5 \mu \mathrm{L}$ de pesticida/100 $\mu \mathrm{L}$ de DMSO, $10 \mu \mathrm{L}$ de pesticida/200 $\mu \mathrm{L}$ de DMSO e $15 \mu \mathrm{L}$ de pesticida/ $300 \mu \mathrm{L}$ de DMSO durante 10 dias em condições padrões $\left(32^{\circ} \mathrm{C}, \mathrm{pH} 5,0\right)$.

\begin{tabular}{ccccc}
\hline $\begin{array}{l}\text { Tempo de crescimento } \\
\text { do fungo }\end{array}$ & \multicolumn{3}{l}{ Medida do halo de crescimento em (cm) } \\
\hline $\begin{array}{c}P . \text { raistrickii } \\
\text { CBMAI 931 }\end{array}$ & Placa controle & $\begin{array}{c}5 \mu \mathrm{L} \text { pesticida/ } \\
100 \mu \mathrm{L} \text { DMSO }\end{array}$ & $\begin{array}{c}10 \mu \mathrm{L} \text { pesticida/ } \\
200 \mu \mathrm{L} \text { DMSO }\end{array}$ & $\begin{array}{c}15 \mu \mathrm{L} \text { pesticida/ } \\
300 \mu \mathrm{L} \text { DSO }\end{array}$ \\
\hline $1^{\circ}$ dia & $1,4 \times 2,0$ & $1,2 \times 1,2$ & $0,8 \times 1,0$ & $0,6 \times 0,7$ \\
\hline $2^{\circ}$ dia & $2,2 \times 2,2$ & $1,3 \times 2,0$ & $1,0 \times 1,5$ & $0,8 \times 1,3$ \\
\hline $3^{\circ}$ dia & $2,2 \times 2,5$ & $1,7 \times 2,2$ & $1,3 \times 1,7$ & $1,0 \times 1,3$ \\
\hline $4^{\circ}$ dia & $2,5 \times 2,5$ & $1,9 \times 2,2$ & $1,4 \times 1,8$ & $2,6 \times 2,4$ \\
\hline $5^{\circ}$ dia & $3,4 \times 3,0$ & $2,2 \times 2,5$ & $1,6 \times 1,8$ & $2,6 \times 2,7$ \\
$6^{\circ}$ dia & $3,8 \times 3,4$ & $2,5 \times 2,7$ & $2,3 \times 2,5$ & $2,6 \times 2,7$ \\
$7^{\circ}$ dia & $4,2 \times 4,5$ & $2,8 \times 3,0$ & $4,7 \times 4,3$ & $2,6 \times 2,7$ \\
\hline $8^{\circ}$ dia & $5,3 \times 6,2$ & $4,5 \times 4,2$ & $4,7 \times 4,3$ & $2,6 \times 2,7$ \\
\hline $9^{\circ}$ dia & $6,4 \times 6,5$ & $4,5 \times 4,2$ & $4,7 \times 4,3$ & $4,7 \times 4,3$ \\
\hline $0^{\circ}$ dia & $6,6 \times 6,5$ & $4,5 \times 4,2$ & & \\
\hline
\end{tabular}


Figura 2. Cultivo do fungo Trichoderma sp. CBMAI 932 na ausência de metil paration (placa controle) e com 5, 10 e $15 \mu \mathrm{L}$ de metil paration/placa. (A) 5 dias de cultivo e (B) 10 dias de cultivo.

A
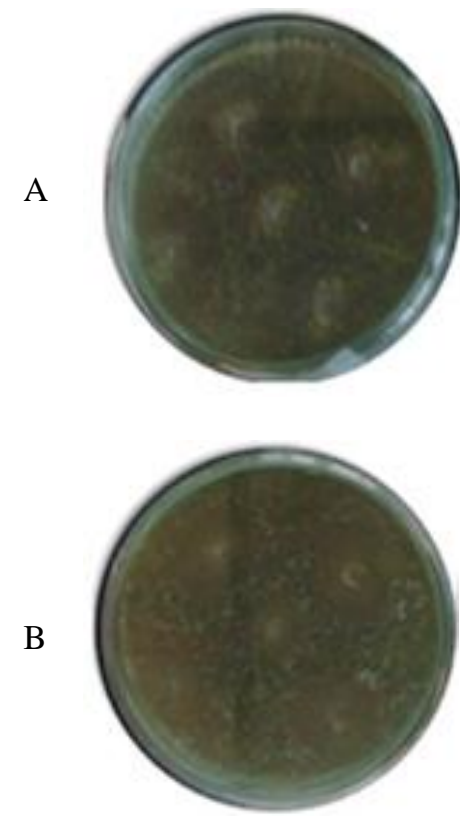

placa de Petri controle
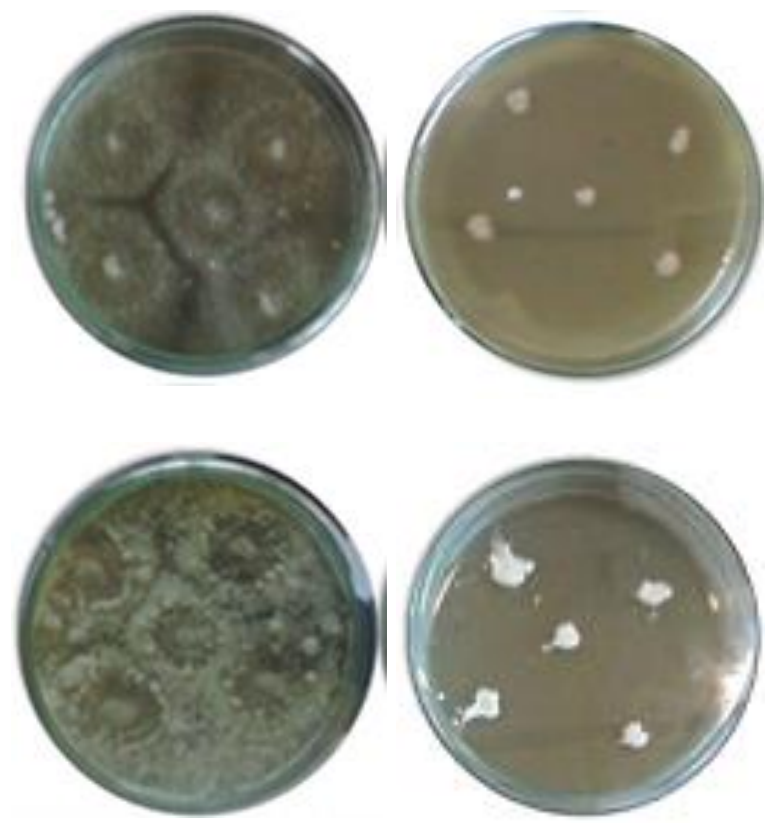

$5 \mu \mathrm{L}$ pesticida/DMSO

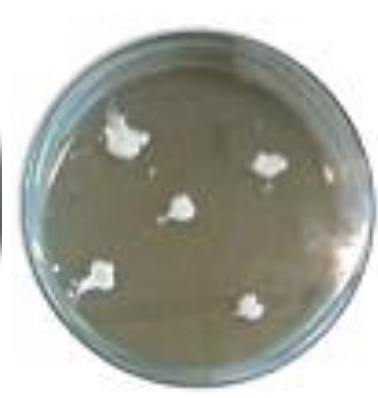

$10 \mu \mathrm{L}$ pesticida/DMSO
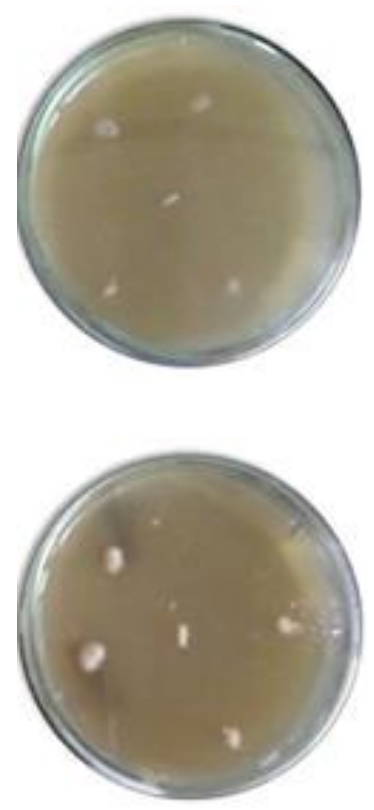

$15 \mu \mathrm{L}$ pesticida/DMSO

Tabela 2. Avaliação de crescimento em meio de cultura sólido malte $2 \%$ e Agar do fungo de ambiente marinho Trichoderma sp. CBMAI 932 frente ao pesticida comercial metil paration nos volumes de $5 \mu \mathrm{L}$ de pesticida/100 $\mu \mathrm{L}$ de DMSO, $10 \mu \mathrm{L}$ de pesticida/200 $\mu \mathrm{L}$ de DMSO e $15 \mu \mathrm{L}$ de pesticida/ $300 \mu \mathrm{L}$ de DMSO durante 10 dias em condições padrões $\left(32^{\circ} \mathrm{C}, \mathrm{pH} 5,0\right)$.

\begin{tabular}{|c|c|c|c|c|}
\hline Tempo de crescimento & & Medida do hal & crescimento em & \\
\hline $\begin{array}{l}\text { Trichoderma sp. } \\
\text { CBMAI } 932\end{array}$ & Placa controle & $\begin{array}{l}5 \mu \mathrm{L} \text { pesticida/ } \\
100 \mu \mathrm{L} \text { DMSO }\end{array}$ & $\begin{array}{l}10 \mu \mathrm{L} \text { pesticida/ } \\
200 \mu \mathrm{L} \text { DMSO }\end{array}$ & $\begin{array}{c}15 \mu \mathrm{L} \text { pesticida/ } \\
300 \mu \mathrm{L} \text { DMSO }\end{array}$ \\
\hline $1^{\circ}$ dia & $3,4 \times 3,0$ & $3,5 \times 3,0$ & $0,5 \times 0,7$ & $0,3 \times 0,3$ \\
\hline $2^{\circ}$ dia & $3,8 \times 3,5$ & $3,9 \times 3,8$ & $1,0 \times 1,5$ & $0,6 \times 1,2$ \\
\hline $3^{\circ}$ dia & $5,5 \times 4,7$ & $4,7 \times 5,2$ & $1,3 \times 1,7$ & $1,0 \times 1,2$ \\
\hline $4^{\circ}$ dia & $6,7 \times 5,8$ & $5,9 \times 6,9$ & $2,3 \times 2,4$ & $1,0 \times 1,2$ \\
\hline $5^{\circ}$ dia & $8,4 \times 7,8$ & $7,2 \times 7,5$ & $2,3 \times 2,4$ & $1,0 \times 1,2$ \\
\hline $6^{\circ}$ dia & Toda a placa & Toda a placa & $2,3 \times 2,4$ & $1,0 \times 1,2$ \\
\hline $7^{\circ}$ dia & Toda a placa & Toda a placa & $2,3 \times 2,4$ & $1,0 \times 1,2$ \\
\hline $8^{\circ}$ dia & Toda a placa & Toda a placa & $2,3 \times 2,4$ & $1,0 \times 1,2$ \\
\hline $9^{\circ} \mathrm{dia}$ & Toda a placa & Toda a placa & $2,3 \times 2,4$ & $1,0 \times 1,2$ \\
\hline $10^{\circ}$ dia & Toda a placa & Toda a placa & $2,3 \times 2,4$ & $1,0 \times 1,2$ \\
\hline
\end{tabular}


Figura 3. Cultivo do fungo A. sydowii CBMAI 934 na ausência de metil paration (placa controle) e com 5, 10 e $15 \mu \mathrm{L}$ de metil paration/placa. (A) 5 dias de cultivo e (B) 10 dias de cultivo.

A

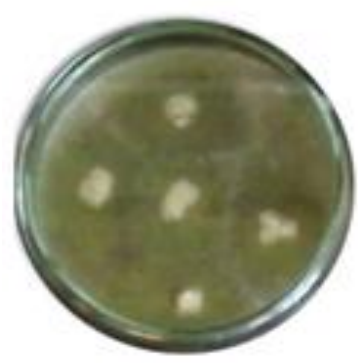

B

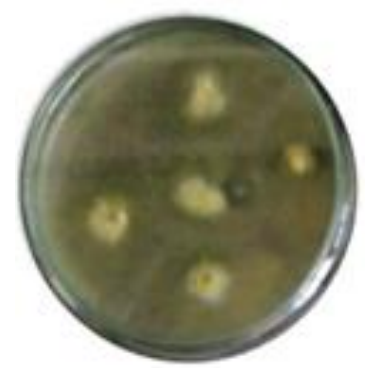

placa de Petri controle
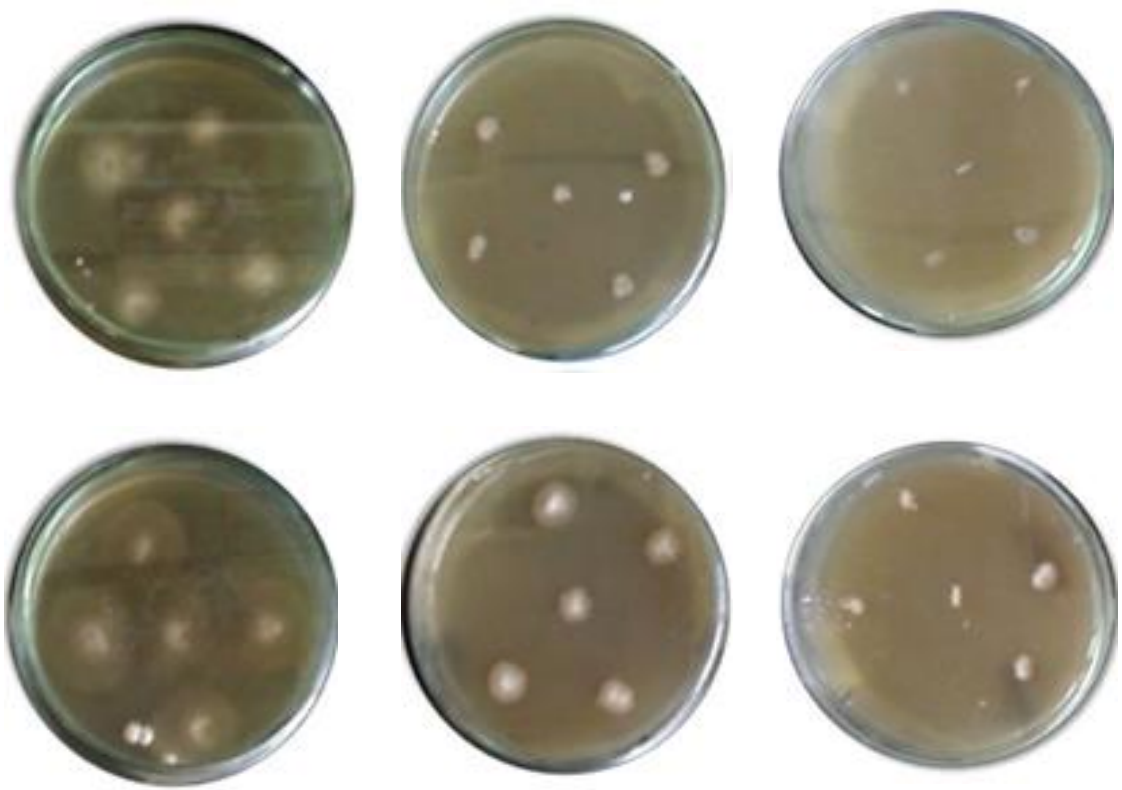

Tabela 3. Avaliação de crescimento em meio de cultura sólido malte $2 \%$ e Agar do fungo de ambiente marinho A. sydowii CBMAI 934 frente ao pesticida comercial metil paration nos volumes de $5 \mu \mathrm{L}$ de pesticida/100 $\mu \mathrm{L}$ de DMSO, $10 \mu \mathrm{L}$ de pesticida/200 $\mu \mathrm{L}$ de DMSO e $15 \mu \mathrm{L}$ de pesticida/ $300 \mu \mathrm{L}$ de DMSO durante 10 dias em condições padrões $\left(32^{\circ} \mathrm{C}, \mathrm{pH} 5,0\right)$.

\begin{tabular}{ccccc}
\hline $\begin{array}{l}\text { Tempo de crescimento } \\
\text { do fungo }\end{array}$ & \multicolumn{5}{l}{ Medida do halo de crescimento em (cm) } \\
\hline $\begin{array}{c}\text { Aspergillus sydowii } \\
\text { CBMAI 934 }\end{array}$ & Placa controle & $\begin{array}{c}5 \mu \mathrm{L} \text { pesticida/ } \\
100 \mu \mathrm{L} \text { DMSO }\end{array}$ & $\begin{array}{c}10 \mu \mathrm{L} \text { pesticida/ } \\
200 \mu \mathrm{L} \text { DMSO }\end{array}$ & $\begin{array}{c}15 \mu \mathrm{L} \text { pesticida/ } \\
300 \mu \mathrm{L} \text { DMSO }\end{array}$ \\
\hline $1^{\circ}$ dia & $2,2 \times 2,2$ & $2,2 \times 1,3$ & $0,1 \times 0,1$ & $0,1 \times 0,2$ \\
$2^{\circ}$ dia & $2,8 \times 2,5$ & $2,6 \times 2,2$ & $0,2 \times 0,8$ & $0,6 \times 0,5$ \\
\hline $3^{\circ}$ dia & $3,2 \times 4,5$ & $2,8 \times 2,3$ & $0,8 \times 1,0$ & $0,8 \times 0,7$ \\
\hline $4^{\circ}$ dia & $4,5 \times 5,5$ & $3,0 \times 3,2$ & $1,0 \times 1,0$ & $1,0 \times 1,0$ \\
\hline $5^{\circ}$ dia & $6,4 \times 7,0$ & $4,1 \times 4,3$ & $1,0 \times 1,0$ & $1,0 \times 1,3$ \\
\hline $6^{\circ}$ dia & $6,4 \times 7,0$ & $5,3 \times 5,4$ & $1,0 \times 1,0$ & $1,2 \times 1,3$ \\
\hline $7^{\circ}$ dia & Toda a placa & $6,3 \times 6,4$ & $1,0 \times 1,3$ & $1,2 \times 1,3$ \\
\hline $8^{\circ}$ dia & Toda a placa & Toda a placa & $1,0 \times 1,3$ & $1,2 \times 1,3$ \\
\hline $9^{\circ}$ dia & Toda a placa & Toda a placa & $1,0 \times 1,3$ & $1,2 \times 1,3$ \\
\hline $10^{\circ}$ dia & Toda a placa & Toda a placa & $1,0 \times 1,3$ & $1,2 \times 1,3$ \\
\hline
\end{tabular}


Figura 4. Cultivo do fungo A. sydowii CBMAI 935 na ausência de metil paration (placa controle) e com 5, 10 e $15 \mu \mathrm{L}$ de metil paration/placa. (A) 5 dias de cultivo e (B) 10 dias de cultivo.

A
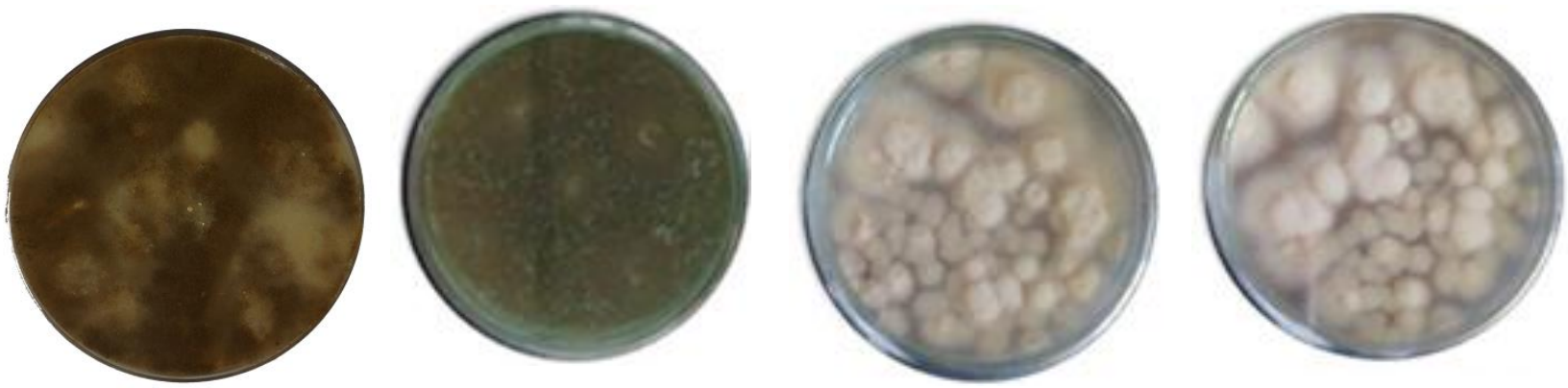

B
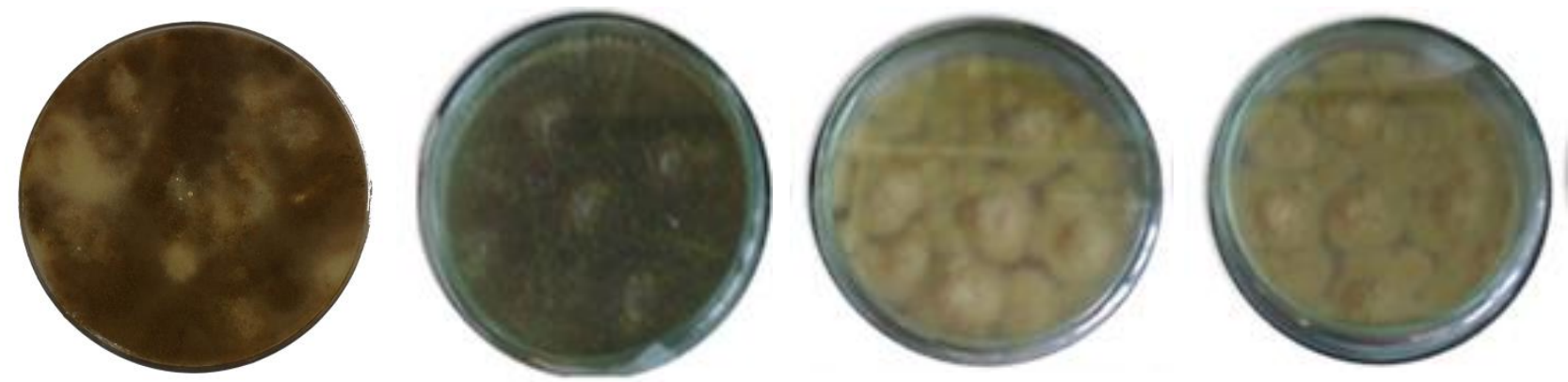

placa de Petri controle

$5 \mu \mathrm{L}$ pesticida/DMSO

$10 \mu \mathrm{L}$ pesticida/DMSO

$15 \mu \mathrm{L}$ pesticida/DMSO

Tabela 4. Avaliação do halo de crescimento em meio de cultura sólido malte $2 \%$ e Agar do fungo de ambiente marinho A. sydowii CBMAI 935 frente ao pesticida comercial metil paration nos volumes de $5 \mu \mathrm{L}$ de pesticida/100 $\mu \mathrm{L}$ de DMSO, $10 \mu \mathrm{L}$ de pesticida/200 $\mu \mathrm{L}$ de DMSO e $15 \mu \mathrm{L}$ de pesticida/ $300 \mu \mathrm{L}$ de DMSO durante 10 dias em condições padrões $\left(32^{\circ} \mathrm{C}, \mathrm{pH} 5,0\right)$.

\begin{tabular}{ccccc}
\hline $\begin{array}{l}\text { Tempo de crescimento } \\
\text { do fungo }\end{array}$ & \multicolumn{3}{c}{ Medida do halo de crescimento $(\mathrm{cm})$} & \\
\hline $\begin{array}{c}\text { Aspergillus sydowii } \\
\text { CBMAI } 935\end{array}$ & Placa controle & $\begin{array}{c}5 \mu \mathrm{L} \text { pesticida/ } \\
100 \mu \mathrm{L} \text { DMSO }\end{array}$ & $\begin{array}{c}10 \mu \mathrm{L} \text { pesticida/ } \\
200 \mu \mathrm{L} \text { DMSO }\end{array}$ & $\begin{array}{c}15 \mu \mathrm{L} \text { pesticida/ } \\
300 \mu \mathrm{L} \text { DSO }\end{array}$ \\
$1^{\circ}$ dia & $4,2 \times 4,0$ & $4,0 \times 3,8$ & $3,5 \times 3,0$ & $3,2 \times 3,0$ \\
$2^{\circ}$ dia & $5,8 \times 4,5$ & $4,8 \times 4,0$ & $4,5 \times 4,2$ & $4,8 \times 3,5$ \\
$3^{\circ}$ dia & $6,2 \times 5,5$ & $5,2 \times 5,0$ & $4,8 \times 4,5$ & $4,9 \times 4,5$ \\
$4^{\circ}$ dia & $6,9 \times 6,5$ & $5,9 \times 5,4$ & $5,3 \times 4,7$ & $5,2 \times 5,3$ \\
$5^{\circ}$ dia & Toda a placa & $6,5 \times 6,2$ & $6,0 \times 5,1$ & $5,6 \times 5,7$ \\
$6^{\circ}$ dia & Toda a placa & Toda a placa & $6,7 \times 6,5$ & $6,2 \times 6,3$ \\
$7^{\circ}$ dia & Toda a placa & Toda a placa & Toda a placa & Toda a placa \\
\hline $8^{\circ}$ dia & Toda a placa & Toda a placa & Toda a placa & Toda a placa \\
\hline $9^{\circ}$ dia & Toda a placa & Toda a placa & Toda a placa & Toda a placa \\
\hline $0^{\circ}$ dia & Toda a placa & Toda a placa & Toda a placa & \\
\hline
\end{tabular}


Figura 5. Cultivo do fungo $P$. decaturense CBMAI 1234 na ausência de metil paration (placa controle) e com 5, 10 e $15 \mu \mathrm{L}$ de metil paration/placa. (A) 5 dias de cultivo e (B) 10 dias de cultivo.

A

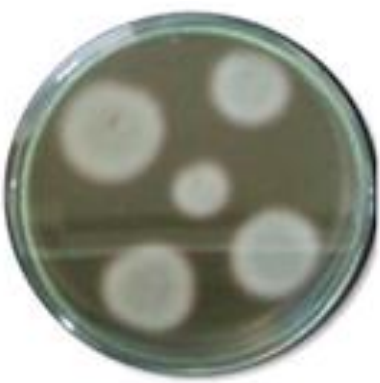

B

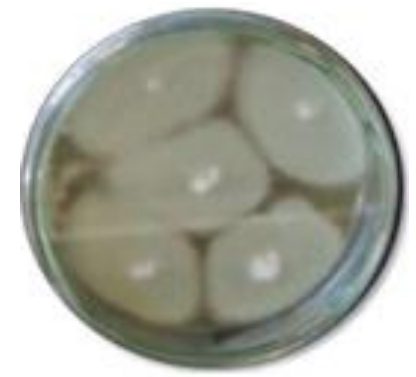

placa de Petri controle
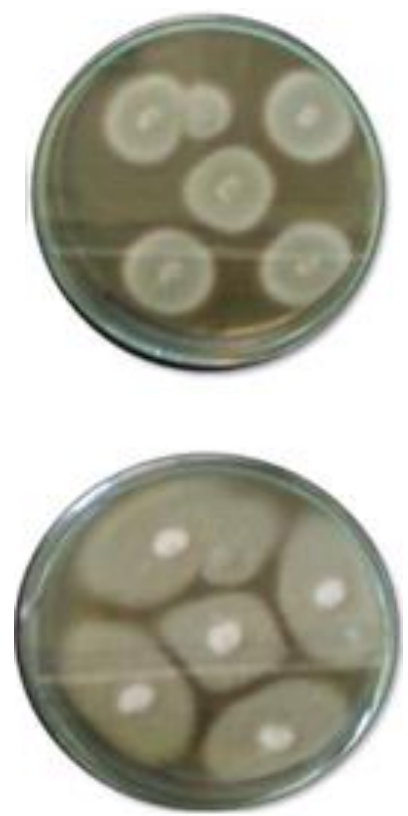

$5 \mu \mathrm{L}$ pesticida/DMSO
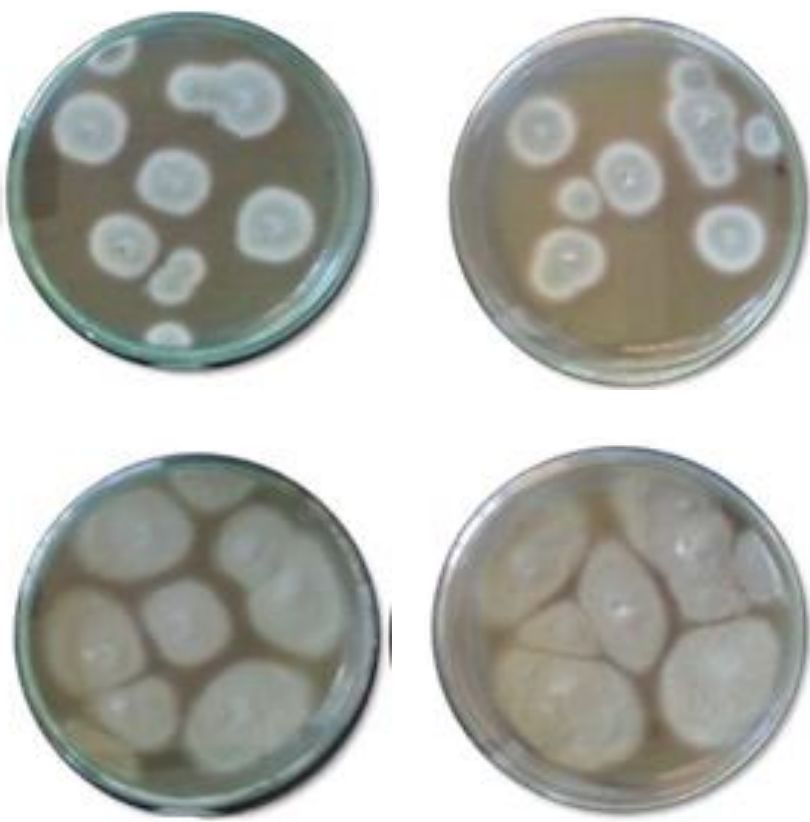

$10 \mu \mathrm{L}$ pesticida/DMSO

$15 \mu \mathrm{L}$ pesticida/DMSO

Tabela 5. Avaliação do halo de crescimento em meio de cultura sólido malte $2 \%$ e Agar do fungo de ambiente marinho $P$. decaturense CBMAI 1234 frente ao pesticida comercial metil paration nos volumes de $5 \mu \mathrm{L}$ de pesticida/100 $\mu \mathrm{L}$ de DMSO, $10 \mu \mathrm{L}$ de pesticida/200 $\mu \mathrm{L}$ de DMSO e $15 \mu \mathrm{L}$ de pesticida/ $300 \mu \mathrm{L}$ de DMSO durante 10 dias em condições padrões $\left(32^{\circ} \mathrm{C}, \mathrm{pH} 5,0\right)$.

\begin{tabular}{ccccc}
\hline $\begin{array}{l}\text { Tempo de crescimento } \\
\text { do fungo }\end{array}$ & \multicolumn{5}{c}{ Medida do halo de crescimento $(\mathrm{cm})$} \\
\hline $\begin{array}{c}\text { Penicillium decaturense } \\
\text { CBMAI } 1234\end{array}$ & Placa controle & $\begin{array}{c}5 \mu \mathrm{L} \text { pesticida/ } \\
100 \mu \mathrm{L} \text { DMSO }\end{array}$ & $\begin{array}{c}10 \mu \mathrm{L} \text { pesticida/ } \\
200 \mu \mathrm{L} \text { DMSO }\end{array}$ & $\begin{array}{c}15 \mu \mathrm{L} \text { pesticida/ } \\
300 \mu \mathrm{L} \text { DMSO }\end{array}$ \\
\hline $1^{\circ}$ dia & $2,6 \times 2,5$ & $2,0 \times 2,3$ & $2,4 \times 2,3$ & $2,2 \times 2,0$ \\
$2^{\circ}$ dia & $2,8 \times 2,5$ & $2,6 \times 2,3$ & $2,5 \times 2,0$ & $2,6 \times 2,3$ \\
\hline $3^{\circ}$ dia & $3,2 \times 4,5$ & $3,0 \times 3,2$ & $3,2 \times 3,5$ & $2,8 \times 2,7$ \\
\hline $4^{\circ}$ dia & $4,5 \times 5,5$ & $3,5 \times 4,5$ & $3,5 \times 5,5$ & $3,0 \times 3,5$ \\
\hline $5^{\circ}$ dia & $6,4 \times 7,0$ & $4,4 \times 5,0$ & $4,9 \times 5,8$ & $3,4 \times 4,0$ \\
$6^{\circ}$ dia & $6,9 \times 7,2$ & $5,0 \times 5,2$ & $5,3 \times 5,2$ & $4,7 \times 4,5$ \\
$7^{\circ}$ dia & $7,2 \times 7,5$ & $5,6 \times 5,5$ & $5,3 \times 5,5$ & $5,2 \times 5,5$ \\
$8^{\circ}$ dia & $7,4 \times 7,8$ & $6,4 \times 7,8$ & $5,7 \times 5,8$ & $6,4 \times 7,5$ \\
\hline $9^{\circ}$ dia & $8,4 \times 8,0$ & $7,4 \times 8,2$ & $6,4 \times 6,7$ & $7,4 \times 8,0$ \\
\hline $10^{\circ}$ dia & $9,0 \times 8,3$ & $8,0 \times 8,7$ & $7,8 \times 7,3$ & $8,7 \times 8,3$ \\
\hline
\end{tabular}


Figura 6. Cultivo do fungo $P$. raistrickii CBMAI 1235 na ausência de metil paration (placa controle) e com 5, 10 e $15 \mu \mathrm{L}$ de metil paration/placa. (A) 5 dias de cultivo e (B) 10 dias de cultivo.

A

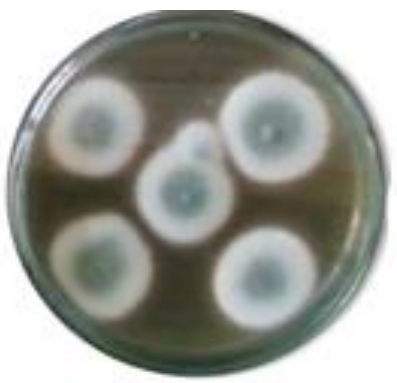

B

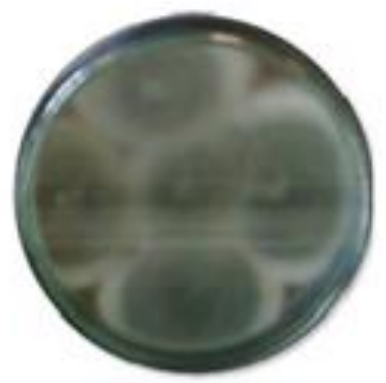

placa de Petri controle
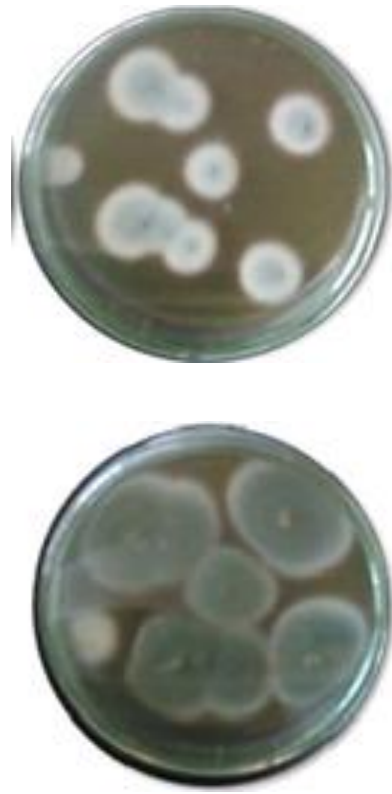

$5 \mu \mathrm{L}$ pesticida/DMSO
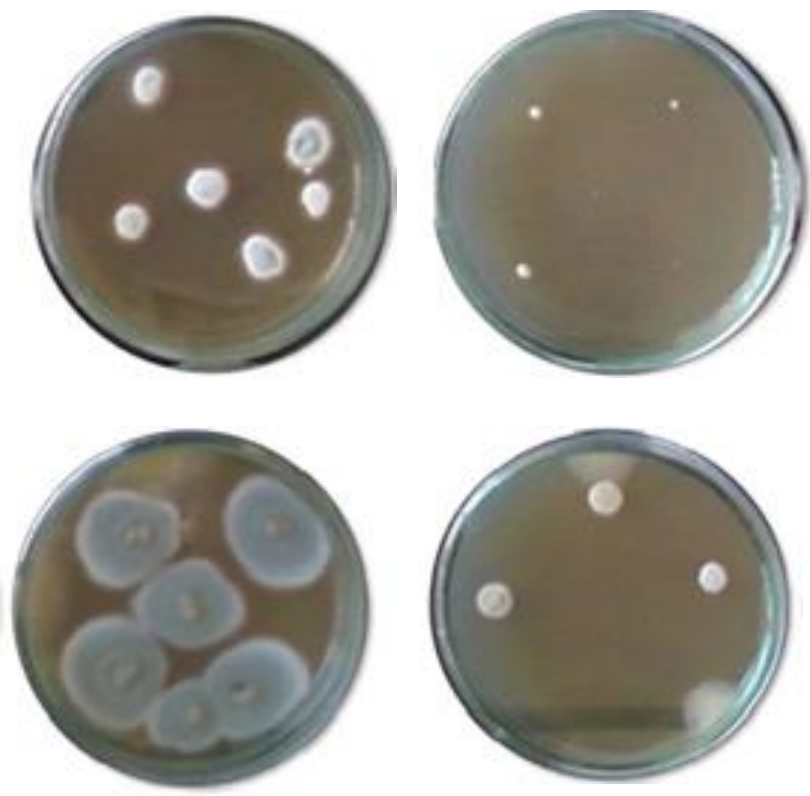

$10 \mu \mathrm{L}$ pesticida/DMSO

$15 \mu \mathrm{L}$ pesticida/DMSO

Tabela 6. Avaliação do halo de crescimento em meio de cultura sólido malte $2 \%$ e Agar do fungo de ambiente marinho P. raistrickii CBMAI 1235 frente ao pesticida comercial metil paration nos volumes de $5 \mu \mathrm{L}$ de pesticida/100 $\mu \mathrm{L}$ de DMSO, $10 \mu \mathrm{L}$ de pesticida/200 $\mu \mathrm{L}$ de DMSO e $15 \mu \mathrm{L}$ de pesticida/ $300 \mu \mathrm{L}$ de DMSO durante 10 dias em condições padrões $\left(32^{\circ} \mathrm{C}, \mathrm{pH} 5,0\right)$.

\begin{tabular}{|c|c|c|c|c|}
\hline Tempo de crescimento & & Medida do $\mathrm{h}$ & de crescimento ( $\mathrm{cn}$ & \\
\hline $\begin{array}{c}\text { Penicillium raistrickii } \\
\text { CBMAI } 1235\end{array}$ & Placa controle & $\begin{array}{l}5 \mu \mathrm{L} \text { pesticida/ } \\
100 \mu \mathrm{L} \text { DMSO }\end{array}$ & $\begin{array}{l}10 \mu \mathrm{L} \text { pesticida/ } \\
200 \mu \mathrm{L} \text { DMSO }\end{array}$ & $\begin{array}{l}15 \mu \mathrm{L} \text { pesticida/ } \\
300 \mu \mathrm{L} \text { DMSO }\end{array}$ \\
\hline $1^{\circ}$ dia & $3,6 \times 3,5$ & $3,5 \times 2,5$ & $2,0 \times 2,0$ & $0,1 \times 0,2$ \\
\hline $2^{\circ}$ dia & $3,8 \times 3,8$ & $3,0 \times 2,5$ & $2,8 \times 2,5$ & $0,6 \times 0,5$ \\
\hline $3^{\circ}$ dia & $4,2 \times 4,5$ & $3,2 \times 3,5$ & $2,8 \times 2,6$ & $0,8 \times 0,7$ \\
\hline $4^{\circ}$ dia & $4,5 \times 5,5$ & $3,5 \times 3,8$ & $2,9 \times 2,8$ & $1,0 \times 1,0$ \\
\hline $5^{\circ}$ dia & $5,4 \times 7,0$ & $4,4 \times 4,0$ & $3,0 \times 3,0$ & $1,0 \times 1,3$ \\
\hline $6^{\circ}$ dia & $6,5 \times 7,5$ & $5,9 \times 4,2$ & $3,2 \times 3,2$ & $1,2 \times 1,3$ \\
\hline $7^{\circ}$ dia & $7,8 \times 7,5$ & $6,2 \times 5,5$ & $3,8 \times 3,5$ & $1,2 \times 1,3$ \\
\hline $8^{\circ}$ dia & $8,4 \times 7,8$ & $6,4 \times 5,8$ & $4,4 \times 4,8$ & $1,2 \times 1,3$ \\
\hline $9^{\circ} \mathrm{dia}$ & $8,6 \times 8,0$ & $7,4 \times 6,0$ & $5,4 \times 6,0$ & $1,2 \times 1,3$ \\
\hline $10^{\circ} \mathrm{dia}$ & $9,0 \times 8,7$ & $8,0 \times 7,3$ & $6,0 \times 6,3$ & $1,2 \times 1,3$ \\
\hline
\end{tabular}


Figura 7. Cultivo do fungo A. sydowii CBMAI 1241 na ausência de metil paration (placa controle) e com 5, 10 e $15 \mu \mathrm{L}$ de metil paration/placa. (A) 5 dias de cultivo e (B) 10 dias de cultivo.

A

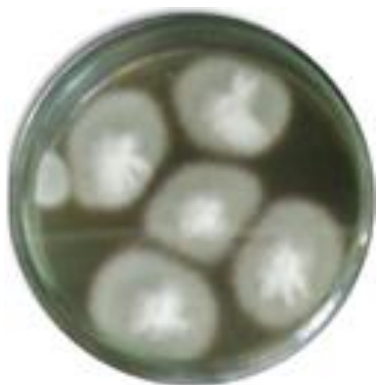

B

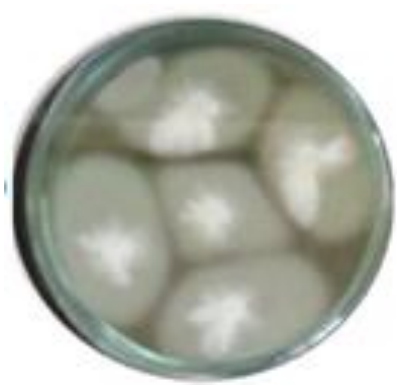

placa de Petri controle
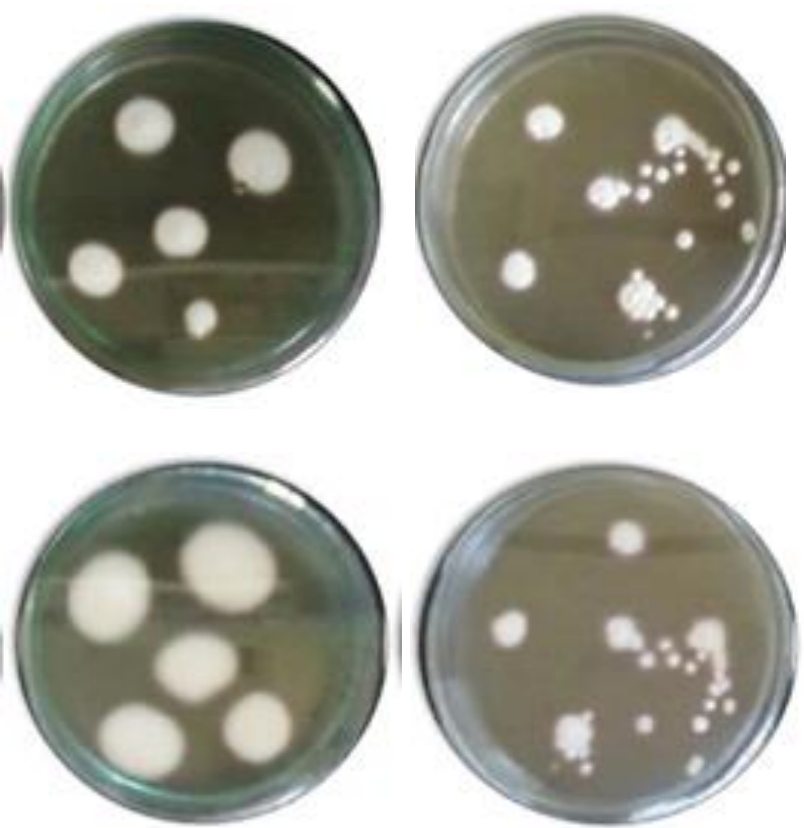

$10 \mu \mathrm{L}$ pesticida/DMSO
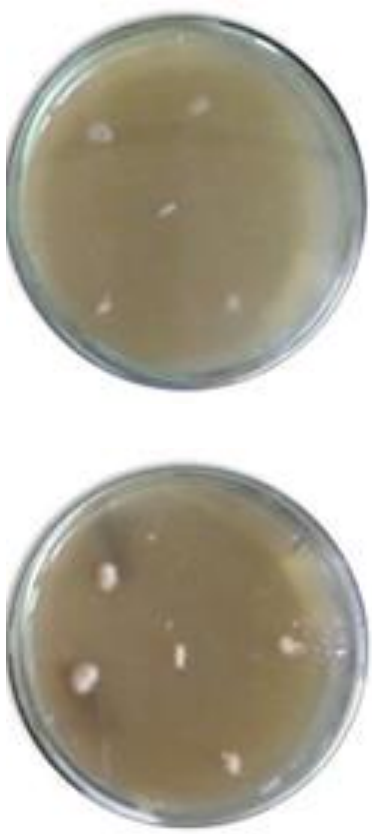

$15 \mu \mathrm{L}$ pesticida/DMSO

Tabela 7. Avaliação do halo de crescimento em meio de cultura sólido malte $2 \%$ e Agar do fungo de ambiente marinho A. sydowii CBMAI 1241 frente ao pesticida comercial metil paration nos volumes de $5 \mu \mathrm{L}$ de pesticida/100 $\mu \mathrm{L}$ de DMSO, $10 \mu \mathrm{L}$ de pesticida/200 $\mu \mathrm{L}$ de DMSO e $15 \mu \mathrm{L}$ de pesticida/ $300 \mu \mathrm{L}$ de DMSO durante 10 dias em condições padrões $\left(32^{\circ} \mathrm{C}, \mathrm{pH} 5\right)$.

\begin{tabular}{ccccc}
\hline $\begin{array}{l}\text { Tempo de crescimento } \\
\text { do fungo }\end{array}$ & \multicolumn{5}{c}{ Medida do halo de crescimento $(\mathrm{cm})$} \\
\hline $\begin{array}{c}\text { Aspergillus sydowii } \\
\text { CBMAI } 1241\end{array}$ & Placa controle & $\begin{array}{c}5 \mu \mathrm{L} \text { pesticida/ } \\
100 \mu \mathrm{L} \text { DMSO }\end{array}$ & $\begin{array}{c}10 \mu \mathrm{L} \text { pesticida/ } \\
200 \mu \mathrm{L} \text { DMSO }\end{array}$ & $\begin{array}{c}15 \mu \mathrm{L} \text { pesticida/ } \\
300 \mu \mathrm{L} \text { DSO }\end{array}$ \\
\hline $1^{\circ}$ dia & $3,4 \times 3,0$ & $2,5 \times 2,0$ & $0,3 \times 0,5$ & $0,1 \times 0,2$ \\
$2^{\circ}$ dia & $3,8 \times 3,5$ & $2,5 \times 2,2$ & $0,6 \times 0,6$ & $0,6 \times 0,5$ \\
\hline $3^{\circ}$ dia & $4,2 \times 4,0$ & $2,8 \times 2,5$ & $0,8 \times 0,9$ & $0,8 \times 0,7$ \\
\hline $4^{\circ}$ dia & $4,8 \times 5,5$ & $3,0 \times 3,0$ & $1,2 \times 1,5$ & $1,0 \times 1,0$ \\
\hline $5^{\circ}$ dia & $5,2 \times 6,0$ & $3,2 \times 3,0$ & $1,5 \times 1,8$ & $1,2 \times 1,2$ \\
\hline $6^{\circ}$ dia & $6,0 \times 6,5$ & $3,9 \times 3,2$ & $1,8 \times 2,3$ & $1,3 \times 1,3$ \\
\hline $7^{\circ}$ dia & $7,2 \times 7,5$ & $4,2 \times 3,5$ & $2,2 \times 2,3$ & $1,3 \times 1,3$ \\
$8^{\circ}$ dia & $7,4 \times 7,8$ & $4,4 \times 3,8$ & $2,2 \times 2,3$ & $1,3 \times 1,3$ \\
\hline $9^{\circ}$ dia & $8,0 \times 8,6$ & $4,4 \times 4,0$ & $2,2 \times 2,3$ & $1,3 \times 1,3$ \\
\hline $1^{\circ}$ dia & $8,8 \times 9,0$ & $4,6 \times 4,3$ & $2,2 \times 2,3$ & $1,3 \times 1,3$ \\
\hline
\end{tabular}




\section{Profenofós}

Figura 8. Cultivo do fungo P. raistrickii CBMAI 931 na ausência de profenofós (placa controle) e com 5, 10 e $15 \mu \mathrm{L}$ de profenofós/placa. (A) 5 dias de cultivo e (B) 10 dias de cultivo.

A
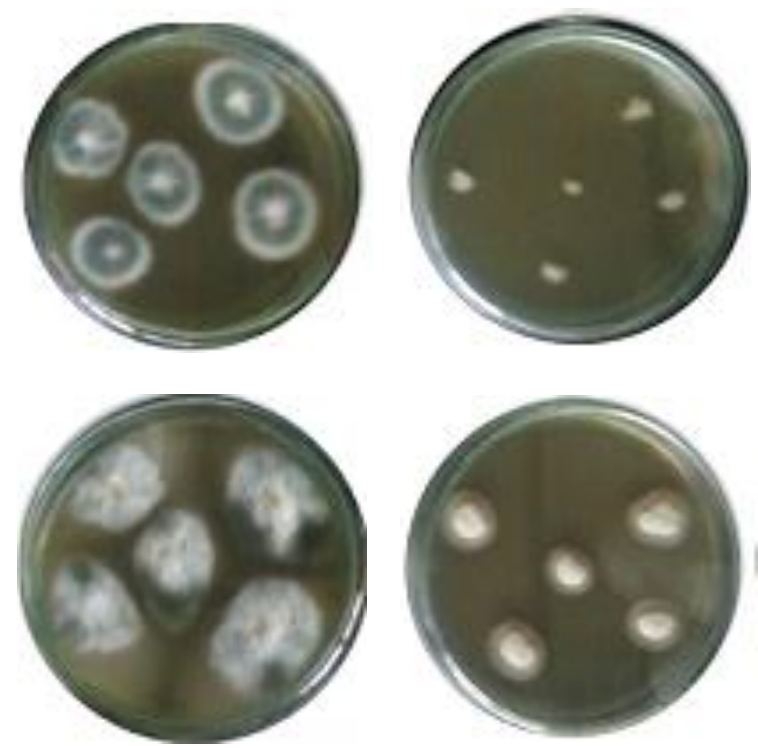

placa de Petri controle

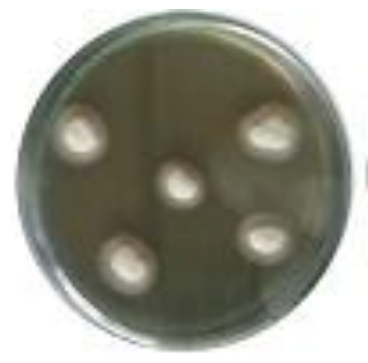

$5 \mu \mathrm{L}$ pesticida/DMSO
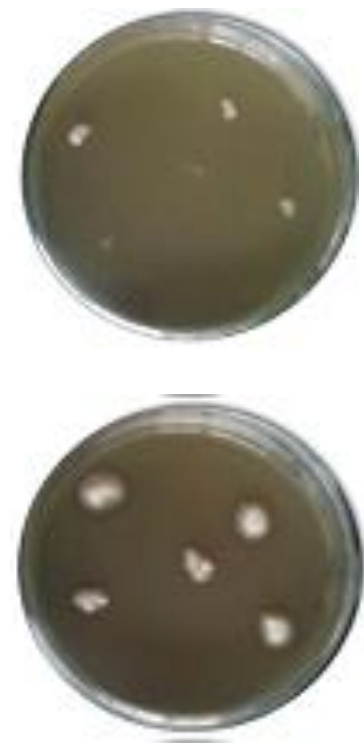

$10 \mu \mathrm{L}$ pesticida/DMSO
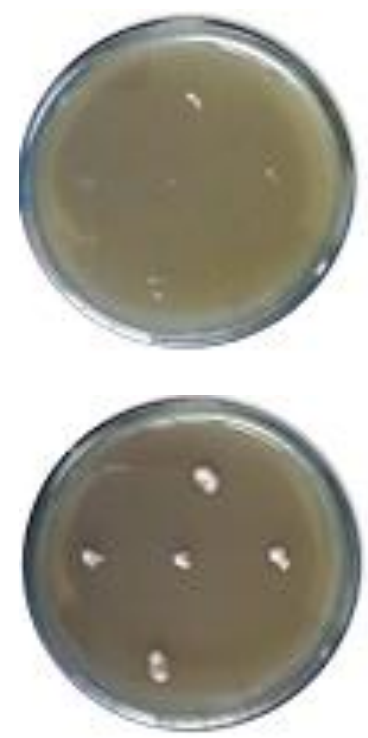

$15 \mu \mathrm{L}$ pesticida/DMSO

Tabela 8. Avaliação de crescimento em meio de cultura sólido malte $2 \%$ e Agar do fungo de ambiente marinho P. raistrickii CBMAI 931 frente ao pesticida profenofós.

\begin{tabular}{|c|c|c|c|c|}
\hline Tempo de crescimento & & Medida do hal & crescimento em ( & \\
\hline $\begin{array}{l}P . \text { raistrickii } \\
\text { CBMAI } 931\end{array}$ & Placa controle & $\begin{array}{l}5 \mu \mathrm{L} \text { pesticida/ } \\
100 \mu \mathrm{L} \text { DMSO }\end{array}$ & $\begin{array}{l}10 \mu \mathrm{L} \text { pesticida/ } \\
200 \mu \mathrm{L} \text { DMSO }\end{array}$ & $\begin{array}{l}15 \mu \mathrm{L} \text { pesticida/ } \\
300 \mu \mathrm{L} \text { DMSO }\end{array}$ \\
\hline $1^{\circ}$ dia & $1,2 \times 2,0$ & $1,0 \times 1,2$ & $0,8 \times 1,0$ & $0,6 \times 1,0$ \\
\hline $2^{\circ}$ dia & $2,0 \times 2,2$ & $1,3 \times 2,0$ & $1,0 \times 1,5$ & $0,6 \times 1,2$ \\
\hline $3^{\circ}$ dia & $2,2 \times 2,5$ & $1,7 \times 2,2$ & $1,3 \times 1,7$ & $1,0 \times 1,3$ \\
\hline $4^{\circ}$ dia & $2,5 \times 2,5$ & $1,9 \times 2,2$ & $1,4 \times 1,8$ & $1,0 \times 1,3$ \\
\hline $5^{\circ}$ dia & $3,4 \times 3,0$ & $2,2 \times 2,5$ & $1,4 \times 1,8$ & $1,0 \times 1,3$ \\
\hline $6^{\circ}$ dia & $3,8 \times 3,4$ & $2,5 \times 2,7$ & $1,4 \times 1,8$ & $1,0 \times 1,3$ \\
\hline $7^{\circ}$ dia & $4,2 \times 4,5$ & $2,5 \times 3,0$ & $1,4 \times 1,8$ & $1,0 \times 1,3$ \\
\hline $8^{\circ}$ dia & $5,3 \times 6,2$ & $2,5 \times 3,0$ & $1,4 \times 1,8$ & $1,0 \times 1,3$ \\
\hline $9^{\circ} \mathrm{dia}$ & $6,8 \times 6,5$ & $2,5 \times 3,0$ & $1,4 \times 1,8$ & $1,0 \times 1,3$ \\
\hline $10^{\circ} \mathrm{dia}$ & $6,8 \times 6,5$ & $2,5 \times 3,0$ & $1,4 \times 1,8$ & $1,0 \times 1,3$ \\
\hline
\end{tabular}


Figura 9. Cultivo do fungo Trichoderma sp. CBMAI 932 na ausência de profenofós (placa controle) e com 5, 10 e $15 \mu \mathrm{L}$ de profenofós/placa. (A) 5 dias de cultivo e (B) 10 dias de cultivo.

A
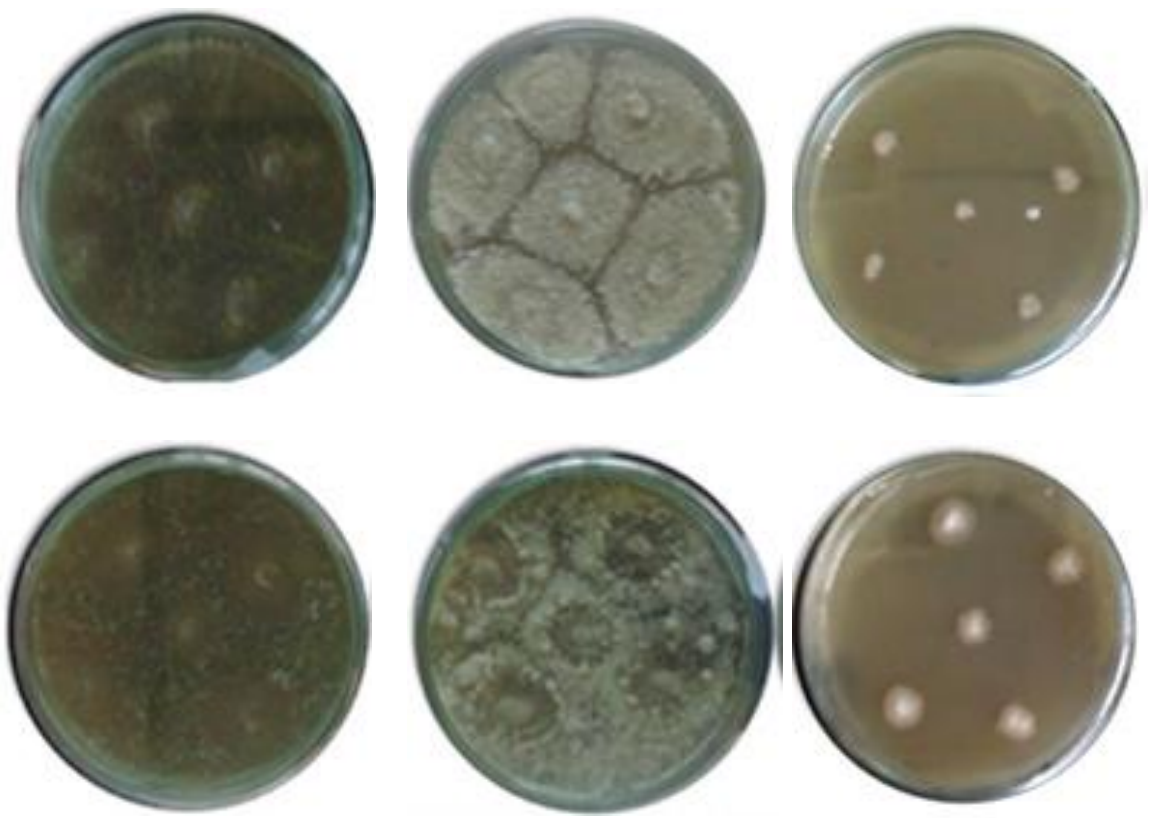

$5 \mu \mathrm{L}$ pesticida/DMSO

placa de Petri controle

$10 \mu \mathrm{L}$ pesticida/DMSO
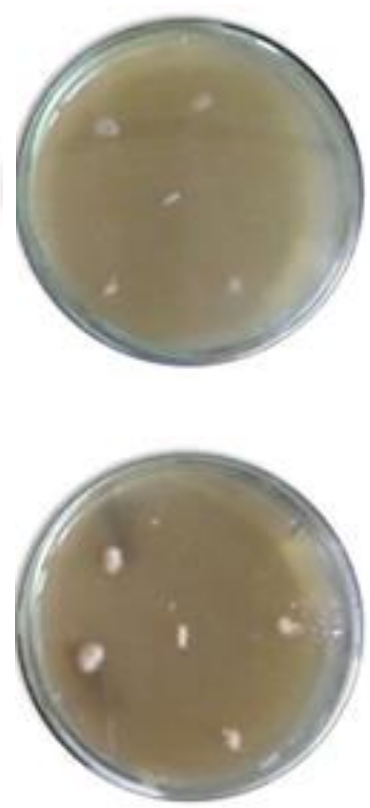

$15 \mu \mathrm{L}$ pesticida/DMSO

Tabela 9. Avaliação de crescimento em meio de cultura sólido malte $2 \%$ e Agar do fungo de ambiente marinho Trichoderma sp. CBMAI 932 frente ao pesticida comercial profenofós nas concentrações de $5 \mu \mathrm{L}$ de pesticida/100 $\mu \mathrm{L}$ de DMSO, $10 \mu \mathrm{L}$ de pesticida/200 $\mu \mathrm{L}$ de DMSO e $15 \mu \mathrm{L}$ de pesticida/ $300 \mu \mathrm{L}$ de DMSO durante 10 dias em condições padrões $\left(32^{\circ} \mathrm{C}, \mathrm{pH} 5,0\right)$.

\begin{tabular}{ccccc}
\hline $\begin{array}{l}\text { Tempo de crescimento } \\
\text { do fungo }\end{array}$ & \multicolumn{3}{l}{ Medida do halo de crescimento em $(\mathrm{cm})$} \\
\hline $\begin{array}{c}\text { Trichoderma sp. } \\
\text { CBMAI } 932\end{array}$ & Placa controle & $\begin{array}{c}5 \mu \mathrm{L} \text { pesticida/ } \\
100 \mu \mathrm{L} \text { DMSO }\end{array}$ & $\begin{array}{c}10 \mu \mathrm{L} \text { pesticida/ } \\
200 \mu \mathrm{L} \text { DMSO }\end{array}$ & $\begin{array}{c}15 \mu \mathrm{L} \text { pesticida/ } \\
300 \mathrm{~L} \text { DMSO }\end{array}$ \\
$1^{\circ}$ dia & $3,2 \times 3,0$ & $2,0 \times 2,6$ & $0,6 \times 0,8$ & $0,3 \times 0,3$ \\
$2^{\circ}$ dia & $3,8 \times 3,5$ & $3,3 \times 2,8$ & $1,0 \times 1,5$ & $0,6 \times 1,2$ \\
$3^{\circ}$ dia & $5,2 \times 4,5$ & $3,7 \times 3,2$ & $1,3 \times 1,7$ & $1,0 \times 1,3$ \\
$4^{\circ}$ dia & $6,5 \times 5,5$ & $4,9 \times 3,9$ & $1,4 \times 1,8$ & $1,0 \times 1,3$ \\
$5^{\circ}$ dia & $7,4 \times 7,0$ & $5,2 \times 4,5$ & $1,6 \times 1,8$ & $1,0 \times 1,3$ \\
$6^{\circ}$ dia & Toda a placa & $6,5 \times 6,7$ & $2,3 \times 2,5$ & $1,0 \times 1,3$ \\
$7^{\circ}$ dia & Toda a placa & Toda a placa & $2,3 \times 2,5$ & $1,0 \times 1,3$ \\
$8^{\circ}$ dia & Toda a placa & Toda a placa & $2,3 \times 2,5$ & $1,0 \times 1,3$ \\
\hline $9^{\circ}$ dia & Toda a placa & Toda a placa & $2,3 \times 2,5$ & $1,0 \times 1,3$ \\
\hline $0^{\circ}$ dia & Toda a placa & Toda a placa & $2,3 \times 2,5$ & \\
\hline
\end{tabular}


Figura 10. Cultivo do fungo A. sydowii CBMAI 934 na ausência de profenofós (placa controle) e com 5, 10 e 15 $\mu \mathrm{L}$ de profenofós/placa. (A) 5 dias de cultivo e (B) 10 dias de cultivo.

A

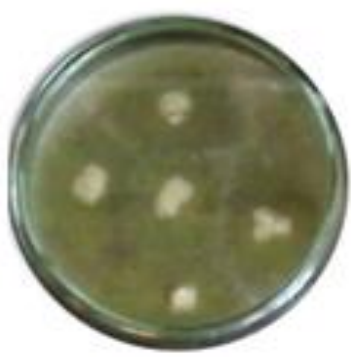

B

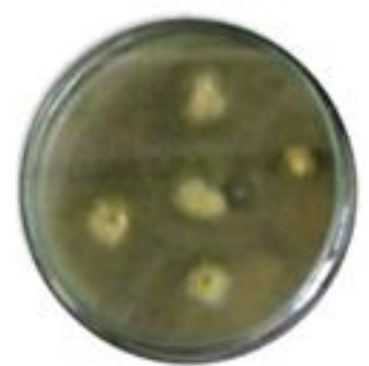

placa de Petri controle
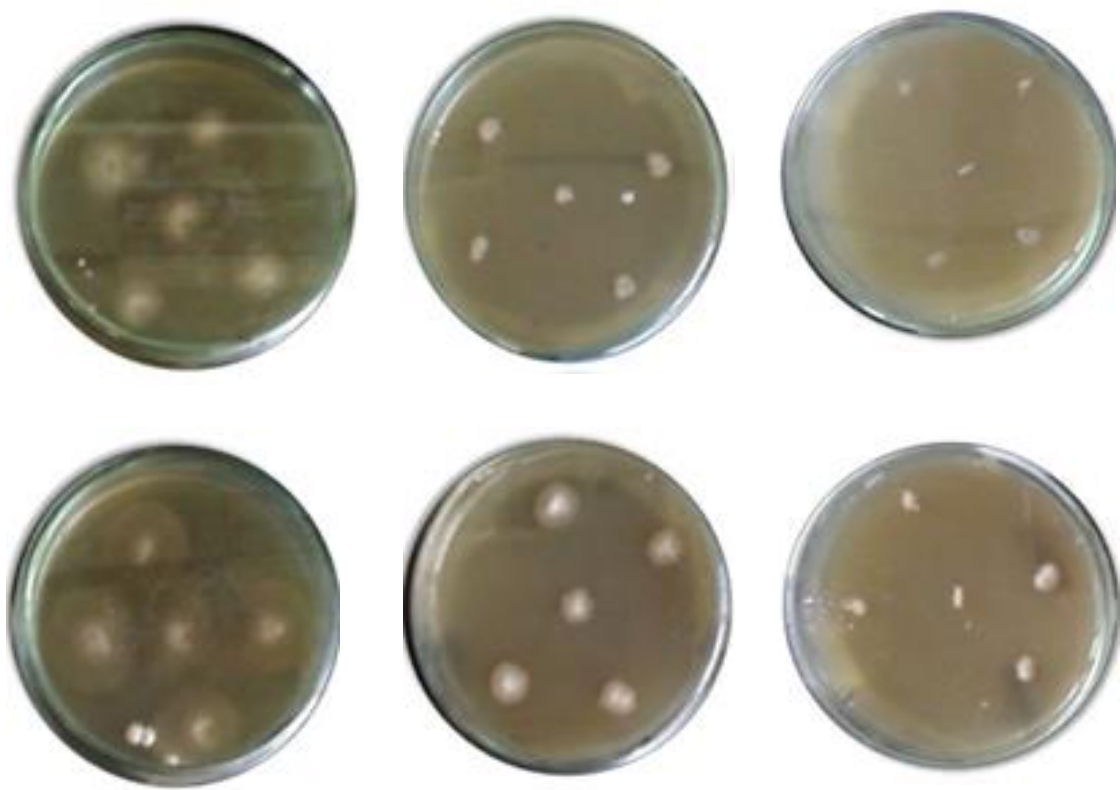

$5 \mu \mathrm{L}$ pesticida/DMSO
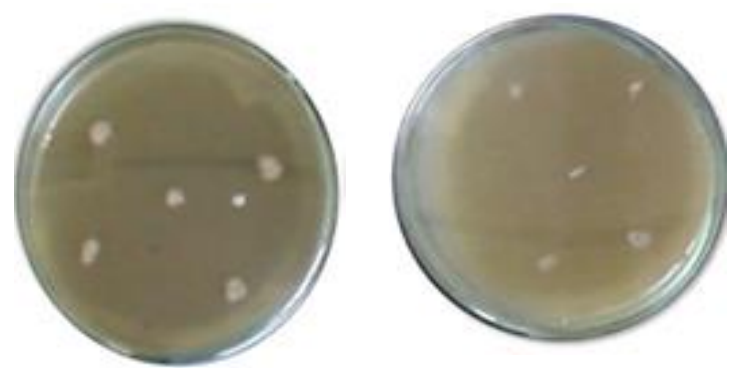

$10 \mu \mathrm{L}$ pesticida/DMSO

$15 \mu \mathrm{L}$ pesticida/DMSO

Tabela 10. Avaliação de crescimento em meio de cultura sólido malte $2 \%$ e Agar do fungo de ambiente marinho A. sydowii CBMAI 934 frente ao pesticida comercial profenofós nos volumes de $5 \mu \mathrm{L}$ de pesticida/100 $\mu \mathrm{L}$ de DMSO, $10 \mu \mathrm{L}$ de pesticida/200 $\mu \mathrm{L}$ de DMSO e $15 \mu \mathrm{L}$ de pesticida/ $300 \mu \mathrm{L}$ de DMSO durante 10 dias em condições padrões $\left(32^{\circ} \mathrm{C}, \mathrm{pH} 5,0\right)$.

\begin{tabular}{ccccc}
\hline $\begin{array}{l}\text { Tempo de crescimento } \\
\text { do fungo }\end{array}$ & \multicolumn{5}{l}{ Medida do halo de crescimento em (cm) } \\
\hline $\begin{array}{c}\text { Aspergillus sydowii } \\
\text { CBMAI 934 }\end{array}$ & Placa controle & $\begin{array}{c}5 \mu \mathrm{L} \text { pesticida/ } \\
100 \mu \mathrm{L} \text { DMSO }\end{array}$ & $\begin{array}{c}10 \mu \mathrm{L} \text { pesticida/ } \\
200 \mu \mathrm{L} \text { DMSO }\end{array}$ & $\begin{array}{c}15 \mu \mathrm{L} \text { pesticida/ } \\
300 \mu \mathrm{L} \text { DMSO }\end{array}$ \\
\hline $1^{\circ}$ dia & $2,2 \times 2,2$ & $2,2 \times 1,3$ & $0,1 \times 0,1$ & $0,1 \times 0,2$ \\
$2^{\circ}$ dia & $2,8 \times 2,5$ & $2,6 \times 2,2$ & $0,2 \times 0,8$ & $0,6 \times 0,5$ \\
\hline $3^{\circ}$ dia & $3,2 \times 4,5$ & $2,8 \times 2,3$ & $0,8 \times 1,0$ & $0,8 \times 0,7$ \\
\hline $4^{\circ}$ dia & $4,5 \times 5,5$ & $3,0 \times 3,2$ & $1,0 \times 1,0$ & $1,0 \times 1,0$ \\
\hline $5^{\circ}$ dia & $6,4 \times 7,0$ & $4,1 \times 4,3$ & $1,0 \times 1,0$ & $1,0 \times 1,3$ \\
\hline $6^{\circ}$ dia & $6,4 \times 7,0$ & $5,3 \times 5,4$ & $1,0 \times 1,0$ & $1,2 \times 1,3$ \\
\hline $7^{\circ}$ dia & Toda a placa & $6,3 \times 6,4$ & $1,0 \times 1,3$ & $1,2 \times 1,3$ \\
\hline $8^{\circ}$ dia & Toda a placa & Toda a placa & $1,0 \times 1,3$ & $1,2 \times 1,3$ \\
\hline $9^{\circ}$ dia & Toda a placa & Toda a placa & $1,0 \times 1,3$ & $1,2 \times 1,3$ \\
\hline $10^{\circ}$ dia & Toda a placa & Toda a placa & $1,0 \times 1,3$ & $1,2 \times 1,3$ \\
\hline
\end{tabular}


Figura 11. Cultivo do fungo A. sydowii CBMAI 935 na ausência de profenofós (placa controle) e com 5, 10 e 15 $\mu \mathrm{L}$ de profenofós/placa. (A) 5 dias de cultivo e (B) 10 dias de cultivo.

A

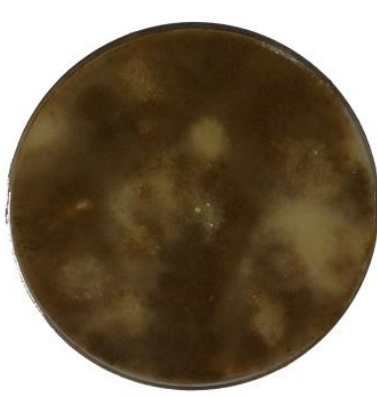

B

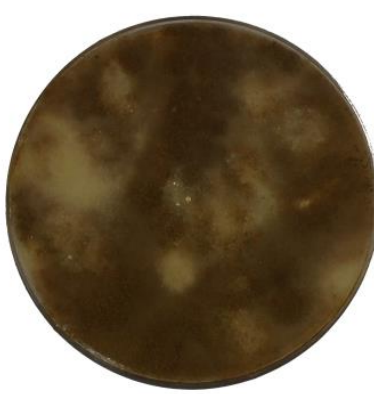

placa de Petri controle
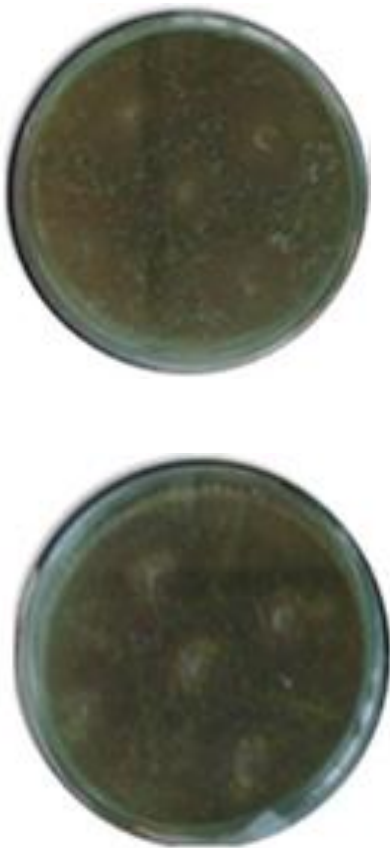

$5 \mu \mathrm{L}$ pesticida/DMSO
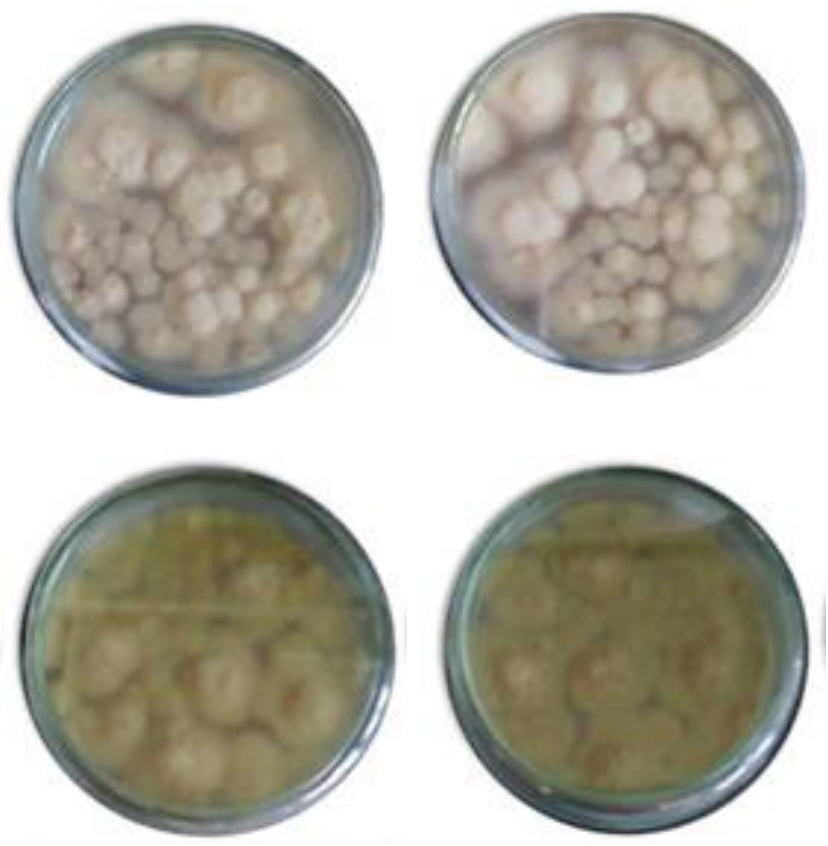

$10 \mu \mathrm{L}$ pesticida/DMSO

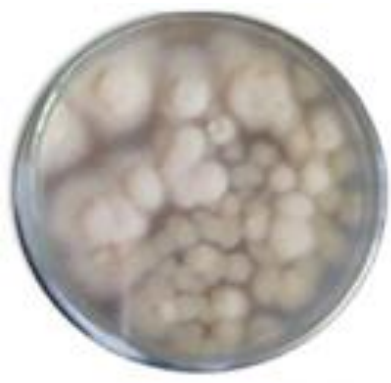

$15 \mu \mathrm{L}$ pesticida/DMSO

Tabela 11. Avaliação do halo de crescimento em meio de cultura sólido malte $2 \%$ e Agar do fungo de ambiente marinho A. sydowii CBMAI 935 frente ao pesticida comercial profenofós nos volumes de $5 \mu \mathrm{L}$ de pesticida/100 $\mu \mathrm{L}$ de DMSO, $10 \mu \mathrm{L}$ de pesticida/200 $\mu \mathrm{L}$ de DMSO e $15 \mu \mathrm{L}$ de pesticida/ $300 \mu \mathrm{L}$ de DMSO durante 10 dias em condições padrões $\left(32^{\circ} \mathrm{C}, \mathrm{pH} 5,0\right)$.

\begin{tabular}{|c|c|c|c|c|}
\hline Tempo de crescimento & & Medida do $\mathrm{h}$ & de crescimento ( $\mathrm{cn}$ & \\
\hline $\begin{array}{c}\text { Aspergillus sydowii } \\
\text { CBMAI } 935\end{array}$ & Placa controle & $\begin{array}{l}5 \mu \mathrm{L} \text { pesticida/ } \\
100 \mu \mathrm{L} \text { DMSO }\end{array}$ & $\begin{array}{l}10 \mu \mathrm{L} \text { pesticida/ } \\
200 \mu \mathrm{L} \mathrm{DMSO}\end{array}$ & $\begin{array}{c}15 \mu \mathrm{L} \text { pesticida/ } \\
300 \mu \mathrm{L} \text { DMSO }\end{array}$ \\
\hline $1^{\circ}$ dia & $4,2 \times 4,0$ & $4,0 \times 3,8$ & $3,5 \times 3,0$ & $3,2 \times 3,0$ \\
\hline $2^{\circ}$ dia & $5,8 \times 4,5$ & $4,8 \times 4,0$ & $4,5 \times 4,2$ & $3,8 \times 3,5$ \\
\hline $3^{\circ}$ dia & $6,2 \times 5,5$ & $5,2 \times 5,0$ & $4,8 \times 4,5$ & $4,2 \times 4,0$ \\
\hline $4^{\circ}$ dia & $6,9 \times 6,5$ & $5,9 \times 5,4$ & $5,3 \times 4,7$ & $4,9 \times 4,5$ \\
\hline $5^{\circ}$ dia & Toda a placa & $6,5 \times 6,2$ & $6,0 \times 5,1$ & $5,2 \times 5,3$ \\
\hline $6^{\circ}$ dia & Toda a placa & Toda a placa & $6,7 \times 6,5$ & $5,6 \times 5,7$ \\
\hline $7^{\circ}$ dia & Toda a placa & Toda a placa & Toda a placa & $6,2 \times 6,3$ \\
\hline $8^{\circ}$ dia & Toda a placa & Toda a placa & Toda a placa & Toda a placa \\
\hline $9^{\circ} \mathrm{dia}$ & Toda a placa & Toda a placa & Toda a placa & Toda a placa \\
\hline $10^{\circ} \mathrm{dia}$ & Toda a placa & Toda a placa & Toda a placa & Toda a placa \\
\hline
\end{tabular}


Figura 12. Cultivo do fungo $P$. decaturense CBMAI 1234 na ausência de profenofós (placa controle) e com 5, 10 e $15 \mu \mathrm{L}$ de profenofós/placa. (A) 5 dias de cultivo e (B) 10 dias de cultivo.

A

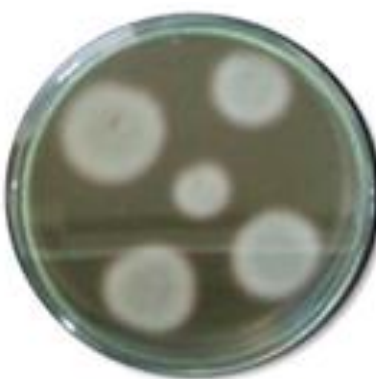

B

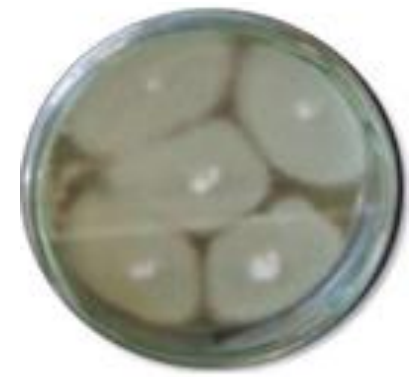

placa de Petri controle
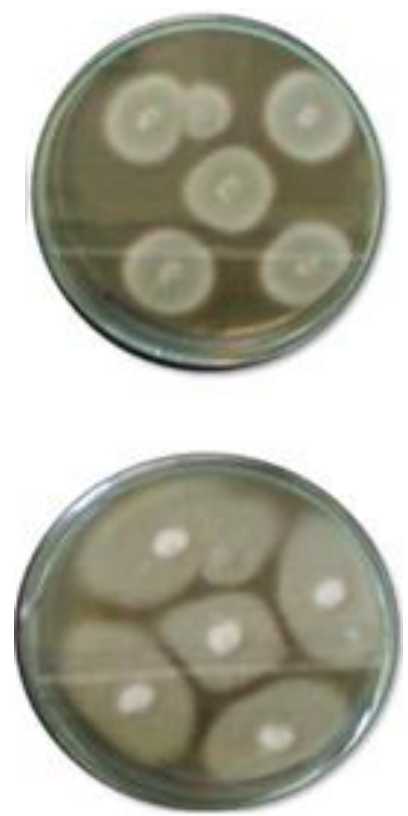

$5 \mu \mathrm{L}$ pesticida/DMSO
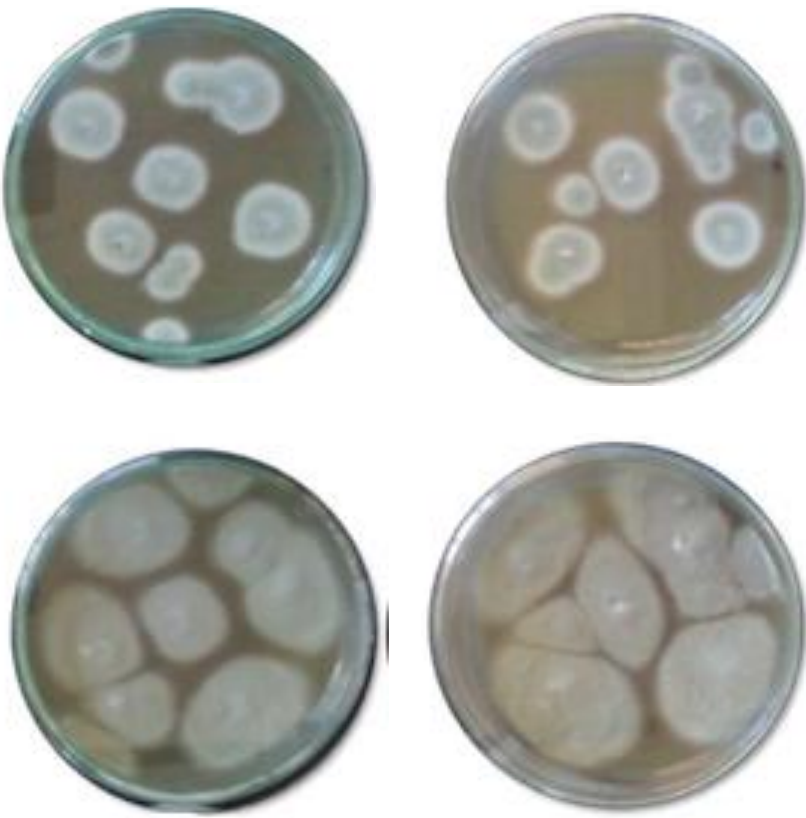

$10 \mu \mathrm{L}$ pesticida/DMSO

$15 \mu \mathrm{L}$ pesticida/DMSO

Tabela 12. Avaliação do halo de crescimento em meio de cultura sólido malte $2 \%$ e Agar do fungo de ambiente marinho $P$. decaturense CBMAI 1234 frente ao pesticida comercial profenofós nos volumes de $5 \mu \mathrm{L}$ de pesticida/100 $\mu \mathrm{L}$ de DMSO, $10 \mu \mathrm{L}$ de pesticida/200 $\mu \mathrm{L}$ de DMSO e $15 \mu \mathrm{L}$ de pesticida/ $300 \mu \mathrm{L}$ de DMSO durante 10 dias em condições padrões $\left(32^{\circ} \mathrm{C}, \mathrm{pH} 5,0\right)$.

\begin{tabular}{ccccc}
\hline $\begin{array}{l}\text { Tempo de crescimento } \\
\text { do fungo }\end{array}$ & \multicolumn{5}{c}{ Medida do halo de crescimento $(\mathrm{cm})$} \\
\hline $\begin{array}{c}\text { Penicillium decaturense } \\
\text { CBMAI } 1234\end{array}$ & Placa controle & $\begin{array}{c}5 \mu \mathrm{L} \text { pesticida/ } \\
100 \mu \mathrm{L} \text { DMSO }\end{array}$ & $\begin{array}{c}10 \mu \mathrm{L} \text { pesticida/ } \\
200 \mu \mathrm{L} \text { DMSO }\end{array}$ & $\begin{array}{c}15 \mu \mathrm{L} \text { pesticida/ } \\
300 \mu \mathrm{L} \text { DMSO }\end{array}$ \\
\hline $1^{\circ}$ dia & $2,6 \times 2,5$ & $2,0 \times 2,3$ & $2,4 \times 2,3$ & $2,2 \times 2,0$ \\
$2^{\circ}$ dia & $2,8 \times 2,5$ & $2,6 \times 2,3$ & $2,5 \times 2,0$ & $2,6 \times 2,3$ \\
\hline $3^{\circ}$ dia & $3,2 \times 4,5$ & $3,0 \times 3,2$ & $3,2 \times 3,5$ & $2,8 \times 2,7$ \\
\hline $4^{\circ}$ dia & $4,5 \times 5,5$ & $3,5 \times 4,5$ & $3,5 \times 5,5$ & $3,0 \times 3,5$ \\
\hline $5^{\circ}$ dia & $6,4 \times 7,0$ & $4,4 \times 5,0$ & $4,9 \times 5,8$ & $3,4 \times 4,0$ \\
$6^{\circ}$ dia & $6,9 \times 7,2$ & $5,0 \times 5,2$ & $5,3 \times 5,2$ & $4,7 \times 4,5$ \\
$7^{\circ}$ dia & $7,2 \times 7,5$ & $5,6 \times 5,5$ & $5,3 \times 5,5$ & $5,2 \times 5,5$ \\
$8^{\circ}$ dia & $7,4 \times 7,8$ & $6,4 \times 7,8$ & $5,7 \times 5,8$ & $6,4 \times 7,5$ \\
\hline $9^{\circ}$ dia & $8,4 \times 8,0$ & $7,4 \times 8,2$ & $6,4 \times 6,7$ & $7,4 \times 8,0$ \\
\hline $10^{\circ}$ dia & $9,0 \times 8,3$ & $8,0 \times 8,7$ & $7,8 \times 7,3$ & $8,7 \times 8,3$ \\
\hline
\end{tabular}


Figura 13. Cultivo do fungo P. raistrickii CBMAI 1235 na ausência de profenofós (placa controle) e com 5, 10 e $15 \mu \mathrm{L}$ de profenofós/placa. (A) 5 dias de cultivo e (B) 10 dias de cultivo.

A

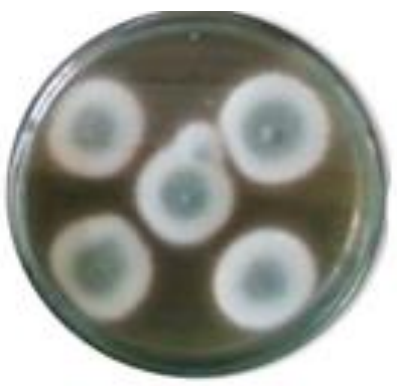

B

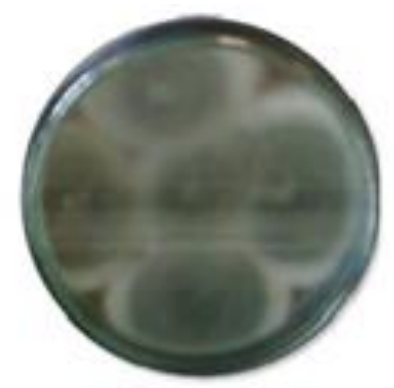

placa de Petri controle
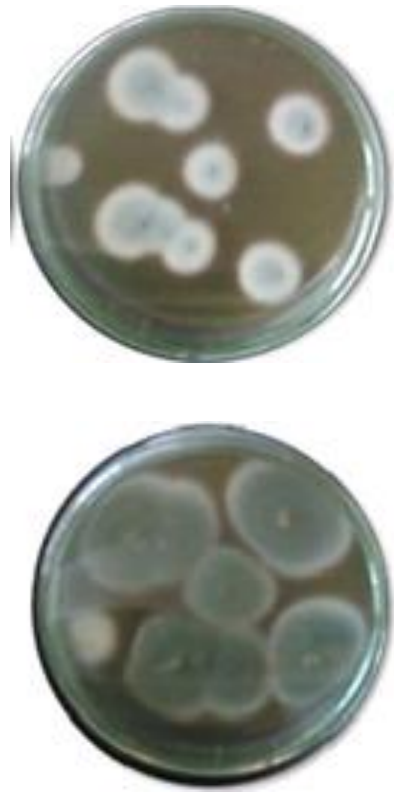

$5 \mu \mathrm{L}$ pesticida/DMSO
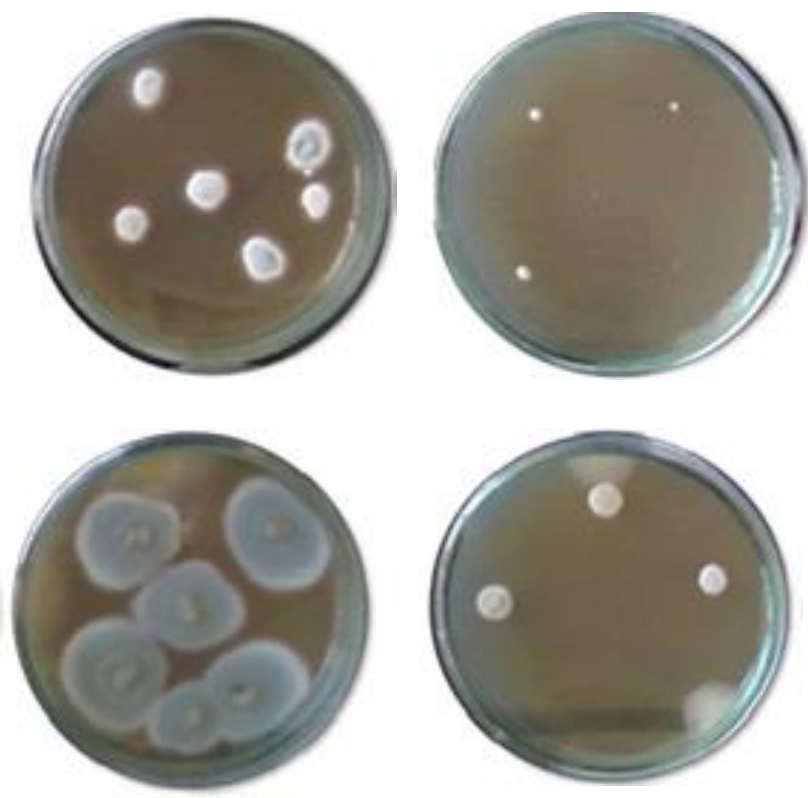

$10 \mu \mathrm{L}$ pesticida/DMSO

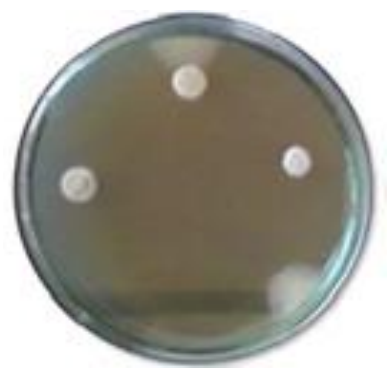

$15 \mu \mathrm{L}$ pesticida/DMSO

Tabela 13. Avaliação do halo de crescimento em meio de cultura sólido malte $2 \%$ e Agar do fungo de ambiente marinho P. raistrickii CBMAI 1235 frente ao pesticida comercial profenofós nos volumes de $5 \mu \mathrm{L}$ de pesticida/100 $\mu \mathrm{L}$ de DMSO, $10 \mu \mathrm{L}$ de pesticida/200 $\mu \mathrm{L}$ de DMSO e $15 \mu \mathrm{L}$ de pesticida/ $300 \mu \mathrm{L}$ de DMSO durante 10 dias em condições padrões $\left(32^{\circ} \mathrm{C}, \mathrm{pH} 5,0\right)$.

\begin{tabular}{ccccc}
\hline $\begin{array}{l}\text { Tempo de crescimento } \\
\text { do fungo }\end{array}$ & \multicolumn{5}{c}{ Medida do halo de crescimento $(\mathrm{cm})$} \\
\hline $\begin{array}{c}\text { Penicillium raistrickii } \\
\text { CBMAI 1235 }\end{array}$ & Placa controle & $\begin{array}{c}5 \mu \mathrm{L} \text { pesticida/ } \\
100 \mu \mathrm{L} \text { DMSO }\end{array}$ & $\begin{array}{c}10 \mu \mathrm{L} \text { pesticida/ } \\
200 \mu \mathrm{L} \text { DMSO }\end{array}$ & $\begin{array}{c}15 \mu \mathrm{L} \text { pesticida/ } \\
300 \mu \mathrm{L} \text { DMSO }\end{array}$ \\
\hline $1^{\circ}$ dia & $3,6 \times 3,5$ & $3,5 \times 2,5$ & $2,0 \times 2,0$ & $0,1 \times 0,2$ \\
\hline $2^{\circ}$ dia & $3,8 \times 3,8$ & $3,0 \times 2,5$ & $2,8 \times 2,5$ & $0,6 \times 0,5$ \\
\hline $3^{\circ}$ dia & $4,2 \times 4,5$ & $3,2 \times 3,5$ & $2,8 \times 2,6$ & $0,8 \times 0,7$ \\
\hline $4^{\circ}$ dia & $4,5 \times 5,5$ & $3,5 \times 3,8$ & $2,9 \times 2,8$ & $1,0 \times 1,0$ \\
\hline $5^{\circ}$ dia & $5,4 \times 7,0$ & $4,4 \times 4,0$ & $3,0 \times 3,0$ & $1,0 \times 1,3$ \\
\hline $6^{\circ}$ dia & $6,5 \times 7,5$ & $5,9 \times 4,2$ & $3,2 \times 3,2$ & $1,2 \times 1,3$ \\
$7^{\circ}$ dia & $7,8 \times 7,5$ & $6,2 \times 5,5$ & $3,8 \times 3,5$ & $1,2 \times 1,3$ \\
\hline $8^{\circ}$ dia & $8,4 \times 7,8$ & $6,4 \times 5,8$ & $4,4 \times 4,8$ & $1,2 \times 1,3$ \\
\hline $9^{\circ}$ dia & $8,6 \times 8,0$ & $7,4 \times 6,0$ & $5,4 \times 6,0$ & $1,2 \times 1,3$ \\
\hline $0^{\circ}$ dia & $9,0 \times 8,7$ & $8,0 \times 7,3$ & $6,0 \times 6,3$ & $1,2 \times 1,3$ \\
\hline
\end{tabular}


Figura 14. Cultivo do fungo A. sydowii CBMAI 1241 na ausência de profenofós (placa controle) e com 5, 10 e $15 \mu \mathrm{L}$ de profenofós/placa. (A) 5 dias de cultivo e (B) 10 dias de cultivo.

A

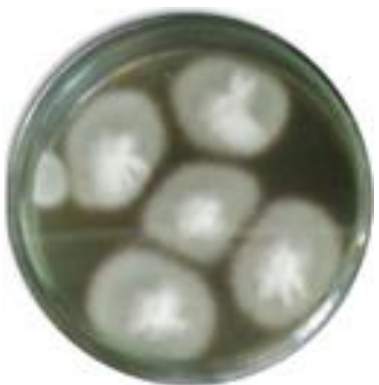

B

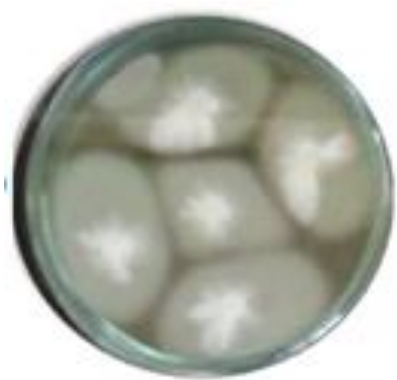

placa de Petri controle
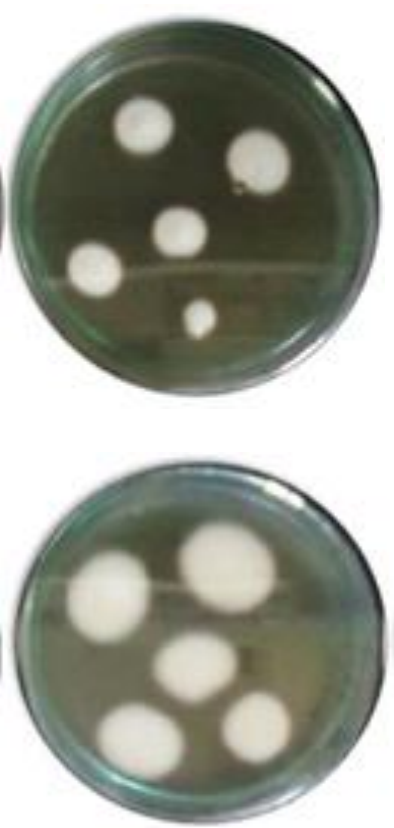

$5 \mu \mathrm{L}$ pesticida/DMSO
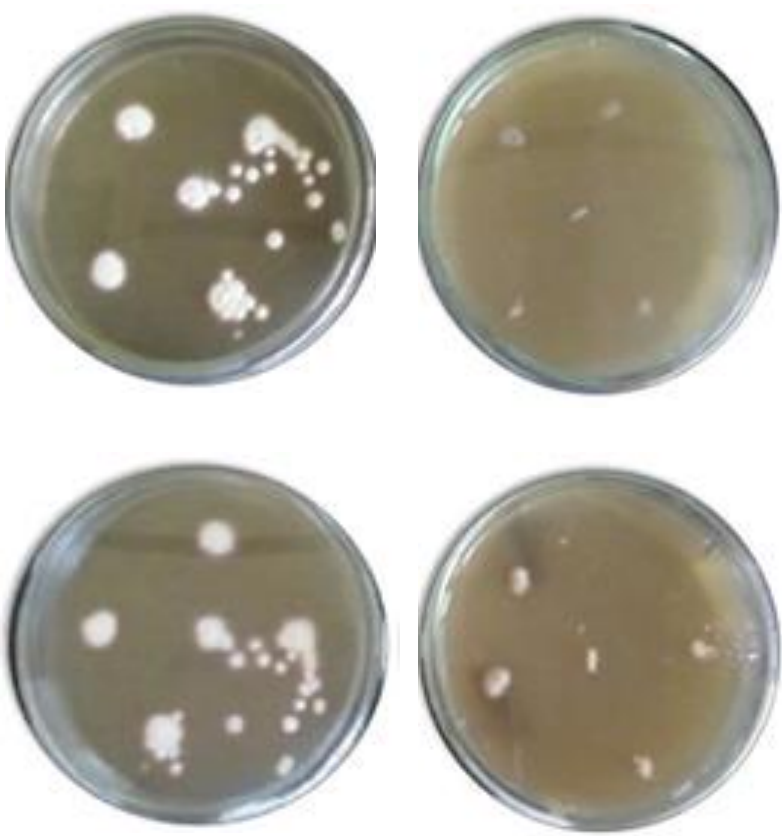

$10 \mu \mathrm{L}$ pesticida/DMSO

$15 \mu \mathrm{L}$ pesticida/DMSO

Tabela 14. Avaliação do halo de crescimento em meio de cultura sólido malte $2 \%$ e Agar do fungo de ambiente marinho A. sydowii CBMAI 1241 frente ao pesticida comercial profenofós nos volumes de $5 \mu \mathrm{L}$ de pesticida/100 $\mu \mathrm{L}$ de DMSO, $10 \mu \mathrm{L}$ de pesticida/200 $\mu \mathrm{L}$ de DMSO e $15 \mu \mathrm{L}$ de pesticida/ $300 \mu \mathrm{L}$ de DMSO durante 10 dias em condições padrões $\left(32^{\circ} \mathrm{C}, \mathrm{pH} 5,0\right)$.

\begin{tabular}{|c|c|c|c|c|}
\hline Tempo de crescimento & & Medida do $\mathrm{h}$ & de crescimento ( $\mathrm{cr}$ & \\
\hline $\begin{array}{c}\text { Aspergillus sydowii } \\
\text { CBMAI } 1241\end{array}$ & Placa controle & $\begin{array}{l}5 \mu \mathrm{L} \text { pesticida/ } \\
100 \mu \mathrm{L} \text { DMSO }\end{array}$ & $\begin{array}{l}10 \mu \mathrm{L} \text { pesticida/ } \\
200 \mu \mathrm{L} \text { DMSO }\end{array}$ & $\begin{array}{c}15 \mu \mathrm{L} \text { pesticida/ } \\
300 \mu \mathrm{L} \text { DMSO }\end{array}$ \\
\hline $1^{\circ}$ dia & $3,4 \times 3,0$ & $2,5 \times 2,0$ & $0,3 \times 0,5$ & $0,1 \times 0,2$ \\
\hline $2^{\circ}$ dia & $3,8 \times 3,5$ & $2,5 \times 2,2$ & $0,6 \times 0,6$ & $0,6 \times 0,5$ \\
\hline $3^{\circ}$ dia & $4,2 \times 4,0$ & $2,8 \times 2,5$ & $0,8 \times 0,9$ & $0,8 \times 0,7$ \\
\hline $4^{\circ}$ dia & $4,8 \times 5,5$ & $3,0 \times 3,0$ & $1,2 \times 1,5$ & $1,0 \times 1,0$ \\
\hline $5^{\circ}$ dia & $5,2 \times 6,0$ & $3,2 \times 3,0$ & $1,5 \times 1,8$ & $1,2 \times 1,2$ \\
\hline $6^{\circ}$ dia & $6,0 \times 6,5$ & $3,9 \times 3,2$ & $1,8 \times 2,3$ & $1,3 \times 1,3$ \\
\hline $7^{\circ}$ dia & $7,2 \times 7,5$ & $4,2 \times 3,5$ & $2,2 \times 2,3$ & $1,3 \times 1,3$ \\
\hline $8^{\circ}$ dia & $7,4 \times 7,8$ & $4,4 \times 3,8$ & $2,2 \times 2,3$ & $1,3 \times 1,3$ \\
\hline $9^{\circ} \mathrm{dia}$ & $8,0 \times 8,6$ & $4,4 \times 4,0$ & $2,2 \times 2,3$ & $1,3 \times 1,3$ \\
\hline $10^{\circ}$ dia & $8,8 \times 9,0$ & $4,6 \times 4,3$ & $2,2 \times 2,3$ & $1,3 \times 1,3$ \\
\hline
\end{tabular}


Cromatogramas de controle biótico do fungo A. sydowii CBMAI 935 em 20 e 30 dias de crescimento em meio de cultura líquido de malte a $2 \%$

Figura 15. Cromatogramas obtidos por CG-EM das extrações das células úmidas e do caldo enzimático do fungo A. sydowii CBMAI 935 na ausência de xenobióticos (reação controle) durante 20 dias. (a) extração do caldo enzimático e (b) extração das células úmidas.

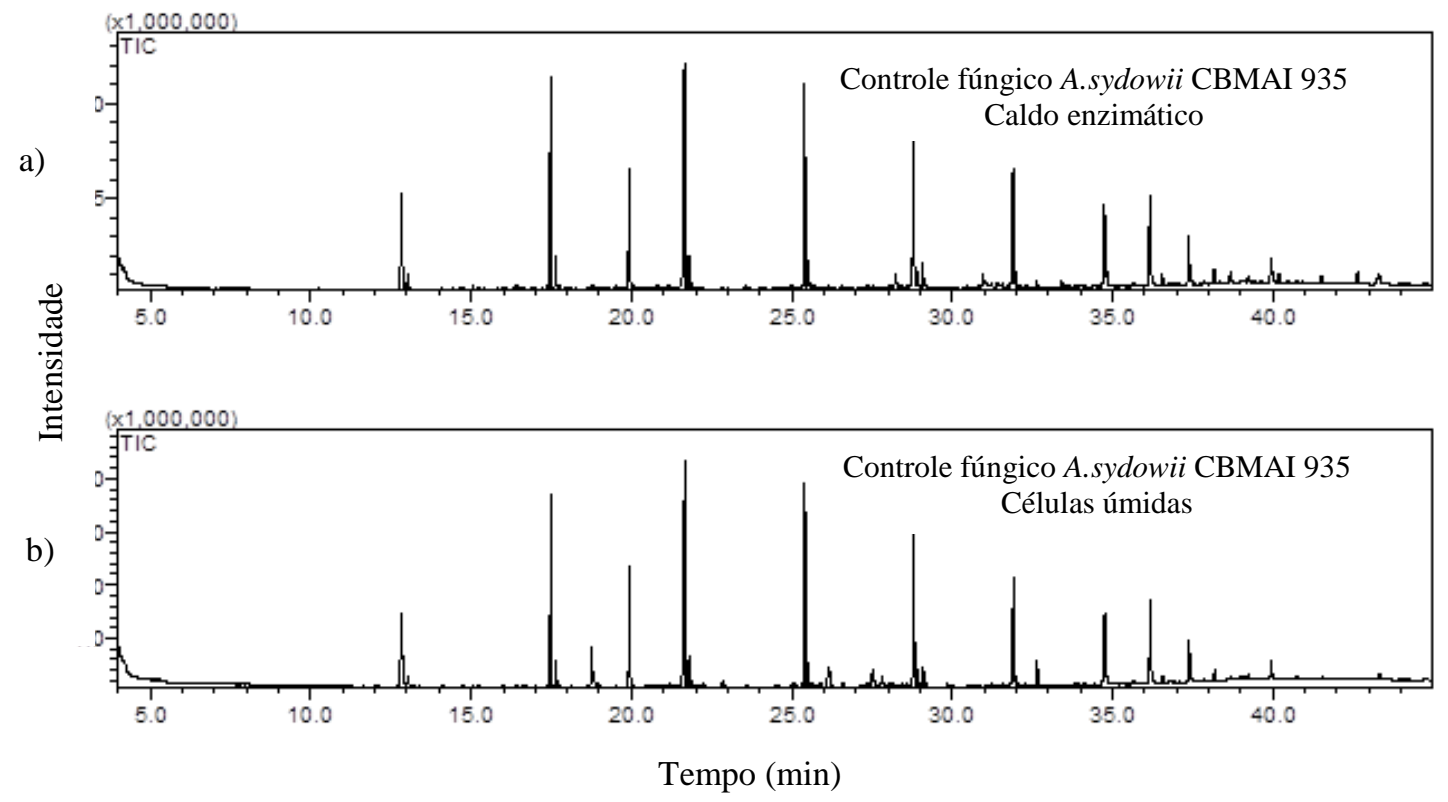

Condições de análise CG-EM: $\mathrm{T}_{\mathrm{i}}=60^{\circ} \mathrm{C}, 2 \mathrm{~min} ; \mathrm{T}_{\mathrm{f}}=280^{\circ} \mathrm{C}, 6 \mathrm{~min} ; \mathrm{r}=6^{\circ} \mathrm{C} / \mathrm{min}, \mathrm{t}_{\mathrm{c}}=45 \mathrm{mim}$.

Coluna capilar DB-5 da J\&W Scientific (30 $\mathrm{m}$ x 0,25 mm x 0,25 $\mu \mathrm{m}$ ). 
Figura 16. Cromatogramas obtidos por CG-EM das extrações das células úmidas e do caldo enzimático do fungo A. sydowii CBMAI 935 na ausência de xenobióticos (reação controle) durante 30 dias. (a) extração do caldo enzimático e (b) extração das células úmidas.

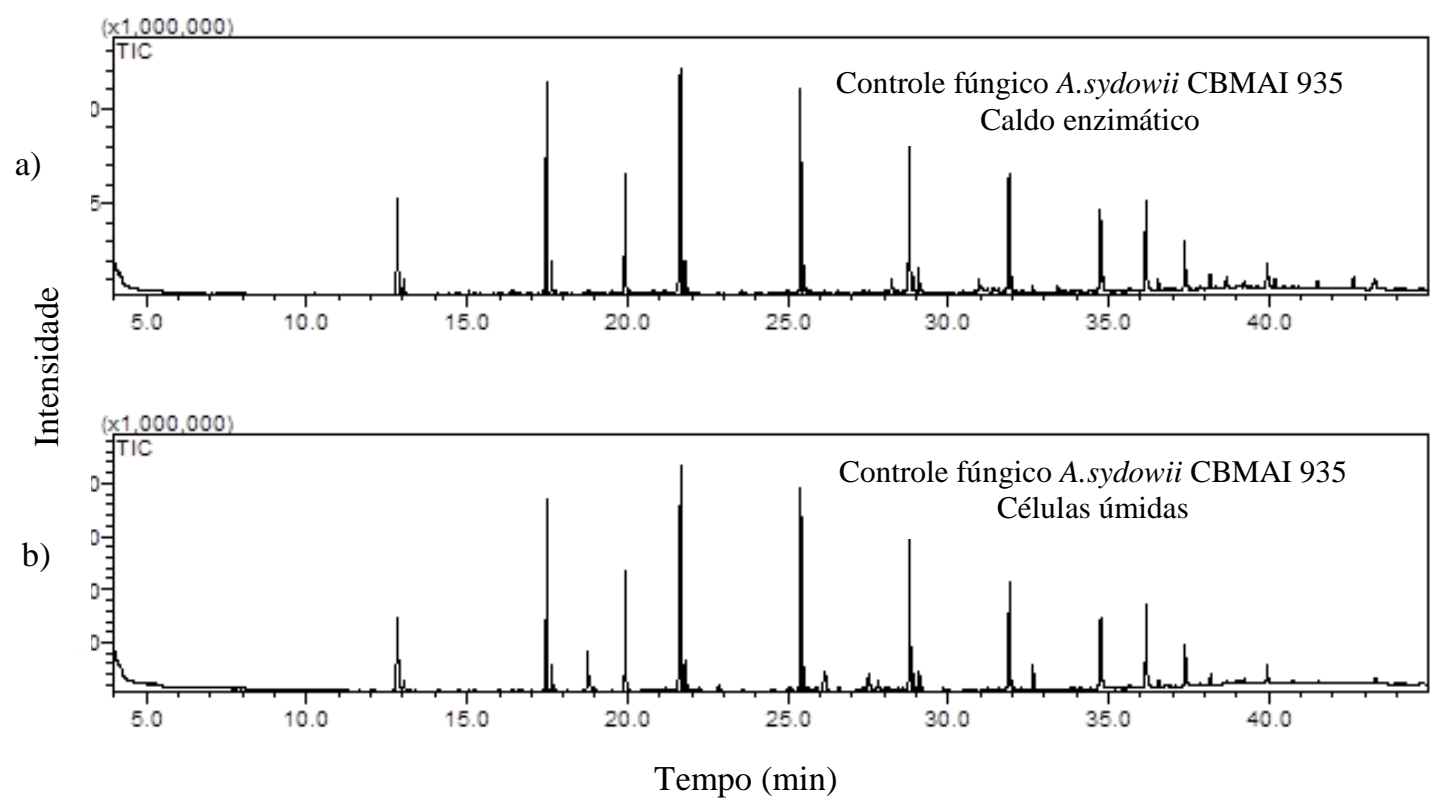

Condições de análise CG-EM: $\mathrm{T}_{\mathrm{i}}=60^{\circ} \mathrm{C}, 2 \mathrm{~min} ; \mathrm{T}_{\mathrm{f}}=280^{\circ} \mathrm{C}, 6 \mathrm{~min} ; \mathrm{r}=6^{\circ} \mathrm{C} / \mathrm{min}, \mathrm{t}_{\mathrm{c}}=45 \mathrm{mim}$.

Coluna capilar DB-5 da J\&W Scientific (30 m x 0,25 mm x 0,25 $\mu \mathrm{m})$.

Tabela 15. Quantidade de massa micelial produzida pelo fungo A. sydowii CBMAI 935 na ausência de xenobióticos em 10 dias $\left(32{ }^{\circ} \mathrm{C}, 130 \mathrm{~g}, \mathrm{pH} 7,0\right)$.

A. sydowii CBMAI 935

$\begin{array}{cc}\text { Reações em triplicata } & \text { Massa fúngica seca }(\mathrm{g}) \\ \text { Reação } 1 & 1,42 \\ \text { Reação } 2 & 1,52 \\ \text { Reação } 3 & 1,54\end{array}$

Tabela 16. Quantidade de massa micelial produzida pelo fungo A. sydowii CBMAI 935 na ausência de xenobióticos em $20 \operatorname{dias}\left(32^{\circ} \mathrm{C}, 130 \mathrm{~g}, \mathrm{pH} 7,0\right)$.

A. sydowii CBMAI 935

\begin{tabular}{cc}
\hline Reações em triplicata & Massa fúngica seca $(\mathrm{g})$ \\
Reação 1 & 1,52 \\
Reação 2 & 1,45 \\
Reação 3 & 1,55 \\
\hline
\end{tabular}

Tabela 17. Quantidade de massa micelial produzida por fungo A. sydowii CBMAI 935 na ausência de xenobióticos em 30 dias $\left(32^{\circ} \mathrm{C}, 130 \mathrm{~g}, \mathrm{pH} 7,0\right)$.

\begin{tabular}{cc}
\hline \multicolumn{2}{c}{ A. sydowii CBMAI 935 } \\
\hline Reações em triplicata & Massa fúngica seca (g) \\
Reação 1 & 1,46 \\
Reação 2 & 1,50 \\
Reação 3 & 1,52 \\
\hline
\end{tabular}


Tabelas de dados de quantificação obtidos por CLAE-UV das reações entre o pesticida clorpirifós com fungo de ambiente marinho A. sydowii CBMAI 935 em 10, 20 e 30 dias de reação de biotransformação em meio de cultura líquido de malte a $2 \%$

Tabela 18. Quantificação da biodegradação de clorpirifós por A. sydowii CBMAI 935 em 10 dias de reação $\left(32^{\circ} \mathrm{C}, 130 \mathrm{~g}, \mathrm{pH} 7,0\right)$.

\begin{tabular}{ccccc}
\hline \multicolumn{5}{c}{ A. sydowii CBMAI 935 $\mathbf{( 5 0}$ mg. $\mathbf{L}^{\mathbf{- 1}}$ de clorpirifós) } \\
\hline $\begin{array}{c}\text { Reações em } \\
\text { duplicata }\end{array}$ & $\begin{array}{c}\text { Massa fúngica seca } \\
\text { Reação 1 }\end{array}$ & $\mathrm{c}^{\mathrm{a}}$ metabólito & $\mathrm{c}^{\mathrm{a}}$ clorpirifós & \% de clorpirifós degradado \\
Reação 2 & 0,41 & $5^{\mathrm{b}}$ & 35 & 20 \\
\hline $\mathrm{c}^{\mathrm{a}}=$ concentração (dados obtidos de duplicatas) determinados por CLAE-UV. \\
b concentração estimada
\end{tabular}

Tabela 19. Quantificação da biodegradação de clorpirifós por A. sydowii CBMAI 935 em 20 dias de reação $\left(32^{\circ} \mathrm{C}, 130 \mathrm{~g}, \mathrm{pH} 7,0\right)$.

\begin{tabular}{|c|c|c|c|c|}
\hline \multicolumn{5}{|c|}{ A. sydowii CBMAI 935 (50 mg.L ${ }^{-1}$ ppm de clorpirifós) } \\
\hline $\begin{array}{c}\text { Reações em } \\
\text { duplicata }\end{array}$ & $\begin{array}{l}\text { Massa fúngica } \\
\text { seca }(\mathrm{g})\end{array}$ & $\mathrm{c}^{\mathrm{a}}$ metabólito & $\mathrm{c}^{\mathrm{a}}$ clorpirifós & $\begin{array}{c}\text { \% de clorpirifós } \\
\text { degradado }^{\text {b }}\end{array}$ \\
\hline Reação 1 & 0,40 & $2^{c}$ & $33^{\mathrm{c}}$ & 30 \\
\hline Reação 2 (caldo enzimático) & & 2 & 32 & 32 \\
\hline Reação 2 (células) & 0,38 & 1 & 34 & 30 \\
\hline
\end{tabular}

Tabela 20. Quantificação da biodegradação de clorpirifós por A. sydowii CBMAI 935 em 30 dias de reação $\left(32^{\circ} \mathrm{C}, 130 \mathrm{~g}, \mathrm{pH} 7,0\right)$.

\begin{tabular}{|c|c|c|c|c|}
\hline \multicolumn{5}{|c|}{ A. sydowii CBMAI 935 (50 mg.L ${ }^{-1}$ de clorpirifós) } \\
\hline $\begin{array}{c}\text { Reações em } \\
\text { duplicata }\end{array}$ & $\begin{array}{l}\text { Massa fúngica seca } \\
(\mathrm{g})\end{array}$ & $\mathrm{c}^{\mathrm{a}}$ metabólito & $\mathrm{c}^{\mathrm{a}}$ clorpirifós & $\%$ de clorpirifós degradado ${ }^{b}$ \\
\hline Reação 1 & 0,36 & 2 & 33 & 30 \\
\hline Reação 2 & 0,35 & 2 & 33 & 30 \\
\hline
\end{tabular}

Cromatogramas obtidos por CLAE-UV das reações de biotranformação entre o pesticida clorpirifós com o fungo de ambiente marinho A. sydowii CBMAI $935 \mathrm{em} \mathrm{10,20}$ e 30 dias de crescimento em meio de cultura líquido de malte a $2 \%$

A Figura 17 mostra os cromatogramas sobrepostos em tamanho reduzido obtidos por CLAE-UV da reação com o pesticida comercial clorpirifós na (cor rosa) com sinal no tempo de retenção em 28, 500 minutos e o padrão analítico do clorpirifós na (cor escura) com sinal no tempo de retenção em 27, 800 minutos e concentração de 50 mg. $\mathrm{L}^{-1}$. Houve uma diferença 
de aproximadamente meio minuto no tempo de retenção dos compostos analizados, devido às análises que foram realizadas em colunas C 18 diferentes, sendo uma das colunas mais antiga e o pesticida comercial que continha outras substâncias indicadas pelo fabricante em sua composição que foram analizadas em CG-EM.

Figura 17. Cromatogramas sobrepostos em tamanho reduzido obtidos por CLAE-UV da reação com o pesticida comercial clorpirifós (cor rosa) e o padrão analítico (cor escura) do clorpirifós com concentração de $50 \mathrm{mg} \cdot \mathrm{L}^{-1}$.

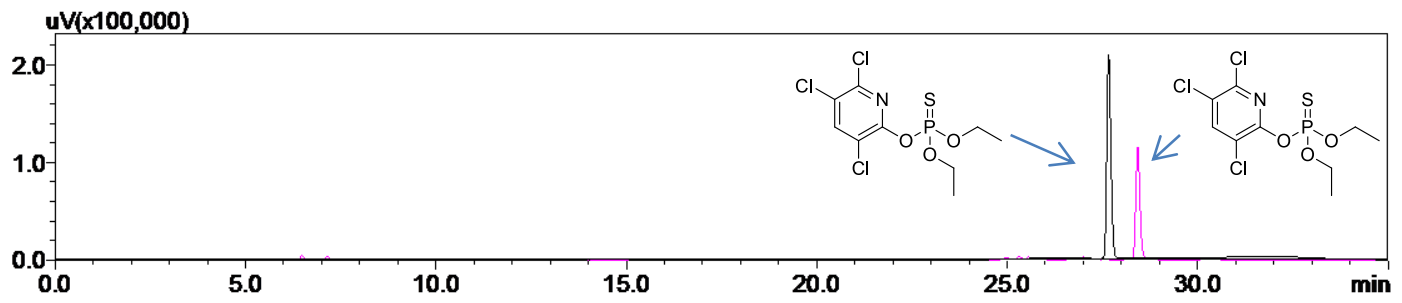

Condições de análise CLAE: ACN/ $\mathrm{H}_{2} \mathrm{O}$ (55:90); fluxo 0,8 mL/ min; $290 \mathrm{~nm} ; \mathrm{t}_{\mathrm{c}}=35 \mathrm{~min}$

Coluna C18 Shimadzu CLC-ODS(M) OD-H $(0.46$ x $25 \mathrm{~cm})$

Figura 18. Cromatogramas sobrepostos obtidos por CLAE-UV da reação com o pesticida comercial clorpirifós (cor rosa) com sinal no tempo de retenção em 28, 500 minutos e o padrão analítico (cor escura) do clorpirifós com sinal no tempo de retenção em 27,800 minutos e concentração de 50 mg.L ${ }^{-1}$.

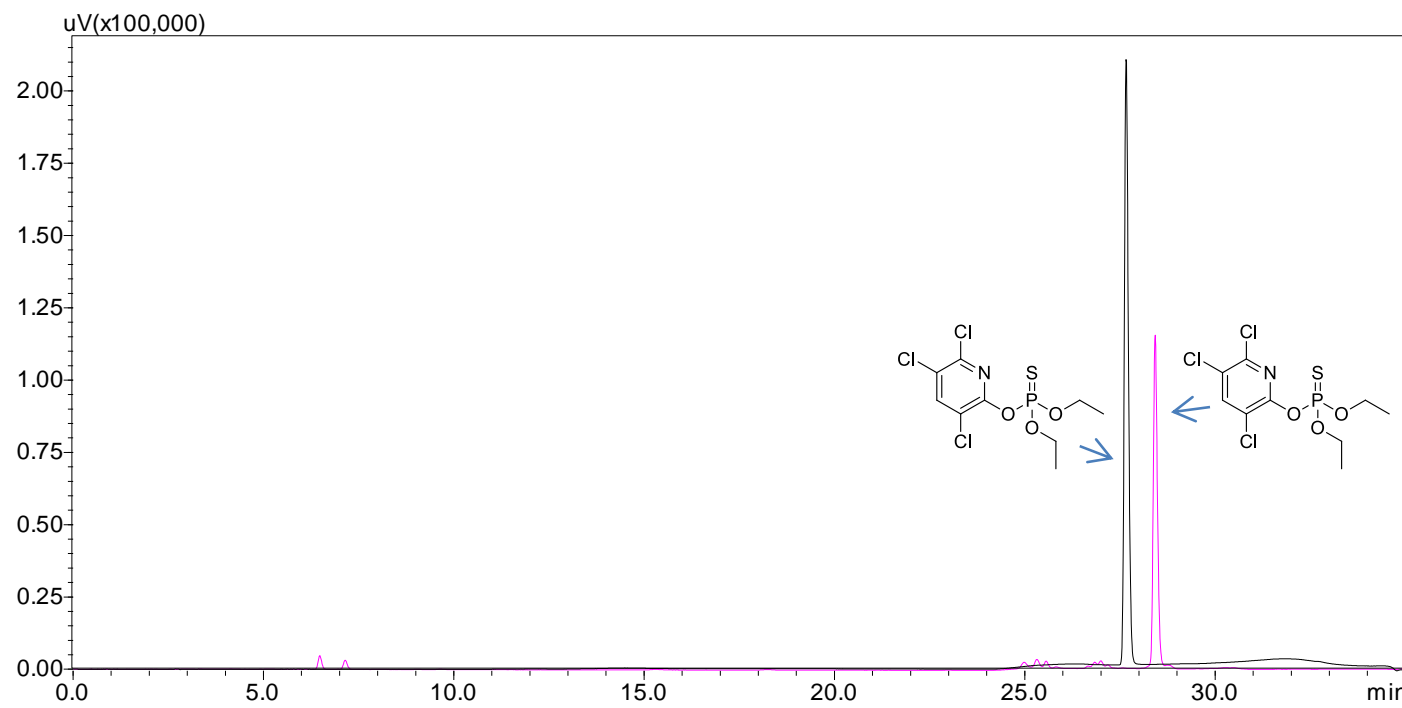

Condições de análise CLAE: ACN/ $\mathrm{H}_{2} \mathrm{O}$ (55:90); fluxo 0,8 mL/ min; $290 \mathrm{~nm}$; $\mathrm{t}_{\mathrm{c}}=35 \mathrm{~min}$

Coluna C18 Shimadzu CLC-ODS(M) OD-H $(0.46$ x $25 \mathrm{~cm})$ 
Figura 19. Cromatograma obtido por CLAE-UV da reação com o padrão analítico do clorpirifós com sinal no tempo de retenção em 27,800 minutos e concentração de $50 \mathrm{mg} . \mathrm{L}^{-1}$.

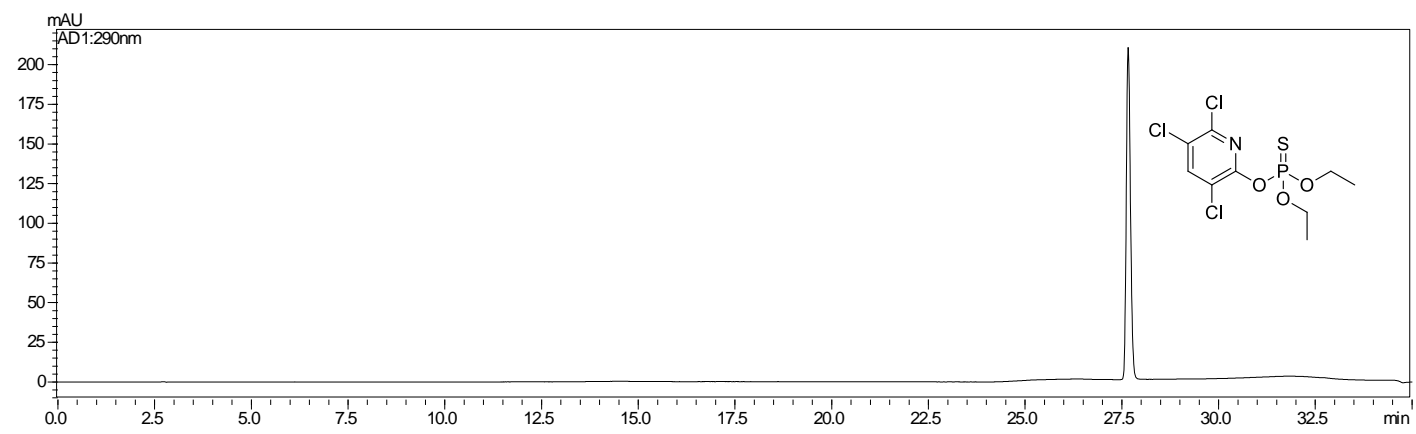

Condições de análise CLAE: ACN/ $\mathrm{H}_{2} \mathrm{O}$ (55:90); fluxo 0,8 mL/ min; $290 \mathrm{~nm} ; \mathrm{t}_{\mathrm{c}}=35 \mathrm{~min}$

Coluna C18 Shimadzu CLC-ODS(M) OD-H (0.46 x 25 cm)

Figura 20. Cromatograma obtido por CLAE-UV da reação com o pesticida comercial clorpirifós com sinal no tempo de retenção em 28,500 minutos.

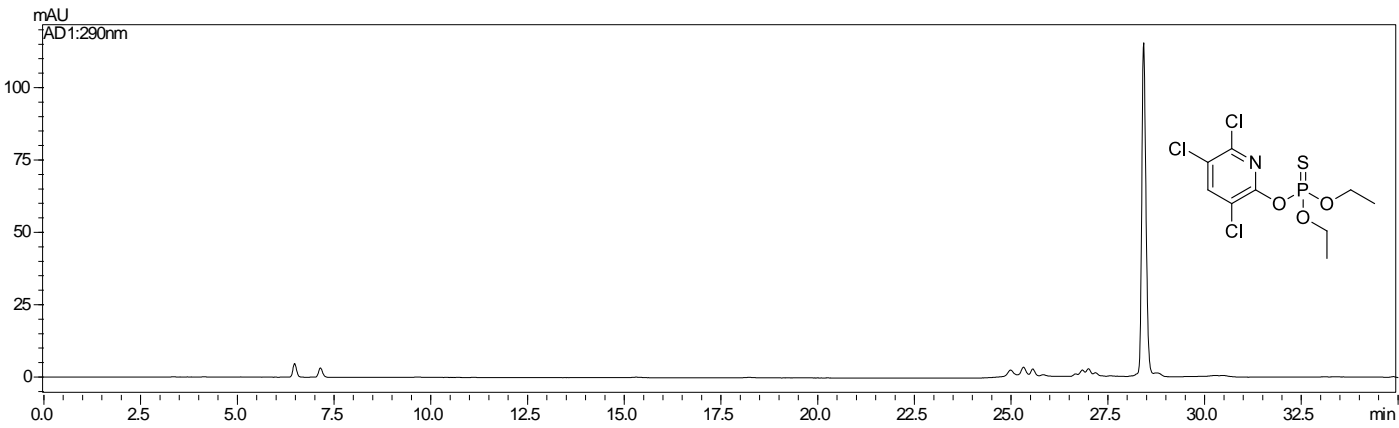

Condições de análise CLAE: ACN/ $\mathrm{H}_{2} \mathrm{O}$ (55:90); fluxo 0,8 mL/ min; $290 \mathrm{~nm} ; \mathrm{t}_{\mathrm{c}}=35 \mathrm{~min}$

Coluna C18 Shimadzu CLC-ODS(M) OD-H (0.46 x $25 \mathrm{~cm})$

Figura 21. Cromatogramas em tamanho reduzido obtidos por CLAE-UV das reações com o pesticida comercial clorpirifós. a) clorpirifós 10 dias de reação b) clorpirifós 20 dias de reação, c) clorpirifós 30 dias de reação. Todos com sinal no tempo de retenção em 28, 500 minutos.

a)

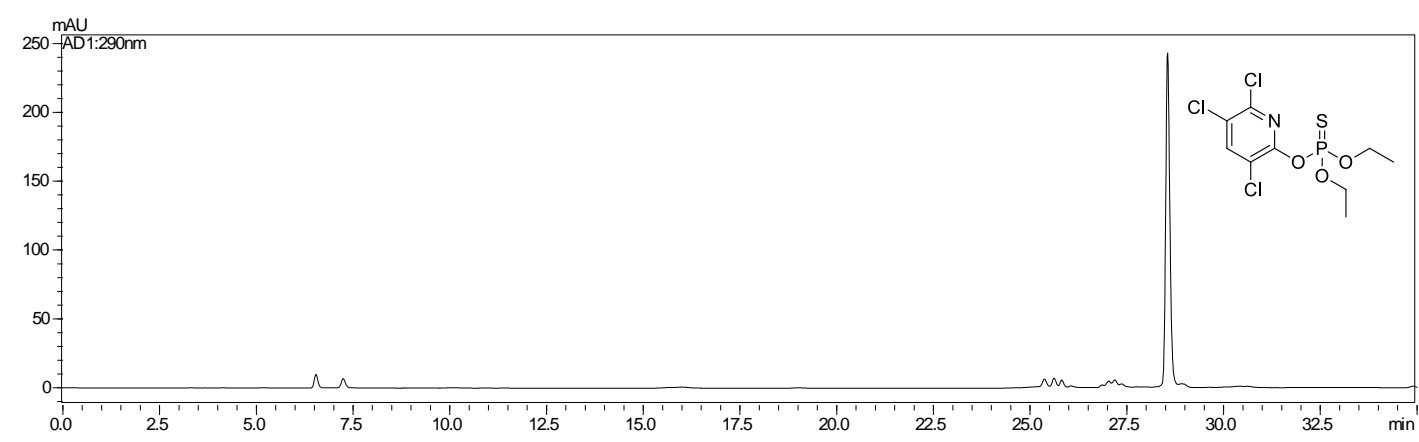


b)

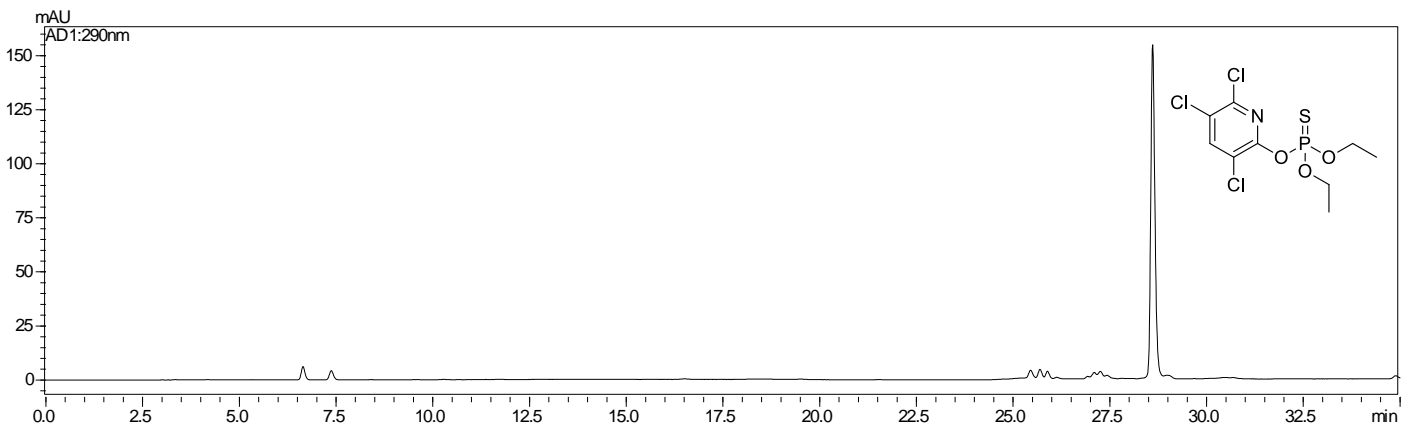

c)

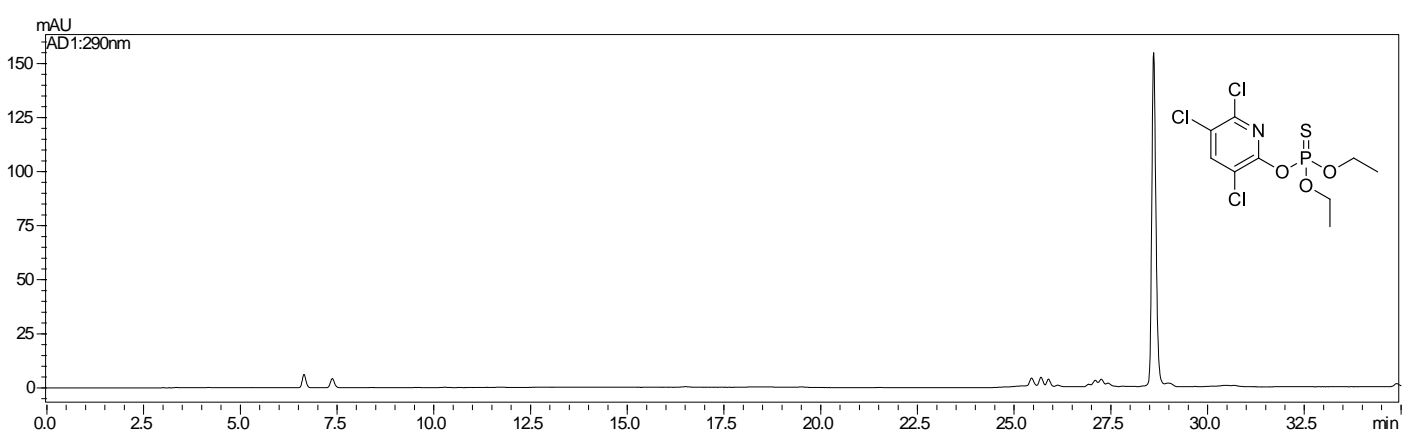

Condições de análise CLAE: ACN/ $\mathrm{H}_{2} \mathrm{O}(55: 90)$; fluxo 0,8 $\mathrm{mL} / \mathrm{min} ; 290 \mathrm{~nm} ; \mathrm{t}_{\mathrm{c}}=35 \mathrm{~min}$

Coluna C18 Shimadzu CLC-ODS(M) OD-H $(0.46$ x $25 \mathrm{~cm})$

Figura 22. Cromatogramas obtidos por CLAE-UV das reações com o pesticida comercial clorpirifós. a) pesticida comercial clorpirifós com $50 \mathrm{mg} . \mathrm{L}^{-1} 10$, b) clorpirifós 10 dias de reação, c) clorpirifós 20 dias de reação, d) clorpirifós com 30 dias de reação com o fungo A. sydowii CBMAI 935. Todos com sinal no tempo de retenção em 28, 500 minutos.

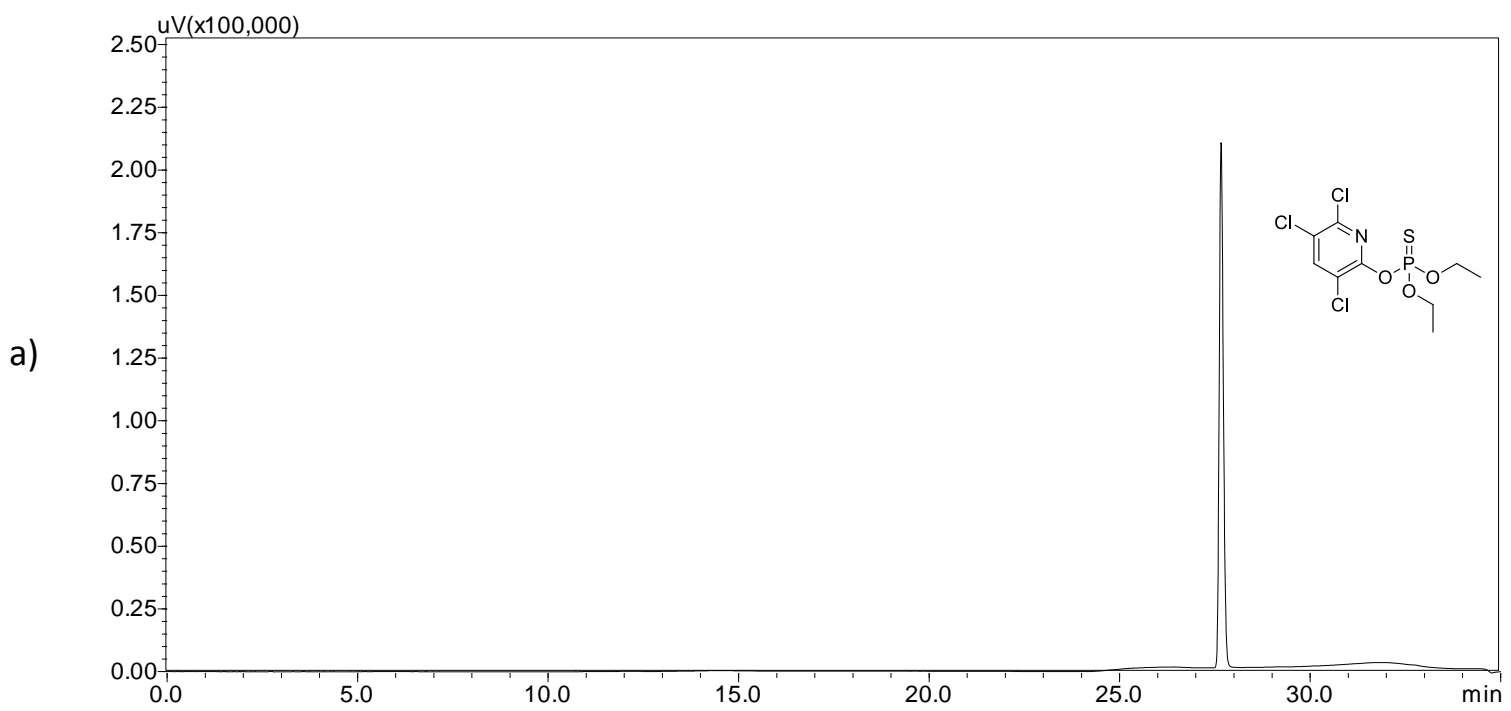




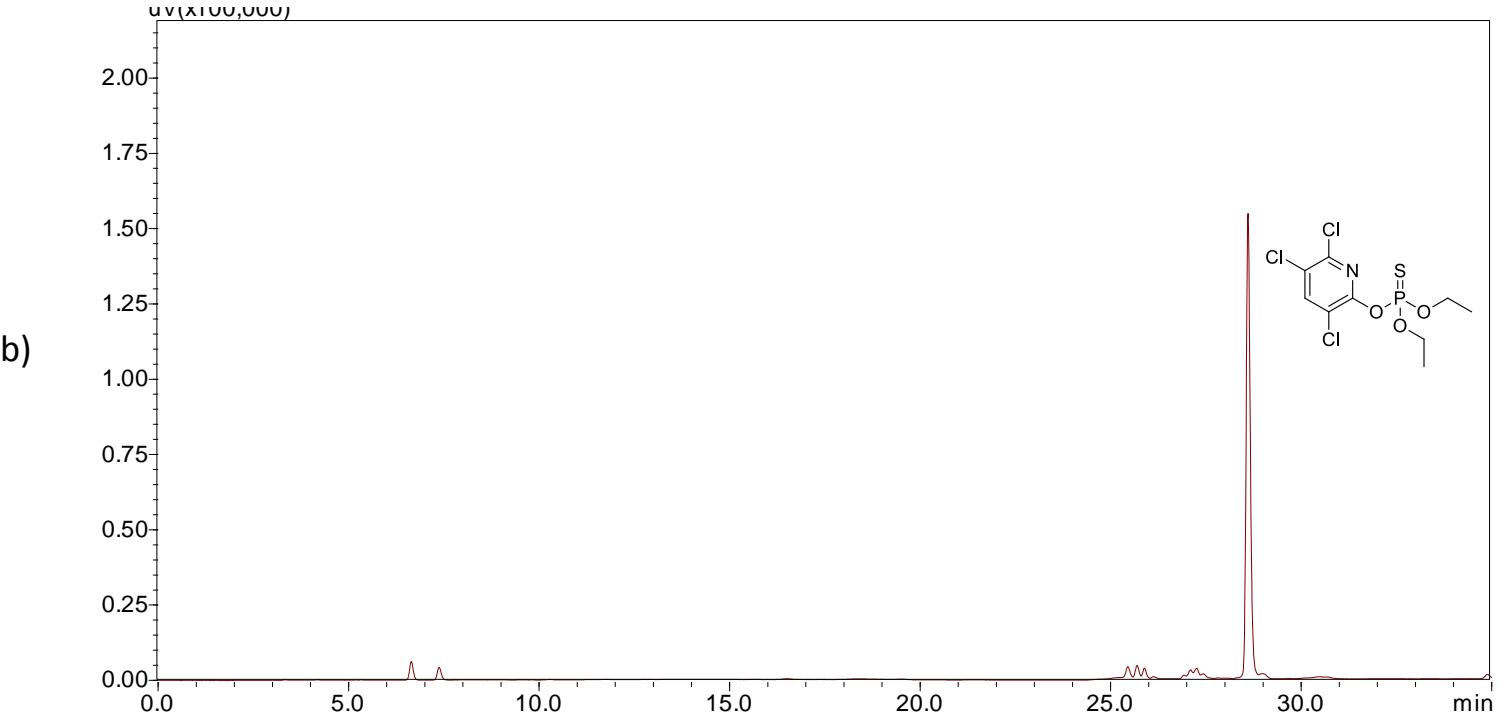

Condições de análise CLAE: ACN/ $\mathrm{H}_{2} \mathrm{O}$ (55:90); fluxo 0,8 mL/ min; $290 \mathrm{~nm} ; \mathrm{t}_{\mathrm{c}}=35 \mathrm{~min}$

Coluna C18 Shimadzu CLC-ODS(M) OD-H (0.46 x $25 \mathrm{~cm})$
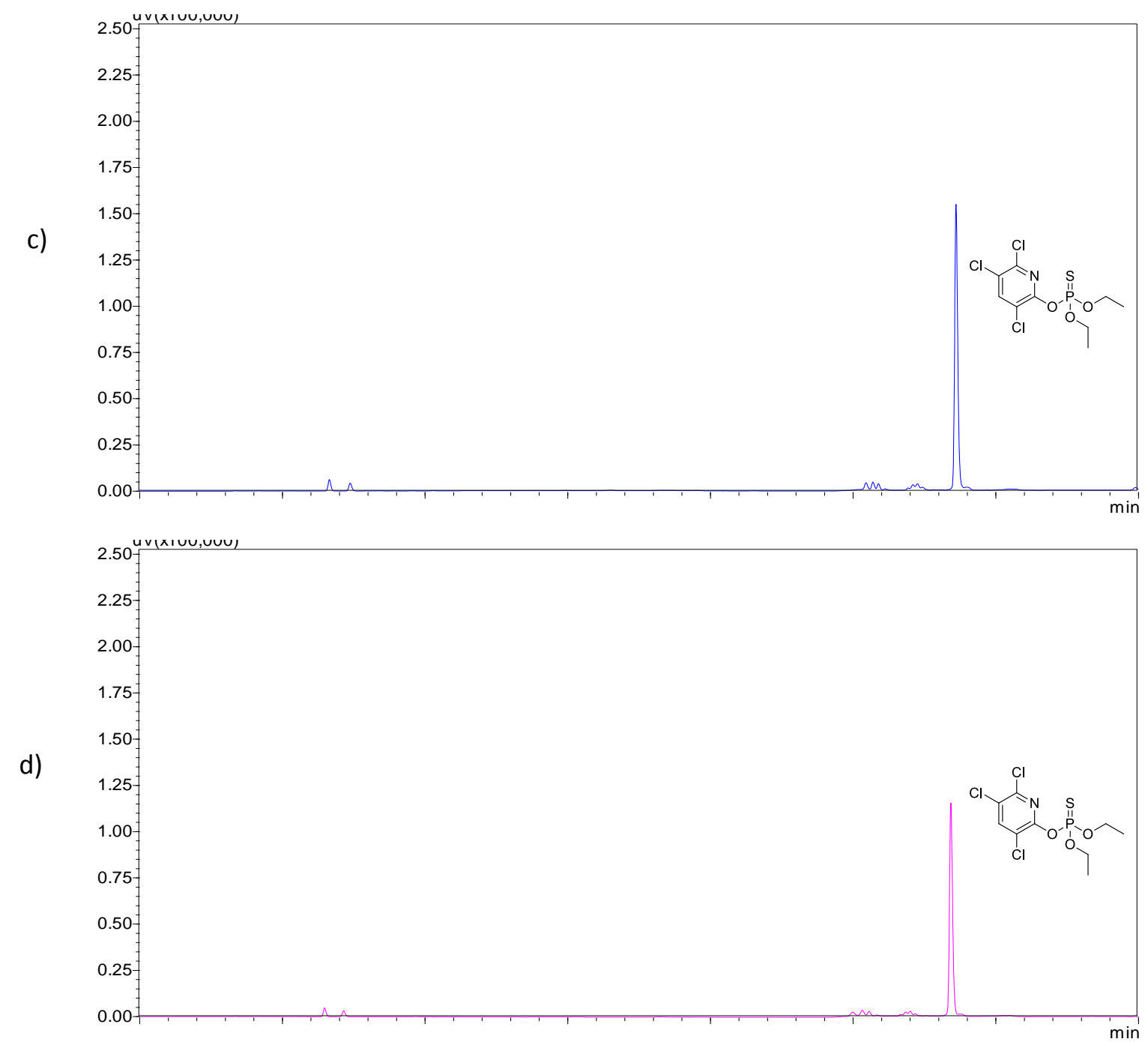

Condições de análise CLAE: ACN/ $\mathrm{H}_{2} \mathrm{O}$ (55:90); fluxo 0,8 mL/ min; $290 \mathrm{~nm} ; \mathrm{t}_{\mathrm{c}}=35 \mathrm{~min}$ Coluna C18 Shimadzu CLC-ODS(M) OD-H $(0.46$ x $25 \mathrm{~cm})$ 
Figura 23. Cromatograma obtido por CLAE-UV de controle para o metabólito 2,3,5-tricloro-6-metoxipiridina com sinal no tempo de retenção em 26,000 minutos.

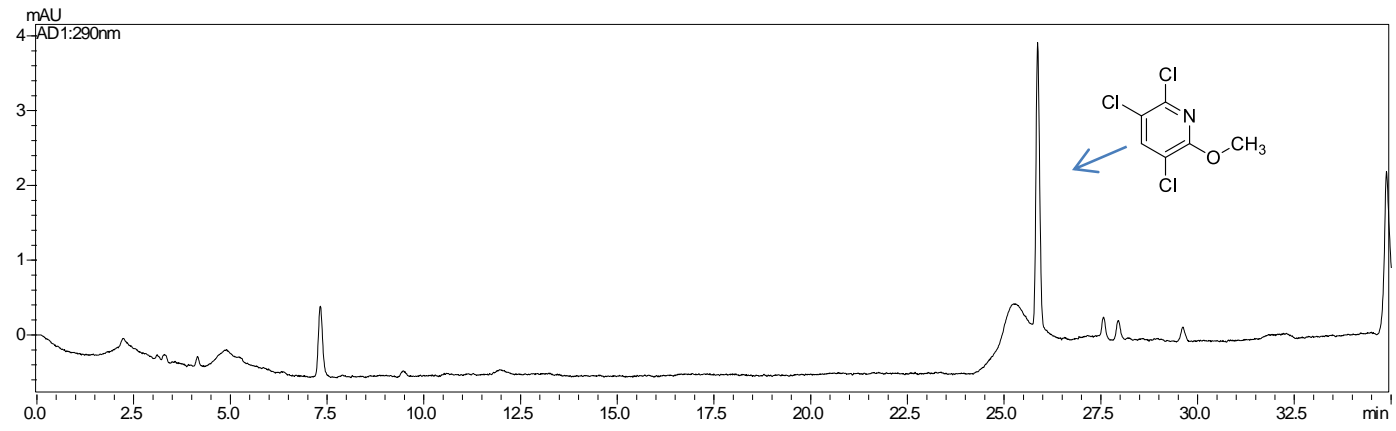

Condições de análise CLAE: ACN/ $\mathrm{H}_{2} \mathrm{O}$ (55:90); fluxo 0,8 mL/ min; $290 \mathrm{~nm}$; $\mathrm{t}_{\mathrm{c}}=35 \mathrm{~min}$

Coluna C18 Shimadzu CLC-ODS(M) OD-H $(0.46$ x $25 \mathrm{~cm})$

Figura 24. Cromatograma obtido por CLAE-UV de controle para o metabólito 3,5,6-tricloro-1-metil-2piridinona com sinal no tempo de retenção em 7, 480 minutos.

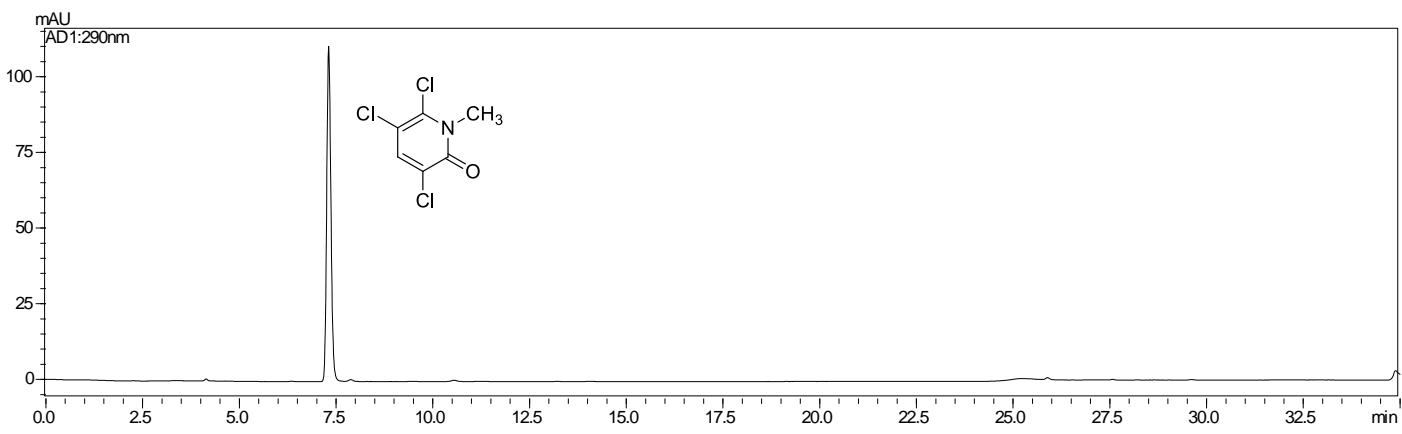

Condições de análise CLAE: ACN/ $\mathrm{H}_{2} \mathrm{O}$ (55:90); fluxo 0,8 mL/ min; $290 \mathrm{~nm}$; $\mathrm{t}_{\mathrm{c}}=35 \mathrm{~min}$ Coluna C18 Shimadzu CLC-ODS(M) OD-H (0.46 x $25 \mathrm{~cm})$

Figura 25. Cromatograma obtido por CLAE-UV de controle para o metabólito 3,5,6-tricloro-2-piridinol com sinal no tempo de retenção em 7, 000 minutos.

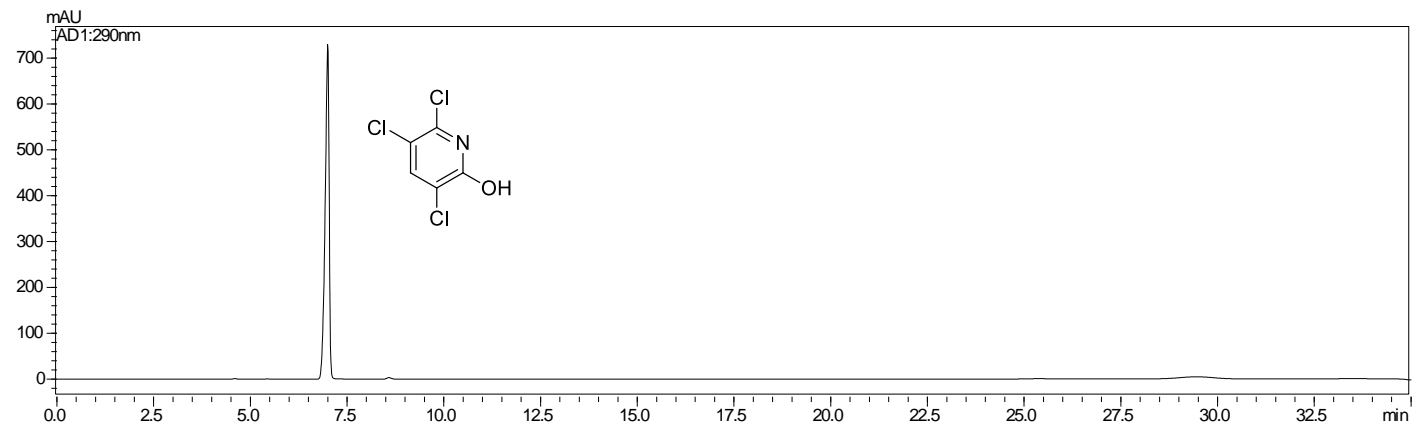

Condições de análise CLAE: ACN/ $\mathrm{H}_{2} \mathrm{O}$ (55:90); fluxo 0,8 mL/ min; $290 \mathrm{~nm} ; \mathrm{t}_{\mathrm{c}}=35 \mathrm{~min}$

Coluna C18 Shimadzu CLC-ODS(M) OD-H (0.46 x 25 cm) 
Figura 26. Cromatogramas sobrepostos obtidos por CLAE-UV do controle do metabólito 3,5,6-tricloro-1-metil2-piridinona na (cor escura) e a reação de biotransformação do pesticida comercial clorpirifós na (cor rosada) com o fungo A. sydowii CBMAI 935 durante 10 dias.

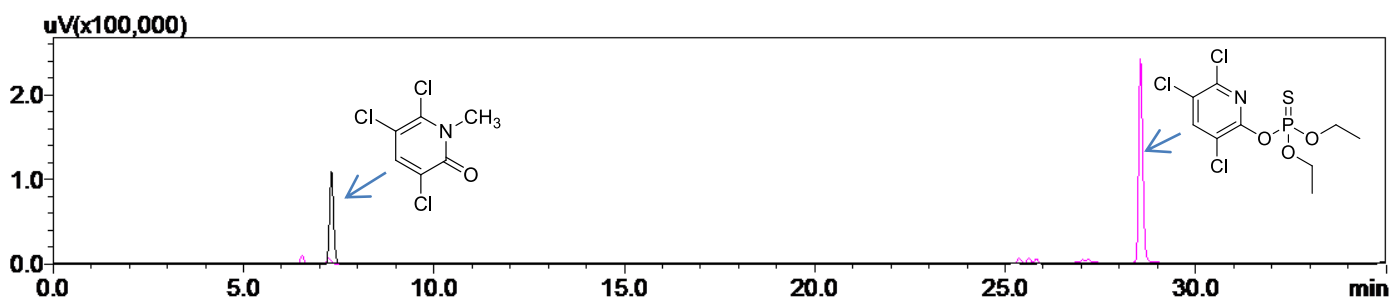

Condições de análise CLAE: ACN/ $\mathrm{H}_{2} \mathrm{O}$ (55:90); fluxo 0,8 mL/ min; $290 \mathrm{~nm}$; $\mathrm{t}_{\mathrm{c}}=35 \mathrm{~min}$

Coluna C18 Shimadzu CLC-ODS(M) OD-H (0.46 x $25 \mathrm{~cm})$

Figura 27. Cromatogramas obtidos por CLAE-UV. a) controle do metabólito 3,5,6-tricloro-1-metil-2-piridinona na (cor escura) e b) reação de biotransformação do pesticida comercial clorpirifós na (cor rosada) com o fungo A. sydowii CBMAI 935 durante 10 dias.

a)
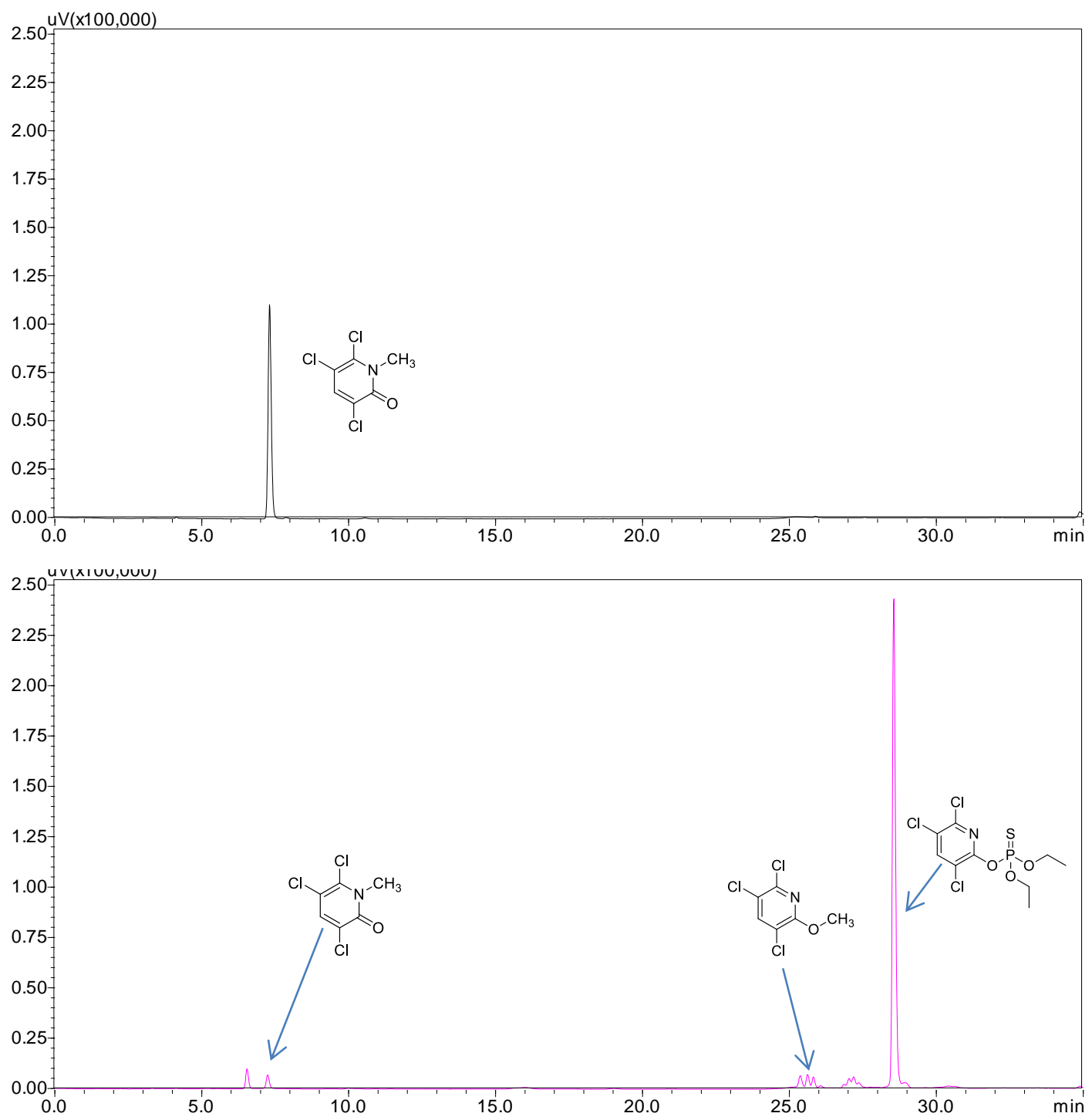

Condições de análise CLAE: ACN/ $\mathrm{H}_{2} \mathrm{O}$ (55:90); fluxo 0,8 mL/ min; $290 \mathrm{~nm} ; \mathrm{t}_{\mathrm{c}}=35 \mathrm{~min}$

Coluna C18 Shimadzu CLC-ODS(M) OD-H $(0.46$ x $25 \mathrm{~cm})$ 
Figura 28. Cromatogramas sobrepostos obtidos por CLAE-UV do controle do metabólito 2,3,5-tricloro-6metoxipiridina (cor escura) e a reação de biotransformação do pesticida comercial clorpirifós na (cor rosada) com o fungo A. sydowii CBMAI 935 durante 10 dias.

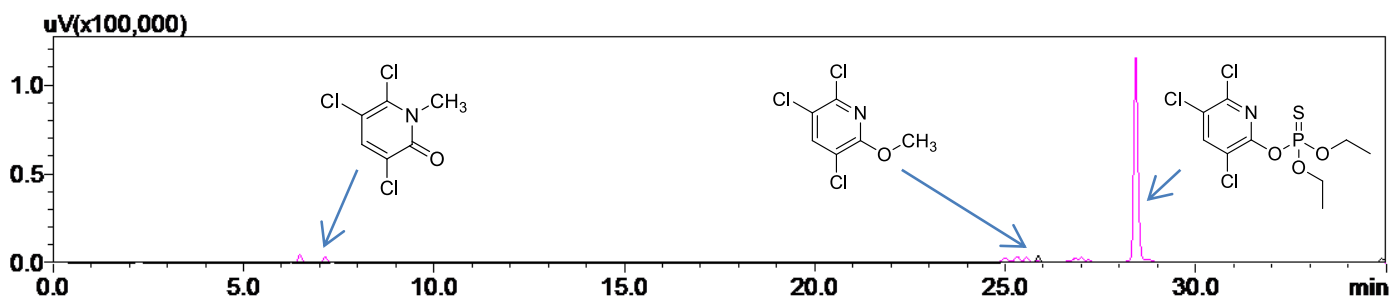

Condições de análise CLAE: ACN/ $\mathrm{H}_{2} \mathrm{O}$ (55:90); fluxo 0,8 mL/ min; $290 \mathrm{~nm}$; $\mathrm{t}_{\mathrm{c}}=35 \mathrm{~min}$

Coluna C18 Shimadzu CLC-ODS(M) OD-H (0.46 x $25 \mathrm{~cm})$

Figura 29. Cromatogramas obtidos por CLAE-UV. a) reação de biotransformação do pesticida comercial clorpirifós na (cor rosada) com o fungo A. sydowii CBMAI 935 durante 10 dias e b) controle do metabólito 2,3,5-tricloro-6-metoxipiridina na (cor escura)
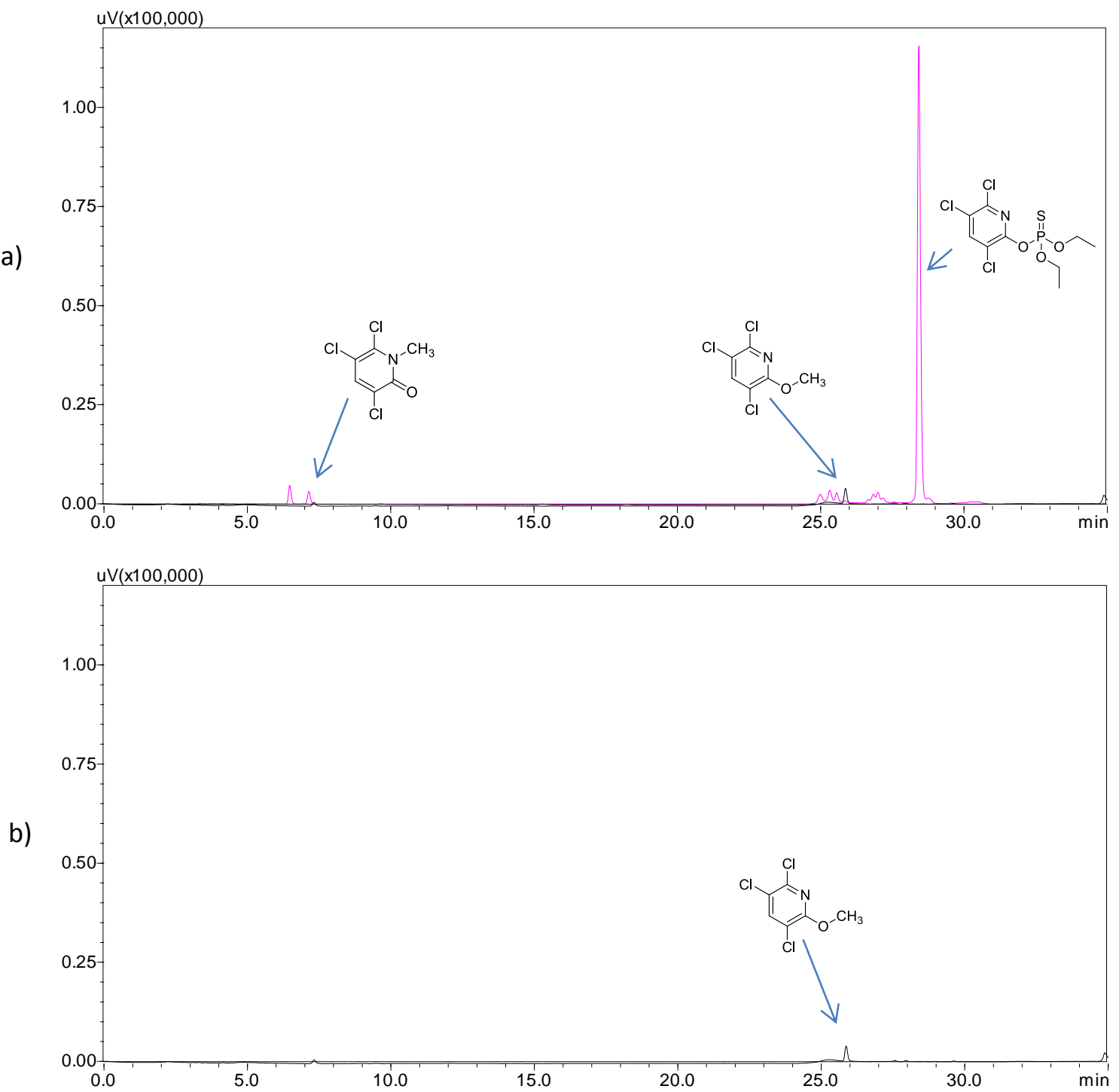

Condições de análise CLAE: ACN/ $\mathrm{H}_{2} \mathrm{O}$ (55:90); fluxo 0,8 mL/ min; $290 \mathrm{~nm} ; \mathrm{t}_{\mathrm{c}}=35 \mathrm{~min}$

Coluna C18 Shimadzu CLC-ODS(M) OD-H (0.46 x 25 cm) 
Tabelas de dados de quantificação obtidos por CLAE-UV das reações entre o composto fenólico 3,5,6-tricloro-2-piridinol com o fungo de ambiente marinho A. sydowii CBMAI 935 em 10, 20 e 30 dias de reação de biotransformação em meio de cultura líquido de malte a $2 \%$

Tabela 21. Quantificação da biodegradação do 3,5,6-tricloro-2-piridinol por A. sydowii CBMAI 935 em 10 dias de reação $\left(32^{\circ} \mathrm{C}, 130 \mathrm{~g}, \mathrm{pH} 7,0\right)$.

\begin{tabular}{cccc}
\hline & A. sydowii CBMAI 935 (50 $\mathbf{~ m g . L ^ { - \mathbf { 1 } }}$ de 3,5,6-tricloro-2-piridinol) \\
\hline $\begin{array}{c}\text { Reações em } \\
\text { duplicata }\end{array}$ & Massa fúngica seca $(\mathrm{g})$ & $\mathrm{c}^{\text {a }}$ metabólito & \% de metabólito degradado \\
Reação 1 & 0,34 & 17 & 100 \\
Reação 2 & 0,33 & 15 & 100 \\
\hline
\end{tabular}

$\mathrm{c}^{\mathrm{a}}=$ concentração (dados obtidos de duplicatas) determinados por CLAE-UV.

Tabela 22. Quantificação da biodegradação do 3,5,6-tricloro-2-piridinol por A. sydowii CBMAI 935 em 20 dias de reação $\left(32^{\circ} \mathrm{C}, 130 \mathrm{~g}, \mathrm{pH} 7,0\right)$.

\begin{tabular}{|c|c|c|c|}
\hline \multicolumn{4}{|c|}{ A. sydowii CBMAI 935 (50 mg.L $\mathrm{L}^{-1}$ de 3,5,6-tricloro-2-piridinol) } \\
\hline $\begin{array}{c}\text { Reações em } \\
\text { duplicata }\end{array}$ & Massa fúngica seca (g) & $\mathrm{c}^{\mathrm{a}}$ metabólito & $\%$ de metabólito degradado \\
\hline Reação 1 & 0,34 & 16 & 100 \\
\hline Reação 2 & 0,33 & 18 & 100 \\
\hline
\end{tabular}

$c^{\mathrm{a}}=$ concentração (dados obtidos de duplicatas) determinados por CLAE-UV.

Tabela 23. Quantificação da biodegradação do 3,5,6-tricloro-2-piridinol por A. sydowii CBMAI 935 em 30 dias de reação $\left(32^{\circ} \mathrm{C}, 130 \mathrm{~g}, \mathrm{pH} 7,0\right)$.

\begin{tabular}{cccc}
\hline & A. sydowii CBMAI 935 (50 $\mathbf{~ m g . L ^ { - \mathbf { 1 } }}$ de 3,5,6-tricloro-2-piridinol) \\
\hline $\begin{array}{c}\text { Reações em } \\
\text { duplicata }\end{array}$ & Massa fúngica seca $(\mathrm{g})$ & $\mathrm{c}^{\text {a }}$ metabólito & \% de metabólito degradado \\
Reação 1 & 0,36 & & 100 \\
Reação 2 & 0,38 & 15 & 100 \\
\hline
\end{tabular}

$\mathrm{c}^{\mathrm{a}}=$ concentração (dados obtidos de duplicatas) determinados por CLAE-UV. 
Cromatogramas obtidos por CLAE-UV das reações de biotranformação entre o composto fenólico 3,5,6-tricloro-2-piridinol com o fungo de ambiente marinho $A$. sydowii CBMAI 935 em 10, 20 e 30 dias de crescimento em meio de cultura líquido de malte a $2 \%$

Figura 30. Cromatogramas obtidos por CLAE-UV das reações de biotransformação do composto fenólico 3,5,6-tricloro-2-piridinol com o fungo A. sydowii CBMAI 935 em a) 10 dias de reação, b) 20 dias de reação e c) 30 dias de reação.

a)

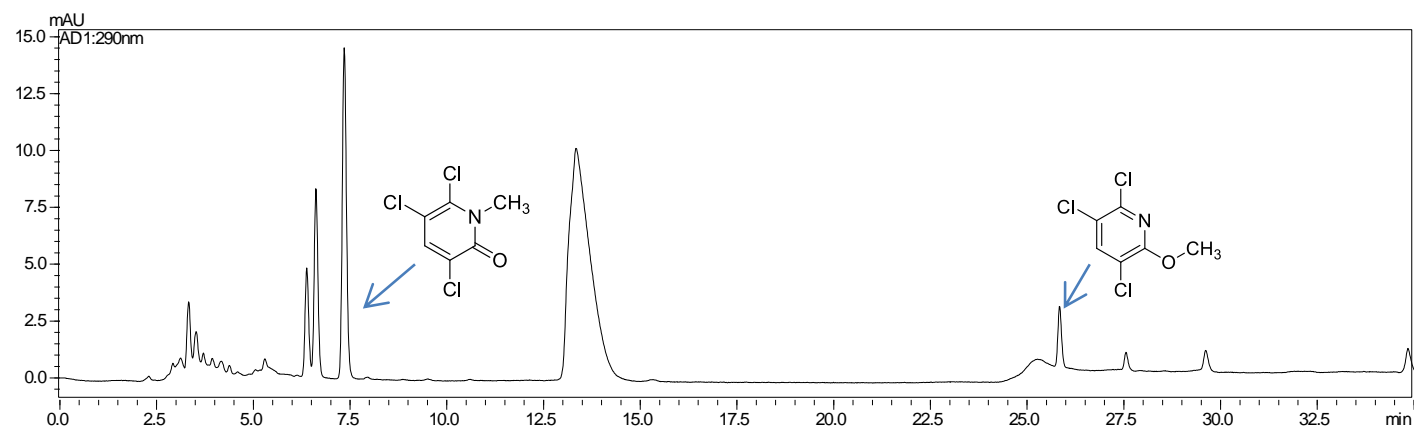

b)

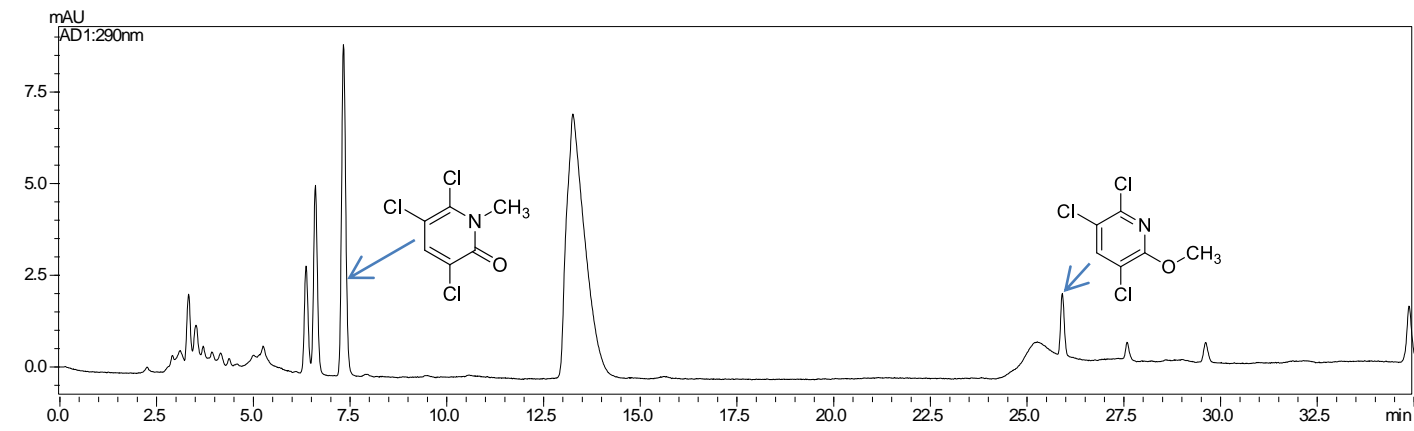

c)

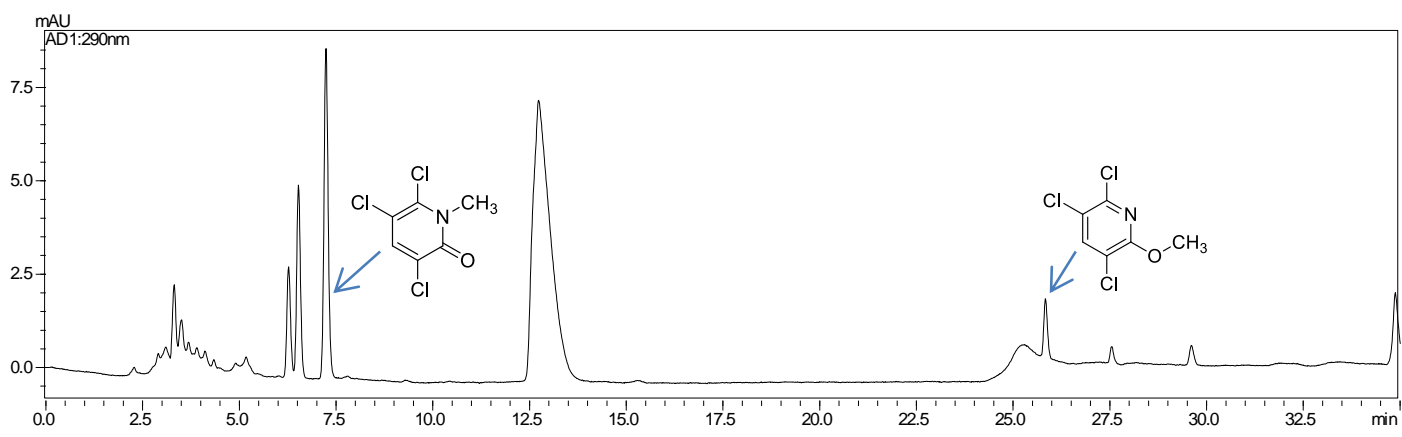

Condições de análise CLAE: ACN/ $\mathrm{H}_{2} \mathrm{O}$ (55:90); fluxo 0,8 mL/ min; $290 \mathrm{~nm} ; \mathrm{t}_{\mathrm{c}}=35 \mathrm{~min}$

Coluna C18 Shimadzu CLC-ODS(M) OD-H (0.46 x 25 cm) 
Figura 31. Cromatogramas sobrepostos obtidos por CLAE-UV do controle do metabólito 3,5,6-tricloro-1-metil2-piridinona na (cor escura) e a reação de biotransformação do composto fenólico3,5,6-tricloro-2-piridinol na (cor rosada) com o fungo A. sydowii CBMAI 935 durante 10 dias.

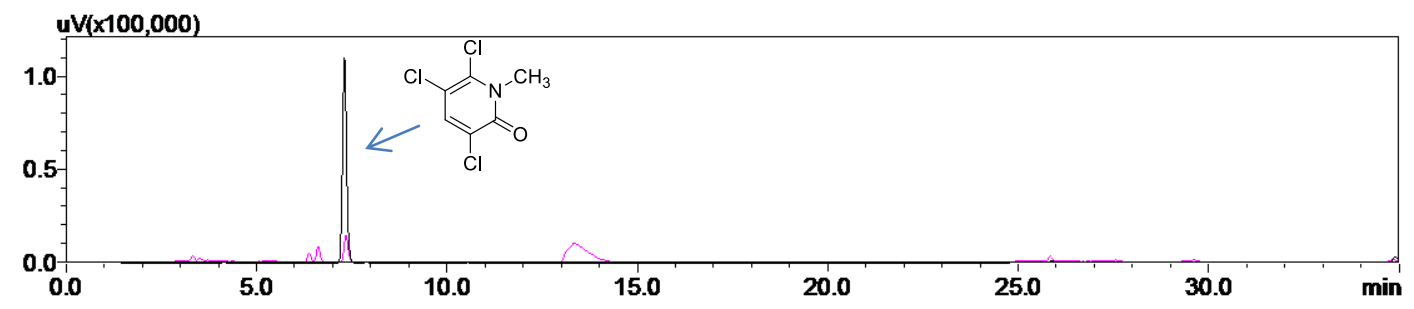

Condições de análise CLAE: ACN/ $\mathrm{H}_{2} \mathrm{O}$ (55:90); fluxo 0,8 mL/ min; $290 \mathrm{~nm} ; \mathrm{t}_{\mathrm{c}}=35 \mathrm{~min}$

Coluna C18 Shimadzu CLC-ODS(M) OD-H (0.46 x $25 \mathrm{~cm})$

Figura 32. Cromatogramas ampliados obtidos por CLAE-UV. a) controle do metabólito 3,5,6-tricloro-1-metil-2piridinona na (cor escura) e b) reação de biotransformação do composto fenólico3,5,6-tricloro-2-piridinol na (cor rosada) com o fungo A. sydowii CBMAI 935 durante 10 dias.
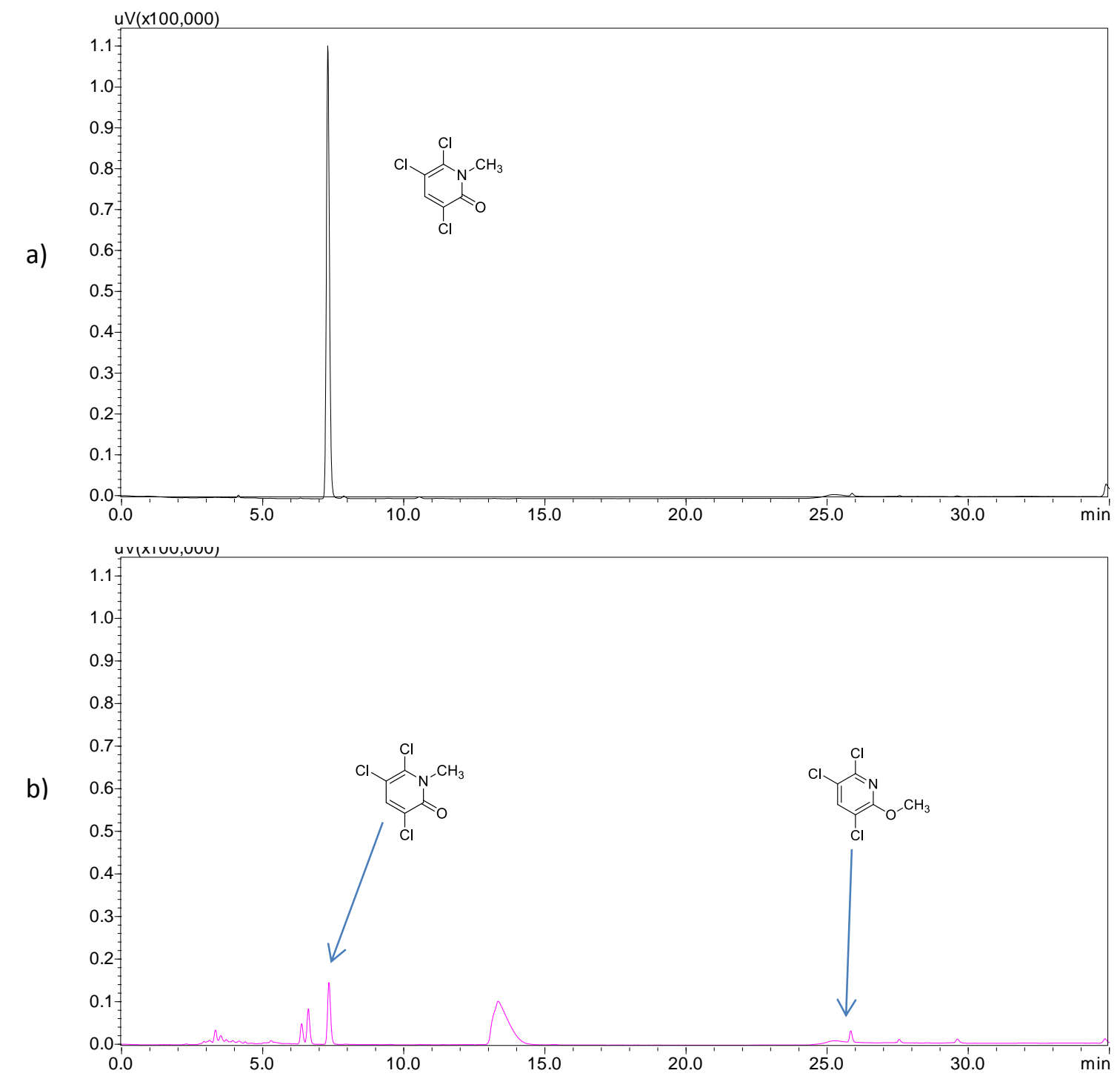

Condições de análise CLAE: ACN/ $\mathrm{H}_{2} \mathrm{O}$ (55:90); fluxo 0,8 mL/ min; $290 \mathrm{~nm} ; \mathrm{t}_{\mathrm{c}}=35 \mathrm{~min}$

Coluna C18 Shimadzu CLC-ODS(M) OD-H (0.46 x 25 cm) 
Figura 33. Cromatogramas sobrepostos obtidos por CLAE-UV do controle do metabólito 2,3,5-tricloro-6metoxipiridina na (cor escura) e a reação de biotransformação do composto fenólico3,5,6-tricloro-2-piridinol na (cor rosada) com o fungo A. sydowii CBMAI 935 durante 10 dias.

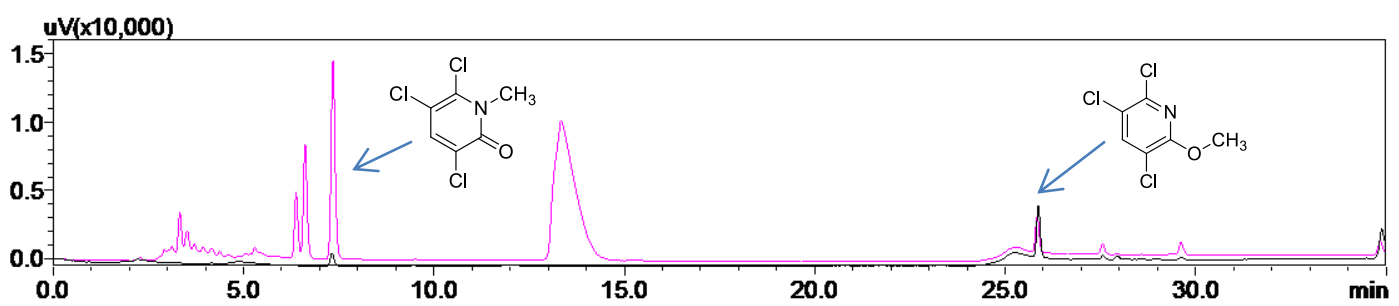

Condições de análise CLAE: ACN/ $\mathrm{H}_{2} \mathrm{O}$ (55:90); fluxo 0,8 mL/ min; $290 \mathrm{~nm}$; $\mathrm{t}_{\mathrm{c}}=35 \mathrm{~min}$

Coluna C18 Shimadzu CLC-ODS(M) OD-H (0.46 x $25 \mathrm{~cm})$

Figura 34. Cromatogramas ampliados obtidos por CLAE-UV. a) controle do metabólito2,3,5-tricloro-6metoxipiridina na (cor escura) e b) reação de biotransformação do composto fenólico3,5,6-tricloro-2-piridinol na (cor rosada) com o fungo A. sydowii CBMAI 935 durante 10 dias.
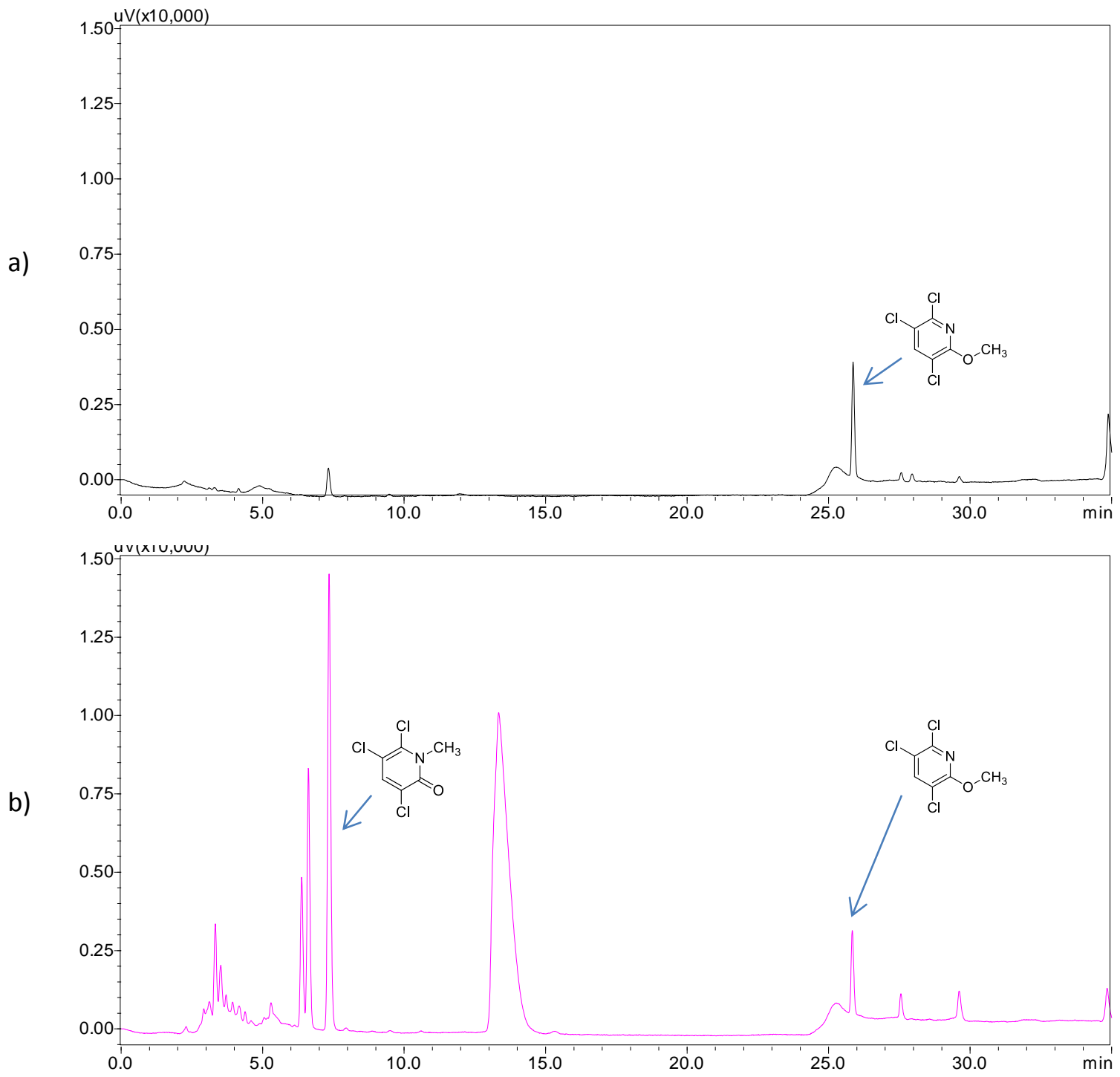

Condições de análise CLAE: ACN/ $\mathrm{H}_{2} \mathrm{O}$ (55:90); fluxo 0,8 mL/ min; $290 \mathrm{~nm}$; $\mathrm{t}_{\mathrm{c}}=35 \mathrm{~min}$

Coluna C18 Shimadzu CLC-ODS(M) OD-H $(0.46$ x $25 \mathrm{~cm})$ 
Tabelas de dados de quantificação obtidos por CLAE-UV das reações entre o pesticida metil paration com o fungo de ambiente marinho A. sydowii CBMAI 935 em 10, 20 e 30 dias de reação de biotransformação em meio de cultura líquido de malte a $2 \%$

Tabela 24. Quantificação da biodegradação de metil paration por A. sydowii CBMAI 935 em 10 dias de reação $\left(32^{\circ} \mathrm{C}, 130 \mathrm{~g}, \mathrm{pH} 7,0\right)$.

\begin{tabular}{ccccc}
\hline \multicolumn{5}{c}{ A. sydowii CBMAI 935 (50 $\mathbf{~ m g . L}^{\mathbf{- 1}}$ de metil paration) } \\
\hline $\begin{array}{c}\text { Reações em } \\
\text { duplicata }\end{array}$ & $\begin{array}{c}\text { Massa fúngica seca } \\
\text { ( })\end{array}$ & $\mathrm{c}^{\mathrm{a}}$ metabólito & $\begin{array}{c}\mathrm{c}^{\mathrm{a}} \text { metil } \\
\text { paration }\end{array}$ & $\%$ de metil paration degradado \\
Reação 1 & 0,29 & 5 & $15^{\mathrm{b}}$ & 60 \\
Reação 2 & 0,25 & 3 & $18^{\mathrm{b}}$ & 58 \\
\hline $\mathrm{c}^{\mathrm{a}}=$ concentração (dados obtidos de duplicatas) determinados por CLAE-UV. \\
b concentração estimada
\end{tabular}

Tabela 25. Quantificação da biodegradação de metil paration por A. sydowii CBMAI 935 em 20 dias de reação $\left(32^{\circ} \mathrm{C}, 130 \mathrm{~g}, \mathrm{pH} 7,0\right)$.

\begin{tabular}{lcccc}
\hline \multicolumn{4}{c}{ A. sydowii CBMAI 935 $\mathbf{~} \mathbf{5 0} \mathbf{~ m g . L}^{\mathbf{- 1}}$ de metil paration) } \\
\hline $\begin{array}{c}\text { Reações em } \\
\text { duplicata }\end{array}$ & $\begin{array}{c}\text { Massa fúngica } \\
\text { seca }(\mathrm{g})\end{array}$ & $\mathrm{c}^{\mathrm{a}}$ metabólito & $\begin{array}{c}\mathrm{c}^{\mathrm{a}} \text { metil } \\
\text { paration }\end{array}$ & $\begin{array}{c}\text { \% de metil paration } \\
\text { degradado }^{\mathrm{b}}\end{array}$ \\
Reação 1 & 0,26 & 3 & 15 & 65 \\
Reação 2 (caldo enzimático) & - & 4 & 14 & 65 \\
Reação 2 (células) & 0,27 & $3^{\mathrm{c}}$ & 10 & 70 \\
\hline
\end{tabular}

$\mathrm{c}^{\mathrm{a}}=$ concentração (dados obtidos de duplicatas) determinados por CLAE-UV.

${ }^{\mathrm{b}}$ total de metil paration degradado (caldo + células)

${ }^{\mathrm{c}}$ concentração estimada

Tabela 26. Quantificação da biodegradação de metil paration por A. sydowii CBMAI 935 em 30 dias de reação $\left(32^{\circ} \mathrm{C}, 130 \mathrm{~g}, \mathrm{pH} 7,0\right)$

\begin{tabular}{|c|c|c|c|c|}
\hline \multicolumn{5}{|c|}{ A. sydowii CBMAI 935 (50 mg.L - $^{-1}$ de metil paration) } \\
\hline $\begin{array}{c}\text { Reações em } \\
\text { duplicata }\end{array}$ & $\begin{array}{l}\text { Massa fúngica seca } \\
(\mathrm{g})\end{array}$ & $\mathrm{c}^{\mathrm{a}}$ metabólito & $\mathrm{c}^{\mathrm{a}}$ metil paration & $\begin{array}{c}\% \text { de metil paration } \\
\text { degradado }\end{array}$ \\
\hline Reação 1 & 0,24 & $2^{\mathrm{b}}$ & 8 & 80 \\
\hline Reação 2 & 0,24 & $1^{\mathrm{b}}$ & 9 & 80 \\
\hline
\end{tabular}


Cromatogramas obtidos por CLAE-UV das reações de biotranformação entre o pesticida metil paration com o fungo de ambiente marinho A. sydowii CBMAI 935 em 10, 20 e 30 dias de crescimento em meio de cultura líquido de malte a $2 \%$

Figura 35. Cromatogramas em tamanho reduzido obtidos por CLAE-UV das reações com o pesticida metil paration. a) padrão metil paration com $50 \mathrm{mg} . \mathrm{L}^{-1}$, b) metil paration 10 dias de reação, c) metil paration 20 dias de reação, d) metil paration 30 dias de reação com o fungo A. sydowii CBMAI 935. Todos com sinal no tempo de retenção em 26, 522 minutos.

a) 200 mAU - AD $1: 274 \mathrm{~nm}$

300

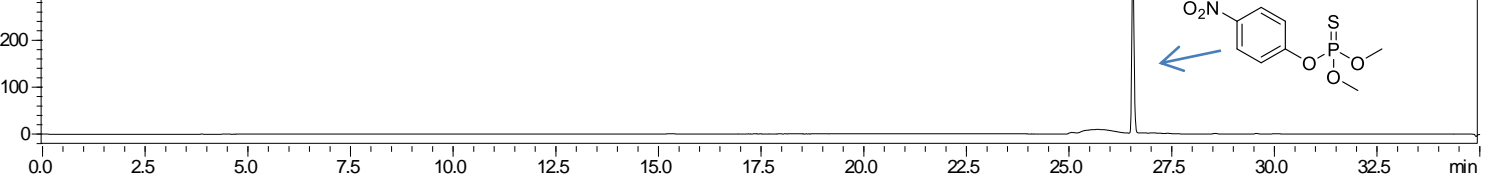

b)

$$
{ }_{50}^{\text {mAU }}
$$
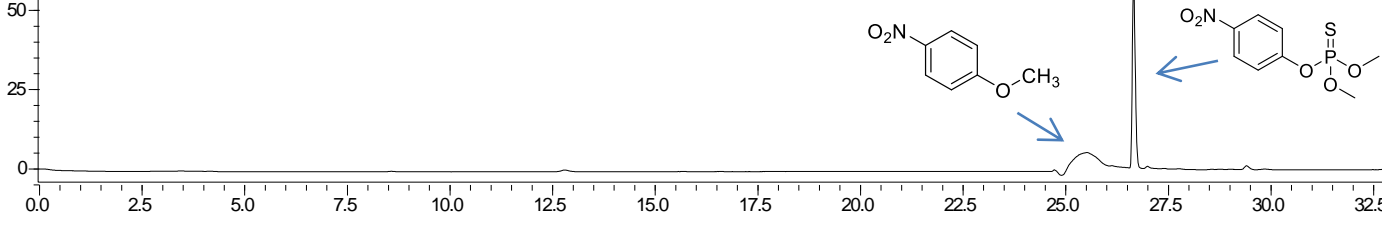$$
\mathrm{mAU}
$$$$
\text { AD 1:274nm }
$$

c)

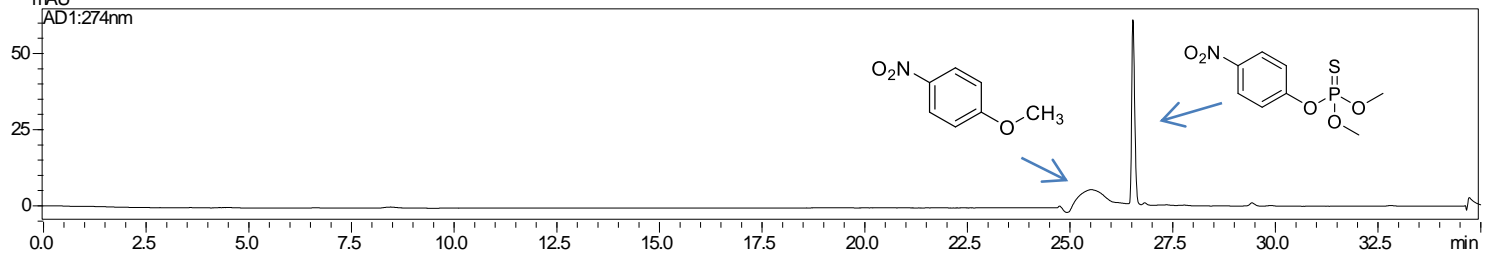

d)

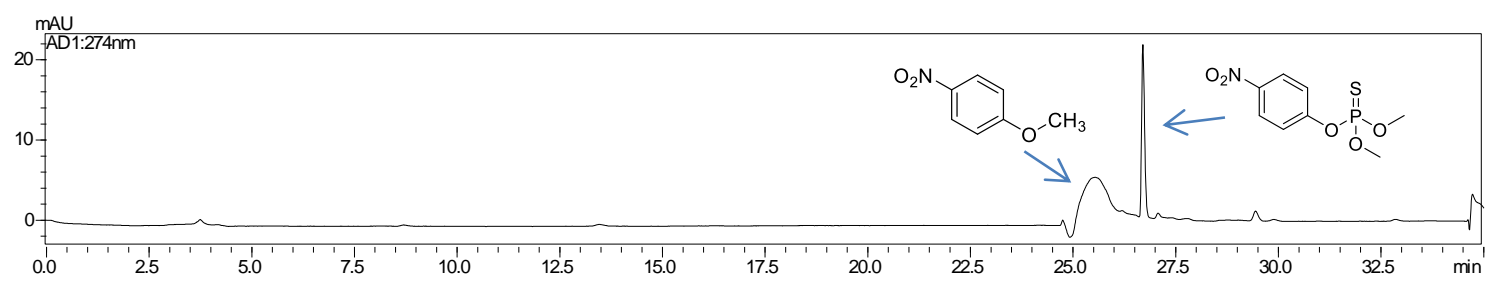

Condições de análise CLAE: ACN/ $\mathrm{H}_{2} \mathrm{O}$ (30:90); fluxo 0,8 mL/ min; $273 \mathrm{~nm}$; $\mathrm{t}_{\mathrm{c}}=35 \mathrm{~min}$

Coluna C18 Shimadzu CLC-ODS(M) OD-H (0.46 x 25 cm) 
Figura 36. Cromatogramas em tamanho real obtidos por CLAE-UV das reações de controle para o metil paration, a) padrão metil paration com $50 \mathrm{mg} . \mathrm{L}^{-1}$, b) metil paration 10 dias de reação, c) metil paration 20 dias de reação, d) metil paration 30 dias de reação. Todos com sinal no tempo de retenção em 26, 522 minutos.

a)

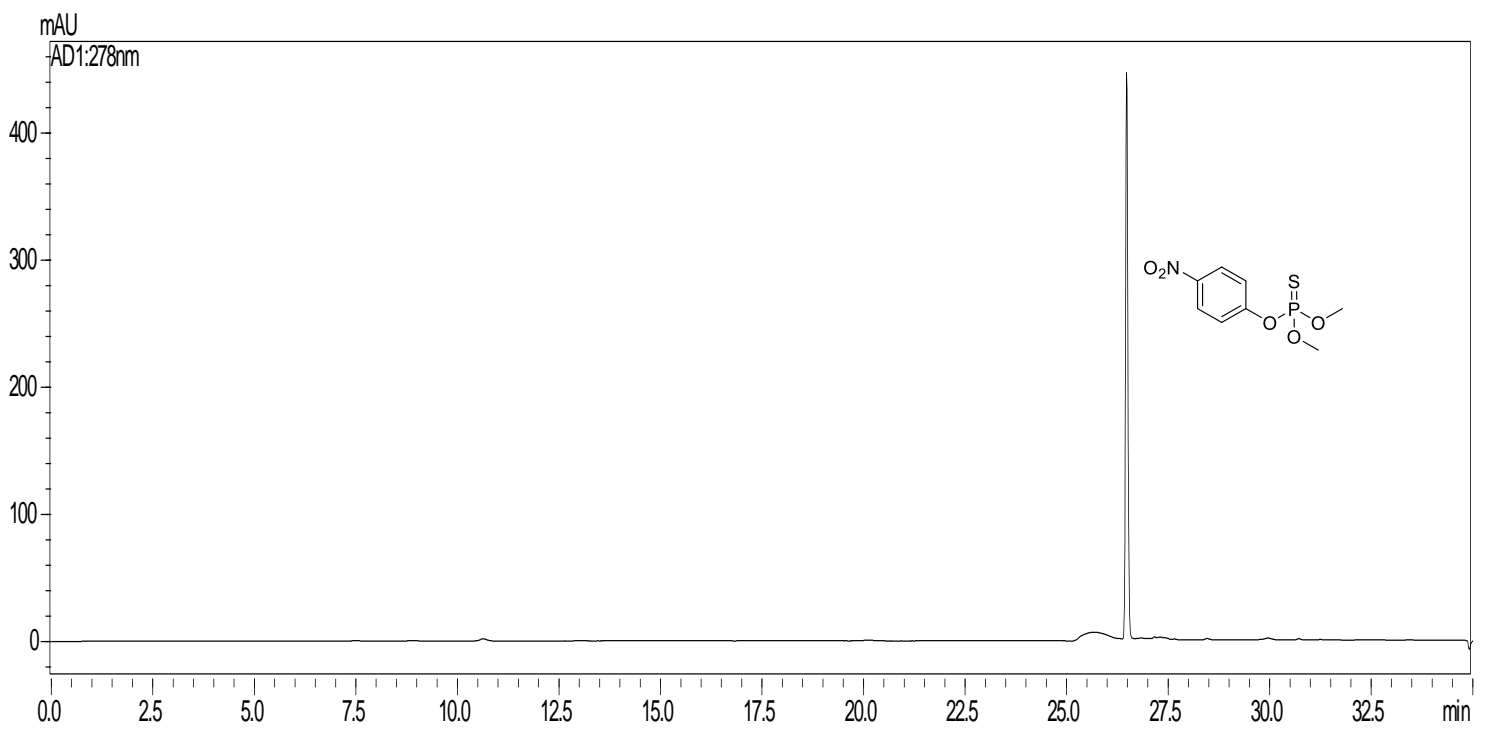

uv(xivu,uvu)

4.0

3.5

3.0

2.5

b)

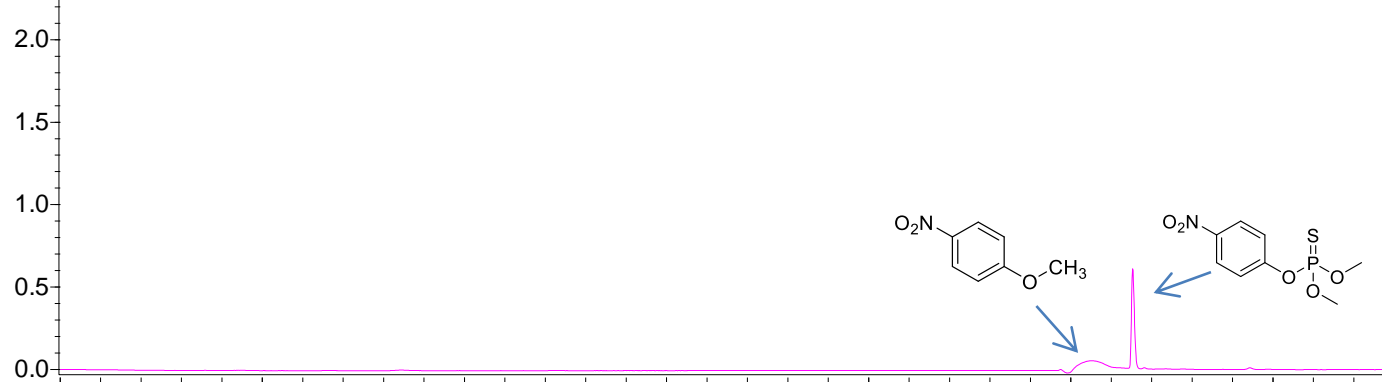

Condições de análise CLAE: ACN/ $\mathrm{H}_{2} \mathrm{O}$ (30:90); fluxo 0,8 mL/ min; $273 \mathrm{~nm} ; \mathrm{t}_{\mathrm{c}}=35 \mathrm{~min}$ Coluna C18 Shimadzu CLC-ODS(M) OD-H (0.46 x $25 \mathrm{~cm})$ 


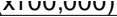

4.0

3.5

3.0

2.5

c)
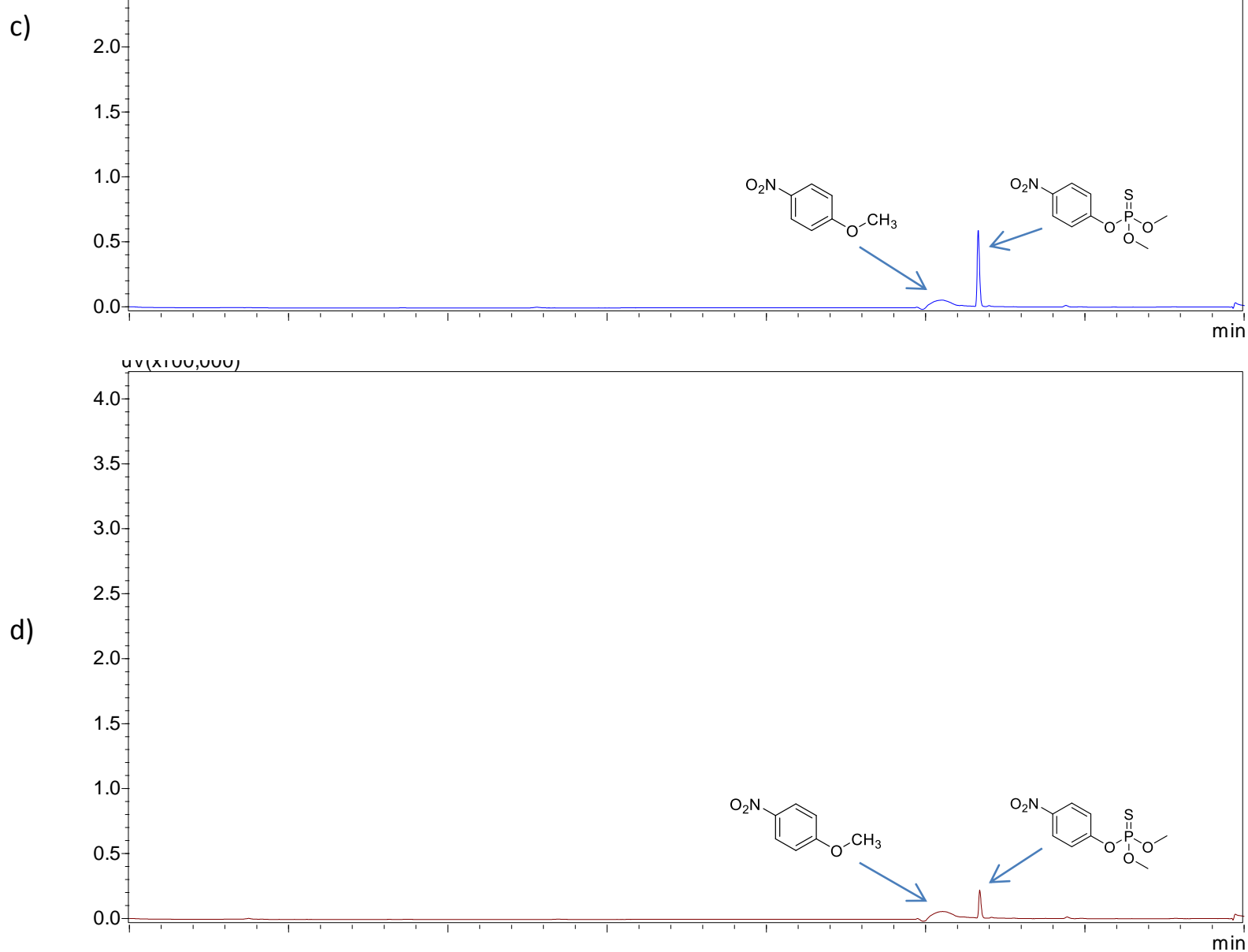

Condições de análise CLAE: ACN/ $\mathrm{H}_{2} \mathrm{O}$ (30:90); fluxo 0,8 mL/ min; $273 \mathrm{~nm} ; \mathrm{t}_{\mathrm{c}}=35 \mathrm{~min}$ Coluna C18 Shimadzu CLC-ODS(M) OD-H $(0.46$ x $25 \mathrm{~cm})$

Figura 37. Cromatograma obtido por CLAE-UV do controle para o metabólito 1-metoxi-4-nitrobenzeno com $50 \mathrm{mg} \cdot \mathrm{L}^{-1}$, com sinal no tempo de retenção em 25,400 minutos.

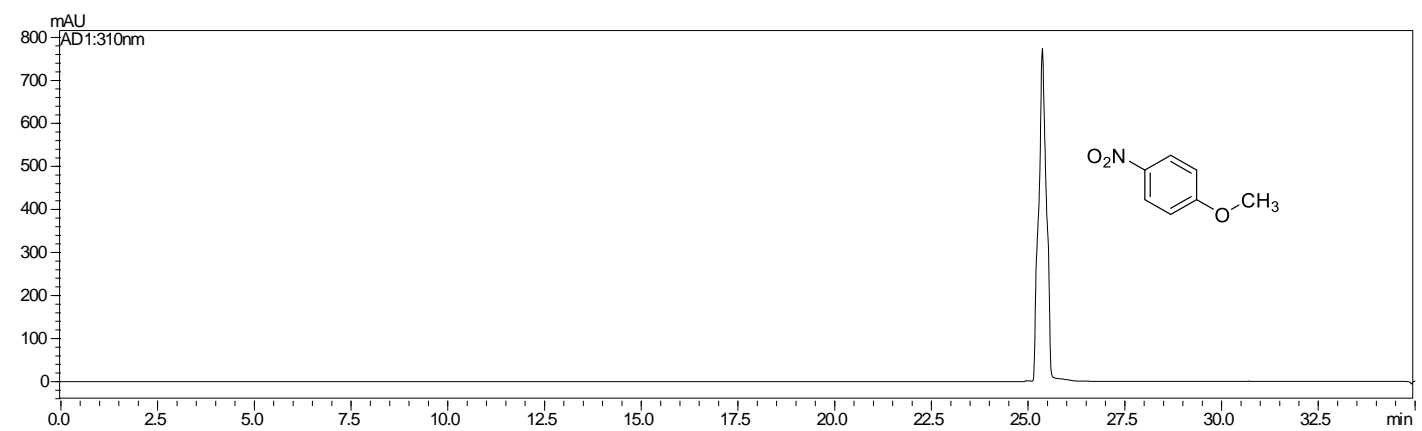

Condições de análise CLAE: ACN/ $\mathrm{H}_{2} \mathrm{O}$ (30:90); fluxo 0,8 mL/ min; $310 \mathrm{~nm} ; \mathrm{t}_{\mathrm{c}}=35 \mathrm{~min}$ Coluna C18 Shimadzu CLC-ODS(M) OD-H $(0.46$ x $25 \mathrm{~cm})$ 
Figura 38. Cromatograma obtido por CLAE-UV do controle para o metabólito 4-nitrofenol com $50 \mathrm{mg} . \mathrm{L}^{-1}$, com sinal no tempo de retenção em 9, 240 minutos.

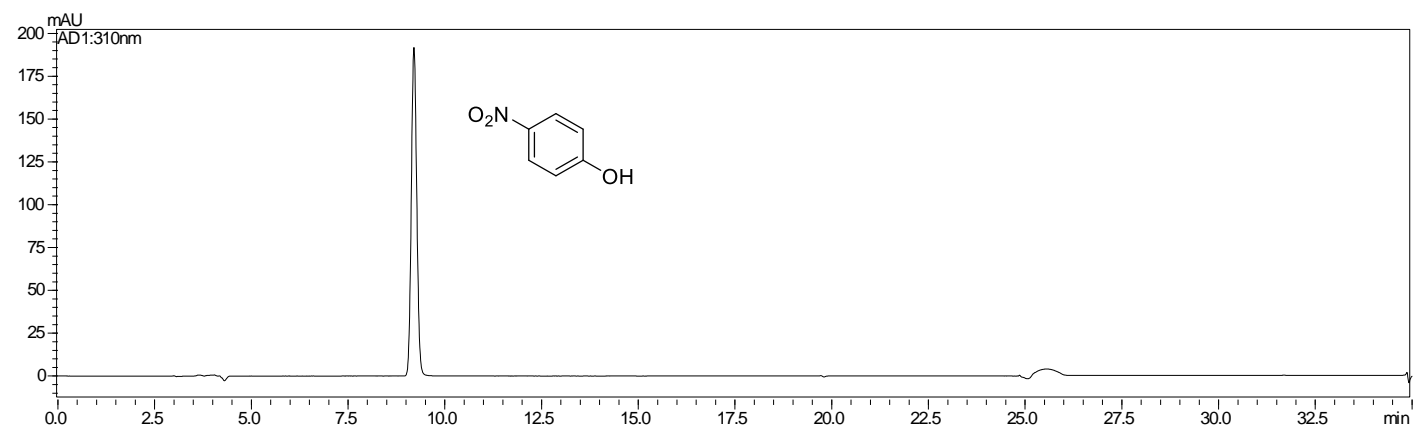

Condições de análise CLAE: ACN/ $\mathrm{H}_{2} \mathrm{O}$ (30:90); fluxo 0,8 mL/ min; $310 \mathrm{~nm} ; \mathrm{t}_{\mathrm{c}}=35 \mathrm{~min}$

Coluna C18 Shimadzu CLC-ODS(M) OD-H $(0.46$ x $25 \mathrm{~cm})$

Figura 39. Cromatogramas sobrepostos obtidos por CLAE-UV entra o controle do metabólito 1-metoxi-4nitrobenzeno e a reação do pesticida metil paration durante 10 dias de reação com o fungo A. sydowii CBMAI 935.

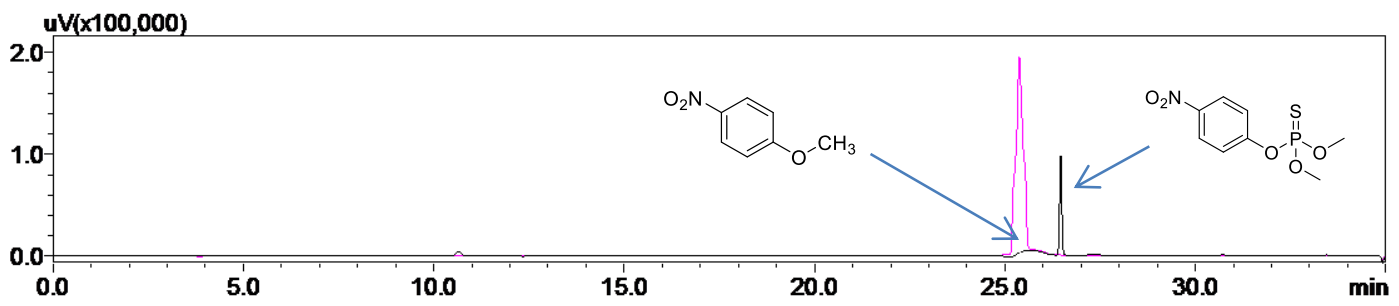

Condições de análise CLAE: ACN/ $\mathrm{H}_{2} \mathrm{O}$ (30:90); fluxo 0,8 mL/ min; $310 \mathrm{~nm}$; $\mathrm{t}_{\mathrm{c}}=35 \mathrm{~min}$ Coluna C18 Shimadzu CLC-ODS(M) OD-H (0.46 x $25 \mathrm{~cm})$

Figura 40. Cromatogramas sobrepostos e ampliados obtidos por CLAE-UV entra o controle do metabólito 1metoxi-4-nitrobenzeno e a reação do pesticida metil paration durante 10 dias de reação com o fungo A. sydowii CBMAI 935.

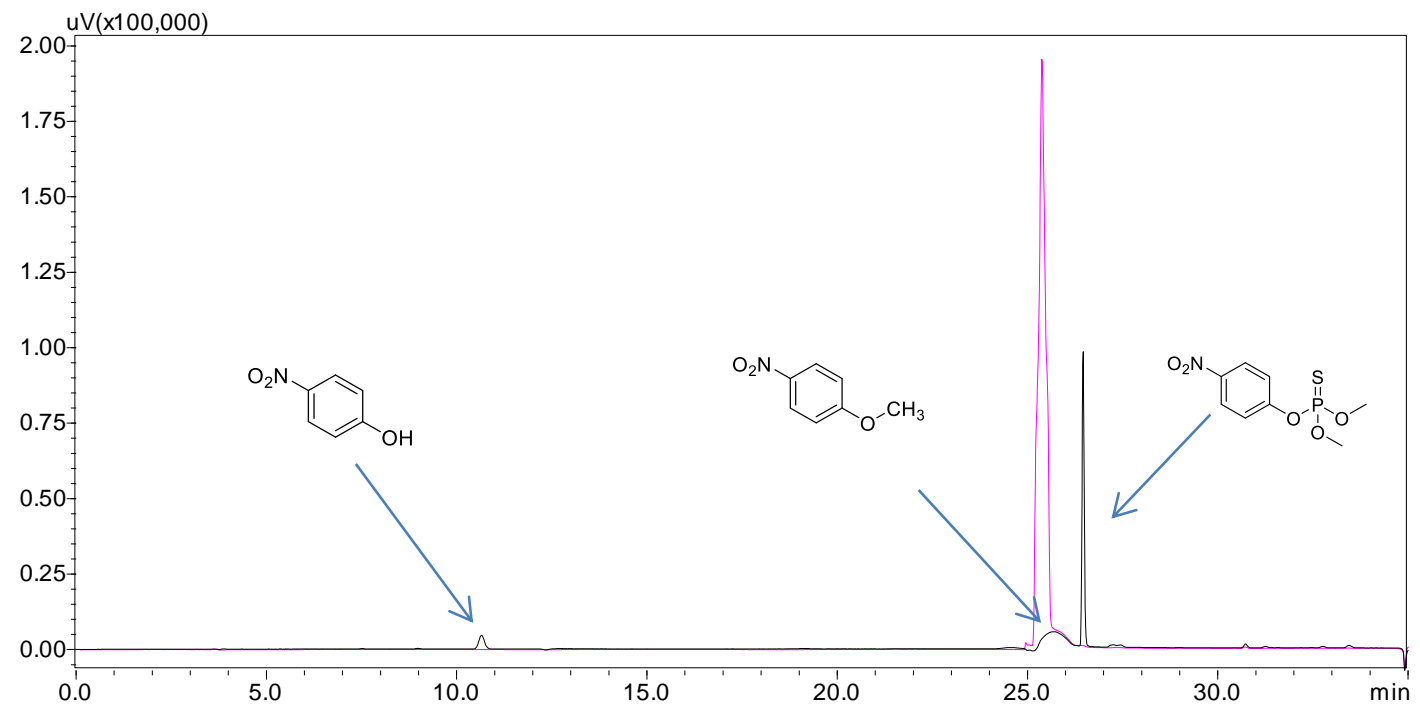

Condições de análise CLAE: ACN/ $\mathrm{H}_{2} \mathrm{O}$ (30:90); fluxo 0,8 mL/ min; $310 \mathrm{~nm} ; \mathrm{t}_{\mathrm{c}}=35 \mathrm{~min}$ Coluna C18 Shimadzu CLC-ODS(M) OD-H (0.46 x 25 cm) 
Tabelas de dados de quantificação obtidos por CLAE-UV das reações entre o composto fenólico 4-nitrofenol com o fungo de ambiente marinho A. sydowii CBMAI $935 \mathrm{em}$ 10, 20

\section{e 30 dias de reação de biotransformação em meio de cultura líquido de malte a $2 \%$}

Tabela 27. Quantificação da biodegradação de 4-nitrofenol por A. sydowii CBMAI 935 em 10 dias de reação $\left(32^{\circ} \mathrm{C}, 130 \mathrm{~g}, \mathrm{pH} 7,0\right)$.

\begin{tabular}{|c|c|c|c|}
\hline \multicolumn{4}{|c|}{ A. sydowii CBMAI 935 (50 mg. $\mathrm{L}^{-1}$ de 4-nitrofenol) } \\
\hline $\begin{array}{c}\text { Reações em } \\
\text { duplicata }\end{array}$ & Massa fúngica seca $(\mathrm{g})$ & $\mathrm{c}^{\mathrm{a}}$ metabólito & $\%$ de metabólito degradado \\
\hline Reação 1 & 0,25 & 18 & 100 \\
\hline Reação 2 & 0,26 & 16 & 100 \\
\hline
\end{tabular}

${ }^{\mathrm{a}} \mathrm{c}=$ concentração (dados obtidos de duplicatas) determinados por CLAE-UV

Tabela 28. Quantificação da biodegradação de 4-nitrofenol por A. sydowii CBMAI 935 em 20 dias de reação $\left(32^{\circ} \mathrm{C}, 130 \mathrm{~g}, \mathrm{pH} 7,0\right)$.

\begin{tabular}{|c|c|c|c|}
\hline \multicolumn{4}{|c|}{ A. sydowii CBMAI 935 (50 mg. $\mathrm{L}^{-1}$ de 4-nitrofenol) } \\
\hline $\begin{array}{c}\text { Reações em } \\
\text { duplicata }\end{array}$ & Massa fúngica seca $(\mathrm{g})$ & $\mathrm{c}^{\mathrm{a}}$ metabólito & $\%$ de metabólito degradado \\
\hline Reação 1 & 0,25 & 16 & 100 \\
\hline Reação 2 & 0,26 & 13 & 100 \\
\hline
\end{tabular}

${ }^{\mathrm{a}} \mathrm{c}=$ concentração (dados obtidos de duplicatas) determinados por CLAE-UV.

Tabela 29. Quantificação da biodegradação de 4-nitrofenol por A. sydowii CBMAI 935 em 30 dias de reação $\left(32^{\circ} \mathrm{C}, 130 \mathrm{~g}, \mathrm{pH} 7,0\right)$.

\begin{tabular}{cccc}
\hline \multicolumn{4}{c}{ A. sydowii CBMAI 935 $\mathbf{~ ( 5 0 ~} \mathbf{~ m g . ~}^{\mathbf{- 1}} \mathbf{d e}$ 4-nitrofenol) } \\
\hline $\begin{array}{c}\text { Reações em } \\
\text { duplicata }\end{array}$ & Massa fúngica seca $(\mathrm{g})$ & $\mathrm{c}^{\mathrm{a}}$ metabólito & \% de metabólito degradado \\
Reação 1 & 0,25 & 15 & 100 \\
Reação 2 & 0,26 & 17 & 100 \\
\hline
\end{tabular}

\footnotetext{
${ }^{\mathrm{a}} \mathrm{c}=$ concentração (dados obtidos de duplicatas) determinados por CLAE-UV.
} 
Cromatogramas obtidos por CLAE-UV das reações de biotranformação entre o composto fenólico 4-nitrofenol com o fungo de ambiente marinho A. sydowii CBMAI 935 em 10, 20 e 30 dias de crescimento em meio de cultura líquido de malte a $2 \%$

Figura 41. Cromatogramas em tamanho reduzido obtidos por CLAE-UV das reações para o 4-nitrofenol, a) padrão 1-metoxi-4-nitrobenzeno com $50 \mathrm{mg} . \mathrm{L}^{-1}, \mathrm{~b}$ ) metabólito 1-metoxi-4-nitrobenzeno em 10 dias de reação, c) metabólito 1-metoxi-4-nitrobenzeno em 20 dias de reação, d) metabólito 1-metoxi-4-nitrobenzeno em 30 dias de reação. Todos com sinal no tempo de retenção em 25, 400 minutos.

a)

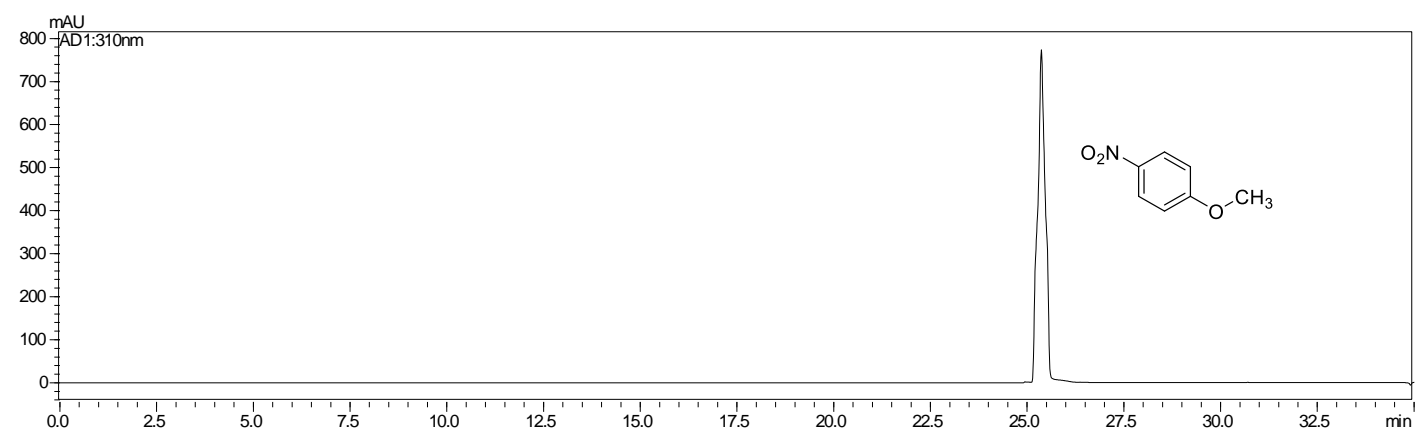

b)
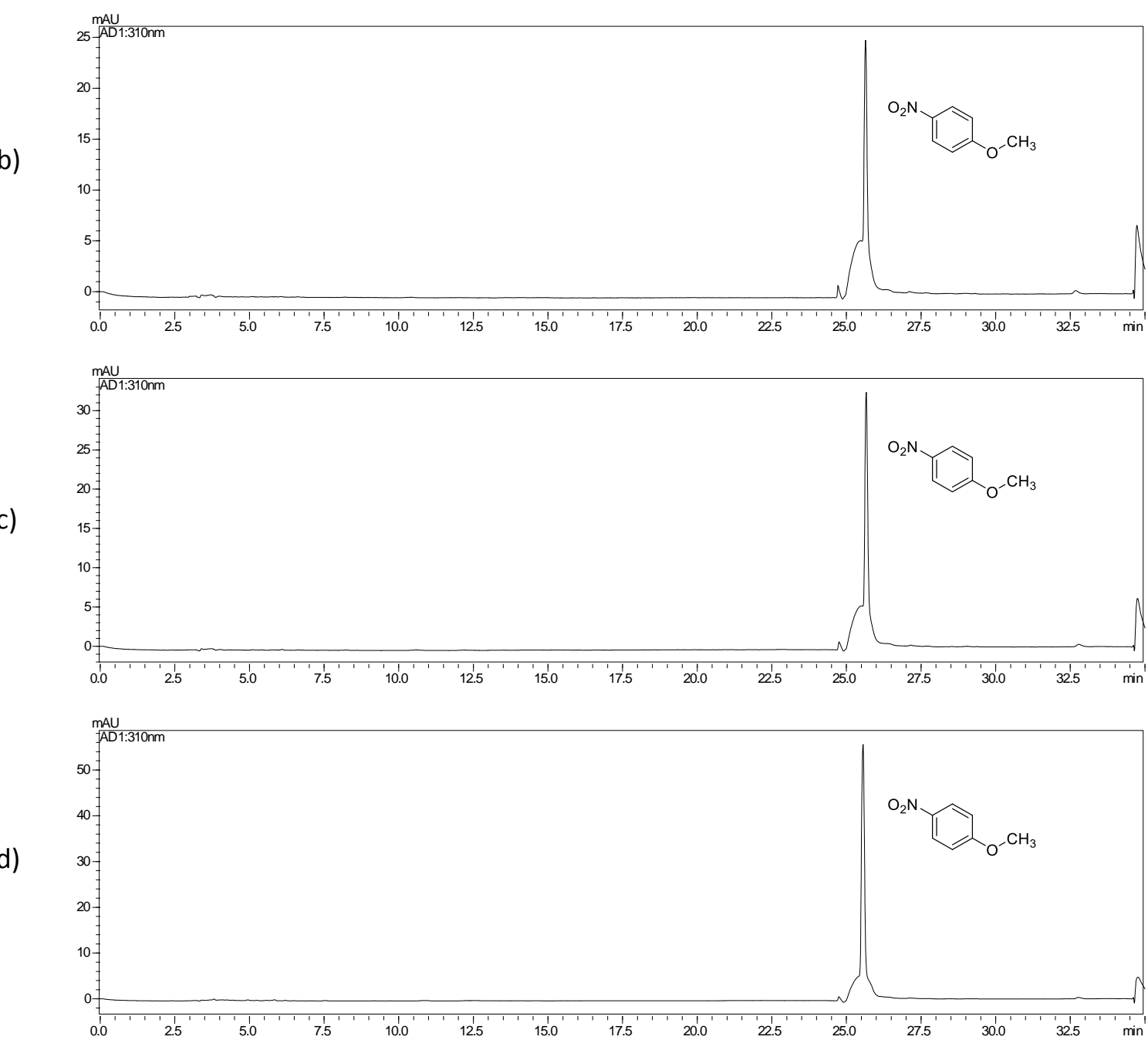

Condições de análise CLAE: ACN/ $\mathrm{H}_{2} \mathrm{O}$ (30:90); fluxo 0,8 mL/ min; $310 \mathrm{~nm} ; \mathrm{t}_{\mathrm{c}}=35 \mathrm{~min}$ Coluna C18 Shimadzu CLC-ODS(M) OD-H (0.46 x 25 cm) 
Tabelas de dados de quantificação obtidos por CLAE-UV das reações entre o pesticida profenofós e com o fungo de ambiente marinho A. sydowii CBMAI 935 em 10, 20 e 30 dias de reação de biotransformação em meio de cultura líquido de malte a $2 \%$

Tabela 30. Quantificação da biodegradação do profenofós por A. sydowii CBMAI 935 em 10 dias de reação $\left(32^{\circ} \mathrm{C}, 130 \mathrm{~g}, \mathrm{pH} 7,0\right)$

\begin{tabular}{lcccc}
\hline \multicolumn{4}{c}{ A. sydowii CBMAI 935 $\mathbf{( 5 0} \mathbf{~ m g . ~}^{\mathbf{- 1}}$ de profenofós) } \\
\hline \multicolumn{1}{c}{ Reações em duplicata } & $\begin{array}{c}\text { Massa fúngica } \\
\text { seca }(\mathrm{g})\end{array}$ & $\mathrm{c}^{\mathrm{a}}$ metabólito & $\mathrm{c}^{\mathrm{a}}$ profenofós & $\begin{array}{c}\text { \% de profenofós } \\
\text { degradado }^{\mathrm{b}}\end{array}$ \\
Reação 1 (caldo enzimático) & - & $2^{\mathrm{c}}$ & $28^{\mathrm{c}}$ & 40 \\
Reação 1 (células) & 0,96 & 2 & 37 & 42 \\
Reação 2 (caldo enzimático) & - & 14 & $0,5^{\mathrm{c}}$ & 40 \\
Reação 2 (células) & 0,64 & 10 & 0,5 & \\
\hline
\end{tabular}

$\mathrm{c}^{\mathrm{a}}=$ concentração (dados obtidos de duplicatas) determinados por

${ }^{\mathrm{b}}$ total de profenofós degradado (caldo + células)

${ }^{\mathrm{c}}$ concentração estimada

Tabela 31. Quantificação da biodegradação de profenofós por A. sydowii CBMAI 935 em 20 dias de reação $\left(32^{\circ} \mathrm{C}, 130 \mathrm{~g}, \mathrm{pH} 7,0\right)$.

\begin{tabular}{|c|c|c|c|c|}
\hline \multicolumn{5}{|c|}{ A. sydowii CBMAI 935 (50 mg. $\mathrm{L}^{-1}$ de profenofós) } \\
\hline $\begin{array}{c}\text { Reações em } \\
\text { duplicata }\end{array}$ & $\begin{array}{c}\text { Massa fúngica seca } \\
(\mathrm{g})\end{array}$ & $\mathrm{c}^{\mathrm{a}}$ metabólito & $\mathrm{c}^{\mathrm{b}}$ profenofós & $\%$ de profenofós degradado \\
\hline Reação 1 & 0,36 & $2^{\mathrm{c}}$ & $23^{\mathrm{c}}$ & 50 \\
\hline Reação 2 & 0,33 & $1^{\mathrm{c}}$ & 23 & 52 \\
\hline
\end{tabular}

$\mathrm{c}^{\mathrm{a}}=$ concentração (dados obtidos de duplicatas) determinados por CLAE-UV.

Tabela 32. Quantificação da biodegradação de profenofós por A. sydowii CBMAI 935 em 30 dias de reação $\left(32^{\circ} \mathrm{C}, 130 \mathrm{~g}, \mathrm{pH} 7,0\right)$.

\begin{tabular}{ccccc}
\hline \multicolumn{5}{c}{ A. sydowii CBMAI 935 (50 $\mathbf{~ m g . L ^ { - 1 }}$ de profenofós) } \\
\hline $\begin{array}{c}\text { Reações em } \\
\text { duplicata }\end{array}$ & $\begin{array}{c}\text { Massa fúngica seca } \\
(\mathrm{g})\end{array}$ & $\mathrm{c}^{\mathrm{a}}$ metabólito & $\mathrm{c}^{\mathrm{b}}$ profenofós & \% de profenofós degradado ${ }^{\mathrm{b}}$ \\
Reação 1 & 0,38 & 2 & 23 & 50 \\
Reação 2 & 0,41 & 2 & 23 & 50 \\
\hline $\mathrm{c}^{\mathrm{a}}=$ concentração (dados obtidos de duplicatas) determinados por CLAE-UV. \\
${ }^{\mathrm{b}}$ concentração estimada
\end{tabular}


Cromatogramas obtidos por CLAE-UV das reações de biotranformação entre o pesticida profenofós com o fungo de ambiente marinho A. sydowii CBMAI $935 \mathrm{em} 10$, 20 e 30 dias de crescimento em meio de cultura líquido de malte a $2 \%$

Figura 42. Cromatograma obtido por CLAE-UV do controle para o pesticida profenofós com $50 \mathrm{mg} . \mathrm{L}^{-1}$ e sinal no tempo de retenção em 28, 600 minutos.

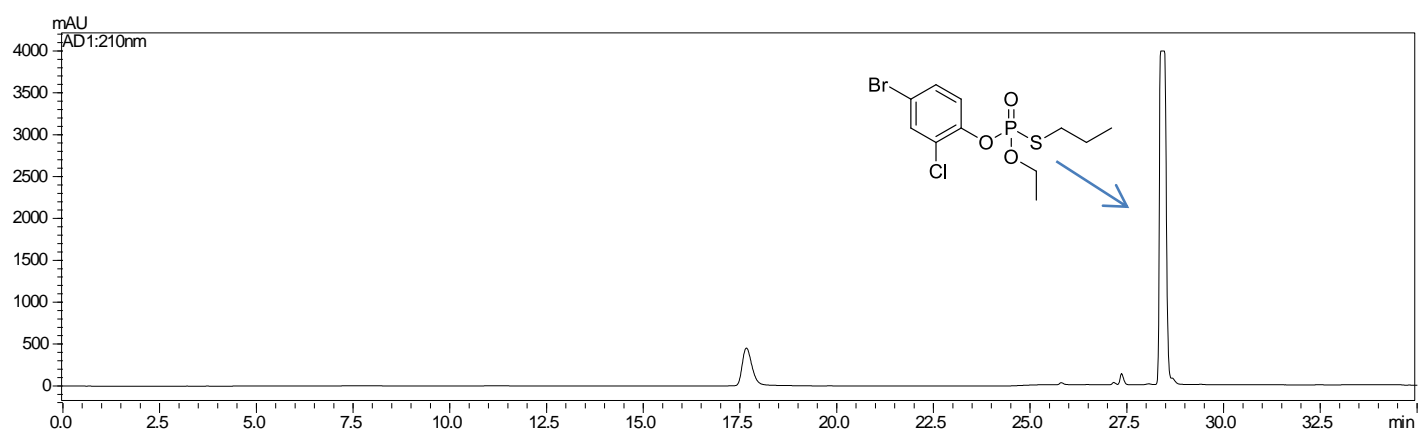

Condições de análise CLAE: ACN/ $\mathrm{H}_{2} \mathrm{O}$ (45:90); fluxo 0,8 mL/ min; $210 \mathrm{~nm}$; $\mathrm{t}_{\mathrm{c}}=35 \mathrm{~min}$

Coluna C18 Shimadzu CLC-ODS(M) OD-H (0.46 x $25 \mathrm{~cm})$

Figura 43. Cromatograma obtido por CLAE-UV do controle para o 4-bromo-2-clorofenol com $50 \mathrm{mg} . \mathrm{L}^{-1}$ e sinal no tempo de retenção em 14, 000 minutos.

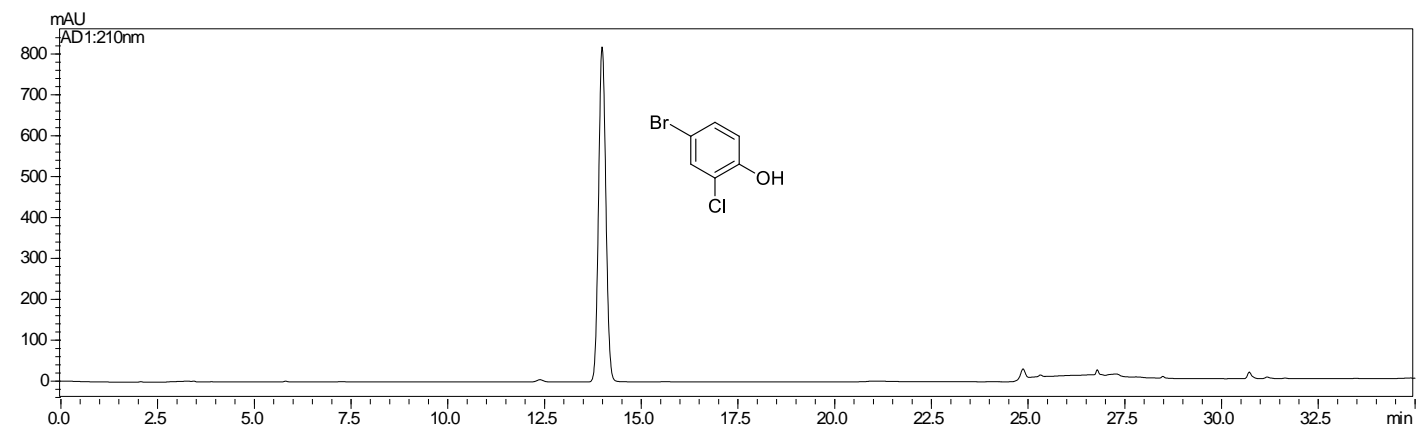

Condições de análise CLAE: ACN/ $\mathrm{H}_{2} \mathrm{O}$ (45:90); fluxo 0,8 mL/ min; $210 \mathrm{~nm} ; \mathrm{t}_{\mathrm{c}}=35 \mathrm{~min}$ Coluna C18 Shimadzu CLC-ODS(M) OD-H (0.46 x $25 \mathrm{~cm})$

Figura 44. Cromatograma obtido por CLAE-UV do controle para o 4-bromo-2-cloro-1-metoxibenzeno com 50 mg. $L^{-1}$ e sinal no tempo de retenção em 26,800 minutos.

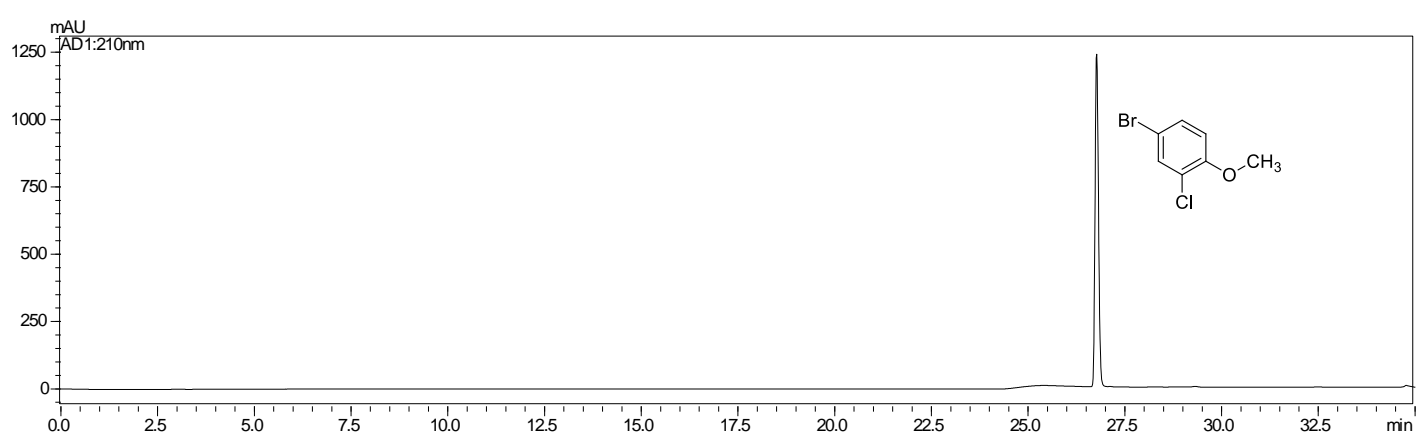

Condições de análise CLAE: ACN/ $\mathrm{H}_{2} \mathrm{O}$ (45:90); fluxo 0,8 mL/ min; $210 \mathrm{~nm}$; $\mathrm{t}_{\mathrm{c}}=35 \mathrm{~min}$ Coluna C18 Shimadzu CLC-ODS(M) OD-H (0.46 x $25 \mathrm{~cm})$ 
Figura 45. Cromatogramas obtidos por CLAE-UV das reações com o pesticida comercial profenofós. a) profenofós 10 dias de reação, b) profenofós 20 dias de reação, c) profenofós 30 dias de reação com o fungo de A. sydowii CBMAI 935. Todos com sinal no tempo de retenção em 28, 600 minutos.

a)

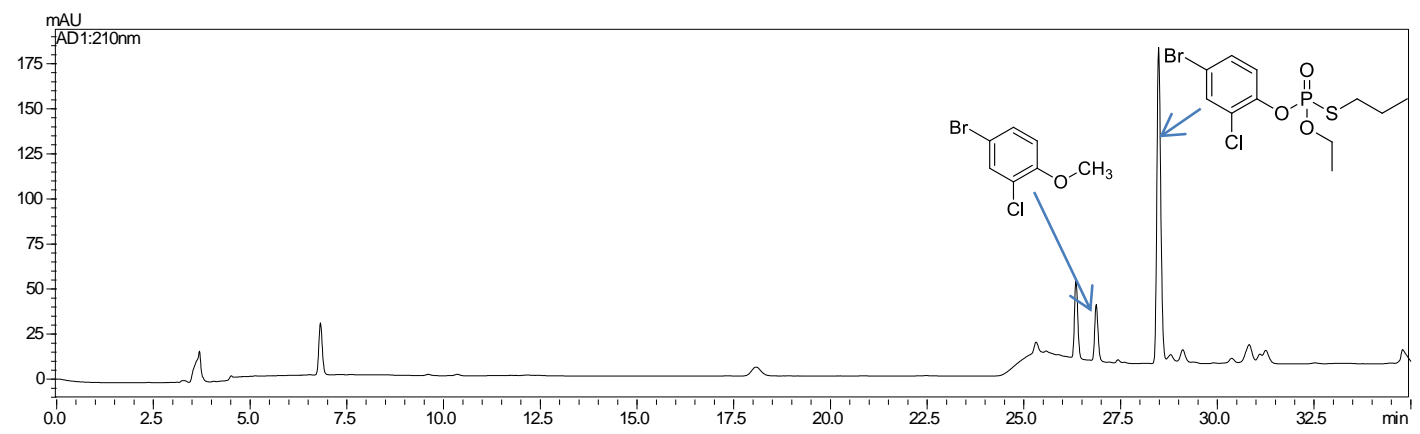

b)

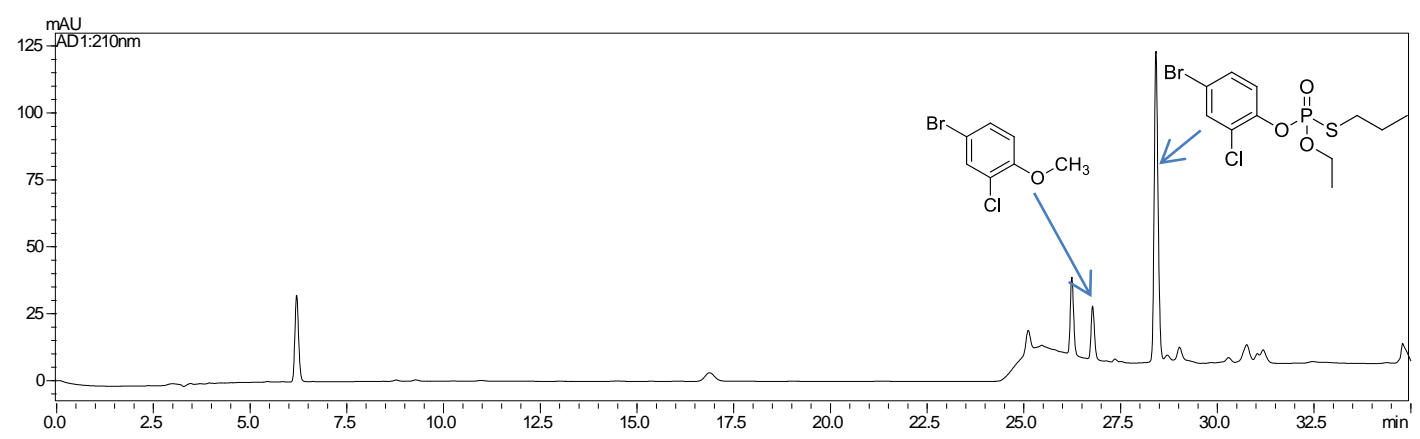

c)

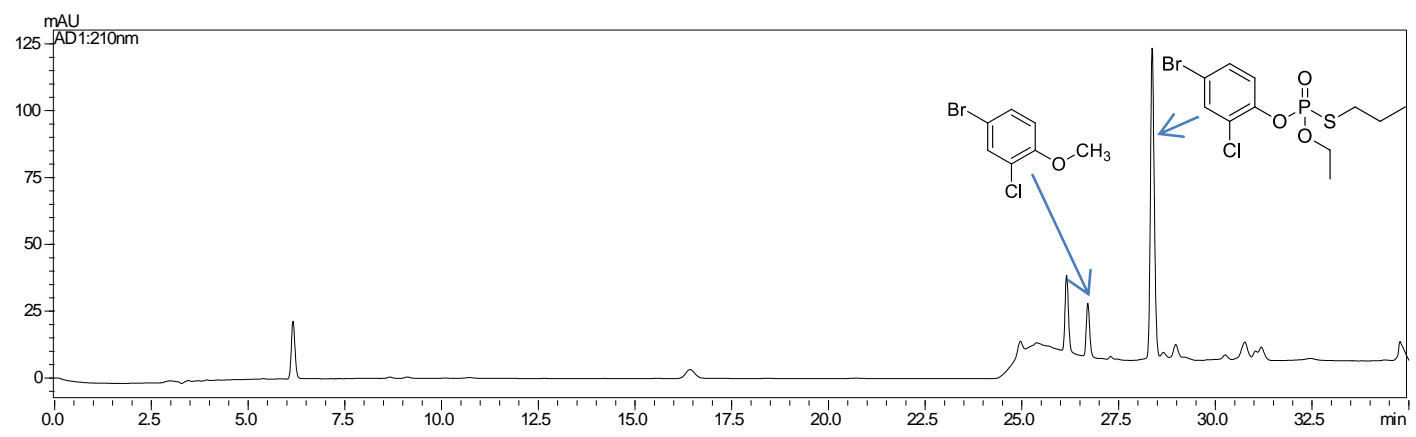

Condições de análise CLAE: ACN/ $\mathrm{H}_{2} \mathrm{O}$ (45:90); fluxo 0,8 mL/ min; $210 \mathrm{~nm} ; \mathrm{t}_{\mathrm{c}}=35 \mathrm{~min}$ Coluna C18 Shimadzu CLC-ODS(M) OD-H $(0.46$ x $25 \mathrm{~cm})$ 
Figura 46. Cromatogramas sobrepostos obtidos por CLAE-UV do controle do metabólito 4-bromo-2-cloro-1metoxibenzeno na (cor escura) e a reação de biotransformação do pesticida comercial profenofós na (cor rosada) com o fungo A. sydowii CBMAI 935 durante 10 dias.

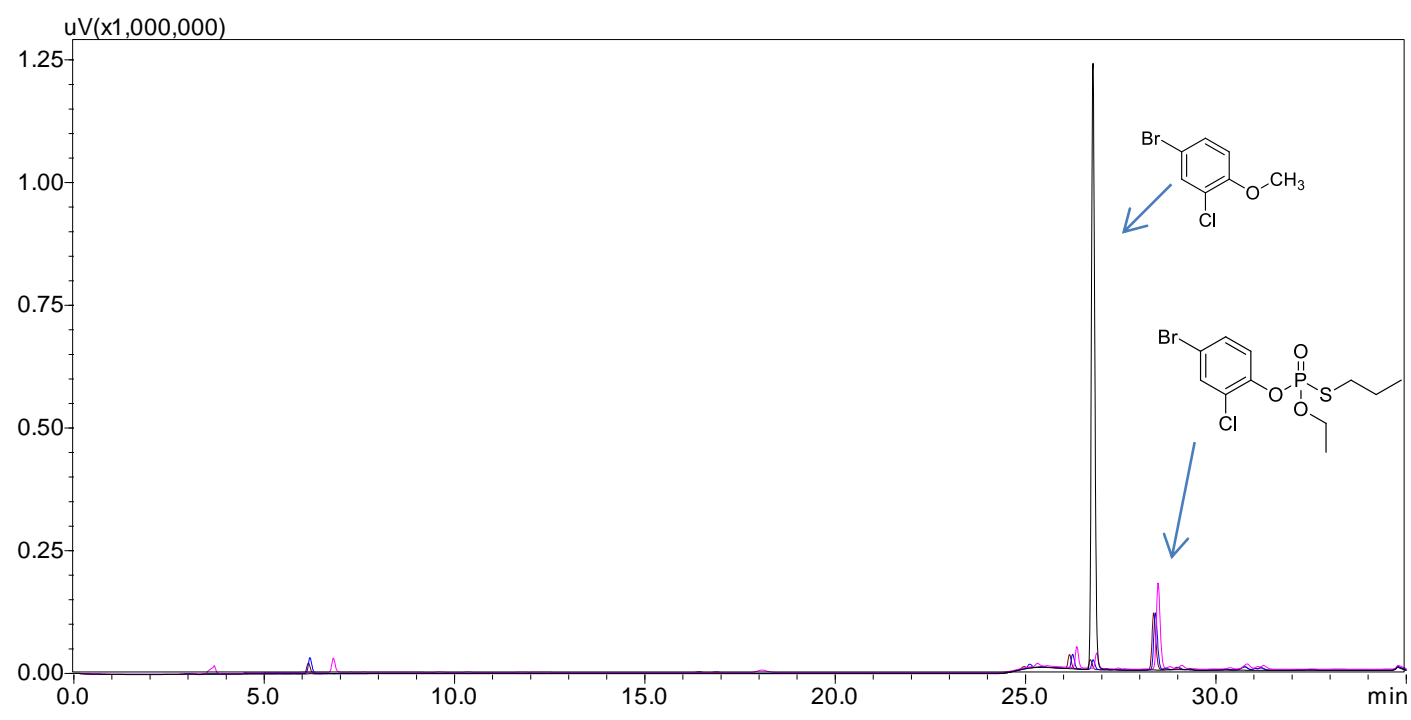

Condições de análise CLAE: ACN/ $\mathrm{H}_{2} \mathrm{O}$ (45:90); fluxo 0,8 mL/ min; $210 \mathrm{~nm} ; \mathrm{t}_{\mathrm{c}}=35 \mathrm{~min}$ Coluna C18 Shimadzu CLC-ODS(M) OD-H (0.46 x $25 \mathrm{~cm})$ 
Figura 47. Cromatogramas obtidos por CLAE-UV das reações com o pesticida comercial profenofós e o metabólito 4-bromo-2-cloro-1-metoxibenzeno. a) 4-bromo-2-cloro-1-metoxibenzeno padrão sintético, b) profenofós com 10 dias de reação, c) profenofós com 20 dias de reação, d) profenofós com 30 dias de reação com o fungo A. sydowii CBMAI 935.

a)

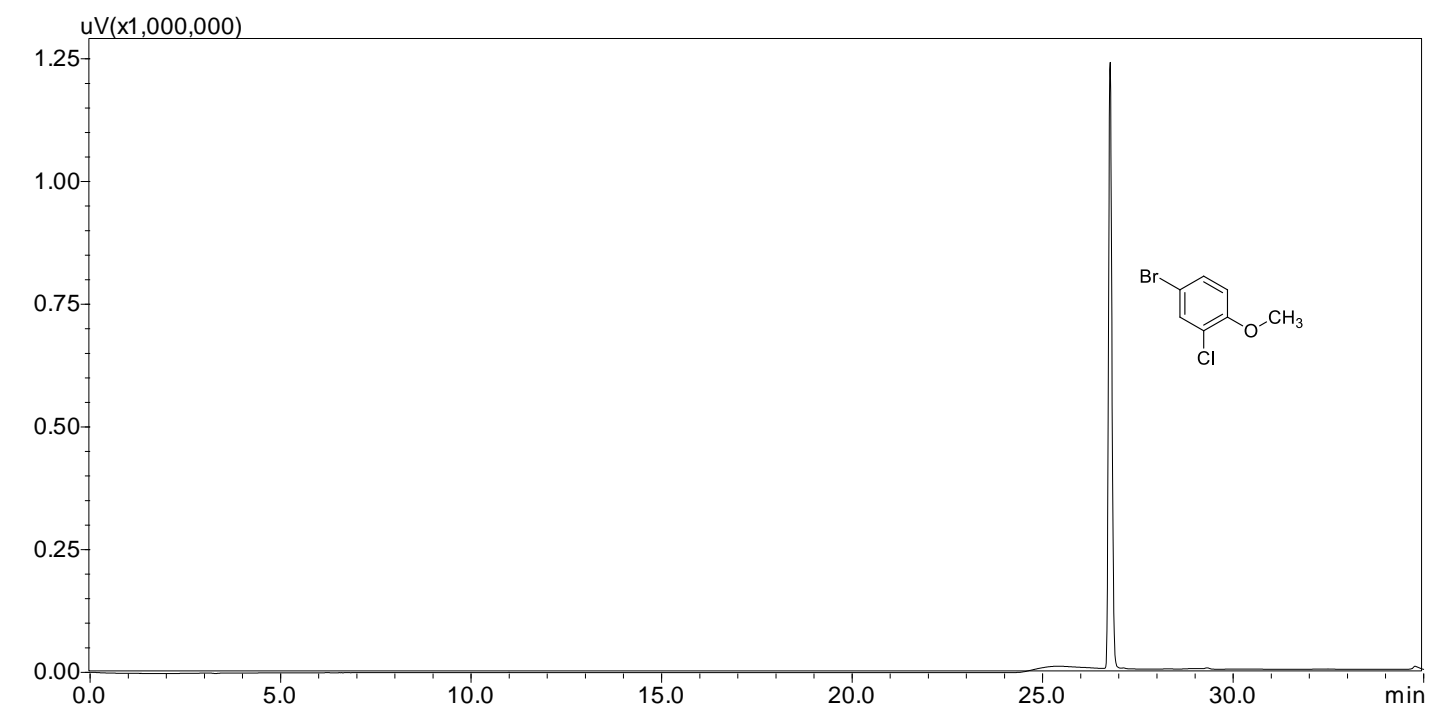

uv(xi,uUu,uUu)

b)

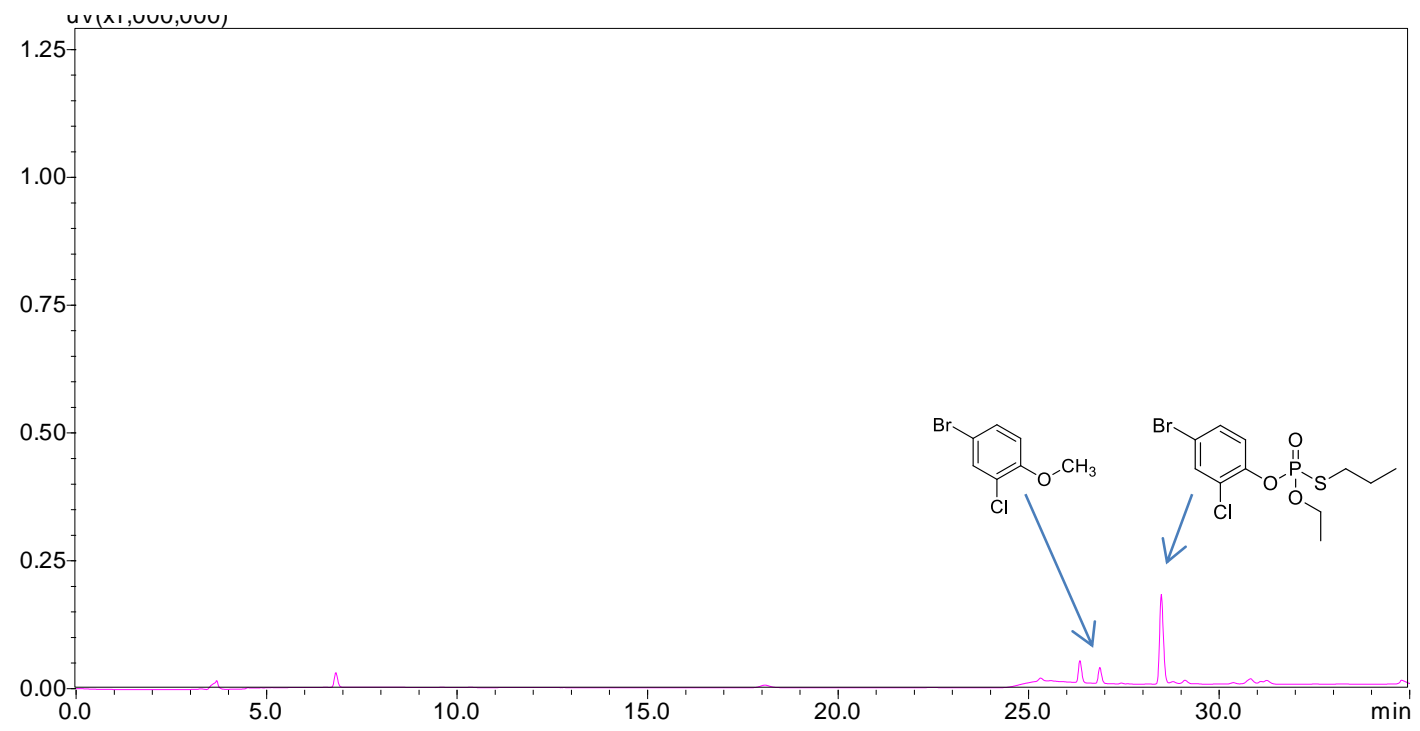

Condições de análise CLAE: ACN/ $\mathrm{H}_{2} \mathrm{O}$ (45:90); fluxo 0,8 mL/ min; $210 \mathrm{~nm} ; \mathrm{t}_{\mathrm{c}}=35 \mathrm{~min}$ Coluna C18 Shimadzu CLC-ODS(M) OD-H (0.46 x $25 \mathrm{~cm})$ 

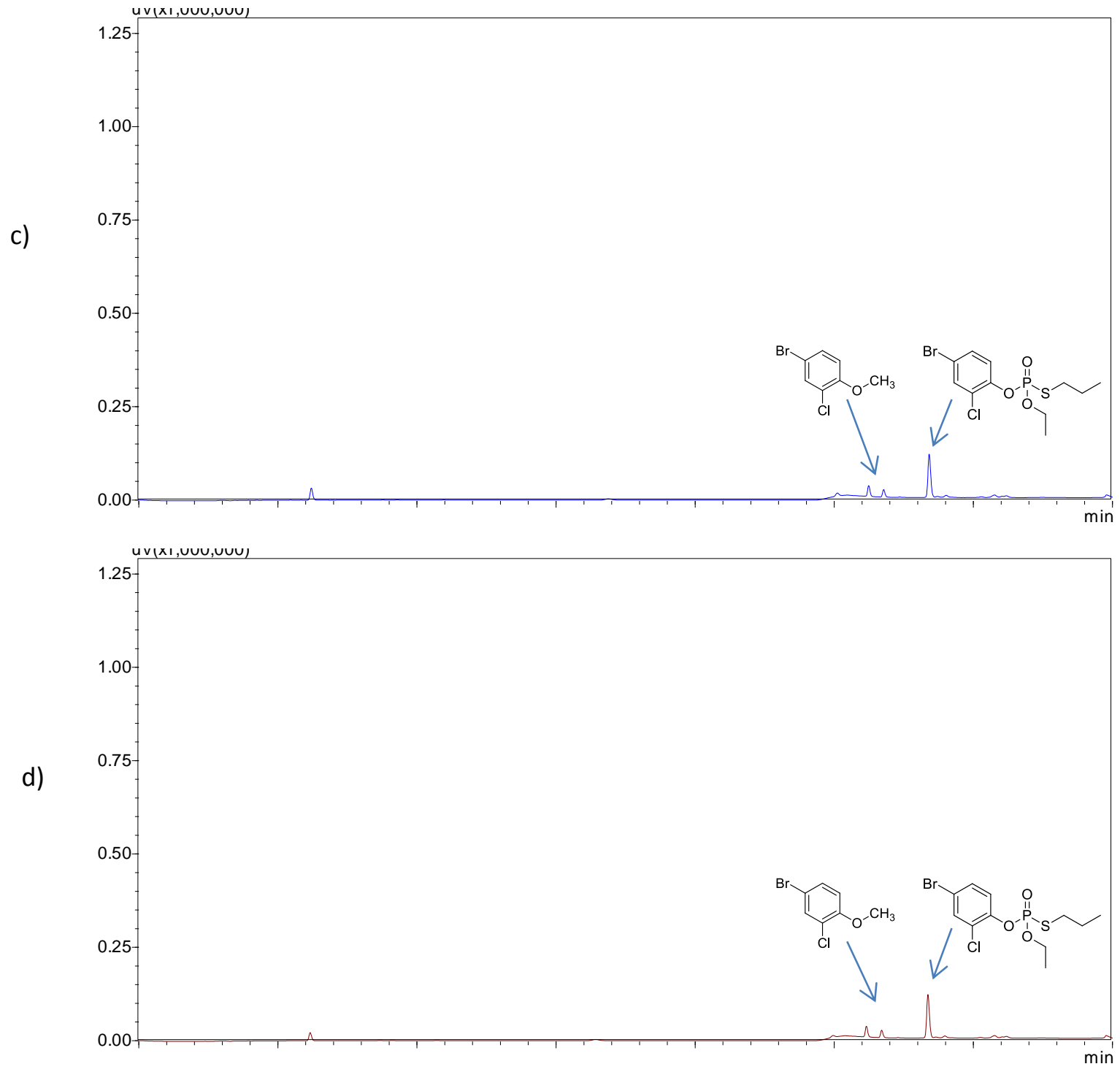

Condições de análise CLAE: ACN/ $\mathrm{H}_{2} \mathrm{O}$ (45:90); fluxo 0,8 mL/ min; $210 \mathrm{~nm} ; \mathrm{t}_{\mathrm{c}}=35 \mathrm{~min}$ Coluna C18 Shimadzu CLC-ODS(M) OD-H (0.46 x $25 \mathrm{~cm})$ 
Tabelas de dados de quantificação obtidos por CLAE-UV das reações entre o composto fenólico 4-bromo-2-clorofenol com o fungo de ambiente marinho A. sydowii CBMAI 935 em 10, 20 e 30 dias de reação de biotransformação em meio de cultura líquido de malte a $2 \%$

Tabela 34. Quantificação da biodegradação de 4-bromo-2-clorofenol por A. sydowii CBMAI 935 em 10 dias (32 $\left.{ }^{\circ} \mathrm{C}, 130 \mathrm{~g}, \mathrm{pH} 7,0\right)$.

\begin{tabular}{cccc}
\hline \multicolumn{4}{c}{ A. sydowii CBMAI 935 (50 $\mathbf{~ m g . L}^{-\mathbf{1}}$ de 4-bromo-2-clorofenol) } \\
\hline $\begin{array}{c}\text { Reações em } \\
\text { duplicata }\end{array}$ & Massa fúngica seca $(\mathrm{g})$ & $\mathrm{c}^{\mathrm{a}}$ metabólito & \% de fenol degradado \\
Reação 1 & 0,40 & & 100 \\
Reação 2 & 0,37 & 12 & 100 \\
\hline
\end{tabular}

$\mathrm{c}^{\mathrm{a}}=$ concentração (dados obtidos de duplicatas) determinados por CLAE-UV.

Tabela 35. Quantificação da biodegradação de 4-bromo-2-clorofenol por A. sydowii CBMAI 935 em 20 dias (32 $\left.{ }^{\circ} \mathrm{C}, 130 \mathrm{~g}, \mathrm{pH} 7,0\right)$.

\begin{tabular}{cccc}
\hline \multicolumn{4}{c}{ A. sydowii CBMAI 935 (50 $\mathbf{~ m g . . ~}^{-\mathbf{1}}$ de 4-bromo-2-clorofenol) } \\
\hline $\begin{array}{c}\text { Reações em } \\
\text { duplicata }\end{array}$ & Massa fúngica seca $(\mathrm{g})$ & $\mathrm{c}^{\mathrm{a}}$ metabólito & $\%$ de fenol degradado \\
Reação 1 & 0,42 & 18 & 100 \\
Reação 2 & 0,35 & 20 & 100 \\
\hline
\end{tabular}

$\mathrm{c}^{\mathrm{a}}=$ concentração (dados obtidos de duplicatas) determinados por CLAE-UV.

Tabela 36. Quantificação da biodegradação de 4-bromo-2-clorofenol por A. sydowii CBMAI 935 em 30 dias (32 $\left.{ }^{\circ} \mathrm{C}, 130 \mathrm{~g}, \mathrm{pH} 7,0\right)$.

\begin{tabular}{cccc}
\hline \multicolumn{4}{c}{ A. sydowii CBMAI 935 (50 $\mathbf{~ m g . L ^ { - 1 }}$ de 4-bromo-2-clorofenol) } \\
\hline $\begin{array}{c}\text { Reações em } \\
\text { duplicata }\end{array}$ & Massa fúngica seca $(\mathrm{g})$ & $\mathrm{c}^{\text {a }}$ metabólito & $\%$ de fenol degradado \\
Reação 1 & 0,45 & 15 & 100 \\
Reação 2 & 0,40 & 18 & 100 \\
\hline
\end{tabular}

$c^{\mathrm{a}}=$ concentração (dados obtidos de duplicatas) determinados por CLAE-UV 
Cromatogramas obtidos por CLAE-UV das reações de biotranformação entre o composto fenólico 4-bromo-2-clorofenol com o fungo de ambiente marinho $A$. sydowii CBMAI 935 em 10, 20 e 30 dias de crescimento em meio de cultura líquido de malte a $2 \%$

Figura 48. Cromatogramas sobrepostos obtidos por CLAE-UV das reações com o composto fenólico 4-bromo2-clorofenol com o fungo A. sydowii CBMAI 935 e o metabólito 4-bromo-2-cloro-1-metoxibenzeno. a) 4bromo-2-cloro-1-metoxibenzeno padrão sintético, b) 4-bromo-2-cloro-1-metoxibenzeno com 10 dias de reação, c) 4-bromo-2-cloro-1-metoxibenzeno com 20 dias de reação, d) 4-bromo-2-cloro-1-metoxibenzeno com 30 dias de reação com o fungo A. sydowii CBMAI 935. Todos com sinais no tempo de retenção em 26, 800 minutos.

a)
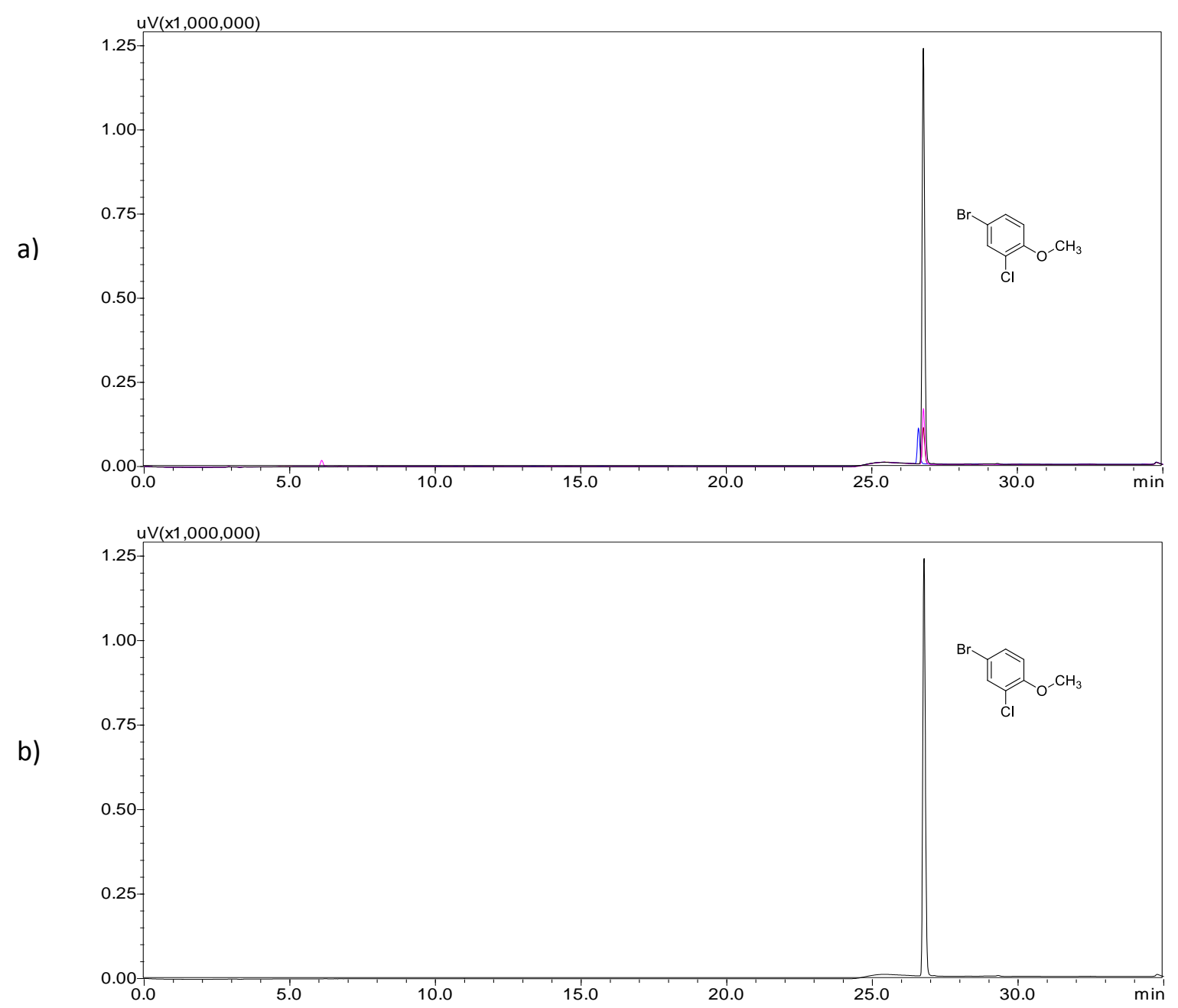

Condições de análise CLAE: ACN/ $\mathrm{H}_{2} \mathrm{O}$ (45:90); fluxo 0,8 mL/ min; $210 \mathrm{~nm} ; \mathrm{t}_{\mathrm{c}}=35 \mathrm{~min}$ Coluna C18 Shimadzu CLC-ODS(M) OD-H (0.46 x $25 \mathrm{~cm})$ 


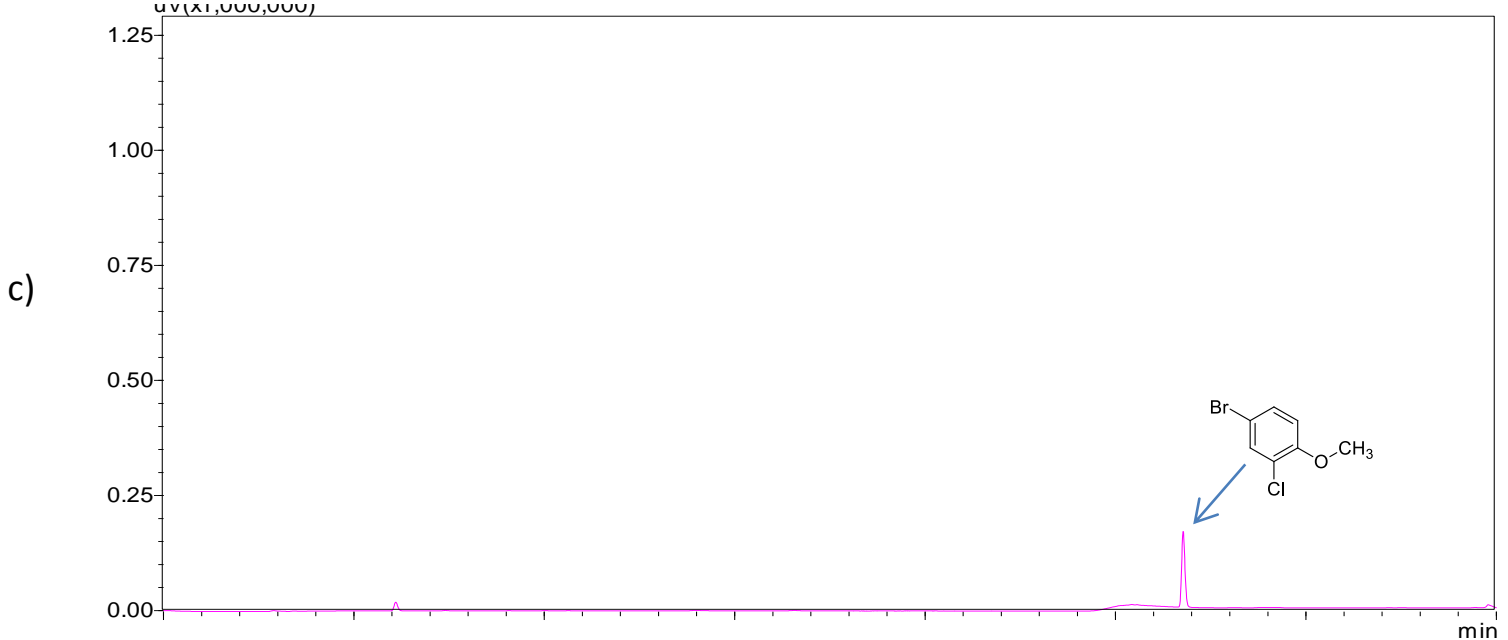

d)
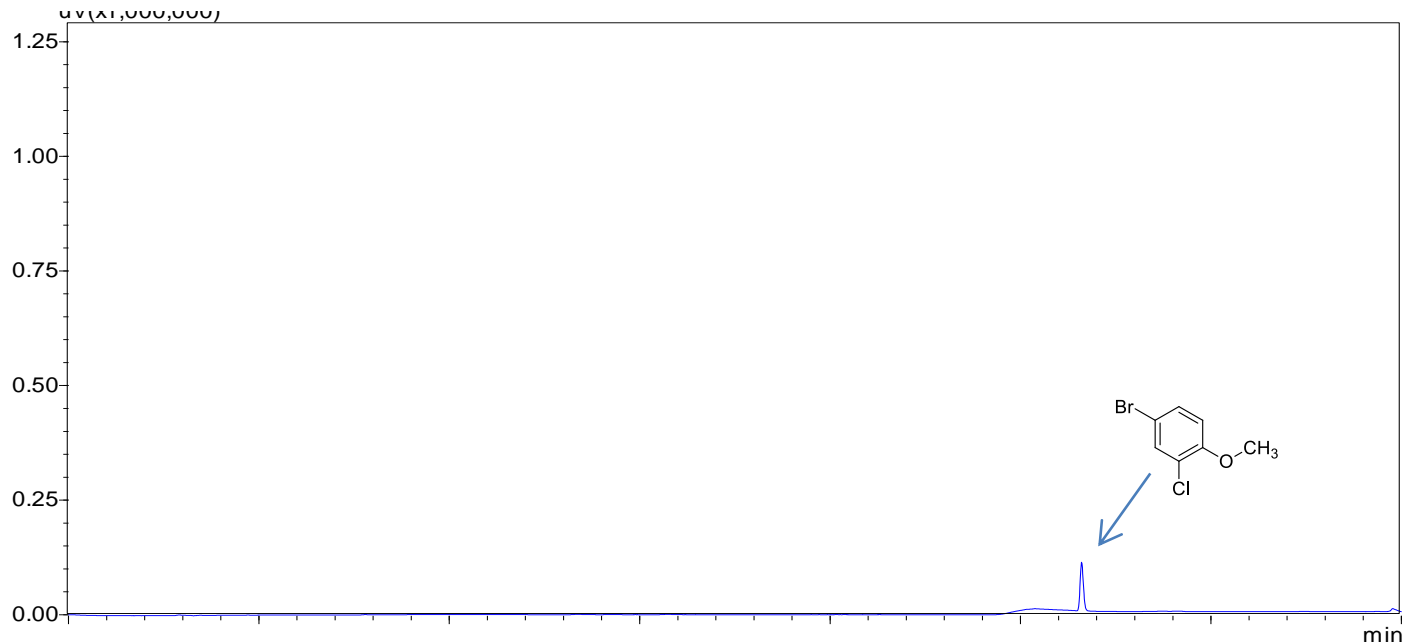

e)

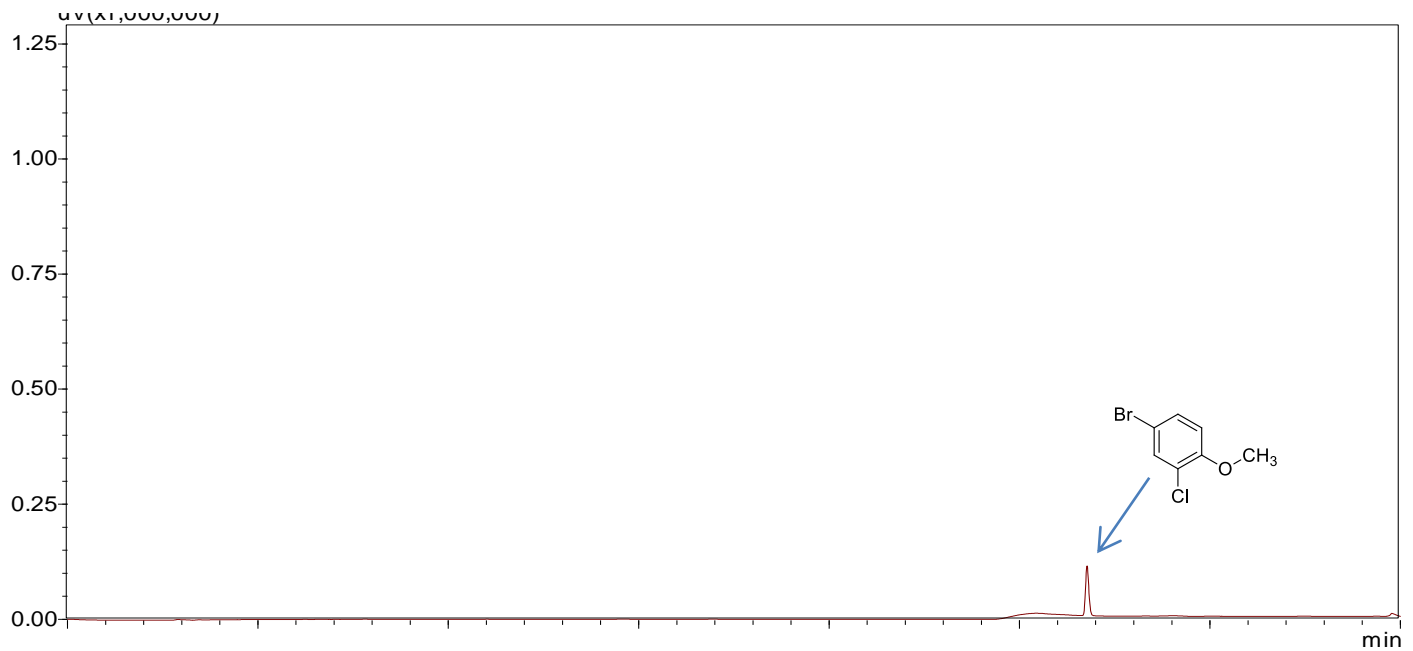

Condições de análise CLAE: ACN/ $\mathrm{H}_{2} \mathrm{O}$ (45:90); fluxo 0,8 mL/ min; $210 \mathrm{~nm} ; \mathrm{t}_{\mathrm{c}}=35 \mathrm{~min}$ Coluna C18 Shimadzu CLC-ODS(M) OD-H (0.46 x $25 \mathrm{~cm})$

Espectros de $\mathrm{RMN}$ de ${ }^{1} \mathrm{H}$ e ${ }^{13} \mathrm{C}$ de substâncias metiladas por síntese clássica e substâncias metiladas por reações enzimáticas provenientes do fungo $A$. sydowii CBMAI 935 que foram posteriormente isoladas e analizadas 
Espectro de $\mathrm{RMN}{ }^{1} \mathrm{H}\left(400 \mathrm{MHz}, \mathrm{CDCl}_{3}\right.$ ) do 4-bromo-2-cloro-1-metoxibenzeno (sintético)

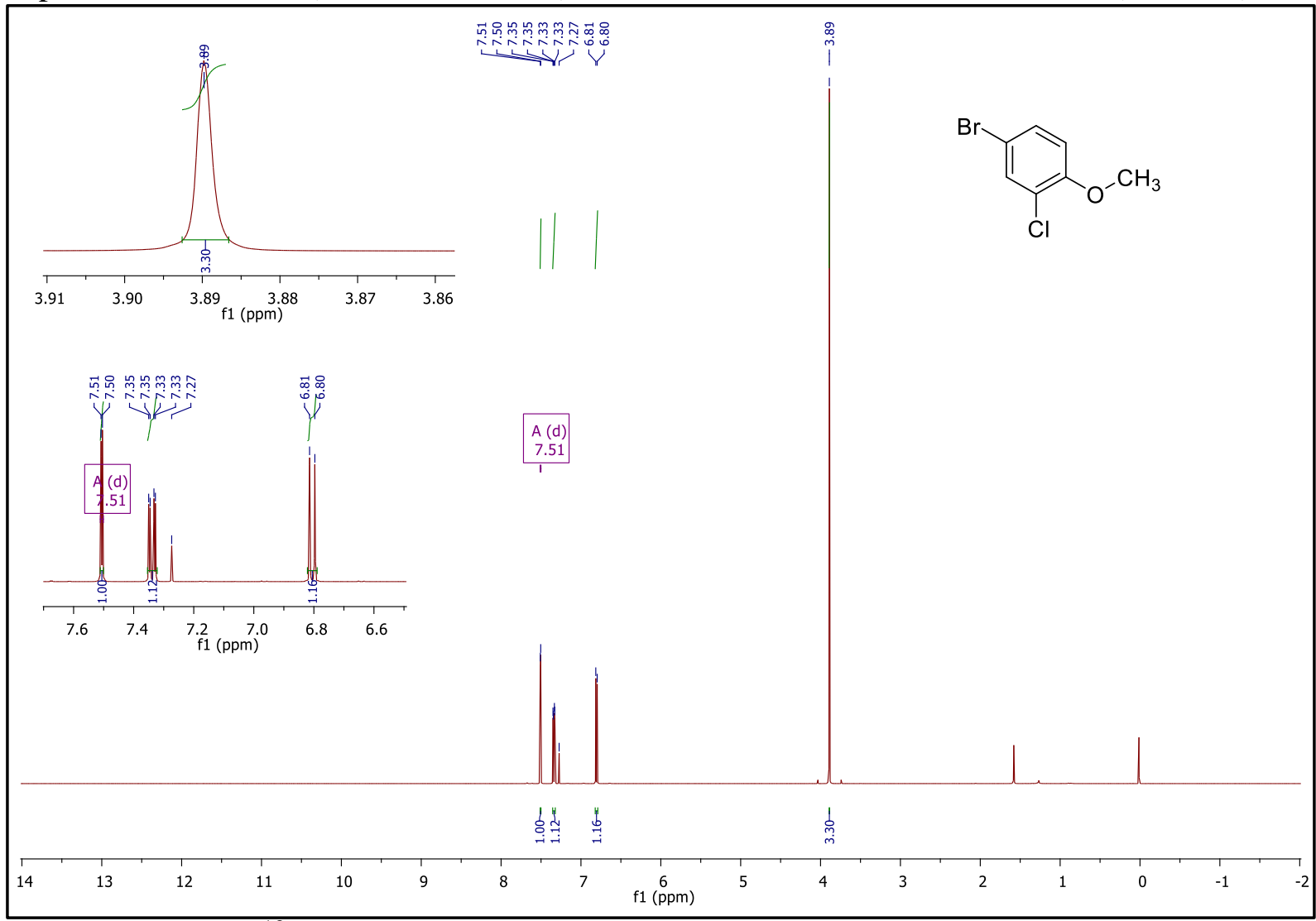

Espectro de $\mathrm{RMN}{ }^{13} \mathrm{C}\left(100 \mathrm{MHz}, \mathrm{CDCl}_{3}\right)$ do 4-bromo-2-cloro-1-metoxibenzeno (sintético)

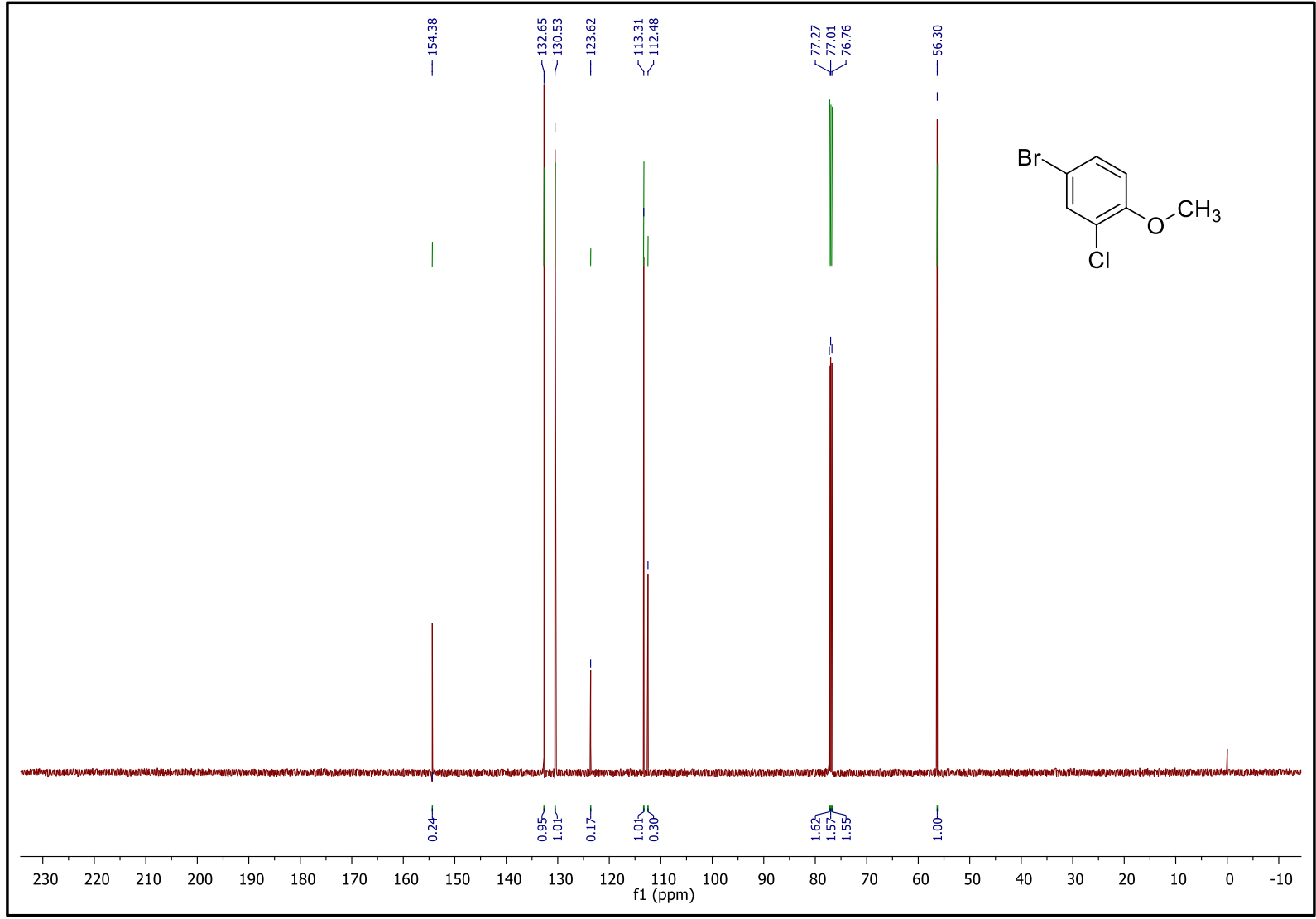


Espectro de RMN ${ }^{1} \mathrm{H}\left(400 \mathrm{MHz}, \mathrm{CDCl}_{3}\right.$ ) do 1-metoxi-4-nitrobenzeno (sintético)

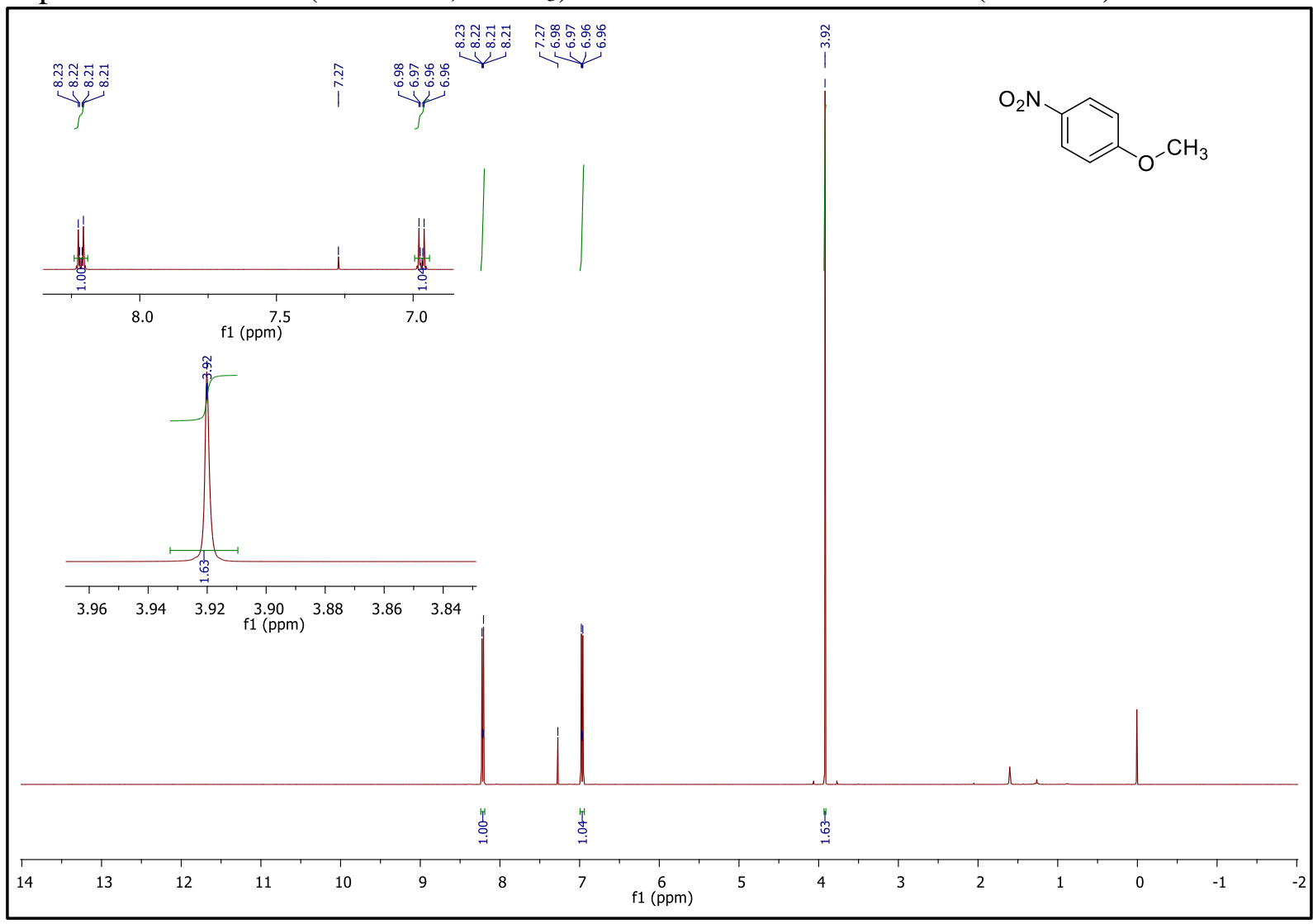

Espectro de $\mathrm{RMN}{ }^{13} \mathrm{C}\left(100 \mathrm{MHz}, \mathrm{CDCl}_{3}\right)$ do 1-metoxi-4-nitrobenzeno (sintético)

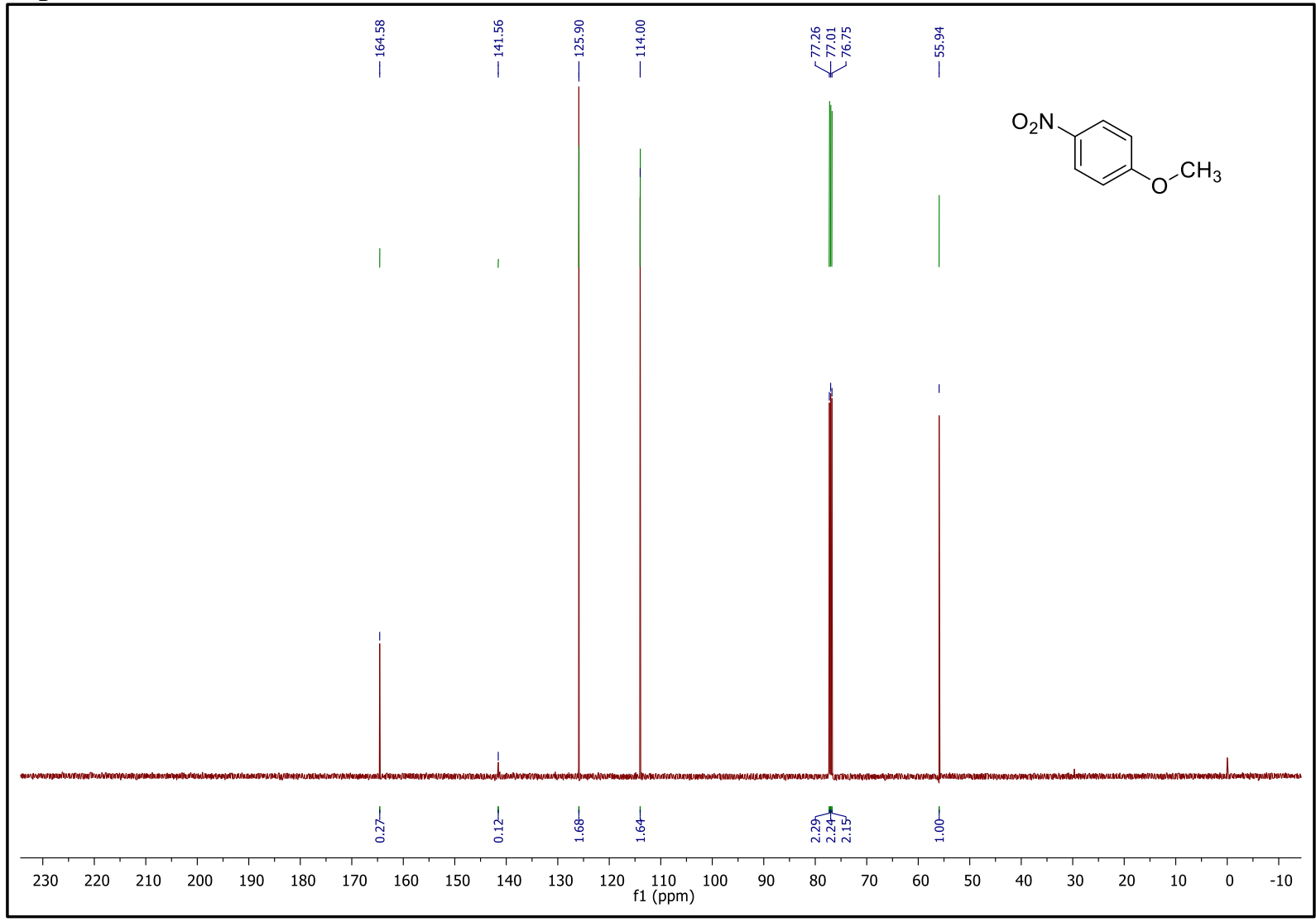


Espectro de $\mathrm{RMN}{ }^{1} \mathrm{H}\left(400 \mathrm{MHz}, \mathrm{CDCl}_{3}\right)$ do 3,5,6-tricloro-1-metil-2-piridinona (isolado)

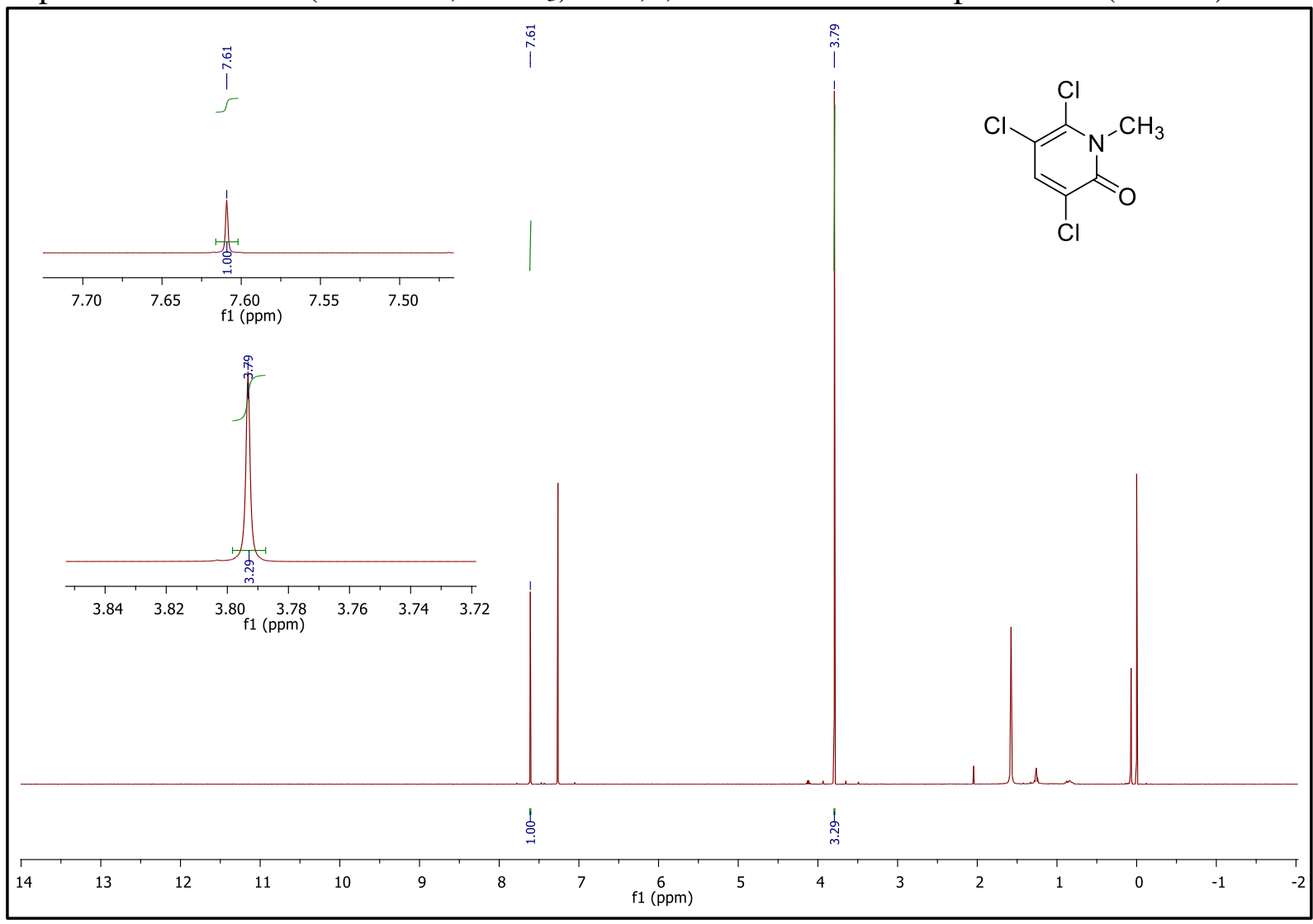

Espectro de $\mathrm{RMN}{ }^{13} \mathrm{C}\left(100 \mathrm{MHz}, \mathrm{CDCl}_{3}\right)$ do 3,5,6-tricloro-1-metil-2-piridinona (isolado)

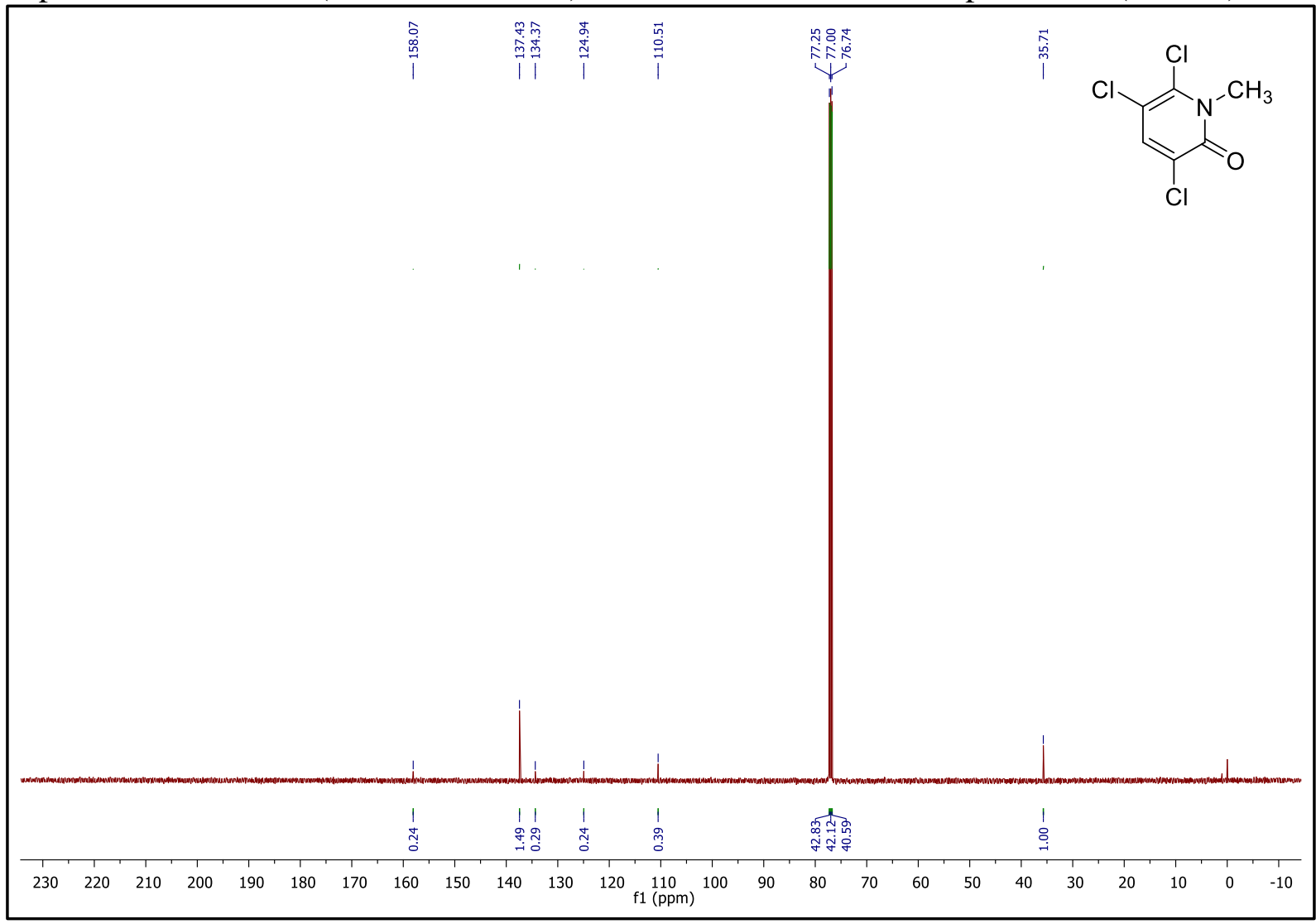


Espectro de $\mathrm{RMN}{ }^{1} \mathrm{H}\left(400 \mathrm{MHz}, \mathrm{CDCl}_{3}\right.$ ) do 2,3,5-tricloro-6-metoxipiridina (isolado)

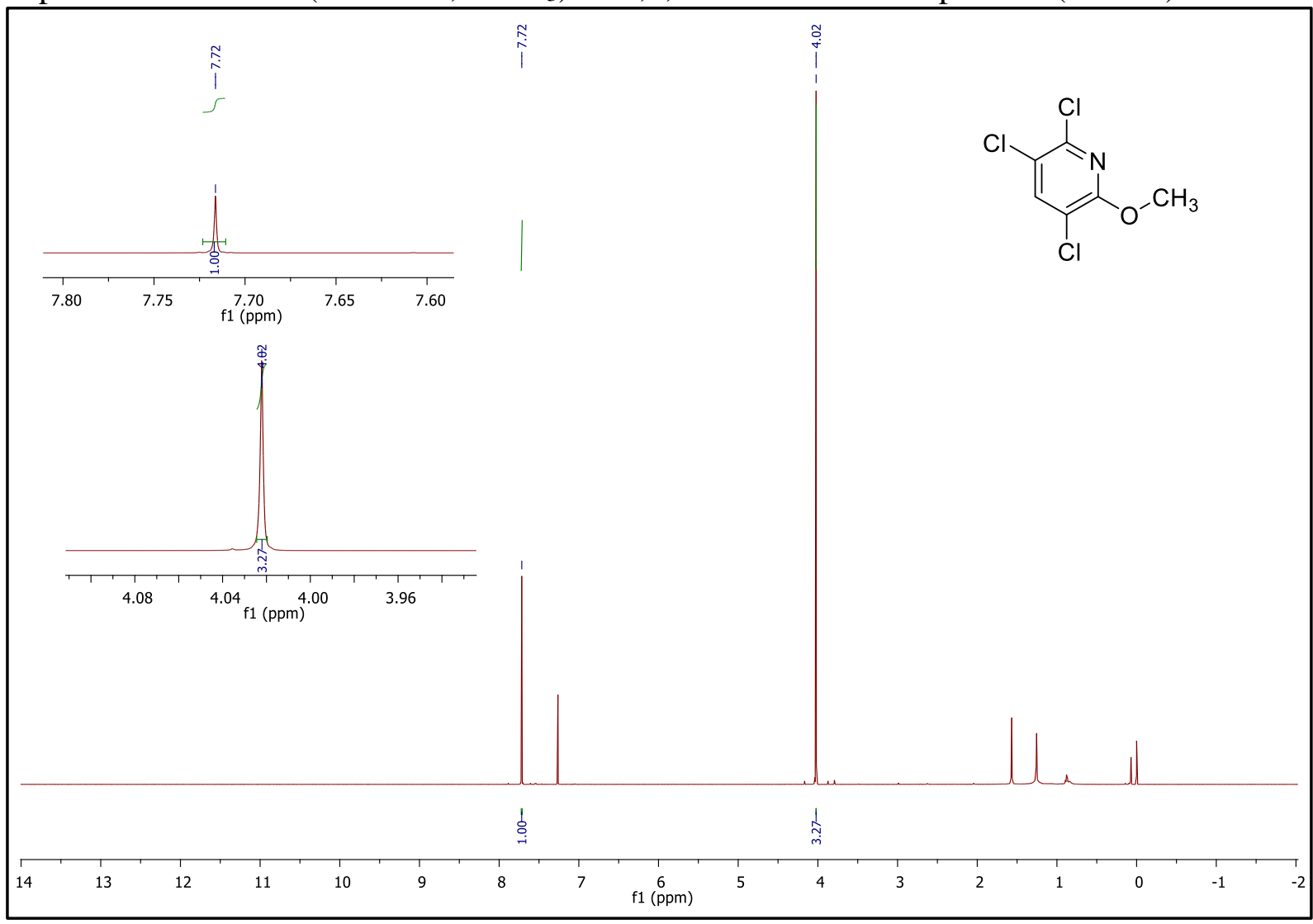

Espectro de $\mathrm{RMN}{ }^{13} \mathrm{C}\left(100 \mathrm{MHz}, \mathrm{CDCl}_{3}\right)$ do 2,3,5-tricloro-6-metoxipiridina (isolado)

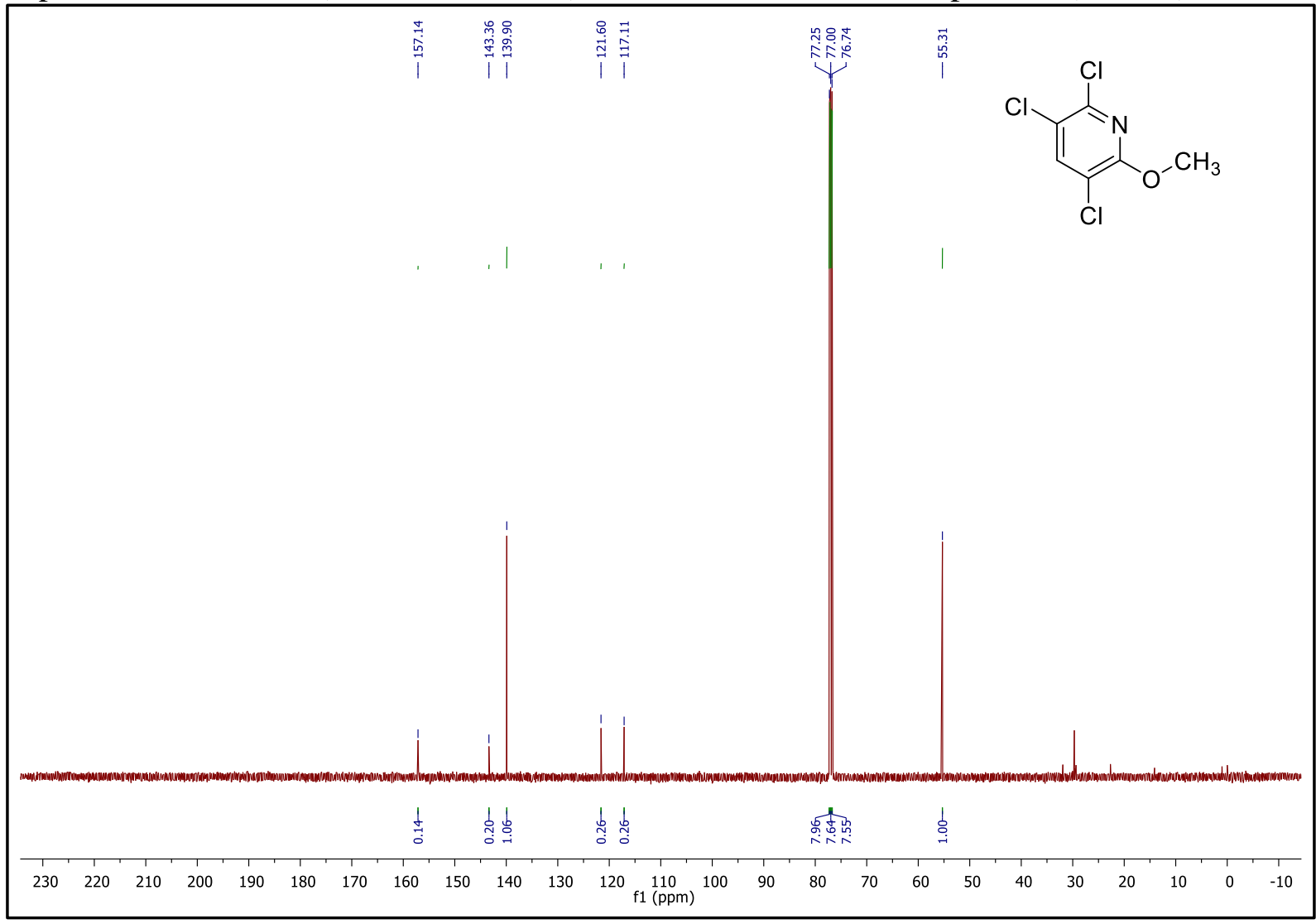


Espectro de $\mathrm{RMN}{ }^{1} \mathrm{H}\left(400 \mathrm{MHz}, \mathrm{CDCl}_{3}\right)$ do 3,5,6-tricloro-1-metil-2-piridinona (isolado)

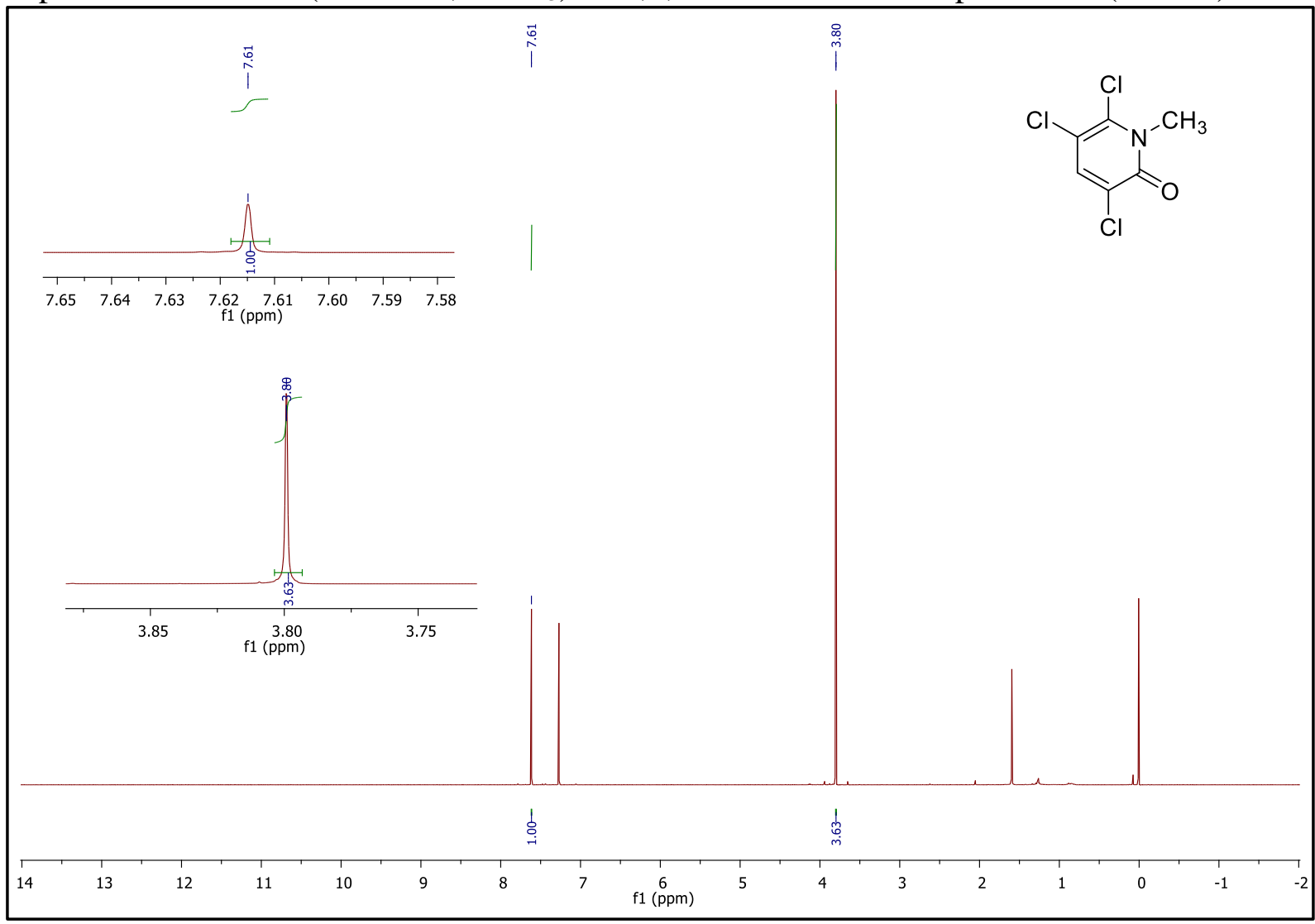

Espectro de $\mathrm{RMN}{ }^{13} \mathrm{C}\left(100 \mathrm{MHz}, \mathrm{CDCl}_{3}\right)$ do 3,5,6-tricloro-1-metil-2-piridinona (isolado)

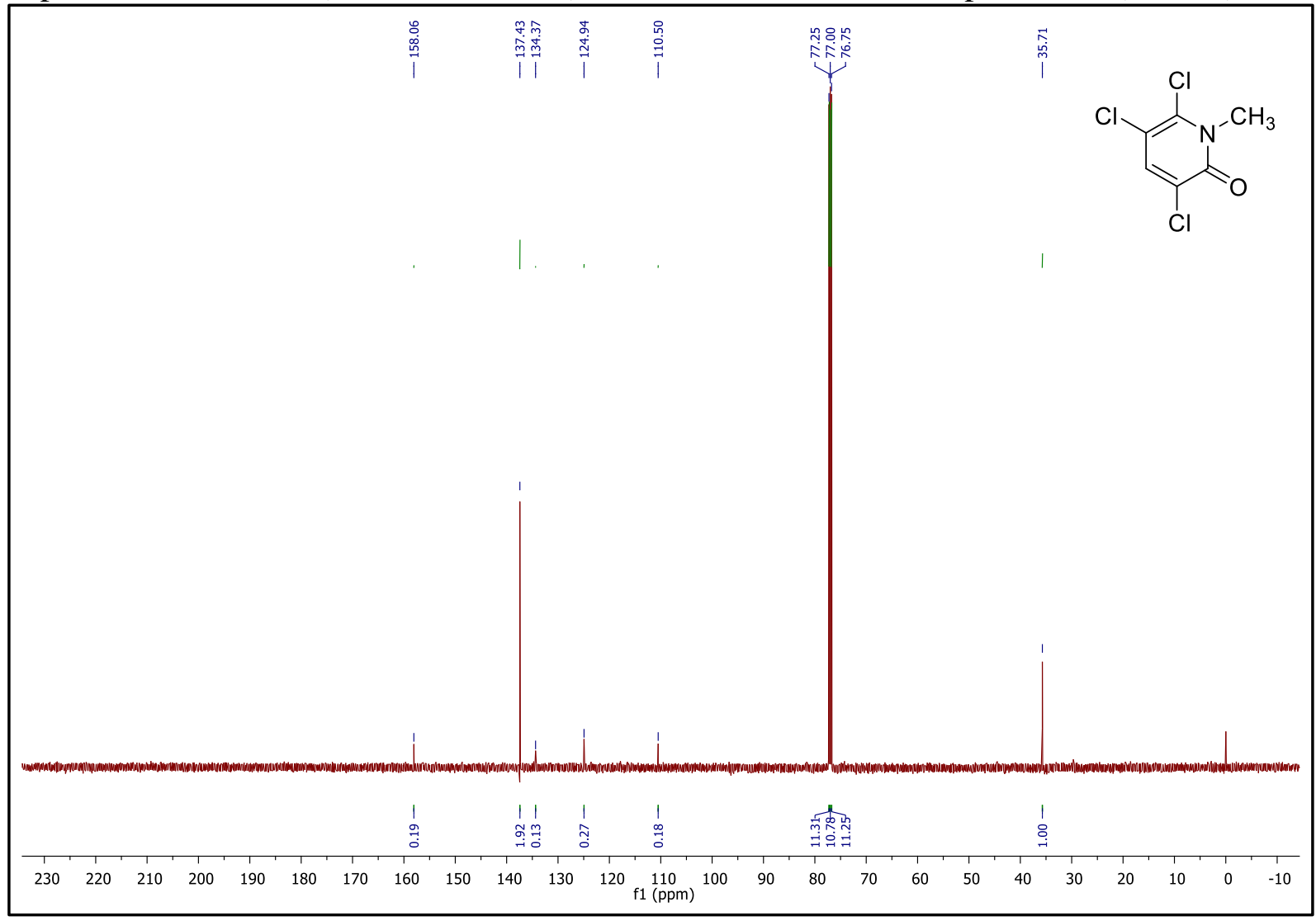


Espectro de $\mathrm{RMN}{ }^{1} \mathrm{H}\left(400 \mathrm{MHz}, \mathrm{CDCl}_{3}\right.$ ) do 2,3,5-tricloro-6-metoxipiridina (sintético)

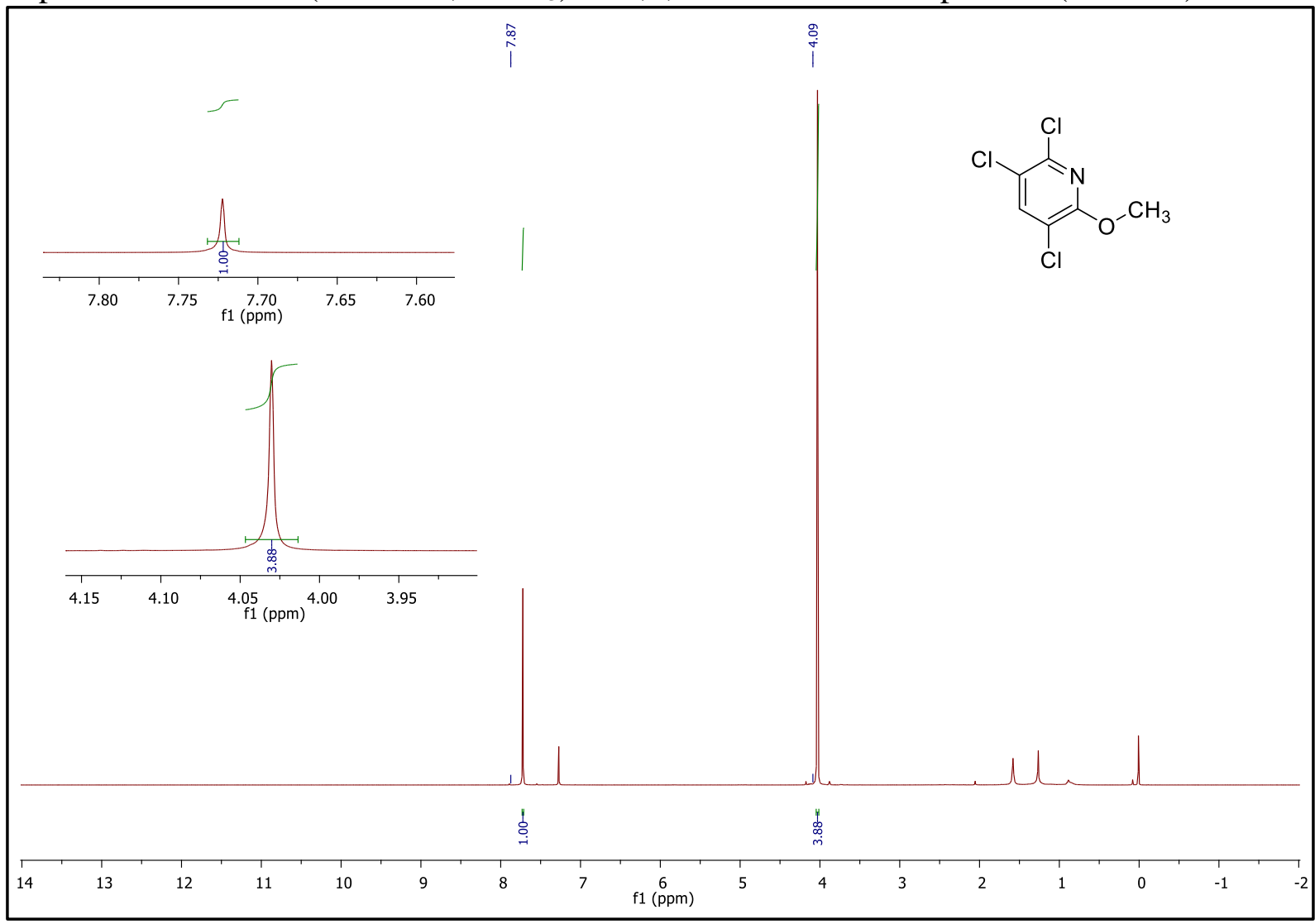

Espectro de $\mathrm{RMN}{ }^{13} \mathrm{C}\left(100 \mathrm{MHz}, \mathrm{CDCl}_{3}\right)$ do 2,3,5-tricloro-6-metoxipiridina (sintético)

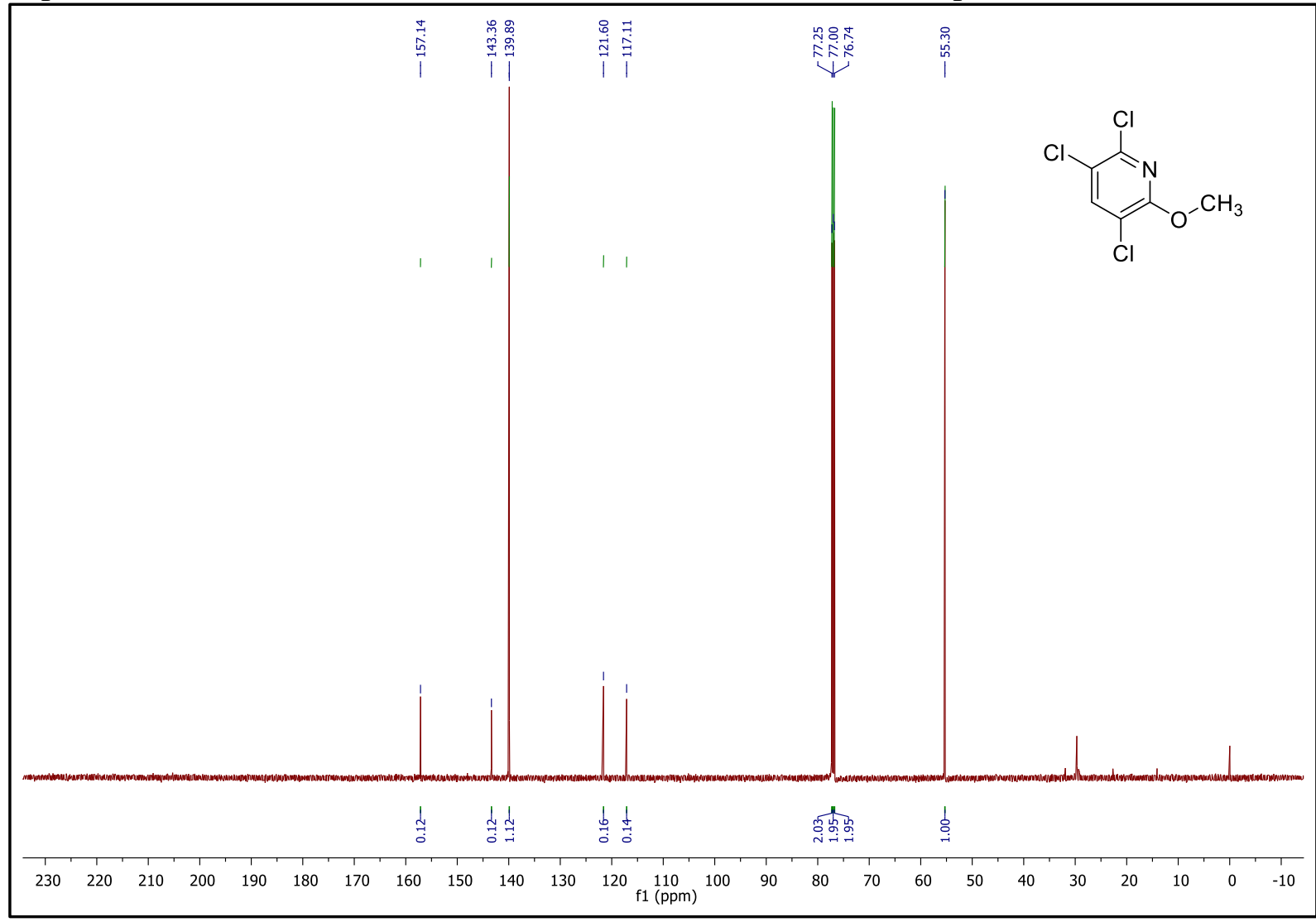


Espectro de $\mathrm{RMN}{ }^{1} \mathrm{H}\left(400 \mathrm{MHz}, \mathrm{CDCl}_{3}\right.$ ) do 1,2,3,4,5-pentacloro-6-metoxibenzeno (sintético)

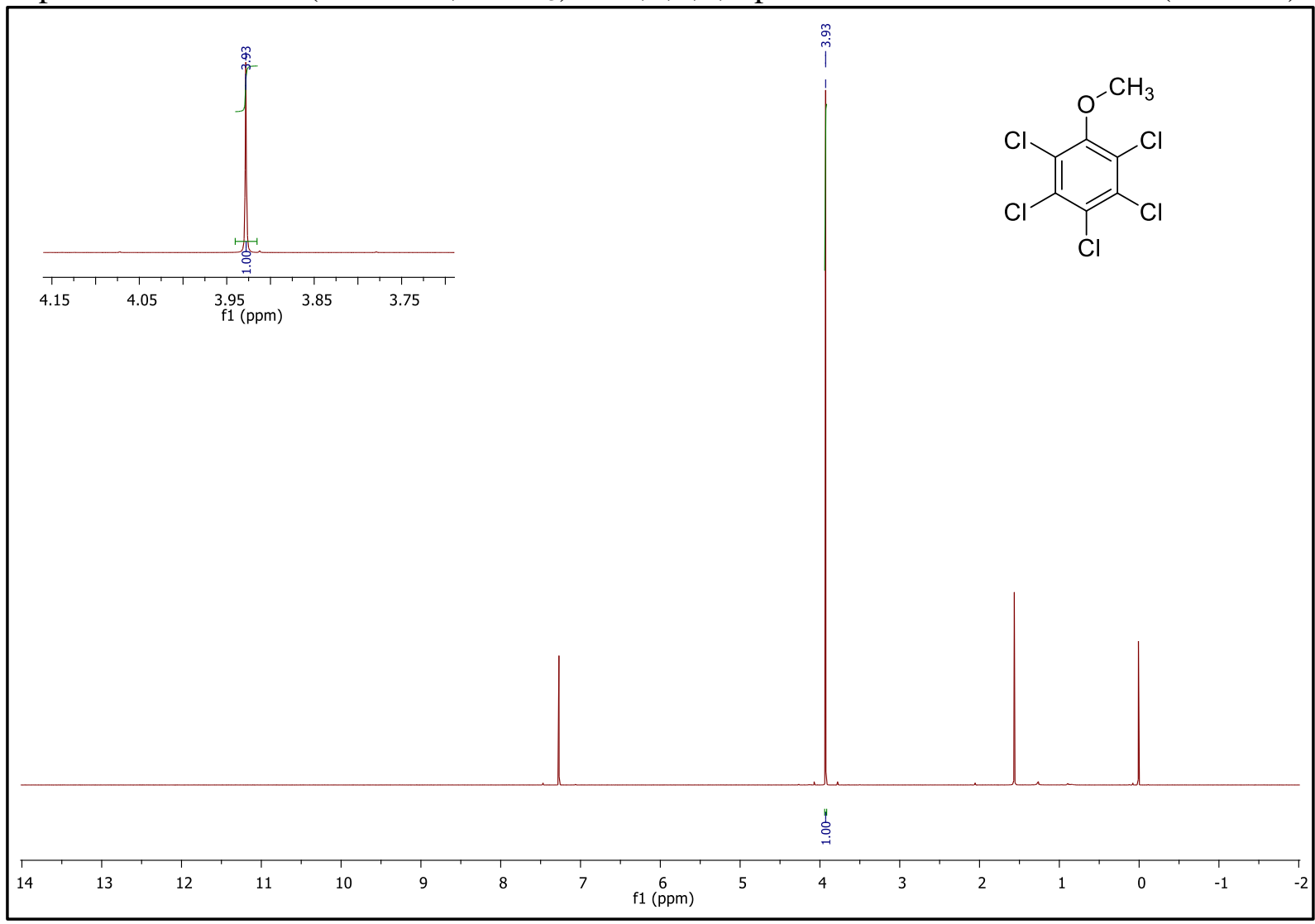

Espectro de $\mathrm{RMN}{ }^{13} \mathrm{C}\left(100 \mathrm{MHz}, \mathrm{CDCl}_{3}\right)$ do 1,2,3,4,5-pentacloro-6-metoxibenzeno sintético

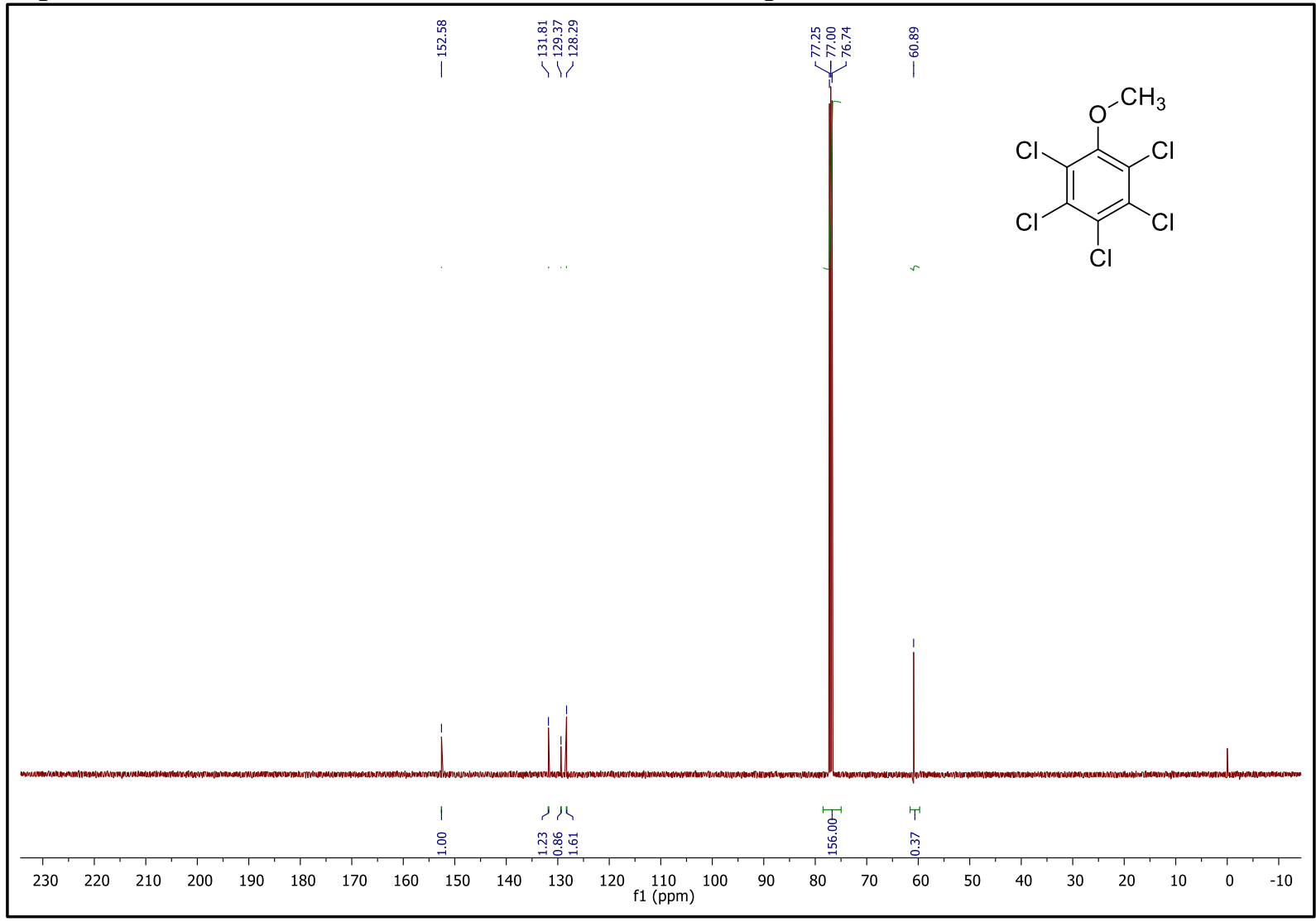


Espectro de $\mathrm{RMN}{ }^{1} \mathrm{H}\left(400 \mathrm{MHz}, \mathrm{CDCl}_{3}\right.$ ) do anisol (sintético)

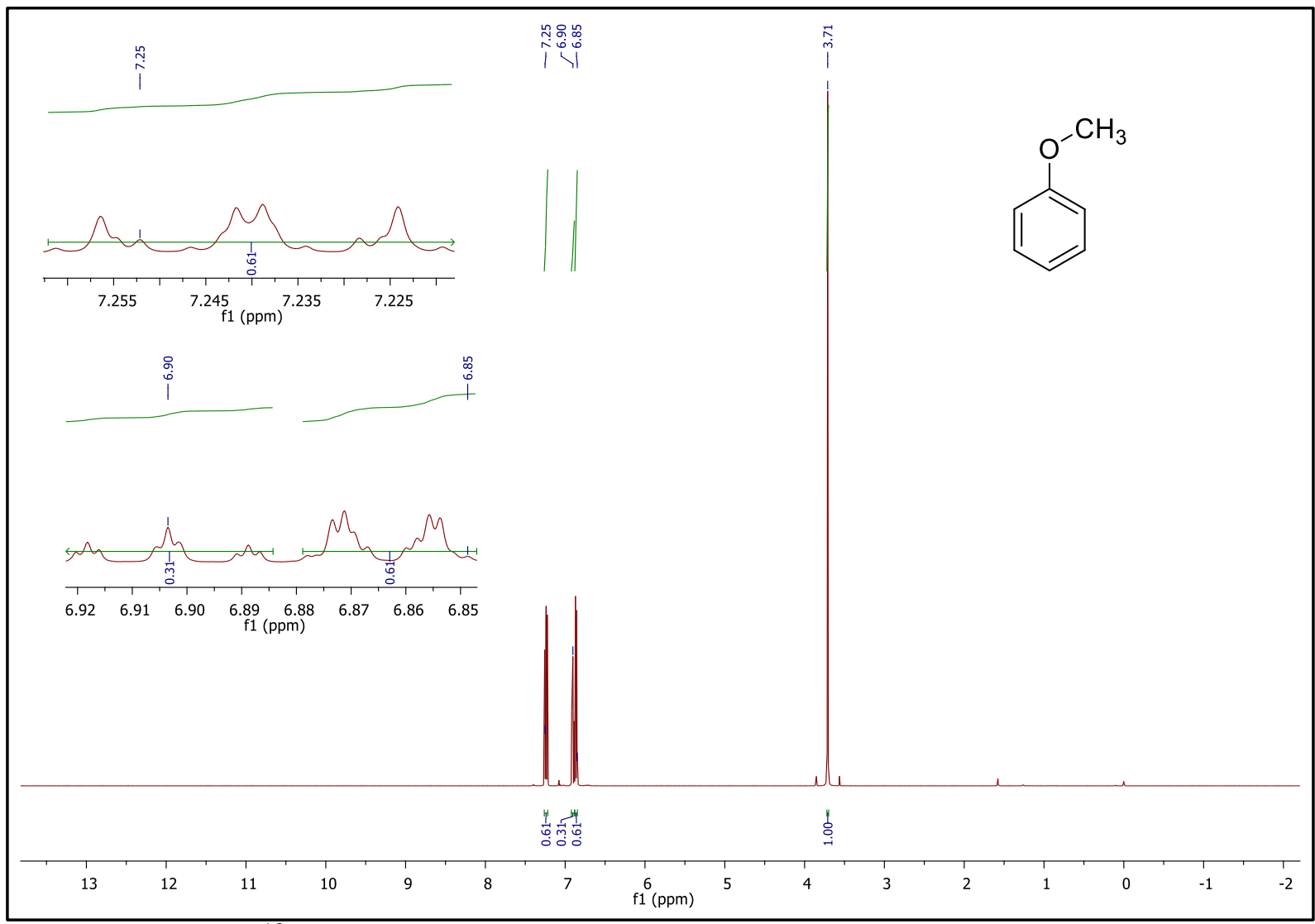

Espectro de $\mathrm{RMN}^{13} \mathrm{C}\left(100 \mathrm{MHz}, \mathrm{CDCl}_{3}\right)$ do anisol (sintético)

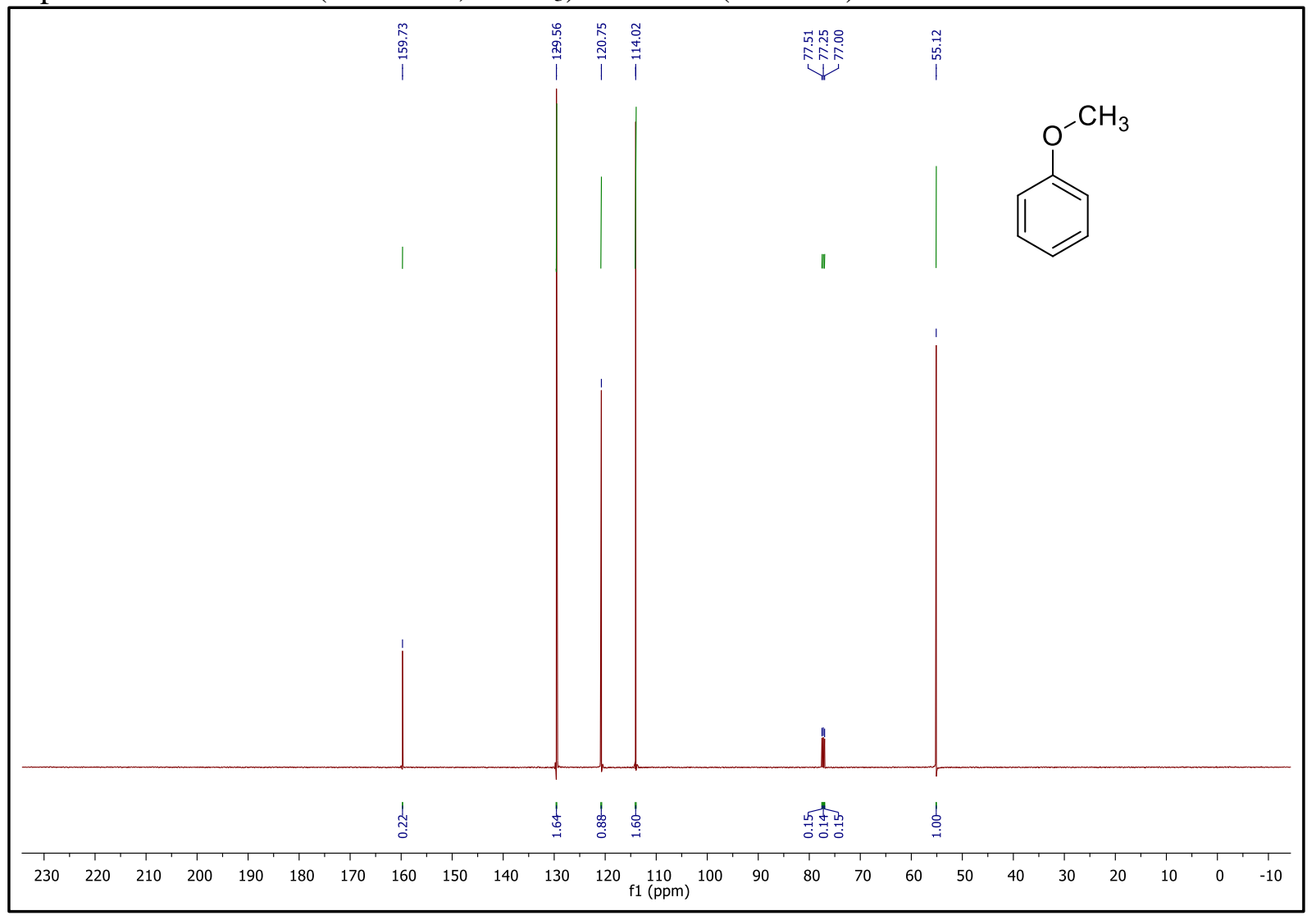


Espectro de RMN ${ }^{1} \mathrm{H}\left(400 \mathrm{MHz}, \mathrm{CDCl}_{3}\right)$ do 1-cloro-2-metoxibenzeno (sintético)

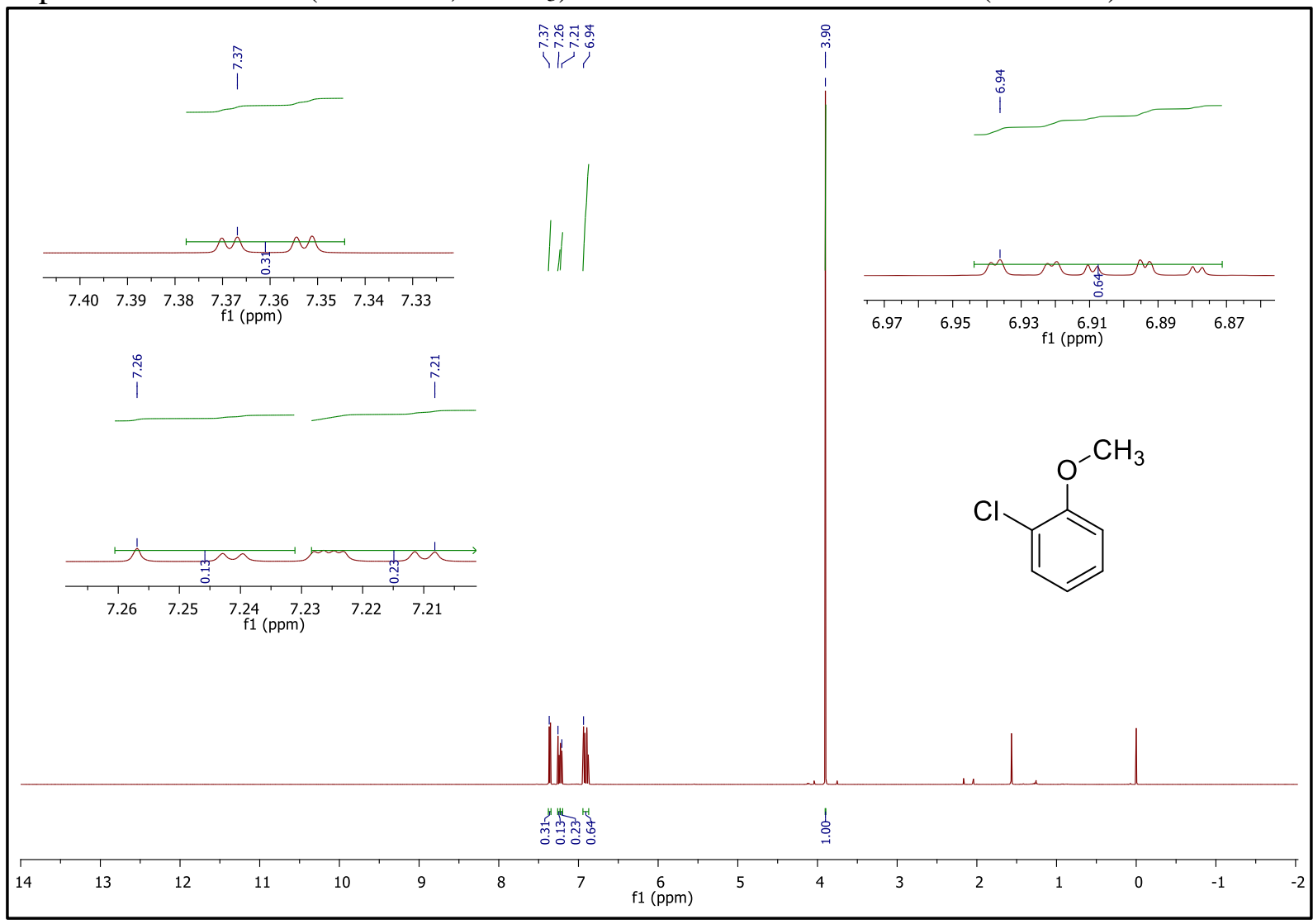

Espectro de RMN ${ }^{13} \mathrm{C}\left(100 \mathrm{MHz}, \mathrm{CDCl}_{3}\right)$ do 1-cloro-2-metoxibenzeno (sintético)

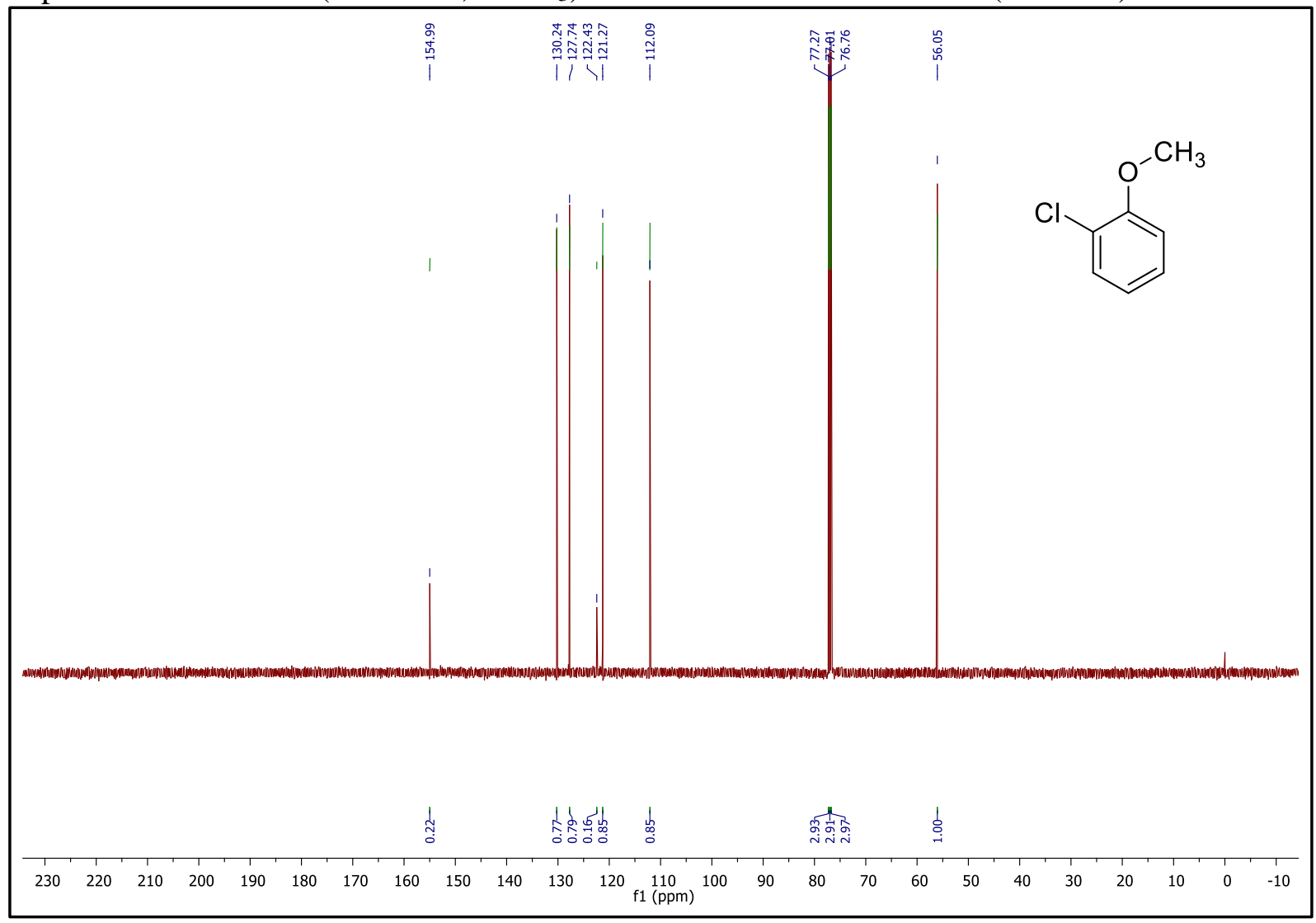


Espectro de $\mathrm{RMN}{ }^{1} \mathrm{H}\left(400 \mathrm{MHz}, \mathrm{CDCl}_{3}\right.$ ) do 2-cloro-5-metoxipiridina (padrão sintético)

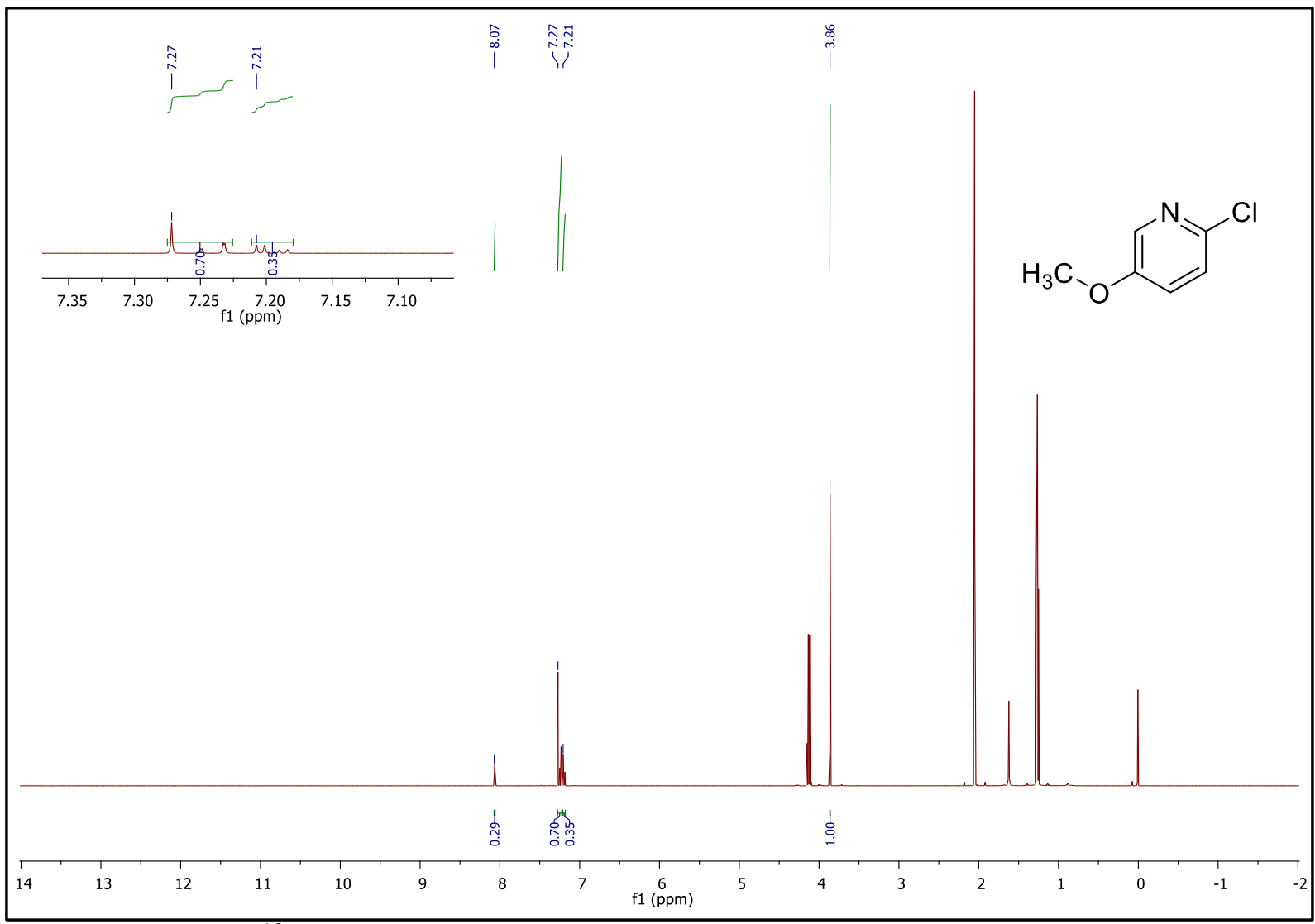

Espectro de $\mathrm{RMN}{ }^{13} \mathrm{C}\left(100 \mathrm{MHz}, \mathrm{CDCl}_{3}\right)$ do 2-cloro-5-metoxipiridina (sintético)

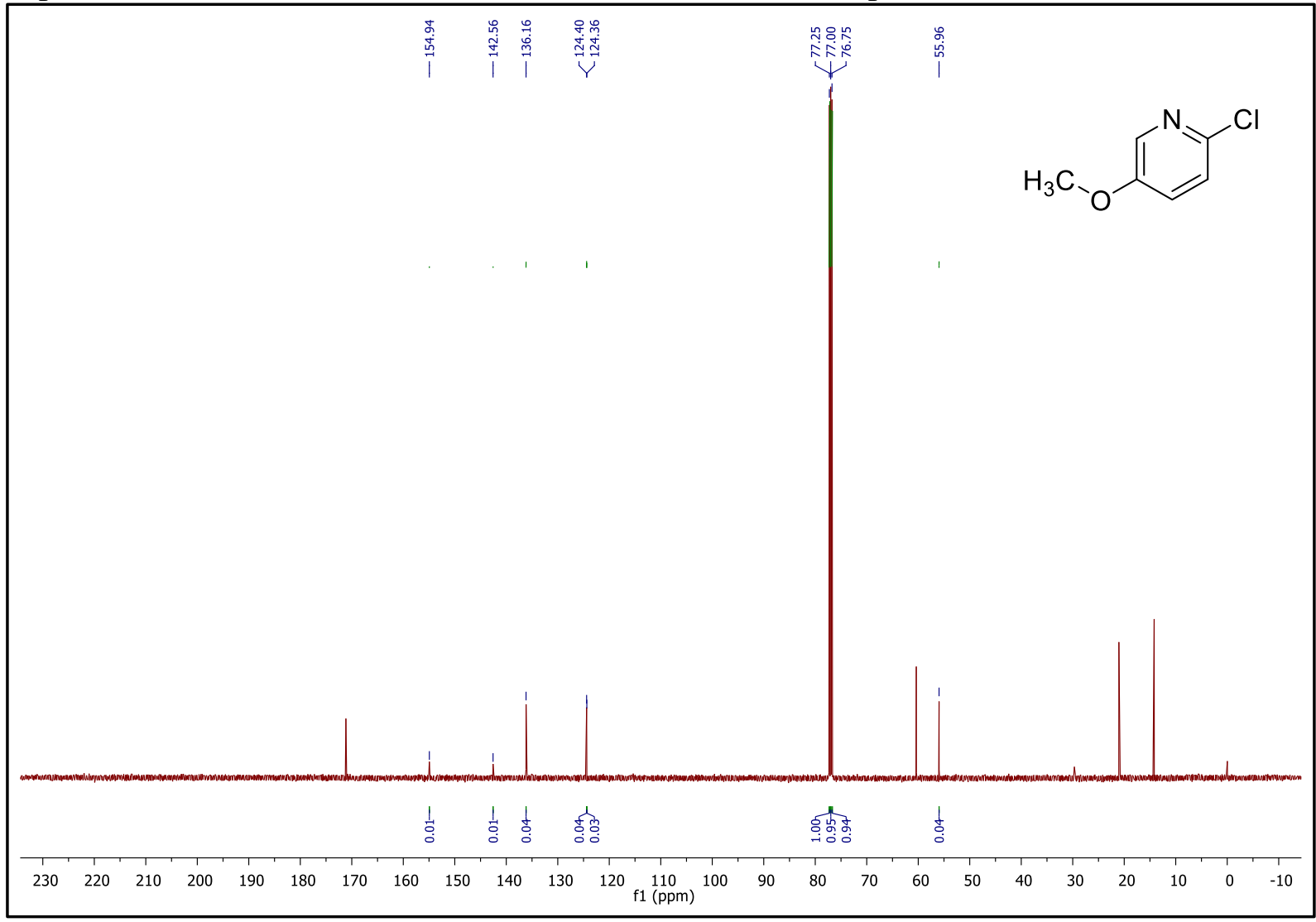


Espectro de RMN ${ }^{1} \mathrm{H}\left(400 \mathrm{MHz}, \mathrm{DMSO}-d_{6}\right)$ do 4-(4-hidroxifenil)ciclo-hexanona (sintético)

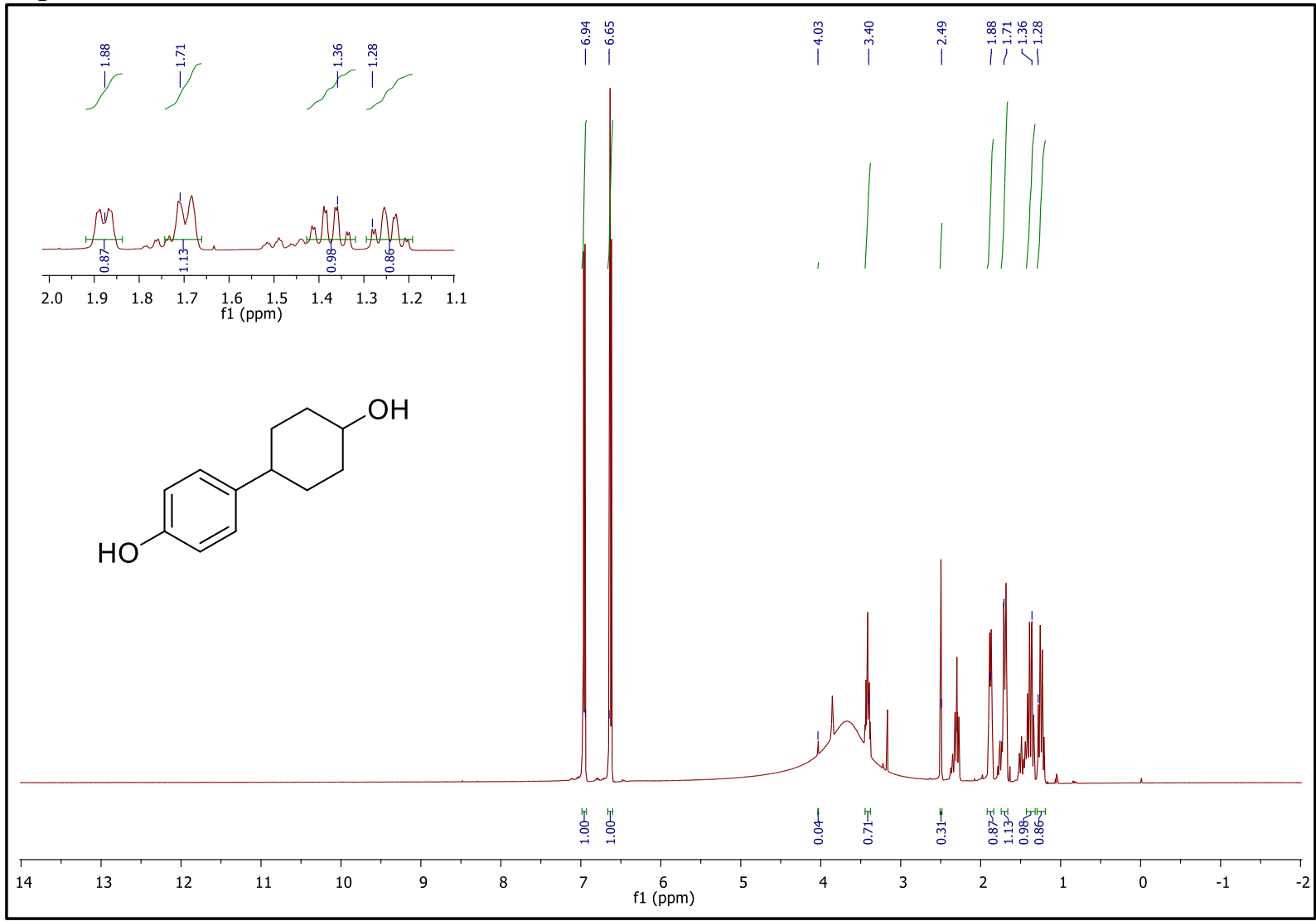

Espectro de $\mathrm{RMN}{ }^{13} \mathrm{C}\left(100 \mathrm{MHz}, \mathrm{DMSO}-d_{6}\right)$ do 4-(4-hidroxifenil)ciclo-hexanona (sintético)

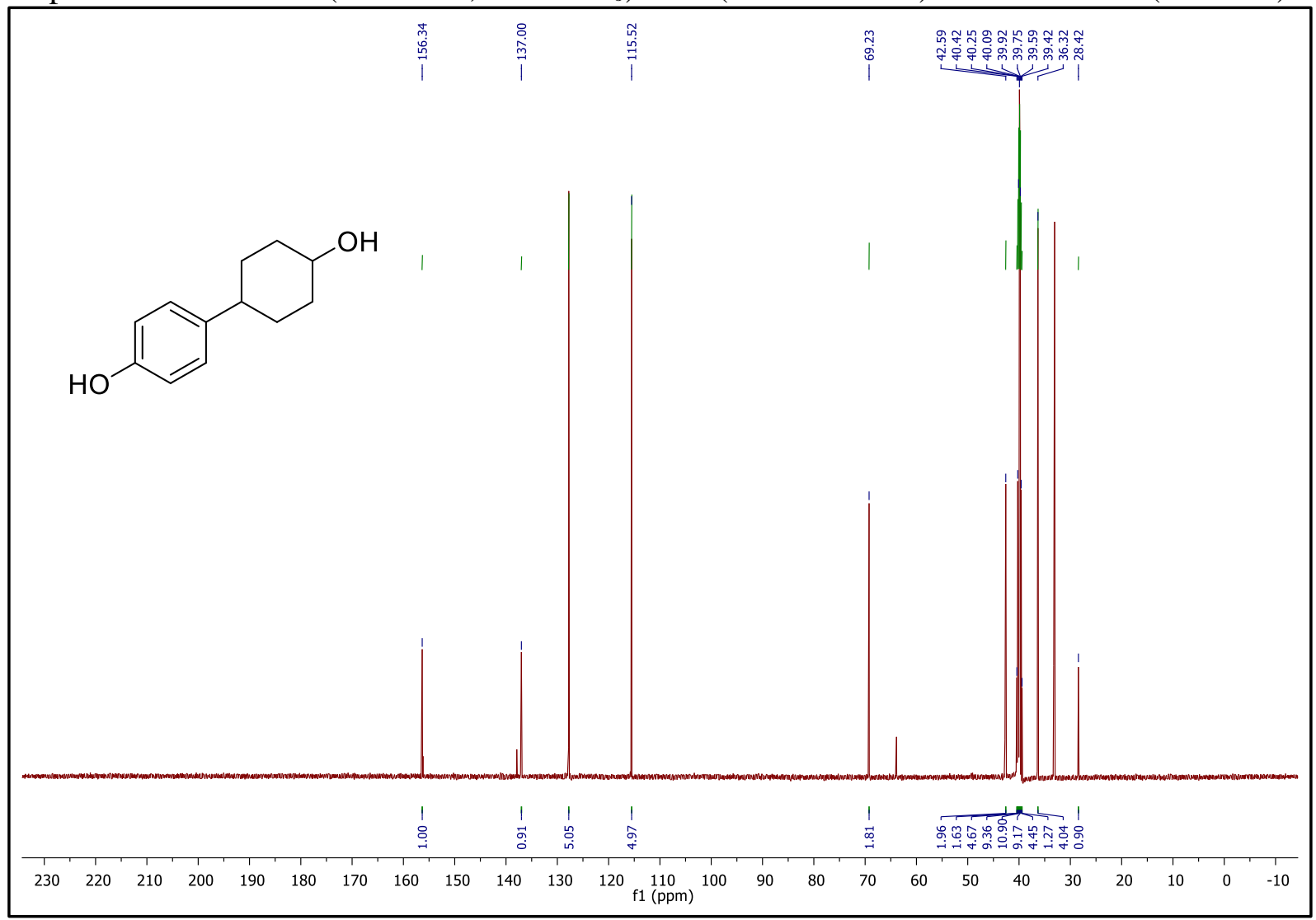


Espectro de $\mathrm{RMN}{ }^{1} \mathrm{H}\left(400 \mathrm{MHz}, \mathrm{CDCl}_{3}\right)$ do (E)-3-(4-metoxifenil)-1-(2,4,6trimetoxifenil)pro-2-em-1-ona (isolado)
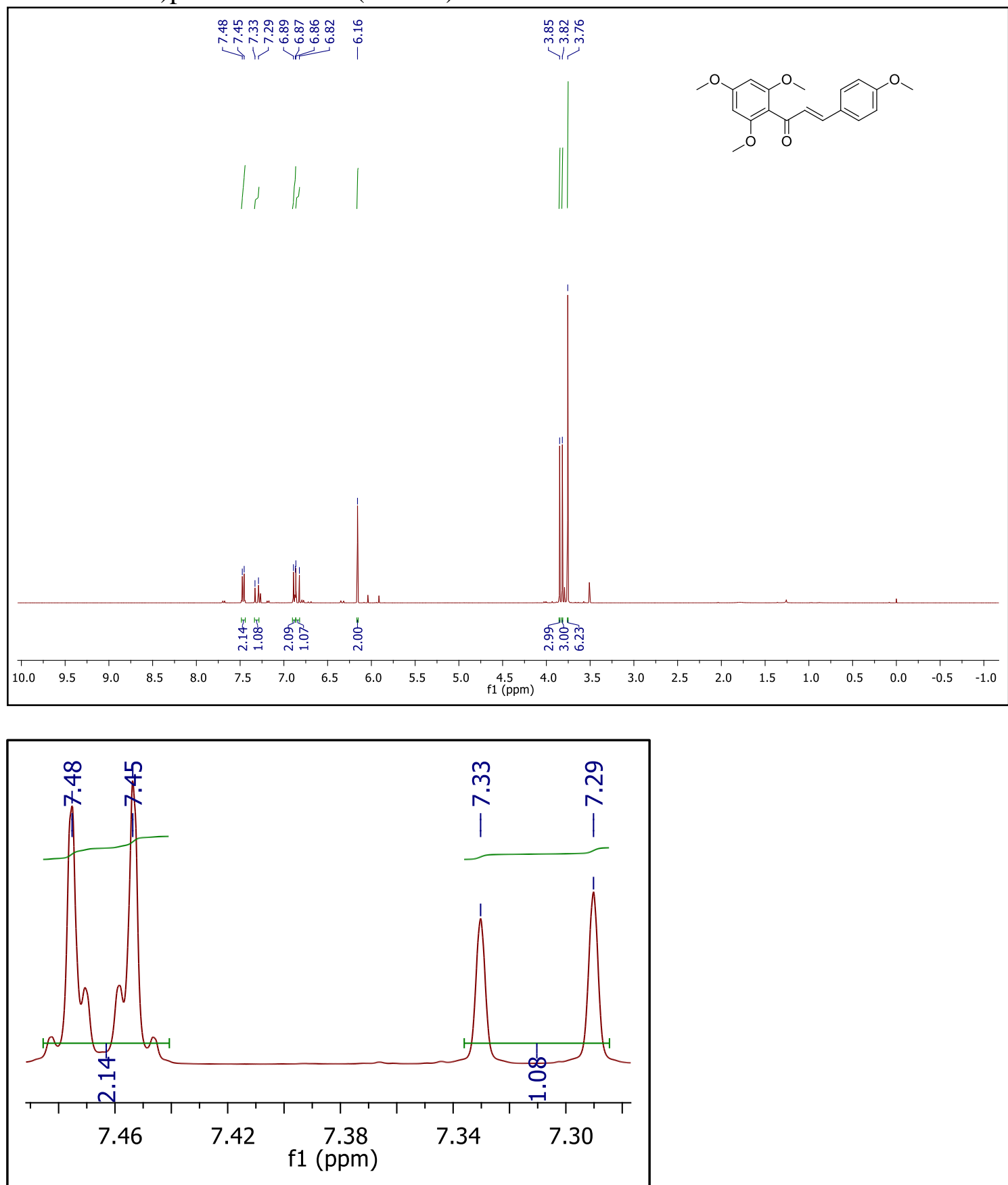


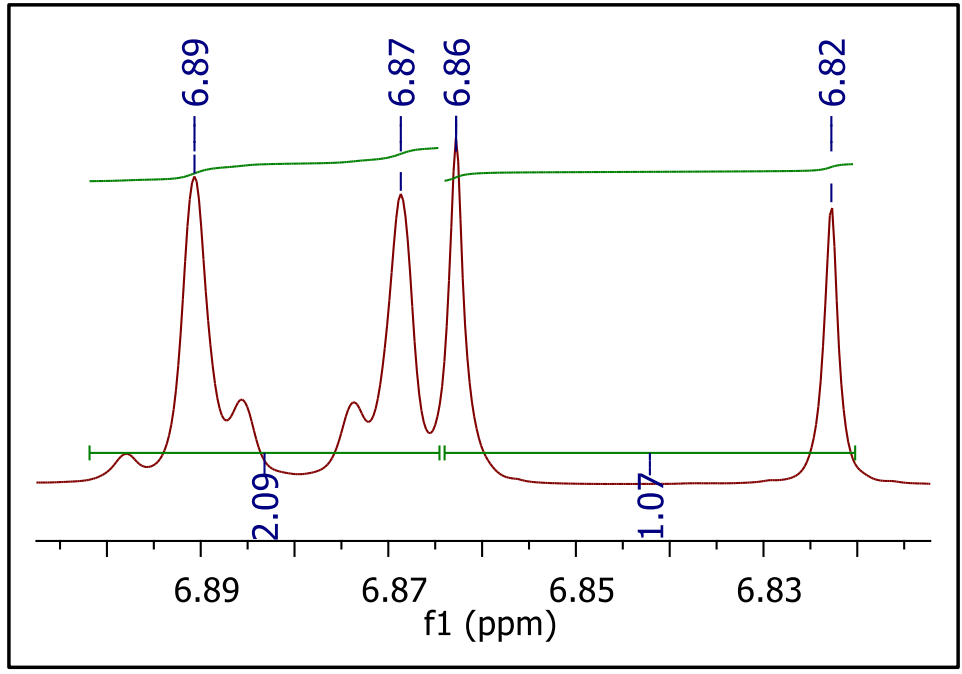

Espectro de $\mathrm{RMN}{ }^{13} \mathrm{C}\left(100 \mathrm{MHz}, \mathrm{CDCl}_{3}\right)$ do (E)-3-(4-metoxifenil)-1-(2,4,6trimetoxifenil)pro-2-em-1-ona (isolado)

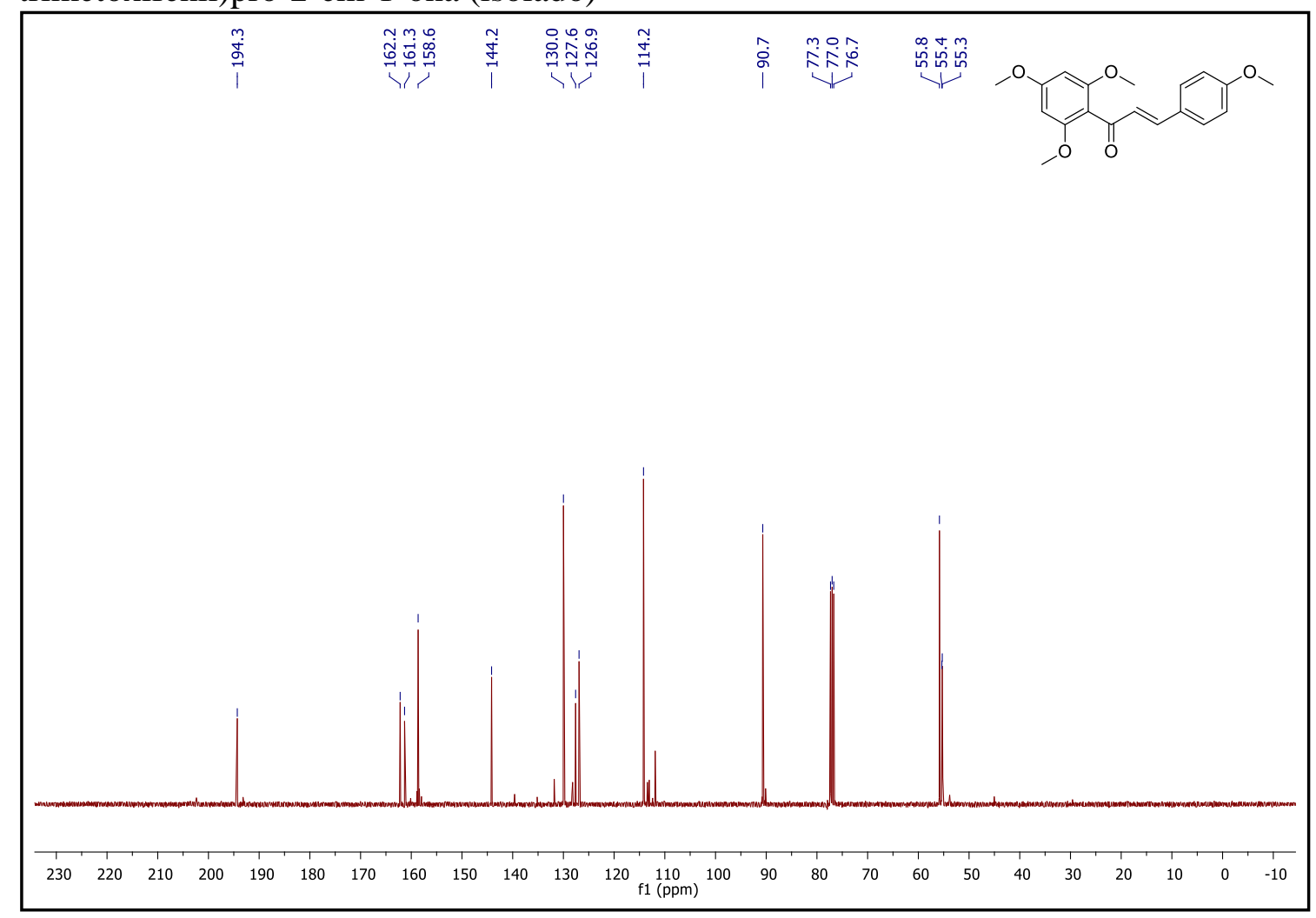




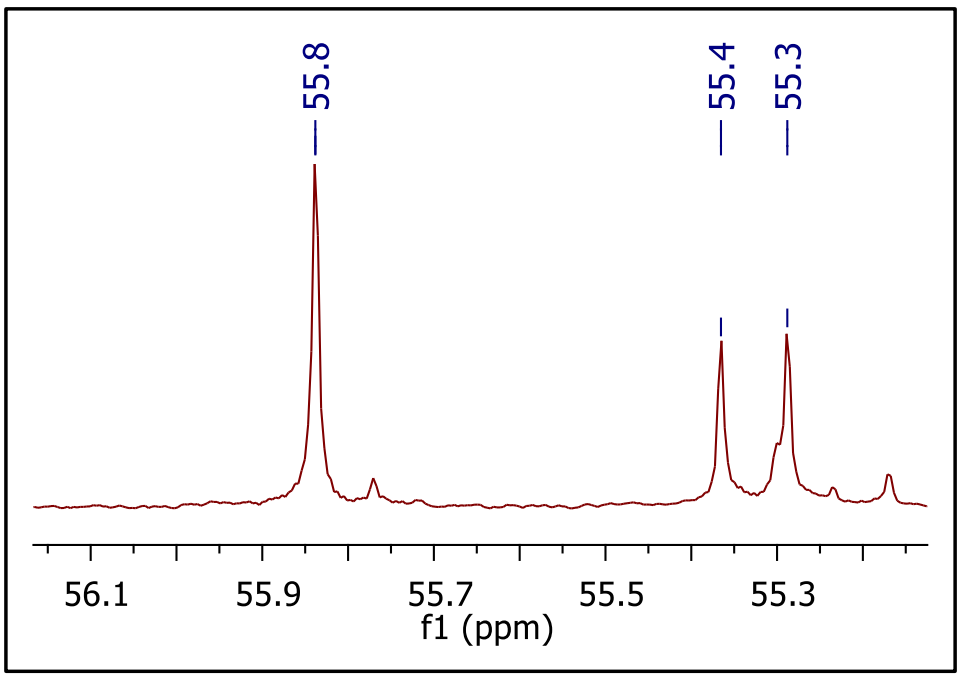

Espectro de $\mathrm{RMN}{ }^{1} \mathrm{H}\left(400 \mathrm{MHz}, \mathrm{CDCl}_{3}\right.$ ) do 5,7-dimetoxi-2-(4-metoxifenil)croman-4-ona (isolado)

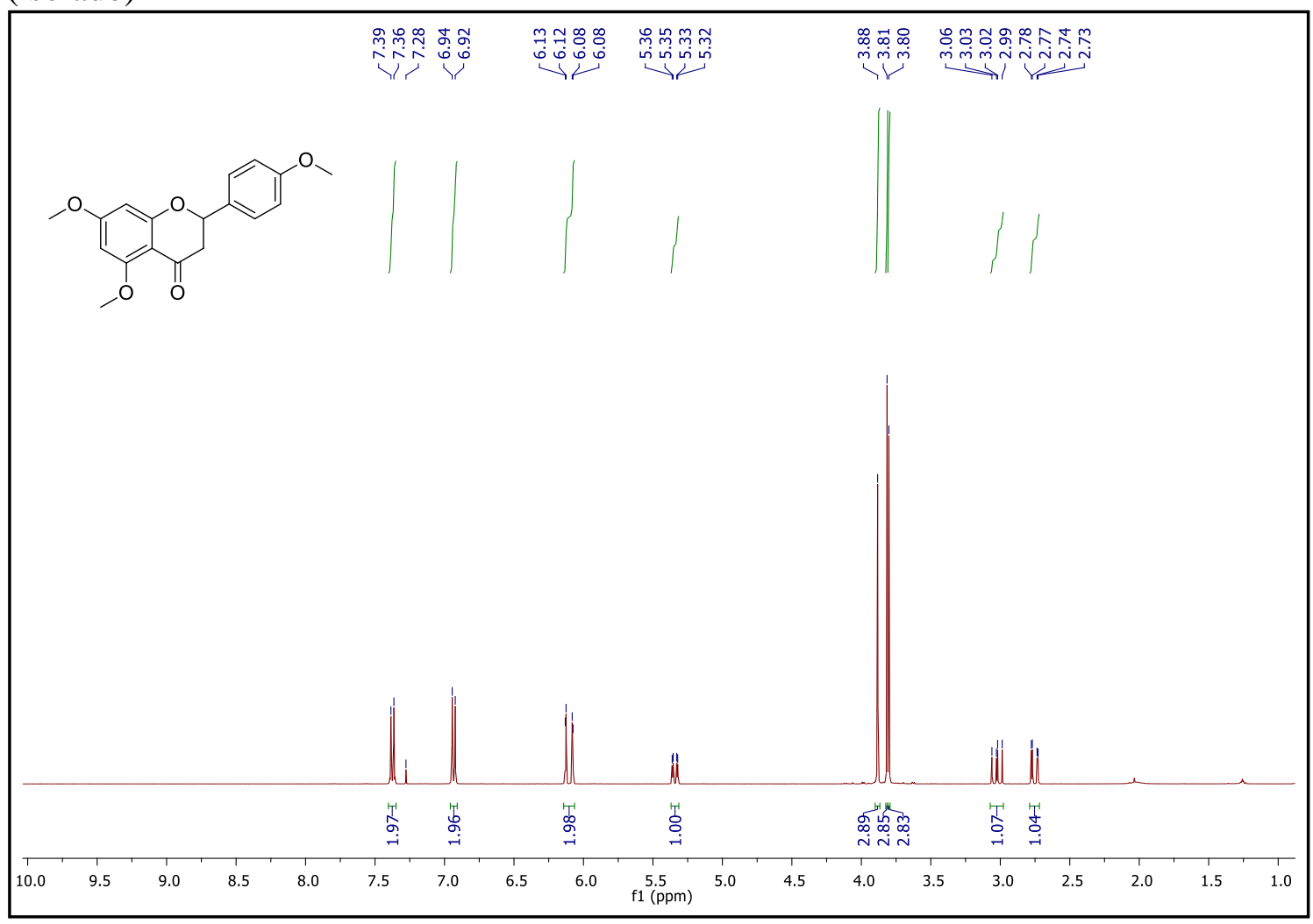



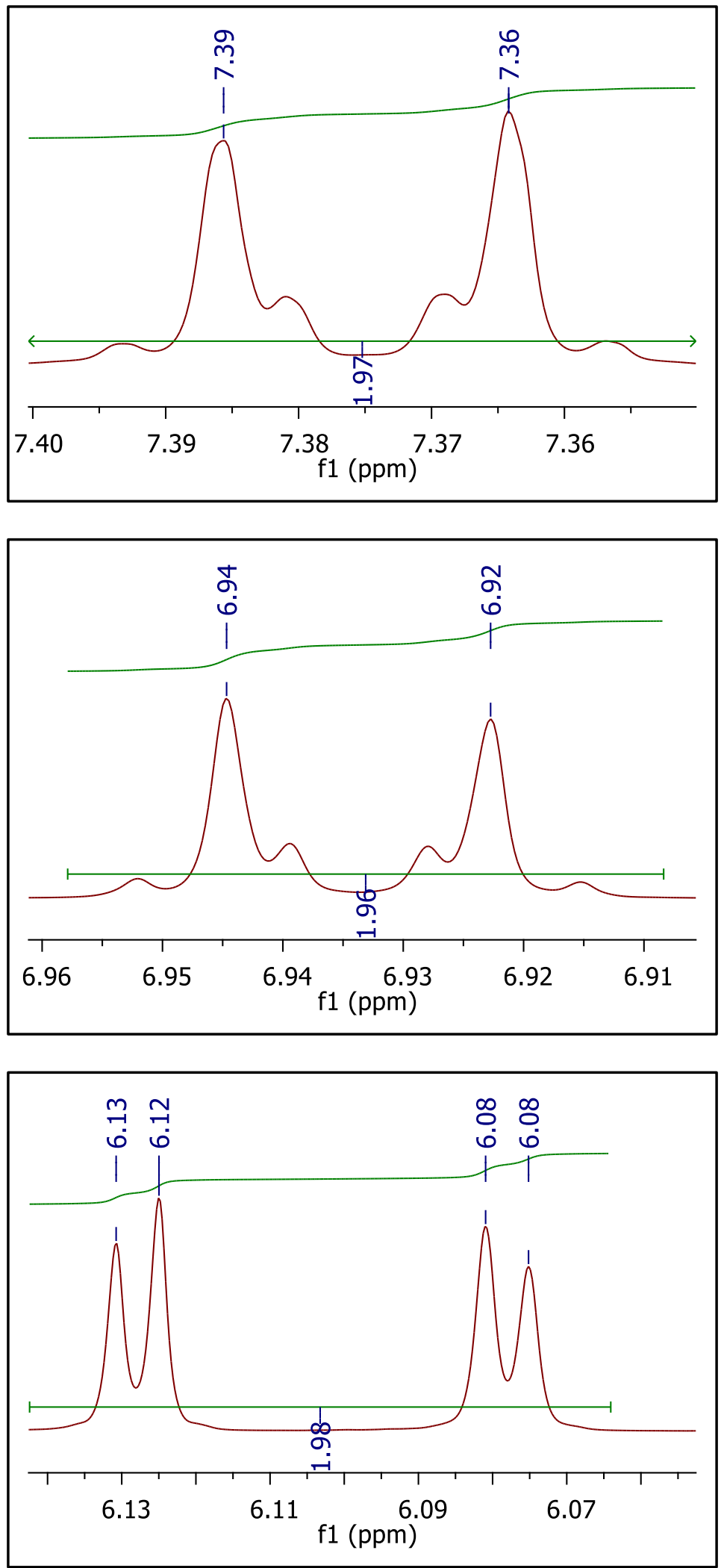

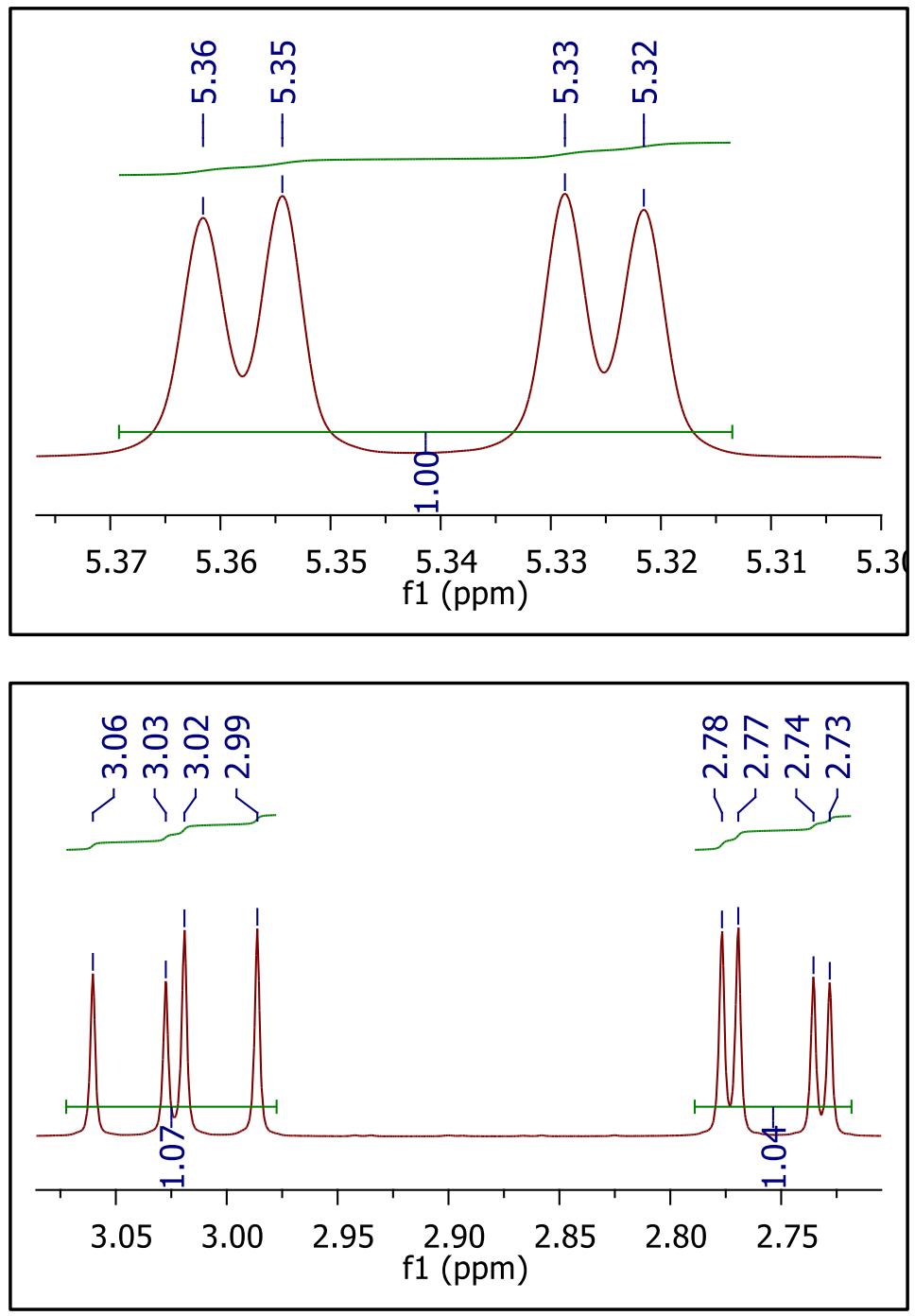
Espectro de $\mathrm{RMN}{ }^{13} \mathrm{C}\left(100 \mathrm{MHz}, \mathrm{CDCl}_{3}\right)$ do 5,7-dimetoxi-2-(4-metoxifenil)croman-4-ona (isolado)

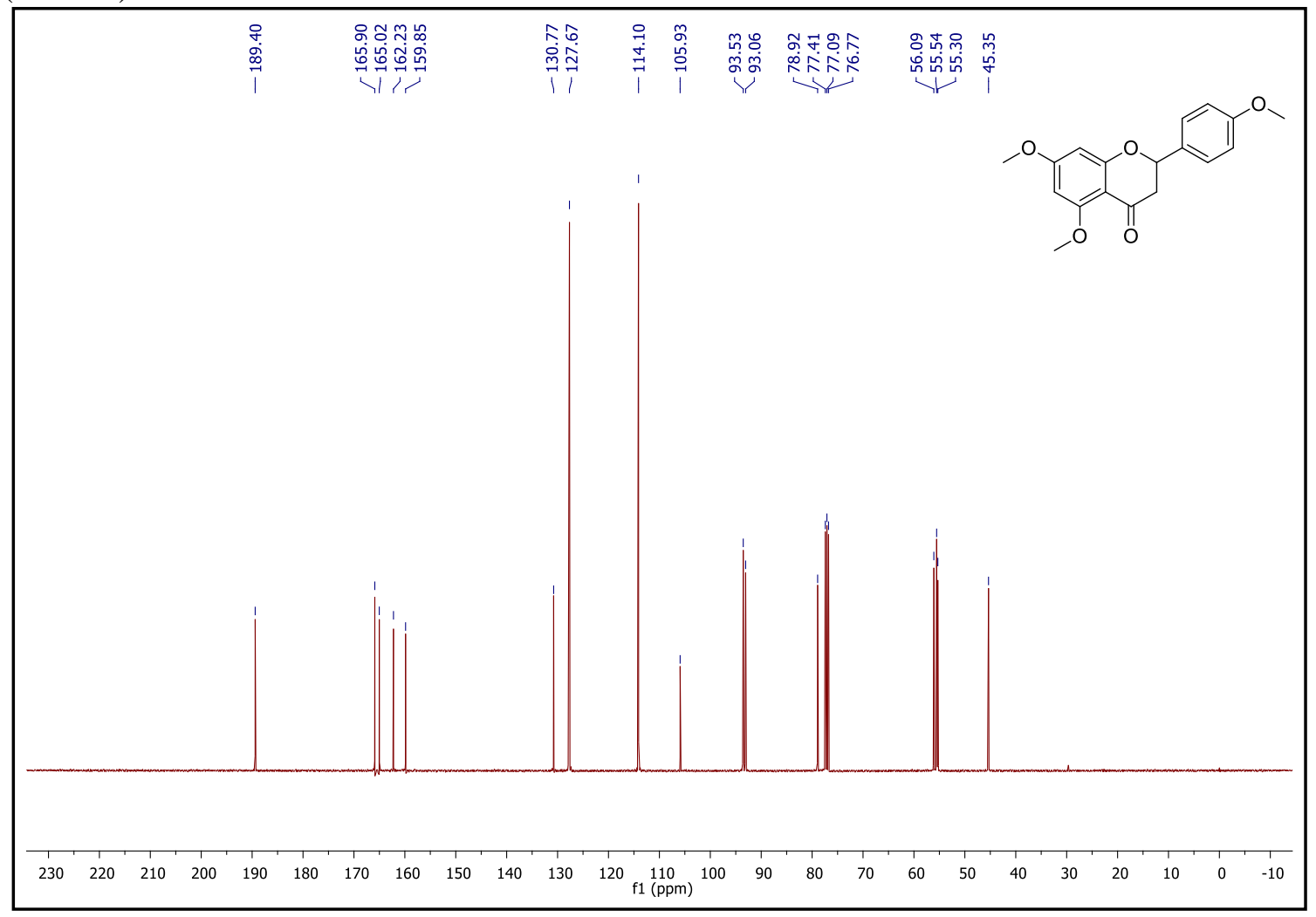


Espectros de absorção no infravermelho dos compostos 5,7-dimetoxi-2-(4metoxifenil)croman-4-ona (isolado) e (E)-3-(4-metoxifenil)-1-(2,4,6-trimetoxifenil)pro-2em-1-ona (isolado)

Espectro de absorção no infravermelho do 5,7-dimetoxi-2-(4-metoxifenil)croman-4-ona (isolado)

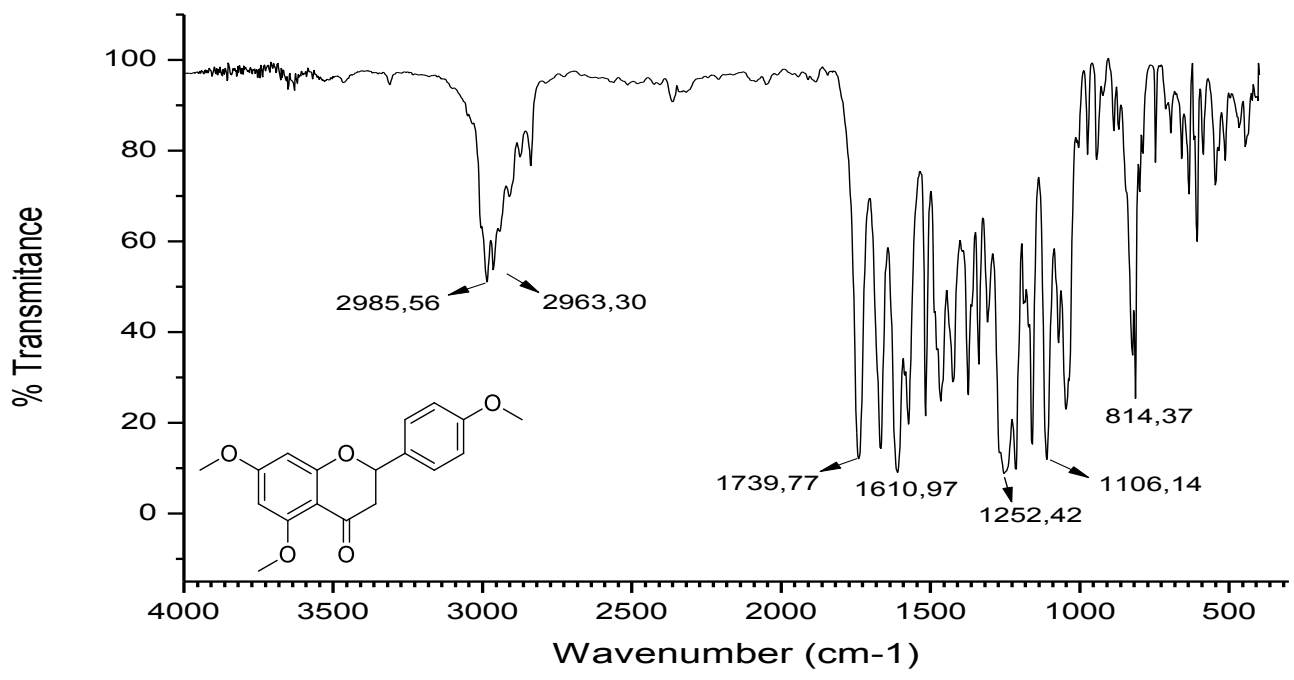

Espectro de absorção no infravermelho do (E)-3-(4-metoxifenil)-1-(2,4,6-trimetoxifenil)pro2-em-1-ona (isolado)

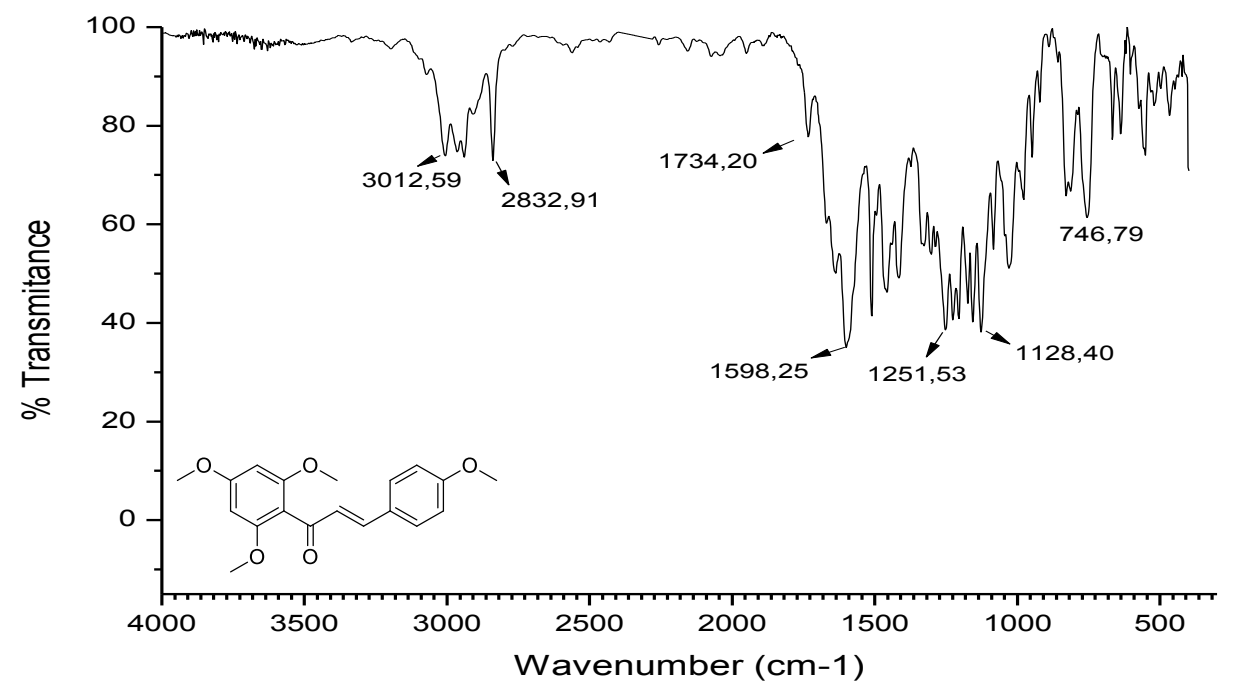

